\title{
DIARIO DEL ALZAMIENTO DE INDIOS CONJURADOS CONTRA LA CIUDAD DE NUESTRA SEÑORA DE LA PAZ
}

\section{1}

Por

FRANCISCO TADEO DIEZ DE MEDINA

\author{
Edición de \\ MARIA EUGENIA DEL VALLE DE SILES
}

\author{
Prólogo
}

GUNNAR MENDOZA L.

BANCO BOLVIANO AMERICANO

$$
\text { LA PAZ - BOLIVIA }
$$

1994 
1164516
$2 \mid 182796$

1981 PRIMERA EDICION

1994 SEGUNDA EDICION

Es propiedad del autor

quedan Reservados Ios Derechos

de acuerdo a ley, bajo el Registro

de propiedad-D.L. N $N^{\circ} 4-1-480-94$

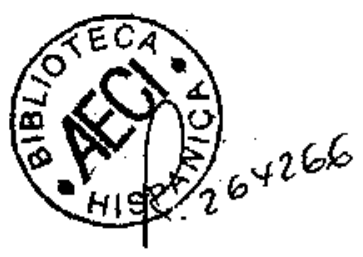


A la ciudad de Nuestra Señora de La Paz 


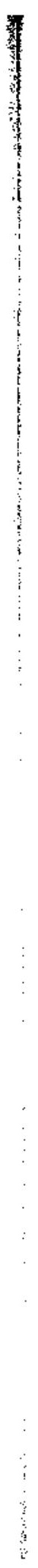




\section{PRESENTACION}

Para el Directorio del Banco Boliviano Americano es singularmente satisfactorio presentar la edición completa del Diario del Oidor Francisco Tadeo Diez de Medina sobre los sucesos del cerco a que fue sometida la ciudad de La Paz en 1781 por las huestes de Tupac Catari, en cuyo estudio Maria Eugenia de Siles ha puesto su privilegiada capacitación profesional de historiadora. De esta mantera el texto del Diario se publica ahora en forma integral, completando su primera parte que fuera editada en 1981, también con el auspicio del Banco.

La presidenta y los señores miembros del Directorio del Banco Boliviano Americano han adoptado aquella decision con el propósito de contribuir a un mayor conocimiento de tan importantes sucesos y difundir los resultados de la tarea llevada a cabo por Maria Eugenia del Valle de Siles hasta muy pocos dias antes de su fallecimiento.

\section{MARIA ISABEL SILES DE MAZZI \\ Presidenta del Directorio del \\ Banco Boliviano Americano}

La Paz, Mayo de 1994 


\section{P R O L O G O}

María Eugenia de Siles es historiadora con formación universitaria especializada (Universidad de Chile) y profesora del ramo en la Universidad Mayor de San Andrés. Pero tanto cono eso, o más, es historiadora por destino vocacional: tiene lo que Gabriel René Moreno, con su acostumbrada penetración incisiva, denominó "la célula primordial del oficio", y bien desarrollada.(1)

Dentro de su especialización historiográfica ha hecho, además, otra especialización: la sublevación general de indios de Charcas de 1780-1782, y, todavía, más específicamente, el cerco puesto por los sublevados a la ciudad de La Paz, conducidos por Julián Apasa, o, para llamarlo con su nombre de guerra, Túpaj Catari. Especialidad esta última que con la presente edición recibe el aporte cuantitativa y cualitativamente más consistente sobre sus aportes anterjores(2), tanto por la significación intrínseca del Diario de Diez de Medina como porque la localización y accesibilidad de fuentes historiogtáficas primordiales debe ser por de pronto la tarea básica del historiógrafo en Bolivia, (3)

Esta especialización temática está solidamente apoyada por investigaciones sustanciales hechas en los archivos claves, o sea los correspondientes a las entidades del sistema colonial español que estuvieron encargađas de la represión del movimiento subversor de Charcas: el Archivo General de Indias correspondiente a la Secretaría del Despacho Universal de Indias; el Archivo General de la Nación Argentina, correspondiente al Virreinato del Río de la Plata; y el Archivo Nacional de Boilvia, correspondiente a ja Audiencia de Charcas.

La razón por la cual tenemos el privilegio de escribir el prólogo para esta edición es, por parte de María Eugenia de Siles, su natural gentileza y la coincidencia de que nosotros hemos tenido la suerte de localizar y editar otro diario de guerra, el del guerrillero de la independencia americana en Bolivia José Santos Vargas.(4)

$Y$ por nuestra parte, la razón para recibir no sólo con honra y beneplácito sino además con cierto derecho el amable encargo, es que hemos trabajado y aún trabajamos en el Archivo Nacional de Bolivia y la Biblioteca Nacional de Bolivia en la localización, ordenación y descripción de los materiales que en esos repositorios exister sobre la sublevación general de indios de 1780-1782 (5), tema general dentro del cual es un episodio particular el cerco de La Paz a que se refiere el diario de Diez de Medina. 
Consecuentemente nos sentimos obligados a corresponder no con un prólogo de mero cumplimiento sino con un trabajo que se sume, si es posible, provechosamente al trabajo esforzado e inteligente hecho por María Eugenia de Siles para preparar y publicar esta edición; y quizá podríamos lograr esto haciendo frente a la oportunidad de llevar a cabo una sucinta incursión de sentido archivistico e historiográfico en los dominios de este tipo particular de fuente historiográfica: el diario.

En cuanto fuente historiográfica, la información que provee un diario tiene ciertas características estructurales y funcionales que le confieren un valor especial de aproximación a la verdad: Desde luego su procedencia, como deposición directa del protagonista o de un testigo presencial de Jos hechos, es decisiva para abonar la calidad de su información; y su consistencia diaria produce además una acumulación y concentración de datos que abona por su parte cuantitativamente esa misma información (Sin olvidar, no obstante, que se trata de un arma de dos filos, porque en las mismas calidades positivas del diario como documento historiográfico pueden residir otras calidades muy negativas que haremos notar adelante). ${ }^{6\}}$

Todo esto por lo que hace a la objetividad de la información. Pero además, si el diario no es del todo impersorral ${ }^{(7)}$ puede constituirse también en una fuente de verdad subjetiva - reflejo de alternativas anímicas- y entonces asume un valor añadido y único como registro autobiográfico, y en general como registro psicológico con respecto a su autor.

Todavía, otra nota de valor en el diario, en cuanto fuente historiográfica, es la extensión comparativamente enorme y variada de su dominio entre los otros tipos de documentos. Cuando se dice "diario" se piensa por lo general en uno o dos tipos; los más obvios, de esta categoría documental, siendo asi que en realidad los límites de dicho dominio son insospechadamente mucho mayores, como lo hará ver la siguiente definición general y la ilustración particularizada de ella. guientes:

Se entiende por diario nn documento en qne concurren las características si-

a) Clase: Ella generalmente es textual o escrita, aunque, de acuerdo con la tecnología disponible actualmente, puede haber también diarios hablados u orajes, en cintas magnéticas $u$ otros medios adecuados de registro.

b) Procedencia: El diario puede originarse en estructuras o funciones oficiales (personas individuales o personas colectivas gubernamentales), o en estructuras y funciones no oficiales (personas individuales o personas colectivas no gubernamentales).

c) Causa: Puede ser compulsiva (en razón de una disposición legal positiva o consuetudinaria) o voluntaria (en razón del simple libre arbitrio del autor).

d) Alcance de la información: Esta pnede refenrse a personas, lugares, acontecimientos y objetos.

e) Secuencia de la información: Esta puede constituir series continuas de actividades y de trámites registrados en sucesión básicamente diaria. 
f) Permanencia: La producción del diario puede tener una duración indefinida u ocasional.

g) Finalidad: Puede dirigirse a satisfacer expresamente la necesidad de obtener información continua (diarios oficiales) a la necesidad de comunicación continua (diarios personales).

h) Estínulo original: Puede ser desinteresado (la cormunicación por la comunicación misma) o interesado (una segunda intención relacionada con un interés personal).

P'udiendo las otras características ser comunes a otros tipos de documentos historiográficos, la esencia exclusiva del diario reside en su relación con la dimensión temporal y con el día como unidad básica de medida de dicha dimensión temporal.

Según estas características básicas, el dominio del diario resulta ser mucho más extenso y variado de lo que se admite dentro de la concepción corriente, como lo ratificará la siguiente enumeración de tipos de diarios, con la consideración adicional de que muchos de eljos, dentro de la documentación boliviana historiográfica del coloniaje, pueden contener referencias más o menos importantes al tema general de la sublevación y al episodio particular del cerco de La Paz, independientemente de que los materiales correspondientes todavía subsistan y sean conocidos o no.

1) Libros de registro de los derechos de la persona humana: (oficiales, compulsivos, permanentes): En toda la variedad de esos derechos (civiles, económicos, cul turales, etc.). Tales son, para citar algunos ejemplos, los libros del registro civil, los registros de pagos de impuestos, los libros de establecimientos de enseñanza, etc., etc.

2) Libros de contabilidad: Oficiales, compulsivos, permanentes (como los libros de cajas reales o tesoros públicos, en el coloniaje) o no oficiales pero compulsivos y permanentes (como los libros de caja de mercaderes). Esta categoría comprende los libros de contabilidad oficiales o no oficiales en toda su cuantiosa variedad, todos ellos con una consistencia diaria. Parece claro que mientras las actividades de los oficiales reales o de los mercaderes de La Paz pudieron continuar durante el cerco, los diarios de conterido económico oficiales o no oficiales de dicha ciudad tuvieron que reflejar las alternativas del cerco relacionadas con los gastos públicos y con las transacciones comerciales.

3) Libros eclesiásticos: Parroquiales, conventuales, catedrálicios (oficiales, compulsivos, permanentes) en sus profusos tipos (bautizos, matrimonios, entierros, de fábrica, de gastos diarios, etc.). En cuanto la actividad primordial de la persona humana (nacimiento, matrimonio y muerte) no cesó -y no pudo cesar-durante el cerco, los libros parroquiales de La Paz reflejarán asimismo en alguna manera las altemativas que el cerco ocasionó en esa actividad. 
4) Libros de acuerdos de corporaciones adninistrativas: Oficiales, compulsivos, permanentes (audiencias, cabildos seculares, cabildos eclesiásticos). En elíos la secuencia del registro informativo no era estrictamente diaria sino bisemanal o semanal, pero por su aproximación a la secuencia diaria pueden considerarse también como diarios. Y en cuanto las juntas del cabildo secular y del cabildo eclesiástico de La Paz continuaron durante el cerco, esos acuerdos, asentados en los libros respectivos, deben comprender también información relacionada con el cerco: anälogamente, los libros de acuerdos de la Audiencia de Charcas coneienen de hecho información relativa a la sublevación general.(8)

5) Dimrios de viaje: Entre las diversas categorías de diarios, los de viaje constituyen no sólo una de las más abundantes sino una de las privilegiadas por la atracción que permanentemente suscitan las relaciones en que el dinamismo de la acción se combina con la fascinación de lo descinocido y exótico.

Los diarios de viaje pueden ser oficiales (compulsivos, permanentes) o voluntarios (ocasionales), y entre los oficiales, podemos remontamos hasta los cuadernos de bitácora, o diarios de navegación, pero además de éstos hay otra variedad prevista en la legislación de Indias. ${ }^{93}$

Las expediciones cientificas y los viajes de finalidad económica, que reflejar la preocupación interesada de los países más desarrollados por los países subdesarrollados como fuentes de reservas naturales, estratégicas y humanas, siempre han originado una cantidad enorme de diarios de viaje.

La célebre expedición científica franco-española encabezada por Antonio Ulloa y Jorge Juan (10) a América del Sur (1735-1745) produjo un registro notable, que si no tiene la forma invariablemente sustancial de diario, adopta dicha forma altemativamente, y en todo caso está a la vista que el relato se basa en anotaciones diarias.

No se conoce ningún diario de viaje que se relacione coetánea y directamente con el cerco de La Paz, o genéricamente con la sublevación general de indios de 1780-1782, pero si el episodio hubiera coincidido con el paso de algún viajero por las áreas afectadas —cosa teóricamente no imposible-m podríamos tentr otro ítem más, y acaso precioso, para agregar a la lista de diarios alusivos al caso.

Confirmando esto tenemos ejemplos de viajeros posteriores, quienes quedaron tan impresionados que no pudieron menos de consignar referencias valiosas a la sublevación y al cerco.

Uno de los ejemplos es el diario del comisionado que el consorcio britárico denominado Potosi, La Paz, and Peruvian Mining Association, de Londres - "una de las novecientas noventa y nueve especulaciones del especulantísimo año 1825" en Gran Bretan̄a--(11) envió al Alto Perú a tratar de adelantarse en obtener opciones mineras. Diario no oficial y voluntario (una vez que el viaje no tuvo conexiones oficiales ni el autor se había obligado a llevar un registro de su viaje) cuenta con un buen número de páginas que reflejan el estupor emocienal causado por la sublevación ge- 
neral, y en particular por el cerco de La Paz, estupor que aún perduraraba en 1825 y que el autor pudo apreciar en las páginas del Diario de Segurola que se transcriben extensamente para beneficio de los lectores de habla inglesa. (12)

También hay un diario de viaje científico (1826-1833) que constituye un ejemplo egregio entre los de su clase, y que se relaciona estrechamente con Bolivia y, adicionalmente, registra observaciones incidentales de interés sobre la sublevación, y sobre el cerco de La Paz en particular, aún siendo medio siglo posteriores. Nos referimos, claro está, al viaje científico de Alcides d'Orbigny y al registro resultante de dicho viaje, (133)

La relación de d'Orbigny corresponde a la categoría de diario de viaje oficial, compulsivo, no permanente. El viaje fue oficialmente patrocinado por el gobierno francés a través del Museo de Historia Natural de París, entidad dependiente del Ministerio de Instrucción Pública, y entre las obligaciones anexas a la asignación de d'Orbigny se contó la de llevar un registro del viaje. La monumental relación histórica del viaje tiene una consistencia perfecta de diario, así como la tiene el itinerario geográfico.(14)

Los problemas relacionados con la situación del indio en Bolivia preocuparon constante, extensa e intensamente a d'Orbigny, preocupación que se refleja en su diario. Además, el viajero fue adquiriendo para sí mismo cuanto material documental pudo relativo a éste y otros aspectos de su viaje. Según esto, durante su estancia en La Paz, d'Orbigny no pudo menos de buscar reminiscencias del cerco, y no sólo eso sino que tuvo la diligencia y la suerte de adquirir un valioso documento al respecto [15]

6) Diarios de descubrimientos y exploraciontes: Asimismo pueden ser oficiales y compulsivos, o privados y voluntarios, y todos ellos no permanentes. En realidad son tombién diarios de viaje, pero deben clasificarse en un grupo especial, entre las fuentes historiográficas de interés americano, porque la legislación de Indias estableció asimismo la obligatoriedad de éstos en particular. ${ }^{(16)}$

Sin embargo, aquí la legislación, como en tantos otros casos, no hizo sino consagrar un uso preexistente, pues son innumerables sin duda los diarios de descubrimientos que ya se habían llevado mucho antes del precepto indiano, comenzando, como es natural, por el Diario en que Colón relata su primer viaje de descubrimiento del Nuevo Mundo. $17 \%$

Una mención especial merecen, entre los diarios de descubrimientos, los de los misioneros que, simultáneamente con el estímulo religioso que los animaba, fueron siempre eficaces aliados de los propósitos del poder temporal. En Bolivia hay buenos ejemplos de esta categoría.(18)

La iniciativa privada, encontrando eco favorable en la iniciativa gubernamental, ha estimulado siempre, por su parte, viajes de descubrimiento dirigidos a la apertura de los consabidos recursos naturales, humanos y estratégicos, y en Bolivia pueden encontrarse buenos ejemplos, no obstante la incipiencia del medio, de los 
diarios subseçuentemente producidos, como el pequeño diario, pero precursor, de un viaje de descubrimiento hacia el área, que resultó luego privilegiada, de la goma elástica en la selva amazónica de Bolivia (19).

7) Diarios personales: El paradigma -o "ejemplo ejemplar", para usar el hermoso pleonasmo en que incurre la Real Academia Española al definir este vocablo en su diccionario- del diario no oficial ni compulsivo, y al mismo tiempo el tipo más popular de este tipo de documento, es el diario personal, en que el estimulo primordial, como hicimos notar atrás, es el ansia de comunicación, y que tanto puede versar sobre el análisis introspectivo como sobre la observación objetiva.

Una muestra de diario personal por antonomasia, como reflejo del yo del ser humano universal, es, desde luego, el de Samuel Pepys, que, obra de un inglés de la era estuardiana, no tiene ni la más remota relación con los indios, ni el cerco, ni Bolivía, pero es tan único que no puede ser omitido ni en la más somera enumeración de este tipo de fuente historiográfica y bibliográfica.(20) Parecería que el haber Pepys escrito su diario en clave criptográfica negase la condición esencial de necesidad de comunicación que atribuimos al diario voluntario: pero esta circunstancia no sólo niega tal condición sino que la ratifica, pues el hecho de que Pepys escribiese su diario en código quiere decir que, en el peor de los casos, escribió el diario para sí mismo, o sea para comunicarse consigo mismo, que es el colmo de la necesidad humana de comunicación.

En la categoría de diarios personales Bolivia no puede ofrecer muchos ejemplos - la explicación de las razones lievaría a una incursión quizás azarosa en la condición del homo bolivianensis - pero hay un ejemplo que vate por cien: La Historia de Potosí (y los Anales, resumen de dicha Historia) que escribió un modesto potosino, a 4,000 metros sobre el nivel del mar, intermitentemente durante treinta años (1702-1736) y entre fríos de $-0^{\circ}$, tienen una consistencia neta de diario personal en la parte que su autor relata como protagonista o testigo presencial, o sea de 1703 a 1736. Combinación, este relato, de observaciones objetivas e inhpresiones subjetivas, su autor podría merecer sin desmedro para nadie el díctum de Pepys potosino. Diario desinteresado además, porque su autor no trivo ningún prmito para publicarlo, no lo dedicó a ningún potentado político o económico, ni se valio de nadie para procurar alguna ventaja o su publicación.(20a)

Luego, quizás inesperadamente pero al mismo tiempo ineludiblemente, tendríamos que incluir entre nuestros diarios personales - pero, a diferencia de Arzáns- interesados, como bien hace notar María Eugenua de Siles, (21) éste de don Francisco Tadeo Diez de Medina, objeto de la presente edición. Siendo sobre un hecho bélico, es, además, un diario personal de guerra, aunque no un diario militar, y así lo intercalamos entre los no escasos que se produjeron durante la sublevación general. (22)

Diario personal, el de Diez de Medina no fue oficial en su origen, pues aunque dont Francisco Tadiso investía ya para eintonces la calidad de oidor de la Audiencia de Santiago de Chile, no escribió el diario como tal oidor ni tuvo encargo oficial 
para escribirlo en tal condición. Sin embargo, en cierta manera Diez de Medina oficializó su diario al remitirlo a la Secretaría Universal de Indias, previo el trámite de atestación notarial sobre su veracidad y sobre su filiación.(23) Una vez incorporado en la documentación del Consejo, el Diario, sin perder su calidad personal se convertía de hecho en documento del Conscjo. 24 ,

Considerado como declaración de un paisano criollo que ve y sufre la guerra, e] interés y el valor de este documento, según hace notar María Eugenia de Siles, se acrecienta por ese solo hecho, que repercute sobre la calidad complementaria de su información, pues si sobre el mismo hecho hay nás de un diario de militat español peninsular, el de Diez de Medina, con los demás diarios personales de paisanos crioilos relativos al episodio, viene a ser una contraparte indispensable:

8) Diario de gierra. Los hechos bélicos, que asumen una significación muy especial en el conjunto te la actividad humana por su contenido de crisis total y suprema, por las responsabilidades que entrañan y por su proyección emocional, han determinado siempre la producción generosa de diarios de guerra que reflejan todas esas circunstancias. ${ }^{(25)}$

Según esto, diario de guerra seria aquel (no permanente) que por disposición legal -positiva o consuetudinaria- o por decision individual voluntaria se lleva para registrar las alternativas de un conflicto bélico. Quiere decir eso que los diarios de guerra pueden ser tanto oficiales como personales. Los diarios de guerra oficiales pueden denominarse más particularnente diarios militares.

No hemos podido localizar una disposición en la legislación española contemporánea del coloniaje americano, metropolitana o indiana, que determine la obligatoriedad de los diarios nilitares, disposición legal que sería análoga a las que comprende la legislación de Indias con respecto a las navegaciones y los descubrimientos que hemos mencionado atrás.(26)

Entre tanto, el primer código militar boliviano, básicamente moldeado, según las disposiciones legales españolas en la materia, contiene disposiciones de subido interés, subre los diarios militanes, disposiciones que sin duda son de origen español y son claramente demostrativas de la preocupación oficial para con el registro de los hechos bélicos. $\left({ }^{27}\right)$

Siendo, pues, la guerra una actividad humana tan universal y tan perdurable, y teniendo el hombre la propensión innata de informar y comunicar, propensión que, según hemos dicho, es el estímulo primordial del diario como tipo de documento historiográfico, es obvio que el diario de guerra tiene una alcurnia tan lejana como ilustre.

El antecedente probatorio casi obvio de esto $\rightarrow$ si realmente se necesitara una prueba - es el relato de Julio César sobre su guerra de las Galias, ${ }^{(28)}$ relato que si, en rigor, no tiene una estructura total y absoluta de diario -o sea un registro de los hechos día por día- es evidente que se hizo sobre la base de anotaciones diarias —un 
diario previo--, y, parcialmente, la sucesión diaria del relato se conserva todavía a trechos.(29)

Las guerras colonialistas de los españoles contra los indios, en particular, han originado diarios, oficiales o personales, dirigidos tanto al registro de las alternativas bélicas como a la atestación de actuaciones y responsabilidades de magistrados, jefes, oficiales y soldados que protagonizaron los hechos.

Un ejemplo muy valioso, en esta línea, es el diario de guerra relativo a una de tantas expediciones represivas contra los indómitos indios calchaquies en el Tucumán en 1634.(30) Escrito aparentemente por un soldado, aunque es manifiesto el interés del responsable de la expedición por recomendar su actuación personal en ella, viene a ser de todas maneras un diario personal de guerra, aunque finalmente pudo oficializarse mediante nua atestación notarial de su veracidad y una presentación probable ante el Consejo de Indias, (31) circunstancias que establecen una analogía curiosa con el Diario de Diez de Medina sobre el cerco de La Paz y la actuación personal que le cupo en él.

No falta un notable ejemplo de otro diario de las guerras colonialistas de los españoles contra los indios americanos, en este caso particular contra los guararies del Uruguay en 1754, cuyo autor ni siçuiera es militar, ni aun seglar, sino un misionero.(32)

De una manera general podría afirmarse que cada episodio bélico constituye un ciclo productor de diarios - entre el todo de la acrecentada y acelerada documentación que necesariamente originan las guerras - . En este entendido pueden establecerse en la historta de Bolivia ciclos correspondientes a nuestros diversos conflictos bélicos: y, dentro de éstos casi sería superfluo encarecer la importancia que asumieron en su momento, y que perdurará permanentemente, la sublevación general de indios de 1780-1782 y la guterra popular de independencia contra España de $1809-1825$.

Quizá no sería inútil tentar una inventariación preliminar de todos los diarios de guerra relativos al ciclo de la sublevación general de $1780-1782$ en conjunto, o sea comprensiva de los hechos acaecidos tanto en Charcas como en el Perát diarios identificados mediante una encuesta muy provisional que da por resultado 17 identificables. Se los enumera en orden de apellidos de autores y de títulos cuando carecen de autor conocido:

1. Alós, Joaquín. Diario de Ia sublevación de la provincia de Chryanta, 1780/. Inédito. Remitido por Alós a la Secretaría del Despacho Universal de Indias, (33) Comprendería los hechos acaecidos desde 1780.IV.21, fecha inicial de la sublevación, hasta 1780.IX.15, fecha en que Alós remite el Diario a España. Personal, e interesado como es obvio. Con su inextinguible codicia, Alós, corregidor de la provincía de Chayanta, foco inicial de toda la conflagración, fue el fulminante que produjo la explosión.(34)

2. Castañeda, Domingo /?/ Francisco de. Diario de los principales stucesos acaecidos en los asedios o cercos que padeció esta ciudad de La paz por los indios desde el día 15 
de Marzo hasta el din 15 de Noviembre del presente año de /17/81. (35) Publicado.(36) Castañeda se auto-identifica como "sargento mayor de milicias" que estuvo "en todas las acciones que van expresadas en este diario", e identifica su propósito "para descartar falsedades con que se visten las telaciones que diariamente corren por el vulgo". Militar subordinado de Segurola, pudo recibir de éste el encargo de hacer el diario, el cual recaería así en la categoría del diario oficial, compulsivo e interesado.

3. Diario anónimo de los sticesos acnecidos cn la ciudnd de La Plata y de las noticias esparcidas en ella con motivo de la sublevacion general de indios, desde el sabado 26 de agosto de 1780 hasta of tomingo 15 de Octubre del mismo ano. 9 f. Inédito. Unico manuscrito conocido, en la Biblioteca Nacional de Bolivia. (37) Personal, voluntario y aparentemente desinteresado.

4. Diario anónimo de lo meva conjuración aue se intentó en la ciudad de La Plats contra todos los curppeos residentes en ella, desde el 10 de marza de 1781 hasta el 1 "de enero de 1784. Inédito. Copia, en Duke University Library (Durham, North Carolina, Estados Unidos de Norte América), Manuscript División, Pertuvian Collection, 3283. El original, en la Biblioteca Nacional del Perú, Lima. Personal, voluntario, no se sabe si interesado.

5. Dinrio comprensino de los fumestos y lastimosos sucesos acaecidos en la villa de Oruro desde el día 9 de febrero de 1781 . Autor, extensión y fechas extremas: se ignoran. Inédito. Localización: se ignora. (38)

6. Diario de los ncontecimientos de la expedición del señor don Ignacio Flores sobre las provincias sublevadas def distrito do to Real Audiencia de Charcas para la pacificación de cllas y socorro de la cindad de La Paz, 1781-1782..(39) Autor, extensión y fechas extremas: se ignoran. Inédito. Localización presunta: Biblioteca Central de la Universidad Mayor de San Andrés, en los manuscritos de la colección de José Rosendo Gutiérrez, en cuya posesión estuvo el original.

7. Diario y relación prolija, jurada que don Jun Gelly hace de los sucesos de la provincia de Chayanta desde el 21 de jumio hasin el 26 de agosto /de 1780/. Inédito.(40) Extensión: se ignora. Localización presunta: Biblioteca Central de la Universidad Mayor de San Andrés, Colección de José Rosendo Gutiérrez, en cuya posesión estuvo el original. Gelly era dueño de un ingenio en el asiento de Chuxicaka, partido de Aullagas, provincia Chayanta, ${ }^{(41)}$ "catalán bullicioso y ansioso de plata", colusionado con el corregidor Alós -que también era catalán-para la expoliación de los indios. ${ }^{(42)}$ Diario personal, e interesado a pesar de cualquier juramento.

8. Diez de Medina, Francisco Tadeo. Diario del alzamiento de indios tonjurados contra la ciudad de Nucstra Señora de La Pnz /... (433). Dos partes. Original de la primera parte en el Archivo de Indias (Audiencia de Charcas, 583) comprensiva del lapso 1781.IL.1-1781.VII.27, que se publica en la presente edición preparada por María Eugenia de Siles: original de la segunda parte, comprensiva del lapso 1781.VII.281781.X.28 que queda inédita, en posesión (único ejemplar conocido) del Dr. Jaime Retamozo Zuazo, en La Paz, siendo verdaderamente lamentable que esta oportuni- 
dad —acaso única, y ojalá no sea asi- de publicar el Diario completo haya quedado malograda, a pesar del ejemplar empeño de María Eugenia de Siles. Diario personal, voluntario, e interesado como resulta del penetrante análisis de María Eugenia de Siles.

9. Elguea, Pedro Ignacio de. Diario histórico de los hechos gloriosos de ta prozincin de su cargo, con motivo de la revolución de aquel remo, 1782. Inédito. La atribución de este Diario a Elguea, corregidor de Arequipa, es provisional; en todo caso él fue quien lo remitió a la Secretaría General del Despacho Universal de Indias, donde presumiblemente se encuentra el original.(44)

10. Ledo, capitán. Diario de la sublevación del año 1780, que escribió un chapetón Ledo, de orden del comandante general don Sebastián Segurola, desde el primer cerco puesto por el insurgente caudillo Julián Catari, sacristán de Calanurca, a quien lo tentan por rey todos los alzados.(45) Publicado,(46) Original (único conocido) en la Biblioteca Central de la Universidad Mayor de San Andrés. Manuscritos, 89. Habiéndose formado por orden de Segurola, en cuya hueste Ledo era capitán, el Diario resulta ser oficial, conpulsivo e interesado.

11. Moya y Villarreal, Ramón. "Relación de las ocurrencias acaccidas en la Villa de Puno con motivo de la rebelion gencral de indios. Escrita por don Ramón de Moya y Villarral, gobemator que fue en aquel tiempo de Chucuito". $20 \mathrm{p}$. Inédito. Copia en Borradores o apuntes curiosos de José Maria Lićvana, vol. 1, John Hay Library, Brown University, Providence, Rhode Island. Estados Unidos de Norte América. Diario personal, voluntario y probablemente interesado.

Otro códice,(47) en la Biblioteca Central de la Universidad Mayor de San Andrés, La Paz, Manuscritos, 128: Diario escrito por Ramón de Moya Villarreal, gobernador de Chucuito, en los años 1780-1781, relatando los sucesos en la provincin de Puno y en general en Chucuito, Lampa, Pacajes, Moquegua, Arequipa y otros Iugares".

12. Relación de sucesos acaecidos en la provincia de Cochabamba con ocasión te ta sublevación de indios alli ocurrida. Inédita . Autor, extensión y fechas extremas: se ignoran. El original debe encontrarse en el Archivo de Indias, pues fue remitido alli por el Virrey de Buenos Aires. ${ }^{(48)}$

13. Relación verdadera de los lastimosos sucesos ocurridos en la villa de Oruro con motivo de haber los mestizos y cholos de ella procedido incuamente a quitar la vida a los españoles europeos que la habitaban. Escrita en contraposición del diario falso que formó, sugerido de su malicia, un parcial de los amotinados en el año de 1781. Autor ignorado. Fechas extremas 1781.II.4-1781.IV.13. Publicado.(49) Personal, voluntario y explícitamente interesado. En el título afloran finalmente a la superficie las tensiones recíprocamente encontradas entre las parcialidades del espectro económico-social del coloniaje, tensiones sin duda preexistentes pero que hizo escalar y objetivar nítidamente la st1blevación india, y que el perspicaz análisis de María Eugenia de Siles aisla y disecciona especialmente entre criollos y españoles perinsulares representados en la ecuación Diez de Medina-Segurola. El "diario falso" a que impugna esta "relación 
verdadera" es el consignado atrás con el $\mathrm{N}^{\circ} 5$, y uno y otro provendrian, respectivamente, de un criollo y de un español peninsular. A estas alturas la pugna de intereses subyacentes como estímulo primordial de tal vaivén de diarios -intereses de personas y de grupos econónico-sociales- ya es claramente notorio como para concluir en que todos estos diarios son más o menos interesados.

14. Reseguín, José. Diario de un teniente coronel de los reales ejércitos don José Reseguin en la expetición del cerco de La Paz, desde el 24 de junio de 1781. (50) Publicado.(51) Personal, probablemente compulsivo (por orden de Segurola), e interesado. ${ }^{(52)}$

15. Segurola, Sebastián de. Diario de los sucesos del cerco de la ciudad de La Paz en 1787 hasta la tolal pacificación de la retelión gencral del Peytí. Publicado.(53) Personal, no habiendo ninguna constancia de que Segurola recibiese instrucción superior para llevar el Diario. Interesado, por provenir del protagonista militar español en el cerco de La Paz: interés que se refleja además en la influencia que Segurola desplegó sobre algunos de sus subordinados militares para que hiciesen, a su vez, diarios.(54)

Un recuento de los manuscritos del Diario de Segurola existentes fuera de duda según la información accesible más a mano arroja un total de siete códices diferentes entre si y coetáneos, ${ }^{(55)}$ siendo muy de presumir que una encuesta formal manifestaría adicionalmente otros ítems aun existentes pero incógnitos, a todo lo cual habría que añadir aún el material análogo que pudo existir y ya no existe.

El núnero de ediciones del Diario de Segurola - hechas tardíamente por personas diferentes y en lugares diferentes-demuestra que fue el más accesible en su tiempo, o sea el que se copió más y circuló más, hecho que se corrobora por el número de manuscritos existentes e identificados. ${ }^{(56)}$

El Diario de Segurola es, cuando menos cronológicamente, el punto de partida para el establecimiento dé los hechos relativos al cerco de La Paz y, más extensamente, a la represión contra los indios simultánea e inmediata al cerco en los territorios adyaceutes. Aparentemente, los demás diarios del cerco de la Paz se compusieron a causa del Diario de Segurola.

En este entendido, ya es hora de pensar en una nueva edición, pero una edir ción crítica, de este Diario, siguiendo el excelente ejemplo establecido por María Eugenia de Siles, con esta edición del Diario de Diez de Mediná. Necesariamente, la nueva edición de Segurola deberia tomar en cuenta todos los manuscritos existentes de su Diario así como las diversas publicaciones que se han hecho sobre manuscritos coetáneos.

16. Sucesos acacidos en esta ciuadad de La Paz con ocasión de haberse rebelado los indios de Calanarcn, Ayoayo, Sicasica, Laja, Viacha, San Pedro y dennás pueblos, siendo el caudillo un indio nombrado Julian Apasa, a quien to reconocian los indios por Catari y le rindieron ciega obediencia.(57) Inédito. El original en el Archivo de Indias, y una copia, hecha según dicho original por José Vázquez-Machicado, hoy en posesión del Sr. Carlos Serrate Reich. Personal, voluntario y presumiblemente interesado. 
17. Valle, José del. Diario de las tropas que salieron del Cuzco, al mando del Mariscal de Campo Don José del Valle, dirigidas a operar contra el rebelde Túpac Amarn, y su prisión. Publicado, ${ }^{(58)}$ Personal, voluntario e interesado.

En resumen; Un sondeo en las fuentes más obvias pone en evidencia 17 diarios real o potencialmente accesibles para el ciclo de la sublevación general de indios de 1780-1782 tarito en Charcas como en el Perú. De estos 17, tenemos:

7 publicados y 10 inéditos.

6 relativos al área La Plata-Potosí-Cochabamba (todos ellos inéditos): 3 relativos al área de Oruro (1 publicado y 2 inéditos); 7 relativos al área La Paz y sus provincias (5 publicados y 2 inéditos); 3 relativos al área Cusco-Arequipa-Chucuito (1 publicado y 2 inéditos).

16 representativos del punto de vista contra los rebeldes: 1 representativo del punto de vista rebelde.

15 personales, voluntarios.

2 oficiales, compulsivos.

17 interesados.

Del ciclo de la guerra popular de independencia de Bolivia contra España sólo vamos a mencionar los dos diarios siguientes, por su posible relación de influencia -siquiera indirecta- con algunos de los diarios citados atrás, así como porque el haber nosotros hecho conocer uno de esos dos diarios ha sido un antecedente justificativo de este prólogo, según queda dicho.(59)

1. Andrés Vargas. /Diario del doctor Andrés Vargas, clérigo presbitero del tiempo que fue capellán de varias guerrillas a favor de la Patria en la provincia de Sicasica, años $1812(?)-1814 / .(60)$

El cura Andrés Vargas "había sido ciego en esta opinión / a favor de la pa. tria/" y estuvo antes de 1814 en las guerrillas de los comandantes Dionisio Lira y Baltasar Cárdenas en el área de la provincia actual de Inquisivi (Departamento de La Paz). Padeció una sañuda persecución por los españoles hasta su muerte (1819), ocasión en la cual se perdió su diario.

Tenemos así et caso, nada ordinario, del primer cura guerriliero en la guerra popular por la independencia de Bolivia - siendo el segundo Ildefonso de las Munecas (1815-1816) - (61); y un caso muy extraordinario según el cual este cura guerrillero hizo un diario; y un caso atin más extraordinario eh que este cura guerrillero autor de un diario acabó influyendo para que un hermano menor que tenía se hiciese a su vez guerrillero e hiciese también un Diario, que es el consignado adelante con el $N^{\circ} 2$.

Esta pregunta es obvia: ¿Escribió Andrés Vargas su crónica en forma de diario por deliberación exclusivamente propia, o se inspiró en alguín antecedente, y cuál 
pudo ser éste? No es imposible la primera alternativa, pero tampoco es imposible la segunda, ni es imposible que el antecedente más a mano hubiese sido el Diario de Segurola, que, según lo dicho atrás, ${ }^{(b 2)}$ tuvo una circulación, no escasa, para la época, en copias manuscritas.

El diario perdido del cura guerrillero Andrés Vargas sobre esta guerrilla primordial en la guerra popular de la independencia americana contra España fue personal, voluntario y, en ausencia de indicios de motivaciones personalistas, desinteresado.

2. José Santus Vargas. Diario histórico de todos los sucesos acurridos en las prowincias de Sicasica y Hayopnya durnte la guerra de a independencia ancricana deste el ano de' 1815 hasta el año 1825. Publicado, (63)

Está dicho que José Santos se hizo guerrillejo a favor de la Patria contra España siguiendo el ejemplo de su hermano, y que decidió llevar un diario siguiendo asimismo el ejempln de su hermano. José Santos era un muchacho de la clase media más bien baja, tenía entonces 19 años de edad, con una instrucción que no había pasado apenas de los primeros años de la escuela primaria, pero es incuestionable que tenía una vocación de escritor e historiador hasta el punto de que el estímulo primordial para "entroparse" en la guerrilla fue ante todo experimentar personalmente la guerra no por la guerra misma sino para poder relatar la guerra en el diario que se habia propuesto a mimitación de su hermano. Aún más, en la guerrilla se hizo tambor para estar siempre junto al comandante, o sea en la mejor posición para escudriñar las cosas. En suma: quiso vivir la guerra para reflejarla en su diario.(64) La certidumbre del caso es irrefragable: vivió la contienda durante diez años, llegó por méritos de guerra hasta el grado de comandante en el curso de ella, pero cuando terminó la guerra - - esta es la prueba final de la certidumbre-, pudiendo proseguir la carrera militar con el grado de tenjente coronel, que es que le correspondia; o ingresar en la burucracia; o volverse comerciante, o ambicionar, en una palabra, algún destino mejor - según los cánones corrientes- para él y su familia, lo que hizo fue convertirse técnicamente en indio al hacerse admitir en un ayllu en calidad de originario $y$ contribuyente al fisco por un pedazo de tierra y quedarse a labrar ese pegujal en un rincón del área que acababa de ser guerrillera: "Triunfante que fue mi opinión se acabaron mis afanes y luego me entré a vivir al monte" (1825).(65)

Tardíamente (1853) buscó un premio por haber escrito su Diario, se esforzó por publicarlo, y hasta lo dedicó al Presidente de Bolivia general Manuel Isidoro Belzu buscando su apoyo para la publicación, empeños que resultaron frustráneos todos ellos y que por otra parte fueron muy posteriores al designio de escribir el Diario.

Tenemos, pues, el caso de un diario personal, voluntario y desinteresado en cuanto a ambiciones materiales se refiere, $\left(k^{(k)}\right)$

Habiendo insistido sobremanera en el problema del interés personal como móvil eficiente en ese tipo especial de documento historiográfico que es el diario, no olvidamos que exceptuando las fuentes con información historiográfica numérica 
(estadística, contabilidad, y por el estilo) cualesquiera otras son interesadas en mayor o menor grado, y aun la información numérica puede ser atectada por falsificaciones.

Sin embargo, en el caso presente de diarios, y en particular de diarios de guerra, se trata de un interés muy específico teñido de alguna malicia personalista relacionada con problemas de responsabilidad, amor propio, ventajas sociales o políticas, imperativos de parcialidad socio-económica, y circunstacias de crisis análogas.

El diario es, pues, un documento historiográfico de doble filo, como deciamos atrás. ${ }^{(67)}$ El filo negativo es aguzado, precisamente, por el interés personalista del autor (protagonista o testigo presencial de los hechos), siencto asi que también el filo positivo (veracidad de la información) se supone que sería aguzado por la procedencia del diario en quien ha actuado o presenciado los sucesos.

La única defensa contra este peligro es la capacidad del historiógrafo de estar siempre alerta: alerta para aplicar oportunamente los contragolpes de la crítica interna de acuerdo a los antecedentes de cada caso, y para usar el filo positivo en Ia disección de la verdad.

En el caso de la sublevación general de indios dé 1780-1782, han transcurrido 200 años antes de que alguien con un recto sentido de la metodología historiográfica haga una primera tentativa por llenar tan lamentable laguna. (66)

Con esta reserva, el diario, como documento historiográfico, puede ser un arma extraordinariamente útil en relación, por ejemplo, con algo de tanta importancia metodológica como el ajuste de una cronología dentro de cada caso, siendo la cronología para la investigación historiográfica como la brújula para la orientación del que está perdido en un bosque.

Sin embargo, un paso metodológicamente previo todavia al ajuste de una cronología, es la localización, identificación, organización, y accesibilización de las fuentes primarias que corresponden a cada caso.

Las fuentes primarias - directas y coetáneas- sobre la sublevación general de 1780-1782 forman sin duda una plétora descomunal.(69)

Un cuadro sumario de ellas incluiria por lo menos estas categorías:

a) Documentaciones oficiales; b) Documentaciones particulares. Esto según una identificación de punto de partida por procedencia de originador o autor.

Dentro de las documentaciones oficiales tenernos (siempre por procedencia de originador o autor) las documentaciones que se actumularon en las estructuras y funciones administrativas del sistema colonial español englobadas en el caso, a saber:

a) Secretaria del Despacho Universal de Indias, en Madrid; b) Virrey del Rfo de la Plata, en Buenos Aires; c) Virrey del Perú, en Lima; d) Audiencia de Chatcas, en La Plata (hoy Sucre). Aparte de los documentos que producian estas entidades, en 
cada una de ellas confluian además los documentos producidos por todas las autoridades y personas subordinadas correspondientes.

Esta documentación oficial, durante 200 años, ha sufrido los embates del tiempo y de la adversidad con los resultados conocidos dentro del ciclo vital de toda documentación de manera que la situación actual es esta: a) una parte -imposible de identificar cualitativa ni cuantitativamente- se ha perdido o destruido para siempre; b) otra parte ha salido de sus fuentes originales y está dispersa;(70) c) una tercera parte se conserva en los archivos de las entidades de procedencia.(71)

Dentro de las fuentes particulares tendríamos la ventolera de todo tipo de documentos de autor espontáneo -declarado o no declarado- a todo lo largo del acontecimiento, tales como: a) relaciones, b) diarios, c) cartas, d) pasquines en prosa y verso, etc. Siendo privada por su origen esta documentación, no hitabo entidades permanentes responsables de su conservación como en el caso de las documentaciones oficiales, de manera que aqui la destrucción y dispersión ha sido mucho mayor, hasta el punto de que apenas aproximadamente podría establecerse un derrotero de identificación y localización sobre la base de los centros urbanos más importantes protagonistas o inmediatamente contiguos con relación a los acontecimientos: La Plata (hoy Sucre), Oruro, La Paz, Puno, Arequipa, Cusco, etc.

Estando identificadas y localizadas sólo nuy parcialmente las documentaciones primarias relativas al caso, la situación es aún más problemática por lo que hace a la organización y accesibilización, (72)

La accesibilización por medio de la publicación de los documentos en particular - publicación de series de documentos, publicación de documentos sueltoses absolutamente mínima en proporción a la masa documental existente.

En este entendido no es sorprendente que el proceso historiográfico de la sublevación general de indios de 1780-1782 en conjunto no haya llegado todavía ni a la instancia sumaria, y que ni siquiera hayan avanzado mucho las diligencias preliminares de policia judicial. En realidad, hasta sigue haciendo falta una narración completa de lo sucedido, un establecimiento y una exposición de los hechos básicos. Se conoce escasamente la silueta general del gran acaecimiento, pero el contenido propiamente dicho es un rompecabezas en qư son inmensurablenente más y mayores los hutecos vacios que los lienos.

Pero el contenido propiamente dicho no se reduce a los hechos bélicos de la sublevaciôn: ésta puso en perspectiva crítica los problemas capitales del coloniaje español en el área andina de América Latina, y ése es --conjuntamente con los hechos bélicos- el contenido que debe ponerse en claro.

Los problemas capitales del coloniaje español en el área andina de América Latina se poeden sintetizar en dos palabras: el indio. Sin olvidar que el trágico problema va mucho más antes, mucho más después y mucho más lejos: mucho más antes, hasta el día en que Colón paso pie por primera vez en las Indias Occidentales para encontrarse con indios; mucho más después, hasta el día de hoy 
y el día de mañana, mientras siga el indio en pie como problema y, mucho más lejos, aquí en América donde haya indios.

La sublevación general de indios de $1780-1782$ viene a ser, pues, como una incisión hecha a todo lo largo del cuerpo del coloniaje que dejó al descubierto todos los órganos palpitantes - buenos y malos- de ese cuerpo, y muchos de los peores continuaron cuando el cuerpo del coloniaje se remodeló dentro del sistema republicano.

Para no mencionar sino un problema del contenido de la sublevación general, a manera de ejemplo, tenemos que la documentación conexa puesta en evidencia hasta hoy día expresa, en su proporción casi total, ante todo el punto de vista colonialista, y no porque así lo haya querjdo alguien sino porque la documentación misma, por su procedencia, (73) debía llegar a ese resultado: quienes produjeron los documentos no fueron otros que los encargados de la represión de los rebeldes. El cerco de La Paz es el mejor ejemplo: todos los testimonios proviener de la parte no solamente no india sino anti-india, una vez que se trataba de una guerra en que la estrategia final era reprimir a los indios. También ejemplifica la situación el caso del "Diario comprensivo..." sobre los hechos de la rebelión de Oruro vistos desde el lado rebelde, ${ }^{(74)}$ que se pierde sin dejar huella, y queda solamente el contra-diario que se escribió para impugnar ese testimorio rebelde, ${ }^{(7.5)}$ no siendo aventurada la sospecha de que pudo haber interés coetáneo y uiterior por hacer desaparecer estus testimonios rebeldes.

Ahora bien: sin escuchar -0 lo que es lo mismo sin conocer- lo que pudieron decir los indios, no hay base para formar un cuadro idóneo del caso, y el rompecabezas tiene entonces un doble aspecto: por falta cuantitativa de material general accesibilizado, y por falta cualitativa de material procedente de la parte rebelde.

No es que falten en absoluto los testimonios rebeldes: siempre dentro del cerco de La Paz, el Diario de Segurola entre sus documentos contiene varios de ellos. Pero compárese la cuantía del materiai anti-rebelde con la del material rebelde, y el resultado no podrá dejar ninguna duda. ${ }^{(76)}$

Una moraleja --aplicable también a muchos de los más serios problemas de la historiografía latinoamericana-(77) fluye espontáneamente: Es imperativa y urgente la necesidad de tuna prospección sistemática en los repositorios historiográficos para localizar e identificar los materiales primarios hoy olvidados, y para accesibilizarlos, sea por medio de guías y/o de publicaciones documentales, a fin de que sean plenamente aprovechados en la edificación de una historiografía consistente con los dictados de la mejor metodologia.

Teviendo presente todo lo dicho hasta aqui, resulta claro que María Eugenia de Siles ha resuelto en forma feliz - con talento, con tesón, con disciplina, y también con suerte, porque el historiógrafo no está liberado de la suerte- los problemas que plantea la investigación historiográfica.

XXIV 
El problema del tema: Si fuera posible establecer una puja entre las cuestiones de la historiografía del coloniaje en Bolivia, la sublevación general de indios de $1780-1782$ podria ganar en esa puja, porque es un tema que resume prácticamente a todos los demás. El historiógrafo tiene que obedecer a una prioridad de temas orientada en el sentido de la mayor necesidad cuantitativa y cualitativa.

El problema de la localización y accesibilización de materiales documentales: María Eugenia de Siles ha hecho una prospección en aguas profundas archivisticas para identificar, localizar y accesibilizar, por medio de la publicación, un documento primario de excepcional valor, como es cl Diario de Diez de Medina, dentro del tema general de la sublevación de indios.

El problema de las fuentes: La prospección de María Eugenia de Siles se ha extendido a la acumulación de fuentes primarias correlativas al Diario, en los repositorios claves para el caso: el Archivo General de Indias, el Archivo General de la Nación Argentina, y el Archivo Nacional de Bolivia.

El problema de las fuentes no textuales: la historiografía actual está aprovechando cada vez más fuentes extra-textuales. La edición preparada por María Eugenia de Siles incluye fuentes cartográficas y gráficas ưnicas en su género.

El problema de la relación disciplinaria e interdiciplinaria: No es imposible, pero es muy difícil que el histodógrafo pueda trabajar solo. María Eugenia de Siles ha sabido y podido ajustar las necesarias relaciones disciplinarias e interdisciplinarias para hacer más fructifero su trabajo.

En suma: el historiógrafo --ya que hablamos en términos de temas y documentos de guerra - debe saber trazar la estrategia y la táctica adecuadas para el objetivo que tiene en consideración. María Eugenia de Siles ha sabido trazar las suyas.

El esfuerzo y el resultado - Lector: tienes en las manos un libro de historiografía boliviana hecho no sólo con pleno dominio del arte y la ciencia del oficio, sino con amor- merecen un homenaje. Nuestro homenaje personal - reiteramos- no tenía que ser de palabra sino de obra: de trabajo que se inspire en el trabajo ejemplar desplegado por María Eugenia de Siles para hacer posible esta edición.

Archivo Nacional de Bolivia

Biblioteca Nacional de Bolivia

Sucre, Junio, 1981. 


\section{ABREVIATURAS}

$$
\begin{aligned}
& \text { AGI }=\text { Archivo General de Indias, Sevilla. } \\
& \text { ANB }=\text { Archivo Nacional de Bolivia, Sucre } \\
& \text { BNB }=\text { Biblioteca Nacional de Bolivia, Sucre. }
\end{aligned}
$$

\section{NOTAS}

(1). Gubriel René Moreno, Juan Ramón Muñoz Cabrera o aventuras de un periodisfa en cinco repúblicas, $1819-1869$, en Gabriel René - Moreno. Bolivia y Argentina. Notas biográficus y bibliograficas. (Santiago de Chile, Imprenta Cervantes, 1901, 553 p.) p. 303.

(2) . María Eugenia del Valle de Siles. 5 Testimonios del Cerco, en Historia y Cultura, n' I, (La Paz, 1973), p. 165-248.

en Historia y Cultura n' 2. (La Paz, 1976), p.177-184.

Túpac Katari y la rebelión de 1781. Radiografia de un catudilo aymara, en Anuario de Estudios Americanos, (Sevilla 1977), p. 633-664.

Notas para una historia econónica de La Paz en la época del cerco de Túpoc Katari, en Antropología, revista del Instituto Nacional de Antropología. (La Paz 1979), p. 20-33.

2 (Bogotá, Enero de 1980), p. 5-18.

- Túpac Katari: el aymara que sitio La Paz, en Correo de los Andes, vol. Ultima Hora, n*340 (La Paz, 1980.X.3), p. 9.

ed. La Paz, 1980. 197 p., ilustraciones, mapas.

Andrés Túpac Amaru y los criollos en Tuile y Sorata, (ponencia presentada al Coloquio sobre Túpac Amaru y su tiempo, Lima-Cuzco, noviembre 1980, inédito, 30 páginas mecanografiadas). en Ultima Hora, n* 419 (La Paz, 1981.II.13), p. 13, 14.

- Hace 200 años, en Ultima Hora. n 425 (La Paz, 1981.III.13), p. 7.

- La Paz amurallada, en Ultima Hora, n 428 (La Paz, 1981.V.24), p.8, 19. 
El episfolario indigena en las rebeliones de Charcas de 1781. Trabajo publicado por Latin American Indjan Literatures, revista de la Facultad de Artes y Ciencias de la Universidad de Pittsbutg.

Bariolina Sisa y, Gregoria Apaza. Dos heroinas indigenas, trabajo publicado en la Colección Juvenil de Biografías. Biblioteca Fopular Boliviana de Ultima Hora, 1981, 52 páginas mecanograliadas.

(3). "En su sinuación presente nuestra historiografía es, pues, en general idconsistente por insuficiencia documental. Sin haber cumplido los requisitos de la recolección, la organización y la publicación de documentos, ella ha dado un saito hacia la elaboración y la crítica.

"De aquí fluye una norma categórica de conducta para los investigadores bolivianos actuales, y es la de remover nuestrus estudios historiográficos de esa anómala situación, volcando lo principal del esfuerzo hacia la tarea de recolectar mús materiales, organizarlos de manera adecuada. y promover la publicación de colecciones documentales.

"Essto significa, ciertamente, algún sacrificio de fama y de gloria personales, pues eso de buscar y rebuscar documentos, arreglarlos y editarlos es algo poco brillante, algo que exige mucha paciencia y mucho trabajo, y es más tentador y más fácil salir por ahí con obras de inspiración personal aunque sea caprichosa. Sin embargo, es indispensable conducir jas investigaciones historiográficas bolivianas por el cauce que estrictamente les corresponde, si se profesa un criterio cabal Je probidad científicis. Y se trata de algo tan urgente e indispensable, que nos atrevemos a decir que mientras no se cumpla tal condición. tendremos que sufrir el mal de una historiografía precaria, es decir, careceremos de la clave maestra de introspección colectiva que eso es precisamente la historiografía y en eso reside su justificación ante la vida; servir pata orientar mejor a un puebio sobre su propio destino", (Gunnar Mendoza L. La contribución de Vicente Lecuna a Ja historiografía boliviana, en Boletín de la Sociedad Geográfica Sucre, t. 45, n 442. (Sucre, 1955), p.337-348.

(4). Tumbor Mayor Vargas. Diario de an soldado de la Independencia altoperuana en los walles de Sicasica y Hoyopaya 1816-1821. Transcripción, prólogo y nacas de Gunnar Mendoza L. Universidad de San Francisco Xavier. Sucre, 1952. 320, una p.

Primera edición hecha sobre la primera versión original autógrafa, trunca. En curso actual de publicación por Siglo XXI Editores México D.F., una segunda edición, preparada también por Gunnar Mendoza L, sobre la segunda versión original autógrafa, completa. [La edición completa ha sido publicada en Mexico, en 1982: José Santos Vargas. Diario de un Comandante de la Independencia Americana. 1814 - 1825. Transcripción, introducción e úldices por Gunnar Mendoza. Ediciones Siglo XXI. 513 p. Introducción de G. Mendoza, XLVI p.]

(5). Ver adelante nota 72.

(6). Ver adelante nota 67 y texto.

(7). Ver adelonte la discusión sobre la categoría de diarios personales (notas 20-24 y texto).

(B). Archivo Nacional de Bolivia, Audiencia de Charcas, Libros de acuerdos, vol.Il, f.452-471. Estos acuerdos tienen la impottante significación de reflejar la reacción del discutioo tribunal de Charcas sobre la sublevación en su distrito. 
(9). "Que Jos pilotos y maestros hagan diarios de sus viajes, y los generales lo compelon a ello: Mandamos a los pilotos y maestres de la carrera de Indias; que en cada viaje vayan haciendo descripción y diario de todo lo que salieren y entraren en los puertos, derrotas y rumbos por donde navegaren cada día los vientos de mar y tjera que llevaren, tempestades y huracanes que sobrevinieren, las corrientes, recalas, islas, arecifes, bajos, escollos y topadoros, y los demâs peligros e inconvenientes que se les ofrecieren, señas, entradas, salidas, fondo, suelo. capacidad, largura, anchura, agua y leña, y las demás calidades de los puertos donde toçaren y entraren, de que ntra vez no hubieren hecho descripción, y traigan relación particular de todo ello por escrito, y la entreguen al piloto mayor y cosmógrafos de la casa de Sevilla, con las venas que el presidente y jueces de la casa los impusieren", lib. 9, út. 23, ley 37, Recopilación de leyes de los reiuos de las Indias, 4 vols. Madrid, 1841.

(10) Antonio Ulloa y Jorge Juan, Relación historica del viaje a la América Meridional, 5 vols., Madrid, 1748. Mapas y láminas.

(10) Edmond Temple. Travels in Varits Parts of Peru. Including a Yearis Residence in Po. tosi. 2 vols, Londres, 1830. Mapa, grabados y viñetas.

(i2) Puede tener algún interés traducir a Temple en este lugar:

"Al traducir el Diario no he cré́do obligatorio seguir la sucesión diariat y dar bajo cada fecha las pequeñas ocurrencias de marchas, contramarchas, salidas, esperanzas, dudas y aprensiones de los sitiados; pero conservando los sucesos principales y condensándolos, he respetado tanto como be podido el sentido literal, para lo cual he contado con la valiosa ayuda de un caballero espanol para desentrunar el sentido del curioso, y muchas veces casi ininteligible, lenguaje del original" (op. cit. p.106).

(13) Alcide d'Orbigny, Voyage dans l'Amerique Meridtonale, 9 vols. de texto y una caja de mapas. París 1835-1847.

(14) La telación diaría del viaje abarca los vols. 1, 2 y 3 primera parte, bajo el título Parie historique; las observaciones geologicas y geográficas están dispuestas también en forma diaria e itineraria en el vol. 3 segunda parte bajo el título Partie géographique.

Hay una versión de la relación diaria o Parrie historique al español: Alcides d'Or bigny, Viaje a la América Meridional. 4 vois. Buenos Aires, 1945. La Partie geógraphique no ha sido traducida.

(15) "Durante ese bloqueo y hasto durante la guerra, no contento con escribir día a día todos los hechos, don Sebastián Segurola, reunió, en un registro especial, todos los informes y documentos relacionados con la rebelión de Túpac Amaru y de Túpac Katari. Ese registro. titujado Libro de Anales y sucesos inemorables de la ciudad de La Paz, contiene no sólo hechos muy curiosos, sino también numerosas cartas de los jefes del partido indígena, que pueden arrojar alguna luz sobre el verdadero espíritu de la insurrección. Poseo ese monumento precioso de las últirtas tentatjvas de los descendientes de los Incas para recuperar su libertad" rop. cit., edición 1945, vol. 3, p. 987 , nota 1 ).

\section{XXVIII}


(15) "Que los descubridores describun su viage, leyendo cada día lo escrito, y firmando alguno de los principales: Dando principio al viage por mar o tierra, comiencen los descubridores a hacer memoria y descripción por días de lo que vieren, hallaren y aconteciere en todo lo descubierto, y habiéndolo escrito en un libro. se lea en público cada día delante de los que fueren a la facción porque mejor se averigúe la verdad, y tirmand de alyuno de los principales, guarden el libro tom mucho cuidado, part que cuando vuelvan lo presenten en nuestro consejo o audiencia, donde han de dar cuentia de lo ciapitulado" lib. 4. tíl. 1, ley 7.

(17) Cristóbal Colon. Este es el primer viage, y fas derrotas y camino que hizo el Almirante D. Cristóbal Colon cuando descubrió las Inditrx, en Martín Fernández de Navarete, ed. Colección de los viajes y descubrimientos cue hicieron por mar los españoles desde fines del siglo XV. (2a. ed. 4 vols. Midrid, 1858), vol. 1, p. 153-3 I3.

ILR; Nicoldis Armenía. Diurio de strs viajes a las tribus comprendidas entre el Beni y ef

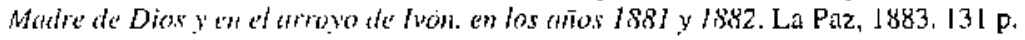

Unid 2a. ed. por el Instiluto Bofiviano de Cultura. Lai Paz. 197G. 141, tind p.

(t) José Ayustín Palacios. Explonación de los rós y lages det departamento del Beni y en especial al Madera, practicada de wdtedel Stipremo Gobierno de Bolivia. La Puz, 1852.

Varias ediciones postetiores.

196) The Dion of Semmef Pepys. 3 vols. Londres. 1923. 2a. ed. completa. La primera habia aporecido en 1893-1894, y ia primera, incompleta, en 1825. Entre otras causas de este retraso edjlorial se cuenta la crudeza de muchos pasajes. Aún la edición conpleta no se atrevió a reproslucir "ilgunos pasajes impublicables".

Hay unil excelente edición abreviada: Everybody's Pepys The Diary of Samuel Pepys, 1600-1069. Abtidged frem the Cemplete Copyrigh Teat and Edited by O.F. Monthead. Londres. 1935. XXIV, 570 p. Liminas.

(20a.) Bartoloné Arzáns de Orsúa y Vela. Historia de la Villa Imperial de Potosí. Edición de Lewis Hinke y Gunnal Mendoza. 3 vols. México, Brown University Press, Providence, Rhode Island (Estados Unidos de Norte América).

Barlolomé Martínez y Vela, (Bartolomé Arzáns de Orsúa y Vela), "Anales de la Vi"la hinerial de Potosí", en Bullivián y Roxas, Archivo Boliviano. Colección de documentos relativos a la historia de Bolivia, durante la época colonial, con un catálogo de obras impresas y de manuscribs, que tralan de esa parte de la América Meridional. (París, 1872, XIV. 535p.), p. 283-487.

(21) Ver los pátrafos "Inagen tei Oidor en el Diario" y "Razones para Jlevar un diario" en el importante "Estudio preliminar" con que se acompiña esta edición.

(22) Véase adelante nota 43 y texto.

(23) Véase al final del Diario de Diez de Medina en esta edición, la dílígencia notarial.

(24) María Eugenia de Siles, como hace notar, ha utilizado básicamente para esta edición el manuscrilo del Diario remitido por Diez de Medina a la Secrefaría Universal del Despacho de Indias, de donde paso al Archivo General de Indias. 
(25) Ver el buen número de diarios de guerra, así como de viaje, que incluye una sola colección de fuentes historiográficas, sin ser especializada en ese tipo de documentos (Pedro de Angelis. Colección de obras y documentos relativos a la Historia Antigua y Modema de las provincias del Rlo de La Plata. 6 vols. Buenos Aires. 1836-1837.

(26) Ver atrás notas 9 y 18.

(27) Código Militar para el régimen, disciplina, subordinación y servicio en los ejércitos de la república boliviona. 2a. ed. San Germán en Laye (Francia), 1845.

"Sección del servicio de armas en el ejército:

"Esta estará al cargo del cuartel-maestre jeneral del ejército quien tendrả a sus órdenes un primer ayudante, dos segundos ayudantes, dos adjuntos y los adictos que sean precisos para el servicio, segun este sea mûs ó menos urjente, y sus atribuciones serán": "Once: El diario histórico del ejétcito y su redacción", p. 380,381 .

"Parte histórica de un ejército o división:

"425. La parte histórica es la relación de los principales acontecimientos políticos y militares referentes a una especie o a una campañi.

“426. La redacción de esta parte histórica, que pertenece exclusivamente al jefe de estado mayor jeneral de un ejército, es la más noble y la más hermosa de sus tunciones y para llenaria con ecsuctitud sin olvidar los más perueños detalles, ni los acontecinientos que él no haya podido presenciar por sí, tendrá a la vista los diarios históricos de los estados mayores divisionarios, y los que el cuartel-maestre jeneral y conductores del tren le pasen mensualmente, resultando la verdad de las contradicciones que en unos y otros pueden encontrar.

" 427 . Por ellas se viene en conocimiento de sus talentos segun el modo que tengan de presentar los acontecimientos, de describirlos y clasificarlos.

"428. Por este medio tiene también la posibilidad de hacer patentes las faltas, de indicar" las acciones brillantes y de citar al tribunal de la opinión y de la posteridad, a todos aquellos de quienes tiene que hablar.

"429. Todos los partes que habrá recibido sucesivamente y sobre los cuales ha debido hacer observaciones, todo lo que puede haber llegado a su noticia sobre los secretos del estado, y sobre las intenciones del jeneral en jefe, finalmente todo lo que ha sabido ú observado, son los dalos que tiene a su disposición.

"430. Pero a fin de que una obra de esta especie pueda obtener una celebridad durable, es preciso sin duda que el asunto merezea algún interés y que cada suceso conserve en ella su carácter: que el lector siga los pensamientos dei jeneral en jefe al mismo tiempo que los hechos; que le acompañe en la concepción de sus planes y en la fluctuación de sus temores, esperanzas y deterninaciones y en fin que lo pasado lo ligue a lo presente y le haga tomar interés en lo venidero.

"431. Mas para poder conseguir esto, es indispensable que el jefe del estado mayor jeneral de un ejército conozca siempre el estado jeneral de los asuntos con respecto a la política: que entienda la guerra en grande y en sus pormenores: que conozca el teatro de ella por su topografia, por 
la historia de todas las campañas ocurridas en él, y por las hombres célebres que han fïgurado allí: que tenga buenas noticias del ejército enemigo en cuanto a su organización, movimientos, operaciones u objeto u objetos succesivos que se propone: es preciso también que le comuniquen las intenciones del Gohiernn y los menores pensamientos del jeneral: que posea el habito de escribir y el gusto de esta especie de trabajo.

"432. Pero a fin de no omitir nada esencial, ni alterar ningún hecho y conservar a cada uno su verdadero carácter, conviene que los escriba a medida que se succeden, y cuando aun se tienen presentes todas las circunstancias que les pertenecen.

"433. La relación de una campaña, de un suceso de guerra importante y aun de una espedición, no se deben remitir sino al ministerio de la guerra, y no debe comunicarse sino al jeneral en jefe.

"434. Su publicación solo se verificará con aprobación del Gobierno, a ló menos hasta el tiempo en que siendo dichas relaciones poco importantes para la política, pertenecen tan solo a la historia", p. 483-485.

(28) Julio César. Los comentarios de Cayo Julio César, traducidos por D. Joseph Goya y Muniain. 2 vols. Madrid, 1978. Mapas y láminas.

(29) Expresiones corroborativas de io dicho, tales cono "al día siguiente", "Hlevaba tres días", "a los diez días". etc.. son frecuentes en el texto (op. cit., passimin).

(30) Año 1634. "Copia de una carta que escribió un soldado del tercio que llevó el señor licenciado don Antonio de Ulloa y Chaves, del Consejo de su majestad y su oidor en la Real Chancillería de los Chatcas, superintendente de las cosas tocantes a guerra de los tres gobiernos, Tucumán, Paraguay y Buenos Aites, cuando fue a ba pacificación de los indios alzados de los Valtes de Calchoquí, Londres y la Rioja de las provincias del Tucumán, en que da cuenta a su senoría del licenciado don Juan de Carvajal y Siude, del Consejo de Indias, visitador y presidente de la Real Chancillería de los Charcas $\$$.A., de los buenos aciertos y bien afortudados subcesos de esta empresa que se reconocen todos al gran valor y prudencia del señor don Antonio".

Este nolable diario, que contiene información de valor excepcional sobre las gueras de subyugación de los españoles contra los indios en este período y en esta área, fue localizado, con afortunada y emperiosa diligencia. por el joven historiador argentino Gastón Doucet en una colección privada de España. El Sr. Doucet está preparando la edición del Diario, y, muy gentilmente, nos ha facilitado la compulsa de la copia folostática que posee así como la autorización para la cita.

(31) El trámite respectivo se hizo ante Pedro de Aybar, escribano público y de cabildo de la ciudad de La Plata (hoy Sucre).

(32) $\mathrm{P}$. Tadeo Xavier Henis. "Diario histónico de la rebelion y guetra de los pueblos guaramis, situados en la Costa Oriental det Rio Uruguay, del año de 1754" (Buenos Aires. Imprenta del Estado, 1836). VII. 60 p., en Angelis, Colección... (cil. atrás nota 25), vol. 5.

(39) 1780.1X.15. La Plata. "Carla N" 16, del Corregidor de Chayanta, don Joaquín Alos. Hace presente cómo por atender al real haber y corregir varios excesos, se le sublevó aquelia Pro- 
vincia. Acompaña cualro documentos anexos, donde está el diario de la sublevación”. (AGI. 1205-6, signatura modema: 443), en José Vázquez Machícado. Catálogo descriptivo det materiat del Archivo General de Indias, referente at thistoria de Botwirt. Universidad Mayor de San Andrés. Instiluto de Investigaciones Históricas, Archivo de La Paz. 5 vols. (La Paz, 1976), vol. 2. N²527.

(34) No obstante estos antecedentes, que fueron muy conocidos y aceptados en todos los niveles oficiales y extraoficiales coeláneos. Alós fue exonerado de loda culpa y mas bien preniado: "1781-1786. Expediente formado contra el capitán don Joaquín Alús, corregidor que fue de Chayanta, a causa de la sublevación de los indios de aquelia Provincia, y declaraciones hechas a su favor, en que aparece libre de los cargos que se formularon. y concediéndole en premio el Gobier. no e intendencia del Paraguay, con el grado de teniente coronel". (AGI. 122-5-1, signalura moderna: Buenos Aires 48), Vázquez Machicado, Catalogo... (cit. atrás, nota 33), vol. 3, $\mathrm{N}^{\circ} 280$

(35) María Eugenia de Siles, Testimonios... (cit. atrás nota 2), p.22, 29-31 y passim.

(36) En José Rosendo Gutiérrez. Documentos para la historia antigua de Bolivia sacudos de la Biblioteca de J.R. Guiérrez. Sitios de La Paz y el Cizco 1780-81. 1.1. (La Paz. Imprenta de la Unión A mericana. 1879. 152 p). p.53-108.

(17) Colección Rüick. $N^{*} 96$.

(38) La única referencia a este Diario se encuestra en la "Relación verdadera..." consignada adelante en esta enumeración con $\mathrm{e} N^{*} 13$. Que existió realmente, queda fuera de duda porque dicha "Relación verdadera..." como se declara en ella, fue escrita precisamente para impugnar a este Diario. Su pérdida es tanto más bamentible cuanto, pot lo que declara tanbién la "Relacian verdadera... ", representa el punto de vista de los sublevados, mientras que prácticamente la totalidad de los diarios del ciclo de la sublevación general están escritos desde el punto de vista antiindio.

(39) José Rosendo Gutiêrez, en sus Dorumenos inéditos... (cit. atrás, nơta 36), da el titulo completo de este Diario "entre los documentos que daremos a la esiampa uhora y que formarán un grueso volumen" (op. cit. p. $2, \mathrm{~N}^{\circ}$ VII), ofrecimiento que no se cumplió quedando el proyecto en el vol. 1.

(40) Incluido tambiến por José Rosendo Gutiérrez. En sus Documentos inéditos... (çit. alrás, nota 36), p. 2 y entre los que se ofreció publicar y no publicó.

(41) 1787. Audiencia de Charcas. Expediente de recurso. Don Juan Gelly, residente en la ciudad de Buenos Aires, sobre él desembargo de su ingenio de Churicala y su mina de la Gaivá. asiento de Aullagas, provincia de Chayanta. 18 f. (ANB. Minas, t. 75. $\mathrm{N}^{\circ} 8$ ).

(42) "Relación de los hechos mas norable acaecidos en lo sublevación general fraguada en los Reymos del Perí por el indio José Cabricl Túpac Amata, gobeinador det pueblo de Tungasuca en la provincia de Tinta, que asociado de otros sus secuaces causó horrorosos estragos deste el año 1780 hasta el de 1782 , en que se reprimió el orgullo de la conjuración", en Revista de Archi. vos y Bibliotecas Nacionales, Limn, vol, 5, 1a, entrega (septiembre 1900), p. 141-298.

(43) Maria Eugenia de Siles tiene la prioridad en la descripción y análisis formal de este Diario en sus Testimonios (cil. atrús, nola 2, años 1973 y 1980), labor que culmina con la presente ediciôn. 
(4ti) 1782.IV.6. Condesuyos de Arequipa. "Cara de dom Pedro Ignacio de Elguea, remitiendo un diario histórico de los hechos gloriosos de ta provincia de stu cargo con motivo de las revoluciones de aquel Reino y demás que expone". (AGL. 121-4-6. signatuta modena: 597), en Vázquez. Machicado. Catrilogo.., (cil, atrás, nota 33). $\mathrm{N}^{\circ} 3205$.

(45) María Eugenia de Siles. Testimonios... (cit. atrás, nota 2), p. 2, 26-29, y passim.

446) En José Rosendo Gutiérrez. Doctmentos inéditos... (cit atrás, nóta 36), p. 3-35.

(47) Alberto Crespo R. "Las armas de los rebetdes" (twabjo presentado al Coloquio sobre Túpac Amaru y su tiempo, Lima-Cusco. Noviembre, 1980, inédito, 18 p. mecanografiadas), p. 10. nota 1. Nuestro aprecio al Prof. Crespo R., por la remisión de su trabajo.

(48) 1782.11.20 Montevideo. "Carta $N^{\circ} 594$ det Virrey de Buenos Aires, enviando para noticia de S.M. ana relacion de sucesos acaecidos en la Provincia de Cochabamba, con ocasión de ta subtevasion de indios alli ocuride. Le acompañ et mantiscrite dosde se relatan fodos los acomecimientos", (AG1. 122-5-17. sigualura moderna: Buenos Aires 64), en Vázquez Machicado. Catélogo... (cil. atrás nota 33). $\mathrm{N}^{*} 378$.

(49) Por José Rosendo Gutiértez en el periódico trisemanal El Citudadono, La Paz, Nos. 910. 12-15, 17, 25, 28-29 (entre 1877.V.26 y 1877.VII.28).

(5) Las cartas que se enumeran a continuación dejaı en duda si Reseguín formó un solo diario o tres:

1782.1I.4. Cochabamba. Carra de don José Reseguin, haciendo presentes sus servicios y méritos en las r'woluciones de indios de attel Reino, e inclayendo el Diario de todas sus opericiones. (AGI. 121-4-4, signatura moderna: 595), en Vázquz Machicado, Cutálogo... (cit atrás, nota 33), $\mathrm{N}^{\circ} 3138$.

1782.1X.9. Oruro. "Carfa de don José Resegun, remitiendo un diario de ta expedicion hecha contra los indios rebeldes refigiados en la montana de Choquetanga". (AGI. 120-511, signatura moderna: 448), en Vázquez Machicado, Catálogo... (cit. atrás, nota 33, $\mathrm{N}^{2} 2676$ ).

1782.X.J6. Potosi. Carta de don Jaan del Pino Marrique, remitiendo original las cartas que ha recibido del comandante de Ortro y Presidente de Charcas, con el diario y carta particular del teniente Coronel Reseguín, relativo a la revolución de Oruro. (AGL. 121-4-4, signatura modenta, 595), en Vázquez Machicado, Catálogo... (cit atrás, nota 33). $\mathrm{N}^{\circ} 314 \mathrm{l}$.

(51) Por José Rosendo Gutiérrez en sus Documenos inéditos... (cit. atrás, nota 36), p. 102-108.

(52) El interés de Reseguín por recomendar sus "servcios y méritos" resulta maniftesto por la reiteración con que hizo sus envíos a Espafia.

(53) Bajo este título en Ballivián y Roxas, Archivo... (cit atrás, nota 20a.), p. XV-282. Otras ediciones:

"Sino y defensa de la ciudad de La Paz en el Perti contra los indios rebelador en I782", en Marqués de la Fuensanta del Valle y otros. Colección de documentos ineditos para la historia de España, vol 76 (Madrid, 1881), p. 372-564. Según un "Ms, propiedad de los editores", y con menos documentos que la edición de Ballivián y Roxas. 
"Se refieren los sucesos más principales acaecidos en el cerco que sufrio la ciudad de La Paz puesto por los indios rebeldes", en la Relación... (cit atras, nota 42), p.244-298, según un manuscrito en posesión đel autor anónimo de dicha "Relación". El relato va hasta 1781. V11.l y no se registran los documentos.

No está demás mencionar, asimisıno, la traducción parcial del Diario de Segurola al inglés citada atrós (notas 11,12 y texto).

(54) Este sería el recuento:

1-3) Las tres publicaciones citadas arriba corresponden a tres códices diferentes como es. tá a la vista.

4) Segurola remitio al Consejo de Indias un códice aparantemente completo según estas cartas: a) 1781.IX.30. Montevideo, Carta del Virrey de Buenos Aires, N ${ }^{\circ}$ 534, dando cuenta del bloqueo y socorro de La Paz, y sus incidencias. Acompaña documentos, entre elios el diario del cerco de La Paz del Coronel Don Sebastián de Segurola. (AGL. 122-5-15: signatura moderna: Buenos Aires 62) en Vázquez Machicado, Catálogo... (cit. atrús, nota 33), Buemos Aires, $N^{\circ} 362$. b) 1782.1 V.2 Montevideo. Carta $\mathrm{N}^{\star} 609$, del Virrey de Buenos Aires, enviando el Diario del Segundo bloçueo de La Paz, y carta de Don Sebastián de Segurola que lo incluye, refiriendo la pérdida te Sorata y culpando a Don Ignacio Flores de no haberla socorrido, acompañando tanibién el des cargo de éste. (AG]. 122-5-17: signatura moderna: Buenos Aires 64) en Vázquez Machicado, Catdlogo... (cit. atrás, nota 33), Buenos Aires, $\mathrm{N}^{\circ} 382$. c) 1782.1.3 Madrid. Minuta de Real Orden al Virrey del Perú y al visitador don José de Areche, para que averigilen separadamente los medios de que se han valido los indios sublevados de aquellas Provincias para aparecer con pertrechos de guerra. Se acompanian los documentos, entre ellos el diario del cerco de La Paz, de Segurola. (AGI. 121-4-4; signatura moderna:595) en Vázquez Maclicado, Catálogo... (cit. atrás, nota 33). Audiencia de Charcas, $N^{*} 3134$. d) 1782.VII.4. Achacache. Carta de don Sebastián de Segurola, incluyendo el diario de los sucesos de lu expedición que practicó contra los indios rebeldes de Collana, Cono y demás que llaman de la Quebrada del Río Abajo, y sucesivamente al interior de las Yungas de Chulumani y da cuenta de haber logrado la más gloriosa pacificación. (AGI. 121-4-4: signatura moderna: 595). en Vázquez Machicado, Catálogo.. (cit. atrás, nota 33). Audiancia de Charcas N $N^{*}$ 3145. e) 1787. VII.1". La Paz. Carta de don Sebastián de Segurola, Comandante de Anmas de La Paz, remitiendo el diario del sitio de la ciudad de La Paz. Se aconnañan dos documentos interesantes. (AGI. 120-5-11: signatura moderna: 448), en Vázquez Machicado, Catálogo... (cit. atrús, nota 33), Audiencia de Charcas. $N^{\circ} 2677$.

5) "Diario de Segurola. Continuación, en Borradores..., cit. atrás en el ítem consignado con el N" 11 en esta enumeración de diarios sobrc la sublevación general.

6) "Copia del Diario conducido por el Gobemador Intendente D. Sebastián Segurola de los sucesos ocurridos en la ciudad de La Paz en la rebelión de indios del año de $1781^{\prime \prime} .29 \mathrm{f}$. (BNB. MSS Moreno). Va hasta junio $29+18$ documentos. Copia coetánea, formato folio.

7) El "Libro de anales y sucesos memorables..." cit. atrás, nota 15.

(55) Segurola desplegó una activa política personalista para recomendar los méritos contrajdos en la campaña contra los rebeldes según se ve por estos ítemes: 
"Lou que compaso don Jacinto Liévana dedicada al mérito del señor don Sebastian de Segurola". Aparentemente ifédita. En los "Borradores..." cit. itrás en el ítem consignado con el $\mathrm{N}^{\circ} 11$ en esta enumeración de diarios sobre la sublevación general.

"Loa que al mérito del brigadier don Sebastian de Segurola compuso por vá de epitalamio don Pedro Nolasco Crespo. puesta en excena en la plaza mayor", publicada en José Rosendo Gutiérrez, Documentos inéditos... (cit. alrás, nota 36), p. 109-1 l6.

(56) La abundante circulación manuscrita del Diario de Segurola -dentro de las circunstacias de la época- apoyaría la posibilidad de su influencia en la composición de estos diatios, y aún de otros posteriores (ver adelante la nota y texto), cencunententente eon el estímulo pecsonal en cada caso.

lnversamente cabe preguntarse de dónde tomo Segurola, sin olvidar tampoco su propio estímulo personal, la idea de su diario, y una posible influencia externa podría encontrarse en los Anales de Potosi (cit, atrás, nota 20a), que a su vez tuvieron una vasta actualidad, popularidad y circulación manuscrita.

(57) María Eugeuia de Siles, Testimonios... (1980), cit. atrás, nota 2.

(58) En Manuel de Odriozola, Documentos históricos del Perí.. vol 1. (Lima, 1863). p. $137-139$.

(59) Ver atrás nota 4 y texto.

(60) Tada la información sobre el diario del cura Andrés Vargas se encuentra en el diario de su hermano (que se consigna adelante con el $\mathrm{N}^{\circ}$ 2). p. 9-10, 22, 28-29, 62-63, 68, 70-71, 129 , 259.

(61) Material básico sobre Muñesas (en orden cronológico de publicación):

Mariano Torrente, Historia de la Revolución Hispano - Americana. t. 2. (Paris, 1830), cap. 9 y 15 , passim.

Bartutomé Mitre. Historia de Belgrano y de la Independencia Argentina, vol. 2 (Buenos Aires, 1927), cap. 33.

Arturo Cosca de la Torre, Mdefonso de las Muñecas y los martires de la republiqueta de Larecaja. (La Paz, 1976). Jornadas Peruano-Bolivianas de Estudio Científico del Altiplano Boliviano y del Sur del Perú, vol. 4, 226 p.

(62) Ver atrós nota 56 y texto.

(63) Dos ediciones, citadas atrás, nota 4. La $2 a$, ed. con el título consignado arriba en el texto,

(64) "Me entropé por ser nás testigo ocular de los hechos". (Diario, 2a, ed, p. 9).

(65) Ibid., p.11.

(66) Hay una estrecha analogía de situaciones entre Arzáns y Vargus en este aspecto (ver atrás nota $20 a$ y texto).

(67) Ver atrás nota 6. 
(68) Eduardo Arze Quiroga. Cronología de las sublevaciones andinas en 1780-1, Presencia Literaria (La Paz, 1981.IL.8), p. 3.

(69) Reiteramos que todo lo que se dice en este aparte se refiere exclusivamente a las tiventes primarias.

(7) Como un ejenplo de dispersión, tenemos materiales tanto oficiales como particulares muy valiosos en repositorios de los Estados Uridos de Norte América, en especial los siguientes: Duke University Library (Durham, North Carolina) Manuscript Division, Peruvian Collection; John Hay Library, Brown University (Providence, Rhode Island); Library of Congress (Waslington. D.C.), Manuscript Division; New York Public Library (New York, N.Y.), manuscript Divi sion, Rich; Yale University Library (New Haven, Connecticut), Latin American Collection.

(71) De acuerdo al principio de procedencia, éstos serían: el Archivo General de Indias (Sevilla) para ta Secretaría Universal del Despacho de Indias; el Archivo General de la Nación (Buenos Aires) para el Virreinato del Río de La Platá; el Archivo General de la Nación (Lima) para el Virreinato del Perí; el Archivo Nacional de Bolivia (Sucre) para la Audiencia de Charcas.

(72) El material existente en el Archivo General de Indias está accesibilizado en parte (ta correspondiente a las documentaciones agrupadas bajo los epígrales de Audiencia de Buenos Aires, Audiencia de Lima y Audienciu de Charcas) gracias al gran trabajo de José Vázquez Machiçzdo en su Catalogo... (cit. atrás, nota 33). No obstante, es muy de suponer que inpontante material, en cantidad y calidad, existe en otros fondos documentales de ese repositorio.

En el Archivo Nacional de Bolivia la serie "Suhlevación general de indios, 1780 1782 " comprende prácticamente todo el material alusivo al ciso, con un total de 370 f́temes entre cartas, relaciones, provisiones, cédulas reales y expedientes relativos a las areas geográtícas (en orden alfabético) de Arequipa, Arque, Asángaro, Atacama, Ayopaya, Carabaya, Carangas, Cinti, Cochabamba, Cusco, Challapata, Charcas, Chitaquilla, Chayanta, Chichas y Lipes, Clucuito, Lanpa, La Plata (hoy Sucre), La Paz, Larecaja, Misque, Omasuyos, Onum, Pacajes, Paria, Pilaya, Pitantora, Poopó, Porco, Potosí, Puno, Quispicanchi, Sicasica, Sorata, Tapacari, Tinta, Tomina, Yamparaes, Yangas. Este malerial cuenta con una Guja prelimina forden cronologico, con un indice general de lugares, personas y materias).

No hay información accesible sobre la situación en este nivel, en los Archivos Generales de Buenos Aires y Lima.

(73) Secretaria General del Despacho de Indias. Virreinato del Río de La Plata, Virreinato del Perí, Audiencia de Charcas, comandantes de las fuerzas militares destacadas sobre las áreas en conflicto.

(74) Ver atrás nota 38 y texto.

(75) Ver atrás nota 49 y texto.

(76) Esta comparación puede hacerse materialmente en el Catálogo... de Vázquez Machicado (cit. atrás, nota 33), así como en la serie sobre "Sublevación general de indios, 1780-1782" del Archivo Nacional de Bolivia: los 370 jtemes de esta acumulacion son anti-indios.

(77) Ver atrás nota 3. 


\section{ARCHIVOS CONSULTADOS Y SU NOMENCLATURA}

Biblioteca de la Universidad Mayor de San Andrés

UMSABC

Archivo de La Paz. U.M.S.A.

ALP

Archivo de la Catedral de La Paz

ACLP

Archivo de la Casa de la Cultura de La Paz

ACCLP

Archivo Nacional de Bolivia. Sucre

ANB

Archivo General de Indias. Sevilla

AGI

Archivo Histórico Nacional. Madrid

AHNM

Archivo General de la Nación. Buenos Aires

AGNBA

Archivo Nacional. Santiago de Chile

$\mathrm{ANCH}$ 



\section{INTRODUCCION}

La Amèrica hispana, a fines del siglo XVIIL, 30 años antes de que se organizaran las primeras Juntas de Gobierno que terminarian por proclamar la Independencia, se vio conmovida por una serie de estallidos revolucionarios, centrados en torno a los años 1780-81. Se trataba de brotes revolucionarios eminentemente populares, que coincidian claramente en su esencia y que se enraizaban en el pensaniento jurídico-político bebido en la propia tradición española. Es decir, eran movimientos típicamente comuneros. Sin embargo, a pesar de su raíz occidental, casi todos ellos usaron como símbolo clave el nombre de Tupac Amaru. Efectivamente, se habian iniciado tales convulsiones con la rebelión del cacique peruano de Tinta, quien desencadenó en el Virreinato del Perú, un levantamiento mucho más vasto y generalizado que las rebeliones locales y comuneras de Nueva Granada, Venezuela, Ecuador $y$, en cierta medida, de Chile.

Desde luego, si este levantamiento implicaba características parecidas a Ios otros, los sobrepasaba enormemente. Había en él, además, ingredientes tan diversos como para permitir posteriomente, el que se lo estudie y califique como una rebelión fidelista, económica, social, étnica, nacionalista, independentista o simplemente campesina.

La extensión de este movimiento fue tan amplia, que abarcó desde el sur de Colombia hasta el norte de Chile y desde el Perú hasta la actual Bolivia y norte argentino, llegando a denominárselo, en la documentación de la época como la "General Sublevación".

Sus implicaciones en Bolivia, la Audiencia de Charcas de entonces, se manifestaron en los movimientos de Chayanta, con Tomás Catari y sus hermanos Nicolás y Dámaso, los de Porco y Paria, Cochabamba, Oruro, Sicasica, Pacajes, Omasuyos, Larecaja, Yungas y La Paz.

Sin lugar a dudas, tales rebeliones no fueron ni las primeras ni las únicas. Desde 1572, año en que se produjo la sublevación de Tupac Amaru I, violentamente sofocada por el Virrey Toledo, se inició en estos lugares del imperio español un largo 
proceso de movimientos indigenales. Tan sólo en el siglo XVIII y antes de que se produjesen los de José Gabriel Condorcanqui o Tupac Amaru II, hubo en este territorio del Perú y Alto Perú, casi una decena de ellos.

Sin embargo, no se puede identificar con los primeros a los que se desarrollaron a fines de ese siglo, entre 1780 y 83 . Los anteriores fueron movimientos breves, muy localizados y obedecieron por lo general a motivos muy concretos de protesta ante alzas de contribuciones, malquerencias o descottento frente al proceder de determinados funcionarios o instituciones. Ellos no implicaron planes políticos independistas y fracasaron siempre porque frente a ellos existía un Estado vigoroso que reaccionaba enérgicamente. En cambio, las rebeliones que sacuden al Imperio, en el tiempo que analizamos, tienen caracteristicas especiales: a los elementos anteriores se suman ahora la extensión y amplitud, la intensidad, el arraigo y la aparición de grandes caudillos. Por otra parte, se ve desaparecer la antigua docilidad, paciencia y sumisión cle los nativos, para ser reemplazada por una áspera violencia, crueldad y enardecimiento. Si antes los indígenas habían manifestado una verdadera incapacidad para mantener y asegurar sus derechos, ahora, en cambio, reaccionaban con actos sanguinarios, latrocinios y odio.

Por otra parte, si bien no puede hablarse de debilidad de parte del gobierno, puesto que a la larga desbarató la sublevación, sí puede asegurarse que manifestaba por entonces una fuerte crisis de acomodación a un nuevo sistema emanado de la mentalidad ilustrada de pna burocracia eficaz, centralizadora y moderna que se había propuesto la reorganización de la administración y la cconomía de las colonias. La crisis se notaba en el choque de la nueva burocracia conla antigua, de corregidores abusadores y prepotentes, en el enfrentamiento con los comerciantes de Lima, quienes a la larga eran los causantes de les odiados repartos de los corregidores, con los azogueros o grandes mineros de entonces y con los aduaneros. Por otra parte, era evidente ahora la fuerte tensión entre los orgullosos criollos afectados por las nuevas medidas que se veían postergados y menospreciados, y lus chapetones "peninsulares advendizos" (muchas veces estaisan muy lejos de serlo) que prescindian tan abiertamete de ellos.

También es cierto que las sublevaciones indígenas del $80-81$ se produjeron cuando en las sociedades indigenas se habian operado grandes cambios en el plano jerárquico y comunal. El análisis de todos estos fenómenos es de por sí tan rico e interesante que podría ser tema de un largo estudio que por supuesto no corresponde efectuar ahora. Lo dicho anteriormente no tiene sino el objeto de ambientar la actuación de Tupac Catari.

La conmoción que produjo este caudillo en las provincias de Sicasica, Pacajes, Omasuyos, Larecaja, Yungas y, sobre todo, el prolongado y dramático cerco de La Paz, así como los problemas que se suscitan dentro de la ciudad, han sido recogidos 
en varios diarios que constituyen un elocuente testinionio que refleja la forma en que los acontecimientos fueron vividos por quienes resistieron el asedio(l). Cada uno de ellos, según la propia índole espiritual del autor, la visión del proceso que se estaba desarrollando o el mayor o menor grado de sensibilidad u objetividad, representa un juicio personal de inobjetable valor histórico frente a los trágicos acontecimientos vividos.

De aquellos diarios sólo han sido publicados el del sargento mayor Castañeda y el del comandante Segurola; el primero ha tenido muy poca difusión y es muy difícil encontrarlo hoy en día, siendo el de Segurola, recientemente reeditado(2), el único verdaderamente conocido, utilizado y citado en los diferentes estudios de la sublevación indigena de Tupac Cätari.

Le corresponde ahora salir a luz al Diario que llevó durante el cerco el oidor Francisco 'Tadeo Diez de Medina. Las primeras noticias que se tuvieron de este documento se deben a José Vázquez Machicado, quien lo encontró en el Archivo de Indias de Sevilla, copiándolo con mucha fidelidad. Posiblemente el bibliófilo pensaba tealizar su publicación con algún estudio como el presente; no se tiene, sin embargo, noticia alguna de que hubiera llegado a hacerlo.

Estando la autora del actual trabajo haciendo un estudio comparativo de los diarios que se llevaron durante el cerco(3), fue informada acerca de la existencia de la copia antes mencionada por parte del escritor Mariano Baptista Gumucio, quien la puso en contacto con su dueño, el doctor Carlos Serrate Reich, que generosamente le obsequió una reproducción de la copia hecha por Vázquez Machicado. Con ella en mano se pudo pedir una xerocopia del Diario original al Archivo de Indias ${ }^{(4)}$. Ese Diario abarcaba en sus anotaciones todo lo ocurrido durante el primer cerco de La Paz.

(1) Seguroba, Sebastián de, Diario de los Sucesos del Cerco de la Ciudad de La Paz en 1781, en Ballivión y Roxas, Vicente, Col. de Doc. relativos a la Hia. de Bolivia, París, 1872. Diez de Medina. Francisco Tadeo, Diario del Alzamiento de Indios Conjuados contra la ciudad de Nuestra Señora de La Pas, AGI. Charcas 583. Cástañeda, Francisco de, Principales sucesos acaecidos en los dos asedios o cercos que padeció esta ciadad de La Paz, en J.R. Gutiérez, Doc, para la Hia. Antigua de Bolivia. La Paz, 1879. Diario de la Sublevación del año 1780. que escribió un Capiatan Ledo, de orden del Comandante S. de Segurola. Archivo. Universidad Mayor de San Andrés de La Paz.

(2) Diario de los Sucesos del Cerco de la Ciudad de La Paz, en 1781, por el Brigadier don Sebastián de Segurola, en Ballivián y Roxas. Vicente, Col. de Documentos relativos a la Hia. de Bolivia 2a. Edición, 1978. Municipalidad de La Pa7.

(3) Del Valle de Siles, María Eugenia, 5 Tesrmonios det Cerco. La Paz 1781. Revista Historia y Cultura, La Paz 1973.

(4) A.G.I. Buenos Aires, 583. 
Publicado el trabajo sobre la comparación de los diarios del asedio, se tuvo ocasión de diagnosticar un documento que parecía ser un nuevo diario. Se trataba efectivamente de unas anotaciones cotidianas que, llegando hasta el 28 de Octubre de 1781, habian perdido los folios iniciales, por lo que no se sabía cuándo se había comenzado a escribir ni quién las había llevado; empezaba el escrito el día 19 de Marzo. La consulta habia sido hecha por el historiador Alberto Crespo Rodas, a quien le había facilitado el documento original el doctor Jaime Retamoso Zuazo. Fácilmente se pudieron cotejar la notas tomadas por el señor Crespo Rodas con las del Diario de Francisco Tadeo Diez de Medina, comprobándose que se trataba del mismo texto. Habia, sin embargo, una novedad; el Diario del Archivo de Indias llegaba hasta el 27 de Julio, donde se cortaba bruscamente el hilo de la narración, con una certificación de verdad hecha por los notarios de La Paz; éste, en cambio, sin aquel corte ni alusión alguna a una interrupción, continuaba en sus anotaciones hasta el día 28 de Octubre. Ninguno de los dos textos estaba escrito de puño del autor; el de Sevilla acusaba una sola mano de copista, mientras el de La Paz denotaba cuatro, presentando además varias correcciones hechas por el propio Oidor, cuya letra la autora de este estudio podía fácilmente reconocer.

El doctor Retanoso permitió a la investigadora conocer el texto e incluso le autorizó a tomar algunas notas de aquella gegunda parte, que correspondía al segundo cerco, pero desgraciadamente no consintió en que se hiciera una foto o xerocopia de él.

Más tarde, en Agosto de 1976, se tuvo ocasión de trabajar en el Archivo General de Indias de Sevilla, donde se buscó afanosamente alguna otra copia de aquella parte, con resultados negativos. Se encontraron, en cambio, otros documentos muy importantes del oidor Diez de Medinà y unas cartas que explican la razón del envío de la primera parte del Diario, así como el anuncio, después de finalizado el segundo asedio, del envío de la primera y segunda parte, escritas sin solución de continuidad, ya que se temía que por intervención de las autoridades de La Paz, se hubiera impedido el arribo a Buenos Aires primero y a España más tarde, de la primera encomienda. Paradójicamente, liegaron a España las cartas y el Diario del primer cerco, pero no llegó, en cambio, el texto completo ofrecido por Diez de Medina.

Se han buscado prolijamente en Buenos Aires los documentos emanados del oidor Diez de Medina, pero no se ha encontrado nada que corresponda a un Diario. Sin embargo, no se considera imposible que algún día salga a flote su texto traspapelado entre otros documentos de la época del Virrey Vértiz.

En el conjunto de los diarios poco conocidos que se escribieron durante el cerco de La Paz, incuestionablemente es el del oidor Diez de Medina, el que reviste mayor significación, sobre todo si se considera que el diario efectivamente estudiado es el del comandante Segurola.

El Diario dei Oidor viene a ser la antítesis de el del defensor de La Paz. Este había sido escrito por un militar español de carrera, que había llegado a la ciudad 
por mandato supertor dos meses y medio antes del cerco; no conocía bien, por lo tanto, la villa, sus contornos, sus vecinos: no sabía nada de las costumbres y etiquetas del lugar, no conocía las lenguas aborígenes ni la idiosincrasia de los indígenas que se agrupaban en los barrios periféricos y, si bien podía haber sentido ya la atracción del mundo americano, se identificaba ésta con Sorata, pues era desde hacía algún tiempo corregidor de Larecaja. Por todas estas razones, sus anotaciones tienen un carácter castrense, son en realidad verdaderos partes de guerra, a través de los cuales el Comandante da cuenta de lo sucedido o explica un determinado plan de acción, en un lenguaje cortecto, preciso, sobrio, pero sumamente frío. Raramente se encuentran en sus páginas referencias a personas que no estuvieran vinculadas con la actividad bélica o a ocurrencias de tipo local que lo muestren como a una persona que vibre, sufra o sienta toda la tragedia que vive la ciudad.

Frente a ese Diario, aparece, en cambio, el de Francisco Tadeo Diez de Medina; su autor es tun criollo con importante actuación pública, que se siente orgulloso de haber nacido en $\mathrm{La}$ Paz donde tiene una posición social y económica destacada. Ama entrañablemente su ciudad y la conoce barrio por barrio, calle por calle, casa por casa. Ubica y distingue a los vecinos, habla el aimara y el quechua, conoce la mentalidad indígena y sabe hablar a los indios en el tono paternalista al que se les había acostumbrado entonces. Conoce también Ja toponimia de la villa y sus alrededores, sufre con verdadera angustia todo lo que le sucede a La Paz, a las otras provincias y al reino entero. Por todo ello las páginas de su Diario, a pesar de estar escritas en un castellano pretensioso, altisonante y alambicado, revelan la vida íntima de la ciudad, con todos los detalles de tipo antropológico, que tanto enriquecen el cuadro social y cultural de la Historia.

Representa tambiến este Diario una expresión riquísima de la tensión que en ese momento viven los criollos y petinsulares. Puede verse a través de sus juicios y observaciones cómo la innegable rivalidad de los dos grupos blancos, en lugar de atenuarse o verse desplazada ante la presión del indígena, ahora enemigo común, se exacerba, crispando los ánimos y acrecentando los mutuos recelos, desconfianzas y menosprecios.

Con una lectura penetrante del texto, puede apreciarse también el juicio que el criotlo tiene del indio a quien respeta y estima en el plano teórico jurídico, menospreciándole en el plano real. En el caso del Oidor puede verse cómo este dualismo anímico lo lleva a contradicciones increibles dentro de las observaciones anotadas en un mismo día. Vacilaciones tan hondas en la mentalidad de aquellos hombres hacen más comprensibles las reacciones que adoptan cuando, sabiéndose vencedores, quieren aplicar lecciones imborrables y castigos defiritivos, llevados a cabo con una saña tan horrible o peor que la de los alzados, a quienes tanto acusaron y reprocharon anteriormente.

Todas estas características son las que hacen de este Diario un documento excepcional; si el otro Diario conocido fue escrito por un militar español, defensor de la 
ciudad, éste fue hecho por un oidor criollo que, como auditor de guerra, habria de condenar a cruel suplicio al principal caudillo indigena, a su mujer y a su hermana.

Las aclaraciones de los hechos narrados por el Oidor, como asimismo las de sus discursos o reflexiones, que aparecen en las notas o en el estudio preliminar, están apoyadas siempre en las fuentes primarias que se han encontrado en los diversos archivos consultados; prescindiendo de las informaciones habitualmente utilizadas, se quiso conocer a fondo lo sucedido para poder así, sumando elenentos aislados, individualizar el proceso histórico de las rebeliones indígenas de 1781 y contribuir al esclarecimiento de lo que ellas fueron así como a determinar el alcance que thenen en la historia nacional.

No puede darse fin a estas líneas introductorias sin agregar unás palabras de gratitud a Mariano Baptista, que no vaciló en participar la noticia de la existencia de este Diario, renunciando al plan de hacer su propio comentario; a Carlos Serrate Reich, que obsequió generosamente una copia del texto para su estudio; a Alberto Crespo Rodas, que no sólo comunicó la existencia de lo que vino a resultar la segunda parte, facilitando los contactos con su dueño, sino que también participó en la elaboración del trabajo, alentando y aconsejando a la investigadora; a Ricardo Retamal, que proporcionó datos importantes sobre las actividades del oidor Diez de Medina en Chile; a Gunuar Mendoza que, con gran amistad, proporcionó documentos y datos e inspiró el presente comentario al abrir un surco imperecedero en este género de publicaciones con su Diario del Tambor Mayor Vargas; a los directores y personal de cada uno de los archivos visitados, que con extraordinaria acogida, atendieron toda clase de consultas y peticiones, permitiendo aptovechar intensamente las breves estadías en las distintas sedes de los respectivos repositorios; a Diego Siles del Valle, que iniciando sus primeras actividades de estudiante de arquitectura, pudo realizar, interpretando las ideas de su madre, el plano de la ciudad en 1781; a Juan lgnacio $\mathrm{Si}$ les del Valle, por la toma de gran parte de las fotografías que aparecen en el texto; a Jorge Siles Salinas, que siempre tuvo una palabra de aliento, una actitud de compresión y apoyo y que colaboró pacientemente en la revisión de los textos.

En forma especial quiero expresar mis agradecimientos al Banco Boliviano Americano que coauspició esta edición contribuyendo, con la publicación de este texto hasta ahora inédito, a la difusión de importantes documentos de la listoria de las rebeliones indigenas, que cumplen este año su segundo centenario.

Consta la primera parte del Diario de Diez de Medina de 51 folios, escritos por ambos lados, con la letra clara y regular del copista de oficio. La copia, bastante cuidada, revela al mismo tiempo, una lectura atenta del autor que borró palabras repetidas, subrayó frases, enmendó uno que otro error ain importancia y colocó algunas palabras olvidadas.

Los folios, de $29,5 \mathrm{cms}$. $\times 20.5 \mathrm{cms}$, están escritos en letra menuda y pareja, manteniendo las filas apretadas desde el comierizo hasta el final, en un término medio de 45 líneas por folio. Se inician con largas frases que, más que a un epígrafe, 
corresponden a un anuncio del tema a que se refiere el escrito. A ellas siguen cuatro folios y medio destinados a hacer un resumen de lo acontecido en los dos Virreinatos a consecuencia de los levantanuentos de Tomás Catari en Chayanta, de Tupac Ama* ru en Tinta y de Tupac Catari en Sicasica. Enseguida se corta la síntesis con un subtítulo que dice: "Ocurrencias en la ciudad de La Paz desde lro. de Febrero de 1781". La narración de tales ocurrencias prosigue sir ninguna interrupción hasta el 27 de Julio de 1781; bruscamente entonces, aparece la certificación de Crispín de Vera y Aragón, P'edro de Mariaca y Rafael de Villanueva, los tres escribanos de La Paz, dando testimonio de que el Diario pertenece al oidor Francisco Tadeo Diez de Medina quien lo ha llevado a lo largo del cerco y añadiendo que "está muy verídico en sus relaciones".

Las anotaciones que van desde el 1ro. de Febrero hasta el día 11 de Marzo, y que corresponden a un preámbulo del cerco, no están escritas día a día; se ve que el autor las redacló recordando lo acontecido entonces y basándose posiblemente en uno que otro apunte.

Sin Iugar a dudas, Ja introfucción anterior a las ocurrencias de La Paz fue añadida después de iniciacto el Diario, seguramente cuando el ántor lo dio a copiar, porque se refiere a hechos que se producen después del tro. de Febrero y a personajes que Diez de Medina iría conociendo a lo largo del asedio. No cabe duda que ideó este sistema para poner en antecedentes al lector que, ubicado en el contexto de la sublevación general, captaría mucho mejor el sentido de lo que había ocurrido en La Paz.

No sin habilidad, Diez de Medina escribe este Diario como si fuera otra persona, con lo que encuentra una fácil coyuntura para atacar a quienes no aprecia, como asimismo destacar indirectamente su propia actuación. A veces utiliza la primera persona del plural y habla de "nuestro comandante" o de que "nos acometieron", otras, en cambio, especialmente cuando hace reflexiones, consideraciones, loas, etc. utiliza la forma impersonal.

La segunda parte del Diario que, como se ha dicho anteriormente, conforma un manuscrito diferente, integra oha copia del Diario. Este texto ha perdido las fojas iniciales, es decir, no posce nu ta introducción, ni el preámbujo anterior al cerco, ni lo sucedido en los primeros días del asedio, materia que en el de Sevilla ocupa 13 folios escritos en ambas caras. Continúa, en cambio, más allá que el del Archivo de Indias que finaliza con las anotaciones resumidas de los días $24,25,26$ y 27 de julio. La copia de la farmilia Retamoso prostgue sin la menor interrupción hasta el día 28 de Octubre. Stıs folios están numerados con posterioridad, el día 18 de Abril de 1906, posiblemente por el obispo Nicolás de Amnentia que fue su dueño. La numeración comienza en el folio 20 , lo que significa que la desaparición de las primteras fojas ocurrió después de 1906, y llega hasta el 176. La narración del segundo cerco, que falta en el de Sevilla, abarca desde la foja 118 vuelta hasta la 176, es decir ocupa 58 folios, lo que corresponde a una tercera parte del Diario completo. 
Las fojas que están en buen estado, miden $30,5 \mathrm{cms}$. $\times 20,5 \mathrm{cms}$., pero no están escritas apretadamente como las del otro manuscrito, puesto que el término medio de los renglones sólo alcanza a 23 por folio; también están escritos con letra menuda.

El nuevo texto revela la mano de cuatro copistas diferentes que varian tanto la ortografía como la puntuación. Este hecho produjo mayor descuido en la copia e hizo que las correcciones y añadidos del autor fueran mucho más frecuentes que en el primer manuscrito. La redacción, en cambio, no varía, manteniéndose las formas indirectas del de Sevilla. Por tratarse, esta vez, de una copia que no estaba destinada a salir de La Paz, no tierie ninguna certificación de verdad por parte de los notarios. Posiblemente, a la salida del Oidor, ел 1782, cuando se dirigió a ocupar su cargo en Santiago de Chile, quedó el Diario en manos de algún amigo o pariente suyo, pero con el tiempo debió traspapelarse, olvidándose con ello su origen, porque cuando Armentia certifica ser su propietario, no hace alusión alguna a quién fue el autor.

Fuera de esta copia del señor Retamoso y del texto, completo también, que el Oidor envió a Buenos Aires para que fuera reexpedido a Esparia, pero que se perdió, como se ha visto, deben haber circulado otras copias en La Paz, porque con ocasión de un traslado y ordenación de los manuscritos de la Sociedad Geográfica de La Paz que posee la Universidad Mayor de San Andrés, se encontró una página suelta de un Diario, que pudo ser identificada como pertenecicnte al del Oidor. Llenaba la narración de lo acontecido el 9 y 10 de Abril, no variaba en absoluto el texto y correspondía al formato del primero de los manuscritos. Desgraciadamente, por más que no se dejó papel sin revisar, no se encontró el resto del Diario dentro de aquel lote de documentos.

En un primer intento de publicar el Diario del Oidor Diez de Medina, se hizo la transcripción según las normas aprobadas en la Primera Reunión Interamericana sobre Archivos, celebrada en Washington del 9 al 27 de Octubre de 1961. Sin embargo, terminada la labor, se pudo comprobar que las particularidades ortográficas, así como las de la composición gramatical, desorientaban al lector actual, que si no está sumergido habitualmente en este tipo de textos, termina por cansarse, dejando de lado una lectura que le habría sido provechosa. En vista de lo cual, tomando ciertos acuerdos, respecto de la transcripción, con los miembros de la Sociedad Boliviana de Historia, los catedráticos e investigadores de Historia de América y de Bolivia de la Universidad Mayor de San Andrés y los directores del Archivo Nacional de Sucre y del de La Paz, se resolvió hacer una transcripción al castellano que habitualmente se habla en el país. Sin embargo, aunque este método ha significado la utilización de una ortografía y puntuación modernas, no ha implicado cambios en la construcción de la frases, que se han respetado por más retorcidas, incorrectas y extrañas que parezcan.

Tampoco se ha modernizado ni corregido el empleo de palabras antiguas o mal pronunciadas, puesto que se ha considerado que su uso revela el habla de la sociedad criolla de fines del siglo XVIII. Es el caso, por ejemplo, de palabras en desuso 
como: bujeros o abujeros en lugar de agujeros; foradar en vez de horadar; priesa, cuasi, misturados; cima en vez de encima; entro en lugar de dentro; sitiaron en vez de situaron; camparias en lugar de campos o campiñas; terminarse a, en vez de dirigirse; descaecimiento, ladrocinios; al arma en lugar de alarma. También se han respetado palabras deformadas por el uso incorrecto, pero habitual en la ciudad. Es el caso de vocablos como: haiga, mesmo, mormollo, la ansia, la hambre; por tal en lugar de con tal; a la frente, en vez de al frente de una compañía.

Por otra parte, ante las discrepancias que todavia existen respecto a la grafía de los términos y denominaciones indígenas y ante el desconocimiento por parte de la autora de este estudio de las lenguas ajmara y quechua, se ha preferido mantener en el título, introducción y notas la grafía del manuscrito, utilizándose, por consiguientes, las mismas formas con que en 1781 se escribian los nombres indigenas, salvo en el caso de las denominaciones toponímicas, donde se ha utilizado la grafía aceptada por las denominaciones actuales de esos lugares, que emanan de los cuadros jurisdiccionales de la administración política del país, así como de los mapas en uso, especialmente del Instituto Geográfico Militar de Bolivià que, sin duda, son los más precisos y cuidadosos.

En la presente edición del Diario, el texto está separado cada cierto tiempo por barras $(/)$ que van acompañadas de la letra $f y$ de un número; corresponden ellas al paso de los folios, según la enumeración que se les ha dado a las fojas contadas ordenadamente, puesto que el texto original las enumera correlacionadamente cada cuatro folios. Cuando junlo al número aparece una letra $v$, significa que se trata de la misma foja en el reverso (vuelta). Este procedimiento facilitará especialmente la ubicación en el texto del Diario de los nombres anotados en los índices toponímicos y en el ononástico.

El Indice Onomástico cubre solamente los nombres de las personas que aparecen en el Diario; no lo integran, por lo tanto, los de las Notas ni los de la Introducción. 



\section{EL OIDOR FRANCISCO TADEO DIEZ DE MEDINA}

Poco se sabe en Bolivia de don Francico Tadeo Diez de Medina. Posiblemente esto se debe a que murió célibe y sin hijos que se preocuparan de recoger los datos existentes sobre su persona 0 a que le sucedió lo que pasa con aquellos que, por tocarles actuar en regiones lejanas, se desvinculan de sus raíces familiares. Sin embargo, aún cuando el Oidor permaneció en Chile por más de 13 años, no dejó allí muchas vinculaciones viviendo más bien con el pensamiento puesto en su ciudad natal(i).

De ahí que los datos generales que se tenían de él, resulten muy contradictorios. José Toribio Medina y Francisco Antonio Encina, basándose en los Archivos de la Audiencia y de la Capitania de Chile, le mencionan simplemente con su primer apellido(2), Nicanor Aranzáez, en su Dicicionario Histórico Biográfico de La Paz, mezclando los datos que tiene de las diversas familias Diez de Medina, lo llama Tadeo

(1) Existe en Sevilla, AGJ. Audiencia de B. Aires, 70, un documento por el cual puede verse que el marqués de Loreto, Virrey de Buenos Aires, pregunta a Segurola, intendente de La Paz, si conviene autorizar la petición del ojdor Diez de Medina, del 25 de Julio de 1784 para pasar de Santiago a esa ciudad, por dos anos. Segurola se opone terminantemente porque "debe recelarse que entrometiéndose en las ocurrencias indiscretas y culpablemente" perjudicard al gobierno. El Virrey le niega en consecuencia la autorización, en Febrero del 85 , para evitar problemas entre ambos personajes. En 1791, muerto Segurola, el Otdor volvio a hacer la misma solicitud, pero esta vez se dirigió a la Corre, de donde obtuvo el permiso por medio de una real orden del 7 de Marzo de 1792. ANCH, Fondos Varios, vol. 142, Capitanía General, vol. 915. Aún cuando se desconoce la causa exacta, se ve que Diez de Medina no lizo efectivo este permiso hasta 1795, puesto que todavía hay firmas suyas en las resoluciones de la Audiencia hasta esa fecha. ANCH, Aud, Stgo, vol, 216. Por otra parte alargo su permanencia en su ciudad natal por varios años, arguyendo la imposibilidad de viajar porque "los muclios corsarios enemigos han infectado este mar del sur en la actual guerra". Finalmente, en 1800, el Rey le ordenó restituirse a su plaza, con lo que atravesó por tierra, cerca de mil leguas en tres meses, llegando a Santiago el 31 de Diciembre de 1801. ANCH, Aud. Stgo. Vol. 216. Es posible que el Oidor no híciera efectivo el permiso para viajar a La $\mathrm{Paz}$, sino hasta después de 1795, porque debió asumir interinamente la presidencia de Chile, desde Junio de 1792, hasta mediados de 1793, reemplazando al gobernador Ambrosio O'Higgins, que debió permanecer largo tiempo en el sur de aquel país.

(2) Medina, José Totibio: Diccionario Biográfico Colonial. Stgo. 1906, -Encina, Francisco Antonio: Historia de Chile, tomo V. Edit. Nacimento, Stgo. 
Francisco Diez de Medina Romero de Saravia. Por otra parte, aún cuando las fuentes documentales insisten en que murió soltero, Aranzáez lo supone casado con doña Antonia Solís de Astorga ${ }^{[3]}$.

Tampoco eran coincidentes las noticias sobre su nacimiento y sobre su muerte. Si Aranzáez no erraba en la data de su nacimiento, que señalaba en 1725, se equivocaba, en cambio, en la de su muerte, que señalaba en 1799. Sin embargo, tomando como base la documentación de la Audioncia de Chile, se podía señalar que su defunción se produjo en 1803, puesto que esta fecha fue expresamente anotada, ya que se registraba la muerte del que, siendo oidor decano, había asumido en 1802 interinamente el gobiemo de aquel reino.

Estas discordancias se aclararon en gran parte con la lectura minuciosa de su testamento, encontrado en el Registro de Escrituras del escribano público Mariano del Prado(4). Había sido otorgado por don Francisco Tadeo Diez de Medina el 25 de Septiembre de 1801 y, cerrado y lacrado, había quedado depositade en manos de su hermana Tomasa del Corazón de Jesús, religiosa del monasterio de la Concepción. En tal documento afirma el Oidor haber nacido en La Paz el 2 de Noviembre de 1725, ser hijo legítimo de Andrés Diez de Medina y de doña María Nicolasa Vidangos y González, vecinos de la ciudad. Asegura su calidad de soltero, así como el hecho de no tener hijos ni descendientes. Declara estar residiendo en La Paz por "real permiso" como asimismo ser Oidor decano de la Real Audiencia de Chile.

Acompaña al testamento encontrado en La Paz un testimonio redactado pur el escribano público de Santiago, Agustín Diaz, el cual certifica que el 11 de Agosto de 1803 , hatlándose el oidor Diez de Medina muy grave, en cama, ha afirmado haber otorgado el testamento ya mencionado, en su ciudad de origen, al que ahora agrega un codicilo por el cual pide se le sepulte en la Recoleta Domínica de Santiago, a Ias 6 de la mañana, sin pompa alguna. Asimismo, ordena que sus albaceas Juan Francisco León de la Barra y Agustín Valdés recojan sus bienes y hagan inventario extra judicial, despachando de inmediato a La Paz el correspondiente certíicado de su muerte, la que se produjo ese mismo día 11 de Agosto entre 6 y 7 de la tarde. Ya el 5 de Noviembre de 1803, en virtud de lo mandado por el Oidor en su codicilo, el gobernador intendente de La Paz abrió el testamento conservado por la madre Tomasa Diez de Medina.

Estos escasos datos encontrados después de afanosa búsqueda pudieron por fin complementarse con los de una "Relación de Méritos y Servicios" encontrada por la autora de este estudio en el Archivo de Indias. Diez de Medina presentó este

13) Aranzáez, Nicanor: Diccionario Histórico Biográfico de La Paz. La Paz 1915. Aranzáez confunde al oidor Diez de Medina con Tadeo Diez de Medina y Mena, que fue regidor de Cabildo y que fue quien casó con doña Antonia Solís de Ulloa. De este personaje descienden las famjlias Diez de Medina que figuran actualmente en La Paz.

ALP. Registro de Escrituras, leg. 183. 
escrito al Consejo de Indias en 1779 para obtener el cargo de Oidor. Más tarde, en Febrero de 1801, cuanto soljcitó, como vidor decano, la regencia de su Audiencia, completó el documento. El cargo no le fue concedido posiblemente por su avanzada edad (5).

La relación de méritos confirma los datos del testamento y añade muchos otros sobre su actuación en Charcas. Así puede señalarse ahora, que don Francisco Tadeo Diez de Medina y Vidangos fue colegial en el Real de San Juan Bautista de La PJata, en el que estudió Filosofia y Leyes, aprobando los exámenes en ambas facultades: que fue pasante de Latirudad y Artes, con aprovechados discipules; que la Audiencia de Charcas le recibió en su tribunal como abogado, y que el 9 de Enero de 1759 le dio licencia para ejercer la profesión en todo el distrito. Ese nismo año, la referida Audiencia le nombró abogado de pobres y al año siguiente el Cabildo de La Plata le nombró defensor de menores.

Instalado más tarde er La Paz, fue por dos años asesor del Cabildo y más tarde alcalde ordinario. En Enero de 1763, el corregidor le nombró atuditor de guerra de las nuevas milicias. En 1765, la Curia Eclesiástica le designó asesor general. En 1767, el Superior Gobiernu y Tribunal de Cuentas de Linta le comisionó como abogado en una pesuluisa en las Cajas Reales de La Paz. Asimismo, le hizo despnés integrar la Junta de Temporalidades de los bienes de Jesuitas Expulsos, procediendo en ambos casos, con "probado desinterés e infatigable celo". Como vecino distinguido $y$ auditor de guerra, asistió a los cabildos y juntas que se realizaron en la ciudad, con motivo de las órdenes que recibió el corregidor don Vicente de la Fita, del Virrey del Perú y de la Audiencia de Charcas, para que sosegara la sublevación de los indios de Pacajes, que habian matado a su corregidor y a otros españoles. En tales circunstancias parece que fue don Francisco Tadeo quien actuó de modo decisivo, pues quienes le recomiendan en la relación de méritos, insisten en que bastaron los preparativos de guerra y la prisión de los principales amotinados para que todo se calmara que se hubiera necesitado realizar la expedición pacífica que habia preparado el propio auditor a su costa.

En Enero de 1777, fue electo por tercera vez alcalde ordinario de primer voto, pero rehusó el cargo, por sus muchas ocupaciones, con la anuencia del Virrey. Por todos estos antecedentes y con las recomendaciones del corregidor y del obispo de La Paz, así como del Virrey Guirior, consiguió Diez de Medina la plaza de Oidor de la Real Audiencia de Chile, en Agosto de 1779.

Tardó, sin embargo, en ocupar este cargo a consecuencia de la sublevación de 1780, que le impidió salir de La Paz, la que abandonó solamente en Diciembre de 1782. En ese lapso de tiempo, el Oidor fue comisionado por la Comandancia General del Virreinato de Buenos Aires para conocer y substanciar las causas de los principales caudilios que actuaron en Soratal y La Paz. Las implacables sentencias que

(5) AGL. Sevilla. Aud. de Chile, 173. 
dictara por entonces, y que hoy tanto ensombrecen su figura, contaron con la aprobación expresa del Visitador General Jorge Escobedo que, el 7 de Noviembre de 1782, le agradeció "el celo y honor" con que había desempeñado esta comisión.

Por último, en Marzo de 1783, tomó posesión de su plaza de oidor en la lejana Audiencia, con el sueldo de 4860 pesos anuales 6 .

Hasta ese año se extienden los datos manifestados en la relación de méritos. Parece ser, por noticias obtenidas en otras fuentes documentales(7), que don Francisco Tadeo no se contentó con enviar sus antecedentes al Consejo de Indfas, para obtener el cargo de Oidor, sino que se trasladó personalmente a la península, y que cuando volvía para ocuparla, haciendo una estación en La Paz, para arreglar sus asuntos, le sorprendió la rebelión general, con lo que postergó su partida cuánto pudo. Debido a Ios roces que en esta capital tuvo con Sebastián de Segurola así como con el fiscal del crimen de la Audiencia de Charcas, Fernando Márquez de la Plata, debió abandonar la villa, compelido no sólo por estas autoridades, sino que por el mismo Virrey que en 12 de Octubre de 1782 le ordenó terminantemente saiir de la ciudad para ir a hacerse cargo de su plaza de Oidor ${ }^{(8)}$.

Ya en los primeros días del año 1783 se encontraba en Santiago, donde el 10 de Marzo juró su cargo. Como se afirma en la nota (1), después de 1795, viajó a La Paz, para no retornar sino a fines de 1801. Al volver, por su calidad de oidor decano, cargo que ocupaba desde 1790 , recibió la gobernación interina del Rejno de Chile, que había quedado vacante cuando Joaquín del Pino Manrique, que la ejercía, fue llamado a ocupar el cargo de Virrey de Buenos Aires.

No vió coronada su carrera el Oidor con la plaza de regente que solicitó en 1801 sino que, por el contrario, se encontró con que el cargo había sido otorgado a Fernando Márquez de :ta Plata, quien en Abril de 1803, pocos meses antes de la muerte de Diez de Medina, fue posesionado en Santiago. Volvieron a encontrarse

(6) AGL. Sevilla. Aud. de Chile 185.

(7) Pleito del corregidor don Fermín Gil de Alipazaga contra Sebastián de Segurola y Fernando Márquez de la Plata. AHNM, Consejo de Indias, Sec. Pleitos, leg. 20397. —Informe de F. Tadeo Diez de Medina al Virrey Vériz. AGI. Aud. de Charcas 583.

(8) En la correspondencia entre Segurola y Vértiz, existe una carta del 6 de Diciembre de 1782 en que el comandante comunica al Virrey que por fin ha salido Diez de Medina, ese mismo día, a las 5 de la tarde. AGNBA 9/5-5-3. Existen asimismo, numerosos autos por los cuales se le ordena salir de La Paz para hacerse cargo de su plaza en Chile. Pleito del corregidor Gil de Alipazaga... AHNM, Consejo, de Indias. sec. Pleitos, 20397. En AGNA, 9/5-5-3, existe un acta del Cabildo de La Puz, 2 Nov. 1782, en que figura un oficio de Segurola, incluyendo una orden del ministro Gályez que alude a un mandato real, por el cual Diez de Medina debe abandonar La Paz junto con el corregidor Gil de Alipazaga, que debe dejar su empleo para dirigirse a Potosí. 
los dos enemigos de antaño; nada se sabe de sus relaciones de entonces cuando eran dos señorones cargados de años. Posibiemente Márquez de la Plata había moderado su actitud anti criolla, puesto que, casado con una dana de origen americano, ocupó un cargo importante en la primera Junta de Gobierno del Chile que se independizaba.

A las escuetas notas documentales no es posible añadir muchas otras que permitan conocer su personalidad. Se sabe que atín cuando pertenecia a una familia numerosa ${ }^{(9)}$, fue heredero de una gran fortuna y de muchas propiedades en la ciudad de La Paz como en las provincias vecinas $(10)$.

Por las citas clásicas que hace en el Diario, así como por las breves noticias de la Audiencia de Santiago de Clijle, que anotan que llegó a esa capital llevando una voluminosa biblioteca, a las que también se refieren algunas cláusulas de su testamento(1]), puede apreciarse que era un hombre cultivado y erudito en temas latitros y biblicos. La relación de méritos alude a que siendo tanta su instrucción en materia forense fue dispensado por la Audiencia de Charcas de los dos años de práctica, otorgándosele antes de lo que correspondía el titulo de abogado. Las recomendaciones del corregidor y del obispo de La Paz, así como las del Virrey del Perú, se refieren a sus "méritos, literatura, calidad, distinción y conocida probidad". Le califican también como abogado experto e inteligente en la conducción de los negocios tanto de la Curia, como de las Cajas Reales, Junta de Temporalidades y aún de la Auditoría de Guerra, y señalan siempre el celo, la honradez y el desprendeniento con que desempeñó cada una de estas funciones.

(9) Por el testamento y evidencias notariales se conoce como a hermanos suyos a: Rita Diez de Medina, casada con Alonso Baptista León. María Josefa Diez de Medina, casada con Juan Bautista Ochotegui. Catalina Diez de Medina, casada con el teniente coronel Antonio Sanjurjo y Montenegro. Tomasa del Corazón de Jesús, que fue abadesa del monasterio de la Concepcion. María Josefa de San Gregorio, monja carmelita. Juana Diez de Medina hermana del segundo matrimonio de su padre, casada con el capitán de ejército José Maria Iriondo y José Mariano Diez de Medina, también del segundo matrimonio, que vivia en Madtid, como cadete de la compañía americana de Guardjas Corpus de Su Majestad.

10) Por el testamento, se sabe que el oidor Diez de Medina poseía al morir. 13 haciendas importantes, distribuidas en las ricas zonas de Yungas y Río Abajo y en el altiplano; una chacarilla con su tambo, a la encrada de La Paz; terrenos y sitios en los bartios marginales de la villa; la casa que ocupa hoy el hotel Torino y el magnífico palacio de una de las esquinas de la plaza mayor, donde se lraila actualmente el museo de Arte.

(t) En el codicilo otorgado en Suntiago antes de morir, señala el Oidor que deja su biblioteca en el monasterio de Santa Rosa, bajo la protección del obispo de la diócesis, don Francisco José de Marán, quien debe vender las obras de mayor circulación para dar el dinero a las monjas. Los tibros extranjeros, en cambio, deben ser vendidos en Lima. 
Insisten, además, las recomendaciones en que su estudio de abogado era el centro de la actividad forense de La Paz y que por todas las razones anotadas no había quien no le buscara y recomendara, tanto en la ciudad como en los pueblos comarcanos.

Parece importante destacar estos juicios sobre su personalidad en vista de que resultan ellos diametralmente opuestos a los que emanan de las cartas e informes del comandante Segurola, del fiscal Márquez de lá Plata, del Virrey Vértiz, y aún de los que podrían surgir de un estudio psico-social de los juicios y sentencias que el Oidor evacuó contra los caudillos de la sublevación. Incluso un análisis en profundidad de contexto de las anotaciones y consideraciones que hace el propio Diez de Medina en su Diario, podría llevar al lector a conclusiones algo diferentes.

Lo interesante es anotar esas diferencias de apreciación -un juicio no debe imponerse en este estudio- en las que la autora de este trabajo ve claramente en juego las circunstancias tan especiales en que actuaron los diversos personajes de aquel drama y los motivos tan poderosos que movieron no sólo a los dos bandos enemigos, sino también a los actores que intervinieron de una y otra parte, quienes además del enemigo común debian enfrentarse a fuertes tensiones de grupo. 


\section{ESTUDIO PRELIMINAR}

\section{La imagen del oidor en el Diario.-}

Compaginando los datos ciertos y concretos que se tienen del oidor Diez de Medina con los que surgen del Diario mismo, puede irse elaborando un estudio que permita no sólo penetrar en la índole del autor y en el valor del manuscrito, sino también en lo que es más importante, en el hecho histórico mismo a que se dirige su atención, es decir, lo que fue el cerco de La Paz, el significado del levantamiento, la forma en que se condujo la guerra, la vida que se llevó en la ciudad sitiada, las relaciones humanas de los vecinos y las de éstos con los atacantes, las tensiones que se produjeron entre los que ejercian la autoridad $y$, en fin, las innumerables facetas que se desprenden del análisis de un documento con las caracteristicas del que se recoge en esta publicación.

Puede iniciarse este intento de penetración del texto considerando las características psicológicas del autor. Se trata de un personaje que escribe sus notas a los 56 años, lo que entonces podía consicterarse una edad avanzada si se tiene encuenta que el obispo Campos, del que se habla siempre en los diarios como de un anciano, tenía solamente 7 años más que él, y que, en cambio, Segurola y Fernando Márquez de la Plata, que eran quienes conducían los asuntos de la ciudad, tenían solamente 41 años; Tupac Amaru tenía 40 años cuando inició la sublevación y Tupac Catari apenas llegaba a los 30 años. La toma de conciencia de sus años es la que hace hablar al autor siempre que critica una acción militar, política o legal, como consecuencia de la falta de experiencia, del exceso de juventud, de la bisoñez de los otros:

"...cuanto quizi, son bisoños del país y para la táctica poco expertos en el reino, manejo y tendencia de los indios y sus costumbres..." Diario, fol. 21.

"...Pudiera este punto haberse mirndo con otra circunspección, como tan grave y gravisimo, si no se fiase solamente de un mero abogado joven e inexperto, llamado auditor de guerra", Ibid. fol. 31 .

Tai detalle, sumado al hecho de que él está de paso en La Paz, puesto que sólo había venido a recoger sus cosas y arreglar sus asuntos para proseguir viaje a su nuevo destino, adonde debía ir a ejercer sus funciones en la Audiencia, como asimismo, el que no perteneciera a las filas nilitares ni siquiera en los grados, más honoríficos que profesionales, que se otorgaban a los criollos de alcurnia, le obligaban a mantenerse alejado de la vida castrense, lo que no dejaba de dolerle, porque ya fuera por su espíritu bataliador, porque se sentía todavía un hombre de 
energías o porque creía poseer aptitudes especiales para la vida militar, se siente siempre con derecho a analizar a lo largo del Diario cada una de las acciones bélicas, para concluir, por lo general, que fueron desastrosas tanto por la falta de estrategia $y$ de sentido militar como por la cobardia y la deficiencia en la dirección.

"...Pudieron haber logrado en ellos algun astigo, pero como no se dieron disposiciones, ni salieron oficinles... y el comnndante se plantó entro de la trinchera... thvieron que retirarse como acostumbrant.. iEs caso extratio, que sientito superior ef mimero de los nuestros al de los contrarios y nosotros con stiperiores armas, tengamos, por falta de generosidad de aimino y denuedo militar, que retiramos sólo al ver cuatro gatos y no hacer cosa de provecho!" Ibid. fol. $34 \mathrm{v}$.

"... De tal antecedente, ¿cual fin podía derivarse sino el funesto y ruboroso de aquella retirada o fuga intempestiva?.. Todo emanado de la falta de orden, arreglo y stibordinación y de so prevenirse has retiradas ni las acciontes comro corresponde". fol. $17 \mathrm{v}$.

No faltan tampoco las alusiones a la ausencia de adiestramiento, a que no se disciplina a las tropas y a que no se les proeura armas:

".. Las tanzas se van desaparciendo, que los sujetos de las compunias recluladas se presentan en la plazn sin ellas y sin los cuchillos atue se les repartieron. Oue muchas gentes no acuden pronto ni todos, cuando se loca al ama, gue hry poca o ninguna subordinacion por falta de disciptina..." fol. $26 \mathrm{v}$.

Lo que permite, por último, afirmar que el Oidor se habria sentido muy contento de que se le hubiera dejado intervenir en las cuestiones castrenses es una curiosisma carta que dirige al comandante Segurola, el día 20 de Marzo, recién iniciado el cerco, con las "Reflexiones que ocurren a un Ministro y Fiel Vasallo del Rey" (AGI-Charcas 583), en las que él, un docto hombre de letras y latines, se permite dar consejos de orden estratégico, disciplinario, lugístico y guerrero, a un avezado militar español, de larga carrera en la Península:

"...sería preciso que el celo notorio del señor comandante para alentar la tibieza o cobardia de algunos vasallos, les hiciese, antes de la salida al campo enemigo, un razonamiento, estando a caballo, dindoles animo, prometiéndoles buena dicha persuadiéndoles a la venganza, de las injurias recibidas en los contpatriotas, hermanos, parientes y en las haciendas y bientes sustraidos; representando la gloriosa fanta que ganaron en el mundo, los de La Paz, sujetando a tan bárbara, infiel canalla... También serín oportuno... se hiciese la salida concreta y sin rumor, $y$ al son de cajas y trompetas al ganar el Alto de la ciudad, en buena orden, oyendo primero misa a las 2 o 3 de la mantana con licencia del Ilustrísimo Señor Prelado y encomendándose todos a nuestro Dios y Serior tie los ejércitos e invocando al nombre del Espiritu Santo con el himmo Veni Sancte Spiritus".

La ingenuidad de estas y otras reflexiones, escritas en tono grandilocuente, que no pueden dejar sin sonreir al lector más ignorante del arte de la guerra, tienen que haber producido en el comandante no sólo gran hilaridad sino un profundo desdén por este funeionario que termina la misiva ofreciendo su "persona y cortos 
arbitrios para acompañarle en la expedición, ayudarle en las distribuciones de su encargo, servirle y servir principalmente a ambas Majestades". Posiblemente, si alguna cluda tuvo Segurola, sobre la idea de acudir o no a tan ilustre vecino, bastó este documento para que, por lo menos en el orden militar, decidiera prescindit absolutamente de su persona.

Desgraciadamente, para don Francisco Tadeo, la situación de estar de paso y de tener designación para ocupar un alto cargo fuera de Charcas, le mantuvo alejado también de intervenir en la vida política y civica de la ciudad. No integró, por lo tanto, ui el Cabildo ni la Real Hacienda ni uingún tipo de tributal u organismo durante el cerco. Para colmo, los acontecimientos que se produjeron en la villa el 23 de Marzo, que revelan bien a las claras el estado de ánimo exaltado y resentido que le embargaba y que iniciaron la larga serie de dificultades y choques con Segurola, teminaron por alejarlo definitjvamente del jefe de la plaza que, orgulloso, intransigente y susceptible llegó a acusarle de intento de sedición (ver Diario y notas, fol. $13 v$.) prescindiendo ostensiblemente de solicitar sus servicios aún en el orden judicial, donde, en realidad, en el plano jeraiquico, estaba sólo por debajo del fiscal Márq⿻uez de la Plata.

De este modo, el Oidor, a pesar de ser uno de los vecinos criollos de más categoría social, de más fortuna, de más prestigio, se vio totalmente marginado mientras ocurrían acontecimientos tan graves para la ciudad. Por ello, se comprende que en el clesarrollo del Diario trate de demostrar, utilizando las formas indirectas a que se ha aludido más arriba que, a pesar de todo, él es una persona importante de la que no puede prescindirse cuando en la ciudad ocurren problemas graves:

"... ctujo tiempo entró triwnfimente el referido Oidor en la casa que habita el comandante, bajo el convento de Ia Merced, $e$ insinuindole que como inteligente del idioma y de las obligaciones de los vasallos, se sirviese hacerles tin discurso concionatorio que afinzase la buena disposición que manifestaban..." fol. 7.

"Compadecido el señor Medina de su relación (la del corregidor Ramón de Anchoris) y del atontamiento con que se le conoció venir, le hizo preparar alojamiento en la casa que posee contigua a in de su morada". fol. $7 \mathrm{v}$.

\section{Razones para llevar un Diario,n}

Hasta entonces no se había puesto en duda su situación ni su prestigio; ahora, en cambio, se prescindía oflcialmente de su persona, ultraje que él debia borrar, demostrando su autoridad moral, la dignidad de su figura, la generosidad de su conducta, así como su conocimiento del lugar, de su gente y de sus lenguas.

Reducida al mínimo su esfera de actuación, el Oidor, hombre acostumbrado a intervenir en la vida pública, a opinar y a sentar cátedra, parece que abrió sus salones para la tertulia cotidiana, como puede verse en las frases acusadoras que le dirige el comandante al responder a una carta suya: "Muy señor mío, ayer tarde 
recibi por conducto de un escribano una carta de Vueseñoría... su contexto se reduce, a tratarme en los términos más irregulares que es posible, y a la verdad pudiera haberme causado novedad... semejante estilo, si no estuviera días hace asegurado con harto dolor mío de que es igual al que usa en los corrillos, conversaciones y particularmente en la tertulia de su casa". (Pleito de Gil de Alipazaga contra S. de Segurola. AHNM; Consejo de Indias, Sec. Pleitos 20397. Pieza N. 6). A través de largas charlas con amigos que desempeñaban cargos y ejercian tareas oficiales, se fue informando de todo lo que ocurría en los círculos del gobierno militar; puede verse por medio de las notas de pie de página que acompañan al Diario cómo don Francisco Tadeo conocia perfectamente el tenor de las cartas, noticias e incluso muchas veces determinaciones del comandante.

Posiblemente, al calor de esas conversaciones fue como nació en Diez de Medina la idea de elaborar el Diario, puesto que, como se ha demostrado anteriormente, las anotaciones cotidianas no se inician antes del 10 de Marzo de 1781. El texto debe haber circulado por La Paz, en las varias copias que se hicieron, con lo que el Oidor encontró la forma de que se conocieran sus opiniones y quejas, sus juicios y criticas, como asimismo sus prudentes, generosas y ejemplares actuaciones, asi como st esmerado cultivo de los clásicos.

Si Diez de Medina consideró titil este procedimiento con respecto a sus coterráneos, con mucha mayor razón lo juzgó oportuno y necesario en lo tocante a las autoridades virreinales y peninsulares, a quienes debió suponer que Segurola informaba, como realmente ocurría, desde su punto de vista. - En el margen de la carta al Ministro Gálvez con que el Oidor acompañó este Diario, el 27 de Julio de 1781 , dice textualmente: "Con atención a lo que expone Segurola en su informe de $1^{\circ}$ de Julio sobre el mal influjo de este Miristro... no merece contestación, ni se pueden apreciar sus noticias hasta que después se verifiçue cuál ha sido su conducta verdadera..." AGI. Audiencia de Charcas 583.

Con tales consideraciones se puede concluir que este documento reviste características muy especiales dentro del género literario a que pertenece, porque si bien es un diario de los acontecimientos que ocurren en la ciudad cercada, y como tal registra las batallas, las actuaciones de los sublevados, los avances de las enfermedades y pestes, el acrecentamiento del hambre y las actuaciones de los personajes más importantes, testimonia al mismo tiempo el sentir de un funcionario ofendido y marginado que se siente portavoz de todo un estamento social, el criollo; el Oidor, en realidad, quiere identificar sus propias quejas con las de todos los criollos y deja establecida en esta forma la existencia de una fuerte tensión entre las dos grandes fuerzas sociales de la ciudad, la peninsular y la paisana, en momentos todavía algo lejanos de la Independencia en los que habría parecido natural que, por lo menos en el interior de la ciudad sitiada por un enemigo común, no tendría que haberse producido:

"Lo cierto es que en la ciutad, desde antes del sitio de los rebeldes, se suscitó con poca politica no sé qué especie de etiqueta pemiciosa entre los espanoles europeos y criollos, 
Las qute al que manda y gobierna dehio apagarlas... porque estos puntos odiosos y de cotejo, si los unos sirvan o sean unds o menos ütiles, son de malas consecuencias, como se vio en la willa te Oruro, y promucren las guerras intestinas o ciniles y son ajenos de toda máxina racional..." fol. $34 \mathrm{v}$.

\section{Tensiones entre criollos y peninsulares.-}

Evidertemente, Diez de Medina exageraba la situación; posiblemente si se hubiera preguritado a otros criollos si lo dicho por el Oidor reflejaba exactamente su estado anímico, lo habrían considerado abultado; el Diario de Segurola o el del capitán Ledo jamás traen alusiones a rivalidades de este tipo. Sin embargo, se puede ver a través de una larga serie de datos documentales que efectivamente existía una fuerte tensión entre los dos grupos. Si Segurola no lo dice en su Diario, lo afirma, en cambio, en sus informes al Virrey o en el pleito sostenido contra el corregidor Gil de Alipazaga; incluso, en una carta al Virrey Vértiz del $1^{\circ}$ de Julio de 1781, con la que acompaña su propin diario, dice, refiriéndose a cómo ha mantenido la posición de la ciudad:

"... a pesar de las miserias, de la hambre y otros contraflempos... a que hat concurrido an sumo grudo los enemigus demésfices que ya ocultos y ya sin mucho rebozo se manifestabn dentro de ha ciudad... no predto menos que hacer presente a vuestra excelencin, in descargo do mi concioncia, ef ate en esta ciudad tiene ef Rey muchos zasallos que no to parecen... y que creo, comprendilos en esta clase, algunos que no se consideran ser del vulgo we las gentes..." AGL, Charcas 595.

Que, como comandante no se fía de los criollos está clarísimo en los nombramientos que hace; todos sus colaboradores más inmediatos son peninsulares. Sofocada la rebelión investiga la conducta de muchos criollos sospechosos de entendimiento con los alzados y persigue y castiga con verdadera saña a los culpables. (Ver: Causa Criminal de Sedición de Antonio Molina que se sigue ante el juez comisionado por la comandancia. ANB. Sublev. de Indios. M/82).

Un español, el sargento mayor Castañeda, se refiere abiertamente a la situación cuando sertala en su Diario que a los criollos se los considera tupamaristas. (Castañeda, Francisco de, "Príncipales sucesos acaecidos en los dos acedios..." en J.R. Gutiérrez, Documentos para Hia. antigua de Bolivia. La Paz, 1879). El obispo Campos, un criollo, en un informe al Rey que envía el 15 de Noviembre de 1781 dice:

"...El origen de esta falsa caltumina ha sido el sistema que aqui se introdujo muy desde los principios de las rebelaciones, de agitarse entre criollos y europeos la odiosa cuestion de nacionistas, que promovieron los ultimos.a(que) comenzaron públicamente a denominarlos fupamaristas". AGI. Charcas 595.

El tema en sí es muy interesante si se lo estudia en el contexto de lo que ocurrió en Oruro y de lo que pasaba en el resto de los dos virreinatos en las últimas décadas del siglo ilustrado, pero habría que establecer si revistió en La Paz el mismo carácter que en las otras ciudades. Los textos citados, más que revelar una situación de animosidad sorda y arrastrada, parecen indicar sospechas de entendimiento entre 
criollos e indígenas, por parte de los peninsulares $y$, como consecuencia, resentimiento de que se dude de su leaitad, por parte de los paisanos. Además, erá curioso que se presentaran suspicacias de este estilo en el caso de La Paz, dado el hecho evidente de que Tupac Catari amenazó por igual a penirisulares y a criollos; solamente cuando Andrés Tupac Amaru, en el segundo cerco, se ocupó de atacar a La Paz, conjuntamente con Apaza, se iniciaron los llamados a los criollos, es decir cuando, sabiéndose lo ocurrido en Sorata -ciudad en la que a pesar de las promesas del sobrino de Tupac Amaru fueron sacrificados por igual todos los varones de raza blanca - era verdaderamente tarde para atraer sus simpatías. De todos modos, con las salvedades del caso, es eviciente que pocos documcntos de la época testimonian mejor que el de Diez de Medina la existencia de un estado tensional como éste y, si realmente carga la tinta, llevado por su propio resentimiento, está anunciando una situación anómala que tendría que estallar algo más tarde.

\section{El Oidor, un testigo presencial.-}

Con todo esto, puede comprenderse que el Diario de don Francisco Tadeo es un documento escrito por un testigo presencial. Aun cuando gran parte de sus notas están dirigidas a referir batallas y describir ataques, salidas, combates y matanzas, en las que él no participó, cabe pensar que vio desde algún lugar estratégico de la ciudad gran parte de aquellos hechos militanes porque los describe con tanto colorido, tanta fuerza y tal lujo de detalles que no es posible creer que los narrara repitiendo simplemente lo que sus anigos le contaron o lo que hubiera podido recoger de los soldados que habian intervenido en esos acontecimjentos:

"Los granaderos fueron acosados de 70 a 80 intios que les arrojaban muchas piedras por sus hondas, pero, guiados por el inglés don Carlos Rogers que avanzaba con su sable $y$ rodela en mano..." fol. $39 \mathrm{v}$.

"... bajaron los enemigos a pelotones y grupos por todos los serderos... Se Ics sintieron más escopetas que otras veces las disparaban atrincherados, por bujeros y comunicaciones que abrieron por entre los casas quemadas". fol. 19.

Por otra parte, puede afirmarse que aún cuando el Oidor estaba marginado de las esferas dirigentes conoció muchos detalles del acontecer cotiadiano que no estuvieron al alcance de cualquier vecino o de los otros autores de diarios. Hay ocasiones en que no sólo se refiere a alguna carta del caudillo Apaza, sino que la copia con mayor fidelidad que la del amanuense oficial del comandante. (La carta $\mathrm{N}^{\circ}$ 2 de la compilación de Segurola publicada por Ballivián y Roxas tiene una frase trunca que se aclara leyendo la transcripción que de ella hace Diez de Medina, en folio 16v.) Incluso puede afirmarse que cuando no consigue conocer algún documento, que Segurola logra manterier en reserva, monta en cólera y lanza improperios contra el comandante o las personas que le rodean:

"... y no que varias personas sin reseroa de madamas curiosas, le tratan, examinan y le hacen aquella replicas..." fol. 25. 
Testigo presencial es, desde luego, cuando describe el estado de miseria y de hambre que va imponiéndose en la ciudad; cuarido habla de las pestes, de los cadáveres que yacen por las calles, de los abusos que cometen los comerciantes, del estado de las casas que quedaron fuera de los muros, del clamor de las mujeres, de las novenas y procesiones que se realizan en las iglesias. Lo es también en cuanto participa como intérprete que aconseja y amonesta a los alzados en aquellos interminables parlamentos con los indios de las parroquias vecinas, que a Segutola le parecen tan inútiles:

"... para que por medio del serior oidor don Francisco Tadeo Diez de Medina, que sale ambos idionas del reino, se les explicasen y diesen a entender sus excesos y obligaciones..." fol. $18 \mathrm{v}$.

Puede considerarse que el gobiemo, a pesar de todo, no ha logrado desplazar al Oidor de la comunidad civica y social de su ciudad; de sus páginas se desprende, en efecto, que los indios aluden a su persona en cartas y misivas, que ha perdido en un incendio la chacarilla que posee en has afterals, que ha hecho construir una nueva trinchera y ha prestado mulas que no recupera y, sobre todo, que ha participado, aunque él lo explique en forma muy personal, en un aconteciniento que Segurola considera acto de sedicion.

\section{Estado de ánimo del Oidor.-}

E] estado de ánimo del Oidor, a veces inestable, crítico, pesimista, otras veces sensato, prudente, legalista, religioso, amante de su ciudad, o por el contrario, apasionado, violento y orgulloso, se refleja claramente en su estilo.

Escribiendo el Diario en forma indirecta e impersonal, como se ha señalado más arriba, el Oidor pudo expresar con acierto tales situaciones psicológicas, puesto que atribuyéndoselas a toda la comunidad, las expone con mucha más energía, sinceridad y detalle. Era más fácil para él describir la ira, la impotencia, el encono y el rencor que le embargaban si atribuía estos sentimientos a todos los vecinos criollos:

"Lo cierto es que el pueblo gime sin que nadie pueda manifestar los ecos de su padecer, por el método de los dos sujetos que lo gobiernan, que todo lo saben, lo comprenden, to necesitan consejos, no los procuran y ni oirlos quieven". fol. 21.

Podia, por otra parte, defender su propia figura de las acusaciones oficiales mucho más efectivamente si lo hacia prestigiando, como de paso, las actuaciones del Oidor de Chile:

"... habiendo acudido a la plaza mayor los seriores fiscal de Charcas, don Fernando Märquez de la Plata, y el oidor de Chile, don Francisco Tadeo Diez de Medina, recién venido de transito para embarcarse en puertos intermedios a su destino, con sus personas y familia. armadas, dando el ejemplo a que son obligados". fol. $6 \mathrm{v}$. 
"El oidor Medina... se incorporó en la cuesta con el segundo trozo, antintado del deseo de focar y palpar el método, orden y oficialidad destinados para el empeño, que en otros dias se habia frustrado. Animó a la gente que subia de mala gana, echando a muchos que se quedaban atrás..." fol. 14.

Ahora bien; cabe preguntarse, si esto era así, por qué interrumpe bruscamente el sistema elegido y certifica notarialmente que el autor es el propio Oidor. Puede creerse que no era éste su plan original, puesto que la otra versión que se conoce no corta el curso de las anotaciones ni aclara quiến es el autor, cosa por lo demás innecesaria, porque es evidente, Id dice el propio Castan̄eda en su Diario, que se sabía que lo llevaba. Lo más seguro es que ante la inminencia de los hechos y el cariz que iban tomando los acontecimientos decidió enviar el escrito porque a su modo de ver sería la mejor defensa suya ante los cargos de los dos altos funcionarios, cuya formulación y contenido concreto él desconocia.

La identificación de su persona con toda la población paceña se hace real y no sólo subjetiva cuando, en algunas partes del Diario, olvida la forma impersonal y utiliza directamente la primera persona del plural:

"Nuestro comandante se acreditó celoso y..." fol. 6

"Hirieron a varios de los nuestros y nos arrojaban machas picdras..." fol. 19.

"Siendo la fortuna el que entro de ella haiga algutos ojos de agua que escasamente nos abastecen". fol. 21.

\section{Escollos del estilo.*}

La parte del Diario que forma el nudo del documento es la que corresponde a las anotaciones que van desde el 13 de Marzo hasta el final; el resto, constituido por la introducción que narra los acontecimientos de la sublevación general, así como los apuntes que corresponden al mes de Febrero y a los primeros días de Marzo - de cuya redacción se desprende que no se hicieron día a día- son las páginas menos interesantes y las que contienen mayores errores e inexactitudes de información.

Es ese núcleo, por lo tanto, el que merece toda la atención en un análisis del texto y el que revela, por la simultaneidad a los hechos ocurridos, la sensación de un fluir de los acontecimientos, de una compenetración inmediata en las actuaciones, sentimientos, sufrimientos; es la parte que constituye verdaderamente el testimonio de vida de los habitantes de una ciudad cercada.

A veces, desgraciadamente, el Oidor olvida la sencillez espontánea del testigo presencial que se limita a describir lo que ocurre en torno suyo y, tomando conciencia de la jerarquía de su cargo o de la responsabilidad que le cabe de decir cosas graves e importantes, destinadas a permanecer para las generaciones futuras, cae en discursos y meditaciones pesadísimas, altisonantes y falsas, llenas de recursos jurídicos, clásicos o bíblicos que le hacen perder todo el encanto, frescura y autenticidad de otros párrafos: 
el ocio... "s puerta para periler las fureras, aniquilar el valor y aventurap la victoriar como, porque en opmión de Salustio, no con los ruegos y stíplicas de las mujeres se consigue ut auxilio de los dioses". fol. 6.

"Y asi, phtede decirse con verdad, que se hizo otro Atlante del hemisferio de la paz; o más propiamente, otro Gylipe, fanoso general de Lacedomonia..." fol. 31.

"... segura camina a sa rum Republica que, olvitada de los medios que la sostsngant, abmza los del descmiso..." fol. 31.

Trozos como esos, dirigidos posiblemente no sólo a los auditores de su tertulia o a las autoridades españoles, sino a la humanidad, con los cuales don Francisco Tadeo quiso mostrar la calidad de su fomación, la profundidad de su cultura y la penetración de su pensamiento, son precisamente las que quitan atractivo al Diario, hacen odiosa su lectura y le muestran como un personaje pedante, pretensioso y adulón (Véanse las páginas finales dirigidas a hacer la loa de Ignacio Flores).

También parecen ingratos al lector otros pasajes en que Diez de Medina, con alardes alambicados y manieristas, pretende demostrar la elegancia de su pluma. Pierde entonces la calidad expresiva de los párrafos simples y, creyendo obtener gracia y galanura, cae en la cursilería y el rebuscamiento:

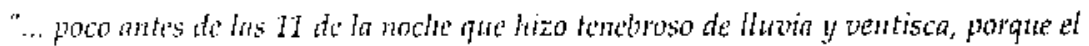
mblato ocultaba el bendicio de la lon ..." fol. 10v.

"Y si el dia de ayer fueron los jubilos y los contentos tan extremados... cuanto más se dihtarian los ánimos festivos rebozando phaceres y expresiones de alegria ..." fol. $44 \mathrm{v}$.

$\Lambda$ veces, el autor, llevado por sentimientos humanitarios, pide justicia y caridad para los habitantes pobres de la ciudad, a quienes no se les procura alimentos o a quienes se explota con el alza de los precios. El lenguaje es entonces perentorio y exigente:

"La mortalidad ha seguido con los dias por la catusa del hambre; la ciudad se halla exhausta de gentes en sus calles... los ninos y muchachos gritan pidiendo socorro por las calles, esquitas y plaza mayor. Los almentos se han constmido sin arbitrio para auxiliar a los menesterosos hambrientos". fol, $42 \mathrm{v}$.

\section{Notas en falso.-}

En cambio, cuando el clamor de justicia se dirige a la actitud agresiva del comandarte hacia los indios, para to cual acude siempre a los argumentos del derecho indiano que se refieren a la guerra justa y a cómo ha de llevarse ésta, adquiere de inmediato una nota falsa, porque es inposible considerarlo haciendo abstracción de las frases despreciativas y duras de otros textos o de la circunstancia de que si bien ahora pide guterra defensiva, horas antes o días después reprocha a Segurola porque no sube al Alto a atacar a los rebeldes y destruirlos en su propia madriguera para someterles definitivamente: 
".. pties su Majestad, en la Ley de Indias, con su gran caridad, desea que se les perdone atin por los delitos cometidos contra su real persona". fol. 31 .

"... no hay facultad para hacer guerra abicrfa a los indios sin licencia det Rey y aqui. por ser agresores de esta población pactfica.. sólo hay arbitrio para hacerles la guerra defensiva..." fol. 31.

"...dulo siempre el señor Oidor que se pueda sacar fruto alguno de anudlos pechos barbaros, obstinados, apóstatas de nuestra fe y rebeldes que, sólo a la vista del rigor podrán aplacarse y subortinarse". fol. $19 \mathrm{v}$.

Tampoco es convincente el Oidor cuando acude a reflexiones de orden moral o religioso. Ellas naturalmente testimonian su catolicismo y posiblemente el de toda la ciudad paceña, pero más que una actitud religiosa, de caridad profunda, de raíz teológica, revelan una religiosidad formal, de frases, novenas, procesiones, actitudes pacatas y juicios condenatorios:

"Y por la aprchensión de dicho tuerfo, debenos rendir muchas gracins a la intercesión poderosa de nuestra Seriora de La Paz, nuestra titular y patronta..." fol. 25v.

"... aquellas nuevas del religioso que se vino al campo enemigo, cutre los rebeldes, que dice misa sin hicencis del ihstrisimo prelado..., whe hace cosamientos sin ella, que entiera y gue por hacer granjeria de estos sacramentos es de presumir se wito al Alto". fol. 32v.

"En este día Domingo se santificó al Sentor con la degollación de ma india que llevaba de la ciudad coca al campo de los levantados...". fol. 30v.

\section{Gracia y espontaneidad.-}

Pero no todo son escollos jiterarios en los escritos del Oidor. Cuando, olvidando reflexiones, discursos y loas, dedica sus notas simplemente a narrar los sucesos del día, ya se refieran éstos a los combates, a la vida cotidiana de la villa, a lo que acontece más allá de los muros, a escenas casi anecdóticas del vivir indigena o doméstico, su lenguaje adquiere notas llanas y sencillas que transforman el escrito en algo espontáneo, fácil y simpático, logrando así obtener la calidad literaria que buscó en vano en la gravedad y pesadez de otros párrafos. Es entonces cuando se ve al funcionaria preocupado pero sereno, al vecino que conoce a los pobladores de La $\mathrm{Paz}$, al personaje importante y bien relacionado, al hombre sensible al dolor de los otros, al fino observador que capta el colorido de ciertas escenas, al criollo amante de su tierra y de su villa y casi diríamos al escritor que sabe expresar el encanto poético de las cosas sencillas:

"... después de haberse conmovido y agitato los moradores, trasladándose a las iglesias y de irincheras para adentro los que habitan fuera de ellas, poblando las mujeres el aire de suspiros, clamores y llantos". fol.9v.

Describiendo un combate en la casa de altos de un tal Garicano, que terminó por incendiarse, se refiere a un indio que disparaba las bocas de fuego y que luchaba vestido muy curiosamente: "... Con cuyn hamareda y Hamas fueron saliendo y 
entregandose, cosa de 47... fuera te otro de cabriolé (capote o levita) encartado, de peluca y sombrevo de tres picos, que dicen se entrego a la zoracidad de las llantas". fol. 19v.

Véase, con referencia al párafo anterior, la escena de la llegada de Mariano Murillo, desfallecido y con los brazos amputados, a quien un "oficial tontificado" no quiere abrirle las puertas porque no tiene órdenes del jefe de la plaza. fol. 38; pintoresca es también la referencia a un balazo que perfora una capa en todos sus pliegues sin causar ningtin daño a su dueño. fol. $40 \mathrm{v}$

Como vecino amante de su ciudad puede vérsele en fol. 45.

No se puede dar término a un juicio sobre el estilo literario de Diez de Medina sin aludir al contraste que existe en sus escritos entre el lenguaje grandilocuente $y$ erudito a que se ha hecho referencia y el empleo de palabras deformadas por el uso poco culto que de ellas hace el pueblo. No parece ser que se deban a errores del copista porque, repitiéndose con mucha frecuencia, no fueron corregidas por el propio Oidor que, como se ha dicho antes, revisó personalmente el Diario:

"Se' haiga hecho mal...". fol.5.

"...se vicron tres cu la mesma forma". fol. 23.

"... en Ia cindad haiga algmos ojos de agma". fol. 21.

"cerrados entro de casa". fol. 37.

"... por los bujeros abiertos...". fol. 32 .

Una ciudad, un muro, un contomo.-

Lo que representa en verdad el núcleo de este valioso documento es, como se ha dicho antes, 10 que ocurre entre el 15 de Marzo, cuando se inicia el cerco, y el $I^{\circ}$ de Julio de 1781, cuando Flores libera la ciudad. Es decir, el tema central del Diario es el testimonio vivencial de lo que sucedió con el primer sitio de La Paz. El Oidor ha logrado, en este sentido, posiblemente sin pretenderlo, que el lector experimente una curiosa sensación, la de sentirse trasladado en un corte espacial y temporal a una ciudad constrexuida por unas murallas, durante un periodo de cinco meses. Ahora bien, como el fenómeno de aislar en ese corte el hecho histórico que fue el cerco de Tupac Catari no lo hace un historiador contemporáneo al lector que habría pretendido imponerle sus puntos de observación, convirtiendo el enfoque en algo estático, sino más bien el propio lector conducido por el mismo autor, que es un personaje que está describiendo día a día la experiencia que vive, se logra penetrar con verdadera vibración emocional esa parcela histórica que conserva de esa manera su eserncia dinámica y viva.

Ubicándose en esa tesitura es ya más fácil inichar el análisis de la situación real que se produjo por el ataque indígena a una ciudad hispano criolla que soporto un asedio de cinco meses. Es decir, hay que pensar que los acontecimientos se 
desarrollaron en una villa defendida por una muralla que separaba a dos mundos; por un lado estaban los sitiados, por el otro lado los sitiadores; dentro estaban los grupos de gente blanca, fuera, los indígenas. Existía, por tanto, una ciudad, un muro que la protegía y un espacio que, rodeando tal muro, servía de contorno a la villa. Esa ciudad, ese muro, ese contomo eran el escenario de una tragedia sufrida por el choque de dos grupos étricos, que hasta ese momento habian convivido en forma más o menos normal y pacifica.

Evidentemente, esta visión de los tres elementos que constituyen la circunstancia espacial del tema estudiado no está presente ni en las anotaciones ni en el pensamiento consciente de Diez de Medina. Se trata solanente de un recurso metodológico de la autora de esta Introducción para poder analizar más organizadamente los mil temas que afloran en las páginas del Oidor.

Siguiendo ese esquema puede darse una mirada ordenada a todo to que el autor dice sobre la ciudad misma y lo que sucede en ella, como también sobre lo que acontece fuera de los muros, en el mundo de los sublevados.

Ahora bien, para que del análisis de los textos no resulte una visión estática del hecho histórico que se observa, se irá, en un segundo paso, al estudio de lo que el Oidor dice sobre las relaciones de esos dos sectores separados por la muralla.

Vida cotidiana en la villa paceña.-

La villa paceña, que antes del cerco comprendía también las tres parroquias de indios de Santa Bárbara, San Sebastián y San Pedro, quedó constreñida por la muralla al casco primitivo del siglo XVI, Los barrios indígenas se habían ido uniendo al centro urbano español por la instalación de vecinos paceños en la zona periférica, intermedia entre aquél y las parroquias de indios. Incluso contraviniendo las reales ordenanzas se había ido desplazando a los naturales de los tres pueblos a Ias zonas marginales de esos barrios. Eso explica el que, construída la muralla, los pobladores hispanos de esas zonas tuvieran que trasladarse por orden de Segurola a la parte amurallada, abandonando sus habitaciones y trasladando los enseres indispensables, para instalarse en claustros de conventos, atrios de iglesias y zaguanes de casas grandes:

"Siendo lo más lamentable que las gentes pobres se hallan durmiendo, olbergados en las iglesias, sacristias, conventos, cementerios, calles, patios de las casas, entre trincheras". fol. $22 \mathrm{v}$.

Nuevas referencias a esos sectores urbanos aparecen en el Diario cuando, al correr de los días, el autor va señalando que los alzados han quemado la casa de fulano o mengano, un determinado molino u obraje, o la chacarilla de éste o aquél.

De las notas del Oidor se desprende que en La Paz amurallada hay grupos de clase alta y adinerada, integrados por españoles y criollos, que son los que contribuyen con sus armas y personas a las milicias, y con sus aportes económicos al sostenimiento de la guerra; distraen las jornadas del asedio en juegos, tertulias y devociones: 
"Y en efecto, acreditaron con este motivo su lealtad, por las asignaciones que cada who hizo, segin sus fondos; whos con vineres, otros con dinero, who vistiendo y atavinuto wha compania, otros costeando alymos espaldones del afrincheraniento". fol. 6 .

El día martes 1 de Mayo anota: ... esperaron a que las gentes saliesen de la iglesia catedral, de misa de 12, donde concurren muchos...". fol. $27 \mathrm{v}$.

Por debajo de ellos se percibe la existencia de un sector mucho más amplio de gente modesta, que integra la tropa, que lleva el escaso comercio que puede mantenerse y que acude a los mercados que organizan los atacartes. Está constituído ese cstamento por gente blanca venida a menos o por mestizos de pretensiones.

Un poco más abajo están los "cholos", mestizos en quienes priman los rasgos indios, que son los que especialmente desempeñan los oficios de amanuenses, sastres, plateros y artesanos y que constituyen el elemento más inestable de la población en lo que se refiere a la traiciones y defecciones: $23 \mathrm{v}$.

"En dicho Alto, descuartizaron an cholo, que corre fie de miestros desertores...". fol.

"El de la nueva, fue un cholo traidor...". fol, 47.

Hay todavía un sector indígena constituído por la gente de servicio y por los indios amigos. A ellos se les utiliza muchas veces como correos o espías, pero ofrecen tan pocas garantías de fidelidad que rápidamente, sobre todo ctando no integran la clientela de alguna casa, se les instala fuera de los muros, con lo que si bien es cierto que se evita un peligro, se les empuja a sumarse a sus hermanos de sangre:

"A poco rato salió... uno de los cuatro capitantes de los indios amigos (que estän en cuatro cuarteles fuera de trincheras, en la ciudad), con su fusil y en medio traje de indio... Lo conocieron, le dijeron: 1 Quitate esa camiseta o traje, que ho te corresponde, deja las amas y ven de paz a tratar con nosotros!". fol. $18 \mathrm{v}$.

Un último elemento social lo constituye el grupo negro integrado especialmente por los esclavos. En el Diario hay pocas referencias a su actuación, pero se nota su presencia por una $u$ otra alusión que les muestra actuando junto a los españoles en la defensa de la ciudad:

"Hacia el Calvario, mataron o degollaron un pobre moro que habia salido en solicitud de comidas o habas, y se llevaron la cabeza". fol. 18.

Como era de suponex, en los primeros meses de asedio la vida no se detuvo en la ciudad; los funcionarios públicos siguieron desempeñando sus tareas en el Cabildo, en las Cajas Reales, en las notarías y en las oficinas fiscales. Por otra parte se ve que nacen actividades nuevas destinadas a la construcción y reparación de armas de fuego y de armas blancas, preparación de pólvora, confección de 
uniformes, almacenamiento y distribución de viveres, actividad hospitalariá y vigilancia nocturna.

".. pasó oficio por el señor comandante al Ayuntamiento..." fol. 6.

"... manifestó nuestro comandante en Junta de Hacienda..." fol. $6 \mathrm{v}$.

"El Gobierno diputó a Don Antonio Saenz de Tejada para acopiar viveres que yn escaseaban..." fol. $6 \mathrm{v}$.

La actividad religiosa se acrecentó con novenas y devociones por medio de las cuales el pueblo elevaba sus súplicas a Dios o a Ntra. Sra. de La Paz: fol. 29 .

"Este día que fue el último de la segunda novena de Nuestra Señora de La Paz..."

Las relaciones sociales se mantuvieron en tertulias y corrillos e incluso en fiestas y saraos en los dias de Carnaval:

"El lunes de carnaval aconteció otro alarma falso... por causa de unos borrachos... que hacian bullicio en el barrio de San Juan de Dios". fol. 6v.

Las mujeres prosiguieron sus labores caseras, sobre todo en las clases más bajas, donde debieron realizar verdaderos milagros para conseguir distribuir y racionar los escasos víveres de que disponian.

Que este ritmo vigoroso de vida fue decayendo más adelante, se evidencia en las páginas del Diario. A medida que pasa el tiempo y se espera en vano el auxilio prometido, el ánimo de los pobladores decae, las instituciones cívicas ya no tienen tareas que realizar porque el comandante militar to ha absorbido todo. Los profesionales y artesanos se hah convertido en meros defensores, los clérigos se han transformado en enfermeros o enterradores, el harnbre ha ido postrando las energías; las enfermedades y pestes han diezmado a los habitantes; la falta de sueño y el agotamiento de los combates nocturnos han adormilado la actitud de alerta anterior y, lo que es más triste, el recelo, la desconfianza y la antipatía entre civiles y militares, entre amigos del comandante o del corregidor, entre la nueva burocracia y la desplazada, entre blancos y mestizos y sobre todo entre criollos y peninsulares, han llegado a límites increibles, debido todo, más que a la culpa de unos u otros, al estado de tensión psicológica producida por el ataque incesante de los indígenas, el hambre acuciante de los pobladores, el hedor insoportable de los cadáveres que yacen en las calles y la esperanza que se frustra día a día.

"La ciudad sigue con la epidemia de la disentería; toda ella es un congoja en la calle se van cayendo los hombres muertos de necesidad...". fol. 34 . razón..." fol. $40 \mathrm{v}$

"... cuyas irregularidades fatigaron y exasperaron al comandante, con fundada

"... a excepción de un centinela nuestro que, por quedarse dormido en el paredón de Riva, se cayo del tejado, fuera de trincheras y fue sorprendido de los indios que lo degollaron". fol. 42. 
Si se medita un poco en las frecuentes frases que el Oidor dedica a la actuación de Bartolina Sisa y de otras mujeres indígenas, se puede apreciar el silencio que guarda respecto a las mujeres españolas. Las frases que se han colocado más arriba sobre su tarea dentro del vivir cotidiano obedecen a una intuición nacida de brevísimas alusiones sobre lo que les ha sucedido a algunas que circulan por las calles y mueren o son heridas por los atacantes, a los clamores que lanzan por el hambre y sufrimiento de sus hijos, a las salidas que hacen para recoger algunas yerbas, a la captura que sufren cuando caen en la trampa de los mercados que preparan los indios frente a los muros. Puede comprenderse con ello que ninguna mujer, dentro de la ciudad, se destacó por su bravura, por su caridad, su sentido de organización, su actividad hospitalaria. Podría pensarse que esta apreciación obedece al poco interés que suscita, en este solterón empedernido, el elemento femenino, pero no puede dejar de reconocerse que tampoco hay frases laudatorias para ninguna mujer española en los otros diarios.

En cambio, se encuentran numerosos textos ricos en colorido para describir episodios de la vida cotidiana en La Paz de aquellos días. Pueden referirse éstos al miedo que se sufre ante los ataques; a la actuación de algunos personajes en las distintas fortalezas; a la subida de los precios; a los efectos de las balas; al estado atmosférico; a la indignación o admiración que se produce en los vecinos por las acciones indígenas; a la triste celebración de las festividades religiosas; a la miseria que va cundiendo dia a día.

"... a un abugudo Avcllaneda, habiendo muerto una mula suya, que muchos días subsistió comiento tierra y aue estaba faca como un esqueleto, le instaron a vender a la rebatiña cada cuarto de cilla por cinco pesos, tanto que las carnes de esta bestia (que no valdría cuatro a seis pesos) rindieron 30 pesos...". fol. 34 .

"... los señalados a resguardar las trincheras se retiraron con sus armas o las ajenas, a dormir a sus cosas con no menor peligro de la ciudad y obligando que de diferentes trincheras viniesen unos en pos de otros..." fol. $41 \mathrm{v}$.

En las notas alusivas a la vida cotidiana, suelen aparecer frases con las que el Oidor hace gala de sentido del humor, pero, a decir verdad, puede apreciarse que resulta ingenuo y rebuscado. Sus expresiones no obedecen a una irenía fina, a un sentido optimista de la vida o a una observación picaresca o sabrosa de lo que sucede, con lo que sus críticas habrian tenido posiblemente mucho más eco:

“... está, al parecer, Bonifacio alias Malifacio Chuquimamani de cabriolé encarnado...". fol. 23.

Es más bien el tono grave, patético, trágico, el que prima en las páginas de Diez de Medina. Con ese tono, añora la anterior grandeza de la ciudad hoy sumida en la destrucción; se lamenta de las injusticias que se producen con la antigua gente de prosapia, hoy marginada; o bien describe el hambre que cunde por todas partes 0 se refiere a las pestes que diezman a la población, a los cadáveres que yacen por las calles porque ya nadie tiene fuerzas para sepultarles. Claro está que no eran éstos 
temas para provocar tranquilidad o placidez en ninguno; también los otros diarios manifiestan dramatismo y tragedia, pero tal vez con mayor sobriedad matizada por tonos más serenos:

"La hambre es cada dia más sensible y asi se ve comer a la gette polve, carne de mulas, de borricos, perros y gatos, no sólo de los que por conter matan de propósito y arrebatan en los calles, si los dueños se descuidnron, sino de los que mueren naturalnente accidentados o de pura fanguezar, se ve que al punto de arrojarlos a las calle's, los descuartizan y aprovechan a la porfía y se llevan la carne los concurrentes". fol. $27 \mathrm{v}$.

"... a don Juan de Higuera le sacaron ya la bala, que parece no haber internado mucho, aunque raro de los aqui heridos... es el que se salva, por la penuria de profesores peritos, que clama in común consternación...". fol. $43 \mathrm{v}$.

Donde el dato, en cambio, es sobrio y escueto, es cuando el Oidor describe la muerte que los blancos infieren a los indios. Sólo protesta alarmado contra una absurda brutalidad, cuando, por orden de Segurola, se ejectuta a prisioneros o indios sospechosos, en la plaza mayor. La descripción se hace detallada, en cambio, si la acción de matar la realizan los indios que torturan a los soldados rezagados, españoles prisioneros o cholos desertores:

"Es corricnte que murieron de 32 a 34 enemigos y que con los heridos pudieron llegar a 80 mis o menos, sin que de los nuestros hubitse más ape salir con la cabeza rota el dicho Rogers". fol. 17.

"... se dice que a los indios prisioneros y alzados... los sentenciun a pena ordinaria de degüello, por lo ordinario, con sólo el mérito de su confesion tomada sin intervención del protector de naturales, sin sumaria.. (si) se suspendiese obrar sobre la marcha, con tanta mortandad... entro de las trincheras... pudiera suceder que verificada la pacificación... hubieran continuado estos indios pagando tos reales tributos...". fol. $30 \mathrm{v}$.

Un señor Saldaña. "que por demasiado indiscreto se arrojó fuera de trincherns... le rodearon y sacrificaron cortandole la cabeza, manos, picrnas, gentiales y corazón, que se llevaron consigo con mucha algazara y sus bailes que en rueda acostumbran". fol. 22v.

\section{El tema de la guerra.-}

Pocos asuntos posiblemente acaparan más la atención de Diez de Medina que los referidos al tema de la guerra. Es allí donde el jurista expresa con más ardor su fallida vocación de militar. No siempre, desde luego, sus puntos de vista son certeros, ni sus críticas aceptables, pero nada le interesa tanto como el referirse a las armas que se usan, a los alistamientos que se practican, a las estrategias utilizadas, al ardor de los soldados, a la disciplina, al estado de las fortalezas o al espíritu que anima a los defensores.

Es en estos aspectos donde se nota con más fuerza la actitud crítica y negativa del Oidor; las armas son escasas, siempre están en mal estado y no se las cuida ni compone jamás; la revisión de las milicias, así como los ejercicios, no se practican 
nunca. Es curiosa en este sentido la insistencia en afirmar que por fin a los tantos y tantos dias de asedio se ha practicado la primera revisión de la tropa, olvidando el autor que ha dicho exactamente lo mismo días antes. Los planes de acción son siempre absurdos y no obedecen sino a la inexperiencia o al desconocimiento geográfico del lugar. Las tropas son atolondradas y cobardes. A los soldados raramente los empuja el celo patriótico o el ardor militar; lo que les impulsa es por encima de todo el pillaje.

A todas esas caracteristicas, agrega, explicando así la inoperancia de las milicias, la indisciplita, actitud constante en todas las tropas, que para el Oidor, más que a una reacción de individualismo del soldado de entonces, se debe a una falla en la conducción, adiestramiento y formación de los cuerpos militares, por parte de ta comandancia:

"... lo que mís cautiva la imaginativa es... que tmos soldados ignaros de las propietades de Marte... se haym principindo a celar por el saqueo o botin". fol. 8v.

"... ¿qué acción podfa regir un cuerpo ast acéfalo, sin disciplina y nada ordenado ni dispuesto?... ¿Chál fin podín derivarse sino el funesto y ruburoso de aquella retirada o fuga interypestiva...?". fol. $17 \mathrm{v}$.

"... Hay poen o nirgtura subordinncinin por falta de disciplina... ni una revista se ha achudo de la gente ni de has armas en 46 dias que lewmos de sitio...". fol. 26v.

Dos personajes que chocan.-

Posiblementc, el pesimismo que envueive al Oidor en todas las anotaciones que sc refieren a la forma en que se lieva la guerra se debe a que las consideraciones de este género están siempre enredadas con los juicios que le merece al comandante Segurola. La antipatía que se tienen ambos personajes es una de las cosas más evidentes a que puede llegarse cuando se indaga en la documentación de ese período. Segurola lo manifiesta sin ambages en los informes a Vértiz o a Gálvez, como puede verse en la correspondencia existente en Buenos Aires o en Sevilla, como asimismo en las fojas del pleito de Gil de Alipazaga. En su Diario, en cambio, no vierte un solo juicio sobre Diez de Medina, limitándose a ignorarlo absolutamente, puesto que no lo menciona jamás.

Por el contratio, el Oidor, que no puede acusar a Segurola de nada concreto, se limita, en sus escritos dirigidos a las autoridades, a defenderse de los cargos que supone, con toda razón, le ha hecho Segurola. En el Diario, en cambio, se explaya, porque allí puede expresar en un enjuiciamiento cuotidiano, cada acto del comandante; puede describir el proceder desagradable y ofensivo que Segurola ha tenido hacia él, pero que no alcanza a constituir un delito del que se le pueda acusar judicialmente, no sólo porque emana del jefe de la plaza que tiene plenos poderes sino también porque no pasa más allá de gestos de desprecio, burla y prescindencia.

Don Francisco Tadeo ve en esta actitud la expresión del choque criolio peninsular y por eso quiere hacer de su problema una situación que concierne a 
todos los criollos. Ya se ha dicho que evidentemente tal tensión existe, pero no puede negarse que en el caso concreto de estos dos personajes el problema no es sólo de este orden; aquí se trata simplemente de dos personas que por sus características psicológicas se repelen, por lo cual nunca podrán entenderse ni juzgarse mutuamente sin suspicacias ni apasionamientos. Ahora bien, con la lectura de la documentación citada se capta una situación muy clara de menosprecio y desconfianza for parte del comandante, que prescinde ostensiblemente de la asistencia y de los consejos del Oidor, a quien considera entrometido, vanidoso, de cortos alcances intelectuales y sobre todo intrigante. En un informe al virrey Vértiz dice: "... se inserta una carta que llena de insolencias y procacidades me escribió dicho señor ministro, sin más causa que su odio y aborrecimiento hacia mí...". Pleito del Corregidor Gil de Alipazaga. Pieza N6.

"Si yo me estendiese a manifestar el espiritu de predominio con que dicho señor Medina, ha vivido siempre en esta ciudad... y que el no haberlo podido lograr sobre mí me ha causado su enemistad..." Pleito de Gil de Alipazaga. Pieza $N^{\circ} 6$.

La actitud de Diez de Medina, en cambio, si bien corresponde, según la documentación citada, a la inagen que se ha trazado el comandante, ya que desde el comienzo le envía instrucciones de orden militar, pronuncia sermones moralistas a los indios, participa en un episodio, el 23 de Marzo, que Segurola califica de subversión, y le dirige cartas muy insolentes para defenderse de los cargos que se lo. van haciendo, aparece muy diferente en el Diario. Allí, el autor se describe indirectamente, como se ha dicho, como un hombre sumamente justo, medido, sereno y generoso, pronto a perdonar cualquier insulto del jefe de la plaza.

Dedica al mismo tiempo interminables párrafos para desacreditar a Segurola. Unos están dirigidos a criticar la forma en que se llevan los asuntos de la guerra; el Oidor no puede perddnar al comandante el que no venciera a los sublevados cuando volviendo de Laja los encontró en el Alto iniciando el cerco; no puede aceptar que limite sus acciones a mantenerse dentro de los muros y no dirija campañas al altiplano, destinadas a derrotar definitivamente a los indios:

"... hoy no se trata más que de aguardarlos, montor cada 24 horas las guardias en trincheras y paredones, desconfiando enteranchte de otra acción para contener los enemigos... Bien que la tropa tampoco se disciplina, no esfá aguerrido y, consiguiontemente, sin uso, expedición ni ejercicio y sin armas de fuego...". fol. $21 \mathrm{v}$.

Critica las salidas fuera cte los muros que realiza el comandante porque están encaminadas a objetivos muy poco importantes o están mal preparadas y peor dirigidas. Le enrostra el que envía oficiales sin pericia que no saben regir los combates y que no logran imponer disciplina a la tropa que se dedica sólo al pillaje o a huir desordenadamente. Le acusa porque se queda en la ciudad y no sale personalmente a conducir las milicias en las batallas:

"... pero sin destinarse oficiales, como siempre, parn las companias, ni quién las comande y gobierne, porque el comandante que los llevó hasta la puertr de la trinchera de las Recogidas, alli se quedo". fol. 33 . 
Otras veces hace ver que Segurola descuida la vigilancia de las fortalezas y no aprovecha las ocasiones para coger o matat a Tupac Catari que se ha acercado imprudente y temerario hasta las mismas puertas de la ciudad:

"... a cxtramuros de Sal Pedro, donde bajo el caudillo conjurado con su comitiva... QQué ocasión para aprehendorlo! Pero cono nada se procura fuera de trincheras..." fol. $16 \mathrm{v}$.

En otras oportunidades, las acusaciones se dirigen a la prepotencia con que ha ido acaparando los hilos de la cosa pública, para lo que, asesorado por Márquez de la Plata, ha desplazado a los funcionarios que detentaban la autoridad. Más allá le enrostra el despotismo con que lieva la conducción de la ciudad donde todos le aborrecen pero callan por temor:

"... fodo corre y pasa por la oista y aprobación del conandante... entiende en causas civiles. aciúa en todo lo político, como si la comisión que tiene na fuese para un solo y cierto efecto, como ol de vice gobernador de armas... sin periuicio de las factiltades del conregidor a atien timen arrollado como min estafermo, por el mucho ceto de la autoridad de los que gobiernat". fol. $35 \mathrm{v}$.

Senala los abusos que permite en cuanto al acaparamiento de los alimentos por parte de algunos comerciantes que prosperan a costa del hambre de la población.

Destaca el poco respeto que le merecen las prácticas forenses, puesto que interroga a los prisioneros por sí mismo, designa auditores de guerra a su antojo y encarcela en lugares que no corresponder:

"El comandante destinó un cuarto a este therto... de la provincin de Azángaro... en la casa donde habita... seria oprortmo se le pusiese en bucha guarda y custodia hasta tas resultas finales de la causa, segin derecho, y to que varias personas... le tratan, examinan y le hacen aquella réplica que le pueden prevenir para sis exculpaciones simuladas y falsas y sean inpeditivas de indogar la verdad...". fol. 25.

En realidad, el recuento de las acusaciones, a veces razonables, otras contradictorias y las más de las veces injustas, revela, más que la ineptitud de Segurola, a quien los autores de los otros diarios o las autoridades le reconocen don de mando, capacidad organizadora y calidad militar, la profunda inquina y animosidad hacia su persona que domina al Oidor. Aunque se ponga la mejor disposición para entenderle e incluso no se sienta simpatía especial por el comandante, es imposible leer tales acusaciones sin comprender que más que un sentido de justicia lo que las anima es un profundo rencor y un resentimiento sin límites hacia el hombre que le ha marginado y no le ha permitido ser el personaje de primera fila que ha sido siempre.

Más allá de la muralla.-

Lo que ocurre más allá de la muralla, en el contorno espacial que ocupan los indígenas, es también tema constante en las páginas de Diez de Medina. Ese 
contomo comprende la parte inmediata, integrada anteriormente a la ciudad, que ha quedado fuera de los muros en los tres barrios de San Sebastián, Santa Bárbara y San Pedro. Los tres sectores ocupan las faldas o cuestas que llevan al Alto, ya sea por los caminos de Lima y Potosí o por los que llevan a Potopoto y Pampajasi. Más arriba de estas cuestas se extienden los campamentos de los atacantes que se han instalado en la zona altiplánica que bordea la gran oquedad paceña on un área bastante amplia. Gracias a esa ubicación vigilan la ciludad y sus alrededores, así como también las vías de acceso por las cuales podrían verir los ejércitos auxiliares.

En tal extensión hay dos puntos claves donde tiene sus cuarteles Tupac Catari: son éstos el Tejar, por donde se dominan los caminos que llevan al Cuzco y a Lima, y Pampajasi que, en el este, controla y relaciona las vías que llevan a los Yungas y al norte.

Por las páginas del Oidor se ve que los indios, que en los primeros meses bajaban desde el Alto hacia la ciudad tan sólo para atacar, van instalándose posteriormente en los barrios abandonados por los espanoles dentro de las casas quemadas y semidestruídas por efecto de los combates, incendios y saqueos, con lo que evitan el trabajo de subir cada noche las cuestas bastante enpinadas que les separan de la ciudad:

"... ellos, a la verdad, se hallon duerios de los extramuros y ciudad quemada, donde moran, habitan y duermen con sus mujeres... con lo que en mucha porte se han relevado de $l a$ pensión de subir al alto de San Pedro y tener que bajar diariamente...", fol. 42.

Los sublevados están así mucho más prontos para sorprender cualquier saljda que realicen los sitiados fuera de los muros, así como más en disposición para aprovechar los descuidos de los vigías, trabajando en la elaboración de forados que atravesando las murallas les dejen penetrar en la ciudad:

"En otras trincheras y paredones por donde acometieron igualmente, foradando con barretas, en especial en el de Carcantin o linea del Calvario, donde abrieron y rompieron algunas brechas". fol. $41 \mathrm{v}$.

En el mes de Junio, se ve que los alzados ya no sólo realizan esta política sino que construyen además con los ladrillos y adobes de las casas destruídas pequeñas defensas y fortalezas frente a los muros para que, protegiéndoles de las balas, les pongan en mejor disposición para dirigir sus tiros, hondazos y mechas o pelotas de fuego:

"... van levantando una trinchera de piedras sillares, arrancadas de calles y tiendas de las casas quemadrs... de donde arrojan piedras y balas contra los nuestros, sin permitirles la salida y haciendo oposición a los guardias de ella y con mayor inmediación y seguridad para batir la ciudad". fol. 42.

"De noche se arrojnron voladores de pólvora con mechas de pajuela sobre los tejados de la ciudad, para incendiarla". fol. 27. 
Catari y su mujer, que bajan bastante a menudo hacia la ciudad o que la rodean cuando var de paso entre el Alto y Pampajasi, suelen quedarse a dormir en estos refugios:

"Que la india concubina del rebelde vino de hacia Potopoto y al subir hizo mansión cu ta garita... con la comitiva de 78 n 20 de a mula y cosa de 800 indios haciéndole salva...". fol. $35 \mathrm{v}$.

A través de] Diario puede apreciarse que la población indigena que habita el contomo de la ciudad y que ataca a los sitiados bajo las órdenes de Apaza es primordialmente aimara, pero también se ve que suelen aparecer por alli personajes que no lo son y que vienen de los campamentos quechuas de Azángaro, Sorata y Achacache. (Véase lo referente al indio Zúñiga y a Pedro Obaya).

El Oidor no subió nunca hasta el Alto, de modo que cuando describe las chozas y tiendas o la vida que se lleva allí, así como los gestos y actitudes intimas y misteriosas de Tupac Catari, se limita a repetir lo contado por el padre Borda, Mariano Murillo o los pocos presos que han logrado huir del campamento indigena. Por ello, sus descripciones son ricas y llenas de color sólo cuando se refieren a escenas que se desarrollan bajo sus ojos, en las inmediaciones de la muralla o en los altos vecinísimos de San Francisco, San Pedro, Quilliçuilli o el Calvario. Las bajadas del caudillo o de Bartolina Sisa constituyen en cste sentido una parte importante de las narraciones. Otras veces sus irases describen combates en alguna de las casas abandonadas 0 escenas pintorescas desarrolladas en los mercades que maliciosamente instalan los indios para sorprender a los vecinos hambrientos que no pueden evitar la tentación de salir para comprar algo que calme el hambre de los suyos:

"Bajo el rebelde Catari por hacia los altos de Sun Pedro, a caballo enjaezado y de cabriolé encarnado". fol. 23.

"Por la mañana esturo Catari en la ceja y cerro del Calvario, con su cabriolé encarnado y guamecido de galón de oro". fol. $42 \mathrm{v}$.

Seguramente el trazo más logrado en la pintura de estas escenas está en la pretendida entrevista de Bartolina y su marido que organiza el comandante para capturar a Julián Apaza. Este hecho ocurre en el segundo cerco, que no queda cubierto con la publicación de esta primera parte del Diario en vista de las razones a que se ha aludido más arriba y que impidieron integrarlo en esta edición. Sin embargo, dado su interés, se reproduce aquí el pasaje copiado por la autora de esta Introducción, cuando el propietario del texto le autorizó su consulta, según lo referido anteriormente:

"5 de Octubre... Esta tarde dispuso nuestro comantante una emboscada en la irinchera y puente de Santa Bórbara y en la de la Rizerilla. Mandó llevar los fusiles ocultos y que los saboyanos se disfrasen el traje o uniforme blanco, y salir la tropa sin orden para no ser vista ni presentida de los rebeldes... y se encamintó... a cosa de las 4 de la tarde, al puente 
de Santa Bárbara. Alli mandó sacar de la pristón que guardaba en el cuartel a Bartolina Sisa, concubina del rebelde Apaza, sin los grillos que fenia puestos, my lavada y compuesta de ropajes ajenos y decentes, la hizo poner visible on la tronera del cañon de dicha trinchera a tiempo que muchos indios rebeldes la esperaban en el atto immediato de esta parroquia de Santa Bárbara. La distinguieron y conocieron; pasaron a llamar o anoticiar al conjurado caudillo Apaza; vino éste a caballo con sortuy verde de paño y calzón negro de terciopelo, asociado de varios cholos rebeldes, a mula y con fusiles y de su secretario o amanuense, que parece nuevo y es un cholo retobado o renegrido, vestido de paño encamado con su wroo camiseta, que estilan los indios, que no se atrevio a aproximarse a la trinchera $y$ puesto a distancia de una cuadra, parece, envió mimeramente de emisarios dos indios de los rebeldes con recaudo o solicitación o memoria del dicho Apaza. La india... le dijo a sistos que ella se hallaba bier asistida y tratada de los españoles y con decencia sacó y mostró sus pies para que vieran que no tenía prisiones y les dijo llamasen a Apaza, de quien pondín su libertad y que viniera, que no tenía prisiones; y les dijo llamasen y timicse sin recelarse de los españoles que no procedian con traiciones, como ellos. El rebelde, aconscjado de ta maldita sagacidad de los cholos, se indispuso con ln llamada y a gritos decin que wo queria bajar, comociendo bien el intento de aprehenderlo (nue dio merito par este caso). I/ sólo se repilieron warios mensajes por medio de In emisión de un indio; éste le trajo pon, wniz tostado, came, dinero y una talega de coca (que nombran chuspa) del uso del mismo Alnaza, recordántola que si reconocía esta prendi. Al fin se refiró Apraz y se matogró d proyecto. Muchos opinan que hubo lugar, tiempo $\mathrm{c}$ inmediación para matarlo, si el connantante tuthiera dado la orden de hacer fuego".

Las actividades que los indígenas desarrollan tanto en el Alto como en las inmediaciones de la ciudad, se refieren también en las descripciones del Oidor, a las fiestas, bailes, fuegos artificiales, borracheras y procesiones que aquéllos organizan para celebrar sus tritufos, el carnaval o las festividades religiosas de Semana Santa, Corpus, el Señor de la Cruz:

El Miércoles 13 de Junio, anota el Oidor que los indios celebraron Corpus:

"Por la noche tuvieron alli iluminaciones, muchos cohetes, cuatro castillos y otros juegos de diversion con muchas cajas, grita y borracheras y los que estaban en las circunferencias de la ciudad los acomprañaban desde ahojo con el bullicio de connetas y vocinglería, como las noches pasadas". fol. $39 \mathrm{v}$.

Al describir las fiestas religiosas Diez de Medina incide en consideraciones muy curiosas respecto al tema. En diferentes párrafos describe indignado la celebración que se permiten "estos paganos" de las festividades cristianas, el robo sacrilego de las imágenes sagradas, el culto "herético" que realizan en capillas improvisadas en el Alto y la presencia indebida de sacerdotes que les hacen de capellanes sin autorización del derecho canónico. Todo esto constituye para el Oidor razón suficiente para acusarlos de ateísmo, idolatría, sacrilegio, herejía y paganismo. No piensa, en cambio, a pesar de todos sus alardes de catolicidad, que éstas son actitudes reveladoras precisamente de lo contrario. Quien lee esos párrafos con un criterio más actualizado comprende que están demostrando precisamente que la penetración del cristianismo era más fuerte de lo que se cree y que, aún cuando las 
actitudes de los indigenas manifestaran el sincretismo y la confusión típicos de la piedad popular americana, expresaban más que nada, que a pesar de estar en una lucha racial con los espanoles que les entregaron la fe, seguian necesitando orar ante las sagradas formas, suplicar a las imágenes santas, bailar, como siempre, para celcbrar las fiestas del Señor y tener junto a sí a sacerdotes que les hicieran sentir también a ellos la presencia de Dios y de la Virgen.

\section{La guerra en el mundo indígena.-}

Uno de los tenas que més interesa al Oidor respecto a los indios es, como en el caso del mundo urbano, el de la guerra. En cfecto, dedica innumerables trozos a describir sus ataques, su estrategia, sus armas; la forma en que descendían del Alto, la ropa que llevaban, la falta de habilidad en el uso de cañones y escopetas, la práctica de los incendios y forados y la presencia constante de las mujeres en los ataques:

"Circumaloron con stis muitres la citdnd como si concurricsen por cómputo diezo doce mil tie allos; bajaron los hombes y acometicron por todas partes con muchedumbre de una pedrea contimia". fol. 15.

"... con of designio te intemn a ho cindad minándola con las barretas que tienen priparadas". fol. $21 \mathrm{v}$.

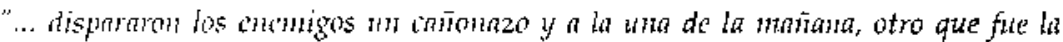
seral de acometer a la cisctad at mincherada... La algazara de voccs, provocaciones, insolencias y atrevimientos son imponderables en medio de diferentes connetas y tambores". fol. 24 .

Cabe preguntatse cuál era la impresión del Oidor acerca de las cualidades psicológicas de los indios. Evidentemente, ésta cambia conforme al estado de ánimo con que don Francisco Tadeo escribe: así, a veces, son seres amables y dóciles a quienes se puede conducir con sermones y amonestaciones y contra quienes es terriblemente injusto llevar un sistema de guerra ofensiva. Otras veces, en cambio, son seres bárbaros y sanguinarios contra quienes no cabe sino el rigor y la guerra. Les describe a ratos como carga pesada para el imperio que no logra civilizarlos, pero páginas más adelante, echando en cara a Segurola su crueldad, los define como sostenedores de la Corona, por ser ellos quienes soportan el peso del trabajo y los tributos:

"No debiendo onitirse que dejados como desde el principio los medios de suavidad y dutam parn la pacificación de estos indios, quedará el Perí.. sin una porción, la más considerable, de estos onsallos. Quedará In Corona sint tributos y sin otras pensiones, pues al fin éstos son la mayor parte de las manos contribuyentes y el todo para las labores y minas de oro y platr que, hasta aquí, son los indios los que sacan uno y otro". fol. 21 .

El tema del indio.-

En lo que no varía nunca, ya sea admirándoles o, por el contrario, para encontrar motivo de achacaries una falta más, es en describirles como personas 
valientes y llenas de coraje, estoicos, perseverantes y tozudos hasta la inconsciencia, en lo referente a la mantención del cerco, a la frecuencia de los ataques que no ceder ni ante las armas de fuego ni ante las innumerables víctimas ni ante los rigores del tiempo. Sin embargo, no ahonda en un análisis de tipo psicológico sobre esta actitud, lo que pudo haberle llevado al tema de los móviles del levantamiento. Diez de Medina señala un cierto sentido de fatalismo en la forma con que el indigena afronta el levantamiento y la obediencia ciega a los caudillos, pero de ahí no prosigue, con sensibilidad moral o conciencia social más honda, a tratar de captar el sentido de la sublevación ni el por qué de la violencia que se ha desatado; cuando raramente señala que todo esto sucede "como un castigo de nuestras culpas", no aclara de qué culpas se trata ni de quiénes las han cometido ni tampoco si se refieren éstas a la vida privada de los vecinos, a la comunidad o a las autoridades públicas:

"... y habernos cerrado entro de las trincheras de la ciutad, por wn efecto de nuestrus culpas". fol 21.

En todo caso, puede asegurarse que a lo largo del Diario no se encuentra nunca una frase en que se reconozcan abusos, injusticias o malos tratos anteriores, de parte de los blancos. Por el contrario, es frecuente el reproche a la ingratitud de los indios que, otvidando los beneficios recibidos y el amor con que se les ha tratado, han faltado a la fidelidad al monarca que les imponía su vasallaje asi como al respeto a los señores a quienes sjempre se habian sujetado en una relación de tradicional paternalismo.

Hablando de los derechos de la religión católica y del Rey dice:

"Este objeto importantisino se ve por las obras postergado... dejando prevalecer al rebelde en los dominios de su Majestad, talando haciendas, usurpando y deprimiendo los vasallos, reales tributos y demás impuestos de elln que corren entorpecidos con los dentás delitos sobre delitos execrables de rebelión que cada día se incrementan". fol. $23 \mathrm{v}$. con ellos.

costumbres de los indígenas y que había manterido un contacto frecuente

Cuando Diez de Medina alude a situaciones de crueldad, de injusticia o de abuso, las señala exclusivamente como efecto de la guerra y sostiene entonces que los españoles, aprovechando la superioridad de sus armas están respondiendo desmedidamente al salvajismo de los indios, con lo que, en lugar de emplear los métodos persuasivos que aconseja el Derecho Indiano, están respondiendo con el mismo espíritu sanguinario de ellos. Desgraciadamente, aún en estos casos se ve, en un análisis más hondo del texto, que reprocha eso a los suyos más que por razones de caridad o justicia por motivos de orden económico o político, puesto que el monarca se verá sin hombres que le tributen y sin brazos que le trabajen. 
No puede sostenerse en ningín caso que el problema del indio constituya un tema vivo en el pensamiento del Oidor. De ahi que no pueda alineársele en alguna posición dentro de la Historia Social de la colonia. Sus clamores en favor de los naturales no serán runca del orden de un humanismo cristiano como el de Montesinos o del padre Las Casas; sus acusaciones, aunque alcanzaran un grado extremo, el 13 de Mayo, cuando con gran pesimismo hace suyas las frases del obispo de Osma, García de Lonyza, presidente del Consejo de Indias en tiempos de Carlos $V$, tampoco permiten identificarle con las posiciones aristotélicas de un Ginés de Sepúlveda, que míra a los naturales de Anérica como seres amentes. No caerá en los alardes románlicos del buen salvaje, pero tampoco los mirará como a seres escasamente desarrollados proverientes de las marismas nebulosas de Buffon. Sus opiniones son simplemente las de una persona a quien nole ha afanado rmucho el tema y que, si ha de opinar sobre él, reacciona con la mentalidad ilustrada del funcionaria borbónico que mira al indio no ya desde un punto de vista religioso, humano o moral, sino simplemente como a un elemento al que debe cuidarse por cuanto es útil a la sociedad a cuyo progreso debe contribuir con su trabajo eficiente y una tributación ordenada.

\section{Los dos Mundos se relacionan.- La lucha.-}

Mucho más podria extraerse de las observaciones del Oidor sobre los dos mundos separados por la muralla, pero dejando al lector que descubra esos detalles en el cuadro de Dicz de Medina, es conveniente fijar atióra la atención, a traves siempre de las notas de don Francisco Tadeo, en la forma cómo esos dos sectores, de los cutales se tiene una impresión más o menos estática, en cuanto son descritos aisladamente, cobran dinamismo y vida al observárseles no sólo en su propia dimensión sino también en su nutua relación.

Efectivamente, constituían esos mundos dos esferas diferentes; una sublevación los habia separado, una muralla expresaba tal división. Sin embargo, era tan fuerte la tradición de intercambios entre los dos campos étnicos, que ni el muro ni la guerra pudieron impedir el que siguieran en comunicación en pleno cerco.

Por supuesto, la forma más frecuente y notoria es la lucha, el asedio, el ataque. A través del proceso bélico se plantean una vez más las diferencias de sistemas y de equipos guerreros. Se aprecia cómo los dos siglos y medio de convivencia de los españoles dominadores con pueblos que no opnsieron resistencia armada impidieron que éstos aprendieran el uso de las armas de fuego manteniendo sus mismas hondas y piedras, hachas, cuchillos y lanzas. En muchas oportunidades, durante el sitio, tuvieron ocasión de tomar fusiles $e$ incluso cañones o pedreros, pero es notorio el que no fueron capaces de utilizarlos si no contaban con la presencia de mestizos que conocieran su manejo o con criollos que libre o forzosamente los dispararan:

"...ecometieron por diferentes partes; se oyeron algthos tiros de fusil de parte a parte... aungue, por no saber, yerran los más sus tiros en vago". fol. $17 \mathrm{v}$. 
Los españoles tuvieron en este sentido gran superioridad, puesto que un disparo de fusil causaba mucho más daño que un centenar de piedras y un disparo de pedrero podía disolver a todo un grupo:

"...estos bárbaros, que fuera de algunos fusiles tan mal gobernados como los pedreros, no tienen más armas que las hondas y piedras, cuyos golpes no matan por to general, como lo ministra la actual experiencia". fol. 27.

Para la lucha cuerpo a cuerpo contaban también con armas blancas, pero este tipo de combate se ofrecía raramente, puesto que los sitiados se mantenían detrás de las murallas y los indios fuera de ellas. Las luchas fuera de los muros eran escasas, ya que si se organizaban salidas estaban destinadas a ataque con armas de fuego, y como lo frecuente en estas expediciones era el fracaso, más que una pelea de hombre a hombre, to que se producía era una huida vergonzosa de los indisciplinados defensores de la ciudad:

"De tal antecedente, ¿cual fin podin derinarse sino el funesto y ruboroso de aquella retirnda ofuga intempestiva?..." fol.17v. fol. 32 .

"Como los indios nos vieron hitr en desorden, wos siguieron con pedrea y alaridos..."

La superioridad de los atacantes sólo se daba en el número de los combatientes, en el hecho de su ubicación en las faldas de los cerros circundantes, especialmente el Calvario y Quilliquilli, desde donde dominaban el movimiento de los defensores en los muros y en las fortalezas asi como en los lugares más vulnerables; y en el hecho de poseer cabalgaduras que, en cambio, los sitiados fueron perdiendo una a una, ya fuera porque se las robaban los indios o porque morian de hambre o porque servian para aplacar la de los soldados.

Es también notorio que, fuese por las razenes que fueran, los indios manifestaban mucha mayor disciplina, tesón y valentia que los vecinos sitiados que, hambrientos, con psicosis de encierro, aburrimiento y cansancio, debian acudir noche a noche a la lucha sin ver éxitos notorios que les hicieran olvidar los continuos pequeños o grandes fracasos en la prolongada espera del arribo de los auxilios que no llegaban:

"... y la inacción nuestro o la cobardia en que estan los ámimos, sim más causa que el corto suceso del lunes 26 de Marzo". fol. 15v.

"La cindad sigue en la epidemia de la disenterin; toda ella es una congoja; en las calles se van cayendo los hombres, muertos de necesidad...". fol. 34.

"No hay trabajo ni industria y asi el comercio ha descaccido; la miseria toma su lugar". fol. 44v.

"El auxilio de que trataron lisonjear al pueblo, no parece ni se sabe de el a punto fijo...". fol. 34 . 


\section{Los parlamentos.-}

Pero también la guerra cansaba a los atacantes, que por eso practicaban otros sistemas de relaciones con los sitiados a través de parlamentos y entrevistas que se efectuaban generalmente buscando la intervención de los franciscanos y a través de los muros posteriores de su huerta:

"Dada parte de estos sucesos al comandante.. se fue a la trinchera y puente de San Francisco, ordenó se' sispendicse ef fuego y dispuso enviar dos religiosos... para que les amonestasen a st nombre, a la subordinación al Rey...", fol. $18 \mathrm{v}$.

En muchas de estas entrevistas se planeaban conversaciones a las que deberían acudir, en lugares determinados, el comandante Segurola y Tupac Catari; como preparación de la reunión se mostraría la buena voluntad de ambas partes con el cese del combate. Pero en realided tales entrevistas no se lievaron nunca a cabo porque, en el fondo, ambas partes comprendían que lo que les movía por igual era el deseo de tender la trampa decisiva que les permitiera en una espectacular sorpresa capturar a los mandos enemigos:

"Y que segrin to nute resultase de esta conferentia, se procederia a lo demás que convenga marn mirtorlos y tratarlos con humanidad, compasión y caridad. Respondicron que para ef dia de monana hunes vendrian y después de haber cesado la guerra por una y otra parte..." fol. $28 \mathrm{v}$.

"...cuando asomó el caudillo con sus clarines... respondió insolente y ebrio como estaba, que to querín.. Sin embargo, mantó el conandante con gran prudencia, que continuase la cesación del fuego, a ver si se convenian a buena razón, porque la calle y cerca de San Francisco hnsta la cuesin, estaban intmiadas de los agresores". fol. 28v.

\section{Cartas y misivas.-}

En busca de tales parlamentos o para amenazar o para llamar a los vecinos a sus filas, fueron frecuentes también, en el intento de relacionar ambos sectores, las cartas de los sublevados, dirigidas a veces en tono atento y formal y otras, duro y combativo, al comandante, al obispo, al propio Diez de Medina o a los vecinos del común:

"A las 10 del día, vino who de estos cholos... con un papel escrito al oidor don Francisco Tadeo Diez de Medina, con esta fima: Yo el seĩor virrey Tupac Catari". fol. 19.

Estas misivas, por lo general, estaban escritas por los amanuenses de Tupac Catari, pero se ve que las dictaba el propio caudillo porque, salvo raras excepciones, todas revelan la misma falta de congruencia y lógica. La mayor parte de estas cartas fueron conocidas por el autor del Diario que a veces las transcribe y otras las resume en absoluta concordancia con las que publicó Ballivián y Roxas acompañando el Diarjo de Segurola:

"...quedo celebrando la aprecinble salud de vuestra señoría ilustrisima. La mía toda está a su disposición. Pues le estimaté a vuestra señoría ilustrisima, el que me avise con 
fijeza de cómo sabe... que vienen natios de Bucnos Aires a acabarmos, cuando Carlos In tiene desamparado al Rey Inga, por las muchas injusticias y robos que experimontomos. Por fin, ¡Dios sobre todos! Nosotros vamos sobre este dictrmen: Lo que es de Dios a Dios y lo que es de César a César...". fol. 16v.

\section{Los espías.-}

También se relacionan ambos mundos con la presencia en uno y otro campo de espias o delatores. Muchas veces son indios $o$ indias del servicio que viven en la ciudad y que encuentran el medio de comunicar los planes españoles a los indígenas. Otras veces son indios que se vienen a la ciudad haeiéndose pasar por gente que huye de la crueldad del caudillo. De todos ellos, Segurola desconfía, por lo que termina haciéndoles colgar en la plaza mayor, en caso de que no logren demostrar su propia identidad. Tal crueldad está en plena concordancia con la de Apaza en EI Alto, que ejecuta en igual forma a los indios fieles que suben por encargo del comandante para averiguar la verdadera situación del campo enemigo asi como el avance de las tropas auxiliares:

"... siendo contuctor de la respuesta... ef mismo indio que con efecto la trajo y se halla en prisión". fol. $38 \mathrm{v}$.

"...se dice que a los indios prisioneros y alzados y a los que de la ciudad salen y los comunican, los sentencian a pena ordirarin de degüello...". fol. $30 \mathrm{v}$.

"... y give en esto concuerda con otro indio, medio tonto, que tambien se vino de dicho Alto", fol. 32v.

\section{Los desertores.-}

Pero no todos los que se mueven entre uno y otro campo son espías o delatores; también es cierto que llegan refugiados. Los que vienen desde El Alto son sobre todo blancos que, habiendo caido prisioneros, logran huir cuando se afloja la vigilancia por el desplazamiento del caudillo a Oruro u otros lugares o por el fragor de algứr combate.

"Dicese también, estar commicado un papel de orden, por el comandmite... para admitir a dos personas que se presume pueden venirse noctumamente..." fol. 32v.

"...y también para dar ligar a que se hubiese venido, hoy a medio día, el religioso de San Agustin, fray Matias Bordia que entró por la misma trinchera con seis escopeteros españoles y mestizos, con sus armas respectivas, que le siguieron interm nuestras fropas se hallaban combatidas de los indios enemigos". fol.33.

Como se ve, otras veces los que llegan son mestizos arrepentidos, que si bien se consideraron al comienzo más cercanos a la causa indigena, no lo siguieron sintiendo así cuando fueron viendo la actuación poco controlada de Apaza o fueron conociendo que la venida de los auxilios espanoles era segura.

También es cierto que entre los que se refugian aparecen indígenas. Estos, generalmente, proceden de pueblos sometidos por Tupac Catari, los que a veces 
aceptaron la incorporación a sus filas obligados por el miedo pero no del todo convencidos del éxito final. En otras ocasiones son colonos de fincas cercanas, cuyos duteños están en La Paz; en ese caso, se vienen a veces por fidelidad a sus patrones o por la esperanza de contar con su apoyo y protección, en caso de una derrota:

"En esfe dá wino wn indio, quient llanó al licenciado don Domingo Silva... nombudo Pedro, de su estancin Condoriri... y le habló por las immediaciones... y le dijo que en estos 15 días wado snbian del paratcro del rebelde Inlian Apaza". fol. 36v.

El proceso inverso, de gente que sale de La Paz para dirigirse al Alto, es también frecuente y se produce con los pobladores indígenas, especialmente en los primeros meses, cuando, como era de esperar, se sienten contagiados del entusiasmo de los atacantes que les invitan a luchar en sus filas con sus hermanos de sangre y no en la ciudad, en contra de ellos. Cuando, más tarde, prosigue el cerco, la esperanza se esfuma y el hambre aprieta, ya no son sólo indígenas los que suben, son ahora mestizos y también blancos. Los últimos, por lo general, no son vecinos de la ciudad sino soldados desertores que provienen de otras provincias y que por eso mismo no sienten el afán de los demás por defender una villa que no es la suya. A estos ulltimos les va muy mal por lo general, puesto que a pesar de que Catari los ha Ilamado en epistolas y recados, desconfia de sus intenciories y les ahorca si no está de buen talante cuando aparecen en su campamento:

"Desertaron fres soldados mestros tic las del Valle..." fol. 36.

"Hoy se nos prestutó en la horca pitesta en el Cerro del calvario, who de los nuestros... Quicrese decir que es at granndero Machicado... que se aptuntó arriba, haber desertado". fol. $42 \mathrm{v}$.

\section{Los prisioneros.-}

Otra forma de intercambio humano es la de los prisioneros. Seguramente, es ésta la más triste, pues a no ser que se trate de personajes que puedan significar la posibilidad de hacerles rehenes, se les ejecuta en ambos campamentos sin mayores trámites. Cuando se piensa que pueden utilizarse sus declaraciones, se les interroga muchas veces para obtener la mayor información posible, pero por lo general, se termina ahorcándoles en la plaza mayor o en el Alto, según la circunstancia, con la misma severidad.

Tal vez el único caso diverso y curioso, en este sentido, fue el de las personas que cayeron prisioneras de los indígenas, cuando éstos organizaron unos singulares mercados en la zona de San Sebastián o San Pedro, frente a las fortalezas de la ciudad, con el árimo de que, empujados los defensores por la necesidad de alimentos, dejasen salir a los poblaciores, descuidaran la defensa y, sobre todo, abrieran las puertas. No cayeron los sitiados tan ingenuamente en la trampa, pero no faltaron vecinos que, viendo que a sus esclavos y sirvientas enviados a la compra no les sucedía nada, salieron también desobedeciendo las órdenes del Comandante. Cayeron en esta forma decenas de personas en manos de los indias, que se las 
llevaron prisioneras al Alto, para ir, días después, devolviendo a los esclavos y a las sirvientas e incluso a las mujeres viejas y feas, durante el segundo cerco:

"Por la mañana pusicron un medio mercado aparente en la plazueta de San Sebastián. de algunos viveres, como que querian comerciar con los mestros que salieron imcantos fuera de trincheras para comprarlos... (Ios rebeldes) salieron repentinamente y nos arrebatnon y aprehendieron sobre 60 personas... y las condwjeron al alto de San Pedro". fol. $37 \mathrm{v}$.

"...las fueron entresacando y separando en dos clases. La una de toda mijer de cara blanca, de buen parecer, de buen ropaje, mina o vieja, casada, las que llevaron a las once y media del dí, prisioneras, al campo enemigo de Muntipata en que se halla el otro rebelde... La otra, de indias y las de mal pelaje, fue repudiada y las enviaron con hibertad a la ciudad... y varias $\sin$ la provisión de viveres a que habian salido, porate al bajar a la ciudad se to quitaron los rebeldes". 5 de Octubre, Diario del segundo Cerco.

\section{Los misioneros.-}

Hay, por último, fuera de tales mercados, que contribuyeron, a pesar de todo, a dar un alivio al hambre, un caso interesante de intercambio humano entre la ciudad sitiada y su contorno, es el de la subida de sacerdotes que voluntariamente deciden irse junto a los indios, no en actitud desertora sino, por el contrario, en misión evangelizadora. El caso más interesante es $\mathrm{el}$ del padre Barriga, un franciscano que se va con los indios con la intención de no abandonarles espiritualmente, ya que ellos mismos han pedido la presencia de sacerdotes que les ayuden a orar y a celebrar oficios y les socorran en el momento de la muerte. Desgraciadamente, a ese hombre que caló más hondo que el Oidor en la mentalidad religiosa del indio, no le acompañó la suerte; un grupo de rebeldes fanáticos te acusó de ser causante de las derrotas sufridas en una de las ausencias de Tupac Catari, con lo que pusieron horroroso fin a sul vida:

"... que al padre franciscano Barriga le ahorcaron hoy al salir el sol, sin que bastasen sus ruegos y que de presente le tienen colgado con otros tres en dicha horca". fol. 20v.

\section{Conversaciones, insultos y burlas.-}

También las relaciones son espontáneas y sugestivas cuando en medio del combate o en momentos de descanso se producen escenas que demuestran la proximidad en que se encontraban atacantes y sitiados; en ellas los dos conjuntos humanos se gritan, se amenazan y se hacen bromas:

"... y se mantuvieron vertiendo muchas crasedades, anenazas y desvergienzas contra los españoles, sus mujeres y aun contra las monjas de los monasterios". fol. 24.

"... y gritando insolencias contra nosotros, nos desafiaban y decian: Pies de gallinas, isalid fuera si sois hombres!". fol. 37.

"Otros decian: Habeis muerto a los tributarios del Rey, sin su licencia, ja ver ahora, cómo le tributarán los difuntos!". fol. $28 \mathrm{v}$. 
"Lo mis fue provocamos e insultamos de palabra. Los muchachos les contestaban de nuestra parte y muchos con gracioso chiste, y asi se les fue en contestanos en algunas trincheras". fol. 24.

\section{La crueldad.}

Las conversaciones mantenidas a través de los muros e incluso la salida de uno que otro defensor para charlar con algún indio conocido, demuestran que desde la ciudad no siempre se disparaba a los sublevados que circulaban junto a la muralla; parece ser que por lo general solo se tiraba contra ellos durante el combate, constituyendo excepciones los casos en que se les sorprendía y se apuntaba contra eltos. Puede afirmarse esto porque cuando ocurre algo así Diez de Medina no sólo lo destaca y celebra su oporturidad sino que de inmediato concluye que si Segurola procediera con igual energía andarían las cosas en forma muy diversa:

"... se conoció... Inter Hantado cinco indios, por la trinctern de Santa Teresa... al capitan don Mariano Billno... gue st sirviera salir fuera pam pedirle perdon... convino a salir de la trinchera... sin armas, purn preaver el fentor y recelo de dichos indios, a quienes fue a tratar pasado el rinchuelo immedinto a la trinchert". fol. 25.

No ocurría asi, en cambio, con los vecinos que se atrevian a ir más allá de los muros. Si salian en busca de combate, lo encontraban siempre y si perdían la batalia, lograban por lo general despiadada nuerte. Si la salida la hacía algún sitiado para recoger verduras of frutas, aunque se tratara de una mujer, merecia por lo general la prisión o el degüello:

"Por los altos de Sm Francisco que Haman de Supaicalle, hallaron degollado un español de los mesfros, alte se prestme salio en solicitud de leña para la cocina". fol. 34v.

"... don Pablo Machicao refirió hnber visto csta mañana matar a los rebeldes, a palos, a uno de los nuestros atue, con otros pobres, habin salido a rebuscar frutos en las sementeras fiera te trincherns", fol. 30 .

Cuando después de alguna de las desastrosas expediciones fuera de muros quedaban rezagados algunos soldados, ya fuera por el pillaje o por la falta de agilidad en la huida, lograban también atroz muerte, con corte de pies, manos y genitales:

"... se arrojó fuera de trincheras con algunos companeros que te dejaron con solo thn sable $y$, aungue mató e hivió a dos enemigos, le rodearon y sacrificaron, cortandole la cabeza, manos, piernas, genitales y corazón". fol. $22 \mathrm{v}$.

Por las observaciones que hace el Oidor se puede pensar que estos actos de salvajismo obedecian más que a un espiritu sanguinario estable, por parte de los indigenas, a un cierto desenfreno que les produce la frecuente absorción del alcohol, pues está claro que, alentados por el ejemplo de su caudillo, alternaban la estoica sobriedad habitual de su vida con desenfrenadas borracheras organizadas para celebrar un triunfo o conmemorar una fiesta: 
"... estos cnenigos... que en sus puestos roban, talan. lienen viveres, alegrías y embriaguez...". fol. 21 .

"Por la noche turvieron alli iluminaciones, muchos cohetes, cuatro castillos y otros juegos de diversion, con muchas cajas, grita y bornchera". fol. $39 \mathrm{v}$.

Sin embargo, su euforia no es constante sino que sufre los mismos vaivenes que los entusiasmos de los cercados que, si se animan con un pequeño triurfo o una buena nueva, caen momentos después en un desalentador aburrimiento.

En la lucha, en cambio, es evidente la constancia de los atacantes, frente a la falta de persistencia del sittado; actitud que resulta explicable si se piensa en la situación psicológica de libertad con que actúa el indio que, poseyendo buenas condiciones físicas, puesto que está bien alimentado, se siente agrediendo a un enemigo que, por el contrario, lucha con hambre y sintiéndose psicológicamente acosado:

"... La mayor parte de los semblantes se hallaban piltdos, lónguidos, enfermos, con los labios secos y cuasi sin respiración, como que estaban a los umbrales de la Parca". fol. 44.

"...empezaron... con algazara y voces, a pifint a los cspañoles y mofarlos, como que celebraban su triunfo y la inacción mesfra o la cobardia en que cstan los ánimos". fol. $15 \mathrm{v}$.

\section{¿Sabe enjuiciar la situación el Oidor?.-}

Sin ánimo de influir en el lector que, por cierto, sacará sus propias conclusiones de la lectura del texto, no se puede poner punto final a esta introducción al Diario de Diez de Medina sin preguntarse si el Oidor comprende o no la importancia del momento que vive, si capta el sentido que tiene la rebelión, si intuye el carácter casi precursor que tienen los acontecimientos, tanto en cuanto es una sublevación indígena contra un régimen colonial, como en cuanto hay una efervescencia criolla contra un estamento peninsular. Si comprende que aún cuando el movimiento se sofoque tendrá repercusiones posteriores, y si captá la circunstancia de su extensión territorial.

Cabe responder a tales interrogantes afirmando que Diez de Medina no fue un personaje dotado de una sensibilidad suficientemente amplia como para comprender y juzgar la situación que le tocó vivir ni para enjuiciar ni analizar el por qué de la sublevación indígena y sus alcances ni para discernir si ésta era de tipo racial, social o económico. Tampoco comprendió la profundidad de las fricciones entre peninsulares y criollos y, por eso, las achacó a la falta de tacto de Segurola sin captar que esas tensiones, que entonces se manifestaban como roces de dos grupos sociales, se identificarían muy pronto con la lucha de dos sistemas ideológicos. No imaginó siquiera que los personajes españoles que chocaron con él y sus coetáneos en la adminisstración de la ciudad actuaban muchas veces movidos por una nueva mentalidad, activa y eficiente, que venía a América a establecer las renovaciones burocráticas de los Borbones. 
A pesar de todo ello se puede afirmar que el Diario posee un valor real, puesto que, como se ha dicho, constituye por sí mismo un testimonio de indudable importancia para penetrar el sentir de una época y poder establecer ahora, con la necesaria perspectiva, conclusiones e interpretaciones sobre esos acontecimientos; ello es así simplemente porque, si bien el Oidor no transmitió su propio juicio, fue portavoz, en cambio, de un grupo de hombres que vio, sufrió y produjo un hecho histórico. Diez de Medina recogió en sus notas descripciones, actuaciones, episodios, gestos, comentarios, que permiten, hoy en día, compnender y valorar lo que hacían y pensaban los habitantes de la ciudad de La Paz cuando, en vísperas de la Independencia, encertados entre muros, soportaban los rigores de un implacable asedio indigena 


\section{PRIMERA PARTE DEL DIARIO DEL OIDOR DIEZ DE MEDINA}

f.1/ Diario del alzamiento de indios conjurados contra la ciudad de Nuestra Señora de La Paz, provincia de los Charcas en el Perú i1!. Su caudillo, Juliann Apaza, hijo que se dice ser de un sacristán, de edad de veintiseis a veintiocho anos. Indio particular o mostrenco del pueblo de Ayoayo en la de Sicasica, cue se nomina asi: Yo el Señor Virrey Tupac Catari, cuyo lugarteniente es Pedro Obaya, mestizo natural de] pueblo de Azángaro, provincia de este nombre y los sublevados de los puebios y provincias comarcanas de Sicasica, Pacajes, Omasuyos y algunos de las de Paria, Carangas y Chulumani o Yungas Chapes, cono asimismo, los más que habitan en el recinto de la ciudad, y se rebelaron habiendo sido amigos al principio. Todos los cuales según los efectos experimentados, se hallaban ya tocados del espiritu general de conspiración y muchos enmascarados cuando los primeros tumultos de la provincia de Chayanta, en Charcas y Tinta en \&l Cuzco (2).

Para dar mejor idea de este Diario, es preciso decir sucintamente y cono que ya son sabidas, las ocurrencias precedictas en las dos provincias de Chayanta $y$ Tinta (3).

(1) Es curioso que el Oidor señaje que la provincia de los Charcás esté en el Pení puesto que pertenecía al virteinato del Río de la Plata, desde 1776. Posiblemente, lo hace con el ánimo de ambientarla en el contex to histórico geográfico de las sublevacioncs indígenas uriginadas en el Perú.

(2) Puede apreciarse que el título del Diario la sido puesto con posterioridad, posiblenente en el momento de ser entregado para la copia, porque está afirmando hechos que sólo se van produciendo a lo largo del desarrollo de los acontecimientos que el autor nara día a día. En efecto, al comenzar el Diario. Diez de Medina no sabe todavia que el culudillo que dirige el cerco de La Paz es Julián Apaza; la figura de Pedro Obnya, por otra parte, sólo aparece cuando está muy avanzado el Cerrco.

(3) Posiblemente, todo el preámbulo introductorio fue escrito posteriomente, para explicar la conexión del movimiento de Tupac Catari con los de Chayanta y Cuzco. Todo esto demuestra que no se trata de un Diario privado sino de uno escrito para ser leído no sólo por sus coetáneos, sino también por las autoridades españolas de Btenos Aires y sobre todo de la Península, a quienes necesitaba poner en antecedentes de lo ocurrido con anterioridad al sitio de la ciudad. 
En la primera principió el fermento por haber suspendido el corregidor Don Joaquín Alós la posesión del titulo de cacique interino que ganó Tomás Catari de una de las parcialidades del pueblo de Macha. Presintió que éste, parece, contribuia a la inquietud o sedición inminentes de la provincia y tuvo por conveniente reducirlo a prisión. Logró el reo profugar para la capital de Buenos Aires, ganó decreto del Exmo. Señor Virrey para el cumplimiento de dicho título. Regresado con él, en vez de aspirar nudamente al asiento del "duo tiana", dícese, diseminó entre los indios la falsa especie de haber conseguido de su Exelencia, libertad de tributos, repartos y obligación del servicio de la mita de Potosí. $Y$ trasladado consecutivamente al triburial de Charcas, que por justas causas acordó aprehenderlo en la cárcel de corte, el corregidor, advertido de los movimientos de los indios, tuvo que pasar escoltado de alguna gente, al pueblo de Pocoata en 23 de Agosto de 1780 al despacho de la mita de Potosí. Allí, reconvenido con el pretexto o escrito que le presentaron, demandando la libertad de Catari, sin más mérito que haberse decretado, resurrieron al dicho tribunal por ella; se vio invadido de una multitud muy considerable de indios de dicho Poconta, el de Macha y otros que estaban preparados y sublevados y que a fuerza de piedras y con la algarazara de trompetas, tambores y pifanos (que han heredado del gentilismo) le derribaron del caballo, le desnudaron y lo condujeron descalzo y prisionero a una montaña retirada, fueta de haber muerto 23 personas de la escolta y, entre ellos, a su asesor Benavides y al escribano Téllez, cortando al primero la lengua y al segundo los dedos, habiendo salvado fugitivos los demás de la escolta del bérbaro furor de la sedición. El buen cura Dr. Arzadum, deseoso de libertar al corregidor, al oir que los indios, conspiraban contra stt vida si no se les entregaba a Catari, se comprometió a su conducción y relajación a la provincia y se apersonó a este fin rápidamente en Charcas, cuyo tribunal, enterado del suceso, mandó relajarle la carcelaria y le remitió a su pueblo en compañía del Dr. Merlo, cura de dicha división de Macha. Con esto logró retirarse el corregidor por caminos extraviados, previriendo las insidias del común ordinario y arribó a La Plata. Cuando volvió Catari a stu pueblo, dio orden para libertarlo y también para prender al cacique de Moscari, Florencio Lupa, a quien mataron en Macha a tiempo que se dilataba la sedición por todos los pueblos. El 10 de Septiembre de 780 se trasladó el motín hasta los extremos de La Plata y fijó insolente, la cabeza y el corazón de dicho Lupa en la cruz de un puesto llamado Quirpinchaca, con una carta audaz en que pedían la soltura de nueve indios de Condocondo de la provincia de Paria, confinante a esta de Chayanta (aqui se ve la inteligencia de la conjuración) que se mantenían prisioneros en la cárcel de corte, como asesinos de sus caciques, los Llanquipachas, ofreciendo en su defecto, acometer y destruir la ciudad; y asi es que el tribunal por subvenir a la paci/f.1v. ficación y obviar el mayor daño, tuvo que prestar deferencia al intento.

El siguiente lunes 11 lograron los muchachos, en Chuquisaca, apresar a Pedro Caypa, indio cacique de Pocoata, quien se denegó a su corregidor para el 
sosiego de aquel tumulto y tuvo la osadía de decirle al tiempo de levantarse aquel butlicio: ¡Corregidor, ya no tienes remedio!, habiéndose entendido que clespués de haber contaminado la provincia de Yamparáez tocó en Chuquisaca, por advertir sus movimientos y preparativos, con las miras de malignidad que se perciben.

Sabedor el excelentísimo Señor Virrey de estos movinientos y otros ulteriores, libró con un gran celo e integridad, las providencias más eficaces y oportunas, cometiendo el gobierno militar de las armas a don Ignacio Flores, teniente coronel de ejército, de notoria instrucción, espiritu y amor al real servicio, para que, con doscientos hombres que primeramente mandó desde Buenos Aires, compuestos de una compañía del regimiento de Saboya, otra del fijo de aquella capital y treinta dragones y con doscientos más que ordenó venir de la provincia de Tucumán, fuera de quinientos que se le informó haber en Chuquisaca de más que regular disciplina, los de Misque y Tomina, pasase a pacificar y subordinar la provincia de Chayanta y las demás donde se siguiese igual alteración y fuesen de este virreinato.

Con la revolución de esta provincia, se destinó de justicia mayor de ella, a don Juan Antonio Acuña, a quien, a fin de Diciembre o principio de Enero de este corriente año, al viajar para Chuguisaca llevando como prisionero a dicho Catari y su amanuense, a distancia de cinco leguas de aquella capital, le asaltaron cincuenta indios (de los que iban a libertar a Catari) y le mataron con cínco sujetos que llevaba en su compañía, sin más tregua que haber disparado a éste un trabucazo, del que le dejó muerto, del mesmo modo que sucedió con su secretario o director. Se incrementó, pues, cada día más, la sedición de esta provincia con diferentes muertes en las minas de Aullagas y otras fatalidades y desastres que por la brevedad no se tocan $y$ han dado no poco que hacer a la Real Audieuela de Charcas ${ }^{\text {(11. }}$

En la segunda provincia de Tinta, también se sabe de público, que el cacique del pueblo de Tungasuca, José Gabriel Tupac Amaru, arriero de mulas o recua, se levantó con los indios de aquella y prendióal corregidor el día 4 de

(1) La versión de los acontecimientos provocados por Tomás Catari no siempre corresponde a la realidad histórica; se ve que el autor la recogió de los partes oficiales o de las narraciones semi oficiales que circularon por $\mathrm{La} \mathrm{Paz}$ en aquel entonces. Tales interpretaciones fueron a veces tan parciales e inexactas que motivaron toda una tevisión de parte de Ignacio Flores, que en su calidad de presidente de la Real Audiencia de Charcas, y por orden del Viırey Vértiz, estudí́ los hecbos, llegando a conclusiones muy diferentes. Tales investigaciones le valieron el odio de los oidores comprometidos, que se vengaron en forma ignominosa después del motín de los liocallas, enviándole preso a Buenos Aires, en donde tras un largo proceso, precisamente porque no había delito, falleció de anargura en la cárcel pública. Todo esto puede encontrarse en la documentación acumulada en la correspondencia entre Vértiz y el ministro Gálvez del año 1783. AGNBA, AGI, Aud. Charcas 543, 555. Gabriel René Moreno estudia estos lzechos en "Bolivia y Perự", Stgo, 1906. 
Novienbre del año anterior, con motivo de un banquete, tomándolo a traición por la espalda. Le fulminó una causa irregular y absurda y le mandó ahorcar con su propio esclavo negro, el 10 del nismo Noviembre, confiscándole sus bienes y caudales que tenía acopiados, de reales tributos y sus intereses peculiares. Y para dar alguna luz de los procedimientos de éste, se insertará a la letra, uno de los edictos, comisión y carta que libró y escribió a los caciques de las provincias inmediatas de Azángaro y Carabaya, que se lec en un testimonio autorizado por don Diego Femández Castañeda, justicia mayor de dicha provincia de Azángaro, su fecha 25 de Noviembre precitado, que son del tenor sigutiente:

"Edicto... Don José Gabriel Tupac Amaru, Indio de la Sangre Real de los Ingas y Tronco Principal, hago saber a todos los vecinos de la provincia de Azángaro, moradores, estantes y habitantes en ella y sus innediaciones de cualquiera estado, calidad y condición que sean, cómo los repetidos clamores que los naturaies de estas provincias me han hecho incesantemente de los agravios que se les infieren por varias personas como por los corregidores europeos y que aunque habiendo producido varias justas quejas a todos los tribunales, no hallaban remedio oportuno para contenerlos y, que pues yo, como el más distinguido debía mirarlos con aquella lástima que la misma naturaleza exige $y$, más con estos infelices, mirando todo esto, con el más maduro acuerdo, ya que esta pretensión no se endereza en lo más leve contra nuestra sagrada religión católica, sino a suprimir tanto desorden, después de haber tomado por acá aque/f.2 llas medidas que han sido conducentes a la conservación de los indios, espanoles, mestizos, zambos, mulatos, criollos, cuya tranquilidad he tenido por indispensable amonestar como amonesto, y a mis amados compatriotas, y en caso necesario mandarles no presten obediencia ni den auxilio a los jueces de dicha provincia ni sus contornos, para efecto de sorprenderme ni a mis allegados, porque, en este caso, experimentarian sus habitadores todo el rigor que el día pide, sin reserva de ringuna persona y con más particularidad con las de Europa; bien entendido que estas se extinguen con totalidad, para que de este modo cesen las perniciosas corruptelas, autoridades y demás pensiones que de los peruanos reciben, mirando en esto las ofensas a Dios, y que cesen éstas, para cuyo desempeño están a mis órdenes cuatro provincias y otras que solicitan mi amparo para sacarlos de la injusta servidumbre que han padecido hasta el día en que espero de la Divina Providencia, me alumbrará para un negocio que necesita toda su asistencia para su feliz éxito, y para que así se tenga entendido se fijarán ejemplares en la capital y demás pueblos de este edicto. Tungasuca, Noviembre 15 de 1780. José Gabriel Tupac Amaru Inga".

"Comisión para prender a los corregidores de Azángaro y Carabaya"...

"Por cuanto el Rey me tiene mandado proceda extraordinariamente contra varios corregidores y sus tenientes por justas causas, que por ahota se reservan, y hailándose comprendidos en el mismo Real Orden, los corregidores de las provincias de Azángaro y Carabaya, como igualmente, sus tenientes generales, y no pudiendo 
yo practicar por mi propia persona estas diligencias tan reencargadas por la piedad del Rey, por tener otras entre manos que piden mi personal asistencia, para que tenga su debido efecto, doy comisión, la necesaria y bastante, al gobernador don Diego Chuquiguanca, quién aprehenderá con la mayor cautela y sigilo y correspondiente custodia a dichos corregidores y tenientes, convocando para el efecto la soldadesca e indios de ambas provincias, manteniendo a los reos en segura prisión, con guardias de vista, negándoles toda comunicación hasta que otra cosa se resuelva, formando exactos inventarios de todos los bienes y papeles que les encontrasen y de que me deberá dar la más legítina cuenta, pues todo corresponde al Real Fisco y buena administración de justicia y resarcir por este medio los agravios que los naturales y otros individuos han sufrido hasta aquj. Hecho en el pueblo de Tungasuca a 15 de Noviembre de 1780 . José Gabriel Tupac Amaru Inga".

"Carta del Alzado": "Señor Gobernador don Diego Chuquiguanca: Muy señor mío y pariente de mi mayor estimación, por orden superior doy parte a vuestra merced, tengo comisión para extinguir corregidores en beneficio del bien público, tm esta forma. De que no hay más corregidores en adelante, como también, con totalidad, se quitan las mitas de Potosi, alcabalas, aduanas $y$ otras muchas introducciones perniciosas. En esta conformidad conumico a vuestra merced mis facultades para que como fiel vasallo del Rey nuestro señor, ejecute con la meyor vigilancia que personalmente lo puede hacer, primero y principalmente, tomando preso al corregidor, a quien se le embargarán todos sus bienes; y convoque vuestra merced, para este efecto, toda la provincia a voz del Rey sin dar a entender el orden, y al mismo tiempo, si reparase vuestra merced, alguna resistencia de indios o españoles, ponga vuestra merced horca en los pueblos de la provincia, advirtiendo que sólo es para los inobediemes. No hay más lugar, remítome a su literatura y discreción, lo que deba ejecutar. Entre tanto, ruego a Dios, guarde a vuestra merced, muchos años. Tungasuca y Noviembre 15 de 1780. B.L.M. de vuestra merced, su may apasionado pariente, José Gabriel Tupac Amaru Inga. /f.2v. Mande vuestra merced sacar copias del edicto original, que se pongan en los pueblos de toda la provincia y puertas de iglesia, para cuya diligencia puede vuestra merced, llamar a un pariente mío, llamado don Esteban Zúñiga, que se halla en esa provincia, pues este sujeto desempeñará a vuestra merced, como que es de casa. Vale".

Este edicto y cartas, presentó don Diego Chuquiguanca, cacique del pueblo de Azángaro, en compañia de su hijo el sargento mayor don José Chuquiguanca, juntamente con el portador del pliego, Pedro Tito, del pueblo de Pampamarca, ante el corregidor de la provincia de Azángaro, don Lorenzo Sata y Zubiría, manifestándolo cerrado como vino, y protestando su fidelidad y amor al Rey nuestro señor.

También son sabidos el combate que presentó Tupac Amaru a la capital del Cuzco, de donde se retiró derrotado por los indios amigos y 300 cholos de aquelia ciudad; la desgracia y mortandad en el puebio de Sangarara e incendio de su iglesia $y$ otros desórdenes y delitos de rebelión que, por notorios se omiten, siendo 
oportuno para aclararios, insertar igualmente la carta misiva que se entrometió a contestar al magistral de la ciudad de La Paz, doctor don José de Paredes, interceptando la que escribía al Cuzco con un peón. Dice así: "Carta de Tupac Amaru al magistral de La Paz..." "Muy señor mío, con ocasión de hallarme en estos lugares de Ayaviri, trajeron a mi presencia un indio que conducía una de vuestra merced, dirigida al doctor don José Pérez, y porque considero que mis guardias y centinelas no le dejaron dar paso adejante, con grave detrimento de su vida,.y amando yo más la yida de cualquier individuo que la nía propia, por dirigirse mis acciones a un cristianísimo celo tan opuesto al de los europeos, que quitan las vidas de inocentes sin recelo del daño de sus almas y porque la dé vuestra merced se encamina sólo a saber novedades acaecidas en mis progresos, yo sin embargo, se las insinuaré con el seguro de mi verdad. Lo primero que vuestra merced solicita, es saber si es cierto que en el pueblo de Sangarara nurieron 600 hombres que me vinieron a dar guerra. Es evidente que don Tiburcio Lahda, don José Antorio Urízar y Guisasola, don Francisco Escajadillo y don Ramón Arechaga Bizarros, capitanes, sàlieron en busca mía, con mil y más hombres de distinción y tropa bien arreglada, quienes perdieron las vidas en espacio de una hora, a excepción sólo de cuarenta y tantos criollos que a fuerza de mi sudor e industria, los pude librar del furor de mis indios".

"Lo segundo, quiere vuestra merced saber de la expedición del Cuzco, y que si las ocho partoruias están a mi bando, a lo que debo decir que sólo siete parroquias están a mi favor, aunque no las habia menester, porque la parroquia de San Cristóbal, que juzgabon estaba a mi disposición, porque cuando antes, regresaba al Cuzco, me aposenlaba en ella, los europeos herejes la asolaron, matando hombres y mujeres, sin más probabilidad que la mala propensión de ellos a perjudicar a los miserables indios; pero, con el favor de Dios, están los malvados en lugar donde pagarán lo que han hecho, pues, aunque tengo al Cuzco sitiado, sólo con once provincias de gente armada, no es poca para los que en él residen, pues la causa de mantenerse hasta ahora dicha ciudad en plé, es porque obro como cristiano, procurando con piedad y haciendo, porque no dejen asolada dicha ciudad, y en ella, los conventos, monasterios de monjas, mujeres y creaturas, y también porque dejando esto en este estado, me partí a buscar a vuestras mercedes que me decían venian en mi solicitud, por carta que me mandaron mis espias y centinelas que tengo en estos lugares. El señor obispo de la ciudad del Cuzco, es cierto que mal informado e inquieto su ánimo, se ha compuesto con sus colegiales, alistándolos para guerra pe /f.3 ro todo eso, creerá vuestra merced que no tiene substancia, sino mucho miedo de los ladrones chapetones que lo han obligado. Me es forzoso hacerle a vuestra merced una breve insinuación de mi empresa, la que solamente se dirige a quitar los abusos, malas costumbres y ladrocinios que se han experimentado por los que han gobernado este reino, en principal los corregidores que repartían sus efectos en precios duplicados, llevándose cada uno de ellos quinientos mil y más pesos, de 
cada provincia, aniquilando de plano a los miserables criollos, sin dejarlos pedir a Dios, nj encomendársele, no oir doctrina cristiana, ni hacer acto alguno de fe, sino toda la vida apurados con los repartos, sin otro Dios que el corregidor, procurando darles todo gusto y si en aigo faltan, el miedo los hace huir a los Chunchos dejando a sus mujeres y familia a vivir con ellos y hacerse a sus costumbres. Igualmente la aduana y alcabala, que perjudicaba a todo el universo, dejándolo, a veces, aún sin el principal; últimamente, la mita de Potosi tan perjudicial, que nunca los indios volvían a sus pueblos. Con apercibimiento de lo que he referido a vuestra merced, podrá insinuarlo a la Junta de Guerra de esa ciudad, para su gobierno, y he celebrado saber están prontos, con su tropa arreglada, lo que encargo es, sea bien gruesa y que así se una con la de Lima y la costa, aunque discurro que, parà mis fuerzas, era necesario reduplicadas armas que las que pudieran caber en esos países, porque conozco con individualidad, que Dios quiere la conservación de mi arreglo. pues cualquiera que ha pretendido ir contra mis armas, se ha perdido enteramente, sin poner de mi parte medio alguno para su efecto. Vuestras mercedes se fian mucho de los de Lima; yo he estado en esa Audiencia y tengo observado que estos son buenos para matar semitas y engullir mazamorra; que también en el Cuzco salió una tropa de ellos a quererla entablar con los mios, mas perdieron las vidas en un momento. Sólo sí, son buenos los de aquella Junta para entretener un pleito o demanda justa y mantenerse de la sangre de los pobres, como a mí me aconteció, que habiendo regresado por allá, discurriendo alcanzar mi pretensa, por haber sido justísima, con instrumentos evidentes, que declaraban mi descendencia de los reyes ingas de este reino, de ouienes soy heredero legitimo $y$ Linico, $y$ aunque en la dicha Audiencia lo conocían y me tenían por tal, nunca quisieron declararme enteramente, por no darme lo que me correspondia y se me había señalado par el Monarca, todo lo que me ha precisado a reparar lo que es de mi obligación, pues ya que Dios Nuestro Señor me ha dado vida, sin atender a mis graves culpas, quiero hacer algún mérito para con $\mathrm{El}$, atento a la obligación que me asiste de mirar y amparar a los del reino, aunque perdiera mil vidas si las tuviera, pues es en alivio del bien común y en contra sólo del mal gobierno, expeliendo sólo acorregidores y a todo chapetón que quiere ir contra mis sanas órdenes. Aunque infiero que por allá concebirán y ponderarán el furor de mis armas, esté vuestra merced cierto, que de mi orden a ninguno han muerto, sino al corregidor de Tinta, a quien para ejemplar de muchos que daban contra la Iglesia, lo mandé colgar y porque tenía muchos más méritos para ello, pero los que se han seguido a morir los han muerto en guerra campal los indios, como a los que han procurado hacerme traición, aunque es cierto que a los más de estos, he perdonado por mandar Dios perdonar al enemigo. También como ilusos habrán culpádome la quemazón de la iglesia de Sangarara, pero aseguro a vuestra merced que los caballeros que vinieron, anduvieron como unos bárbaros, porque habiéndose introducido estos en dicha iglesia, iniciaron la guerra de allí, y de un cañonazo me mataron seis indios en el cementerio de la iglesia. Yo llevaba ánimo 
de que nadie pereciese, por lo que escribí tına dirigida a los criollos que allí estaban, y oyendo esto los chapetones quitaron las vidas a varios, estando el Santísimo Sacramento descubierto, causa de que el cura de esa doctrina cogió a Nuestro Amo y se salió fuera con El, y quiso Dios que la mesma pólvora que introdujeron adentro prendió fuego a la iglesia y la consumió /f.3v. Para que vuestra merced conozca el modo con que he procedido, anoticio a vuestra merced cómo viendo el peligro en que se hallaba la ciudad, nuandé dos embajadas con dos sacerdotes y tres segiares para que les explicase a lo que yo iba, además de escribirlo yo por carta al Cabildo Eclesiástico y Junta de Guerra, y hasta ahora no he tenido respuesta, y aunque el sef̃or obispo quiso responderme personalmente, saliendo a mi real a hablarme, se lo impidicron los malvados, atemorizándolo podía morir con alguna bala desviada, y de este modo, han procurado que por tal cual europeo que se le quiere quitar el que robe, procurando el bien de su alma, se pierda toda una ciudad. Tengo hecho informe a Su Majestad, representándole ni designio y pronetiéndole adelantar otro tanto, de lo que le daban los ladrones del reino, y vuestra merced crea que así se mantendría en paz y quietud y que se repararian las cosas de Dios con la adoración debida, $\sin$ tener muchos dioses corregidores y ministros, que con capa de $S_{u}$ Majestad hostilizan más a los miserables. Todo esto se ha procurado por mi, por ser mi obligación hacerlo, por único descendiente del Rey último del Perú y su heredero legítimo y no había quien se dedicase a jibrarlos de manos de faraón. Mucho más dijera a vuestra merced en estos asuntos pero, las ocupaciones no me dan lugar y sólo ruego a Nuestro Señor, me lo guarde muchos años. Chuquibamba y Enero 26 de 1781. Beso la mano de viestra merced. Su muy seguro servidor José Gabriel Tupac Amaru" (b).

Supuestas las inicuas atrocidades, mortandad, hurtos e incendios que comete el maldito Tupac Amaru y causó en diferentes pueblos y provincias hasta el Collao y la de Lampa (donde vino) y que fue inspirando la sedición en todas las del Cuzco y contaminando las de Guamanga y provincias de Charcas se ha de notar la oculta inteligencia que tuvo con los indios de la provincia de Chayanta y otras sublevadas muy de antemano y acaso, desde ahora seis años, según opinión de algunos, como lo da a entender aquella solicitud de los indios ce Chayanta por los nueve prisioneros de la de Paria, su confinante, y pueblo de Condocondo. Y asi es que esta fue la segunda que se levantó y siguió a Chayanta, entre las del distrito de los

(1) Como en el caso anterior, también el Oidor narra la sublevación de Tupac Amaru, basíndose en las versiones oficiales. Esta vez, sin embargo, al agregar la copia de las cartas del caudillo Aman, deja entrever que existe una versión diferente, la de los naturales, que justifican su proceder con toda tna temática político social, así como con una distirta natración de los acontecimientos. 
Charcas (1). Porque habiéndose encaminado descle la villa de Oruro, el corregidor de dicho Paria, don Manuel de la Bodega y Llano, con la escolta de setenta hombres armados, al pueblo de Challapata, a efecto de sosegarlos y subordinarlos, porque se le habían rebelado del todo y negado la obediencia, depontendo de poder absoluto los caciques y justicias ordinarios que habia nombrado, y sublevando otros de su facción. Sucede que con su arribo a aquel pueblo el Domingo 14 de Enero del corriente año, a las cuatro de la mañana, logró aprehender cinco de los delicuentes cabezas. El día siguiente, Lunes, a las tres de la tarde, le asaltaron un simúmero de indios amotinados con el designio de libertar los presos y acabar con los de la escolta, en tales términos que mataron al desdichado corregidor y sus acompañados, con la escasa suerte de haber también salvado fugitivos uno u otro; con lo cual se quitaron la máscara y se alertó toda la provincia de Paria, trascetzdiendo este cáncer a la inmediata de Carangas, su confín, cuyos indios mataron igualmente a su corregidor en el pueblo de Colguemarca, a fin de Enero o principio de Febrero. Con estos movimientos los vecinos y moradores de la villa de Oruro, noticiosos de que los indios de Chayanta y Paria pretendían trasladarse a ella y cometer los mesmos estragos, tuvieron que mantenerse en expectación y sobre las armas con el conocimiento universal de que estos traidores no quieren tener quien los gobierne, ni más que quitar del medio a los corregidores buenos o malos./ f.4.

El día 10 de Febrero se verificaron aquellos recelos y acometieron a media noche los indios de Paria y Chayanta a la villa de Oruro, en el numero de cuatro mil con el pretexto de socorrcrla. Los cuales, juntos con los cholos de ella, dieron contra los europeos y algunos criollos, habiéndolos tomado dispersos y descuidados en sus casas. Mataron hasta veinte y nueve sujetos de aquel vecindario y comercio, con más catorce esclavos suyos. Son los siguientes: don José Endaiza, de Buenos Aires, Larao, Palazuelos, Salinas y su cajero, don Juan Blanco, don José Martínez, Lagrava, Pavía, oficial mayor de Caja, Bustamante, don Vicente Fierro y su hijo, don Ventura Ayarza, Casas, Caballero, Bullin, el alcalde ordinario Llano, Garcia, don Melchor Rodríguez, el Pasiego y su compañero; ignórase el nombre y apellido de los demás. Los que salvaron vivos fueron: los dos Sorzanos, Portillo, Gurruchaga, Herrera, Rubín, Santander, Santelices, Quixoga, don Juan Antonio Martínez, don Manuel Soto, el chileno Soto, Royo, Muguruza, el alcaide. El corregidor de la villa y los dos oficiales reales se ocultaron.

Los sublevados saquearon las casas de muertos y vivos, y opinan pasar el hurto de más de dos millones de pesos. De la Caja Real se dijo, sacaron doce zurrones de plata sellada, que por lo regular suelen componerse de dos mil y quinientos pesos fuertes cada uno, y se distriburyeron entre los amotinados, pero se

(1) Tanlo jos informes oficiales, como las opiniones de los observadores y participantes en el solocamiento de los movimientos revolucionarios indigenas, coinciden en sostener fa relación y el entendimieuto existentes entre los dos caudillos Tupac Amaru y Tomás Catari. 
falsificó. Los que no reservaron ni las iglesias ni las vestiduras sagradas, pues a dos refugiados en el convento de San Francisco, que tomaron por desfigurarse y librarse la investidura del santo hábito, los conocieron y mataron con tal violencia que no dieron treguas para quitarlos. A los más asesinaron en sus casas y la mañana siguiente los llevaban arrastrados de los cabellos a la plaza mayor, donde los amontonaron sin permitir su entierro, por decir que se los comieton los perros, para después incendiar los huesos y arrojar las cenizas al aire, hasta que a ruego y llanto de los padres dominicos que salieron en procesión con el Santísimo, consintieron que los llevasen a enterrar (1). Treinta y tantos de los indios que se hallaban en dicho tumulto y despojo, ascguran fueron los peores unos de los que hacen viajes a los Andes de Yungas y otros del pueblo de Sicasica [?\}.

En éste y toda la provincia de este nombre, con motivo de haber pasado a elia doce de los indios alzados de la de Chayanta a mediados de Septiembre del año anterior de 780 y del nombre y fama de los de aquella provincia de Sicasica, de alzados famosos y guerteros, a fin de imbuirles para que se levantasen contra los corregidores, europeos y todos los de cara blanca (3), se suscitó la diabólica especie entre ellos, de si debian pagar los tributos al Rey Católico, nuestro señor o a su Rey Inga Tupac Amaru. Com esto el corregidor interino, don Ramón Anchoris, de mucho juicio y suavidad $y$ beneficio a elius, se manejaba con tiento y moderación, sinresolverse a dejar ba provincia, aun con los movimientos de Chayanta y Paria, receloso de que en su ausencia se alborotase la Provincia. Tuvo noticia de hallarse

(3) Al hacer la síntesis de los sucesos de Orumo. del día lo de Febrero de 1781, el ojdor Diez de Medina cifa tonbres. aunque no del todo exactos ni completos, pero el cambio se ve que desconoció, o no quiso reconocer, la índole del novimiento, que fue provocado por un grupo de criollos que queriendo levantarse contra los peninsulates del lugar, lamaron en su ayuda a los indios de Puria. Desencadenado el motín e iniciada la matanza, a los cabecillas les fue casi imposible controlay el desborde de los indios que, mocivados de antemano por las consignas de Tupac Amaru, no hacian muchas diferencias entre chupetones y criollos.- El autor, culpando a los indios, agrega que se les juncaron "los cholos" (mesizos) para matar a los europeos y a algunos criollos, pero no menciona siquiera la posibilidad de que estos últimos fubieran podido cometer tales demasias.

(2) Estu frase que asigna el mayor thínco a los indios comerciantes a "tragineros", viene a confirmar la tesis del historiador ârgentino Oscar Comblit. que supone a este tipo de indigenas, agentes activos del movimiento de Tupac Amaru. Society and Mass Rebellion in EightecnthCentury Perú and Bolivia. Oxford University Press 1970-.

(3) Diez de Medina no ve una relación directa entre los movimientos de Paria, Oruro y Sicnsica con los del Cuzco; la conexión con la rebelión general se habría producida a través de Chayanta.

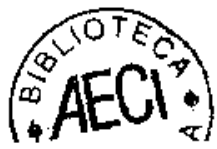


los demás indios de sus pueblos en un punto crítico, con las noticias de Tupac Amaru y su rebelión y en consultas para insidiar su persona por medio de la sublevación dispuesta.

El 11 de Febrero dicho, sabedor el corregidor Anchoris, por un mozo, (a la mesma hora de la noche antecedente) del suceso y desgracia de la villa de Oruro, según lo confirmó después, se halló a la madrugada en la cama, con la novedad de parte del cacique don Pablo López para que luego saliese del pueblo, por haber veruido los indios de ambos ayllos, aquella noche, con ánimo de matarle. Tuvo así por bien, de retirarse al momento y con disimulo de su capital, bien que descarriado, para el pueblo y valle de Caracato, de la misma provincia, desprendiéndose de los dos alcaldes que aquella hora se le presentaron y considera fueron espias, con el pretexto de mandarlos a cierta orden judicial. A poco rato do haber salido este corregidor del / f.4v pueblo de Sicasica, se lienó su casa de los indios principales y demás, como los yanaconas de estancias particulares, que con efecto se habian convocado y buscaban su persona. Al ver su retirada pretendieron dorar su iniquidad, manifestando un sentimiento aparente, coin el intento supuesto de lo que solicitaban para que los nombrase un cacique y segunda. En este mismo dia tramaron escribir una carta que condujeron al día sigaiente 12 , al pueblo de Caracato donde ya estaba un español, don Bartolomé Oyardo y un indio principal de Sicasica e hilacata, Ascencio Condori, y esa con el contexto satisfactorio de haber sido aquella convocación, para que les nombrase de cacique a don Juar Bartolomé Vargas. Expresan la perversidad de algunos malévolos, que le informaron mal para su ausencia, lo penoso que les era el carecer de su vista y buen corazón y que les mandase el nombramiento de dicho cacicazgo en el susodicho, que con efecto les otorgó, por tal de pacificarlos y tenerlos gratos.

El dicho día 12, le avisó el indio hilacata de la estancia de Ayoamaya (tres cuartos de legua del pueblo de Sicasica) por medio de su amo don Fernando Ramos, que estaba en Caracato, que luego procurase salir de este pueblo para la ciudad de La Paz, sin creer nada de las mentiras que le escribieron los indios y otros, puesto que él también estaba citado con toda su gente para pasar al pueblo de Sicasica y juntarse con los demás para matarlo si volvía a ét y asaltarlo descuidado, caso de seguir en Caracato. Con este antecedente y la noticia que el 22 de Febrero a las ocho de la noche le comunicó un vecino, de que los indios por sorprenderlo y matarlo aquella noche, tenían embargados los caminos de Yungas y La Paz, manteniéndose varios de Sicasica en el ríos, se ausentó sobre la marcia y a la hora, para el pueblo de Sapaaqui, junto con don Lorenzo Aragón y don Mariano Castel, su amanuense, donde se mantuvo oculto en casa del primero.

El 24 de Febrero, víspera del carnaval, se declaró la rebelión del pueblo de Sicasica, después que el jueves anterior 15 dicho, se verificó en el pueblo de Caracollo, distante ocho leguas de la villa de Oruro para esta ciudad. En el primero, 
fue muy considerable el alloroto, y mataron los indios, con la bárbara ferocidad que acostumbran al cacique de Urinsaya don Pablo López, su madre, mujer e hijos; al alcalde Ambrosio, a la mujer del otro cacique de Aransaya, Apaza y su hijo y a Eugenio Nina, asi mesmo, indios. $Y$ de los españoles, a don Tomás Zelada, maestro de postas, don Lorenzo Anover, don Tomás Alarcón, don José Bausas, don Manuel Fuentes, don José Díaz, Ortiz, don Pablo Pineda, don Pedro Guzmán, su mujer e hijas, don José Calderón, Sebastián el platero, don Cipriano Ocaña, don Vicente Ocaña, Pedro el platero, el mozo die Loayza y otros varios que se ignoran sus nombres. Se sabe que no reservaron a los párvulos y que a diferentes sujetos sacaron de la iglesia, para asesinarlos, conjeturándose que pasen de cincuenta los muertos, iuera de los que pudieron huir.

Cundió el fuego al pueblo de Ayoayo, ocho leguas de Sicasica, donde, y en sus contornos, mataron a los que encontraban de cara blanca; entje ellos a doña Josefa de Loza, anciana, dos subrinas, una nieta y a don Javier Villacorta; a la mujer del platero y sus cuatro hijas, habiéndose refugiado en Ia iglesia don Bartolomé Arzabe, azoguero y el administrador de tabacos, don Mariano de Larreinaga, que salieron prófugus del pueblo de Sicasica (1).

En este paeblo de Ayoayo fue donde se erigió en cabeza de motín el indio Julián A paż, originario de êl (2), intitulándose: Yo el Señor Virrey -y con el supuesto sobrenombre de Tupac Catari, sinónimo del apellido Tupac Amaru, que en el idioma general o yuichua significa serpiente relumbrante. Lo mismo, identicamente importa la primera en el idio/f.5 ma aymara. En ambos significa lo mismo el Tupac, que es of término brillante o relumbrante. El Amaru es la serpiente en quichua, y en el aymara, el Catari. Dícese que este indio sangriento y carnicero o bestia feroz, que se arroja sobre el primero que encuentra o ve, física o intencionalmente, sin que le haiga hecho mtal (y que tarde o temprano pagará las execrables inauditas agresiones y tanta sangre de inocentes que por sus diabólicas máximas ha hecho correr por raudales) con motivo de la sedición de Ayoayo, logró interceptar un peón y la correspondencia que mantenía aquel Tomás Catari de Chayanta con el perverso traidor Tupac Amaru, en la cual, dándole el primero razón de sus progresos en Chayanta, Ie incluía unos papeles pertenecientes a su linaje, familia

(1) Las noticias de to ocurrido en Sicasica, Ayoayo, Calamarca y Caracato, las obtuvo seguramente de los informes que en La Paz dio el corregidor de Sicasica D. Ramón de Anchorís, una vez que pudo refugjarsc en ella. AGNBA 9/5-5-3.

(2) Comunmente los documentos de ha época del cerco le suponían originario de Ayoayo, sín embargo, el mismo Oidor. al enviar copia del juicio, que como auditor de guerra, le siguió en el Santuario de las Peñas, el 14 de Noviembre de 1781. (Bibitoteca Nacional de Buenos Aires 018991) anota que en realidad procede the Sicasica, del ayliu de Sulcavi. 
y descendencia (1) y que por la sustancia de ellos maquinó subrogarse en el lugar de dicho Catari, de quien sabía haber ya muerlo. Y aún corre, que fingió haber éste resucitado en su persona $\{2\}$, quedando al mismo tiempo entcrado de las intenciones pérfidas e inicuas de Tupac Amaru. Dejémoslo pues, por ahora, tevolviendo este pueblo y otros, por cartas y comisiones, y vamos a los demás de la provincia de Sicasica para obviat confusiones, aunque con el Diario tengamos que retroceder a las ocurriencias de esta ciudad \{3\}.

Consecutivamente se alteraron los pueblos de Calamarca, cinco leguas de aquel, donde mataron al cacique pasado de Ayoayo, don Eusebio Urbina y su mujer y al de Sapaaqui, el 3 de Marzo, donde así mesmo asesinaron a la mujer del cacique, sus hijos y demás familia, muchas mujeres españolas que se habian refugiado en la iglesia, de modo que murieron pocos hombres porque previriendo el daño, supieron salvar sus vidas con la fuga.

El 4 de Marzo escaparon del pueblo inmediato de Caracato, cosa de ocho hombres, y la clemás gente, refugiada en la iglesia (cuyas llaves artancaron de poder del cura, doctor don Alejo Sanjinés, arrostrando a matarlo si no tas entregaba) perecio y fue víctima del furor bárbaro de los indios, que con la sangre que corría de los cuerpos degollados, no sólo bañaron toda la iglesia, sino que todo el piso fue un lago de ella; robaron las alhajas sagradas, saquearon los bienes de] vecindario, quemaron el pueblo y aún destecharon la iglesia y apenas escapó el dicho cura, a quien llevaron prisionero para el pueblo de Sicasica.

Siguió la revolución por este valle adentro, al pueblo de Luribay, con iguales destrozos que los otros, ignorándose el número de muertos, que serian pocos, por los muchos que pudieron retirarse a los Yungas.

(1) La noticia de que el nombre de Tupac Catari, así como la idea de constituiruc en jefe de los rebeldes hubiera nacido de la intercepción de carlas entre ios dos candilios, aungue parezca bastante peregrina, era la voz común por aquel entonces. Fin efecto, Segurola lo anota en su Diario de los Sucesos del Cerco dé la Ciudad de La Paz. p. 10.- Es posible que hubiera algo al respecto, porque en las Declaraciones de Julián Apaza a que bemos aludido, dice: "que sabe que la causa de su prisión es la de haherse constiulido en cabeza de alzamiento"... "por facultad que le dispensó un Catiri por unos papeles que le dió en el pueblo y alto de Sapahaquí, confiriéndole por ellos el título de Virrey"...

(2) Tal idea tan lejana a la logica puede sin embargo tenerse en cuenta al hacer un análisis psicologico de Tupac Catari, gue en varias ocasiones obra en forma un tanto misteriosa para rodearse de un cierto prestigio con el que podín anmentar su reputación.

(3) Al decir que debe retroceder con el Diario. a las ocurrencias de la ciudad, está demostrando que agrego esta lntroducción después de funalizado el Diario. 
En el asiento de Araca sucedió to propio y sólo se sabe, perecieron muchas mujeres y niños.

En el pueblo de Yaco hirieron al cura, ayudante y un religioso cuaresmero; mataron al ayutante de Ichoca, don Jomás Valdés y mutrieron muchos españoles, mujeres y niños, con destrozo y combustión de las casas.

Del valle y pueblo de Quime, compuesto de muchos esparioles, no se tiene razón alguna y se presume hayan perecido, una vez que no la hay de que hubiese alguno escapado.

En el pueblo de Inquisivi, se dice que aquellos indios dieron muerte a su cura, pero no se sabe de positivo, sí sólo, que tumultados los indios, hicieron destrozos y ejecutaron muchas muertes.

En el de Capinata, varios españoles murieron, de ambos sexos y sólo se sabe haber sido uno de ellos el cacique Gutiérrez, y que lo desolaron todo.

En el de Cavari, salvó el cura, de huida a pie. Arruinaron el pueblo en dos horas, ignorándose los que hubiesen muerto. En el de Mohosa, también se dice, degollaron loda la familia del cura y aún corre que al eclesiástico don Manuel Ramallo también le dieron muerte atuera del pueblo.

En el te lchoca, se cuentan seis muertos en el destrozo de casas y haci/f.5v. endas de españoles, taladas, saqueadas y destruídas en éste como en todos y repartidas entre lus indios sublevados, con sus frutos, ganados, aperos y demás pertrechos, porqui el intento se determina a quedarse con las heredades y acabar no sólo ton los espantoles sino con todo hombre de cara blanca o que viste el traje de ellos. Si algunos han salvado ha sido tomando el traje de indio y haciéndose al bando de ellos.

\section{OCURRENCIAS EN LA CIUDAD DE LA PAZ EL $1^{\circ}$ DE FEBRERO DE 1781}

Hecho cargo don Sebastián de Segurola, teniente coronel del ejército y corregidor de la provincia de Larecaja, desde 2 de Enero del año corriente, de la comandancia o gobierno militar de las armas, prinero por nombramiento del señor regente de la Real Audiencia de Charcas, quien le mandó que en lo económico se expidiese con dirección del señor don Femando Márquez de la Plata, fiscal de lo civil de ella y comjsionado por el superior gobierno para asuntos de la Aduana en dicha ciudad, y después por subdelegación para estos países del teniente coronel don Ignacio Flores, comisionado principal del exelentísimo Señor Virrey, como se ha dicho (1).

(1) Fermando Márquez de la Plata fue nombrado por Juan José de Vértiz el 16 de Mayo de 1780 "juez y principal comisionado" en relación con los disturbios ocuitidos en La Paz con molivndel establecimiento de ha Aduana y pago de atcabala. AGI. B. Aires 60 . El 28 de Julio 
empezó a reclutar las armas de los vecinos y moradores de la ciudad, pero con la desgracia de haberse acopiado muy raras por la desconfianza o inadvertencia de los interesados o porque no se llevó el asunto a pura y debida ejecución (1).

Ilegó a La Paz y cuando todavía estaba invesligando aquellos problemas -se desprende de se correspondencia con Vértiz. AGNBA. Charcas 9/5-5-3. - se produjeron los acontecimientos provocados por Tomás Catari y Tupac Amaru. Márquez de la Plattı, basándose en la responsabilidad que le exigia su cargo así como en el conocimieano que habia adquirido de las provincias de la Siena, pidí́ al Virrey, el 27 de Noviembre de ese año. el envío urgente de 400 hombres de "Iropa arreglada" y de un jefe militar de "graduación, pericia, prudencia y conocimiento práctico de estas regiones" que dependiere del presidente de Charcas en sus operaciones y estuviere conforme en todo con Vertiz. AGNBA Clarcas 9/5-5-3. A esa petición añadio, el 2 de Diciembre de 1780. un plan de organzación del virreinato del Río de la Plata. en Gobiernos Militares que se extendieran desde Chichas hasta Lampa. El 26 de Diciembre volvío a informar a Vérliz sobre la situición en La Paz; en esta ocasión le apremió para que nombrara un militar que pudiera hacer frente a la "desunión de los vecinos, a la poca subordinación" y a las necesidades de organizar la defensa. Sugirió entonees los nombres de Ignacio Pinedo y de Sebastián de Segurola. corregidor de Larecrija.

No sería raro que ya hubiera hecho dro tanto con Iguacio Flores, a quien conocía bien por haber trabajado juntos en la cuestión de la Aduana, porque ya éste, en su calidad de teniente coronel. gobernador de armas en las provincias alzadas en Charcas, habia influído en el presidente regente de. Charcas para que el 17 de Diciembre de 1780 nombrara a Segurola como comandante de armas de La Paz. Flores avisós al Virrey de exta designación el 15 de Enero de 1781; en esa ocasión le insiste, en que conociendo los problemas do La Paz y sabiendo que Fernando Márquez de la Plala está ocupado en graves așuntos económicos. le solicitó este nombramiento al presidente de la Audiencia, AGNBA. Charcas 9/5-5-3.

Efectivamente, en el nombramiento que Jeronimo de Ruedas, presidente regente de la Audiencia, le hace a Segurola, Je ordena suspender sus tareas en el corregimiento de Larecaja y trasladarse a La Paz. Le aclara además que el el ejercicio de sus nuevas tunciones se "entenderá en todo lo econónico con Fernando Márquez de lá Plata", y en lo demâs con el Presidente y con Ignacio Flores. AGNBA. Charcas $9 / 5-5-3$.

(1) Es evidente que el Oidor quiere sentar la lesis de que Segurola logro juntar pocas armas. No deja bien claro, en cambito, la razón de su aseveración; dice que podía tratarse de "desconfianza e inadvertencia de los interesados". pero no señala quiénes eran los desconfiados, ni de quién desconfialaan. ¿Eran los vecinos? ¿Desconfiaban de la idea de que la sublevación llegara a La Paz o desconfiaban de un comandante venido de fuera? ¿Quiénes eran los interesados? ¿Los moradores de la ciudad que poseían ammas o los organizaciores de la defensa? Añade otra posibilidad. la de que se hubieran reunido pocas armas porque el asunto no se llevó con "pura y debida ejecución". Queda flotaudo en el aire la misma anbigüedad; ¿quiénes actuaron sin ejecutar las cosas en forma "pura y debida": los vecinos, el corregidor o el comandante? 
La ciudad tenía cosa de 100 fusiles antiguos y pesados y tuvo que deshacerse de 200 en meses anteriores y con motivo de los movimientos de los indios chiriguanos, para cuya contención los pidió la superioridad de Charcas (1)

11. Es interesante rolejar lás cifras del Oidor con las que Fernando Márquez de la Plata, en su calidad de fiscal, anota en un informe que eleva el 6 de Diciembre de 1780 al Virrey Vértiz. Dice en aquel documento. que pasó a ver la ameria "la que encontró bastante arreglada" y con las armas en butro estado. "siendo el número de fusiles hasta unos cienro, algo más de quinientas tanzas. ałgunos sables y bayonetas, más de sesenta unifomes, cerca de dos mil cartuchos, algunas balas y un cuñoncito de campaña cálibre 2". Añade que a eso hay que agregar "blguna pólvora" que está encargada y hasta cuatro quintales de balas que var a bacerse. También se reliere a 100 fusiles enviados a la Plata para detener a los chiriguanos, como también a umos 190 que por orden de la Audiencia se enviaron a Juan de Pestaña para la expedición del Matogroso: con alguna ingenuidad cree que todos esos van a recuperarse, al unotar que ellos "deberán agregarse a su tiempo" AGNBA. Charcas 9/5-5-3.

El día 5 de Enero, el corregidor Fermín Gil de Alipazaga entregó ante nolario el inventario de lo que desde 1774 existía en la Real Sala de Armas bajo el cuidado del capitán Vicente Peñaranda. En ese documenlo figurant clupas, calzones, birretinas, camisas de brelaña, corbatincs. cartucheras, bolsas granaderas y botines para unos 60 o 70 oficiales. Tambien se anotam 12 sables pequeños. 277 bayonetas, 290 fusiles, 365 lanzas, 17 sables, 375 cartucluos de pólvora, 2465 balas de fusil, 2 cureñas para cañones, 2 cañones (1 quebrado), 6 carpas grandes y 220 piedras de fusil.

No fueron esos los items recibidos por el comandante, porque el escribano Crispín de Vera y Aragón añade al final que se le devolvicron las tres lojas del inventario a Segurola en conformidad a lo corregido y concertado. AHNM, Pleito del corregidor Gil de Alipazaga contra S. de Segurola y F. M. de la Plaia.

También puede verse a través del pleito aludido, que Segurola, antes de obtener tal inventario, había conseguido que el capitán Pejaranda le entregara otro, con lo que realmente existía en la Sala de Armas; también se anotaban alli las cosas que se babian mandado a hacer con los fondos propios de la ciudad y con los obtenidos por parte del corregidor. Figuran en estu Jista: 100 fusiles compuestos y expeditos, 73 uniformes para granaderos, menos, 7 calzones, 55 birrelinas, 21 sombreros viejos, 68 cartucheras usadas, 40 corbatines, 50 pares de botines viejos, II sablecitos, 100 bayonetas, 270 porta fueiles, 372 Janzas, 17 sables o machetes toscos, 11 alabardas viejas, 1 cureña, su pedrero y sus ruedas y 6 carpas de costales sin palos ni estacas. A eso se agregaba lo hecho de mievo que consistía en: 27 vestidos, 27 sombreros de tres picos, 60 cartucheras de hojalata forradas en baqueta, 400 piedras de fusiles, 1 balero, 6 _ quinlales de plomo de lo que hicieron balas, 8 arrobas de pólvora, con las que se construyeron los cartuchos que llenaron dos petacas. 
y los remitió el corregidor incautamente, dejando desarnada la ciudad, por obedecer (1). No se tomó providencia alguna en todo Enero, ni hasta aquí, paraa copiar víveres ni disciplinar la gente (2), ni el corregidor de La Paz, don Fermín Gil de Alipazaga, tampoco lo hizo, por falta de facultades o, porque parece, todos fueron tropiezos, articulos y dificultades, para recurrir al dinero de las Cajas Reales, con la calidad de reintegro (3).

(1) Si Diez de Medina censura al corregidor por haher mandacto eșis atmas incuutanente dejanclo la ciudad desarmada, F. Márquez de la Plata le acasa ell cambio por haber querido proceder con precipitación y falta de prudencia. al señalar que quisor publicar banclo cuitndo se recibieron las primeras noticias de la subleváción de Tupac Amara, para alistar a la gente. Al fiscal le parecia que alarmando asi al vecindario sólo se jba a corseguir alejar a fos proveedores de víveres como a Ios menestrales e indios, en monentos en que en La Paz habia bastantes oficiales y no existía, en cambio, "shhuado alguno alistado". Le presionó entonces para que con "maña y reserva" solo advirtiera a los vecinos de conflian/a para c|ue babilitasen sus armas, como asimismo, a los dueños de tambos y posadas para que diariamente dievan cuenta ale los nonbres, del lugar de procedencia y del número de fourasteros que recihfan. Titmbién le hizo organizar rondas noclumas con moradores honsados y volunarios. AGNBA, 9/5-5-3.

(2) Asegura el Oidor que en todo el mes de Encro, es decir cumdo la baz esta ya en manos de Segurola, no se ha hecho nada por conseguir viveres ni discipluar gente. Por el contrario. Márquez de la PJatio. informando al Virrey el b de Febrero de 1781 sobre la urgencial que tiene el comandante de auxilios y de instrucciones, lo dice que no obstante ef abandono en que se halla en este sentjdo, ha puesio gran "actividad y esmero para habilitarse para obrar defensiva u ofensivamente". AGNBA. Charcas 9/5-5-3.

Efectivamenle, a través de la documentación acumulada en el plecito citado del corregidor Gil de Alipazaga contra Segurola puede aprcciarse una gran actividad por parte del comandante que se preocupa de organizar las milicias, de obtener con el obispo de La Paz alojamiento para las tropas en el Seminario, y ante las Cajas Reales para gue se le faciliten los fondos necesarios destinados a organizat la defensa y lí ohtención de viveres.

Existe asimismo una vasta documentación sobíe la adquisición de víveres y su reparto a las tropas, pero desgraciadamenle las cuentas certificadas se iniciati sólo en Febrero. es decir, después que Segurola obtiene la autorización pata extraer fondos fiscales.

(3) Existe una larga documentación que permite apreciar la exactitud de lo afiranado por el Oidor- El corregidor Gil de Aljpazaga habfa solicitudo, en Diciembse de 1780 a a las Cajas Reales que se le autorizara la extracción de 20 mil pesos para organizar la defensu. Lus oftciales de las Cajas se negaron protestando que no estaba entre sus atribuciones acceder a tai petición. Ante las insistencias del corregidor, que actaiba ahora apoyado en la legislación indiana, se le quiso demostrar que el peligro no era grave puesto que el fiscal Fernando Márquez de la Plata, que poséa autoriznción para retirar tondos de las Reales Cajas, había devuelto el día 15 de Diciembre $5 \mathrm{mil}$ pesos que hábír retirado para los mismos fines. 
No hay más preparativos que algunos pedreros, bien cortos, que había mandado fundir el corregidor, alguna poca pólvora $y$ halas y la compañia de granaderos, que éste la tenia en disciplina militar por medio de don Carlos Rogers, inglés de nación, y que la mandó continuar nuestro comandante militar (1), quien nombró de coronel de milicia de la infantería de esta ciudad a don Antonio Pinedo, del Orden de Santiago y vecino ya de la ciudad de Buenos Aires, donde se halla casado; y de sargento mayor general de órdenes, a su hermano don Ignacio Pinedo, capitán del ejćrcito y vecino. De suerte quue, por falta de dineros, no se avanzồ cosa de mayor sustancia en todo el Enero pasado, hasta que llegado el 13 de Febrero, un peón extraordinario de Charcas, con la referida subdelegación del señor Flores, con las facultades que tenía de Su Fxcelencia para recurrir por los gastos necesarios a las

El corregidot. ante la nueva negativa del defensor de la Real Hacienda, José María de Sanjurjo. protestando la inminencia del peligro y afrontando las responsabilidades de su aciuación. procedió a retirar los $20 \mathrm{mil}$ pesos pasanclo por cncima de las formalidades y exiglendo las llaves por la fuerza. En electo, el 19 de Diciembre procedió a la extracción del dinero dejando resguardo, avisando a la Audiencia y entrcgatsdo los fondos posteriormente al lesoreto proveedor don Ramón de Rojas.

Todo csto habia ocasionando escenas bochornosas de acusaciones y recelos entre los miembros dal Cabildo y de las Cijas Reales. Fermín Gil de Alipazaga, temendo loda la razón de su parte, halsia actuaklo, sin embargo, con grau corpezá y falta de tacto, pasando por cncima de autoridades tán importantes como Fernando Márquez de la Plata, quien, indignado, se quejó al presidente de la Audiemcial y al Virrey. AHNM. Pleito del corregidor Don Femión Gil de Alipazaga... Pieza N"1.

(1) El autor del Diario, al afirmar tal cosa. no sólo quiere ignorar lo actuado por el comandante sino también to hecho por el corregidor anteriormente. Sin embargo, se puede constatar por la documentación que Gil de Alipazaga entrega a Segurola, así como por lo que el propio comandante afirma en su Diatio y en sus notas a lgnacio Flores que el corregiodor había mandado labricar 24 pedreros, 1500 granadas, 5000 cartuchos y 1500 lanzas. Asimismo había enviado comprar a Oruro 30 quintales de cobre y habia reunido en La Paz 50 quintales de plomo y 30 de pólvora.

Por orra parte, el 4 de Enero, Gil de Alipazaga tabla de enviarle a Segurola las tistas de las compañías existentes, que son 10 de infantería, 6 de caballería y 1 de granadems. E] comandante se queja en los primeros días de Encro de que las listas ofrecidas no llegaron nunca a sus manos, pero reconoce que posee por sus propias diligencias las listas de 7 compañías de infantería y 5 de caballería.

Es evidente que gran parte del material no llegó a obtenerse por las dificultades del cerco y por los avatares de la misma lucha, pero no puede cierlamente acusarse al corregidor de una absoluta negligencia, como lo hace el Oidor en su Diario y el propio Segurola en sus informes dirigidos a la Audiencia y al Virrey. AHNM, Pleito del coregidor Fermín Gil de Alipazaga... Piezas $n, 1$ y $n .2$. 
Cajas Reales de Potosí, Chucuito y, previniéndole actuase todos los necesarios, ocurrió a esta Real Caja, que con efecto la tiene franca y a su disposición (1).

Con esto, y la noticia funesta de la desgracia y fatalidades de la villa de Oruro, el 10 de éste, y que grasaba el vicio de la sublevación de indios, respirando para esta ciudad, se trató de la construcción de trincheras y fortalezas en el principal recinto o centro de ésta, que empezó el 6 del corriente Febrero, por deliberación tomada en Junta de Hacienda, bajo la dirección de don Manuel Franco, coronel nominado de las milicias imaginarias del pueblo de Songo, provincia de Larecaja (2), y de los respectivos diputados que para cada una se nombraron (3),

(1) Si diffeiles fueron los trámites del corregidor Gil de Alipazaga para conseguir fondos de las Reales Cajas, más largos y embrollados fueron los del comandante Segurola en Febrero de 1781; en efecto, no sólo hubo de enfrentarse al defensor de la Real Hacienda sino también a los oficiales de las Cajas y al propio Cabildo. Se celebró por fin una Junta de Real Hacienda, y en ella Segurola luvo que demostrar que los fondos extraídos por Alijazaga se habían agotado, que la situación era gravísima y que no había Pondos Propios. Sc discutió acaloradamente sobre Ja peticion, sobre el ramo que debía provecr los fondos e incluso sobre la cantidad solicitada. Por fin el 7 de Febrers el defensor José María Sanjurjo dio su aprobación y se concedieron lus 60 mil pesos demandados por Segurola.

Parece que en esta ocasión la intervención del corregidor fue tan altopellada $c$ insolente que nuevamente el fiscal Márquez de la Plata, a quien quisu hacer intervenir en las reuniones, pasando por encima de las normas y jurisdicciones, le acusa de tener un "genio propenso a invertir los órdenes de derecho, la paz y la tranquilidad". Por otra parte, la Iunta de Real Hacienda acord 6 ino ser necesaria la asistencia del corregidor en los futuros acuerdos por el entorpecimiento que ocasiona con su genio para las prontas providencias que exigen las actuales circunstancias del Reinon. AHNM, Pleito del corregidor Fermín Gil de Alipazaga... Pieza n. 3.

(2) Las milicias del pueblo de Songo aparecen en la lista que Segurola enyía a Vértiz. el 20 de Enero de 1782 para manifestar el mérito de los oficiales; figuran allí, como coronel del regimiento de Dragones de Songo de la provincia de Larecaja don Manuel Tomís Franco, como sargento mayor, don Protacio de Armentia y, como capitan, don Jose Benito Rodríguez. AGNBA. 9/5-5-3.

(3) La extraña ređacción del autor en este párrafo no permite entender quiénes son esos "diputados"; podrían ser los miembros del Cabildo y de las Cajas Reales que integraron la Junta de Hacienda, pero también podrían ser los responsables de los diferentes sectores de las trincheras o incluso "alcaldes de barrio" encargados de cada una de las manzanas en que se pudo dividir el recinto amurallado, práctica que se siguió en la Revolución de 1809, según informa un documento de la época, analizado por José Vajzquez Machicado en "Las Horcas de Goyeneche". Doc. pera Hia. de la Revolución de 1809. Vol. HI, pág. 606, La Paz, 1954. 
dejándose fuera de ellas las tres partes de la ciudad por /f.6. el terreno quebrado y la falta de armas y acaso por la urgencia del tiempo avanzado (1).

(1) La idea de llevar a cabo la fortificación de la ciudad amurallándola, contó con fuerte oposición por parte de lá Junta de Hacienda y del corregidor que la consideraban costosa e innecesaria. AHNM. Pleito del corregidor Gil de Alipazaga... Pieza n. 10 y n. 13. Segurola lo afima asimismo en su Diario, cuando dicc: "determiné auropellando las contradicciones y oposiciones que se me presentaron, fortificarla pare su defensa". Segurola, Sebastián de, Diario de los sucesos del cerco de la ciudad de La Paz, en 1781, en Ballivián y Roxas, Vicente, Col. de Doc. relativos a la Hiá de Bolivia. París, 1872, pág. 6.

Los arquitectos Mesa-Gisbert. basándose en una copia que existe en la Municipalidad de La Paz, hecha posiblemente por Florentino Olivares a fines del siglo XIX, de una tela original de la época, exlraviada hoy día. y que muestra la ciudad amurallada, así comoen otra copia del plano original de la villa hecho por el intendente Fernando de la Sola en 1796 para la instalación del alumbrado, y en los dos cliseños de La Paz, ubicados en los ángulos inferiores de los cuadros dedicados a los Landaeta, existentes en la lglesia de San Juan de Dios, luan podido deteminar con precisión los limites del recinto amurallado. Los historiadores citados pudicron establecer así que las trincheras se construyeron sobre las fronteras naturales de la ciudad nuclear, es decir, el rio Choqueyapu y el riaciuelo Cadchuani pur el reste, st río Mejatira por el este, el Choqueyapu en una de sus vueltas por el sur, y las faldas de los cerros del Calvario y Quilliquilli por el norte. En una nomenclatura actual estos limites podrím fijarse en las calles Catacora por el note. Bueno por el este, Mariscal Santa Cruz y Pérez Velasco por el sur y Pichincha y Jaén por cl oeste.

La muralla estaba reforzada en algurias partes con fuertes que el Oiner llama "espaldones". Uno de ellos daba a la actual plaza Pérez Velasco y otro a las faldas del cerro del Calvario.

Seńalan también los arquitectos Mesa-Gisbert que la ciudad se comunicaba con el exterior por pucrtas que daban a las vías de acceso ya existentes entonces. Las más importantes erats las de Santa Teresa y la Riverilla en la parte nor este; la de Las Recogidas en el sur este y las de San Sebastián y del Tejar en el sur oeste. José de Mesa y Teresa Gisbert, Desarrolio Urbano de la Ciudad de La Paz. Trabajo presentado a la mesa redonda sobre la Revolución del 16 de Julio de 1809, convocada por el Instituto de Investig. Historicas de la Municipalidad de La Paz, 1968. (Copia mimeografiada utilizada con permiso de los autores).

La alusión a las "tres partes de la ciudad" que quedaron fuera de las murallas se dinge a los sectores de ha villa que, ubicados más allá de los límites mencionados, constítufan barrios com bastante dersidad de pobiación. Habían sido primitivamente "parroquias de indios", es decir, Jugares habitados exclusivamente por naturales, pero ya a fines del sigJo XVIII, en las partes nás cercanas a la ciudad espanola habitaban nurierosas familias de mestizos y blancas de condición más humilde o dedicadas a las labores menestriles o artesanales. Eran estas parroquias Jas de San Sebastián, San Pedro y Santa Bárbara. A través de los diferentes Diarios del cerco (Jos de Diez de Medina, Segurola, Ledo, Castañeda) puede verse que a esa población que no pudo defendérsela por medio de fortalezas se la hizo entrar a la parte amurallada, 
El 15 de febrero se tocó un al arma falso a la media noche, porque estando unos hombres en el hurto de unas sementeras o chacras hacia la garita y cuesta de San Pedro, se hicieron sensibles a los guardias que vinieron a dar parte de que los indios sublevados se iban ya internando a la ciudad. La inquietud y el alboroto fueron muy considerables; todas las gentes acudieron armadas y como pudieron, manifestando su espíritu y fidelidad y una bella disposición para el real servicio. Nuestro comandante se acreditó celoso, y distribuyó las patrullas por las calles, que él mismo fue cèlando, hasta que, esclarecido el engaño, quedó la ciudad en algún sosiego, aunque las nuevas de la inquietud solapada de los pueblos inmediatos turbaban bastantemente los ánimos.

El día (sic) se pasó oficio por el señor Comandante al Ayuntamiento para excitar a este vecindario por un donativo para las cosas de la guerra próxima y otro al ilustrísimo señor Obispo de esta ciudad, doctor Gregorio Francisco de Campos, para la misma contribución de parte de los eclesiásticos. Y en efecto acreditaron con este motivo su lealtad, por las asignaciones que cada uno hizo según sus fondos; unas con víveres, otros con dinero (1), unos vistiendo y

portando sus enseres,provisiones, ropa y animales y se la distribuyó en claustrus, patios y zaguanes. Fueron esas gentes precisamente las que sufrieron con mayor rigor el hambre, el fro y las enfermedades que tan crueinenle diezmaron a la población durante el asedio. Cor. María Eugenia de Siles, 1781: El Calvario de una Ciudad. Revista Cordepaz, 1973.

(1) En la Biblioteca de la UMSA exisle una serie ale documentos que permiten comprobar la exactitud de lo anotado por el Oidor. Los donativos son voluntarios y generalmente se apuntan en el concepto de promesas que se harán efectivas en un momento dado. Figuran en las listas: dinero contante, dinero que se oblendrú con la venta de la coca. esclavos, amas, caballos. mulas, borregos, cabezas de ganndo vacunn, adobes, cal y madera para la construcción de las trincleras, faroles para el alumbrado, pertrechos de guera, uniformes para las milicias, chalonas, otras carnes saladas, joyas, etc.

Estos ofrecimientos se hicieron por lo general ci Cabildo abierto, pero a los que no asistieron se les visitó después por medio de oficiales de las milicias acompañados por un notario público. Ante el apremio de armas y dinero y, sobre todo, ante el tertibje flagelo del hambre $y$ las pestes, volvieron a solicitarse estas ayudas colectivas varias veces durante la sublevacion. Cuando se recogia lo ofrecido se otorgaba un recibo de las Cajas Reales y sus oficiales llevaban chenta exacta de los donativos. Lo curioso es que aunque los compromisos de efectuas donalivos tenían un carácter voluntario, se exigieron y cobraron como si fueran materia de un delito de deuda pública, siguiéndose a muchos de los oferentes juicios y pleitos cuyo curso se extiende casi hasta 1800. UMSABC/M. IJ7-147-159-168-170-171 y 173. 
ataviando a una compañia in, otros costeando algunos espaldones del atrincheraniento, y los señores del venerable Deán y Cabildo, la suma de ocho mil pesos a esmerosdel amor y celo al real servicio (2). Siendo nuestro ilustrísimo prelado el principal móvil y concurrente en dicha cantidad, no obstante la continua erogación de sus pobres, que se han aumentadio, y sus crecidos empeños pendientes y causados con motivo de su ausencia dilatada al Concilio provincial de La Plata.

En estos dias acostumbran juntarse los oficiales y vecinos con el Comandante en casa de don Antorio Pinedo, donde pasan las noches en vela, recelosos de algin asaito del enemigo y de prevenirlo con puntual remedio, aunque es corto el número para el buen deseo y fuera mejor destinar espías, fuera de la ciudad y en ella.

El día 14 de Febrero, consecuente a la resolución tomada en Junta de Hacienda el 7 dicho, sc convocó la gente de la ciudad de todas las clases, se alistaron en compañías y se entregaron a sus capitanes y respectivos oficiales milicianos y se mandaron después acuartelar en diferentes casas de la ciudad con el prest de cuatro reales diarios los de caballeria, inclusive la manutención de cabalgaduras, y tres reales los de infantería, unos y otros surtidos de lanzas (3). Y ojalá fuesen con la

¡I Don José Dítalos. vecino, ayudane mayos del batallón de La Paz ofreció vestir a una companfía de negros. El monto lolal de los 50 uniformes mandados a hacer a su costa fue de 500 pestes, qut fueron entegados el 26 de Febrero. Los recibos otorgados para la confeccion de esos unifomes que incluyen lis varas de pañete azul, bayeta, jerga, algodón hilado, zapatos, sombreros de oveja. etc., constituyen valiosas piezas para la posible Historia Económica que considere el cálculo de precios en aquella época. UMSABC. M/117 y 138

(2) En uno de los documentos anotados más artiba figura el obispo Francisco Gregorio de Campos

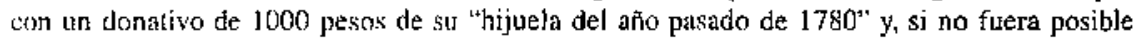
cobrarla jor el itraso en los pagos, podrá obtenerse de la plata labrada que posee.

El deán González Pabón dona 300 pesos de su hijuela. El arcediano don Martín de Landaeto cede de su hijuela 2683 pesos.

Se obtiene de los donativos eclesiásticos: 890 pesos en efectivo, 7568 pesos de las hijuclas y 730 de los sinodos. Resultando un tolal de 9118 pesos. UMSABC.M/117.

(3) Ni el Diario de Segurola ni ninguno de los otros que se escribieron durante el Cerco anotan este dato. (Diario de Francisco de Castañeda, en J.R. Gutiérrez. Documentos para Ja Hist. Antigua de Bolivia, La Paz 1879. -Diario del Capitán Ledo. UMSABC, M/89- Fragmento de un Diario Anónimo, copiado por Vázquez Machicado en el Archivo de Indias). Un estudio de las planillas de pago de las tropas permite comprobar que los sueldos corren, en una anotación 
orden de disciplinarlos en las armas, de que penden los aciertos y trofeos de Belona, asi por reparo de la ociosidad y que el mismo hacer nada es principio de cometer muchas maldades y puerta para perder las fuerzas, aniquilar el valor y aventurar la victoria, como porque en opinión de Salustio: no con los ruegos y súplicas de las mujeres se consigue el auxilio de los dioses, sino que velando, obrando y aconsejando con prudencia se adquiere la felicidad y todo se dé favorable, pero donde reina el ocio y el descuido, no hay que hacer rogativas porque los dioses están enojados. Máxima que bien cristianizada en las repúblicas católicas, en quienes vive la fe y son infinitas las almas justas que piden al verdadero Dios y Señor nuestro por el remedio de las públicas necesidades, se hace por sí, más / f.6v. recomendable.

El día 16 de Febrero se pasó nuevo oficio a su ilustrísima a fin de que mandase desembarazar el colegio que fue de los jesuitas extinguidos, aplicado al Seminario, que lo está ocupando, para que pudiesen acuartelarse las gentes por compañías y en particular la de granaderos, la que en efecto se acuarteló en dicho colegio mediante Ja condescendencia de su ilustrísima, aún siendo a costa de la estrechez y atraso de la enseñanza de los colegiales seminaristas y demás juventudes que se hallan floreciendo en la profesión establecida de los estudios mayores, mediante la gran atención y desvelo paternal de su ilustrísima, pues al primer oficio, temerosos de sus atrasos, había ofrecido allanat, más bien, su casa episcopal, que no

formal y cuidada, desde el 1 de Febrero de 1781, figurando desde entonces los 18 regimientos que compusieron las milicias de La Paz. UMSABC, M/152.

La referencia a los 4 reales pagados a los de caballería y los 3 a los de infantería no ha podido ser corroborada con exactitud; el "Cuaderno" que presentaron al visitador general y al super intendente de Real Hacienda, Miguel Antonio de Llano, tesorero propictario de la Caja Real y Juan Esteban Muñoz, teniente contador de dicha cantidad, con las cuentus correspondientes a las entradas y salidas que se llevaron a efecto en las Cajas Reales de La $\xi_{a z}$ en la época de las rebeliones, no permite calcular ei sueldo exacto que percibieron los capitanes. tenientes, sargentos, tambores ni soldados, porque en los pliegos de pago de los divesos regimientos no se anota el número de hombres que integraban las Compañías y, cuando suelen aparecer cifras individuales, no está seĩalado a cuántos días, semanas o meses corresponden esas cantidades. UMSABC. M/152.

Sin embargo, confirma lo sostenido por el Oidor una orden del 21 de Diciembre de 1780, dada por el corregidor Gil de Alipazaga al tesorero don Ramón de Rojas para que entregue al coronel Manuel Tomás Franco 200 pesos para pagar la tropa acuartelada desde el 17 de Diciembre; la orden indica que los soldados ganan 3 reales diarios, los cabos tres y medio, los sargentos cuatro y los tambores tres. AHNM. Pleito del conegldor Gil de Alipazaga... Pieza $\mathrm{N}^{\circ} 1$. 
el dicho colegio, como lo hubicra hecho en virtud de su gran circunspección y exactísima palabra (1).

El 23 de Febrero manifestó nuestro Comandante en Junta de Hacienda la carta que le escribió el señor teniente coronel don Ignacio Flores, fecha en la Plata a 2 de Febrero del corriente año, en que acompañándole copia de las cartas circulares que escribió el excelentísimo señor Virrey a los corregidores de Puno, Azángaro y Lampa, le comunica o subdelega sus facultades para el gobierno de las armas en este distrito y sus provincias, con las de tener a su disposición las Cajas Reales de Potosí y ciudad de Chucuito y asimismo las de poder impender los gastos necesarios, y para lo tocante al prest de la soldadesca acomodarse en lo posible al reglamento que le remitió su excelencia, con cuya orden cesaron las dudas y dificultades precedentes para recurrir a la Real Hacienda y se lograron aquellos ensanches para tratar de la defensa del Estado (2), aunque no para el acopio esencialísimo de víveres, por

hallarnos ya con el tiempo avanzado y próximo el enemigo, sin tregua para recurrir por ellos a los hugares distantes, que ofrecen la proporción, aunque las sementeras

(1) Existen oficios cambiados entre el Comandante y el obispo Francisco Gregorio de Campos sobre la posibilidald de ukar el Seminario para acuartelar tropas. El Obispo pide que en to posible se solucione el problemat por medio del Cabildo secular y su corregidor, pero en definitiva acepta ceder el Seminario.

Por otra parte, existe documentación que permite ver que el 9 de Febrero de 1781 Segurola envió una nota al corregidor para que "providencie por vía de auxilio" la distribución del alojamiento de las guarniciones. El corregidor contesta el mismo día al oftcio con otro de tonos muy agresivos en el que pide la lista de las companías que necesitar alojamiento atsi como la respuesta del obispo. El Comandante envía la nómina, reconoce haber tratado la idea de ocupar el Seminatio con el prefado y manifiesta las dificultades que esto acarrea al obispado. En cuanto a las provocaciones del corregidor, le dice que le contestará cuándo y dónde correspondatporque no puede "contraerse a usar semejante estilo... por no ser propio de su crianza ni costumbres". AHNM. Pleito del corregidor Gil de Alipazaga... Pieza $\mathrm{N}^{\circ} 1$.

(2) Diez de Medina demuestra, por lo general, estar bastante bien informado respecto a las nedidas de gobierno y hacicnda que se tomaban por parte del Comandante, de las Cajas Reales y del Cabildo. Desgraciadamente, la autora de este comentario no ha encontrado la carta de Flores a que alude el Diario ni tampoco el acta de la Junta de Hacienda en que Segurola la habría hecho conocer-- Existe un oficio de Márquez de la Plata del 28 de Febrero de 1781, al Virrey, que confirma en gran parte lo aseverado por el Oidor respecto a los privilegios otorgados a Ignacio Flores. pero no se refiere en absoluto a que se hubieren hecho conocer el dia 23 de Febrero en una Junta de Hacienda, AGNBA. 9/5-5-3. 
del contorno de la ciudad y valle inmediato a Potopoto, pudieran hacer mucha costa, si saben aprovecharlas (1), o gustaran tomar algún consejo (2).

El 25 de Febrero libró providencia nuestro general de Junta de Hacienda, que también Ilaman de guerra, con noticias de haber arribado al asiento y mineral de Suches, provincia de Larecaja, con graves hostilidades, mortandad y saqueo, un comisionado de Tupac Amaru, Lucas Sesenarro, con la turba multa de los indios

(1) Según Diez de Medina, parecería que sólo desde el 23 de Febrero en adlelanle se empezaron a acopiar afanosamente los víveres; sin enbargo. Fernando Márquez de lit Plata, el 5 de Ënero de 1781 informa a Vértiz que Segurola ha llectacio el I de Enero y que ya se ocupa del acopio de armas y viveres. AGNBA. 9/5.5-3.

Es evidente. no obstante, gute los alinentos fuercin escasos y que su recolección se hizo con tardenza. Ya se ha podido conslitiar que este error se cometió expecialmente por la falta de "fondos propios" del Cabildo y por los odiosos obstáctos yue debicron vencer el Corregidor y el Comandante para obtener ayuda económica de parte de las Reales Cajas.

Añade Segirola que dificultó la recolección de viveres la pobreza de las cosechas que no permitió encontrar granos ni semillas por ninguna parte. El Oidor insiste en que las sementeras vecinas, asi como Jas de Polopolo, habrian poxido proporcionarlis, pero es raro que no hubicra acudido a ellas Anomio Saenz de Tejadil, buen conocedor de La Paz. nombrado como proveedor general pur Segurolia y la Junta de Hacienda.

Este funcionario presentó al funalizar el cerco una cuenta detallada de las entradas y saljdas que se efectuaron en el ramo de la alimentación. Figuran alli 11079 libras de maíz, 24122 libras de harina, 14276 de trigo. 6225 raciones de pan, 97722 libras de chuño, 10818 libras de charqui y cecinas, 3270 libras te chalonas y trorregos, 3620 de quirua, 1950 de cañngua, 3466 de habas, etc. En todo caso, si estas cilras parecen bastante considerables, sobre todo si se tiene en cuenta que estaban destinadas exclusivamente a ba tropa, resultan escasísimas cuando se estudian las listas de raciones entregadas a cada compañía. UMSABC. M/109.

El problema tel aprovisionamiento del resto de la población caía en el campo de las labores del Cabildo; desgraciadamente, no se ha encontrado cuenta ni constancia alguna de que se haya practicado algo en este sentido. La terrible mortandad y el hecho evidenciado en todos los testimonios de la época del hambre que abligó a los pobladores a coner cueros, petacas, perros y gatos, comprueba besidia o impotencia del corregidor y del Cabildo en este sentido.

(2) A lo largo de todo el Diario así como en su defensa ante las irnpugnaciones del Comandante, que sustancia el Oidor ante la Audjencia de Charcas, acusará siempre a Segurola de no querer oir consejos de parte de los conocedores del lugar, de los sitios aledahios, de tos indios, de sus lenguas. Por otra parte, Segurola se quejará siempre de este personaje como de un entrometido que se cree con el derecho de opinar y aconsejal en lodo orden de cosas. 
sediciosos (1), nombrando a don José Pinedo, primo de los susodichos, para que pasase a auxiliar al corregidor de Pumo, don Joaquín de Orellana, con las gentes de las provincias de Omasuyos y Larecaja y ciento veinte y tantos hornbres de estas milicias, cuatro cariones o pedreros, pólvora y halas y ocho mil pesos en dinero, extraídos de esta Real Caja (2).

(1) El dato del asilto a Suchess. asiento de un minerul de oro de la provincia de Larecaja, está rambién tecogido por Segurola, quien aseg̣ra que se debió a una irrupción de los indios de Carabaya que, aunque sólo duró un día. ocasionó grandes perjuicios y temores. El Comandante señala en su Diario que este hecho le hizo tomar fa determinación de lanzar ya sin más demoras la expedición de José de Pinedo. La columna debia dirigirse primero a Larecaja y a Omasuyos para formar con las gentes de aquellas provincias un cuerpo de más de 2000 hombres bien organizados: sólo entonces proseguician a ponerse en contaclo con los corregidores Orellana y Moya.

(2) Como es sabido, el corregidor de Puno Jaiquin de Orellana realizó una formidable defensa del territorio de Chacuito y Puro. Cuando organizaba la campaña pidió ayuda a los corregidores de Omasuyos. Larccaja. Pacajes y sohre todo al de La Paz, cabeza de todas alguallas provincias.

El Cabildo de csta villa, a trelvés de largas consideraciones y consultas, comprobó la absoluta carencia en cue se hallabo de gentes, arnas y fondos. Debido a ello, se produjeron todos esos curiosos. proiongados y alambicados tránites para extraer dineros de las Cajas Reales. por parte del liscal de la Audiencia de Charcas y del corregidor Gil de Aliparaga a qute liemos aludido más arriba. Tales actuaclones terminaran pacos días antes de lá lleguofa de Segurola y eso explica que el corregidor se limitara a dirigir autos a las demás provincias para que prepararan a su vez tropas, armas y dinero tanto para la expedición a Lampa, Chucuito. Azángaro y Paucarcolla, como para la defensa de las propios lerritorios. AHNM. Pleito del corregidor... Pieza No 2.- AGNBA, 9/5-5-3.

Segurola, bien informado del estado de li sublevaoicin, como asimisno del retraso en que se encontraban los preparativos de una expedición en La Paz. se esmer $\hat{\text {, una vez }}$ vencidos los problemas pecurnarios, en preparar una columna de auxilio al mando del coronel de milicias José de Pinedo

Los datos sobre el número de pedreros, pólvora, hombres, etc., que proporciona el Oidor tienen gran conendancia con los que cita el Comandante en su Diario. Por otra parle, en el cuaderno de los gastos de guerra entregado al intendente y al visitador general por la Real Comladuria de La Paz, figuran 8000 pesos recibidos por José de Pinedo el 27 de Febrero de 1781, por lo "acordado el 25 de Febrero para la expedición a Paucarcolla para auxiliar a los soldados que vienen de Larecaja como para auxiliar la villa de Puno". UMSABC, M/139-141. 
El 26 de Febrero, Junes de carnaval, aconteció otro al arma falso, como el pasado, a las 11 de la noche, por causa de unos borrachos que pendenciaban o hacian bullicio en el barrio de San Juan de Dios y se transtornaron por ciertos genios noveleros, con la invectiva de ser indios que acometían (1). En cuyo caso no fueron inferiores el cuidado y la inquietud del pueblo, como también el buen celo del Comandante y de las gentes, habiendo acudido a la plaza mayor los señores fiscal de Charcas, don Fernando Márquez de la Plata y oidor de Chile, don Francisco Tadeo Diez de Medina (recién venide de tránsito para embarcarse en puertos intermedios a su destino) ${ }^{(2)}$ con sus personas y fanilia armadas, dando el ejemplo a que son obligados. Bien que estando las trincheras cuasi concluidas, aunque del material deleznable de tierra y lodo, dan suficiente arbitrio de nuestro resguardo, debiendo por ello aplaudirse esta buena obra debida a la aplicación de nuestro Comandante.

El 28 de Febrero se repitió otra providencia, alli, para que se haga/fol.7 saber este anxilio y comisión al dicho corregidor Orellana y al gobernador de Chucuito don Ramón de Moya (3). Los cuales en carta del 21 del corriente Febrero, pidiendo el subsidio de veinte mil pesos para la guerra con aquel rebelde, la cual es y será de verdad el ante mural o escudo de estas provincias, ministran razón de los tres encuentros que el 9, 13 y 16 dicho, sostuvo, famosamente, el dicho Orellana en

(i) Precisamente para evilar esle tipo de ocurrencias Segurola había pedido el 22 de Encm de 1781 al corregidor Fermin Gil tpule publicara un auto por el cual se prolibiera a los vecinos, desde las oraciones en adelante, andar por las calles en grupos que pasaran de tres personas, fomar corrillos en las esquinas y salir de las casas después de las 11 de la noche. Asimisino. no debia permilirse tocat durantc la queda, cajas, lambores, clárines $y$, con mayor razón. disparar coheles, escopetas o producir cualquier olro tipo de ruidos. Si esto no se cumplia debía arrestarse al culpable por medio de las patrullas y castigársele por inobedencia. EJ corregidor contestó la nota al día siguiente, diciéndole que labía publicado por bando el aulo correspondiente y que labía doblado las patrullas en las rondas nocturnats.- AHNM, Pleito del corregidor Gil de Alipazaga... Pieza $\mathrm{N}^{\circ}$ 13.-

Se ve por to anotado en el Diario del Oidor, que la vigilancia se había aflojado un tanto por tratarse de las celebraciones del camaval.

(2) No debe olvidarse que sólo al final del Diario Diez de Medina se identificará como el autor del escrito. De allí que muy frecuentemente se referirá a las actuaciones del oidor de Chile como si hablara de una tercera persona, para poder destacar sus propios gestos de valentía, generosidad, cordura, piedad, paciencia, etc. En esle caso, haciéndole actuar junto al fiscal de la Audiencia de Charcas, aprovecluará además para explicar por qué se encuentra elł la Paz, siendo Oidor del Reino de Chile.

(3) Coincidiria este dato del Oidor con el que seĩala Scgurola el su Diario, cuando dice qtle mientras José Pinedo se dirigía a Larecaja y Omasuyos, remití a Orellana, por otra vía, auxilio de dinero y municiones. S. de Segurola, Diario de los Sucesos... pág. 8. 
las inmediaciones del pueblo de Samán, en el cerro de Tacacora junto al pueblo de Calapuja y en el campo de Mananchili, con destrozo y mortandad de muchos indios y fuga de los demás sublevados con sus caudillos Sanca e Ingaricona, comisionados del maldito Tupac Amaru que, destinados con el título de coroneles, vinieron reclutando indios de las provincias de Lampa y Azángaro, arreando ganados para auxiliar su rebelión con sangrientas muertes de cuantos españoles y mestizos encontraban, sin distinción de sexo ni edad. Designios depravados a que sigue opuesto a firme rostro, el valeroso Orellana, cortando aquellos auxilios que pudieran aumentarse en las provincias de Puno y Chucuito, de suerte que, si perdidas ambas, se agregasen a los indios de ellas los de Lampa, Azángaro y Carabaya, formasen un ejército formidable que encumbrase los trajdores pensamientos del conspirado, con detrimento de la religión y de los intereses de su Majestad y del puáblico y de la vida de los vasallos españoles y de cara blanca ${ }^{11}$.

El gobierno diputó a don Antonio Saenz de Tejada para acopiar viveres que ya escaseaban, y así fudo comprar unos pocos trigos y recoger unos chuños embargados del cacique de taja. Y es regular sean muchos los apuros y conflictos si la desgracia y el pecado nos precisan y nos ciñen a habitar atrincherados (2).

1. Se ve que el autror del Ditrio captó perfectamente la importancia del plan de Orellana de hacerse f'uerte en lumo. Je modo que esta ciudad sirviera de antemural o escudo para las provincias del Collao. Tal objelivo, que Orellana portiadamente pudo mantener hasta el 26 de Mayo de 1781, no lire comprendido por el comandante general José del Valle que, al despoblar la capilal de la provincia de Puno, contribuyo eficazmente al robustecimiento de Diego Cristóbal Tupic Amaru en Azángaro y de Andrés Tupac Amaru en Larecaja y Omasuyos.

(2) EI Oidor, presintiendo los males que sobrevendrían a ba ciudad, escribe estas frases en las que relaciona la desgracia con el pecudo. Los padecimicntos son consecuencia del pecado. Este pensamiento. que apareccŕ́ muchas veces en las páginas del Diatio, está muy en concordancia con un documento analizado por José de Mesa y Teresa Gisbert, "Exhortación Vespertina hecha a los moradores de Ja M.R.L. y Valerosa ciudad de La Paz por el deán de su Iglesia Catedral D. Antonio González Pabón en el tiempo en que dicha ciudad estuvo asediada y combatida por los Indios Rebeldes". Madrid, 1785, en "Los Paceños y el Cerco de Tupac Calari". Aportes Documentales sobre la Rebelion de Tupac Catari. Fac de Humanidades y Ciencias de la Educación. UMSA, La Paz, 1972.- En aquel discurso, el deán de la Catedra! exhorta a los fieles para demostraries que la sublevación era la consecuencia del mal proceder de los cristiunos que provocaron el levantamiento y que, sin tomar conciencia de ello, segufan conduciéndose dentro de la ciudad amurallada con crueldad, avaricia, ambición, maledicencia y frivolidad sin comprender lo que el Señor quería decitles a través de los castigos que se estaban padeciendo. 
El 28 de Febrero, miércoles de ceniza, los clérigos don Cipriano y don Martín de Valdivia, tenientes de cura en la parroquia de San Sebastián, de virtud, doctrina y ascendiente en los indios de ella, después de haberlos exhortado y amonestado en la fidelidad, amor y subordinación al Rey (por prevención de nuestro ilustrísimo y amado prelado y del dicho Oidor a estos eclesiásticos), lograron presentarlos con sus caciques, alcaldes y mandones en la casa y presencia de nuestro comandante, quien, enterado de la leattad y sumisión que a una voz ofrecieron a Su Majestad, les trató y recibió con agrado, ofreciéndoles libertad de repartos futuros y de tributos y otras franquezas, y que por su servicio en la guerra les agraciaría con dos reales diarios; a cuyo tiempo, entró triunfalmente el seferido Oidor en la casa que habita el Comandante, bajo el convento de la Merced, e insinuándole que como inteligente del idioma y de las obligaciones de los vasallos, se sirviese hacerles un discurso concionatorio que afianzase la buena disposición que manifestaban; hízolo así, en alta voz, desde el corredor, estando los indios abajo en el patio (it, y les explicó igualmente los privilegios, repetidos encargos y beneficios que debian a la piedad y patemal amor del Rey, exitándolos a imitar el ejemplo y obediencia de sus mayores que nunca habian causado novedad (2). Ios respetos de Dios, del Rey, de la patria, con otros pasajes que por entonces se conocieron haber inprimido en su ánirno, intitulándoles que serían indios realistas, como supiesen pormanecer en su lealtad y haciendo que a Io uíltimo aclamasen al nombre augusto de Su Majestad, diciendo por tres veces ;Viva el Rey Nuestro Señor don Carlos Ill! y celebrándoles en cada una, su amor y fidelidad al Soberano (3).

Hallándose en este acto, liegó en este mismo día a la casa del Comandante, don Ramón de Anchorís, corregidor de la provincia de Sicasica (dividida), en un traje a pergenio bien desdichado, quien insidiado de los indios de su provincia y aún acosado, pues se dirigian a matarlo, tuvo que retirarse prófugo del pueblo de Caracato, donde se habia trasladado y últimamente del inmediato a aquel de

(1) Aún cuando se habría deseadón mayor senciljez ell la descripción que hace el autor. puede caplarse todo el colorido de la escena que se desarrolla entre las autoridades indígenas, el comandante y el Oidor, bajo los balcones de aguella casa vecina al convento de La Merced.

(2) Una vez más. Diez de Medina aprovecha la nalzacion del juramento de fidelidad de los indios de $S$. Sebastián pora destacar indirectamente su propia actuación; puede apreciarse que considera su intervención como importantísima y decisiva.

(3) Segurola en su Diario no hace alusión a este cpisodio. pero se refiere, en cambio, a que los indios de San Sebastián. San Pedro y Santa Bárbata "aparentaron en ese tiempo una hipócrita fidelidad ofreciendo al servicio de nuestro soberano el sactificio de sus vidas". S. de Segurola. Dírio de los sucesos... p, 12. Puede apreciarse que. aunque la actitud de Segurola hubiera sído como ta describe Diez de Medina, no puso en el hecho descrito la ingenua esperanza del Ojdor. 
Sapaaqui, habjendo destigurado con el traje religioso y hábito de San Francisco que le proporcionó del Esteban Tórres, dueño de la hacienda de Tomoza; y se retiró de dicho Sapaaqui, el Domingo de carnaval, 25 del corriente mes, con bastantes tragedias, apuros y necesidades de alimentos, y si aquella noche no se extravia del ca/fol.7v mino ordinario, introducido en unas huertas de árboles frutales, le hulvieran acaso asaltado los sublevados que le seguian. Conpadecido el Señor Medina de su relación y del atontamiento con que se le conoció venir, le hizo preparar alojamiento en la casa que posee, contigua a la de su morada (1); con cuyo arribo se confirmaron aquellos sucesus acaecidos en su provincia.

En este día libró el comandante una orden circular, dirigida por el señor fiscal Plata, consecuente al bando mandado publicar en Lima de orden del señor visitador del reino, para que los corregidores y principalmente los curas de las doctrinas, les explicasen en sustaneia ta libertad entera de repartos de corregidores, en lo futuro, y que como perseverasen fieles $y$ en sosiego se les concederian otras franquezas. Dúdase que aquí aproveche, en las circunstancias de hallarse ya la rebelión a la puerta y alterados los más de los pueblos o si contribuirá a insolentarlos. Dios quiera que se verifique el buen deseo (2)

Jucves 1 de Marzo. El cura de la parroguia de Santa Bárbara, doctor don

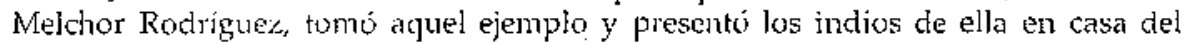
Comandante, manjfestando stu fidelidad y deseo de servir al Rey y a la patria; fueron admitidos con igual benignidad que ayer los de San Sebastián y en los mismos términos.

El 2 de Marzo partió el dicho don José Pinedo, con 115 personas de escolta y lanzas, bajo de su crpitán don Francisco Valencia, 4 cañones, 20 fusiles de granaderos (que en la penuria actual incrementan la falta), pólvora, balas de metralla y ocho mil pesos en dinero de Caja Real, con el designio de combinarse en el pueblo de Achacache, con los de la provincia de Omasuyos y Larecaja y marchar a la villa de Puno por los de Moho, Vilque. El pueblo repata que este auxilio no se encamine en derechura desde Achacache, camino real, por el Desaguadero, a los de lla provincia de Chucuito, para consultar de paso y con su presencia a cualquier alteración y a la quietud de los indios y pueblos muy considerables, cuando por aquella vereda poco usada pudieran no poder avanzar tanto logro y aín demorarlos los ríos del tránsito

(1) Naevamente, el autor del Diatio destaca la importancia y generosidad del Oidor; debe haber sicto uno de los pocos vecinos que podía permitirse el lujo de ceder una casá al alligicio corregidor.

12) En el unno 82 (178)-82) del Archivo Capitular de La Paz existe una copia del Decreto de Segurola a que se refiere el Oidor. Está expedido el 28 de Febrero de 1781. 
que, con el tiempo actual de lluvias, son de crecidas avenidas. Excediéndose algunos (aunque no es creible) a decir que el dicho Pinedo ha tomado esic sendero por subvenir a su hacienda que está hacia el Collao, saqueada y talada de los indios alzados de Tupac Amaru (1).

Día 3 de Marzo. Ocurrieron las noticias de haberse incendiado los pueblos de Caracato y Sapaaqui, según se tiene dicho, que aquellos con parte de los de Sicasica pasaron al pueblo de Chanca, sedujeron sus indios (que son los peotes malvados) y después de talar y saquear aquellas haciendas, descendieron a las de Río Abajo de esta ciudad, robando y embriagándose con el vino y bodegas de las haciendas de Tirata, Millocato y Guaricana, cuyos negros y mayordomos fueron asesinados, con los demás de cara blanca, habiéndose erigido en cabeza de los de dicho valle el hilacata o mayoral de dicho Guaricana, de quien vivía muy confiado su amo, el magistral de la iglesia de esta ciudad.

Este día se vino el cura de Viacha, provincia de Pacajes, don Juan de Mundaca, conduciendo una carta que puso en mano del ilustrísimo señor obispo, y por fidelidad de un indio pudo haberla de la del mesmo conductor la cual era dirigida al común de Viacha por el nucvo rebelde suscitado en el pueblo de Ayoayo, provincia de Sicasica y se firma Tupac Catari, intitulándose virrey (2). En la que convoca a levantamiento a aquel común de indios, anunciando su venida; cuya carta mandó pasar luego su ilustrísima al Conandante con su notario Hipólito Quinteros, en compañía del dicho curra, que trae razón del mal semblante de sus indios. $Y$ es de presumir que la mesma seducción se haya comulucado a los pueblos de las provincias comarcanas, una vez que se supone comisionado del rebelde Tupac Amaru. En este día concurrió la solicitud del cura de Mecapaca, que lo es de aquel valle, doctor don Gregorio Pérez de Arescurinaga, pidiendo por mano de su sobrino, el doctor don Antonio Paredes, el auxilio de 50 hombres para que juntos/fol.8. con los de aquel pueblo y sus indios que estaban en buena disposición, pudiesen contener la sedición que por aquellas partes iba cundiendo porque los rebeldes venían seduciendo y propulsando a los pueblos y aún matando a los indios que resistían levantarse. Se le denegó la instancia, aunque con un corto auxilio que

(1) Ninguno de los otros diarios del cerco recoge esta observación del Oidor. Queda la duda de si el comentario sobre el itinerario de José Pinedo procedía realmente del pueblo o si obedecia a una suspicacia del propio Diez de Medina.

(2) Esta es la primera vez que figura el nombre de Tupac Catari en las anotaciones diarias. Esto demuestra que el título y el preámbulo fueron agregados posteriormente. 
regresase a los cuatro días a la ciudad, pudiera quizá remediarse. $Y$ aún se dice que se ejecutó la negativa, no obstante la próvida interposición de nuestro ilustrísimo prelado, que apoyó por un oficio suplicatorio la solicitud de este buen cura (I).

Día 5. Se mantuvieron bebiendo los vinos en las dichas haciendas del Río Abajo y fueron en parte internando con la sedición al pueblo de Cohoni y diferentes haciendas de aquel contomo hasta el asiento y mineral de Araca, donde cometieton crecida mortandad de espanioles y blancos, encaminando al mesmo tiempo, diferentes mensajes para alterar y atraer a su facción al dicho pueblo de Mecapaca y al de Collana.

El lunes 5 dicho, de Marzo, vino el clérigo ayudante del curato de Viacha, don Antonio Durán, con la noticia de hallarse los indios de él, en bandos; unos fieles y otros traidores, y que a los primeros los había dejado por su condescendencia, en la iglesia, para exceptuarios, caso de que nuestro comandante deliberase tomar algún remedio o temperamento. Resolvió éste por sí y por la dirección que tiene, formalizar una expedición de 700 hombres, más o menós, de infantería y caballería, al comando del prccitado don Maruel Franco; quien salió de esta ciudad a las siete de la unche, para dicho pueblo. Se sienta comunmente llevar la orden de pasar a cuchillo, sin distinción de personas, a todos los indios que en dicho pueblo se hallasen fuera de la iglesia; de saquear e incendiar sus casas aplicando para sí el saqueo que hiciere cada soldado, a fir de alentar los ánimos con este cebo. Es de temer la resulta, o porque su rudeza y falta de disciplina militar no prometen favorables efectos si se origina algún encuentro, o porque aquella orden terrible (si es cierto) no se compadece ni con aquel medio prudente (aunque tarde) de franqueza de tributos y repartos de corregidores, que importa la providencia circular de 28 de Febrero, ni con los de suavidad y paz con que se ha de procurat reducir a los indios alzados y atraerlos al real servicio sin guerra, robos ni muertes, como es de la ley $8 \mathrm{a}$, título 4, libro $3^{\circ}$ de las recopiladas de Indias; ni menos con la ley 9a, siguiente a aquella, que prohibe hacer ni presentar guerra a los indios si no fueran agresores, y con mano armada rompieren la guerra contra los vasallos, tíerra pacífica y poblaciones, porque si no bastaren todns los requerimientos que convengan y deben proceder, podrán ser entonces castigados como justamente merecieren, y no más, porque para hacerles guerra abierta y formada, se ha de dar primero aviso al Supremo Consejo de Indias, para que Su Majestad provea lo que convenga. Permita el cielo que no sea la empresa del día para enconar los ánimos ni darles de nuestra parte ejemplo con muertes, hurto e incendio, aunque con ellos han principiado los sublevados; y que la falta de presencia de muestro general en este principio o primer acto (puesto que se queda en la ciudad con admiración patética de los sensatos), no nos pare algún perjuicio irreparable (2).

(1) Ni Segurola ni los autores de los otros diarios se refieren a este episodio.

(2) Los juicios tan prudentes y estinables que vierte en este párrafo el Oidor no están en consonancia con los que pronunciará en otras partes del Diario ni con las sentencias que dictará después del cerco para condenar a muerte a Tupac Catari, Bartolina Sisa y Gregoria Apaza. 
Día 6 de Marzo. Se retiró el dicho cura de Mecapaca a la ciudad, receloso de los excesos y atrocidades de aquel motín ya principiado.

Día 6 dicho, volvió neustra expedición a las oraciones. Por los circunstantes en ella, de excepción, se sabe que habiendo asomado a dicho pueblo a las 4 y media de la mañana y, acordándolo nuestra tropa, dió la orden don Manuel Franco, de que a cuantos encontrasen en las calles o durmiendo en sus casas, se matase a fuego y espada, sin distinción de mujeres ni párvulos. Cumplióse la ordeł en términos que acaso no concuerdan con la humanidad y nuestra piadosa religión cristiana, porque a diestro y siniestro mataron y degollaron párvulos de pecho, otros tiemos de edad, mujeres que incautamente dormían con stus hijos y maridos. Saquearon varias casas y últimamente las incendiaron con la mor/fot. $8 \mathrm{v}$. tandad que según la común acepción pasaría de doscientas personas de ambos sexos. y que hubieran sido más si el justicia mayor de aquel pueblo y provincia de Pacajes, don Manuel Inocente Villegas y el capitán don Pedro Parja, no hubjeran mediado, favoreciendo a muchos que pudieran tomar el asilo de la iglesia. Siendo lo más scnsible que los nuestros, profanando su inmunidad, hubjesen muerto entro del cementerio cinco o seis personas que iban a tomar el mismo asilo y que los más de estos muertos hubiesen sido de los indios fieles. El caso, después de averiguado por el mismo eclesiástico Durán, fue que los indios leales habian tratado con éste, refugiarse en la iglesia, discurtiendo que los que saliesen de esta ciudad sólo fuesen a prender o atraer a paz a los demás que se manifestaban conspirados, sin imaginar el tal degollación ni carniceria; y bajo de este supuesto vino cl clérigo con el mensaje. Los indios, como no guardan reserva ni secreto en sus determinaciones, se infiete que hubieron de comunicar su intento con los desleales y que, de acuerdo unos con otros, dipusieron que los traidores se refugiasen a la iglesia, misturados con los leales, quedándose los fieles igualmente interpolados fuera de ella, y en strs casas, con la satisfacción éstos, de que conociendo su fidelidad el clérigo ayudante, serviría de escudo y testimonio para que los nuestros no les agraviasen, antes sí, premiasen o aplaudiesen y protegiesen su lealtad. $Y$ así fue que los más inocentes murieron y sajvaron los pérfidos en la iglesia, porque tratándose allí mesmo de los muertos que conocía el dicho eclesiástico, decia: éste y quién son de los fieles. Confusión y daño que hubiera evitado nuestro general con su presencià (l), pues hubiera sabido distinguir ante todo, por dicho eclesiástico, la identidad de sus personas, suavizar y sosegar acaso los alteradus, con su respeto y la autoridad o a lo menos evitar escena tan sangrienta y lamentable ${ }^{22\}}$, para cuya discreción se regula,

(1) Esta alusión a los males que se podrian hober evisado si Segurola sc hubiera encontrado presente, es frecuentísina en el Diario; no queda bien en claro si se trata de uls reconocimiento de sus aptitudes o de una icusación a la inoperancia del comandante.

(2) El episodio está recogido en forma muy diferente por Segurola. Reduce la fuerza as 400 hombres de lanza, 30 granaderos y 30 oficiales sueloss. Eleva, en cambio, el número 
no ser sujeto el pobre de Franco que, aunque fiel y de espiritu, no profesó al fin aquella incumbencia ni tiene las luces necesarias para tanta importancia (1).

Los indios alterados y refugiados en la iglesia, que se aparentaban ser de los fieles, sabían que el cuerpo del motín se hallaba en una estancia, cuatro leguas distante de Viacha $y$, por lisonjearnos, al parecer, con el espíritu venenoso de la venganza, decían que en aq̨delia estancia tenían los rebeldes muchos ganados y que sería conveniente ocuparlos. El dicho Franco tragó la píldora dorada y se determinó al acto, que hubiera emprendido, si la gente que estaba sin alimento y con el pervigilio pasado, no lo escusa. Dúdase del suceso si lo emprende, o si hubiera podido volver persona a la ciudad, una vez que incautos fuesen a buscar al enemigo tumultuado. Al regresar de dicho pueblo se encontraron con otro grueso de gentes del pueblo de Achocalla y, partiéndose de entre ellos cuatro de a caballo hacia los nuestros, manifestaron su origen y fidelidad y que habian tenido un encuentro con los sediciosos, que venian de los pueblos de Sicasica, Ayoayo y Calamarca, con el fin de seducirlos para su facción o de hacerles guerra, pidiendo que para resistirlos se les auxiliase con alguna tropa nuestra porque, de lo contrario, recelaban ser rendidos por la mayor fuerza y violencia. No se hizo juicio ni se defirió a la petición. Supónese que franco carecia de la facultad necesaria. Con este evento, lo que más cautiva la inaginativa es el incubarse que unos soldados ignaros de las propiedades de Marte y auin de preliminares, se ltayan principiado a cebar por el saqueo o betín, última $y$ final consecuencia de la guerra y victoria completa. Si mañana nos hallamos con los enemigos (que amenazan) a cuestas ¿qué defensa podrăn actuar estos plesbiscitos? ¿ni qué acción sustentarán que primeramente no se termine al hurto y al pillaje, aventurando las personas de honor y las acciones? (2).

muertos a 300 . Se refiere a que se perdonó a los refugiados eu la iglesia porque protestaron fidelidad al monarcá. No menciona para nada una autorización de saqueo. ¿Qué hay en el fondo de estas discrepancias? ¿Un deseo por parte de Segurola de disminuir la gravedad de los acontecimicntos? ¿Una frialdad militar extrema que no se inmuta ante acontecimientos tan dramúticos? ¿O una versión exagerada y novelesca por parte de Diez de Medina?

(1) El Oidor mantiene a lo largo de todas sus anotaoiones uir juicio muy desdeñoso contra el coronel Franco.

(2) Aún cuando Segurola no se refiere a los saqueos de la soldadesca en las anotaciones de los primeros dias de Marzo de 1781, es evidente, por lo que se desprende de los otros Diarios como de los informes de Flores y Reseguín, que dichos saqueos, que se iniciaban por entonces. 
Día 7 dicho, entró el motín en el precitado pueblo de Mecapaca donde se dejaron subyugar los indios y no dejaron español ni blanco a vida. $Y$ habiendo encontrado en el camino entre las haciendas de Guaricana y Guayguasi a unas españolas con sus maridos, hijos, negros y criados, con dos cargas de plata sellada, porción de oro, plata la / fol.9. brada, alhajas y homenaje, los pasaron a cuchillo, hasta 19 personas, sin exceptuar los arrieros, y les hurtaron todos sus bienes y mulas (1). Lo que también ejecutaron con otros arrieros que del pueblo de Irupana conducian dos pearas de coca a la ciudad y se habían acampado la noche anterior, poco más abajo del puesto de aquella cesgracia, sin que pudiese salvar más que el mayordomo de Guayguasi, don Casimiro Loyola, que dudoso de la sublevación pasó a reconocer aquel suceso y se halló acosado de los indios de la rebelión que to aguardaban emboscados en una encañada, hasta que picando la bestia y atropellando a varios pudo salvarse su persona y de paso arrebatar a su mujer e hijos, aunque se le desgració uno, tierno de edad, a quien no tuvo tiempo de conducirlo y lo mataron los alzados que venían por la retaguardia, con sangrientas carnicerias en las haciendas del tránsito y en los inocentes que viajaban o que huian de su furia, pero con la desgracia de ser asaltados (2).

Días 7, 8, 9, 10 y 11 de Marzo. En éstos vinieron los indios del pueblo de Viacha, 4 leguas de la ciudad, y ratificaron su obediencia a nuestro Comandante, quien, por distintivo, mandó que a éstos y a los demás fieles de la ciudad, para que fuesen conocidos de amigos, a diferencia de los alzados, se surtiese de divisas o

constituyeron una práctice habitual en la conducta de fas tropas, lo que ocasionó muchas veces indisciplina; retrasos en las marchas y también alıondamiento del odio y del deseo de venganza.

(1) Los trágicos episodios ocurridos a pequeños grupos de familias no siempre merecen atención en las anotaciones del Comandante, que tenía que mirar a un ámbito más amplio y complicado. Sin embargo, cuando el Oidor o los otros Diarios los registran, constituyen una variada gama de escenas de ia vida cotidiana en aquellos azarosos días de la sublevación: puede imaginarse el cuadro que ofrecían los dueños de haciendas que, atemorizados, abandonaban sus propiedades emigrando hacia La Paz, cons sus familias, criades, esclavos, joyas, plata labrada y sellada y sus cosas de mayor valor, alcanzando muchas veces homorosa nuerte en el camino en lugar de una côlida acogida en la ciudad.

(2) Se puede comprender que el Oidor conocíb bien todos estos detalles de lo acontecido con las personas que huían de las haciendas de Rio Abajo y con el mayordomo Casiniro Loyola cuando se conoce su testamento, pues en ét resulta que dọn Francisco Tadeo Diez de Medina es propietario de la hacienda Guayguasi. 
listones de cinta encarnada $y$ los trajesen en la montera (1). Recurrieron también los indios del pueblo de Palca, provincia de Yungas, distante 6 leguas, implorando auxilio, por medio del cura o su teniente y por la interposición del ilustrisimo señor obispo, por decir que aquellos indios también estaban divididos en bandos de lealtad y alzamiento; y que los fieles auxiliados podían sujetar a los otros, pues la conspiración habia cundido a dicho pueblo y a los del Río Abajo y valle de Mecapaca, Caracato, Sapaaqui, Collana, Chanca y denás confederados. Ignórase los motivos porque se hubiese denegado dicho auxilio, aún interpuesta la süplica de su ilustrísina (2), que se repitió asf́ para este pueblo como para el de Achocalla. Súpose al fin que prevaleció la sedición y que trascendió al valle del Totoral, Lambate y Taca, con numerosa mortandad de españoles en estos pueblos, de mujeres y párvulos. De modo que nuy raros pudieron salvar para esta ciudad. Ya sabiamos así la común alteración de los pueblos comarcanos y que se hallaban los indios de una inteligencia, y por eso crecian el conflicto y sobresaltos de la ciudad, escasa de armas y víveres y falta de disciplina militar en sus moradores, aunque de pocos días a esta parte se haya principiado con los de lanza y se continúa con la compañáa única de granaderos, no obstante que están faltos de fusiles, por descompuestos y por la fojera del armero. El mayordomo de los obrajes de la Asunción, de esta ribera, don Cayetano Menéndez, que se mantenía con los indios amigos de aquel recinto al reparo de las invasiones de los sublevados y enviaba prisioneros a algunos indios, que serían atalnyas enemigos, se restituyó a la ciudad, como también varios de sus moradores desde sus haciendas $y$ las de Yungas, al susurro de la presente conmoción.

Día 32 de Marzo. Llegó por parte de noche, a esta ciudad, el corregidor de la provincia de Omastyos don José Joaquín Tristán y Muzquía, quien, sabedor de haber prendido el fuego cn su provincia y de haberse publicado el día de ayer 11, en el pueblo de Laja de su distrito, sejs leguas de ésta, un edicto o convocatoria de parte del indio alzado de Ayoayo, nominado Tupac Catari que se figura comisionado del rebeide Tupac Amaru, y de la alteración de dicho pueblo, que conspiraba contra su vida, conforme a las idees diabólicas de éste, contra los corregidores y ministros de justicia de Su Majestad, no tuvo más tiempo que para disponer la caballería y retirarse aceleradamente para esta ciudad a pesar de los estímulos de su propio

(1) Segurola, en su Diario (pág. 12), manifiesta profunda desconfianza frente a estas demostraciones de fidelidad. Sin embargo, seguramente por la presión del obispo y de vecinos como el oidor Diez de Medina, les concedió un distintivo escarlata, signo de lealtad. Se trataba de una escarapela o cucarda roja que los indios se colocaban en sombreros y monteras

12) El hecho de que el Comandante no auxiliara a estos pueblos se debía a que, a pesar del juramento de fidelidad, los indios se plegaban al alzamiento de Sicasica, Ayoayo y Calamarca. Mandar grupos de auxilio a Palca o a orras comarcas vecinas era agotar inútilmente las escasas fuerzas de la Paz. Dizrjo de Segurola, pág. 12. 
honor, con que resolvió mantenerse hasta este último punto, por tal de atender a la subordinación y sosiego de los indios, con no poco riesgo de su persona, y a la expedición auxiljar de don José Pinedo para la villa de Puno, pues contribuyó a ella con sus provincianos armados en todo lo posible, acreditando su celo por el real servicio.

El día 13 de Marzo, dispuso nuestro Comandante repetir otra expedición para el referido pueblo de Laja y, con efecto, la emprendió partiendo en persona a las 8 de la noche, / fol.9v. con bastante expectación del pueblo, con las tropas de infantería y caballería, varios oficiales de honor y entre ellos don Ignacio Pinedo, capitán del ejército y don Antonio Bilbao la Vieja, uno de sus edecanes, que sirvió de cadete varios años en las guardias españolas, la compañía de negros, los indios amigos y atros de armas blancas, que bien harían 800 personas, fuera de los indios. Condujeron cuatro pedreros con sus cureñas, artillería, munición y demás pertrechos. Dícese por estimación común, terminarse a castigar a los indios de dicho Laja, del mismo modo que en el de Viacha, y que renovó el prometido del boín o saqueo en favor de la soldadesca con el mismo designio de animarla (1). Si este acometimiento, en derechura, antes de requerir los sublevados con suavidad, dulzura y prudencia y antes de experimentar la agresión, sea la ofensiva y no la defensiva, que parece nos compete, o si sea éste, remedio para contenes la sedición o para el sosiego y la subordinación, el tiempo es quien nos lo dirá. Dios se sirva perdonar nuestras culpas y nos haga merecedores de su divina piedad! (2).

Al partir y al medio salir de la cuesta del Cuzco, es regular sintiese, como sucedió a la ciudad, que los indios sublevados de la puna y pueblos de Sicasica, Ayoayo y Calamarca, se hallaban, unos en el Alto de esta ciudad y otros, o los más (que después se supo) combatiendo en la campaña dentro, con los indios de Achocalla, que no solamente los resistían, sino que en esta tarde y noche, repetidas veces pidieron auxilio a nuestro Comandante para ser sostenidos en su fidelidad (3).

(1) Por el contrario, el Comandante escribe en su Diario (pág. 14) que "la caballería e infantería sólo cuídó de saquear el pueblo"... "sin haber atendido ni obedecido cuanto se les mandó".

(2) El Comandante había anotado, antes de referirse a eșta expedición punitiva, que la sublevación había prendido más abiertamente que en otras regiones en el pueblo de Laja.

(3) Como se ba visto, Segurola anota en la pág. 12 de su Diario, que los indios de Santa Bárbara. San Pedro, San Sebastián y los de "los pueblos cercanos" aparentaban una "hipócrita fidelidad". Ante ella había tomado una decisión de "sobrellevarlos y distinguirlos" con la cucarda en la montera, pero manteniendo respecto de su actiund una profunda desconfianza, to que explica que jamás les enviara los auxilios que pedían. 
$Y$ ojalá que se emprendiese este camino en derechura, no sólo con este recomendabe fin sino con el de cortar la raiz y derrotar a los sediciosos en combinación con los nismos indios de Achocalla y los anigos de esta ciudad, que quizá se lograra el remedio decisjvo y conveniente al servicio de Dios y del Rey, porque el dirigirse a Laja antes de declararse reheldes sus indios, dejando en sustancia, por el otro extremo, salvoconducto al enemigo que se halla a la puerta de la ciudad, cuasi desarmada y sin fuerzas, se parece a una expedición oblicua y prematura (1). Después de las 8 , poco más, de esta noche, se mandó tocar al arma y tañer la campana mayor de esta iglesia, por don Antonio Pinedo que, como coronel creado de la infantería de esta ciudad, quedó encomendado del vice gobierno de las armas de ella (omiso el corregidor), sustituycndo las veces del Comandante (2), quien, es regular oyeșe al sahir por la cuesta las campanadas (3). Lisonjeábase por elio, el pueblo, de su regreso o que puesto en El Alto guiīase a la izquierda del canino, a buscar y refrenar al enemigo que tenía en una parte, distante un cuarto de legua, y en otia, dos leguas cuanto más de campo llano. Pero confirmados después en que la expedición marchaba para Laja, crecían nuestros sobresaltos a la media noche, después de haberse conmovido y agitado los moradores, trasladándose a las iglesias y de trincleratas para dentro los que habitaban fuera de ellas, poblando las inujeres el aire de suspiros, tlamores y llantos. Se iluminó toda la ciudad y Jas torres de la iglesia mayor. Se congregaron las demás gentes con las pocas armas que habian quedado. Se situaron cuatro pedreros, uno en cada esquina de la plaza mayor y se reforzaron las trincheras o fortalezas, en lo que cabe, cono también lo espaldones, esperando por minutos la invasión del enemigo que csta noche

II Leyendo el Diario de Segurola (pag. 12) se puede apreciar que el cumaudante no organizó su expedición a Laja llevado for la precipitución o la impericia mititar, como insinúa el Oidor. sino que, por el contrario, habiendo comprobado que los que se habian instalado en la Ventanilla, a cuatro leguas de La Paz, eran precisamente los que habían jurado fidelidad en Viactia $y$ ahora se hibian unido a los de Sicasica, Ayoayo y Calamarca, trazo todo un plan de atague. Pensó que caycnto sobre Lajá. principal foco de la rebelión, vencería a sus pobladores, sujetándoles defitilivamente, para sorprender posteriorinente por la rclaguardia a los situados en las cercanias de la sapital. Para ello, contaba además con que se encontraria al retorno de Laja con 300 hombres salidos de Sotata, provincia de Larecuja, que habian salido para dirigirse a $\mathrm{La}$ Paz auxiliando de paso a las provincias de Omasuyos, también alzadas.

12. Puede apreciárse en estas frases una tácita alusión a las tensiones entre el corregidor y el comandante. En todo caso, debe comprenderse que, habiéndose establecido por las autoridades superiores del virreinato un gobierno militar para La Paz, ya no correspondian al corregidor responsabilidudes de este tipo.

(1) Ninguno de lus otros Diarios (Segurola, Ledo, Custañeda) hace mención al tañido de campanał que pudiera haberse oído en la cuesta cuando subía al Alto la expedición que se dirigía a Laja. 
no descendió y se mantuvo en El Alto con la algazara de voces, cometas, pífanos y tambores (i).

Día 14 de Marzo. Fue mayor el conflicto porque se veía más engrosado el enemigo en El Alto o cuesta de Potosí y que empezaban a descender para la ciudad con muchas banderas de diferentes colores, cornetas y vocería notable, hasta que el dicho don Antonio Pinedo mandó tocar al arma con dicha campana a cosa de las 2 de la tarde, creciendo los sobresaltos y sorpresa de los ciudadanos y mujeres que igualmente recurrían al asilo de la ciudad y de las iglesias. La penuria de armas obligó a que a las 5 y más de la tarde, mandase distribuir el dicho vice comandante cuatro o más cajones de cuchullos sin que la priesa o aturdimiento de los ánimos diese arbitrio para ordenar por listas /f. 10 y compañías y por medio de los capitanes, la distribución. En cuyo acto tomaban los que no debían, otros con multiplicación y otros quedaron sin parte (2). Se internaron, pues, con efecto los indios a los extremos de la ciudad y por parte de noche a la población; fuera de ella, mataron los pocos que encontraron de ambos sexos y cuando toda la ciudad se hallaba asi oprimida, sintiendo por una parte la falta del Comandante y de nuestra gente, por otra, la peruria de armas y por otra el que no se hubiese dirigido en derechura contra el enemigo suspendiendo su dirección a Laja (3). siendo al mismo tiempo varios de dictamen que de este lugar se encaminatía para Calamarca con la intermisión de dos o tres días más (tiempo que exitaba nuestras funestas meditaciones), se resolvió y dispuso que un eclesiastico, don Clemente Rodriguez, partiese en alcance de nuestro comandante y fuese con aviso de apuro

(1) Esta descripción del pánico de la población y de las medidas que se tomában por primera vez ante la posibilidad del ataque indígena constituye un valioso testimonio para una historia de la vida cotidiana en la época del cerco. Desde ese día en adelante se desurrollarían noche a noche escenas semejantes.

(2) Puede pensarse que desórdenes y confusiones tan graves cono las descrilas, que se repitieron con cierta frecuencia, justificaban el que Segurola, muchas veces, prefuriera quedarse en la ciludad, enviando a ótros para oapitanear las tropas que debian efectuar alguna salida fuera de los muros.

(3) El Oidor formula aquf́ tres graves y precisas acusaciones a la comandancia militar de Segurola: 1) Que el Comandante con su gente no estaba enıla ciudad en los momentos de mayor peligro, por haber acudido a Laja. Anteriormente, en cambio, cuando se produjo la expedición punitiva a Vacha, le acusó de no haber acudido a ella, quedándose en la cindad.- 2) La penuria de armas.- Ya se conocen las causas y pormenores de esta falta de amamento.- 3) El no haber suspendido la expedición a Laja cuando había tantos rebejdes en los altos de La Paz. Ya se conoce el pensamiento de Segurola al respecto. 
por el camino extraordinario de Songo, el cual regresó, suponiendo haber recibido una pedrada en la cara y serle imposible verificar su marcha por la multitud de indios, que dijo, tener cercada la ciudad. A las nueve y más de la noche, vino y entró por la puerta de San Francisco un mulato de los nuestros, que fue con la expedición dicha y refirió que nuestro Comandante, sabedor por el teniente de alguacil mayor, don Rafael Arteaga (a quien se le encaminó esa tarde, por dicho don Antonio Pinedo) de nuestras estrechuras, regresa paua ésta. Lenitivo que dilató no poco nuestra espreranza. En esta noche en que se pensó tocar las filas de la Parca, las buenas mujeres dieron el más piadoso ejemplo de edificación, implorando el favor divino y confesandose en las iglesias y en las casas donde se combinaron estas señoras devotas y piadosas matronas.

A las diez y media entró don Manuel Borges, portugués de nación, con tuno o dos más, que se habian inclúdo en la expedición, quienes confrontaron con la noticia que condujo el ntulato. A las once se empezó a oir el estallido de los pedreros en $\mathrm{El}$ Alto de esta ciudad, camino de Lima, con la algaraza de los indios, y aún se dijo que los indios levantados que habian inlernado a la ciudad, subian presurosos al Alto a congregarse con los suyos. Con esta grata nueva que nos trajo la atención, se suscitó la universal complacencia de los ciudadanes discurriendo que, pues nuestro Comandante se hallaba en las Ilanuras del Alto con superioridad de armas, sacaría una satisfacción ventajosa de los rebeldes, castigándolos y subordinándolos como convenga y que no volviese a casa sin que las cosas quedasen remediadas arriba, puesto gle de otra suertc tampoco sería conveniente perder las ventajas del sitio ganado.

Como se oía que el estruendo duraba continuamente sobre dos horas, determiuó el dicho don Antonio Tänedo enviarle auxilio de gente y armas, puesto que el enemiqo se hallaba arriba, habiendo contribuido a este fin el oidor don Francisco Tadeo Diez de Medina y don Felipe Loayza, proveedor y doctoral de esta Iglesia, los que, apersonados en la plaza mayor, manifestaron su celo y amor por el real servicio y la patria, tanto que el primero allanó la dificultad a aquella hora intempestiva, de mulas, sin reservar las de su pesebre (aunque todas se perdieron al regreso) para conducir la munición y otros pertrechos de guerra, pidienido $y$ suplicando por sí mismo las escopetas del vecindario, con que se habilitaron los demás granaderos que se quedaron de la expedición por falta de ellas (1), $Y$ habiéndose esperado a la aurora, salieron sobre 100 hornbres de caballería al mando

(1) Nuevamente puede observarse cómo el autor indirectamente destaca la eficacia, oportunidad, capacidad organizadora y desprendimiento de su persona. 
del capitán don Pedro Ramírez de la Parra con más los dichos granaderos y algunos de infantería de las companías de lanzas; cuando este auxilio avanzaba las inmediaciones del Alto, ya bajaban algunos sujetos de la expedición, sin que tuviese que operar el auxilio, pues luego que se presentó éste al Comandante, quedó enterado de la determinación que había tomado para volver a la ciudad con todas las tropas, dejando El Alto tomado y pensando acaso volver a tomarlo con la facilidad y desembarazo con que partió de la ciudad antes del cerco. No sabemos lo que será, puesto el enemigo en la parte superior y ventajosa. Poco conocimiento del terreno y falta de consejo para poder regir la táctica en los casos de la guerra y sus combates y contemplar la situación de los lugares y la posición y orden del ejército y de la empresa, porque el buen gene /f. 10v. ral ha de prevenir y combinar todo lo futuro, esperando cual otro Phylopemen, ilustre jefe griego de Megalópolis, las campañas a las campañas y los terrenos a los terremos $(n)$.

Miércoles 15 de Marzo. Volvió el Comandante con toda la gente de oficialidad y así mesmo con los auxiliares, a las 11 del día. El pueblo que juzgaba haber derrotado al enemigo y que calmarían los cuidados y temores de la sedición, lo confirmaba así, al oír los repiques de campanas y alegría con que le recibieron a su ingreso, pero después de comprender lo ocurrido anoche y esta madrugada con los sublevados que huyeron impunes, sin formal castigo y que la acción defensiva quedó informe y ellos dueños de la campaña, empezó a vaciar el discurso, cubriendo la imaginativa de reflexiones bien patéticas, aunque por otra parte se desahogaba la esperanza para despejarlos una vez que la noche pasada fue iniciado este logro.

Sábese por los de la expedición que antenoche, al salir de la ciudad; sintieron con efecto a-los enemigos, estimando, con todo el Comandante, seguir su ruta al pueblo de Laja; que ocupó la marcha de los nuestros la distancia de una legua por su dispersión y mucho desorden; que antes y a las inmediaciones de Laja se hallaron con la resistencia de unos 25030 indios, que apostados sobre un cerro a un lado del camino, los resistieron valerosamente y con admirable vigor, combatiéndolos de piedras arrojadas por sus hondas, hasta que empeñados y socorridos del auxilio pedido a los compañeros que con el Comandante estaban quemando las casas de las

(1) Diez de Medina acusa claramente a Segurola de haber abandonado El Alto a los sublevados. Piensa que la situación habría sido muy diferente si se hubiera luchado con mayor denuedo, aprovechando el auxilio enviłdo desde la ciudad para acabar con los rebeldes, expulsaindolos definitivamente de La Paz. Tal tesis del Oidor constituye una constante a lo largo de todo el Diario. 
estancias dei común de aquellos y, la soldadesca, saqueándolas (1). Algunos de los mestros tuvieron que subir al cerro e impender aigún calor y fatigas para haberlos destruido a balazos, a vista de que aún habiendo quedado en el número de tres, todavia no dejaron de combatir hasta rendir el último alierto, que es la barbarie más feroz de lidiar aquel corto número de individuos contra el cuerpo de los nuestros, superior a elios en fuerzas y en armas (2).

En el pueblo de Laja no se hizo mayor novedad porque se halló exhausto de los indios rebeldes, desierto y con sus casas trasteadas. Sin embargo, parece que no dejaron de incendiarse una que otra. Y como nuestra soldadesca lievaba la ansia del pillaje excitado, que asi se les frustró, acometieron a las casas de una pobre española, del cura, del cacique y otros y las saquearon y puede decirse de la primera, que sin dejar estaca en pared. El Comandante, que se acampó en el cementerio, pensando pasar alli la noche, supo del apuro y conflictos de la ciudad, determinó confiscar todo el ganado mayor y menor de las circunferencias y estancias saqueadas que confinan a dicho pueblo, y acopiadas que fueron, los trajesen convoyando los inctios amigos y los nucstros. Conno sucedió que habiéndose adelantado tres o cuatro de la expedición con las miras de recogerse temprano a la ciudad y compensar el pervigilio del dia lunes, luego que presintieron a distancia el bullicio de la sedición en los altos de la ciudad tuvieron que sorprenderse y retroceder para incorporarse con los nuestros y avisar de aquella novedad, con lo cual los de la primera partida hicieron alto aguardando a la scgunda donde venía el Comandante, a distancia de tres cuartos de leguas, bien que todos sin orden y muchos, dispersamente. Que para la combinación más pronta se dió aviso al Comandante, la cual verificada después de algún tiempo y de haberse dispuesto el orden de la marcha, se puso en movimiento por el camino de esta ciudad hasta que poco antes de las 11 de la noche (que hizo tenebrosa de lluvia y ventisca porque el nublado ocul taba el beneficio de la luna) se encontró hacia las inmediaciones del Alto, con la turba multa de los

(1) De la naración del Oidor pereciera desprenderse que el Comandante dirigía el incendio y el saqueo de las casas de Laja. Segurola sefiala, por el contrario, la indisciplina de la tropa oue "sólo cuidó de saquear el pueblo luego que llego a él sin haber atendido ni obedeciojo clanto se le mand6" (pag. 14).

12) Aunque no es muy parecida la descripción que hace Segurola de la toma de este cerro, coincide con Diez de Medina en considerarla como una empresa dificilísimá que sólo pudo cumplirse después de cuatro ataques porque los indios "peleaban con una desesperación imponderable" (pag. 14). 
amotinados que acometían a los nuestros con mucha algazara y aullidos, a manera de los moros, expeliendo una lluvia de piedras por medio de sus hondas, cuyos chasquidos aumentaban el mormollo. Los nuestros los deshicieron con el fuego de las escopetas terminadas [dirigidas] sin objeto. Los rechazaron a la parte donde sentían el susurro y venian los hondazos, /f. 11 aprovecharon alguna intermisión, echaron pié a tierra dejando las caballerías en la campaña y sin seguridad, y formaron un cuadro a discreción de nuestro Comandante, colocando en cada esquina un pedrero, porque los indios, que no saben de posición, tan presto los acometian por los costados como por el frente y la retaguardia (1). Asi se mantuvieron hasta el amanecer, haciéndoles fuego continuo, con que los rechazaban y pudieron evitar el daño, bien que antes de la formación de dicho cuadro trataron de medio ordenarse y combatieron en infantes con conocidas ventajas.

Comumnente se siente que la lluvia de piedras y furia de los indies fueron tan extremosas que arredraron no poco el ánimo de los nuestros que, confusos con la oscuridad, recibían el desconsuelo de no poder regir sus tiros y defensa. Aquí es donde se señalaron el espiritu y bizarria del teniente coronel don Juan Bautista Zavala, vizcaino de nación (2) y uno de los vecinos más honrados de esta cjudad; porque levantando la voz y avanzando al enemigo de los primeros, excitó cl valor de los circunstantes esforzándolos con expresioties propias de su juicio y prudencia y añadiendo a los europeos este raciocinio: ¡Valor cántabros generosos, qué se diría de vuestra gloria, de vuestra fama y de vuestra fidelidad al Monarca y a la patria si a vista de un enemigo tan ruin descaeciesejs de las generosidades con que naturaleza os produjo! ¡Seis horas nos restan hasta la aurora, tiempo corto para explicar nuestro brio, nuestra constancia y nuestra lealtad! (3). Y a este tenor siguió discreta y providamente sus oficios, correspondiendo a los indios con gritos y con retos, pues decia: ¡Avancen, maten a esos pícaros traidores! Y como le acompañaba el eco con

(1) El Oidor, que no estuvo en el campo de batalla en el amanecer deb día 15, describe el episodio de la lucha en El Alto como seguramente se lo nuráron: de ahí que coincida muy poco con el Comandante, que hace un informe de tipo militar de la estrategia utilizada, de la actuación de las diversas compañías y de todos los otros pormenores que se anotan en un parte de guerra.

(2) Aunque sin caer en el lenguaje altisonanle del Oidor, también Segurola, que por lo general es parco en destacar las aciuaciones de sus subalternos, se refiere varias veces en lib anotaciones de esa jornada a las actuaciones oportunas y valientes del teniente coronel Juan Bautista Zavala.

(3) Conocido el estilo hiterario de Diez de Medina, no es muy fácil determinar si estas frases tan despectivas sobre el enemigo eran realmente de Zavala o si correspondían más bien al concepıo del Oidor. En todo taso. no se ajustan al juticio del Comandante, que en esta ocasión señala que los alzados lucharon con "un espíritu y pertinacia tan horrible que desde luego pudieran servir de ejemplo a la nación más valiente" (pag. 14). 
que le seguian los circunstantes, a la verdad que los intimidaban y ahuyentaban y que algunos de los nuestros se vigorizaron, manifestando el semblante placentero y desahogado, lo que contribuyó mucho para que, animada nuestra gente, se procediese a dicho cuadro.

También se señalaron en esta expedición el teniente coronel don José Antonio Sanjurjo y Montenegro, que recibió una pedrada formidable en el pie y acreditó su valor cuando la resistencia de aquellos indios de Laja, uno de los primeros que marchaba a la vanguardia y lado del Comandante, con don Manuel Borges, portugués de nación, sujeto de conocido valor. El capitán don Dionisio Escauriza, magnánimo, de instrucción sobresaliente y dotado de bellas máximas, que con su ejemplo y posición a la primera fila, animaba no poco en la formación. El hermano Juan Sainz, coadjutor de la orden de San Camilo de Lelis (1), muy certero en el manejo de las armas y una gran presencia de espiritu y otros más, oficiales milicianos, que realmente desempeñaron con honor sus obligaciones.

Los indios hubieran quedado escarntentados si la noche favorece a los nuestros y si ellos no toman la traza de echarse en tieria al tiempo que presentían el fogonazo de nuestros pedreros, cuya metralla pasaba por cima de ellos, sin operación, sino es uno, que parece la tuvo al amanecer, en cuyos crepúsculos y después de ahuyentadus los enemigos para el camino de Viacha, saltudó la devoción del Comandante, dando gracias con toda la gente a María Santísima, señora nuestra, y tomó después de algunos pasajes la resolución de internar a la ciudad. Dícese que no faltó persona que extrañase la orden, profiriendo esta interrogación: ¿Qué, nos vamos a la ciudad? Como que se graduaba no ser tiempo de ello y que la ofensa estaba inulta. Otro, parece le dijo, convendría mantener aquel puesto ventajoso, a que contestó no había menester consejos de nedie ${ }^{[2] .}$

Los indios mucrtos que se vieron expuestos en la campaña, convienen los sensatos que no pasarían de 50 , sin computar heridos, que son inaveriguables, aunque otros varían y aumentan el número, por genio o por invectiva o por

(1) Orden religiosa creada por San Camilo de Lelis en el siglo XVI para prestar asistencia a enfermos y mortbundos. A sus frailes se les conoció como "Camilos" o "Padres de Ja Buena Muerte". En La Paz luvieron tma existencia rnuy corta, pues llegaron en 1775 y desaparecieron con la Independencia.

(2) Las alusiones del autor a actitudes tan soberbias de parte del Comandante son frecuentes a lo largo del Diario. 
complacencia del pueblo (1). De nuestra parte, murieron un granadero, que por su ardor se avanzó mucho al enemigo y don Esteban Torres (que ayudó a salvar al corregidor de Sicasica). Los hurtos de caballería y armas que cometieron los de nuestra propia soldadesca irritan la atención porque varios oficiales tuvieron que perderlas y descender a pie a la ciudad una legua. / fol. llv. Sin que después de ahuyentados los indios y aún la noche del combate se pudiese lograr una ordenación formal, como que todo fue un desgreño y una confusión, aún al retirarse a la ciudad, y que cada cual vino dispersamente, cuando y como le dio la gana habiendo entrado el Comandante sólo con parte de la comitiva y mucho después, la compañía de negros y granaderos que quedaron atrás. Al fin el enemigo queda hecho señor y dueño de la campaña y del Alto (2). Pero los efectos nos los hará sentir el tiempo, porque si de una arista mal encendida suele originarse la voracidad dc un incendio cuasi interminable, ¿qué será cuando dejemos sin apagar las llamas de un volcán como el que se deja en parte tan superior y dominante a la ciudad? (3).

Día jueves 16 de Marzo. Se experimentó el marmollo de cometas y tambores de los indios en los altos (4), Entraron algunos a los extramuros y casas fuera de

(1) Segurola tambiến sefiala que al amanecer se vió en el campu de lá lucláa, con mucha extrañeza de parte de los españotes, un número escaso de iuclígenas muertos. Pero, mís adelante añade que al descender hacia la ciudad se aclaró el misterio porque se vió algo aś como 400 a 500 cadj́veres despeñados u ocultos entre las piedras y matomales. La costumbre de esconder a los muertos por parte de los alzados fue mantenida a to sargo de todo el asedio, obcdeciendo a li intención de ocultar el número de bajas.

(2) Después de leer frases tan claras sobre el derrotismo, la indisciplina y b desastrosa siluación de las tropas españolas, es curiosa la insistencia del Ojdor, expresada en frases atribuídas a otros. en la idea de que no se debíb abandonar El Alto.

(3) En realidad, la batalla del Alto o de la Ventilła, cono también se la llama, no fue una derrota para los paceños puesto que las fuerzas indígenas no pudieron cerrar la entrada a la ciudad ni impedir el paso del ejercito de Segurola: por el contrario, fueron ellas las que debieron retroceder hacia Viacha.

Francisco de Castañeda, en su Diario, siempre elogioso para el Comandante, celebra ja jornada como un triunfo extraordinario de sus tropas. Segurola, en cambio, con mayor seriedad, si bien acepti haber ganado la batilla, considera en el fondo que la situación es desastrosa, porque los enenugos, que son diez o doce veces más numerosos de lo que se suponía, han quedado dueños del Alto, y él debe hacerles frente con un ejército exiguo, indisciplinado e ineficaz.

(4) La actitud tomada en los días anteriores, 14 y 15 de Marzo, y que prosiguió después de la entrada de Segurola manifiesta ya claramente la irtención de cercar la ciudad, propósito no abandonado sino hasta la llegada de Jgnacio Flores, el 30 de Junio, con las tropas de auxilio; constituye este largo período de 109 dias lo que se ha liamado el Primer Cerco. 
trincheras y habiéndose tocado al arma a las 11 del día, por medio de la campana, salió el Comandante con la oficialidad, granaderos y varios de caballería, que bien compondrían 700 y así mesmo, con los indios amigos y cuatro pedreros, por la cuesta que llaman de Potosi, con cuya vista se ahuyentaron los enenigos internados, los que se presentaron acordonados en la ceja del Alto, hondeando con piedras y arrojando galgas de ellas, de cuantioso tamanio, de arriba para abajo. Los nuestros sitiaron los pedreros \{1\} a un lado de la cuesta, sobre un morro y aunque se les hizo fuego con ellos y los fusiles, no hubo novedad mayor y el Comandante mandó retirar la gente. Si esto fue tentativa para tomar El Alto o verdadera intención, no lo sabemos, aunque el acto no marifestó empeño alguno 〈2).

Día 17 de Marzo. Considerando el Comandante que hoy pudiesen arribar al alto de Laja las gentes que sabe vienen de su provincia de Larecaja, por tal de auxiliarlos y lograr de la ocasión para recuperar aquel puesto ventajoso que quiso dejar y conduce para rechazar al enenigo, mandó tocar al arma y, del mesmo modo que ayer, se encaminó con nuestra gente a la cuesta de Lima, dividido en dos alas, la una, que ascendia por la cuesta que llaman de Calpani, a la izquierda y la otra, por un deshecho, a la derecha, que hace una especie de mesada, dejands, en el centro el camino ordinario. Se les hizo algún fuego con pedreros y fusiles y los indjos respondian de arriba con los hondazos te piedras, de modo que la diligencia fue también de mera tentativa, puesto que el Comandante se retiró con nuestra gente de media cuesta.

Día 18 de Marzo. Desde las 12 del día se sintieron en la ciudad tiros de fusiles en El Alto y puesto que se termina [se dirige] al pueblo de Laja, con mucha grita de los indios enemigos, lo que acostumbran al combatir. Bien presumia el pueblo que hubiese sido refriega con los auxiliares de Larecaja, que ayer se pensó guarecer y hoy no, hasta que a la una y más de la tarde, los vimos presentados a caballo en la misma ceja del Alto y que a poco rato empezaron a descender algunos por un sendero poco trillado a un lado del camino, descarriadamente y con rara celeridad, con el desigrio de dar aviso a la ciudad. Pero después de algunos minutos fueron bajando los demás por dónde y cómo pudieron, levantando una polvareda considerable, con el tropel de las bestias y galgas de piedras muy crecidas y con multitud de hondazos que les arrojaban los aizados al descender de arriba, en cuyo acto perecieron varios españoles de los venidos. Cuando entraron los primeros con el aviso a la ciudad, mandó el Comandante tocar al arma y salió cerca de las tres:de la tarde por dicha

(1) Pusieron en nn sitio.

(2) Con la leclura de los otros Diarios, fnede verse que el Oidor no se entero de que la salida efectuada el día 16 de Marzo estaba destinada a castigar a los indios die San Pedro por haber viclado el juramento de fidelidad en las batallas de los días anteriores. 
cuesta de Laja, con la mesma escolta, o alguna más, de los días anteriores (t). Muchos de los libertados entraban a la ciudad cuando él salia, a otros encuntró al principio de la cuesta, otros en el Tejar y otros más arriba, todos bien dispersos. Sin embargo, siguió adelante a tomar El Alto y aún hizo regresar a muchos o los más, de los venidos de Larecaja. Procuró la subida (sin orden alguno, como las anteriores) y cuando se hallaban una cuadra / f.12 distante del mesmo Alto, el capitán don Pedro Ramírez de la Parra, don Manuel Lorenzo Lucero, don Guillermo Dorado y otros dos o tres a caballo, de espiritu, y que a poco trecho les seguía don Juan Fernando lturralde, capitán de granaderos (de conocidos alientos y pundonor) comandando su compañía. Al ver nuestro Comandante que a su edecan Bilbao le había tocado tibiamente en el hombro una de las piedras que despedian los rebeldes y que se quejaba más de lo regular, mandó otra vez tocar la retirada y entró a la ciudad con los nuestros (2).

Los que, por común sentir, perecieron en El Alto y la cuesta fueron hasta 30 sujetos y entre ellos el oficial don Taboada (sic), don Ambrosio Vázquez, gallego de nación, muy honrado y minero de oro y sobresalientes facultades en dicha provincia de Larecaja, fuera de otros españoles. A tiempo de la refriega en El Alto, lograron estos auxiliares hallar despejado el campo y ahuyentado el enemigo, tanto que los que estaban a la siniestra, hacia la cordillera, tuvieron que hincárseles y pedirles perdón. La desgracia consistió en la extraña disposición del teniente coronel miliciano de aquella provincia don Manuel Santalla que venía comandando esta gente, quien debiendo mantenerse en el puesto ventajoso del Alto y echar para la ciudad las mulas cargadas de muchos viveres, cantidades de oro y plata, alhajas y equipajes, para asegurar estos intereses bajo de su salvaguardia en El Alto; lo que hizo fue mandar que estas cargas se situasen o retuviesen en la campaña, en el centro de su tropa y con el pretexto especioso de dar aviso a la ciudad para que pudiese auxiliarlos y retirarse él, dejando acéfalo el cuerpo de su comando. A vista de tal ejemplo empezaron a descantillarse y seguirle el rumbo algunos; los demás que vieron esto, se intimidaron

(1) Ninguno de los otros Diarios recoge la noticia de que se oyera combatir en El Alıo desde las 12 A.M. y de que sólo se saliera a las 3 P.M. Por el contrario, conectan la lucha con el loque de alarma y la salida inmediata de las tropas. Cabe pensar que al Oidor le interesa demostrar la culpa que al Comandante le cabe en cuanto al desastre y huida de las tropas sorateñas.

(2) La leve pedrada a que se refiere Diez de Medina, se convierte en "rodadas de piedras que venían cerro abajo" en el Diario de Segurola. La referencia al edecán Bilbao que hace el Oidor se aclara con la lectura de otros documentos (Pleito del corregidor Gil de Alipazaga... ); se habrín producioo por entonces serios choques entre Segurola y los principales paceños que no veían con buenos ojos la prepotencia de este personaje. El Comandante vivía en casa de la marquesa de Aro, madrastra o madre del joven edecár Bilbao. De este modo, la antipatía que el Oidor siente por Segurola la exijende a la fanilia de la marquesa. 
y tomaron también la fuga precipitada, con cuya vista los enemigos volvieron rapidamente sobre ellos, mataron aquellos pocos de honor que les hacian fuego y se defendían. Siguieron cuesta abajo otros y allí continuaron aquella mortandad con dano de varios heridos y maltratados. Tomaron varias escopetas, pistolas y armas blancas y principalmente el cumulo de todo aquel equipaje y caudales de ingentísimo valor, que parece ocupaba de 30 a 40 pearas de mulas cargadas, puesto que la expedición consta de 500 hombres, inclusos en ellas los ciento y tantos soldados que el 2 de Marzo salieron de esta ciudad con don José Pinedo, destinado auxifiar de nuetro Orellana, corregidor de Puno (t). Rara desgracia de día y rara falta de consecuencia el no haberse repetido temprano la diligencia de ayer, para que al mismo tiempo de salvar este auxilio y dichos intereses, ganar el sitio ventajoso del Alto, que como se ha visto se tuvo por aquellos cuando ahuyentaron a los alzados.

Por los que fueron con aquel dicho I'inedo, se sabe que éstos se juntaron con las gentes de la provincia de Omasuyos en la capilla de Santa Rosa o pampa de Quequerani, juristicción del de Mojo, en la de Paucarcolla y siguieron la marcha hasta el de Vilque Chiquito, poco distante de la villa de Puno donde, anticipados con un día, los nuestros de Charasani, de la provincia de Larecaja, mataron algunos mandones del relrelde. Tupac Amaru y quemaron algunas casas. Los indios tumultuados de é] se mantenían en los cuntornos y serranías de dicho Vilque. Que el siguiente dia Sábado, trabaron los nuestros combate, sin que to presenciase el comandante don Jose Pinedo, que se mantuvo en la casa del cura, ni que proveyese de munición a los suyos, por lo que no se dispararían 50 fusilazos. De suerte que los dos mil y quinientos hombres combinados alli, de las tres provincias de Omasuyos, Larecaja y Pacajes, mataron sólo a palos y lanzadas, cerca de mil indios, habiéndose sofocado cosa de 300 en la laguna inmediata de Titicaca, donde se tiraron como una manada de ovejas, que /f.12v. consecutivamente pasaron a un cerro distante tres cuartos de legua, frente al pueblo de Guancane donde igualmente mataron varios indios con derrota de los que se hicieron fuertes en este puesto y fueron acosados de nuestro fuego, con prisión de 48 indios vivos; y si hay quien diese buenas disposiciones, pudieron haber traído vivos a los demás sediciosos que se hincaron y pidieron perdón, contribuyendo a ello la ninguna subordinación, principalmente los

(1) También se reliere el Comandante a la actuación desastrosa de los lrombres de José Pinedo y de las tropas sorateñas, pero no culpa a Santalla, simplemente lo ignora. En cambio, el sargento mayor Castañeda, en su Diario, se refiere expresamente a la fuga precipitada y vergonzosa de los soldados, que en esio siguieron el ejemplo de su comandante, Manue] Santalla. 
de Charasani por falta de jefe que ordenase to conveniente y se presenciase en la campaña. Los dichos indios vivos confesaron haber recibido aquella noche antes una carta de Lucas Sesenarro, comisionado del rebelde Tupac Amaru, prometiéndoles su venida con nueve mil indios de auxilio. $Y$ con esto se retiraron los nuestros al dicho Quequerand. Que el domingo siguiente, antes de emprenderlo, pasaron de los nuestros 200 al pueblo de Guancane en solicitud del cura don Bernardo Peralta, a quien tenían preso los indios sublevados, que también se derrotaron con bastante mortandad, conduciendo al cura de Vilque con su equipaje que después arrebataron los sublevados a la subida de Vilque, causando ta muerte del capitain don N. Aliaga, de Omasuyos y la de un sastre Monroy, que sucedió en la refriega del dicho Sábado. Que vinieron los nuestros y muchos de Larecaja, embarazados, desde la noche antes, con los ganados mayores y menores y otros muebles del pillaje, se encontraron con una ernboscada de dos mil indios metidos en las quebradas y barrancos a las cuadras de Vilque, junto al cerro que Ilaman del Calvario y es donde sustrajeron el equipaje del cura. Que este Comandante, adelantado de las tropas y alcauzándolo el dicho cura y el de Vilque para que auxiliase su recobro, no se prestó ni se pudo lograr, porque el saqueo no dio arbítrio a retroceder la soldadesca. Que el designio de dicho Pinedo era encaminarse a su hacienda en la provincia de Lampa, que taló y sałueó el Tupac Amaru, para lo que mandó acopiar el ganado de los indios, pero con noticia de que venía el dicho Sesenarro lo abandonó y lo tomaron los nuestros (1).

Que el lunes tuvieron tercer combate en dicho Queq̨uerani con los indios, que los cercaron por dos partes y duró desde las 4 de la manana hasta las 5 de la tarcle, hora en que se retiraron los enemigos, habiendo hecho falta bastante los nuestros que, adelantados a su libito en el saqueo no se hallaron presentes (2). Que el martes se retiraron los de La Paz con permiso de dicho Pinedo quien quedó en Quequerani con sólo 700 hombres, fuera de ciento y tantos que condujo un tal Botello de Combaya y llegó el dicho martes. Que el siguiente miércoles alcanzaron a los de La Paz los de Omasuyos con el cacique don Mateo Verástegui, dando razón de que se venían por haberse aumentado en Quequerani el número de los indios, presumiendo por ello que así hubiesen desfilado los restantes por falta de orden, con riesgo de Pinedo y de

(1) No puede saberse si las acusaciones en contra de Pinedo corresponden a un hecho cierto puesto que ninguno de los otros Diarios menciona tal cosa; tampoco se hal encontrado documentación amplia sobre su expedición. En todo caso, puede apreciarse que con este comentario el Oidor quiere dejar como algo confirmado lo que antes anotó como una sospecha del pueblo en los momentos en que partía la expedición de Pinedo. Se ve claramente que la figura de don José Pinedo no le es grata, pero nada se sabe sobre la calusa de esta inquina.

(2) Las continuas referencias del Diario de Diez de Medina, como de los otros, a la indisciplina, falta de coordinación, cobardía y, sobre todo, rapiñas y saqueos. están demostrando claramente que la dominación española se apoyaba en una organización burocrática más que en un sistema 
los cuatro pedreros si, como es regular, no se retira prontamente. Que con noticia de venir los del pueblo de Sorata, provincia de Larecaja, armados, hasta el número de quinientos y más hombres, fueron los de La Paz en solicitud de ellos, con el fin de combinarse, como lo hicieron en la estancia de don Manuel de Herrera. Que por la multitud de los indios que sitiaban estos altos y dudarse que irian, se hizo consejo de guerra a pedimento del capitán de esla ciudad, don Francisco Valencia y resolvieron continuar la expedición a la ciudad. Y habiendo partido a las 7 de la mañana llegaron a este Alto a las 12 del día, habiéndoles hecho campo los indios rebeldes que se retiraron unos para el lado del ingenio y otros para el camino de Potosi, que mandó echar pie a /f.13 tierra dicho Santalla a los de fusil y se siguieron los sucesos apuntados (t).

Día 19 de Marzo. No hubo novedad. Los levantados se mantuvieron acordonados ch los altos y quemaron algunos ranchos o casuchas de indios que estan a la falda del cerro y cuesta de Potosí. Es de creer se mantengan aguardando los efectos de las reclutas y convocatorias que sabemos ha prevenido el principal cabeza. En este dia por repararse que las más gentes de la ciudad estaban sin alistarse ni acuartelarse se mandó concurrir a todas clases en la plaza mayor y se

militar. Richard Konetzke. en e] tome il, Epoca Colonial Aınérica Latina. Hist. Univ. Siglo $X X 1$. demuestra que uma verüdera planifíación de las ejércitos coloniales solo se hizo desde 1763, pere que ni por elto se logró obtener un "ethos" profesional especificamente militar. Por lo generut. en las clases bajas se sentía una gran repugnancia a sental plaza de soldado. Tal hecho explica el que los soldados rechutados a la fuerza cometieran desordenes y excesos que los superiores no siempre podian controlar. En el siglo XVIIt, ios privilegios y el consiguiente prestigio social, atrajeron a los criollos acaudalados a las plazas de oficiales, pero no por ello se enpeñaron en conseguir una instrucción militar seria ni una conciencia de sus responsabilidades. Estc problema está claramente schảado en los informes al respecto. enviados por Areche y Escobedo al ministro Gálvez.

(i) Desgraciadanente, ia falta de orden, claridad y sencillez en la síntesis que hace el Oidor de lus noticias recibidas por parte de algunos de los hombres de las luestes de José Pinedo, inipide esclarecer los hechos ocumidos en las provincias de Larecaja y Omasuyos antes del cerco de La Paz y del de Sorata. Las andanzas de los ejércitos formados por los hombres de esas dos provincias y las compoñas llevadas desde La Paz, por Pinedo, son muy poco conocidas y dificilmente se encuentra alguna referencina allas en las historias de la rebelión. 
fueron con efecto alistando después de 76 días de haberse tomado posesión de este gobierno militar (1).

Día 20 de Marzo. Bajaron incendiando los contrarios otros ranchos que, con los de ayer, se juzga sean de los indios amigos de San Pedro y se hallan más internados para la ciudad, bien que en la mesma campaña. Por la mañana condujo prisioneros cinco o seis indios entre vivos y heridos el sargento mayor don José Antonio Campos, sobrino de nuestro ilustrísimo prelado, que pudo haber fuera de las trincheras, hacia Potopoto, con unos pocos voluntarios que le acompañaron y si se le prestase el auxilio que pidió a la plaza, pudiera haber sido mayor la satisfacción que ofrecen la actividad y valor de este buen vasallo.

Dia 21 de Marzo. Quemaron las caserias considerables o el llamado tambo de Solís, arriba del Tejar, en la cuesta de Laja y varios ranchos de indios amigos que están por aquellas pertenencias. Así con disimulo manifiestan los indios su designio de entrar sucesivamente al incendio de la ciudad, tentando el semblantc que hacemos.

Día 22 de Marzo. Quemaron las casas del mesmo Tejar y demás inmediatas como asimismo las que están por las cabezadas del pueblo de San Pedro, extramuros de la ciudad. A vista de igual insolencia, salió nuestro comandante fuera de trincheras, entre 1 y 2 de la tarde, con la infantería, caballería, indios amfgos y pedreros, por la cuesta de dicho San Pedro o Potosí. Lo mismo fue sentir los enemigos a los nuestros que retirarse presurosos y fugitivos para los altos, abandonando el acto del incendio en que alli se mantenian. Buenc sental para poder remediarlo si se contjnúa este remedio y aún para escamentarlos, porque la campaña de San Pedro no admite galgas ni la posición superior que tienen arriba, y tiene su declive suficiente para favorecernos.

Subió asi escoltado nuestro Comandante hasta cerca del puesto que llaman El Crucero. Los enemigos por diferentes partes nos hondeaban, pero huyendo, y otros desde la ceja. Don N. Umaveitia, dependiente de nuestro Comandante, que por su viveza y ardor se empeñó a acosar a un indio por lo quebrado de la serranía, parece tuvo la desgracia de que tropezando o cayendo su caballo, le asaltase la emboscada de unos indios y le hubiesen muerto a vista de los muestros que, cuando fueron a socorrerle, ya no tuvo remedio y ni aún pudieron recoger su caballería, que ganaron los enemigos. Lo que fue de común sentimiento, recogieron su cadáver y le portearon a la iglesia del convento de San Francisco. Los nuestros parece que mataron e hirieron algunos pocos indios y se retiraron a la ciudad.

(1) Este dato resulta bastante extraño si se piensa en las listas de las compañias a que hace mención el defensor en la introducción de su Diario y que figura en las cuentas de pagos de las Cajas Reales.

Según el Oidor, este enrolamiento se hacía por primera vez; lo curioso es que ningunu de los otros Diarios lo menciona. 
Día 23 de Marzo, viemes. A las 8 del dia fue el Comandante al funeral de su dependiente Unaveitia, estando el enemigo a los extremos de la ciudad, quemando ya los extramuros y casas de San Pedro. El pueblo se conmovio e irritó no poco, y aún parece que, quejándose del gobiento, arrojaron por esto algunas palabras de alguna turbación intestina, que resenticla por el corregidor de la ciudad, lo pusieron en cuidado, quien por suavizarlo y consolarlo, al oír que se extrañaban no se tocase al arma y salir a contenerlos del nodo que el día de ayer, pasó a la casa del oidor de Chile y le dio noticia de la octirrencia. Se le dijo que, pres el corregidor estaba hecho cargo de la ciudad y tranquilidad püblica, no había embarazo para que mientras el Comandante estaba en su (unción mandase tocar al arma (1) y formar la gente para que estuviese dispuesta a las ór/f.13v denes del Comandante y que, en tales circunstancias, cualquiera del pueblo podría tener derecho a ello (2), Con lo cual lo practicó así y consecutivamente mandó un oficio político al comandante, con el escribano del Cabildo, Pedro de Mariaca, y la noticia de su disposición, y que la gente estaba ordenada, pidiendo viniese o comandarla como era de su obligación.

¿Quien dijera que este comedimiento recomendable de aguardar en sustancia al comandante con la mesa puesta, sustituyendo su falta, produjese los efectos contrarios a la intención que llevaba el corregidor de sosegar al pueblo y remediar la audacia del enemigo en circunstancias tan críticas! Asju fue, porque el señor Plata, fiscal de Charcas lo mismo fue saber que el corregidor mandó tocar al arma que bajar a la plaza indignado, repudiar al corregidor su comedimiento y expresar que él y no otro mandaba en la ciudad (3); inmediatamente se encaminó para el de San Francisco, mandó salir de la iglesia al Comandante, le imprimió de sus ideas y le trajo acompañado de varios a la mesma plaza y, aunque antes de tocar en ella había recibido el oficio del escribano, sin embargo, vino airado el comandane en busca

(1) Segurola, en su calidad de comandante militar, hubía prohibido que se tocara la campana sin su orden expresa para no producir alarmas innecesarias en la poblacion. AHNM. Pleito del corregictor don Fermin Gil de Alipazaga... Pieza $N^{\circ} \mathrm{l}$.

121 Si era difícil establecer los límites jurisdiccionales de los diversos cargos de la administración colonial, en épocas normates, mucho más lo exa en los momentos de la sublevación. La Audiencia de Charcas y, en última instancia, el virtey Vértiz mantuvieron al mismo tiempo y sin disponer la cesación de funciones del corregidor, a un comandante militar, Sebastián de Segurola. con funciones militares, administrativas y econónicas; a un fiscal de la Audiencio. Fernando Márquez de la Plata, como comisionado del Rey y con prerrogativas en el orden jurídico, administrativo y económico. Fácil es comprender cómo toda esta confusión en las tareas administrativas fomentaba los roces entre los funcionarios y complicaba los asuntos de gobierno.

13) Asi lo entendía Márquez de la Plata, en su carácter de comisionado del Rey. 
del corregidor que se hallaba hacia el Cabildo y le dijo en voces altas que él mandaba en la ciudad y que por ser el corregidor el primer alzado lo mandaría ahorcar. Como el señor oidor Medina había salido ya a la plaza a sosegar, como io hizo, acuellos ánimos turbados que se le manifestaron y puclieron haber causado no poca turbación a no ser el disimulo y prudencia con que supo barajar sus intentos, se llegó en aquel lance y medió el que pudiese causar las resultas que temía en tiempo tan grave y apretado. Dijo se cortasen etiquetas y disensiones y se operase con unidad entre todos, conforme lo requería el día, en servicio de Dios y del Rey.

El mismo corregidor, al cargo de don Sebastián de Segurola, de que se le habia quitado el comando, repuso satisfactoriamente que ese no era su intento sino meramente suplir su lalta como lo acreditaba aquel oficio del escribano. Parece que esto trae su origen de otros resentimientos particulares y antecedentes de uno y otro, con dicho corregidor; y es dolor ver que se fermenten en el conflicto en que nos vemos con la muerte a los ojos (1). Por eso siguió su enojo el Comandante y repitió a voces estando la plaza inundada de gentes, que, pues se le había qunado el comando, no queria comandar más; amagú por su retiro a su casa, con el semblante abochornado, haste que ambos ministros, el deán y doctoral de esta iglesia (que hace de provisor) y otros circunstantes trataron prudentemente de serenarlo y persuadirle que el prevenir y juntar la gente a sus órdenes no era quitarle sus facultades. Y por más súplicas y convencimientos que le hicicron caminando, o se puede decir, que arando por la plaza, en seguimiento suyo, no hubo forma de que cediera.

Continuaron las insinuaciones, mudadas en deprecaciones y después de una terquedad notable, propuso que iría solo a ponerse a la frente de las gentes venidas de su provincia y corregimiento de Larecaja (poco útiles) (2) y que otro mandase las armas de la ciudad, aludiendo por el corregidor (si esto será lo mismo que decir: no quiero servir a Dios, al Rey y a la patria; con escándalo y admiración del pueblo, estando hecho cargo de ello). Prosiguieron con todo las súplicas y fatigado se avino a reasumir sus facultades quedando cortada la ekiquela. A este tiempo, salió exalado de su cama, enfermo en silla, el ilustrísimo señor obispo doctor don Gregorio Francisco de Campos, noticioso del suceso y, como pacífico y buen pastor, consolidó y ratificó la reconciliación del corregidor con los seriores fiscal y comandante. Y mencionando éste, a su ilustrísima que el primero le había ofendido, ei corregidor, en demostración contraria y cristiana, arrojó el sombrero al suelo, se hincó de rodillas en la plaza pública a los pies del Comandante y los besó erı señal de que no pensó

(1) Ya se ha aludido muchas veces a esas rivalidades y polémiças que liegaron no sólo hasta la Audiencia y el virrey, sino hasta el Consejo de lndias y el Monarca. AHNM. Pleito del Corregidor Gil de Alipazaga ...

(2) Siempre que el Oidor Diez de Medina se refiere a tropas venidas de Larecaja, de donde era corregidor Segurola, las tilda de "poco útiles". 
agraviarlo, pidićndole perdón con las lágrimas a los ojos y la edificación y aún constemación del pueblo it). Retirado su ilustrisima dispuso /f.14 el Comandante saliesen los nuestros en dos trozos, uno de caballería, comandado por el bizarro capitán don Dionisio Escauriza (2), para el campo de La Capilla y el otro, de granaderos, la mayor parte de caballería e indios amigos y cuatro pedreros, para la cuesta de Potosi, con la orten de ganar aquel alto, comunicada a don Manuel Franco.

(1) Los aconlecimienos. así natrados por el Oidor, no aparecen en el Diario de Segurola. Consta. sin cmbargo. por el Pleito aludifo mís arriba. la impottancia que el Conandante les atribuyo. Las cosas. conk podrí verse. efan hastante graves y constimyen un exponente nuy claro de la tensirin en que por entonces vivian peninsulares y criollos. En las fojas 38 a 43 de la Pieza No1 de] Pleito. Tiguran diversos testimonios de lo acontecido el día 23 de Marzo de 1781, hechos a petición de Seguola, por lus coroncles Salvadon Cardón de la Puente, Manuel Tomás Franco. Anionio Pinedo y el iyudanle mayor del regimicnto de infantería, don Juan Francisco Borges. -De cllos se flesprende gue la asomadi indigena no era más grave que las anteriores, que los coroneles se opusieron i] toque de la campana de alarma, haciendo avisar al Comandante para que acudiera in la plazis, que a lal actitud el corregidor respondió enviando a Cardón de la Puente. a buema parte- "vaya V.M. a la mierda, quc yo soy quien manda aquí..." - mientras le almentazaba con el bastön. Resultuba también que el Oidor Diez de Medina, tan conciliador en su propia narración, dilisa voces llamando a los criollos: "iEa paisitnos, la causa es nuestra y así es preciso defenderla!". Añaden que esiabr muy claro el deseo de que "el populacho les nombrara por commulantes". Asimismo, se refieren a que cuando venían hacia la plaza Scgurola y Mírquez de lit Platia, se les acercaron a dar explicaciones el Oidor Diez de Medina y el corregidor Gil de Alipazaga con parte de la oficialidad y que el Comandante les respondió que connciendo "tl espiritu a que se dirigian sus ideas "tomara el mando el corregidor y que él se convertitia en el tullimo soldado els servicio de ambas majestades. Que ante la insistencia de Segurola de renunciar, se produjo la intervencion apaciguadora de algunas personas y de la oficialiulat y la tropa que le aclanaban como a su comandante; por último, señalan que llego el obıspo, enlermo y en silla de manos y que logró cálmat los ánimns consiguiendo se amistasen comandante y corregidor, lo que hicicron "abrazándose en público". En los testimontos de estos cuatro militares, indos ellos peninsulares, se teconoce que Segurola dijo al corregidor que "êl era el mayor alzado y le mandaria ahorcar, porque le habia usurpado su ministerio y alborotudo la gente". Timbién se refieren a que el Sr. Medina dijo: "que todos eran vasallos del Rey y debian defender la ciudad".

(2) El Oidor no menciona a este capitán en la narración de los hechos producidos en la plaza de la ciudad el día 23 de Marzo; sin embargo, figura en las declaraciones de los coroneles como uno de los que con más insolencia se quejó de la inacción de Segurola. 
El oidor Medina, considerando que el Comandante habia de salir como ayer para dicha cuesta, montó a caballo, se le presentó pidiéndole destino y ofreciendo acompañarle; como reparó que no pensaba en salir lo hizo solo y se incorporó en la cuesta con el segundo trozo, animado del deseo de tocar y palpar el método, orden y oficialidad destinados para el empeño, que en otros días se habia frustrado. Animó la gente que subía de mala gana, echando a muchos que se quedaban atrás y a robar las sementeras. Estaban en el mismo Crucero, aunque con desgreño notable; los hondazos de piedra eran innumerables. Don Manuel Franco que llevaba el comando conoció, sín duda, la falta de oficialidad y la del Comandante que se quedó en la ciudad y que el peligro era manifiesto y asi dispuso la retirada, que se hizo pausada y sin estrépito, puesto a la vanguardia el Oidor, conteniendo a la gente que quería precipitarse y el daño, que entonces fuese sensible (1). Con esta diligencia se contuvo el incendio principiado y que el enemigo se retirase a su campo en E! Alto. Murieron unos cuatro o cinco indios y algunos más que mataron los del primer trozo en el campo de La Capilla, habiendo muerto de los nuestros, don José Prado, al regresar Ios nuestros y libertádose el coronel don José de Campos, hermano de su ilustrísima, muy celoso del servicio del Rey y de los señalados en esta ocasión, quien habiendo salido con algunos voluntarios de fusil a San l'edro, se vio desamparado de los compañeros e irrumpido de los indios que por poco no le sorprenden, hasta que pudo salvar a las ancas de la caballería de uno de los nuestros.

Día 24, sábado. Entró el incendio de los indios tocando a la ciudad por los términos de los barrios de Chocata y San Sebastián y mataron los nuestros tres o cuatro enemigos, como ha sucedido en los días anteriores, por medio de las correrías a que salieron nuestros infantes y caballería.

Día 25, domingo. Condujeron los enemigos las mulas robadas de los españoles y empezaron a cosechar furtivamente los frutos sazonados de las sementeras de los aitos de San Pedro y campo de La Capilla, sin que se tomase providencia para evitarlo.

Día 26 de Marzo. Salieron al amanecer nuestras gentes, con cuatro pedreros, indios amigos y cosa de 800 pesonas de infantería y caballería 23, y entre ellos muchos oficiales y el padre Juan Sainz, al valle inmediato de Potopoto, donde se decía hallarse los indios desprevenidos durmiendo entre los cebadales, con facilidad de aprehenderlos y castigarlos. Y fueron a las órdenes del dicho don Manuel Franco, por haberse quedado entro de trincheras, el Comandante. A primera instancia, lograron ahuyentar a los enemigos que se retiraron a la otra banda del río Orcoaviri (Orcojahuira), a un cerro arriba, donde tenian su acampamento y víveres. Se

(1) Una vez más, en forma indirecta, el autor del Diario destaca su propia actuación tan discreta. valiente, generosa y oportuna.

(2) Segurola señala solamente la participación de 600 hombres. 
empeñó el Franco en acosarlos y en pasar aquel río, descendiendo por una bajada fragosa que de propósito habian cegado los indios, y ascendiendo por el otro tếrmino y cuesta, no menos escabrosa y entorpecida. Puestos en la falda de aquel cerro, batieron $y$ ahuyentaron a los indios, con el fuego de los nuestros y de los cuatro pedreros que allí situaron, mataron e hixieron a varios de ellos y tocaron en su alojamiento. Y aunque el Franco quería empeñarse más arriba, lo excusaron los nuestros, por lo que dispuso la retirada que se hizo sin orden, precipitada y en confusión. Los indios, que repararon el desorden con que de aquelta parte bajaban al rio, conocieron el temor de los nuestros y se rehicieron, acometiéndoles por la espalda con intrépida ferocidad y violencia. Los nuestros que lo repararon, y tenían encima, no podian apurar la bajada por aquella cuesta y por eso, los más de la retaguardia tuvieron que abandonar sus cabailerías, escopetas y demás armas y echarse cerro abajo. Unus rodaban por açuellas fragosidades, espinos y matorrales, otros, medio bajaban como podían, otros se desbarrancaban y otros se hallaron en el río, sin atinar en el modo. Pasado éste, tuvieron que ascender a la llanura de Potopoto, repechando sin vereda, con las fatigas, sustos y apuros /f. 14v. que se vienen a la consideración.

En el rio mataron a palos y pedradas de los visibles al capitán don Manuel de Herreia, al portugués don Manuel Borges, Urrola, Pradel, Villanueva, Deheza y el precitado don Manuel Lucero. Y de los de la soldadesca, hasta 30 de ellos, según se regula. $Y$ si los enemigos no se ceban en el despojo de las bestias y armas abandonadas y vesturtio de nuestros muertos, hubiera sido mayor el estrago porque pudierm sorprenderlos de modo que pucos pudieson contar el suceso.

Todo emanado por la falta del Comandante (1), y corta madurez de dicho Franco (2), que no debjó empenàrse a internar nuestra gente por aquel río inundado de pedrones que corre por una encañada profimda y que con respecto a este caso, pudiera llamarse el sepulcro de los vivos. Habiendo ejecutado la acción tan incautamente que mandó achuar a retirada jantamente con las mulas cargadas de los cuatro pedreros, cuando a medir el lance con alguna reflexión militar o siquiera, prudente, debiera habersc mentenido en el puesto o llanura que habia ganado sobre la otra parte del rio, donde batieron los enemigos y disponer que los pedreros

(1) Es muy explicable que el Oidor extrañara la presencia del Comandante en Potopoto si se considlera que éste habia preparado personalmente aquella salida, estudiando previamente el terreno y planificando el ataque. (Diario de Segurola, pág. 24).

(2) Aun cuando es efectivo que el Oidor no trata con muchas consideraciones a don Manuel Franco, debe reconocerse que también otros le recriminaron en aquelia ocasión su falta de pericia en la dirección del combate. Ver Diario Anónimo copiado por J. Váaquez Machícado, estudiado por M.E. de Siles, en Cinco Testimonios del Cerco. La Paz, 1781. Rev. Hia y Cultura. 
volviesen con anticipación a plantificarse en el alto de esta otra parte del río para contener, como hubtera sucedido, a los enemigos con sus fuegos siempre que ellos nos acometiesen a la retirada. En la cual sin duda, hubieran acertado con el resguardo e igual posesión de los pedreros, obviándose aquellos muertos y pérdidas y principalmente el que los indios nos hubiesen ganado en el mesmo rio los cuatro pedreros con sus cureñas. $Y$ si el teniente coronel, don Juan Bautista Zavala (a quien el comandante mandó aposłarse con toda la caballería, a la vuelta de Santa Bárbara, con la orden de impartir auxilio a los nuestros, caso de pedirselo oficial nuestro, y no otro), sabedor por un indio, te aquella derrota nuestra en el río, no se anticipa con la caballería, atravesando de oficio loda la campaña de I'otopoto, hasta haberse presentado sobre la ceja y arredrado a los indios que seguían como leones a los nuestros, hubiera sido mucho más crecido el número de aquellos desgraciados. Y aun así, no se contentaron los nuestros que venian de huida, de haber tomado la Jlanura de Potopoto en que pudieron refaccionarse, ordenarse y rebatir al enemigo sino que desfilando sucesiva y dispersamente venian a carrera a tomar el asilo de la ciudad sin que el Franco ni nadie pudiese contenerlos ni remediarlo. Con esto $y$ haber huído también los de caballería, se retiró igualmente el dicho Zavala, habiendo perecido varios de aquellos 30 muertos y algunos granaderos de esta campaña de Potopoto, por donde venían acosando los indios hasta el mismo alto de Santa Bárbara y trinchera de este nombre, con extraordinaria audacia e intrepide\% (1).

Entraron muchísimos heridos y golpeados por la cabeza, cara y otras partes del cuerpo, llenos de contusiones de las piedras, de que muy raros fueron los libertados; y varios oficiales volvteron semi vivos e inmóviles, a las ancas de nuestra caballeria, que pudieron lograr para no perecer en el sitio.

Nuestro Comandante había salido con algunos de su comitiva a los altos de San Francisco (2) én que actuaban, por otra parte, el incendio los enemigos, con el buen efecto de haberlos precavido y rechazado a aquéllos; se le notició allí que pedían auxilio los nuestros de Potopoto; volvió a la ciudad con los suyos, atravesó la plaza al alto de Santa Bárbara con el objeto de auxiliarlos, pero como de allá divisase que Zavala con la caballería se mantenía sobre el alto del río, suspendió continuar y se contentó con la regulación de que a vista de nuestra caballería, firme en un

(1) Segurola tambien scñala que lus indios llegaron en la persecución de las tropas que huian hasta las puerlas de las trincheras, produciendo tal pánico que hasta las milicias que estaban en la plaza se refugiaron en la catedrai.

(2) Segurola no menciona ninguna salida suya; más bien, refiere que envió a tales barrios, para hacer frente al ataque indígena, al coronel Cardón. 
puesto, no podría caber la derrota de los nuestros \{1\}, Con cuyo espectáculo se hizo el dia más funesto y melancólico para la ciudad y visiblemente se vieron descaecidos los ánimos de los hombres, sin hacer, ya se ve, reflexión de aquel desorden y disparate de trascender a la otra banda del rio (2), y que los muertos en la guerra no deben ser instrumento de anonadar o disminuir el espiritu y el valor, antes si, para empeñarse mas a la defensa de nuestros derechos y de los compatriotas que murieron con el honor de sacrificar su vida por el Rey y por la patria.

Día martes, 27 de Marzo. Nos acometieron los indios que vinieron en extraordinaria multitud de los altos y de la parte de Potopoto, por todas las trincheras, toda la ma/f.15. ñana y tarde, con una liuvia continua de piedras y hondazos. Les rebatieron los nuestros con el fuego de escopetas y mataron cerca de 100 indios, según opinión común. Se trajo por los indios amigos, que también hondeaban, uno vivo, de los contrarios, del pueblo de Machaca, quien dio la noticia (prematura), de que el señor Flores se hallaba en Oruro con cinco mil hombres, lo que consoló mucho a la ciudad, aunque los sensatos no podían convenir en tal anticipación, combinadas las circunstancias de que las tropas de Buenos Aires, a mediados de Febrero, no habian llegado todavía a Chuquisaca y que lo fragoso y dilatado de las provincias de Chayantit y Paria requerían más tienpo del mediado para que se viese en Orturn. Se tocó este día al arma para reforzar las trincheras y fuera de la de Samta Bárbara se dispuso una emboscada nuestra de 10 escopetas, con que murieron 15 alzados.

Día 28 de Marzo, miércoles. Se tocó al arma a las 8 de la mañana. Los indios empezaron a manifestarse por los altos del Calvario, San Sebastián y Achachicala $y$ por los de San Pedro. Circunvalaron con sus mujeres la ciudad, como si concurriesen por cómputo, $10012 \mathrm{mil}$ de ellos; bajaron los hombres y acometieron por todas partes, con muchedumbre de una pedrea continua. Repiten que murieron más de 100 indios en diferentes puestos. Siguieron incendiando las casas fuera de

(1) El Comandante no se refiere a ninguna actuación de Zavala; por el contrario, al describir el pánico producido en las milicias, dentro de la ciuclad, señala que por ello no consiguió quién le siguiera fuera de las trincheras a sostener a los derrotados.

(2) Ahora el Oidor se muestra más ecuánime al señalar cono causa del desastre no sólo a la torpe dirección de Franco sino lambién al desorden c indisciplina de la tropa. Cuando Segurola analiza la denota, señala que el proceder de estas tropas bisoñas le hizo comprender la imposibilidad de intentar otra empresa sin el auxilio de tropas veteranas. (Dlario, pág. 25). El capitán Ledo adjudica la derrola a la tropa, cuya acción se reduce a robar. Castañeda añade que se ha atribuído tal fatalidad "a la impericia del Comandante que rigí esta empresa", pero que êl estú seguro que todo se debió a la cobardía y desobediencia de la gente. (Diario de Casıñeda, pág. 60). 
trincheras, con fiereza y tenacidad, por los mechones de fuego que tráan atados por los palos (del modo mesmo que ayer martes), por los altos de San Francisco, Recogidas, San Sebastián, los bajos de San P'edro y Santa Bárbara y por el extremo de la montaña del Calvario. Ayer y hoy nadie salió fuera de trincheras ni procuró como los dias pasados el remedio de este daño que causaba la angustia, clamores y aprecio del pueblo, quien gemía reconcentrando su dolor en el pecho. A las 6 de la tarde se retiraron al Alto y a Potopoto y por la noche ardieron algunas rasas, aunque no tantas como la pasada, mediante los incendiarios nocturnos que quedaban. Son muchos los hurtos que han practicado, porque primero saquean el homenaje, plata y alhajas y víveres de las casas de los vecinos y luego prenden el fuego. Si se repitieran las diligencias de salir y despejarlos como el viernes 23 , lunes 26 de éste y los anteriores, quizá se previniere tanto mal, puesto que hay la experiencia de ahuyentarlos por medio de las correrías pasadas, porque la desgracia de ayer lunes, no debe ser motivo para tanta timidez e inacción (1), principalmente cuando el que la gobernó es un paisano con el oropel de miliciano de Indias que no tiene ni la profesión de Marte, ni las instrucciones conducentes a tar importante objeto [?].

Día jueves, 29 de Marzo. Bajaron del Alto, muchos más indios que ayer, surtidos de los pueblos de Tiahuanaco, Guaqui, Laja, Guarina, Pucarani, Viacha, Calamarca, Ayoayo y Sicasica, con muchos que hay de Paria, gobernados de un tal Marcelo Calle y de un tal Catari (que se dice infurdadamente) y a quien llaman los indios, su' rey, haciendo Bonifacio Chuquimamani (amanuense que fue de esta notaria), de secretario y Felipe Villalobos, tinterillo que fue del pueblo de Berenguela, los capitanes y consultores de aquel picarón, nuevo rebelde, distinto de Tupac Amaru, que se simula hoy, virrey, desde el Desaguadero para los Charcas (3),

(1) Segurola, como se ha ser̃alado, había llegado a la conclusión de que no se debían practicar nuevas salidas si no se comaba con tropas veteranas; el Oidor, olvidande las consideraciones que le mereció el desastre del día 26 , vuelve a insistir en que sólo se puecle despejar la ciudad de los ataques indigenas mediante la organización de expediciones que salgan de las fortificaciones que encierran la ciudad; de ahí que no perdone al Comandante una medida militar que le parece manifestación de pusilanimidad.

(2) Con un lenguaje rebuscado y altisomante, el Odior vuelve a cubrir de menosprecio al coronel Franco.

(3) Si se tiene en cuenta que las menciones dirigilas a Tupac Catari, que aparecen en la Introducción, fueron agregadas con posterioridad a la conclusión del Diario, puede comprenderse que sólo a fines de Marzo se va delinenndo su tigura como la del principal caudiho del levantaniento en las provincias del Collao y en cl asedio de La Paz. 
quien bajó en este día y el anterior miércoles, a caballo (de los robados a los españoles en la derrota del lunes 24 y las demás anteriores en El Alto, de los de Soratai), y dicen se alojó en una de las casas de San Pedro.

El incendio que en este día se les dejó practicar (1), fue notable, pues ya el fuego contanina a las demás casas, últimas que están sobre el río, inmediatas a las trincheras, habiéndose desolado todo el barrio precioso, cuantioso y muy considerable de San Sebastián, compuesto de casas de altos y muy buenas fábricas modernas (2). Sin que se haya actuado la menor correría ní más remedio que atrincherarse los españoles en una tercia parte de la ciudad y su centro y eso con conocido riesgo por la línea que llaman del corro del Calvario.

Se resistio hoy a los indios que invadieton por diferentes fortalezas y principalmente por la de la Caja del Agua, donde es corriente, acudieron sobre dos mil indios honderos, sin que hiciesen más daño que herir a uno nuestro en el brazo habiendo sí, nuerto alli de 30 a 40 indios, fuera de varios que también fueron muertos en otros puestos /f. $15 \mathrm{v}$. y pasaron, según voz común, de ciento. Se cmpczaron a retirar a la 3 de la tarde $y$, de paso, continuaron con el incendio que duró là noche, ell muchas casas. Se pilló a un indio de Guatina con su cruz de tafetán encarnado en el hombro, a manera de las que dicen provee el rebelde Tupac Amaru (3), y al sastre Mariano, de la cittdad, que se incorporó con los conjurados.

(i) La observación de Diez de Medina dirigida a seĩalar que Julián Apaza se alojó en una casa de San Pedro y que los subievados produjeron un incendio en San Sebastián, que "se les dejó practicar". está claramente destinada a demosirar la inoperancia y negligencia con que él considera que Segurola lieva la tirección de los asuntos militares.

23 Es notable el entusiasmo con que el Oidor describe el barrio de San Sebastian que, en la zona vecina a las murallas, era moderno, con casas de alto y buenas construcciones. A. Crespo, $R$. Arze, F. Romero y M. Money detnuestran en La vida cotidiana de La Paz, 1800-1825, Edit. Universitaria, La Paiz, 1976. que en esos barrios que constituian la parroquia de S. Sebastián, antiguo pueblo de indios, las propiedacies pertenecím, como en S. Pedro y Santa Bárbara. a "los caciques naturales", que las habíu heredado de sus antecesores. Debían haber sido por ello propiedades intocables; sin embargo, en 1817 los propietarios suiren cercenamientos y usurpaciones. Las frases del Ojdor demuestran que tales hechos se habían practicado ya por los uños del levantamiento de 1781.

13. En Já documentación referente a la sublevación de 1780-81, hay frecuentes referencias a distintivos usados por los rebeldes, que se suponían siempre provenientes de imposiciones de Tupac Amaru; es muy posible, sin embargo, que su uso se debiera a sugerencias de los distintos caudillos, porque no siempre coinciden las descripciones que se hacen de ellos. En este caso se trata de una cruz encarnala que se lleva en el hombro; otras veces se habla de una cruz de paja que se lleva cn la montera o de una cuerda que cuelga del cuello. 
Reventó la culebrina en el fuerte de La Paciencia, hirió a don José de Rojas y le quebró la pierna, como a un sobrino suyo, el brazo. Murió uno con dos heridos más.

Día viemes 30. Bajaron los indios en no menos multitud, por diferentes senderos y sobre 70, de a caballo, del alto de San Pedro, a las campañas que llaman de La Capilla, campo de San Pedro y El Tejar; no acometieron sino condujeron a pacer los ganados y ellos vinieron a cosechar las cuantiosas sementeras que talaron, arrasaron y exterminaron llevándose los frutos a nuestra vista y paciencia, a las 3 de la tarde. $Y$ hallándose a media cuesta, empezaron como los moros, con algazara y voces a pifiar a los españoles y mofarlos, como que celebraban su triunfo y la inacción nuestra o la cobardía en que están los árimos, sin más causa que el corto suceso del lunes 26 de este Marzo. ¡Raro lamento y raro ajamiento de la Real Corona! ¡Oh y quién nunca lo viera ni presenciara! (1).

Este y el día antecedente se conjetura que los indios pasen de ocho mil individuos. Siendo lo más lamentable el incendio, saqueo y acometiniento de las casas de los vasallos pobres, que según lo atrincherado, no pueden gozar de la real protección del Rey, universal para todos y para cada uno de los vasallos, a fin de defenderlos de semejantes irrupciones enemigas y amparar sus personas y bienes. Asimismo, se les vio bajar muchas bestias cargadas, se intiere, de los despojos, caudal, oro, plata y monedas que han saqueado entro y fuera de la ciudad, con el designio de portearlo al pueblo de Collana y preservarlos de los dragones y comitiva del señor don Ignacio Flores, de quien se ha dado en decir que ya venía para esta ciudad y se hallaba en la villa de Oruro, pasando a cuchillo a semejantes rebeldes.

Día sábado 31. Prendieron a la familia, dos hijos y suegro de Bonifacio Chuquimamani, con algunos indios e indias. Y aseguró el cura rector de la catedral, don Pablo Machicado, que habjendo salido de madrugada, fuera de trincheras, unos 25 voluntarios con escopetas, prendieron 23 indios. Bajaron los sediciosos en gran multitud y a pelotones por distintos lugares; acometieron con un trozo a la trinchera de la Caja del Agua, con muchos hondazos de piedras. Murieron algunos de ellos, por el fuego de los nuestros. Acabaron de incendiar todas las casas imnediatas a San Francisco y San Sebastián. Bajó el pseudo rey, que se retiró a las 4 de la tarde, con la mayor parte de la gente alzada, habiendo tomado posesión de la ciudad en la chacarilla de Oquendo o Monje. De esta bajada de los conjurados se dio parte (según don Francisco Oquendo) al Comandante por don Protacio de Armentia, a tiempo que estaba de conversación con los Pinedo, en el monasterio del Carmen, sin más respuesta ni remedio que el seguir con la conversación.

(1) En el fondo, se trata de una nueva crítica a Segurola. 
Día domingo $1^{\circ}$ de Abril. Bajaron los indios por diferentes puestos con mucla algazara. Continuaron quemando las casas que estáu a la orilla o borde del rio y hacia San Sebastian. y la mayor parte de ellos acudió contra las trincheras de la Caja del Agun, adonde arrojaron una lluvia de piedras. Recibió una pedrada en el petho el Comantante, bien que remisa. Se retiró luego de aquei puesto hasta que don Juan Calderón, regidor y copitán de milicias, que la guardaba y es un vecino de honor y buen vasallo, viendo el clamor del pueblo que ansiaba salir fuera de trimcheras a contener tanto incendio (que se ha mirado con inacción y cerrados entro la ciuctad) y vengar sus agravios y principalmente los de Dios y del Rey, les abrió las puertas en dos ocasiones sucesivas, de modo que en la última salieron sobre 600 indios amigos, mestizos honderos y algunos españoles voluntarios con 12 fusiles o pocos más y combatieron con más de dos nuil indios, segur opinión comúrn, con tanto acierto que les acosaron fuertemente, los retiraron y ahuyentaron con muerte de 12 de los contrarios y muchos heridos y golpeados que se vieron los cargaban los mismos indius, del mesmo modo que lo hacer con los muertos, pues luego que caen pro las balas, los levantan por los pies y / f.16 llevan los cuerpos boca abajo. Cuando el acto de csta refriega, volvió el Comandante a dicha trinchera, hizo cargo de la puerta abierta, hasta que respondió dicho Caldercin no había podido contener la gente que esforzaba por defenderse. Y viendo el buen exito con que iba la salida, se vio precisado a disinularla y a apoyar los buenos efectos de ella (t). Este día, hay opiniones de que moririan más de 100 indios enemigos, aunque otros computan hasta 50, fuera de heridos. En el barrio de San Sebastián quitaron los indios una escopeta a don Gregorio. . (sic) yerno de Pacheco, bien que en diferentes partes llevaron sus golpes y fueron nuriendo hasta dicho número y se retiraron a las 6 de la tarde para los altos.

Día 2 de Abril. De madrugada pillaron los indios cosa de 40 de los nuestros que salieron fuera de puertas, por cebada. Murieron varios de ellos, aunque se opina sobre el número de muertos, pero se cuenta entre ellos a un negro del señor obispo y otro del alférez real Foronda. Bajaron a las 9 del día los enemigos, ordenados $y$ formados cuasi todos, por la bajada de Potosí, para aparentar mayor multitud y no dispersos y por diferentes senderos, como otra veces. Acometieron por diferentes trincheras con muchos hondazos, pero sin presentar el cuerpo sino a cubiertas de las paredes fronteras de la casas que han quemado, que es donde lo más del día se acogen atisbando y descollando de rato en tato las cabezas para poder regir las hondas. Con todo, se dice que murieron sobre 40 enemigos aunque hay opinión de

19. Una vez más el Comandante queda en situación desmedrada: como él no hace ninguna referencia a este episodio, nada se sabe de bo que hubiera pensado al respecto. 
que podrían pasar de 60 a 70 . Se retiraron a las 5 de la tarde, los más, quedando los otros en San Pedro y los extramuros quemados.

Se prendió un hombre blanco con fusil, espada y a caballo que nos hacía daño desde el campo enemigo, matando e hiriendo de improviso a los que andan por las calles descuidados, entro de la ciudad y sus trincheras. De los cuales conjeturan hay unos 10012 con sus escopetas, aunque corre que son sólo siete it.

Se pasó en este día por mano del reverendo padre guardián de San Francisco, fray Manuel Arrivi, una carta por duplicado que escribe el ilustrísimo señor obispo de ésta, al caudilio que manda en el alto de San Pedro y al otro que se infiere haiga en el de Santa Bárbara, en la cual les hace el oficio de un buen pastor, los concita a su arrepentimiento y retiro a sus habitaciones en buena paz y subordinación y les ofrece que como pidan perdón de sus excesos, su ilustrísima se interesaria a impetrarlo, para así preservarlos de su ruina y exterminio y del rigor de los dragones de Buenos Aires y demás tropas, que ya sabían ellos mismos, venían de aquella ciudad. Se nota que estas cartas desdeñaron admitir o recibir los indios, cuando se trató de dárselas por la cerca de la huerta del convento de San Francisco, por mano del padre Cortés y un lego fray Pedro, expresando no podín tomarlas sin saber la voluntad de su rey, en la expresión de unos, y de su virrey, en la de otros; hasta que habiéndose escrito una como carta a nombre de José Gabriel Tupac Amaru, su fecha a 29 de Marzo de 81, al dicho reverendo guardián, en que con notable desgreño se le prevenía no admitiese corregidores, chapetones ni mestizos en su convento, porque de lo. contrario los reduciría a cenizas, pues tenía sobre $20 \mathrm{mil}$ indios y pesos a su disposición, sin que su ánimo fuese otro que quitar pechos y tiranías, sin tocar a los sacerdotes, iglesias, conventos, monasterias y destruir a los que se opongan a este objeto. Se logró de esta oportunidad, para haberse encaminado las dichas cartas de su ilustrísima como si fuesen respuesta a aquélla y aún parece que el padre guardián les puso el nema, diciendo ser su. respuesta a ella (2). Remedio que, si como ahora, lo solicita el gobierno al principio, hubiera conducido no poco, como medio de suavidad y dulzura, a

(1) Esta es la primera vez que el Oidor se refiere a un hecho evidente, la presencia de blancos en las tilas indígenas. Después de vencido Tupac Catari. Segurola persiguió con saña a los blancos sobrevivientes de quienes se sabia que habian luchado junto a jos rebeldes. A.N.B. Sublev, de lndios. 1782 M/62, C Carta de F.M. de la Plata a Vértiz. AGNBA, 9/5-5-3.

(2) Los otros diatios se refieren solamente a que el obispo respondiô el dia 3 a una misiva de los alzados recibida en esa misma jotmada. Segurola la entmera como documento $N^{\circ} 1$; reproducida por Ballivián y Roxas en la edición del Diario de Segurola, corresponde exactamente a lo anotado por Diez de Medina y, aunque está [irmada por José Gabriel Tupac Amaru, nada tiene que ver con su estilo ni con su grado cultural. 
tiempo que el enemigo venia a acometer la ciudad, juntando y atrayendo gente, por el camino de Calanarca a ésta (1).

Dia martes 3 de Abril. Bajaron los indios con poca algazara y al fin incendiaron la casa y tainbo (alias posada) de Simbrón, fábrica moderna y de costo que está arriba del puente y trinchera de San Sebastián, y fueron quemando otras casas consecutivas. A la madrugada mataron /t.16v. cuatro indios amigos, que fueron por verduras y buscar alimento, hacia el Calvario. Y se libertó don Guillermo Dorado, atin habiéndosele aflojado la cincha de la caballería, pues se acomodó a salvarse, matando un indio que le acosaba.

Vino la respuesta a la carta del ilustrísimo prelado, por la misma cerca de San Francisco y mano de un iego del convento, concebida en los términos siguientes: "Ilustrísimo sejor don Gregorio Francisco de Campos. Doy pronta respuesta a la de Vuestra Señoria llustrísima, y por ella quedo celebrando la apreciable salud de Vuestra Señoría Ilustrísima, la mía, toda, usta a su disposición. Pues le estimaré a Vuestra Señoria Ilustrísima, el que me avise con fijeza de cómo sabe Vuestra Señoria Il ustrísima el que vienen navíos de Buemos Aires a acabannos, cuando Carlos IIl tiene desamparado al Rey Inga, por las muchas injusticias y robos que experimentamos. l'or fin Dios sobre totos; nosotros vamos sobre este dictamen: lo que es de Dios a Dios y lo que ess de César a César, pero si es ya de lo Alto el que nos hemos de acabar, todo se cumplirá, la voluntad de Dios ell todo y por todo, porque como dicen, el mal fruto, cortarlo desde las raíces, así nos acabaremos todos, y a Dios, quien guarde a Vuestra Señoria Ilustrísima por muchos años. En este alto de la Batalla, hoy 3 de Abril de 1781. Beso las manos de Vuestra Señoría Ilustrísima, su amante vasallo, Yo el señor Virrey Tupac Catari" (2).

Esta carta es al parecer de letra de Bonifacio Chuquimamani, quien corre, la escribió en este pueblo y extramuros de San Pedro, donde bajó el caudillo conjurado, con su comitiva; recibió la de su ilustrísima y contestó ésta, según se infiere, pues vino la respuesta en menos de dos horas. ¡Qué ocasión para prenderlo! Pero como nada se procura fuera de trincheras y todo el cuidado es tocante ai arma y distribuirse la gente para montar la guardia en ellas y espaldones, como hoy lo dijo

1) No cabe sino el desconcierto cuando el Oidor se refiere a estos temas, puesto que no sc avienen estas opiniones al deseo constantemente manifestado de salir de los muros y vencer definitivamente a los indios como tampoco a su actuación posterior en Peñas, cuando juzga a Catari desde su posición de vencedor.

(2) Tal carta está incluída en el Diario de Segurola, como la $\mathrm{N}^{\text {2}} 2$. Se ve que el Oidor la conoció personalmente, puesto que la reproduce con toda fidelidad, añadiendo incluso una frase que aciara una expresión trunca en la transcripción de Ballivián y Roxas. 
en público el capitán don Dionisio Escauriza, de honor, espíritu y buen vasallo del Rey (1), es preciso pasar por este tósigo, por evitar alguna guerra intestina que, con no poco fundamento, debe recelarse, mediante la estrechez de víveres, peirdida de casas y bienes, con que el pueblo se halla consternado, al mesmo paso que muy disgustado. Se recogió la gente enemiga a las 4 de la tarde, a sus fuertes en los Altos. Mató 14 indios, en este día, en dos fortalezas, el padre Juan Antonio Sainz, de la Buena Muerte (2). Nos quitaron dos escopetas, la una del sordo Bolaños, quien mató a uno y pudo librar. Y corre que nosotros quitamos otra, de uno de a caballo y sable.

Día 4 de Abril, miércoles. Bajaron los enemigos dispersos y por hacia el Campo de la Capilla. No hicieron mayor novedad pues se emplearon en robar y talar los frutos de las sementeras, que fueron acarreando al Alto y, al subir a cosa de las 4 de la tarde, de retirada y, muchos con dichos frulos, salieron de la ciudad cosa de mil y quinientos indios de los amigos con algunos voluntarios de escopetas; los excitaron a batalla y los hicieron retroceder para aceptarla y aunque la amagarono hubo alguna tentativa de refriega, piedras y algunos tiros de los pocos fusiles que habia, de parte a parte, no hubo cosa mayor, porque si en unos había miedo, en los otros temor. $Y$ así fue que se retiraron (3), estando una emboscada nuestra a la subida de San Francisco, compuesta de algunos granaderos y otra hacia la calle Ancha de San Sebastián, de aquellos voltantarios y buenos vasalios, de espiritu y entre ellos el padre Juan Antonio Sainz, que se señala, acompañado del doctor don José Mariano Sanjurjo Diez de Medina, abogado que hace de comisario de guerra, y contribuir al buen tratamiento y buen régimen de los indios amigos que le escoltaron. Llamaron pues a los contrarios, dispusieron la retirada y se emboscaron a la espalda de unas paredes de la primera calle, por donde internaron muy furiosos, con mucha algazara, los enemigos, los que con la descarga repentina de escopetas de dicha emboscada, fueron cortados y aturdidos y quedaron llenos de horror y sumo

(I) Nueva alusión a la inefícacia del Comandante.

(2) ¿Curioso proceder en un fraile de la orden de La Buena Muerte! El padje Sainz habia transformado su misión de pastor de las almas en la de externinador de indios.

(3) Es evidente que al comienzo del cerco quedaron dentro de los muros graut parte de los pobladores indígenas de las parroquias de S. Pedro, Sta. Bárbara y S. Sebastí́n; son los indios amigos a que se refiere el Oidor. Estos mismos son los que, lentemente, a medida que se acrecentaba el hambre y parecía asegurarse el triunfo de las sublevados, desertaron y abandonaron la ciudad.

Las frases de Diez de Medina manifiestan extraordinarianente bien la situación psicologica que se producia en los indigenas cuando debian luchar frente a frente con sus hernanos de raza. 
silencio, hasta que con el mesmo, fueron desfilando y retirándose muy funestos at Alto con el nimero de dos mil y más individuos que a cómputo prudencial se computaron.

Como en este día se dio la noticia volandera al Comandante, de que los indios amigos se hallaban cortados de los enemigos, tuvo a bien, según se dijo, de mandar en socorro de aquéllos un piquete de dichos granaderos, comandados de don Carlos Rogers, inglés de nación, quien los ha disciplinado y es de valor y fidelidad. Al tiempo que estos salian por la calle arriba de San Francisco, se hallaron los enemigos con la llamada falsa de la emboscada del padre Juan, en la calle Ancha, $y$ al aconieter por ambas calles, se hallaron con los golpes de fusil encima y fueron así rechazados. Es corriente que murieron de 32 a 34 enemigos y que con los heridos pudieron llegar a 80 más o menos, sin que en los nuestros hubiese más que salir con la cabeza rota, el dicho Rogers, y el padre Juan con una pedrada en la pantorrilla, fuera de las muchas que en dos ocasiones, en El Alto y Potopoto, tiene ya en el cuerpo.

Parece que el Comandante no aprobó la salida fuera de trincheras, por no haber precedido su permiso; tiene en rigor razón, pero rebaja mucho, atendida la inacción o tibieza o no sé qué con que corren las cosas $y$, con mucho, atendido el consuelo que ha recibido el pueblo con este y el anterior inmediato suceso de la Caja del Agua. Los enemigos acudicron al convento de San Francisco, llamaron un lego de los lugares santos y reconvinieron por la respuesta de su ilustrísima. Se les dijo que, cuando de su carta resultaban tanta insolencia y disparates, ¿qué respuesta podían prometerse? Este dia aseguran muchos que vieron bajar en andas al llamado Tupac Catari, vestido de encarnado, y que se apostó hacia el pueblo de San Pedro, extramuros de la ciudad. ¡Raro atrevimiento, si es cierto!

Dia jueves, 5 de Abril. Descendieron del Alto los enemigos por la cuesta de Potosí. Acometieron por diferentes parles; se oyeron algunos tiros de fusil, de parte a parte, y los suyos desde las troneras que han roto entre las paredes de las casas fronteras y quemadas, aunque por no saber, yerran los más, sus tiros en vago. Algunos de los ruestros han sido sorprendidos, heridos y uno que otrn muerto, de ellos. Hoy dispuso el Comandante dos correrias de fusiles, una por el barrio de San Sebastián y otra para el extremo opuesto de Santa Bárbara y con los indios amigos divididos en partes correspondientes. La de San Sebastián la comandó don Manuel Franco, con menos gente y tuvo buen efecto, porque después de la oración regresó sin dano en los nuestros y con muerte de 30 enemigos. Ni tampoco tuvo el grueso de éstos que se retiraron y corrieron para Santa Bárbara al rumor de que allí existía, haciendo fuego, el otro trozo de los nuestros. De modo que corrían los indios como hormigas y en número de más de ocho mil, según cómputo prudente, y transitaban con gritos y a carrera por las cabeceras de San Sebastián, altos de San Francisco, San Pedro y demás campos que van a salir al de Santa Bárbara. 
Para donde habŕa salido la segunda y mayor partida, a las tres y media de la tarde, sin formación, sin orden de acometer ni de la retirada, que son los preliminares de la guerra, se vio que no solamente salieron de los nuestros los útiles y destinados para pelear (que serían unos 300 hombres fuera de 108 indios anigos), sino muchísimos inútiles, meramente curiosos de a pie y caballería, encapados y sin armas algunas, con más varias mulas aparejadas que se sacaron por forraje, por la carencia de cebada entro de las trincheras, estando la calle inundacta de estas gentes curiosas y aún de mujeres que dejaron salir. Se apostaron en el alto de Santa Bárbara los nuestros, en distintos lugares, a grupos y sin otra fomación que la que observan los indios enemigos, pero con buena suerte al principio, porque los nuestros y los indios amigos rechazaron a los contrarios hasta los altos de Potopoto y aún mataron a muchos, cuyo número es vario con gran diferencia, porque thos ascienden al de 400 , otros al de 200 , otros a 100 , a 80, a 60 y hay personas que los rebajan hasta cinco y hasta dos jcosa rara! Ello es, que los nuestros quedaron dominando, dueños del sitio ventajoso y alto de Santa Bár/f. 17v bara, cuando repentinamente empezó a desfilar la gente nuestra inútil (con la ocasión de rctirada) a huir sin motivo y con celeridad, calle abajo. Los nuestros de honor, que con esto pensaron hubiese alguna emboscada o corte de indios, recelosos, Jos siguieron, actuando una retirada descuadernada e infeliz. Los contrarios, que estaban en las cercaníis altas, al vernos correr nos invadieron con tanta violencia que dieron con los nuestros en la bajada y calle de Santa Bárbara, por donde tampoco había desahogo para esta huída precipitada por aquel numeroso concurso de gente que cubria la calle y no dejaba libre el paso, por lo cual, sin poder acelerarlo y estancados los nuestros, unos caían, otros rodaban, otros pasaban por cima de los que caidos y pisados se hallaban debajo y por los suelos, dando así tiempo al enemigo para que los hubiesen avanzado y matasen más de 50 individuos de los nuestros, y entre ellos dos granaderos, un eciesiástico, clérigo don Cayetano Avendaño (que como fiel vasallo salió a la acción con escopeta), don José Laray, hombre decente pero anciano y otros cuatro de los soldados, con un tal Farfán, de los de Araca y varios indios amigos. Los enemigos nos acometieron ya, sin poder regir la honda, hiriéndonos con sus palos, sables y otras armas suyas. $Y$ si hay disposición para retroceder, se hace en ellos una camicería a mano, que quizá hubiera contribuido a su último escarmiento, porque se siente hubo más número de los nuestros que los invasores enemigos (pues el trozo principal de los del alto de San Pedro, se habían retirado al principio alterados de los fusilazos, sin haber osado a tocar en el de Santa Barbara) o porque no puede haber cosa peor para el indio que huirle la cara, a vista de que entonces se ensoberbece y acomete con furor y rabia; cuando, por el contrario, se le arrostra aunque sea en poco número, se acobarda, intimida y huye.

Supónese que habiendo salido el Comandante tarde y de los últimos, cuando ya lo habian hecho los nuestros con aquel desorden y estaban con el mismo 
en el alto de Santa Bárbara, ¿qué acción podía regir un cuerpo así, acéfalo, sin disciplina y nada ordenado ni dispuesto? De tal antecedente, ¿cuál fín podía derivarse sino el funesto y ruboroso de aquella retirada o fuga intempestiva, que el mesmo Comandante se rio necesitado a actuarla de los primeros? Todo emanado de la falta de orden, arreglo y subortinación y de no prevenirse las retiradas ni las acciones, como corresponde (1).

Este dia mataron de un balazo, los enemigos, a un soldado que hacia la guardia en el espaldón de la Parada e hirieron por la mañana a una mujer, con otro balazo. Esta tarde salió al alto de Santa Bárbara el señor fiscal don Fernando Márquez de la Plata, dando buen ejemplo de su celo al servicio.

Día 6 de Abril. Bajaron pocos indios del Alto, porque los más se quedaron desde anoche emboscados entro de las casas quemadas de la ciudad y campañas inmediatas. No hubo especial novedad ni movimiento, y por la tarde a las 4, se vio bajar al nominado Tupac Catari a caballo tordo con cabriolé encarnado, pistolas y jaez, con una comitiva de 400 a 500 indjos armados, en dos alas y algunos de a caballo, por la bajada o cuesta que llaman de Potosí y después de que podrían internar a la quebradita o extramuro, cuando más. Volvió a subir a los 10 o 12 minutos de haber entrado, no sólo con los que trajo consigo sino con más de seis a ocho mil indios y varios de a caballo, que iban reclutándolos de las campañas, con todas las bestias y caballos robados a los espanoles, que estaban pastando en las circunferencias de la ciudad y sus campos, tanto que muchos salían tirando la suya de diestro. Se vio que salieron con el mismo orden de formación en dos líneas con que bajaron. El principal conjurado iba cuasi de los primeros, le seguian los indios así formados y todos en gran silencio, hasta que puesto a media cuesta, empezaron con la algazara acostumbrada y siguieron rindiendo homenaje a su caudillo con las banderas, con las hondas en mano y con muchos tiros o salvas de escopetas y así siguieron hasta haber avanzado El Alto. El Tupac Catari, dicen, bajo con mascaroncillos dorados en cada rodilla que Ilaman mascaipachas, y en cada hombrera, y un sol al pecho como acostumbran Jos incas. Otros indios subían sin orden y a pelotones, no sólo por el mismo sendero de Potosí sino /f.18 por todos los que hay, y son varios, que ascienden a los altos y estaban ocupados de este tumulto; por donde se infiere que estos bárbaros alzados quisieron hacer ostentación de sus fuerzas y poder $y$ hacerlas visibles a la ciudad. Cualquiera al ver que así se retiraban los del alto de San Pedro con sus mulas y muchos cargados de los trutos o viveres hurtados, hubiera consentido en que se retiraban del todo y que tenian alguna

(1) Aun cuando el Oidor coincide con los otros autores de los Diarios en cujpar de este descalabro a los defensores que no obedecen. no se organizan, se ofuscan y huyen produciendo el pánico, no puede, en el fondo, dejar de señalar al Comandante como el gran responsable de todo. 
novedad para elio, a no conocerse la tendencia novelera y llena de apariencias de todo indio. Se mantuvieron asi en el alto y fuerte que corre han hecho alli, de carpas robadas y casuchas de paja que llaman chuxllas. A las 10 y más de la noche se sintieron la algazara, cornetas y algunos tiros de fusil, que siguieron hasta bien tarde. $Y$ a las 9 de ella, también se oyeron por la parte del Calvario o Quilliquilli, otras cornetas con mucha gritería de los del alto de Santa Bárbara, sin que hubiese novedad mayor.

Día 7 de Abril, sábado. Empezaron a bajar hacia la campaña llamada de La Capilla y a cosa de las 7 de la mañana pur la cuesta de Potosí y otras veredas inmediatas, en crecido número y en dos alass, como por la del Cuzco y aitos del Tejar. En esta madrugada nos aprehendieron unos 10 indios amigos, los contrarios, que parece los lievaron consigo. $Y$ antes de la aurora sacaron por la cerca que foradaron, de la huerta de San Francisco, cosa de 30 indios que estaban abrigados entro del convento, como otras que parecian pobres por falta de habitación y causa del incendio y habian sido mujeres de los alzados, las que clamaban por retirnrse con ellos mediante la hambre de que se quejaban. La multitud de indios constaria de seis a ocho mil, pero compuestos de varias mujeres que bajaron por el Tejar y de los del otro partido y grueso del alto de Santa Bárbara; todos los cuales empezaron a retirarse ordenados o procesionalmente por la cuesta de Potosí, con su caudillo y demás de a caballo, a las once y media del día. Quedarmse las dos tercias partes más o menos, parados y después sentados a media cuesta, mientras el cabeza subió con la comitiva de la otra tercia parte y con las mismas salvas y homenajes que ayer a su fuerte en el Alto y a cosa de la una de la tarde empezaron a dispersarse en los alrededores y campañas. Los indios de la parte o cuesta del Cuzco, bajaron hasta la calle de San Francisco, donde esta tarde se halló una bandera encarnada y en ella un papel escrito que en sustancia decia que nosotros les entregásemos a los tres ladrones (habla de tres corregidores que con otros hay en la ciudad) y prendiésemos a los chapetones o europeos, porque de lo contrario, reducirian, hoy dia 8 , a paveza.y cenizas a todos los de la ciudad (1), la que se soplarian como un hueso en tres horas de tiempo, pues tenían segura y prevista la situación de su entrada a ella y tendrían que experimentar el rigor de su Julián Puma Catari (ya no es Tupac Catari) (2). EI designio vano de estos indios en las bajadas de ayer y hoy, ya con esto se conoce, que es aparentarnos mucha gente y poder y pensar en el disparate de aterrarnos y sojuzgarnos bajo de sus bárbaros sediciosos dictámenes. Sin que en este día hubiese

(1) Segurola incluye esta carta en su Apéndice, con el $N^{\circ} 3$.

(2) Efectivamente, la carta está firmada por Julián Puma Catari. No queda tampoco en claro en la edición de Ballivián y Roxas si se trala de una equivocación del secretario de Apaza o si esta misiva la dictó Puma Catari, otro de los caudillos colaboradores de los Tupac Amaru; en todo caso ésle se llama Carios y no Julján. 
otra novedad particular. A los del alto de Santa Bárbara, cuando aquella dispersión y alín antes, se les vio regresar y bajar a su puestos.

Día 8 de Abril. Amanecieron los enemigos tronando muchas camaretas; empezaron desde la madrugada a bajar, en mucha parte dispersos y en grupos y desordenados, por todos los senderos que hay para los altos; fijaron dos banderas encamadas en la cima y embocadura de la cuesta de Potosi y, hasta las 10 del día lo que han hecho es acordonar la ciudad sin movimiento. Hacia el Calvario matarono degollaron un pobre moro que había salido en solicitud de comidas o habas y se llevaron la cabeza (1). A poco más de las 10 del día, bajaron Jos demás, ordenados en dos filas, por la cuesta de Potosí, con su caudillo, muchos a caballo, con aderezos ticos y seis de ellos con cabriolés encarnados y pistoleras que han hurtado. Entraron los nás a la ciudad y se emboscaron entre las quebradas, habiendo quedado cosa de 800 o mil indios así ordenados, a la calce de dicha cuesta, donde se mantuvieron inmóviles hasta las cuatro y más de la tarde. El caso fue que los primeros indios alzados que asomaron a la calle de San Francisco, gritaron /f.18v. que pues ellos venían de paz, no se les tirase con los fusiles ru se les hiciese daño y que lo mismo harían ellos. A poco rato salió don $N$. Velarde, uno de los cuiatro capitanes de los indios amigos (que están en cuatro cuarteles fuera de trincheras en la ciudad), con su fusil y en medio traje de indio, con los suyos. Lo conocieron, le dijeron: Quítate esa camiseta o traje que no te corresponde, deja las armas y ven de paz a tratar con nosotros. Hizolo así y después de haber pasado a ellos, los abrazó y comprendió su designio de hacet amistad bajo de las condiciones disparatadas que se inscribieron en el pasquin de ayer i?

Dada parte de estos sucesos al comandante, los difirió con sinceridad y, sin conocer la malicia, mandó tocar la campana mayor y al arma y se fue a la trinchera y puente de San Francisco; ordenó se suspendiese el fuego y dispuso enviar dos religiosos de San Francisco para que los amonestasen a su nombre, a la subordinación al Rey y sus ministros, ofreciéndoles indulto a nombre de Su Majestad, con tal de que se retirasen a sus reducciones en sosiego y acreditasen su rendimiento y contricción. $Y$ después de algunos instantes les envió otro religioso para que les dijera que enviasen dos 0 tres de sus principales y si pudiese ser a Bonifacio Chuquimamani (que es el tinterillo y espíritu que anima esta sedición), bajo la salvaguardia de las piedades del Rey y palabra del señor comandante, de que

(1) Se trala de un negro.

(2) Segurola nunca se fió mucho de estos indios amigos que desertaban con facilidad para irse con los de su propia raza, que les ofrecian, por entonces. mayor seguridad, posibilidades de alimentos y lodo un plan de reivindicaciones. Su instalación en cuarteles fuera de los muros efa la decisión militar más prudente, con respecto a ellos. 
no les harian daño alguno, para que por medio del señor oidor don Francisco Tadeo Diez de Medina, que sabe ambos idjomas del reino, se les explicasen y diesen a entender sus excesos y obligaciones, con todo lo que conduzca a restablecer la paz y subordinación con que deben vivir sujetos a Dios y al Rey Nuestro Señor (1). Y que según lo que resultase de esta conferencia se procedería a lo demás que convenga para mirarlos y tratarlos con humanidad, compasión y caridad. Respondieron que para el dia de mañana lunes vendrian. Y después de haber cesado la guerra por una y otra parte se vieron los indios amigos que hablaron y se trataron con los enemigos (y aquella vez de verdad los sedujeron), se les distribuyó la yerba que llaman coca y la mascan y aprecian mucho. Hasta que a las cinco de la tarde se retiraron los contrarios en el mesmo orden procesional, por diferentes lugares y el caudillo con el mayor trozo, por la cuesta de l'otosí, con las mismas salvas del día de ayer. Y en efecto, esta noche no hubo novedad alguna ni movimiento.

Día 9 de Abril, lunes santo. Bajaron los indios a más de las 9 del día, por seis senderos de los que hay para subir a los altos, desde la ciudad, ordenados y perfilados como el día anterior. Se mantuvieron emboscados en los arrabales quemados y muchos al pie de la cuesta. Avisaron que su caudillo, el Tupac Catari, bajaría después de comer arriba, en su fuerte, y que la serial de que bajaba habian de ser los clarines y que éste con Pedro de tal (que se dice ser sobrino de lupac Amaru) y otro, se presentarian para dicha amoneslación. Así se mantuvieron las cosas, hasta cosa de las 2 de la tarde, en que empezó a descender el motín por la calle de San Francisco, con el dicho Tupac Catari vestido de cabriolé encarnado, de galones, camiseta de terciopelo negro, chupa encarnada de galón, pero ebrio e incapaz de ser tratado. Concurrió antecedentemente una carta que, al parecer, es de letra de Bonifacio, escrita al padre predicador del convento de San Francisco, en que firmando con fecha de este día, se explica así: El señor virrey Tupac Catari dice que advierte a la ciudad, tener sobre $140 \mathrm{mil}$ indios en los alrededores de la ciudad (2), para reducirla a cenizas, que para sosegarle se le entreguen las armas, se abran las trincheras, que salgan los europeos fuera, para sus tierras, quedando perdonados los criollos para siempre, y que de lo contrario todos serían pasados a cuchillo. Y luego concluye con decir que ya está dispuesto de lo alto así, porque lo que es de Dios a

(1) Segurola no menciona para nada la intervención del Oidor. Retiriéndose a este episodio, demuestra la poca confianza que le merecen estos parlamentos. Diez de Medina, en cambio. indirectamente aprovecha para destacar su actuación, su conocimiento de las dous lenguas y sus principios de justicia, caridad y fidelidad al Rey.

(2) En la edición del Diario de Segurola liene el $\mathrm{N}^{\circ} 4$. Allí se mescionan solamente 100 mil indios. 
Dios y lo que es del César al César (1). Al fin salieron los padres y, en especial, fray Joaquin N., el predicador mayor, cuando asomó el caudillo con sus clarines a la casa de campo que el señor oidor Medina posee en el extramuro y extremo de la ciudad (2), y reconviniéndole para que bajara a la amonestación o exhortación para que le esperaba dicho señor Oidor. Respondió insolente y ebrio como estaba, que no quería sino que se le entregasen los corregidores presentes y pasados que estaban en la ciudad, sus tenientes, curas, ayudantes o escusadores suyos, oficiales reales y depen/f.19 dientes suyos de la Aduana, europeos y hacendados, para degollarlos (que en sustancia es comprender a todos), que se les entreguen nuestras armas y cañones, en el convento de San Francisco y se franqueen las frincheras, con otros dislates propios de un bárbaro traidor, apóstata, rebelde, iconoclasta, sacramentario, sacrílego y lleno de otros crimenes que han acreditado los alzados y él, en este caso de sedición (9). Sin embargo, mandó el Comandante, con gran prudencia, que continuase la cesación del fuego, a ver si se convenían a buena razón, porque la calle y cerca de San Francisco, hasta la cuesta, estaba inundada de los agresores. Les mandó con el qoctor don José Mariano Sanjurjo Diez de Merdina a decir que estaba dispuesto a perdonarlos siempre que se subordinen $y$ rindan y que si seguian con la guerra que han roto de mano armada cantra los vasallos del Rey y esta ciudad, estando como estuvo, pacífica, se seguiría con el fuego contra ellos. Es cjerto que salió dos veces con este orden el dicho doctor Sanjurjo, aventurado en su vida, porque ninguno hubo en Ja trinchera de San Francisco que quisiese hacerlo, y habjende cumplido con esta dulce insinuación del Comandante, respondió el indio tuerto, Pedro de tal, to mismo que vino diciendo aquel religioso predicador. Por lo cual se les mandó a los rebeldes despejar ta calle; se les hizo señal para ello, no quisieron, hasta que se les descargó y se les retiró con muerte de cuatro de ellos, de suerte que con los que cayeron después de esto, en otros fuertes o trincheras, fueron 14 los que murieron hoy de los alzados. A eso de las cuatro y más de la tarde, se

(1) Las misivas, decretos y escritos dictados e inspirados por Tupac Catari revelan una cultura muy pobre en el caudillo situindole en este aspecto muy por debajo de cualquiera de los Amartu. La alusión a la frase evangélica de "Dad al César' lo que es del César y a Dios lo que es de Dios" es frecuente en esios decumentos, peso nunca se sabe realmente qué quiere decir con ella.

(3) Por el testamento de don Francisco Taden Diez de Medina, otorgado en La Paz en 1801 , Registro de Escrituras, leg. 183, Archivo La Paz, se sabe que esa casá de campo a que se refiere el Oidor, era una chacarilla, situada en el barrio de Chocata, a la entrada de la cuesta de Potosí, que contaba con casa, bnenta de árboles, horno, amasijo y un tambo pequeño con 13 cuartos y 12 tiendas a la calle.

(3) La curiosa combinación de epítelos con que Diez de Medina condena a Tupac Catari, permite apreciar como ahora ha variauo el concepto que tiene sobre los indios. 
retiraron los indios silenciosos y desordenados para El Alto, por las cuestas de Potosí y de Cuzco y se llevaron un religioso francisco. Barriga, para que les diga misa en dicho Alto, expresando tenían alli para lo mismo al cura de Guaqui, Limachi y a un religioso agustino ${ }^{(1)}$.

Día martes santo, 10 de Abril. Bajaron los enemigos a pelotones y grupos por todos los senderos. A cosa de las ocho de la mañana incendiaron varias casas por los barrios de Sarta Bárbara, cabecera de Carcantia y por San Francisco. Se les sintieron más escopetas que otras veces; las disparaban atrincherados por bujeros y comunicaciones que abrieton por entre las casas quemadas, desde las uiltimas que estaban más inmediatas, frente a las trincheras y ciudad. En el cementerio de San Francisco nos mataron tres indios amigos baleados y a un medio fatuo Cañizares en Ja calle adentro, antes de llegar al puente de San Francisco. Manejaban sus escopetas y disparaban también por dichas troneras. Hirieron a varios de los nuestros y nos arrojaban muchas piedras guarecidos entro de las mismas casas y contra dichas trincheras. Este día se supo que los indios pongos y otrus de las estancias de este vecindario que contribuían al servicio doméstico y los habia mandado retirar fuera de trincheras, el señor Comandante, al cuartel de los indios amigos que está afuera, se habian pasado al Alto, al campo enemigo en más número de 100 individuos y que otros alistados nuestros de los lamados cholos hicieron to mismo y algunos llevándose las lanzas con que, a falta de fusiles, estaban armados. A las 10 del día, vino uno de estos cholos, Antonio Endara, natural de la ciudad, con un papel escrito al oidor don Francisco Tadeo Diez de Medina, con esta firma: "Yo el señor Virrey Tupac Catari" - su fecha de ayer 9 del corriente, en que después de extrañarle que ya retardaba su residencia en la ciudad y remitirse a otro papel antecedente (que no ha recibido), le dice desgreñadamente que su ánimo era a la ciudad, que espera tenga algún fruto para que los reverendos (habla de los de San Francisco) recojan las armas, pues entonces serán amigos pero de lo contrario seremos enemigos acérrimos, hasta la muerte y asi no sea de rigor sino que todo sea de a buenas poque a lo contrario se verán arruinados infaliblemente porque el tiempo me ofrece asi, ya yo estoy pronto a hacer. Este papel lo pasó el dicho Oidor con su sobrino el doctor don José Mariano Sanjurjo, acompañado del mismo portador Endara y una carta que escribió al señor Comandante, ofreciendole en ella hacer en respuesta cuanto se le

(1) La presencia forzada o voluntaria de sacerdores junto a los rebeldes es constante. Sometidos los indios, muchos de ellos volvieron a las ciudades, utros fueron duramente juzgados. -El caso del padre Barriga es muy impresionante; todo hace suponer que subió al Alto por la íntima convicción de no abandonar espiritualnente a los indios. Su sentido apostólico le nereció pocos días después el martirio. 
mande y sea del servicio del Rey, como tan obligado a desempeñarlo, de su parte (1). Le respondió consecutivamente el Comandante, que desde luego le contestase, manifestando a los indios su iniquidad y los piadosos fines con que el Rey dirige sus providencias hacia los indios, y que el Comandante $/ 1.19 \mathrm{v}$. como fiel vasallo, procuraria concurrir a su pacificación y bien. Escribió esta respuesta (que resulta del papel separado) y se la pasó con dicho doctor Sanjurjo, como lo previno, quien la entregó a dicho conductor Endara, dejando copia en los autos de la materia. $Y$ aunque está concebida en términos de hacer ver a los levantados los respetos que debian a Dios y al Rey y sus obligaciones políticas y cristianes y desengañando al caudillo de su falso titulo de virrey, de sus alucinaciones y engaños en que estaba, como de los delitos cometidos de rebción, dudó siempre el señor Oidor que se pueda sacar fruto alguno de aquellos pechos bárbaros, nbstinados, apóstatas de nuestra fe y rebeldes, que sólo a la vista del rigor podrán aplacarse y subordinarse (2).

En varias trincheras murieron este día, algunos indios de balazos y se presume salieron otros heridos. Se retiraron para los altos entre cuatro o cinco de la tarde, quedando muchos emboscados en los aliededores de la ciudad, fuera do los del alto de Santa Bárbara, que tienen hecho su fuerte en el valle inmediato de Potopoto a la otra parte del rio Orcoaviri. (Orcojahuira).

Día miércoles santo, 11 de Abril. Empezaron a bajar los indios desde antes de las seis de la mañana, cual ninguno invadieron con muchas piedras a las trincheras y con fusilazos que tiraban desde las casas quemadas fronteras y más inmediatas. En la de Santa Teresa hirieron con una bala en la cabeza a don Mariano Reyes, escribano de la provincia de Pacajes y teniente de capitán de aquellas milicias, que estaba de guardia. Y como en la de San Francisco continuaban los balazos y lluvia de piedras y estaban acosados los nuestros, resolvieron salir fuera de esta trinchera, por propia determinación de don Simón Núñez, uno de los capitanes de los nidios amigos. Matias Salazar, oficial barbero, un Sánchez de la provincia de Lampa y otros dos más, con sus escopetas y atros mozos de arma blanca, los cuales con los indios amigos lograron cercar las casas del tambo de Las Harinas y las de un Garicano en

(1) Segurola no se refierc para nada a esti cnrta, no la enumera ui la incluye en su documentación. El capitán Ledo, en cambio, anota su llegada. La autora de este estudio encontró ùna copia de lal curta, así como la respuesta que envió el Oidor con autorizáción del Comandante. Sevila AGl. Charcas, 583. El hecho de que el defensor de La Paz no la incluyera en su prolijo inventario ni la mencionara, es una prueba más de su anjmadversión hacia Francisco Tadeo Diez de Medina, de quien prescinde ostensiblemente en su Diario.

(2) Una vez más, Jas contradicciones del Oidor; después de todos sua llamados a la utilización de los medios pacíticos, declara ahora que sólo el rigor podrá aplacar y subordinar a los indios. 
que estaban emboscados los enemigos en crecido número; los fueron castigando con algunas muertes cuidando al mesmo tiempo de que no profugasen mientras de la ciudad salía el auxilio, que pidieron repetidas veces y mandó el señor Comandante después de mucho tiempo, con el cual se hizo una mortandad competente en los cercados y habiéndose tenido 43 de ellos en la casas de altos de dicho Garicano de donde arrojaban por el balcón y las ventanas abajo piedras, adobes y ladrillos; tomaron los nuestros el partido de incendiar la casa, con cuya humareda y llamas fueron saliendo y entregândose cosa de 47 y uno más que se arrojó a la calle por una ventana, fuera de otro de cabriolé encarnado, de peluca y sombrero de tres picos, que dicen se entregó a la voracidad de la llamas y es ano de los que en dicha casa manejaba la boca de fuego contra nosotros (1). De suerte que vinieron a esta plaza 49 prisioneros, fuera de la cabeza que cortaron a un tuerto que, por huir se precipitó al río.

Sin embargo de aquel cerco, no dejaron de huir muchos enemigos que se libraron por la demora del auxilio y tal vez fuesen más a no haber tenido la viveza de subirse a la torre y media naranja de la iglesia (inmediata de San Francisco). El coronel don Manuel Franco, el tenjente coronel don Juan de Higuera y cuatro sujetos más, que con sus fusiles, no sólo contuvieron a la mucha indiada que descendía en socorro de los que así fueron cerrados y hubieran, acaso, catisado mucho daño en los nuestros y quizá líbrado los suyos, sino que los ahuyentaron con la muerte de 14 de ellos fuera de los que irían heridos. Ello es que los nuertos en ambas casas cercadas y una tienda donde se habían cerrado y atrancado algunos, legaron al número de 141 indios que hasta esta noche se contaron con motivo de eclar los cadáveres a un extremo de la ciudad. Con esto se animó mucho nuestra gente que estaba intimidada y todo el pueblo se regocijó con vivas aclamaciones en obsequio de nuestro augusto Monarca, y así mismo con la buena suerte que tuvimos en la parte de San Sebastián, donde los nuestros mataron varios enemigos, como en la trinchera de la Caja del Agua en que murieron treinta y tantos, y 10 en la de Santa Teresa, fuera de heridos en todas partes. Puédese conjeturar prudentemente, que en este día pudieron haber muerto cosa de 300 indios (2), y de éstos /f.20 los más robustos y que se presentaban capitaneando como si fuesen los más valerosos e intrépidos guerreros, inciuyéndose en este número, aquellos 43 que trajeron vivos, los que

(1) En la narración de este combate, en que todos los Diarios coinciden el reconocer el valor "imponderable" con que lucharon los indios, son de gran interés sociológico los datos del Oidor al describir la tenida tan curiosa del indio que luchaba con peluca, cabriolé encarnado y sombrero de tres picos.

(2) Los éxitos militares de aquel día están anotados en todos los Diarios en forma más a menos semejante; tienen gran coincidenciá en el detalle coponímico de los lugares en que se combatió aś como en el número de los muertos. 
parece han de ser 51, inclusive dos aprehendidos en otros puestos. Sin que de los nuestros haiga muerto uno, a Dios gracias, a la reserva de algunos heridos de piedras.

Este día fue glorioso y el primero en que las armas del Rey han acreditado su poder y por eso la celebridad de campanas y alegría de las gentes fueron tan particulares que aún contribuyeron al desmayo y temor de los enemigos que, a las cuatro de la tarde se retiraron escarmentados para los altos de San Pedro, habiéndolo hecho el caudillo Tupac Catari de los primeros y con mucha celeridad, en su caballo tordo, propio de don Félix Diez de Medina, que le perdió en Potopoto en aquella acción mal gobernada del lunes pasado. Pero a media cuesta, por disimular los indios enemigos su derrota, se pusieron a practicar escaramuzas y bailes a caballo y a pie, con mucha algazara; en cuyo intermedio y mientras llegaron al Alto, camino de Potosí, en la mayor parte se divisó que iban ahorcando los enemigos en la misma Ceja, en la horca que habian fijado, tres individuos de los nuestros y aún, se diviso por anteojos, que iban tirándoles de los pies entre mucho concurso y gritería. Se presume sean de los cholos que se nos rebelaron y se fueron al campo enemigo; lo que parece propio del la justicia divina pues este suceso no sólo evita el recelo en quel estábamos, de que muchos de ésta los siguiesen y se trocasen en enemigos, sino que irritados y desengañados de hacerlo, se hallan más animosos que nunca contra los indios enemigos, para la defensa de los derechos del Rey y de la patria.

Todos son efectos admirables de aquel infinito; portentoso Señor Sacramentado, cuya vencrable institución en la cena se celebta en tal día como el de mañana jueves santo, y propios del desagravio de los delitos execrables que estos insolentes sacrilegos han cometido en las iglesias, vulnerando el sagratio y sagrada eucaristía, efundiendo las formas sacramentales por los suelos con la perversa expresión de ser una masa fabricada por el sacristán y lá iniquidad de traer eir el bolsillo, el llamado Tupac Catari, un porta viático que, aplicándolo a su oído y mirándolo siempre que qujere o no hacer o conceder algttna cosa, se deja decir: "Este me dice que no lo ejecute o que lo haga", scgún le da la gana, a este borracho traidor. Presumiénclose por ello, que quizá tiene entro de él, alguna o algunas formas de las preparadas para el viătico. "Incenderunt igni Sanctuarium tuum. In terra polluerunt Tabernaculum nominis tui. Psalmo 73" (1).

Día jueves santo, 12 de Abril. Bajaron los indios dispersamente, desde las seis de la mañana hasta las nueve y más del día, pero por ambas partes, de San Pedro y Santa Bárbara; serían cosa de 1200 . No hicieron invasión y se mantuvieron

(1) La referencia a esta práctica de Tupac Catari concuerda con lo narrado por el padre Borda, an prisionero suyo, en el informe que le solicitara Segurola cuando logró refugiarse en la ciudad después de escapar del Aito. Es un dato interesante para un estudio de la personalidad carismática de Julián Apaza. 
emboscados en las circunferencias y casas quemadas de la ciudad. Los de Santa Bárbara dieron su paseo por toda la línea y serranías del Calvario y se apostaron con algunos de a mula, hacia el alto de Quilliquilli, manteniéndose la tarde sentados en la Ceja, del mismo modo que estuvieron el dia de ayer, viendo la plaza y vivando cuando entraban los indios prisioneros, los que se degollaron en este día y en los extramuros, de orden del Comandante (1),

Se vino del Alto un indiecito llamado Antonio Tapa, de 12 a 13 años de edad, de la estancia de Chúa, quien examinado, dice fue prisionero de los enenigos, que lo aprehendieron en las pertenencias de San Pedro recogiendo habas, y que se pudo escapar esta mañana por entre las piernas de los prisioneros que en El Alto tenían de nuestra parte y los sacaron para ahorcarlos ayer tarde, como sucedió en el número de 30 de ellos, fuera de las mujeres de la ciudad, prisioneras, a quienes mataron a palos y con las cabezas destrozadas. Que después de esta horrible ejecución y que hubieron colgado tres o cuatro en la horca que tienen levantada sobre el mismo camino y ceja a la vista clara de esta / f.20v. ciudad, el muchacho se mantuvo toda la noche oculto hacia unas piedras y que vio se retiraba de huida una manga de indios con motivo del golpe que ayer recibieron, recelando no les toque la mesma suerte. Que con la madrugada y por la misma razón, desertó otra manga de ellos. Que la determinación era ya de retirarse y levantar el sitio en estos días; que ayer se retiraron heridos y cuasi nuertos al Alto, sobre 50 indios, fucra de los muchos que allí había de los mesmos desde ahora días y los que habían también muerto en días pasados en crecido número y, finalmente, que al padre franciscano Barriga a quien compelieron a decir misa en los días anteriores, le ahorcaron últimamente, hoy al salir del sol, sin que bastasen sus ruegos, y que de presente le tienen colgado con otros tres en dicha horca, como lo indican los bultos que así están visibles. Aseguraitdo que el rebelde Tupac Catari estuvo fuera en el campo, cuando este fracaso sacrílego y que lo improbó y llevó muy a mal previruendo sí que mañana se llevase a enterrar el cuerpo dei religioso ahorcado al pueblo de Achocalla, sin que por ello hubiesen acometido a la ciudad. El muchacho es hábil y vivo y se ratifica en este y otros hechos sin variedad. Los indios se retiraron entre tres y cuatro de la tarde para su Alto sin otra novedad que haber bajado y volver a subir.

Día viernes santo, 13 de Abril. Fue quieto; bajaron dispersamente unos pocos indios por habas y rebusco de frutos que han cosechado en nuestras campañas. A

(1) La descripción de la escena de los indios sentados en tas faldas del cerro, dando vivas a los prisioneros que se degollaran en la plnza, demuestra la proximidad en que podían situarse impunemente los atacantes. Asimismo, puede verse que los sitiados degollaban a los prisioneros indigenas del mismo modo que éstos lo hacían con los suyos en El Alto. 
las dos de Ja tarde empezaron a bajar unos 300, hasta media bajada, quitados algunos que descendieron hasta San l'edro. Satieron algunos con fusiles a dicho San Pedro, que se mantuvieron sin empeñarse porque los indios estaban distantes y a media serranía, provocándoles de boca, como lo acostumbran muchas veces, y con algazara se llevaron prisionero un cholo, de nuestra parte.

Volvió el Antonio Endara qui llevó la carta exhortatoria del oidor don Francisco Tadeo Diez de Medina, quien la entregó al caudillo. Dice que convino a primera instancia en los consejos pero, que hablándole al oído su secretario o tinterillo, quien se la leyó, salió prorrumpiendo: "¿cómo he de bajar solamente con tres personas a riesgo de que hagan algo conmigo?". Dejó la cosa suspensa y sin fruto. Que al ver ahorcar, dicho Endara, y matar sobre 100 personas, inclusive las mujeres de las que se fueron rebeladas y prisioneras de la ciudad, tomó la traza de que un muchacho de los cinco que tenía para su servicio el padre franciscano fray Manuel Barriga, de los de la ciudad (que se le habian agregado) le pusiese en una cuartilla de papel un sobre escrito a dicho señor Oidor, con el cual tuvo pretexto de bajar y venirse de los indios a la ciudad, como que días anteriores fue enviado del rebelde. Que lo hizo poco después que ayer, de mañana, liubiesen ahorcado al padre dicho. Que los indios marcharon de unatrugada ayer y el miércoles en la noche por Achocalla en algún múmero considerable. Que el Tupac Catari o Puma Catari (según varía en el liamarse y firmarse) estuvo cuantio la muerte del religioso hacia las pertenencias de la cuesta de Laja, para donde había madrugado, habiéndose enojado de regreso al saber de ella, maltratando con palos y piedras a les indios agresores, que dice fueron los del pueblo de Calamarca a quienes quería castigar y acabar llamúndolos descomulgados, hasta que aonagó retirarse con los dineros y bienes hurtados que mandó cargar y lo hizo hasta cerca de Viacha, de donde las indias con ruegos y lágrimas le obligaron a volver. $Y$, finalmente, que para el domingo de Pascua tenía determinado bajar a la ciudad con los cuatro cañones o pedreros que nos ganaron, de los cuales el uno estaba montado en su curena y los dos persaban mancjartos en el suelo porque sus cureñas estaban descuadernadas, con aplicación de sus hierros para lanzas que iban fabricancto unos herreros que se nos rebelaron de la ciudad. Los mesmos que estaban componiendo los 10 fusiles que tenian los cnemigos y no más, siendo su designio invadirnas por el alto de la Paciencia.

Murieron el dicho escribano Reyes y el Sánchez, éste, de aquellos cinco que voluntarios salieron anteayer al cerco de los indios que mataron y se castigaron, quien fue /f.21 herido de nuestra parte y por equívoco, de una bala que le atravesó los hombros y su muerte es sensible por dejar muchos hijos y mujer. En El Alto se divisaron cuatro altares, los dos medianos, de la embocadura de la cuesta de Potosí para abajo, con sus dos banderas y formados de palos, y otros dos mayores más abajo. Entre 7 u 8 de la noche hubo procesión de Semana Santa con muchas luees, en 
El Alto, la que se repitió a las 11, divisa la ura parte hacia la cuesta de Laja y la otra por el término opuesto, hacia los altos de La Capilla (1).

Día sábado santo, 14 de Abril. No bajaron los indios o no se les vio y si lo hicieron sería uno que otro. Cuando los repiques de la gloria y aleluyas, asomaron en fila y crecido número a la ceja del Alto y luego batieron a la vista de la ciudad tres banderas blancas. Sin que en este dia hubiese novedad sobresaliente ni otra que la del bloqueo en que nos tienen los indios, sitiados no sólo por víveres que no internan a la ciudad ni es permitido solicitarlos en sus fértiles campañas que la circunfieren por haberse dejado apoderarse de ellas enteramente al enemigo y habernos cerrado entro de las trincheras de la ciudad, por un efecto de nuestras culpas (2), sino por la falta de agua y fuentes que no corren, por haber cortado los enemigos, desce el principio del sitio, las cañerías o acueductos de la ciudad y extravasado por el río las aguas abundantes que se disfrutan. Siendo la fortuna el que entro de ella haiga algunos ojos de agua que escasamente nos abastecen y la desgracia nuestra que no se piense ni se trate de despejar a estos enemigos que no han de retirarse de otra suerte, una vez que en sus puestos roban, talan, tienen viveres, alegrias y embriaguez a esmeros del hurto y que son el pábulo aliciente para radicar a estos malvados en cualquiera situación.

Hoy acabaron de degollar 19, último resto de los 57 prisioneros que se liquidaron y cercaron el miércoles santo. Si se hubiera salvado uno de ellos (que nada importaba) y se le hubiera enviado a su caudillo con el desigrio de tratar de paz y con la propuesta de que con tal de su retiro y subordinación se libertaría la vida a dichos prisioneros del miércoles santo y aún se les dejaría en libertad, pudiera que acaso se lograse este fin tan encargado por las leyes, por la caridad y la prudencia y principalmente por la piedad del Rey, o que a lo menos se les diese este ejemplo de humanidad, para que ellos se atemperasen en su fiereza, crueldad y tiranía con los muertos, que se cree no puedan ser más extremos en el corazón del hombre (3). Lo cierto es que el pueblo gime sin que nadie pueda manifestar los ecos de su padecer por el método de los dos sujetos que lo gobiernan, que todo lo saben, lo comprenden, no necesitan (como lo publican) consejos, no los procuran y ni órlos

(1) No puede conocerse la ortodoxia ni el contenido profundo que estas prácticas religiosas pudieron haber tenjido, pero en todo caso revelan la penetración y aceptación de un cristimismo litúrgico y ceremonial.

(2) En las consideraciones del Oidor no se ve que esas culpas estén relacionadas con los procedimientos usados con los indios con anterioridad a la sublevación.

(3) Desgraciadamente estas frases adquieren una nota falsa cuando se las sitúa en el contexto del pensamiento del Ojdor a lo largo del Diario, así como de su conducta en el juicio de los prisioneros al final del levantamiento. 
quieren, cuando quizá a la verdad, son bisoños del país y para la táctica poco expertos en el reino, manejo y tendencia de los indios y sus costumbres; y lo que es más, desdeñan hacer aquellos consejos o juntas de guerra que aún los generales más valerosos, peritos y heroicos no desdeñaron formarlos, como lo dicen las historias (1). ¡Raros ensalmos y raro gobierno! No debiendo omitirse que dejados, como desde el principio, los medios de suavidad y dulzura para la pacificación de estos indios, quedará el Perú exaurido de mucha parte de ellos y sin una porción, la más considerable, de estos vasallos. Quedaría la corona sin tributos y sin otras pensiones, pues al fin, éstos son la mayor parte de las manos contribuyentes y el todo para las labores y minas de oro y plata, que hasta aquí, son los indios los que sacan uno y otro \{i?.

Ellos son, ciertamente, malos, traidores, rebeldes, apóstatas, ateístas, iconoclastas, sacramentarios, incendiarios, ladrones, cuatreros, asesinos, feroces, sacrilegos y profanos, pero no por eso se ha de olvidar el tranquilizarlos y teducirlos a la fe y subordinación ni perder de vista tan importante objeto (3). Esperando solamente la venida (de tiempo indefinido) de los dragones y otras tropas del señor Flores, que envió, mandó y destacó el celo próvido del excelentísimo señor Virrey de Buenos Aires /ff.21v. cuando se sabe que vinieron con las miras de pacificar la provincia dilatada y fragosa de Chayanta, que fue la primera turbada, lo que requiere tiempo, una vez que el 18 de Febrero se sabe no habían arribado todavía a Chuquisaca. De maás, que aún concluída allí la pacificación, se siguen las provincias confinantes de Paria, Oruro y Carangas, que también han menester de tiempo y excluye la idea de que se lisonjeen (hacer 20 días) para que estén al tocar en esta ciudad, que es el motivo porque hoy no se trata más que de aguardarlos y nudamente hacer montar cada 24 horas las guardias en trincheras y paredones,

(1) Las acusaciones eslan dirigidas a Segurola y a Fenando Márquez de la Plata; si bien revelan la justa queja que podía emanar de un viejo conocedor del ambiente y del país, también es cierto que manifiestan el encono del criollo importante que se siente desplazado por unos peninsulares eficientes pero desdeñosos frente a ciertos vecinos de la ciudad. - Existen cartas de Segurola a Vértiz, en que quejándose de Diez de Medina, insiste en que pretende intervenir y aconsejar en todo. AGNA 9/5-5-3.

(2) Quizá sea ésta una de las pocas veces en que un funcionario reconoce con tanta precisión la importancia vital que para el sistema colonial tenía el indio, que era quien tributaba y quien trabajaba. Lo normal era señalar los beneficios que el sativo recibía de la presencia española y no los que el monerca recibía del indio.

(3) Este es en el fondo el verdadero juicio que al Oidor le merecen los indjos. De allí que, dentro de un sistema paternalista, se los deba tranquilizar, reducir a la fe y subordinar, para no perderlos como útiles vasallos. 
desconfiando enteramente de otra acción para contener los enemigos con el escarmiento que necesitan desde luego (i). Bien que la tropa tampoco se disciplina, no está aguerrida y consiguientemente, sin uso, expedición ni cjercicio y sin armas de fuego, con las cuales se ve desempenarse a otros muy bien; pero ya hay penturia de ellas. Dispóngaseles el ánimo e instrúyaseles en lo posible o permitido para que siquiera aprendan el denuedo y sepan presentarse al enemigo a firme rostro, que es lo único que se necesita para triunfar de el. Porque la experiencia nos enseña que, arrostrados, no subsisten en batalla sino que huyen aún a la vista de fuerzas muy inferiores (2).

Día domingo de Pascua, 15 de Abril. Este día bajaron unos 300 a 400 indios y volvieron a subir al Alto al cabo de una hora y media. Después de haber sacado de la iglesia y parroquia de San Pedro no se sabe qué homenajes. Nos mataron cinco de los nuestros de la gente pobre que había salido a la campana en rebusco de víveres. Por la tarde salió el Comandante con algunos granaderos y oficiales y trajeron unos palos y la campana mayor de dicha iglesia de San l'edro y otra de la de Santa Bárbara $(3)$, donde es comín asaltaron cosa de veinte $y$ tantos, de los cuales murieron dos, y se retiró luego. Se está entendiendo por el teniente coronel Juan Bautista Zavala, ejemplar y celoso vasallo, en la fábrica de una fortaleza hacia la línea o pertenencias del cerro del Calvario por donde amagan a acometer a la ciudad los enemigos, y se sabe que lo tienen proyectado.

Día Junes de Pascua, 16 de Abril. Empezaron a bajar los indios por todos los senderos y cuestas como otras veces, desde las 7 de la mainana hasta más de las 9 de elia. Algunos 19 de a mula volvieron a subir al Atto después de haberlos convoyado a las circunferencias de la ciudad donde se mantuvieron emboscados. De parte a parte hubo algunos fusilazos y los más de los nuestros se dirigían de las trincheras. Según estimación común, bajaron cosa de tres mil individuos o poco más. Y se verifico la noticia que anoche trajo un indio nuestro, Esteban de tal, a quien habian hecho prisionero los enemigos, que desde hoy, volvían a invadimos y comenzar

(1) Criticando los métodos de Segurola, deja de manifiesto sus contradicciones; acaba de señular la conveniencia de atraerios por medios pacíficos y. sin embargo, ahora pide un escarmiento.

(2) Esta aseveración del Oidor está en completa discordancia con la opinión que sobre la actitud de Jos indfgenas en batalia encontramos no sólo en ocras páginas de su Díario, sino en la opinión general de todos los que dirigieron las guerras o participaron en ellas.

(3) A traves de la lectura de ios otros Diarios, se sabe que tos rebeldes estaban despojando a las tres parroquias de extramutos de los ornamentos, vasos sagrados e inígenes para conducirlos a los santuarios que improvisaban en El AJto. Con esta acción del Comandante se tratabu de salvar lo poco que quedaba en ellas. 
con la batalla grande, que piensan seguir éste y los días siguientes de la semana actual, con el designio de internar a la ciudad minándola con las barretas que tienen preparadas. Cosa difícil porque atisban solamente de lejos, metidos entre paredes sin ponerse a tiro de fusil. Lo cicrto es que no dieron mayor cuidado (como se tenga vigilancia), a no temerse y estar en casa las resultas del bloqueo por las hambres y necesidades que ya estrechan y obligan a oir tantos lamentos de los pobres y nuchos que no lo parecen y se están arrojados por las calles, iglesias, conventos y cementerios, tanto que se empieza a tropezar en los cadáveres arrojados por la ciudad (1).

Dia martes de Pascua 17 de Abril y miércoles 18. Bajaron los indios, no en corto número, desde las 8 de la mañana. Nos tomaron cuatro individuos de los nuestros ( $y$ ayer cinco), que los dejan salir por viveres y por forraje al campo, con el riesgo que dice la experiencia, sin tomarse en esto formal remedio. En el Alto de Potosi, en una horca pequeña, distinta de la grande que está en la embocadura de la cuesta, se divisaron pendientes tres o cuatro individuos que, se discurre, sean de los nuestros, que nos aprisionaron hoy. Murieron hoy, de hambre y necesidad, dos personas en la calle de San Agustin y el uno / f.22 fue auxiliacio del licenciado don Gavino García Lanza. Es cierto que ya se sienten el rigor y calamidades del cerco, siendo el mayor Jamento que en cinco semanas que hoy se cumplen, sólo sigamos con la deliberación de guardar trincheras y paredones, cerrados, sin víveres, dejando crecer cada día más y más la insolencia de los indios y sus crímenes de rebelión y los gastos que diariamente se aumentan, en sueldo y prest de la gente acuartelada a expensas de la Real Hacienda, y pudieran ya evitarse, una vez que no basta para la experiencia aquel remedio y que es forzoso despejarlos y no dejar de mano el punto esencial de actuar y disciplinar la gente para su mayor y posible acierto (2).

Como el día de ayer reparó, por rara ćasualidad, el riesgo proximo de que tos indios puedan entrar a la ciudad, principalmente por las casas que están al extremo

(1) Con esta referencia puede apreciarse que, aún cunndo sólo ha transcurtido un mes del sitio ya se ve a la gente de la ciudad debilitada, ociosa y aburtida. Asimismo, ya se encuentran cadaveres arrojados en las calles como consecuencia del hambre y la miseria.

(2) El Oidor, en sus impaciencias, olvida los juicios que ha emitido sobte la calidad de las tropas y acusa nuevamente al Counandante que por su inoperancia mantiene a los vecinos dentro de las murallas en vez de salir a combatir fuera de las fortalezas. Posiblemente, y como lo anota en alguna parte del Diatio, él hubiera querido que 8egurolin, como Oreilana, el corregidor de Puno, también sitiado por los indios, saliera fuera de los muros pars atacar a los indios en sus propias posiciones vecinas a la ciudad o incluso para liberar a uno que otro pueblo cercano. Olvida, sin embargo, gue el cerco de aquella ciudad no era permanente como el de La Paz, asi como tambièn la lopografía de la villa de Puno, que está situada en una zona plana junto al lago 'Titicaca. 
por arriba de la plaza mayor, el oidor don Francisco Tadeo Diez de Medina, asociado de dos canónigos de este coro, por el bajo y ridículo tamaño de las paredes de una casa, fáciles del acceso enemigo y sin fuerza alguna, repitió hoy dia 19 para enterarse mejor de aquel puesto (que hasta aquí no se había remediado) y previno al doctor don José Mariano Sanjurjo, su sobrino, que a su costa se levantase allí un fuerte, dando un corte fuera de dichas casas y calce de sus paredes, de modo que quedasen en elevación, según la situación del terreno y que consecutivamente se levantasen las paredes que sirven de muralla, y por la parte interior se terraplanasen, poniéndose escalas para que los nuestros puedan hacer la costa a la defensa, caso de acometer el enemigo por esta parte (1).

En el día de ayer 18, bajaron los indios con dos pedreros corrientes, montados en sus cureñas, de los cuatro que nos ganaron ruborosamente en Potopoto, el día 26 de Marzo y Ios situaron en la montaña que hacia el llamado Calvario donina la ciudad. Los dos primeros cañonazos empezaron sucesivamente cerca de la una de la tarde, cuyos puntos fueron muy altos, pues se recibió una bala de bronce, cuasi de cuatro onzas de peso, en uno de los corredores de la casa de dicho Oidor, que arrojó el segundo cañonazo. Después han ido bajando los puntos y, como batieron la trinchera de la Caja đel Agua, ya se sintió que llegaban las balas últimas sobre el tejado de una casa inmediata de don Teodoro de Vera y Arag ‘n, donde cayó una de cinco onzas de bronce, que mandó recoger y la manifestó el valeroso capitán de guardia de ella, regidor don Juan Calderón (2), quien a los tiltimos de la tarde franqué la puerta para que hubiesen salido algunos oficiales voluntarios a rebatir ai enemigo y procurar la restauración de los dos canones, inclusive unos 18 granaderos. Se hizo tarde y no hubo la mejor disposición para ello y, asi hecha la correría, se retiraron a la ciuciad, habiendo muerto tres de caballería de los contrarios, fuera de otros que mataron hacia la trinchera de la Paciencia, con más un indio de a pie. Los tiros de los fusiles enemigos, en el día de hoy 18 , (emboscados entre las paredes de las casas quemadas que les sirven de trincheras) fueron muchos, cual ningún dia, bien que, Dios mediante, sin desgracia en los nuestros. Se retiraron los adversos a las cinco y más de la tarde. El teniente coronel Zavala sigue con la obra del fuerte hacia la línea del Calvario, con la actividad que acostumbra.

Día dicho, 18 de Abril. Bajaron: los enemigos por las cuestas de Potosí y Colpani, en mayor número que ayer, según opiniones, a las 9 del día. Empezaron a cosa de las 11, con los tiros de sns fusiles, que fueron pocos. Dispararon dos de los

(1) Si estos datos son cierlos, como parece, no puede dudarse del evictente descuido por parte del Comandante y de los mandos militares en lo que se refiere a la defensa, que es a lo que se reduce por entonoes la acción bélica.

(2) La noticia concreta de las balas de bronce que caen en casas perfectamente idenlificadas da a la narración de estos hechos un gran realismo. 
pedreros que nos ganaron, desde la cima y alto de Quilliquilli que domina y descubre a esta plaza mayor y calles de la ciudad, a cosa de las 11 del día y, con seis u ocho cañonazos, cesaron en el resto del dia, sin que hoy hubiese más desgracia que habernos sorprendido y muerto, los enemigos emboscados en las quebradas y serranías del cerro del Calvario, a uл mozo nuestro, que en pos de viveres se había avanzado mucho para arriba.

Don Guillerno Dorado, que es de arrestos y animoso, con un piquete de voluntarios, logró dertibar hacia San Sebastián un enemigo de a caballo que derribó con un tiro de fusil y luego le tomó la bestia, que era buena, y puso en huída a varios de ios enemigos. Se ha sentado que /f.22v. un Pestaña salió ayer por Santa Bárbara con su escopeta y que hallando a unos enemigos durmiendo, los sorprenclió y puso en fuga luego que les disparó el fusil y que dejaron una o dos escopetas, que recogió con un sable, un cabriolé de grana y un sombrero fino de castor.

Se empezó en este día, por el doctor Sanjurjo, con la fábrica de la trinchera en aquel peligroso puesto tan expuesto, que en el día de ayer se refirió y sigue otra trinchera que en la misma línea del Calvario mandó el gobierno fabricar al capitán don Roque de Manzaneda, vecino de juicio y muy hombre de bien. Con cuyas obras puede quedar con alguma moral seguridad toda aquella carrera del Calvario, donde las casas incendiadas son muchas y causan compasión como todas las circunferencias de li cjudad. Siendo lo más lamentable, que las gentes pobres se hallen durniendo y albergadas en las iglesias. sacristías, conventos, cementerios, calles, patios de las casas, entre trincheras, sus zaguanes y otros lugares poco comunes [1. Y si el día de ayer cuando se avisó al comandante que los indios enemigos conducían bajando los cañones por el barrio (quemado) de San Sebastián, no se desestima el aviso, pudieran haberse restaurado a poca diligencia (2).

Día jueves 19 de Abril. Nos saludaron los indios enemigos con dos cañonazos consecutivos de pedreros desde el alto de San Pedro, a cosa de las 6 de la mañana; repitieron a la hora uno o dos más y a cosa de las 8 de ella dispararon otros dos pedreros hacia el Tejar, donde se aseguró existir a las 9 del día, hora en que se vieron entrar pocos indios del Alto, cual ningín otro, o porque muchos madrugarian o se quedaron emboscados en los extramuros o porque de positivo el número de ellos está de presente diminuto y en bella proporción de derrotarlos si se quisiera,

(1) Cunnto se piensa en la ciudad sitiada, no siempre se capta la situacion tan dura por la que atravesaban los que teniendo sus casas fuera de las muraitas debieron abandonarias con todos sus enseres para refugiarse en los patios y zaguanes de las casas y conventos, en las iglesias y sacristías, en los cementerios y trincheras. Esta referencia permite tener una vivencia clara de lo que ocurín con más de la mitad de los pobladores.

(2) Nuevo desacierto de Segurola a los ojos del Oidor. 
para después sojuzgarlos y subordinar a los que queden, porque como el indio es por su genio bullicioso y aparente en sus acciones, no es capaz. de encubrir su muchedumbre y fuerzas, que antes procura ostentar al presentarse disperso por máxima, para que parezca mayor su número. Tampoco es creible que hoy mantenga la mayor parte de su gente emboscada pues, cuando la multitud de los días pasados, sabía muy bien acreditarla. $Y$ más cuando se sabe se han retirado los más a cosechar sus sementeras y que el tiempo actual es de hacerio.

Acometieron desde medio día a la fábrica del fuerte de Zavala y los otros dos que se construían en la tinea del Calvario; se les fue conteniendo hasta que tocada la campana, a las tres de la tarde y media, acudieron con fusiles a los tres puestos y se hizo una salida, principalmente a la campaña de Cusipata y Caja del Agua, donde se dice acudieron dos mil indios poco menos, de ambos altos de San Pedro y Santa Bárbara. Se trabó refriega y se computan 60 muertos de lus enemigos fuera de los que, heridos, se retiraron, con los que se reputan ciento. Se retiraron al fin de la tarde, mucho después del sol puesto. De nuestra parte hubo la muerte de don N. Saldaña, natural de Trujillo y ayudante de las gentes venidas de Larecaja, que, por demasiado ardor indiscreto, se arrojó fuera de trincheras, con algunos pocos compañeros (que le dejaron), con sólo un sable, y aunque mató e hirió a dos enemigos, le rodearon y sacrificaron, cortándole la cabeza, manos, piemas, genitales y corazón, que se llevaron consigo con mucha algazara y sus bailes que en rueda acostumbran.

A Jas siete y tres cuartos de la noche empezaron a batir la ciudad y su plaza mayor con dichos pedreros y balas rasas de cobre, de cuatro onzas de calibre (de las campanas que se llevaron de San Sebastián y Santa Bárbara, según se estima) y también con algunas piedras que se han tomado. Hasta las 11 y más de la noche, dispararon 13 cañonazos y continuos fusilazos, por las fortalezas y consecutivamente en el resto de la noche hasta cerca de las $B$ de la mañana siguiente. Ejecutaban a pausas unos y otros tiros y con mucha gritería, toda la noche, sin que hayan causado daño, porque levantaban los puntos bien alto, de modo que las balas pasabar por cima de las casas y aún de las bóvedas de la iglesia catedral.

Dia viernes, 20 de Abril. Se retiraron los indios que habian pernoctado dispa / $f .23$ rando la noche anterior con los pedreros y fusiles disparados para el alto de San Pedro, a cosa de las siete y media de la mañana. A cosa de las 8 dispararon uno y luego siguieron los cañonazos seguidos hasta más de la 1 del la tarde; en ella dispararon uno u otro y por la noche no los hubo hasta las 11 de la noche y más, en que se oyeron dos de ellos, pero sin desgracias por las punterías altas que parece permite la divina misericordia. Los tiros de fusiles no fueron tan repetidos como el día de ayer, ni de tanto número. Se tiraron algunos indios a las 3 de la tarde a su campo por la señal que acostumbran de fogata y humareda para convocarse. La noche fue en lo restante quieta. Hoy se manifestó una cabeza colgada de la horca que tienen. El día de ayer se vieron tres en la mesma forma. 
Día sábado, 21 de Abril. Se retiraron por la mar̉ana, para su campo, algunos pocos indios que habian quedado emboscados para la corta gritería y bullicio de cornetas, a ratos, de la noche pasada. A las vcho y tres cuartos de la mañana empezaron a batir la ciudad con los dos pedreros y una eficacia y continuación sucesiva y en todo lo más del día desde las 10 de la mañana siguieron con los mesmos cañonazos desde el alto de Quilliquilli, pausados y sin causar daños por la elevación de sus tiros, hasta cosa de las 3 de la tarde en que se retiraron para los altos con mucha grita, habiéndose reparado que en el alto dicho, de Quilliquilli, donde se vio asomaron varios de a mula con el fin de retirar los enemigos allí apostados, éstos los celebraton con muchas voces de aclamación y homenaje, revolcándose por el suelo y echando sus monteras en eI aire, en señal de regocijo de que se les hubiese presentado sir duda alguna el caudillo, en semejante puesto. Quedaron en el resto de la tarde y la noche solamente los centinelas que acostumbran, sin novedad y en silencio, aunque por la noche se oían las cornetas por algunos ratos, en las circunferencias quemadas de la ciudad.

Día domingo 22. Fue tranquilo, no bajaron los contrarios. A la 11 condujeron varios de a mula, cosa de 30 mulas sueltas que transitaron por el alto de Quilliquilli y se terminaron por cl arribaje que acostumbran hacer por la cima y ceja de las serranías que circundan la ciudad, hasta que bajando al río tomaron la cuesta de Potosi para el Alto. Por la tarde salieron varios de los nuestros a Santa Bärbara y provocaron a los centinelas que estaban en los cerros. Hubo uno que otro fusilazo de ambas partes, sin acción considerable y se retiraron. Por la noche a cosa de las 7 resonaron dos clarines con rattcha grita de indios en el alto de Quilliquilli y luego cesó, acaso por la destemplanza y llovizna que había. Se oían sí, algunas cometas en los extremos de la ciudad pero en realidad la noche siguió en sosiego. Y a eso de las 11 de ella hay persona eclesiástica que dice oyó el bando que publicaron a son de cajas, clarines y violines, sin haber comprendido más que esta voz: los haremos cecinas (que es la carne seca y salada).

Dí lunes 23 de Abril. A las 7 y más de la mañana, descendieron los indios por la cuesta de Potosí hasta cosa de un mil de ellos y dispersamente con mucha grita, cajas, clarines y las banderas diferentes que siempre portean y acostumbran. Desde poco antes de las 10 del día, los cañonazos de los pedreros, sttuados en el cerro de Quilliquilli, fueron continuos hasta cerca de las 3 de la tarde, en que empezaron a retirarse para El Alto sin más desgracia que haber una bala quebrado el pie de una india, al pasar por la plaza mayor.

Bajó el rebelde Catari por hacia los altos de San Pedro, a caballo enjaezado y de cabriolé encarnado y unieren decir algunos que con el sombrero llamaba a los nuestros, como si fuese a salir fuera de trincheras y lidiar en batalla, que es desafio. En el alto del Calvario estuvo, al parecer, Bonifacio, alias Malifacio Chuquirramani, de cabriolé encarnado con bastón y quitasol verde, haciendo señales alusivas ał 
mesmo caso de desafio, y tomando tierra del suelo y sacudiéndola en polvo con las manos, como que daba a entender, convertiría en él, la ciudad.

Este día se tomó un indio semi vivo, de un balazo, de la estancia de Apaña de las carmelitas, que murió a poco rato sin declarar cosa mayor. Se hizo experimento por la ventana del campo santo a espalda de la iglesia catedral, que domina en un alto y tiene vista en derechura a la cuesta de Potosi, de una media culebrina que se acabó de fundir y salió defectuosa o con el cañón dirninuto. $Y$ al /f.23v. primero, es corriente que derribó tres enemigos que iban subiendo a pelotones, los que con este golpe se dispersaron y se retiraron con toda celeridad. Es opinión corriente que en este día murieron cosa de 20 de ellos, en distintas trincheras.

Día martes 24 de Abril. Por la avería que ayer tuvieron los enemigos con dicha media culebrina o cuasj mortero, bajaron a las 8 de la mañana dispersos y no por la acostumbrada cuesta de Potosi, por donde lo hacian los más, por lo regular, y tocaron en la ciudad por hacia la parte que llaman del Tejar. Dispararon dos cañonazos con los pedreros a tiempo que estaban a salir al patibulo o suplicio a que fueron condenados Enrique Escobar y otro mestizo Patón de laaja (causados de traidores por la inteligencia que se dice, con los indios), pero silı daño. En la trinchera de San Juan de Dios nos mataron un oficial de artillería de un tiro de fusil. El ruido fue este día ninguno y algunos se lisonjean de que los indios van descaeciendo de su altivez e insolencia, cuando el remedio parcial de acudir a la custodia de trincheras y mudar guardias se duda que pueda bastar a desvelar y despejar los enemigos. Que la hambre apura cada día más y más y que ni ha habido en los 42 días de sitio, ni hay otro recurso que el de la salida al Alto para desbaratarlos y echarlos y que si no nos viene algún auxilio de fuera y siguen los enemigos sitiándonos, al fin será forzoso actuarlo, para buscar al menos víveres, ya que no por lo primero de sostener los derechos de la religión católica y del Rey (1). Este objeto importantisimo se ve por las obras postergado y a la real Corona vuinerada, dejando prevalecer al rebeIde en los dominios de su Majestad, talando haciendas, usurpando y deprimiendo los vasallos, reales tributos y demás impuestos de ella, que corren entorpecidos con los demás delitos sobre delitos execrables de rebelión que cada día se incrementan. Sin que baste a moverlos el ejemplar del

(1) Una vez más la idea de que debe salirse hasta El Alto a acacar a los indios. No dice, sin embargo, el Oidor, a cuál de los frentes del Alto habría que atncar, ni tampoco qué medidas deberian tomarse en la ciudad para defenderla de los sublevados que ocuparan los sectores no atacados, que lógicamente bajarín sobre la ciudad en cuanto vieran salir de las murallas al Comandante con las tropas. 
caballero Orellana, corregidor interino de Puno y paisano solamente (1), que con menos armas que esta ciudad, menos fuerzas y sin tener la gente que hay en ésta, de lustre y honor y con sólo aquellos pobres, aquí y en dicha villa, llamados cholos (que hoy se detestan por cobardes, cuando no se les disciplina) (2), ha logrado muy buenas ventajas sobre los indios levantados, aseclas del maldito Tupac Amaru, y ha merecido derrotarlos en distintas campañas, no siendo aquellos superiores en el numero a esto ru concurriendo en dicho corregidor la militar pericia que reside en nuestro comandante. Parece que el cielo por nuestras culpas niega el concurso para no haber obtenido otra satisfacción que la casual del miércoles santo y que no se trate hasta aquí de los medios que nos puedan llevar al término feliz de quietud y servicio al Rey y de entablar la subordinación tan encargada.

Por parte de tarde fueron degollados $10 \mathrm{u} 11$ indios, unos, según corre de los amigos, porque hondearon a los enemigos con hondas vacías o en amago y, otros, de los mismos, por causa de comunicación con los levantados (3). Hacia la revuelta del cerro de Quilliquilli, tuvieron esta tarde la celebridad de toros, con dos clarines y mucha grita. En dicho alto, descuartizaron un cholo, que corre fue de los nuestros, desertores. Le cortaron las manos, cabeza y pies y echaron el cuerpo montaña abajo a nuestra vista (i).

Concluyóse la tarde sin novedad ni otro bullicio y así mismo siguió la noche, pero a las doce y cuarto de ella, dispararon los enemigos un cañonazo y a la 1 de la maniana otro, que fue señal de acometer a la ciudad atrincherada pues ya se mantenían emboscados como lo estilan entre las paredes de las casas incendiadas fuera de trincheras (5). La algazara de voces, provocaciones, insolencias y atrevimiento son imponderables en medio de diferentes cornetas y tambores. La

11) Al señalar que Orellana es paisan, quiere demosurar la bravura de un criollo que se improvisa como militar, frente a la excesiva prudencia del peninsular que en este caso es un militar de profesión.

(2) El autor del Diario deja bien en claro la presencia de este tercer estanento social, tnenospreciado por criollos y peninsulares.

(3) Segurola tenía razón en desconfiat de estos indios que, encontrándose en una situación tan incómoda, frecuentemente traicionaban a los españoles para ayudar a los suyos.

(4) Lá situación de los mestizos era especialmente critica, puesto que se desconfraba de ellos en ambos campos. Los españoles temían sus truiciones y deserciones, y los indios, a su vez, no les acogían calurosamente, como se ve a través de las palabras del Oidor, cuando se decidían a abandonar Ja ciudad.

(5) El recurso de utilizar estas casas como trincheras frente a trinchcras, como, asimismo, el de refugjarse en ellas en la nochc, evitando el subir y bajar las cuestas, fue una medida inteligente y práctica por parte de los atacantes. 
noche no fue tenebrosa, pero tampoco dejaba percibir a los enemigos, sino que por la grita y pedrea se regían los tiros de nuestros fusiles, fortalezas y espaldones, que no fueron pocos. Ellos siguieron con ferocidad y tesón nunca vistos; jugaban ellos las hondas sin objeto y vagamente. Salieron uno $u$ otro lastimados de nuestra parte, pero sin peligro. De la de los indios se presume racionalmente que murieron y salieron muchos heridos, porque hacia el río, bajo del puente de Santa Teresa, por los altos de San Francisco y Recogidas, se vieron varios lagos o parajes regados de sangre. Quieren decir que / f.24 en una casa de San Sebastián se hallaron cosa de 36 enemigos muertos, fuera de los que acostumbran llevar y llevarian consigo por otros bartios y salidas al Alto y los heridos, que aún corre condujeron a mula y a caballo por eso de las Recogidas. Es cierto que la ciudad estuvo rodeada de esta invasión por todas partes, pero también lo es que estuvo bien reforzada de guamición y armas en los 28 puestos que tiene de custodia en sus circunferencias, mediante las oportunas providencias de nuestro Comandante. En esta parte se retiraron a las cinco y media de la mañana y en los pelotones que ascendían por la cuesta de Potosi parece hizo alguna operación el dicho cuasi mortero, por uno de los tres tiros disparados (aunque no de mayor consideración) desde el campo santo dicho de esta iglesia. Antes de todo a prima noche se vieron las candeladas de los enemigos en la ceja de los cerros y rededor de la ciudad, en señal de convocatoria. Y en este día, se vieron en la horca del alto de l'otosi, dos individuos y una cabeza al medio, pendientes de ella. La cabeza se presume ser del que ayer descuartizaron de nuestros desertores.

Miércoles 25 dicho. Fue tranquilo (1). A la 1 de la mañana nos dispararon un pedreto del alto de Quilliquilti; a las 2, otros dos tiros pausados y consecutivamente se levantaron la grita y algazara de los indios con todos aquellos improperios, injurias, desvergüenzas y osadía contra los españoles (que llaman káras), que antes de esta sedición ni se vieron ni oyeron. Pues, aquel silencio hipócrita, modestia y rendimiento aparentes con que el indio se manifestaba en presencia del español, se ven trocados en aversión y rencor implacables, y en la insolencia y descaro que cada dia se ven en crecimiento.

La pedrea en esta noche (igual a la pasada en lo menos tenebrosa) fue escasa y sin aquel fervor que la pasada, con tibieza conocida de los enemigos aún en el vocear y menos número de individuos, que acreditaban los mismos ecos. Lo más fue provocarnos e insultarnos de palabra. Los muchachos les contestaron de nuestra

(1) Posiblemente el Oidor confundió el dia en que se produjeron los ataques más serios, porque mientras él señala que el día 25 fue tranquilo, tọdos los otros Diarios se refieren a terribles ataques en la noche, de los que resutan 300 indios muertos; en cambio, el día 24, de tantos avatares según Diez de Medina, está calificado por los otros autores como un día en que no ocurrio nada grave. 
parte y muchos, con gracioso chiste y asi se les fue en contestamos en algunas trincheras. Se fueron retirando antes de rayar la aurora, temerosos del cañón o mortero nuestro y, un cuarto de hora antes de hacerlo, dejaron el manejo de las hondas y piedras por hacia los altos de San Pedro, Recogidas y San Francisco y se mantuvieron vertiendo muchas crasedacies, amenazas y desvergüenzas contra los españoles, sus nujeres y aún contra las monjas de los monasterios. Dícese que moririan tres enemigos y que hubo una corta efusión de sangre cerca de la trinchera de Santa Bárbara. Y en este día se vieron en la horca del Alto los mismo tres objetos que ayer nos manifestaron colgados. A la aurora, las compañías y gentes que estuvieron en la plaza cantaron tres avemerías y el alabado y luego aclamaron festivamente ;viva el Rey! Lo que se hizo también la mañana pasada en la misma plaza mayor y trinchera de San Francisco, como que fue la más acometida.

Jueves 26 de Abril. Fue quieta on todo el día y la noche entera, a la reserva de una u otra corneta que se oyó a eso de las 7 de ella, y unas candeladas en los altos de San Pedro y casas allí inmediatas; que serían para cocinar los enemigos.

Viemes 27 de Abril. No hubo novedad ni parecieron los enemigos, a excepción de los centinelas que tienen en diversos puestos. A las once y tres cuartos del día asomó por la trinchera de San Sebastián un indio que, introducido, dijo ser de Charasani, provincia de Larecaja, enviado con carta para el Comandante por don Diego Oblitas, citumlo, y haciendo el mensaje que se refirió de que venía el dicho Oblitas con tropas auxiliares, en servicio del Rey y surtidas de españoles, buenas armas y dos mil indios de dicho Charasani, fuera de otros. La ciudad se conmovió y regocijó no poco pues las gentes por las calles expltcaban incautamente los júbilos de alegría que sentían en su corazón, para alivio de nnisstra calamidad y remedio del hambre que desde la semana anterior obliga a los menesterosos a coner las carnes de mulas.

Luego que fue conducide a presencia del señor Comandante con la carta que le entregó, concebida en términos de darle aviso de dicho auxilio (1), concluyendo no du /f.24v. dase de él, mandó tocar al arma por medio de la campana mayor acostumbrada y de los tambores para salir con las tropas de la ciudad a combinarse con el auxilio anunciado, como que éste era el designio expresamente solicitado por dicha carta, para que así no pudiesen perecer los auxiliares en manos del enemigo. El indio vería con una montera guarnecida de un filete de galón o trencilla y en un ropaje decente que no acostumbran los de Charasani, en su pergenio, por lo general raído y mísero. No se sabe si se notó esta circunstancia y luego que al principio dijo llamarse Juan Cruz y que a poco después varió a las repreguntas, expresando

(1) Segurola consigna esta carta con el $N^{n} 6$. 
llamarse Antonio Manani, dio sólo entonces materia para recelar de él y su mensaje. Se notó que la carta era fecha del día, cuando él aseguraba haber salido ayer con la carta, que la fecha era de una estancia que decia estar innediata al pueblo de Laja, de un nombre ignoto, como que sobre la marcha le desconoció el corregidor de la provincia de Omasuyos (a quien toca dicho pueblo), don Jose Joaquín Tristán y Muzquis. Con esto lo llevó consigo el Comandante a su casa para mejor examinarlo y poner en claro la verdad con el cotejo de la firma del dicho Oblitas. Interín quedaron las tropas prontas en nuestra plaza mayor. Parece que pudo conjeturarse ser el indio del pueblo de. Sicasica o sus inmediaciones; se llamaron algunos individuos de aquel territorio, destinados y presentados por su corregidor, don Ramón Anchoris; uno de ellos, don Simón Núniez, natural de Lima y minero junto a Sicasica, entró y luego que vio a dicho indio portador, le conoció y llamó por su nombre, diciéndole: Zúniga ¿qué hay? El indio se cortó y respondió que así se llamaba. Y luego dijo el primero, era un peón de su ingenio, que conocía mucho y que aún le debía unos pesos por su libro. Confesólo el indio y pidió no lo mataran pues él confesaría la verdad de lo que habia, como lo hizo, aseverando de plano ser emisario del llamado Tupac Catari, enviado del Alto con dicha carta [i]. Es regular que de su confesión resulte la trazá que ya se dirà.

A cosa de la 1 de la tarde se sintió y aún se divisó en el alto inmediato a la cuesta de Laja mucha algazara de los indios enemigos, con varios y repetidos fusilazos; sus pedreros los disparaban a menudo con diferentes cornerías y grita y mutaciones del terreno como si estuviesen en grande refriega y combate con los pretendidos españoles e indios del auxilio supuesto. A las dos y media de la tarde se divisaron que bajaban derrotados, a mula, los dichos españoles fingidos (que no eran otros que los mismos indios alzados en ropaje de españoles y militares y aquellos que tienen cabaliería y son los capataces). Bajaban sin formación por la cuesta. Primeramente descendjeron cinco de elios, seguian cosa de ocho, luego unos siete y asi bajarían hasta $60 \circ 70$ de a mula. Los indios de a pie, enemigos, amagaban a invadirlos y ofenderlos. Los seguían dispersados, con hondas y galgas de piedra que arrojaban oblicuamente desde lo alto (bien que con tiento para no ofenderlos a la verdad), y bajaban por toda la montana sin sendero, como si los acosasen. Se reparó que hacia el puesto llamado el Tejar los cinco primeros de a caballo se incorporaron y que con sable en mano avanzaban a los enemigos hacia la parte superior de ellos y que los rechazaban. Que lo mismo fueron ejecutando más empeñados según iban congregándose los de caballería, y reunidos éstos, sustentaron sobre hora y media un

(1) Cuando el Oidor abandona el tono grave $y$ grandilocuente y refiere las cosas con espontaneidad, logra que los episodios narrados adquieran de inmediato mayor calor y los personajes cobren vida real. Parecería que el lector está presenciando la escena que rodea a la jodentificación de Zúñiga. 
combate aparente o simulado, en aquel puesto inmediato al Tejar. No sólo se oian los tiros de fusiles contra los enemigos sino que se reparaban dos cosas que ponian al manifiesto el engaño. La una, que por lo regular sólo ponían la seba en las bocas de fuego, sin cargarlas y asi daban un fogonazo nudamente, sin estallido. La otra, que cuando cargaban y disparaban, simulaban los enemigos caerse mtiertos. Los de la retaguardia avanzaban por delante y aquellos a su espalda se levantaban del suelo. Estando así combatiendo, se advirtió que repentinamente, se destacó uno de a caballo, de los de su cuerpo y que bajaba a toda carrera por la cuesta a tomar la ciudad, como que venia perdido en solicitud / f.25 de implorar auxilio de ella para Ios sitios que al parecer se mandfestaban en apuros. Y en efecto, ello es que se presentó uno de uniforme azul y vuelta encarnada a caballo enjaezado (y éste es aquel huerto, cabeza de la sedición, que se intitulaba sobrino del rebelde Tupac Amaru con el nombre de Pedro Sánchez) (1), a la puerta de la trinchera de San Sebastián y que, introducido a larciudad, fue conducido por el Comandante mismo a su casa, donde le tiene.

Acerca del modo de presentarse en la trinchera este tuerlo, hay tres opirtiones: una es que los mozos de brio y un eclesiástico, don Mauricio Illanes, que se habian salido fuera de trincheras a ver si aprehendian algunos enemigos emboscados, por eso del barrio incendiado de San Sebastián, luego que le vieron bajar por la calle antes de tocar en el puente que hay junto a la casa de Simbrón, lo conocieron, lo aprehendieron y lo trajeron preso a cntregario en dicha trinchera. Otra es, que habiendo dejado la escopeta que traía consigo, fuera de trinchera, en otro sujeto o en una pulpcría, vino acelerado a la de San Sebastiấn diciendo a gritos ¡Auxilio, auxilio! y que uno de los guardias que se mantenian fuera de las puertas, al conocer que era de los levantados, se le llegó diciéndole ¡Señor mi amol, le aprehendió del brazo y le derribó mientras que otro le sujetaba la rienda del caballo. La tercera es que se vino voluntario a las trincheras en derechura y entregó la escopeta en ejla y dijo que no sólo se venía a pedir perdón y entregarse sino a denunciar que los enemigos tenían una emboscada si salía el auxilio de la ciudad y que no se creyese a la carta de dicho propio porque era fingida, ni saliese tal awxilio, lo que comunmente se dice que profirió entro de la ciudad cuando ya estaba aprehendido. Dícese tambiến que aunque vino pidiendo jAuxilio, auxilio! no era para que éste saliese de la ciudad y representar el papel de fingimiento para contribuir a la traición, sino pidiéndolo para si y su persona. Se varía tanto en esto como en las ocurrencias de la sedición, que cuesta dificultad desentrañar, a veces, la

(1) Ej Oidor equivoca el apellido; se trata de Pedro Obaya, de quien ya se labía ocupado antes, como se recordará. Es el famoso personaje enviardo posiblemente por Diego Cristóbal Tupac Amaru desde Azángaro y que se hizo pasar por sobrino de Iosé Gabriel Tupac Amanı. Los indios del Ato le llamaron Rey Chiquito. 
verdad, que suele quedarse en celajes y confusión, pero en este particular el proceso podrá instruirlo correspondientemente.

El Comandante destinó un cuarto a este tuerto apelidado Obaya natural de la provincia de Azángaro, obispado del Cuzco, en la casa donde habita. Aunque antes de tomarle su confesión y siendo menester carearlo con el indio portador de la carta, Zúniga (prisionero), sería oportuno que nadie los comunicase y que al primero se pusiese en buena guarda y custodia hasta las resultas finales de la causa, seguin derecho, y no que varias personas sin reserva de madamas curiosas, le traten, examinen $y$ le hagan aquellas réplicas que le pueden prevenir para sus exculpaciones simuladas y falsas y sean impeditivas de indagar la verdad y su venida ficta para apoyo de la traición trazada por el enemigo (1), como debe recelarse por el modo que se destacó acelerado de aquella engañosa pelea.

A las 5 y más de Ja tarde, viendo aquellos combatientes falsos que no salía de la ciudad el socorro de que se lisonjearon para ayuda del auxilio inventado o verudo en apariencia, se retiraron los enemigos por varios senderos y ambas cuestas de Potosí y de Laja, a los altos; y se descubrió la emboscada de los que se habian ocultado en una quebrada grande que desde El Alto desciende al río que baña la ciudad y está adelante del Tejar y se computó que serán como unos seis mil indios más o menos, inclusos en este número los 400 o 600 que so aparentaron en este combate fingido. El tejido era, segín se manufiesta, cortar o tomar a los nuestros en el centro (si salían), luego que hubiesen pasado la dicha quebrada grande. De modo que unidos los del combate y arrostrándonos por la vanguardia y los de la emboscada repentinamente, por la retaguardia, concibieron poder derrotarnos y que, mientras este lance, los indios de Santa Bárbara (emboscados así mesmo en aquellos altos y escondrijos) hasta el número de dos mil, en que se conjetura asediasen la ciudad, entrando se apoderaran de ella, una vez que saliese lo principal de sus fuerzas y de sus armas en socorro de los auxiliares venidos (2).

(1) En estas frases del Oidor hay uno evidente molestia de parte suya frente al proceder de Segurola, que no ha actuado en conformidad al procedimiento penal, pero también puede adivinarse el profundo resentimiento que le embargaba, puesto que siendo él un Oidor, no se le consultaba para nada en el asunto, siendo así que hasta las "madamos curiosas" tenían acceso al prisionero. Posiblemente entre aquellas damas estaba la marquesa de Aro, puesto que el Comandante vivía en la casa que ésia poseía en la actual casa de los marqueses de Villaverde.

(2) La concepción de este plan ingenioso, que revela la inteligencia del Tuerto Obaya, viene a confirmar cuán equivocado estaba el Oidor en su constante idea de que sólo sáliendo fuera de los muros y atacando a los indios en El Alto se los vencería. Puede comprabarse a través de esta estratagema cómo deseaban los alzados que Segurola cometiera precisarnente este error. 
Esto último se conoció por la casualidad de haber llamado cinco indios, por las trincheras de Santa Bárbara /f.25v al capitán don Mariano Bilbao (que hacía en ella de guardia) por su nombre, manifestándose eran de su hacienda y que se sirviera salir fuera para pedirle perdón y pedirlo a la ciudad; con efecto, lograron de la sinceridad de este individuo, que convino a salir de la trinchera con un arequipeno sin armas por precaver el temor $y$ recelo de dichos indios a quienes fue a tratar pasado el riachuclo inmediato a la trinchera al pie de un alto. Allí se le llegó el uno con la montera en mano y empezando a tratarle en muestras de paz y amistad, se halló reprendido y llamado para ocupar su lugar por el Comandante a quien el capitán don Pedro Ramírez de la Parra, que ha dado pruebas de su valor; celo y cuidado, principalmente en la custodia de está trinchera (donde turna con aquél), había mandado dar aviso de este suceso por recelar que aquella llamada era maliciosa y que quizá arrebatasen los indios enemigos y emboscados que había reparaito anteriormente, al dicho Bitbao, obligando acaso a que en su defensa saliesen los circunstantes en esta trinchera y que mientras lo hacían, tomasen los

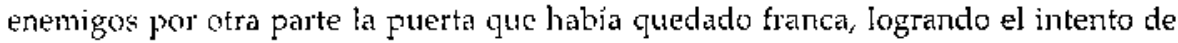
introducirse a la ciudad. Lo que quizá sucede, si tan presto no acude el Comandante y retira al oficial. Siendo de notar que esta llamada de los cinco indios la hicieron a tiempo en que ya consideraban hubieson salido las tropas de la ciudad a consecuencia del socorro pedido por aquella carta fingida. $Y$ aunque le protestaron traer una lista de los indios que dijo solicitaban la paz y el perdón y venir aquelia noche con ella y la señal de tres hondazos, no lo hicieron asi, antes bien, luego que se cerró la trinchera, empezaton los enemigos a amenazarnos con las insolencias que acostumbran y a arrojar por las hondas unos globos de fuego sobre una casa inmedjata a dicha trinchera, con el fin de incendiarla,

Parece que el dicho tuerto Obaya es bien desahogado, avieso y picarón. Cuenta pasajes que no merecen asentir con tal autor, hasta otros convencimientos. Refiere sí, que el principal cabeza no es tal Tupac Catari sino Juliân Apaza, indio del pueblo de Ayoayo, provincia de Sicasica, zafio y muy borracho, lo que ya se había oido anteriormente (1).

(1) Las declaraciones de Obaya confirmando que Tupac Calari es Julián Apaza, demuestran que después de un mes y medio de asedio, no se tiene todavía pleno conocimiento de la verdadera identidad del caudillo. Puede apreciarse también que, a pesar de que ambos personajes estaban actuando en conjunto, no se sentían unidos por lazos muy fuertes. puesto que Obaya en estas circunstancias no vacila en hablar mal de Catari, como también lo hará posteriormente este último en su confesión, refiriéndose al Tuerto. 
Y pot la aprehensión de dicho tuerto debemos rendir muchas gracias a la intercesión poderosa de nuestra Señora de La Paz, nuestra titular y patrona (1), que en el último día de su novena nos ha presentado a este facineroso, móvil de las maldades y calamidades de esta conjuración, pues con su audacia y astucia ha sabido animat a los indios a los excesos execrables que tal vez no cometen sin su presencia o no los elevan tanto de punto, como lo dice todo el tejido y urdido que hemos visto en los indios y su barbarie este día, sugeridas probablemente por este malzín diabólico. Pudiéndose hoy adaptar a nuestro caso y por nuestra devoción a María Santísima, señora nuestra, aquella visión maravillosa del ángel que estaba. sobre aquel grande edificio llamado el mole de Adriano, envainando su espada, en señal de que cesaban la ira de Dios y la pestilencia de Roma (2), porque habiendo descendido de su colocación en el aitar mayor de esta iglesia catedral a otro mole o trono que le dispuso la devoción fervorosa, en forma de altar para invocar en la novena dedicada, su soberana protección, nos anuncia esta reina de los ángeles, la señal de estar aplacados lo enojos de su divino hijo, puesto que nos trae por sus pies a un caudillo arbitrista, feroz y traidor, un quid pro quo de los diablos que tantos daños y calamidades nos ha inferido y que nos to presenta rindiendo por sus manos y sus pasos, su espada, sus armas, y su infernal saña, con la esperanza de que nos sobrevengan más propicias las ocurrencias ulteriores, hasta el feliz éxito de conseguir la paz de su soberano título y la subordinación de estos levantados al servicio y obediencia del Rey y sus ministros (3), sin que dejen de advertirse dos reparos: el uno leve y jocoso reducido a que el caballo en que se nos / f.26 presentó este taerto, le conoció su dueño que le perdió en Potopoto el lunes 26 de Marzo, de aquella funesta expedición; el uniforme pertenecía a don Bernardino Pradel, quien murió allí, en dicha escena lamentable; la cartuchera de terciopelo y galón de don José Ignacio Deheza, que también expiró allí mismo; la escopeta, sable y pistolas de otros interesados de ésta, de suerte que este bribon se surtió matizado de los colores

(1) La imagen original de Nta. Sra. de La Paz es una talla en madera obsequiada por Carlos V y que se conserva en el Tesoro de la Catedral. La efigie vestida que se venera hoy en día fue tallada posiblemente por algún artifice autóctono a fines del siglo XVI. Se la ha atribujdo incluso a Tito Yupangui, el autor de la Virgen de Copacabana.

(2) En este alarde de erudición, el Oidor se refiere a la tradición del medioevo romano que atribuye la salvación de la población de la ciudad, afligida por una terrible peste, a la aparición del arcángel Miguel con su espada en la tumba de Adriano; la leyenda hizo que el monumento pasara a llamarse Castillo de San Angelo.

(3) En esta prolongación de la mentalidad religiosa de la conquista, Diez de Medina atribuye a la Virgen el apresamiento de Obaya. Cabría preguntarle al Oidor si María no amaba también a los indrgenas o si no veía causas justas en el clamor del levantamiento. 
- equipaje ajenos. El otro es considerable, porque a no estar nuestros ánimos intimidados y recelosos por la calidad nuda o no expedita y sin disciplina de la gente o, a no hallarse con la tibieza que se experimenta, la maquinación de la emboscada o ficción tramadas se debieran regular de útiles, asi porque en la ciudad hay suficientes individuos para rebatirlos y castigarlos hasta donde convenga y para stbordinar los que queden (estuviesen o no emboscados), dejando al mesmo tiempo guardada la ciudad para rechazar la otra emboscada de Santa Bárbara; como por no ser quebrado el puesto donde combatian fingidanente y nos aguardaban. La llanura nos relevaba de la pensión de subir por toda la cuesta al Alto y del peligro de las galgas de piedras sin necesidad de combatir contra el golpe de las hondas y pedreas que, regidas de arriba para abajo, son de impulso y contrapeso y consiguientemente más temibles ${ }^{1}$ ). Y pues la divina Señora, asi nos favorece, confiemos librando el remedio de nuestros males en sus soberanos pies. Ulimamente, retirados los indios al Alto, tuvimos la noche en sosiego a la reserva de seis o siete cañonazos de pedreros que dispararon en el Alto entre 1 y 2 de la mañana.

Sábado 28 de Abril. No hubo novedad hasta cosa de las 11 del día, en que bajaron sobre dos mil seiscientos indios más o menos, del Alto, se emboscaron, entre las casas quemadas y altos de San Pedro, las Recogidas y San Francisco; dispararon varios y sucesivos fusilazos contra nuestras trincheras, espaldones y los nuestros que andaban por las calles. $X$ en este intermedio vinieron algunos y fijaron una bardera encarnada de que pendían dos cartas. La una rotulada al Comandante y la otra a don Javier Pacheco, en la cerca del convento de San Francisco, hacia la parte superior de la puerta colatcral de su iglesia. Pasó uno de los nuestros a quitarlas, como lo hizo, sin riesgo, y se mandaron ambas cartas al Comandante. A éste parece le escriben por disfrazar, acusando al tuerto, y que èl era la causa del incendio y dajos que habian cometido, el inductor de todo y el autor de la ficción que ayer tramaron y concluyendo que el Comandante tenía el campo libre y que le mandase en lo que fuere servido, al llamado Tupac Catari, a cuyo nombre es la carta. La cual, contestada que fue por nuestro Comandante en los términos de ofrecerle el perdón con tal de que se sosieguen y subordinen, se volvió a fijar en la misma bandera y en el mismo sitio donde la habían puesto los enemigos (2). Los que estando a la mira y sin ofender volvieron a conducir su bandera con la respuesta del Comandante y consecutivamente se retiraron al son de sts trompetas en compañia de su principal

(1) Con increible tosudez el Oidor, que ha descrito con detalle el plan de los indigenas para lograr sacar fuera de los muros al Comandante, por la seguridad que tienen de que fuera de ellos le vencerán, insiste todavía en que se debió salir a combatir más allá de las fortificaciones.

(2) Segurola consigna en su compilación li carta de Tupac Catari, con el número 7 y su respuesta con el número 8. 
caudillo Catari o Julián Apaza (que con varios de a caballo había bajado a los extramuros de la ciudad y chacarilla del oidor Medina) y de los demás que descendieron, para su fuerte a eso de las tres de la tarde. $Y$ aunque para confabular con ellos había dispuesto el Comandante y prevenido al eclesiástico don Martín Baldivia, de virtud, y que posee en el idioma aymara el talento de la palabra, no se proporcionó porque no parecieron ni era tiempo por más que se lisonjeaban de un buen estado.

La carta para dicho Pacheco se dice que suena a inteligencia con los enemigos y parece es relativa al nombramiento que maliciosamente figura el enemigo, de capitán de criollos que le dice haber librado (1). Parece que ella se explica con el contexto de que por el tuerto Obaya había conspirado contra los criollos, sin que éste fuese su ánimo. El espíritu es pensar entibiar a los criollos, para ver si dejados de la defensa que actúan muy leales, tenga el contrario menos resistencia para sus intentos y para el de sacrificar no sólo a los europeos sino los criollos, como sucedió en la villa de Oruro, bien que no hay, gracias a Dios, el monor recelo de la lealtad de los criollos españoles. $Y$ si no hay más mérito que el de la carta dicha parece también dura /f.26v. la prisión de dicho Pacheco, su mujer, yerno, hijas y familia, porque a tener alguna correspondencia con el enemigo fuera clandestina, con cuya calidad no combina el hecho de enviar aquella carta al manifiesto con la del Comandante, a cuya mano había de pasar precismente. De más de esto no sabemos si el fin del enemigo (que tiene en $\mathrm{El}$ Alto varios cholos nuestros que regentan sus ideas), es diseminar alguna cizaña entre los vasallos y malquistarlos de este o de otros modos. Mañana vendrá otra carta a otro, y ese otro día a otro, en iguales y semejantes términos fingidos de supositicia conunicación o inventivas y, si hemos de creerlos, sería negocio de enredar a todos y que se introduzcan guerras civiles en la ciudad, con perjuicio del servicio del Rey y de la causa pública (2).

Dícese también que se han pasado al Alto o campo enemigo 600 indios de los amigos. Es cierto que muchos de éstos se comurican nocturnamente con aquéllos y que por esto y los recelos de que incendian la ciudad los echaron fuera de trincheras en distintos cuarteles.

(1) Esta carta, tan larganente meditada por Diez de Medina, está también comentada por el capitán Ledo, en su Diario. En cambio. Segurola, que procedió según estos dos autotes con gran energía contra Pacheco, no sójo no la consigna, sino que tampoco hace la menor alusión al acontecimiento.

(2) Todas estas consideraciones del Oidor, que Segurola quiere ignotar en el Diario, pero que, en cambio, anota en los informes al Virrey. están demostrando la efervescencia que existía dentro de la ciudad como resultado de las tensiones entre peninsulares y criolios. 
En este estado sobrevino la dificultad de que fuera de ellas no tenian ni había proporción de comprar comestibles, cuya necesidad pudo haberlos obligado a trasladarse con el enemigo. En este día, derribó a uno de a caballo, a mucha distancia, don Bernardo Galio, capitán de artilleros, con un fusilazo, desde la trinchera nueva que hizo fabricar el Oidor de Chile. Estos enemigos de a caballo son los cabezas de la rebelión que arrean a látigos y chicote, para combatir, a los indios enemigos, de los que se sabe que muchos han venido y siguen forzados en la guerra y en los acometimientos a la ciudad.

Día domingo 29 de Abril. No hubo novedad. En San Pedro parece mataron los nuestros uno de a caballo y otro de a pie. Bajaron cosa de 60 indios en dos filas por la cuesta de Laja y se emboscaron y por la tarde hicieron lo mismo algunos que descendieron, los cuales, con sus centinelas y cometas hicieron algazara toda la noche, sin invasión. A las cinco y media de la tarde se vieron conducir los dos pedreros al alto de Quilliquilli, siendo sensible que las lanzas se van desapareciendo, que los más sujetos de las compañias reclutadas se presentan en la plaza sin ellas y sin los cuchilios que se les repartieron. Que muchas gentes no acuden pronto ni todos, ctiendo se toca al arma, que hay poca o ninguna subordinación por falta de disciplina y que ni una revista se ha actuado de las gentes ni de las armas en 46 días que llevamos de sitio y muchos no están siquiera en lista y la pasan ocultos en las casas, iglesias, y conventos, por su poco honor y no reclutarlos (1). ¡Dios nuestro Señor y la Virgen Santísima de La Paz nos asistan!

Dia lunes 30 de Abril. Bajaron por todos los caminos y veredas del Alto, de seis a siete mil indios (2), según cómputo prudente, y por la de Potosí, con dos banderas blancas, en línea por el frente, formados en dos filas y con varias banderas encarnadas en el centro. Estaban al pié de la cuesta y todavia mucha parte del cordón estaba tendida en la ceja del Alto, y por las otras dos cuestas grandes bajaron también en tres filas. Así ordenados, se emboscaron en las casas quemadas de la cudad, a las 11 del día; se fueron dispersando por la circunferencia, y los del alto de Santa Bárbara y Potopoto, que habían pasado (sin duda que de noche), al Alto, para bajar y ostentarnos sus fuerzas, se fueron volviendo a su común situación y cerros del Calvario y alto de Quilliquilli, quienes, luego que dispararon en los de San

(1) Nuevamente el Oidor encuentra un notivo para censurar a Segurola; sin embargo, en anotaciones anteriores ha señalado que por fín se han efectuado enrolanientos y revistas de las tropas. Es interesante, en cambio, el dato de que en la ciudad hay personas que por no alistirse permanecen ocultas en casas, iglesias y conventos.

(2) Posiblemente el Oidor abulta mucho la cifra, porque el Comandante anota solamente que en este día bajo mayor número de indios. 
Sebastián, dos cañonazos de pedreros, levantaron la grita. Poco después dispararon dos pedreros del alto de Quilliquilli y luego se vino en conocimiento de haber traído habilitados los cuatro pedreros que perdimos en la desgobernada función de Potopoto el 26 de Marzo (1). Sigujeron, pues batiendo nuestra plaza y calles de la ciudad con ellos y bastante empeño, fuera del fuego continuo que nos hicieron. Y esta es la paz de que, vanos, nos lisonjeamos con la carta de anteayer sábado, en que se franqueaba el campo /f.27 libre al Comandante. Duró el fuego enemigo hasta más de las 5 de la tarele, y se notó que con un cañón hiciercin diferentes posiciones en cuatro puestos distintos, desde los altos de San Francisco para los de las Recogidas, y disparándolo consecutivamente en cada uno. A las 10 de la noche prosiguieron con dichos cañonazos, a menudo, por toda ella, hasta el amanecer, con fusilazos que tampoco cesaron.

Acometieron los enemigos a los fuertes de la Caja del Agua, San Francisco y Santa Bárbara; los nuestros les hicieron bastante fuego y en el primer fuerte tres cañonazos de pedreros, estando muy inmediatos tos asediadores. No se saben los heridos ni muertos porque se los llevan consigo y cargan por costumbre los indios. Nos hirieron un granadero de an balazo, y de grave peligro, desde la casa guemada de Simbrón, estando en la suya inmediata al fuerte de la Paciencia, cuya situación en alto domina a aquella. Parece que en este día vino una carla de los enemigos, que la fijaron en una bandera como anteayer (2), en que se dice piden al tuerto Obaya y que se les devuelva, amenazando conto sjempre lo hacen, destruir por esta noche la ciudad. Se desentendieron de contestar a lo menos dereclamente a la carta del Comandante. De noche se arrojaron voladores de pólvora con mechas de pajuela, sobre los tejados de la ciudad, para incendiarla y hubo asinismo un corto combate de pedrea en los fuetres de San Francisco; Caja del Agua y San Juan de Dios, de pocos enemigos y mâs grita que otra cosa.

Día martes primero de Mayo. Amanecieron y prosiguieron toda la mañana los enemigos emboscados con aañonazos y fusilazos frecuentes. A la cinco y media dé la madrugada se les disparó desde el campo santo, con la culebrina media, a los que se iban en pelotón de recogida para El Alto; se vieron caer uno u otro que se los cargaron. Desde las 12, fueron aquellos tíros contrarios, más pausados y raros. Este día notaron, el tesorero oficial real Llano y don Dionisin Escauriza, lamentándose de

(1) También Segurola apunta que se ha podido apreciar que por prinera vez Ios sublevados tienen los cuatro cañones en uso.

(2) Segurola registra esta carta el día anterior con el número 9. seīalando ademús que llegó con ella otra, la número 10. Se ve que Diez de Medina no la cotoció porque no se refiere nunca a ella. Se trata de una mișiva dirigida a Segurola, firmada por "todas las comunidades de las cuatro provincias", pero cuyo estilo y redacción revela la misma mano que las firmadas por Tupac Catari. 
la falta de pólvora, concluyendo que de presente y en especial la noche del martes pasado al acometimiento nocturno, se iban supliendo para el servicio con la de los particulares, pedida por vía de suplemento, sin que haiga contrato formalizado con el sordo Bolaños, dedicado a fabricarla por su buena devoción sin pacto formal ni plazos ni que se le remunere, for obligación para el acopio necesario. Por cuya causa crecen los cuidados de la ciudad cuya tuición está en la pólvora, al mismo paso que los días van cosumiendo los pocos viveres que quedan, aguardándose el auxilio de tropas del caballero Flores, quien no sabemos cuándo vendrá. jCaso raro que no se lee en las Historias! Que stendo mayor el número de los sitiados y con más armas, instrucción y honor que el de los bloqueadores y éstos, bárbaros que fuera de algunos fusiles tan mal gobernados como los pedreros, no tienen más armas que las hondas y piedras (cuyos golpes no matan por lo general como lo miristra la actual experiencia), nos tengan a raya, así oprimidos dentro del piso y terreno de seis a siete cuadras en círculo, sin disposición ni espíritu para rebatirlos, castigarlos y proveer la ciudad de carnes y comestibles (1). Tienen por sistema dejar prevalecer los desórdenes inauditos de la sedición y que el maldito conjurado se mantenga en la usurpación absoluta de estos estados y dominios def Rey, manejando el despotismo y aún el santuario, puesto que por su mano se administra el santísimo sacramento del altar, echando com la custodia las bendiciones a los alzados para venir a la guerra, que tienen misa a su discreción én la tienda de campaña, que mandó comparecer a varios eclesiásticos, como don Sebastiàn Limachi, cura de Guaqui, don Isidro Vargas, escusador del pueblo de Palca, al religioso agustino y lo que es más al cura de Achacache en Omasuyos, don José Mariaca quien, es corriente vino al Alto (sin duda que propulsado), a rendirle obediencia y haberie dicho misa tres dias, hasta que (dicen) regresó el jueves pasado para su doctrina, con papel u orden del Apaza (2). Todo lo cual como lo precedido anteriormente, podía mover a tratar del remedio, sostener los derechos del Rey y sacrificar la última gota de sangre en defensa de tan altos respetos, como los de la religión, los de su Majestad y de la pa/f.27v. tria. Sin acabar de comprenderse cómo haiga valor para irritarse al oir los consejos más saludables y proferir indignaciones públicas contra las personas de carácter y

(1) Nuevo reproche a la "falta de cspíritu" del Comandante. Al Oidor no le cabe en la cabeza, a pesar de lodo lo que ha experimentado, que se permanezca en la ciudad y se soporte el sitio de estos "bárbaros" mal equipados que ni siquiera saben disparar.

(2) Todas las noticias que se dan sobre Tupac Catari lo muestran muy dado a rodearse de un hálto religioso y de un ambiente eclesial. 
autoridad que, sentidos por un discreto celo, se han visto precisados a tomar el justo grito y desahogo de la queja y compasión (1).

A las cinco de la tarde y por la noche, cesaron los cañonazos que a pausas seguían desde prima noche a la algazara de los indios, al son de cometas. Acometieton tibiamente después de las 12 de ella, a algunas fortalezas, más con voces obscenas e insolencias que con piedras, del modo que la noche anterior y en ambas con pervigilio del vecindario. A las 12 del día esperaron a que las gentes saliesen de la iglesia catedral, de misa de 12, donde concurren muchos, y dispararon a este tiempo, dos pedreros consecutivos, pero sin daño.

Miércoles 2 de Mayo. Nos dispararon de mañana los cuatro pedreros, pero pausadamente. Bajaron cosa de 400 indios del Alto, a las 11 del dia; se emboscaron entre las casas quemadas de la ciudad y los del lado de Santa Bárbara se fueron poniendo en la ceja de las montañas al lado del Calvario y Quilliquilli y a la una y tres cuartos dispararon ocho cañonazos de pedrero, desde el alto irumediato, camino de Coroico, batiendo la plaza mayor y casas del Oidor don Francisco Tadeo Diez de Medina, en la que cayó una, a la segunda disparada sucesiva de los cuatro pedreros dichos, con mucha algazara de los indios que los custodian. Asimismo se fueron disparando algunos fusilazos por distintas partes de la ciudad.

A las cuatro y media de la tarde se retiraron algunos indios para El Alto por las veredas que hay diferentes y no por los caminos comunes, recelosos de nuestra culebrina. La hambre es cada día más sensible y así se ve comer a la gente pobre carne de mulas, de borricos, perros y gatos, no sólo de los que por comer matan de propósito y arrebatan en las calles si los dueños se descuidaron, sino de los que mueren naturalmente accidentados o de pura flaqueza, pues se ve que al punto de arrojarlos a las calles los descuartizan y aprovechan a la porfía y se llevan la carne los concurrentes, que son muchos (2).

(1) Diez de Medina vuelve a insistir. reprochando el proceder del Comandante, en la irritación que le causa a éste el que "personas de carácler y autoridad" pretendan aconsejarle. No queda muy en claro si "el justo grito" y la queja de desahogo son las de todos los vecinos o las del propio Ojdor. En todo caso se puede comprender que dentro de los muros se viven tambiên momentos de profunda efervescencia.

(2) Estos hechos anotados por el Oidor y que también consigna el capitan Ledo son un índice del hambre que sufria la población de La Paz; se sabe quc ese fue el foco más grave de infección, pues generalmente tales animales morían envenenados por haberse alimentado a su vez de los cadáveres que yacían en las calles sin enlerrar. 
Corrió la voz de haber regresado un propio de la villa de Oruro al Comandante, con el anuncio de la venida del caballero Flores y el auxilio de su tropa, aunque esto necesita confirmación.

A las nueve $y$ tres cuartos de la noche, empezaron los levantados a batir la ciudad desde aquel puesto donde situaron esta tarde los cuatro pedreros, y varias partes de la ciudad, con tiros de escopetas; unos y otros hicieron fuego vivo toda la noche $y$ a las 12 más o menos de ella, trasladaron los pedreros al Alto mismo y al cementerio de la parroquia de Santa Bárbara de donde disparaban a la calle de La Merced, plaza mayor; calle de Mercaderes hasta tocar y pasar la trinchera de San Sebastián, donde un cañonazo quebrantó tres lanzas de los guardias. Los rebeldes tuvieron sus danzas y rochelas en esta noche, víspera de la Exaltación de la Cruz, que la celebraban los indios con sus borracheras acostumbradas. Los cañonazos duraron hasta las 7 de la mañana, a menudo.

Jueves 3 de Mayo. Se vino un mozo de la provincia de Sorata, a quien y a otro hicieron prisioneros los rebeldes hace 17 dias. Al compañero le ahorcaron y a éste por sus ruegos y porqute les ofreció servir le salvaron y le destinaron de escopetero y le dicron una escopeta que la trajo consigo. Llaman a estos de escopeta, granaderos. Trae razón de que un Murillo, nuestro desertor, es el valido del conjurado, que da todas las ideas de la guerra; que no piensa el indio en subordinarse sino en seguir la guerra, lisonjeado de regular la ciudad de La Paz por suya y por ganada.

Al Apaza se le vió partir a caballo de la parte de Potopoto, donde parece durmió anoche, para El Alto, por el mismo extramuro de San Pedro, con poca escolta y un caballo tordo enjaezado con todo adherente que le llevaba otro, de dietro, fuera del almofrez de cama que iba en una mula. Era fácil haberlo preso y aún haber restaurado anoche los cuatro pedireros si se pensara en elío y más cuando el público lo clama y no faltan resueltos que lo siguiesen y que hoy y anoche eran muy aparentes por la común borrachera y fiesta de la Cruz en que se hallan, con muchos bailes y danzas (1). Y el dicho sorateño tefiere que en El Alto hay cinco clérigos con el religioso /f.28 agustino y un francisco venido de Oruro (2).

Viernes 4 de Mayo. Bajaron algunos indios y varios de los que manejan escopetas, a mula. Se emboscaron entre las casas y tueron disparando varios tiros (sin otro movimiento) a las calles de la ciudad y los nuestros hasta el fin de la tarde. Esta mañana derribaron los de nuestro fuerte de San Juan de Dlos a uno de a mula que llevaba otra. Antenoche se huyeron seis soldados de Larecaja, para El Alto, de

(1) Nueva acusación a Segurola; en su incapacidad, no aprovecla los momentos oportunos para rescntar pedreros ni apresar caudillos.

(2) El religioso agustino es Fray Małias Borda, que más tarde logró escapar hacia la ciudad y que informó detenjdamente sobre lo que ocurrfa en El Alto. 
los que aprehendió cuatro el capitán Sánclez que estaba de guardia en una trinchera y anoche se fueron cuatro de los de Sicasica con el pretexto de que se retiraban para el Río Abajo y mineral de Araca (1). Y a este paso y con los muchos muertos ya podremos en breve contar con la ciudad exhaurida de gentes y con su último desastre. A las 3 de la tarde empezaron a disparar los pedreros los rebeides, hasta cosa de las 4 y media de ella. $Y$ a las 2 y tres cuartos de la madrugada los continuaron muy a menudo trasladándolos a distintos puestos, con muchos fusilazos, habiéndose experimentado la algazara, voces y tropel de injurias de los conjurados, con algunos chasquidos de hondas y pedrea en toda ella, hasta la aurora. En este día mataron los alzados desde la casa de Simbrón (quemada) un soldado que estaba de guardia en la fortaleza de San Sebastián, de un tiro de escopeta con mecha.

Sábado 5 de Mayo. Al salir los indios para su Alto al amanecer, les dispararon dos cañonazos de culebrina sucesivos, de la ventana del campo santo a espalda de la iglesia Catedral. Y está válido que del uno murieron scis de cllos y que anoche en eI fuerte de las Recogidas derribaron los nuestros siete de los rebeides. El día fue quieto pero, desde prima noche, comenzaron con la vocería de insolencias y desde la media noche, con repetidos tiros de escopetas que fueron disparando hasta el ananecer.

Domingo 6 de Mayo. Se retiraron al aclarar el día los indios al Alto, pero siguió esta madrugada y toda la mañana el fuego de sus escopetas. Se divisaron pendientes de la horca que tiener los sublevados en el alto y camino de Potosí, dos cuerpos, el uno desde anteayer y, en una picota, una cabeza. Por la tarde salieron cosa de 60 granaderos y algunos oficiales por salitre, al alto de Santa Bárbara, para la fábrica de pólvora, que nos escasea tanto. Al retirarse les acosaron por la espalda, cosa de 300 indios. Hicieron que huían los nuestros y luego volvieron sobre ellos, y con dos piquetes emboscados a prevención les hicieron bastante fuego. Los rebeldes se entregaban a cuerpo raso, como que querian venirse a las manos, pero se les contuvo, tanto que se retiraron precipitados con algunos muertos y heridos que en opinión juiciosa del ayudante mayor de granaderos, don Carlos Rogers, inteligente en el manejo de las armas, que ha disciplinado a dichos granaderos y es vigilante en el servicio, serían de 40 a 50 los computables entre unos y otros. Y luego, al principio de la noche, con buena luna hicieron su retirada (ordenada a nuestra trinchera), manteniendo aquel fuego correspondiente para rechazar al enemigo, sin que de nuestra parte hubiese avería. Hoy, con esto, podrá confirmarse lo que puede la fuerza del orcien y de la formación militar. Estos mismos rebeldes invasores al retirarse a las serranías de Santa Bárbara lo hacían con mucha grita y algazara, como

(1) Puede apreciarse que las deserciones no sólo se producían entre los indios amigos y los mestizos, sino tambien dentro de las filas del ejército. 
si celebrasen algún triunfo suyo. Lo que acostumbran con estudio y siempre que se les da alguna friega como ésta, para damos a entender que no flaquean de su ánimo ri se intimidan. Esta noche hubo bastante rujdo y voces de ellos por las casas quemadas, pero no cosa mayor, con las injurias e insolencias que siempre vierten. Como ellos ocultan, retiran y se llevan luego, cargados, los muertos de los suyos, en el combate, se esparció la voz de que uno gritaba anoche iya están rendidos mis hombros de tanto cargar cuerpos muertos! La verdad se libra en el público testimonio. A las 11 de la noche, se sabe enterraron en Santa Bárbara los rebeldes, con muchos auliidos, grita y llanto, los muertos en este día.

/f. $28 \mathrm{v}$. Lunes 7 de Mayo. No hubo novedad ni movimiento; como no han corrido ayer ni hoy los pedreros disparados, infiere el pueblo que los han porteado los conjurados al puebio de Calamarca, 12 leguas de la ciudad, para resistir el auxilio de las tropas con que debe venir el señor Flores y de que ellos tienen noticia, a cuyo efecto han puesto en dicho pueblo multitud de indios, fuera de los que nos cercan, seguin presunción conrún.

A las 4 de là tarde se repitió al alto de Santa Bárbara la misma salida de ayer, compuesta de los granaderos, oficiales y veciuos, en más número que ayer y de la compañia de negros libres a que se agregaron algunos esclavos. Martuvieron el fuego sobre hora y cuarto con mucha frecuencia y descargas. A la grita acudían los enemigos alojados en el campo de La Capilla y San Pedro, corriendo como una exhalación y, según se juzgaba, pasaban el río por bajo de la ciudad y tomaban la vuelta para juntarse con los suyos hacia Santa Bárbara, donde concurrieron por prudente regulación de 600 a 700 y no en aquelia multitud que otras ocasiones. Se emboscaron entre las paredes y casas quemadas descubriendo por instantes la cabeza y así ocultos aventaban piedras sin tino por sus hondas, cuyos batidos eran pocos. Se retiraron los nuestros con la luna, pasadas las oraciones, en tropel y sin orden porque, antes de la refriega se había retirado el Comandante del dicho puesto, hacia la puerta de la trinchera, dejando el comando al pobre oficial o paisano gallego, desgraciado don Manuel Franco (1), y por providencia divina y haberse dentrado los indios primeramente a registrar el cementerio e iglesia de Santa Bárbara, no sucedió el infortunio que otras veces.

Se discurre variamente acerca del número de los enemigos muertos, pero juiciosamente pueden regularse de 20 a 25 , fuera de los que cargaban heridos y no serian pocos, asi por las descargas continuas como porque los nuestros se apostaron muy bien, en cuatro lugares, por nuestro Comandante, a principio de la salida al

(1) Como puede verse, el coronel Franco no ha logrado que el Oidor modifique ef triste jujcio que le merece su persona. Tampoco ha olvidado Diez de Medina que "este pobre ofjcial desgraciado" es gallego. 
Alto y también porque de la fortaleza de Santa Teresa y por la espalda de una casa contigua a ella, se hizo bastante fuego al tiempo que ocurrían a juntarse a pelotones y al acometernos les batian los nuestros por la espalda. Cuando los rebeldes, en vista de nuestra retirada, ganaron el alto de Santa Bárbara, ya estaban los nuestros junto a la trinchera y otros entro de la ciudad y asi fue que ninguno salió dañado, salvo un granadero a quien hirieron de un balazo, pero con buena esperanza de vida. Para cuyo éxito contribuyó la emboscada nuestra de fusileros, en dos boca calles inmediatas a la puerta de la trinchera, gobernada allí por el Comandante, conien deterúa a los nuestros que a carrera y desordenados bajaban del alto de Santa Bárbara. La cual cón su fuego detuvo a los enemigos en el mismo alto y acaso mató e hirió a algunos. A poco después siguieron con la algazara de voces e injurias y chasquidos de hondas con muchas piedras de buen tamnano que arrojaban contra la trmchera, la calle adentro y casas inmediatas, por mucho espacio y luego se dispersaron por los alrededores de la ciudad con la misma grita y padrea y acómetieron a algunas tríncheras, principalmente a las de San Francisco y Caja del Agua, de la cual derribaron cinco indios muertos. Otros cinco mataron con un pedrero disparado desde el fuerte nuevo, que dirigió el capitán don Roque Manzaneda, al tiempo que por la tarde pasaban a combinarse con los suyos y hallarse en el combate. Desde el de San Juan, mató uno don $N$. Donaire y dos más se fueron heridos de balas.

Esta noche y la pasada, los indios se lamentaban gritando que matábamos a los que de nin̄os nos sirvieron y mantuvleron con su trabajo, como si fueram pájaros y vizcachas o conejos en quienes debieran emplearse los tiros de escopetas. Otros decían: ¡Habéis tnuterto a los tributarios del Rey $\sin \mid$ su licencia, a ver ahora cómo le tributarán los difuntos! ¡Ahora iremos a darle parte de estos estragos que cometéis sin su licencia, a ver ahora cómo le tributarán los difuntos! ¡Ahora iremos a darle parte de estos estragos que cometeis sin su licencia! Otros expresaban su dolor envuelto en quejas y en ira. ¡Bueno está, vosotros nos mataís como a perros! A ver ahora ¿quién ha de hacer el servicio y el trabajo para vosotros? Y a este tenor seguían la grita con la pedrea toda la noche, como locos o desesperados, hasta que al amanecer se retiraron cosa de 300 al alto de San Pedro y los demás al de Santa Teresa y su campo (1).

/f.29. Martes 8 de Mayo. Bajaron a las 9 del día, cosa de 300 indios y a las 12 , de 60 a 80 . Tocaron la llamada por sus cornetas y se mantestaban alborotados; fijaron una bandera encarnada en la montaña del Calvario, colreteaban como dispuestos a combatir $\dot{y}$, en efecto, por la tarde, nos aguardaban hacia Santa Bárbara, emboscados

(1) ¿Cortesponderían estas quejas a la ironia indígena que adivinaba bien en qué sentido podían preocupar sus muertes a la Corona? Si no era así, y las frases nacían más bien de una reconstrucción imaginaria del Oidor, mostraban, en todo caso, muy claramente, una inquietud que, más que en el plano jurídico-moral, afectaban el tereno positivo y práctico de los dominios del Rey en las Indias. 
en la montaña y escondrijos. Pero el Comandante omitió la salida nuestra fuera de trincheras y ordenó que saliesen por salitre algunos granaderos y voluntarios al campo de la Caja del Agra, a cosa de las cuatro y media de la tarde. No acudieron los rebeldes allí porque nos aguardaban en el alto de Santa Bárbara, en más número que en los dias anteriores y sólo nos dispararon dos pedreros del alto de Quilliquilli y otros dos de otro que está arriba de San Sebastián, frontero al fuerte de la Paciencia y con esto salimos de la imaginativa de haberlos conducido a Calamarca a contrarrestar al señor Flores. Fueron pocos los cañonazos y dichos granaderos se retiraron antes de las oraciones, sin novedad alguna. Por la noche hicieron su grita por las cincunferencias de la ciudad con sus cornetas, sin otra cosa que merezca atencion. En el fuerte de la Paciencia hubo una competente pedrea de hondas sin daño nuestro. En la Misericordia se énterraron 16 de la ciudad, epidérnicos y hambrientos y en San Juan de Dios muchos más (11.

Miércoles 9 de Mayo. No hubo novedad porque unos indios bajaban y otros strbian entre dia. El rebelde con varios de caballería bajó a Potopoto y volvió al Alto. A las 4 y más de la tarde salieron 30 granaderos por salitre para pólvora, hacia la Caja del Agua, y regresaron a hora competentc. Por la noche hubo la grita que las noches pasadas. Este día, que fue cl último de la segunda novena de nuestra Señora de La Paz, se tomó un muehacho, al parecer, de los alzados, y lo trajo prisionero un tnozo mayordomo del alcalde ortinario don Juan Pedro Indaburu, a quien le dijo le llevase a presencia del Comandante, a quien le traŕa una carta y tenia de hablarle a solas, y habiendo así sucedido, le dio una carta del religioso agustino destinado en Tiquina (2), que sabenuos vino del campo enemigo, en que le avisa que el auxilio de los nuestros se hallaba en el pueblo de Sicasica, de donde debian salir el día de ayer martes para esta ciudad y contra los rebeldes, haciéndole las prevenciones cómo deban portarse los nuestros, mientras tanto. A las doce y media del dia, se mandó tocar la campana, pero extraordinariamente pausada, hasta 12 tañidos, sin caja 0 llamada. Suceso extraordinario que dio materia al discurso, pero a poco rato se supo era señal de avisar al Alto el recibo de la carta dicha. Si tal auxilio viene, el caso es un portento de esta divina Señora que así nos explica sus favores en los dos días últimos de la celebridad y cultos de ambos novenarios.

Y a la verdad que el día es ya de los críticos, porque, según vamos, si no viene el auxilio no hay esperanza de redentor ni para despejar los rebeldes y levantados y quitar el sitio y ni para salir fuera y buscar comestibles que reparen la presente

(i) Es nolorio que dentro del gran número de víctimas que se produjo dulante el asedio, correspondiố la mayor parte a los que perecieron a causa del hambre y las epidemias.

(2) Era una carta del padre Borda, Segurola la consigna con el No. Il. 
urgencia de ellos, acompañada (días hacen) de la epidemia y de la desenteria que nos va consumiendo, con la hambre, mucha gente. Sólo hoy en el hospital de San Juan de Dios se hallaban expuestos por parte de la mañana 17 cadáveres. En el Carmen, Catedral, Sagrario y otros conventos, y en especial, en la Misericordia, se han humado varios que, epidémicos y desfallecidos han terciado con sus días. Esta noche hubo la misma grita de indios que la pasada y decian: "iya vienen en nuestro favor los otros españoles y veremos con que facultades nos habéis muerto vosotros!" Luego aclamaban y decian "iViva el Rey de España, el señor don Carlos IIl!". ¡Ojalá, y lo dijeran con el corazón y las obras!

Jueves 10 de Mayo. No hubo tampoco cosa mayor. A las 11 de la mañana salió el buen capitár de indios, don Simón Núnez, con seis españoles voluntarios, fuera de las trincheras para cazar volatería; divisaron seis indios bajo de un árbol y dícese mataron a los cinco y que el uno corrió luego. En otro puesto parece mataron uno más. A las 12 se disparótdel campo santo la culebrina contra unos que ascendian la cuesta de Potosí; no alcanzó el tiro y lo mismo con la disparada, que se repitió consecutiva. Desde antes del medio día, se dispararon también continuos fusilazos por los enemigos y a las 4 de la tarde, dos pedreros, a tiempo que de esta plaza /f.29v. mayor salían cosa de 60 escopetas entre granaderos y algunos oficiales con el Comandante para una correria que duró poco, en Ia calle Ancha y plazuela de San Sebastián, con muerte de tres enemigos. No hicieron daño los pedreros dichos y sólo una bala vino y se estampó en la pared de la galería del oidor don Francisco Medina.

En el fuerte que ya concluyó Zavala de fabricar y se llama San Miguel (nuestro patrón invocado en este caso), por una de las dos disparadas de nuestros pedreros aseguran que cayeron muertos tres o cuatro de los rebeldes. La noche fue quieta y no hubo novedad. Al salir a San Sebastián, tomaron prisionera una india que llevaba al Alto de los alzados, dos capas y un cabriolé.

En este día se supo que la carta que ayer trajo aquel muchacho, vino con otra inclusa, para el tlustrísimo señor Obispo (1), escrita por el religioso agustino fray Matías Borda, que estuvo en Tiquina, quien, refieren, asegura por consolar la ciudad, que el auxilio de soldados quedaba por salir de Sicasica para ésta y que él trataría de venirse aquel día de mañana, con motivo de bajar a mudar las centinelas de los indios y daría mejor razón y más viva de las cosas del enemigo, pues escribía aquellas cartas con muchos sustos y sobresaltos. Que venian los soldados con los indios amigos que habia en dicho Sicasica comandados por un tal Bolaño, el que se sabía ya, nunca quiso seguir el partido del conjurado Julián Apaza. Que Murillo es

(1) Segurola no hace referencia alguna a tal carta. No figura tampoco en su compitación. 
arrepentido puesto que condujo convoyando a dicho muchacho y que con éste mandó decir al Comandante que, aunque el corría con el manejo de dos pedreros, siempre había elevado la puntería al dispararlos para no hacernos daño (como se ha visto), aunque el otro que corria con los otros dos pedreros y era un mulato de Tacna, la hacia baja. Que estaba el Murillo vestido de uniforme antarillo para que señalasen su persona y dispuesto a entregar a las tropas auxiliares que venían no sólo los cuatro pedreros sino la cabeza del rebelde. jDios lo haga! Aunque es sensible la poca cautcla de no haberse silenciado profundamente esta noticia favorable, porque si de acá la participan al enemigo, cono sucede con lo más dispuesto, se malograría y corren riesgo las vidas del religioso y del Murillo $y$, si Dios nos saca y viene el auxilio, nuestro salvamento hasta este punto será obra intacta de la Virgen Santísima, señora nuestra y su poderosa inlercesión, porque si de propósito se estudiase es nuestra desgracia no podria salir más ajustada, como la que hemos tenido desde los primeros pasos del principio (1). Murieron y se enterraron varios cuerpos en la Misericordia y el hospital de San Juan de Dios.

Viernes 11 de Mayo. Por la mañana, a las 7, salieron por los altos de las Recogidas unos pocos voluntarios de los nuestros con nueve o diez escopetas y algunos de lanza y hondas, acaudillados del padre Juan Sainz y junto a la garita de la cuesta de Potosi divisaron tres tiendas de campaña de los enemigos, a quienes acometieron estando durmiendo, con las dichas lanzas, palos, cuchilladas y tiros de fuego; unos se vestían, otros huian desnudos y a medio vestir. Otros dispararon contra el interior de las tiendas de camparana, $y$ así mataron 12 indios incluyendo tres mujeres. Como los rebeldes, en crecido numero, bajaban por todos los senderos de los altos a acosarlos, se pusieron en fuga para esta ciudad sin daño, a la reserva de los golpes que recibió Ignacio Sosa, hombre de edad que perdió el fusil y fue acometido por varios indios que a palos lo tenían ya en el suelo para matarle, a cuyo tiempo te auxiliaron los compañeros, haciendo fuego a los enemigos que le sitiaban, los que huyeron, habiendo muerto en el puesto, cinco de ellos. $Y$ así dice el padre Juan, que fueron 17 los muertos (2), Los indios enemigos, luego que los nuestros descendían para la trinchera inmediata, tiraban piedras desde el. alto de las Recogidas y gritaban insolentemente. Luego dispararon desde el alto de Quilliquitli;

(1) Nueva crítica al Comaddante: comete tales desadiertos. que parece que se hubiera propuesto perder la ciudad.

(2) Es realmente chocante encontrár en las páginas de este Diario las descripciones de las actuaciones del padre Sainz, que no merecen la menor censura de parte del Oidor. El fraile de la Buena Muerte no se limitaba a tomar las armas para la defensa de los vecinos, sino que organizaba pequeñas expediciones de salidas fuera de los muros para matar a mansalva a grupos de indios sorprendidos en el sueño. 
traspasó una bala rasa la cabeza de un mozo sastre llamado Angel, ya de edad, en esta plaza mayor y quedó muerto en el sitio. La noche hubo la mesma bulla de indios que las pasadas. Dícese que se vino del Alto uno de los nuestros a quien habían aprehendido los rebeldes y que confirma la noticia del auxilio. También corre, se destacaron por el caudillo Apaza mil indios del Alto, contra los que vienen, para reforzar los que parece tiene destinados en Calamarca.

/f.30. Sábado 12 de Mayo. Empezaron a disparar los pedreros a las nueve y media de la marana y continuaron hasta más de las 12 del cía. $Y$ al salir los fieles de la iglesia Catedral de la misa del tercer novenario de Nuestra Señora que ayer se inició, los dispararon contra el pelotón de ellos, pero sin desgracia. los enemigos que anoche pernoctaron con el bullicio, subieron al Alto esta madrugada y para subrogarlos bajaron otros, poco antes de las 11 del día y se emboscaron en el río de San Pedro y paredes de las casas quemadas, en los extramuros. El cura rector de la Catedral, don Pablo Machicao, refirió haber visto esta mañana matar a Ios rebeldes, a palos, a uno de los nuestros que con otros pobres habia salido a rebuscar futos en las sementeras fuera de trincheras (1), al que desampararon, sin embargo de componer más número que los 15 indios que (cuando mảs) los acometieron. Mataron los rebeldes de un balazo a un muchacho, en la esquina del monasterio de la Concepción. Se fundieron hoy dos pedreros en la Caja Real, donde está la fundición y ahora 6 u 8 dias, se fundió una culebrina que salió buena por la superficie externa y, aunque por el conducto interior tenía algún defecto y rebabas, parece podian allanarse estas fallas y ponerse servible.

Esta tarde, a las 4 , empezaron la revista de la tropa, comptresta de dos mil doscientos y tantos hombres que están a prest del Rey fuera de oficiales que no lo gozan (2). Se revistaron hoy cinco compañías con falla de gentes y se susurró en el público que algunos capitanes tomaban la ración y sueldo por entero (3), cuyo daño (si es cierto) pudiexa evitarse o disminuirse con la revista mensual mandada por orden

(1) Tales salidas, en las que siempre se arriesgaba la vida, están frccuentemente consignadas por el capitán Ledo. Muestran claramente el estado de hambre por el que pasaba la ciudad.

(2) Generalmente, los oficiales que pertenecian a las fanilias más acomodadas se habían enrolado sin goce de sueldos y pagándose sus propios gastos de guerra.

(3) En ese caso los capitanes no habrían dado cuenta de las bajas y habrian cobrado el prest de toda la conqañía. Sin embargo, la uutora de este trabajo ha revisado las planillas de pago de todas las compañas, supervisadas a su vez por los oficiales de las Cajas Reales y puede asegurar que no era tan fácil nometer estos desfolcos, no sólo por el control implacable de los funcionarios reales y del provisor general, sino lambién porque siendo muy escaso el número de componentes de cada compañía, era dif́cil ocultar la muerte o desaparición de los soldados. 
del señor Virrey, de la cual se han acordado a los 60 días del bloqueo que sufrimos, fuera de los antecedentes del cuartel.

Esta noche hubo candeladas en la cumbre de los cerros, hacia la cuesta de Laja y Potopoto. Discúrrese ser efecto de haber notado los tebeldes la revista en la plaza mayor y considerar que salíamos a rebatirlos, para con dichas candeladas convocarse y aguardarnos prevenidos, pero no se sabe de positivo lo que significan, porque antenoche no supieron de tal revista ni la vieron y tuvieron las mesmas candeladas. A prima noche hubo vocería, pausó algo y, desde la media, la continuaron. Dispararon dos pedreros en el alto de San Pedro (por donde se vió conducirlos por la tarde) y entre 2 y 3 de la mañana. A las 4 y más de ella, dispararon consecutivamente los cuatro en el mesmo alto. Anoche se tomó una india que, introducida por el paredón de la trinchera de San Juan de Dios, por una cuerda, refirió la novedad de que trajeron los sediciosos una mulas cargadas de cabezas de españoles y de los uniformes de los dragones de nuestro auxilio, que indignan y necesitan de autenticidad (b). Dicen algunos que el fuego de dichos cuatro pedreros putede ser de camaretas, porque los dos cañones fueron a Calamarca con Juliắn Apaza.

Domingo 13 de Mayo. Amanecimos quietamente; los nuestros salieron en corto número fuera de trincheras a la campaña. Parece que los rebeldes nos mataron un cholo e hirieron a otros de riesgo, en el campo, y es extraña la condición cruel de estos indios, que, atin después de muertos, todavía apalean a los muestros, aún cuando de paso ven casualmente arrojados los cuerpos muertos por el suelo, por cuya perversidad y rencores y las muchas que hemos paipado estos días (2), se hace digna de memoria aquella prolija descripción del religioso dominico fray Tomás Ortiz que, como tan docto y experto en el genio, condición y costumbres de los indios caribes de Tierra Firme, la hizo de orden del señor don fray García de Loayza, obispo de Osma y presidente del Consejo de Indias en tiempo del señor Emperador Carlos V, por observarse que casi las mismas taltas, vicios y excesos cometen estos levantados. Será muy del caso el transcribirla. Dice asi:

(1) La escena descrita por Diez de Medisa, de la india introducida a la ciudad por medio de cuerdas, enriquece el cuadro de la vida cotidiana de La $\mathrm{Paz}$ en aqueltos dias. Desgraciadamente. para una complementacjón del cuadro. ninguno de los otros Diarios se reficre a este episodio ni a la historia de las inulas cargadas de cabezas y uniformes de los soldados auxiliares.

(2) Estas frases del Oidor, referidas a la crueldad de los atacantes, vienen a demostrar la ceguera con que juzga los acontecimientos; unos dias antes, ha descrito la matanza de unos indios indefensos, dirigida nada menos que por un sacerdote, sin el menor comentario adverso; ahora, sin embargo, se rasga las vestiduras por la crueldad de los rebelces.

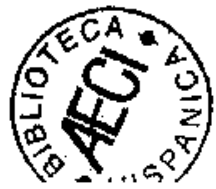


"Que eran sometidos más que generación alguna; que ninguna justicia habia entre ellos; que andaban desnudos y no tenían vergüenza; que eran como asnos abobados, alocados e insensatos: que no temían en nada matarse, ni matar, ri guardaban verdad si no era en su provecho. Eran inconstantes, no sabían que cosa era consejo, ingratísimos y amigos de novedades; que se preciaban de borrachos y tenían vinos de diversas frutas, raices y granos (es aquí la chicha), eran /f.30v. bestiales en sus vicios; ninguna obediencia ni cortesía tenían mozos a viejos ni hijos a padres; que no eran capaces de doctrina, ni castigo, eran traidores, crueles, vengativos, enemiguísimos de religión y que nunca perdonaban, eran haraganes, ladrones y mentirosos y de juicios pocos y apocados; no guardaban fe ni orden ni guardaban lealtad maridos a mujeres, ni mujeres a maridos; eran hechiceros, agoreros y rigrománticos, cobardes como liebres, sucios como puercos, comían piojos, arañas y gusanos crudos donde quiera que los hallaban; no tenían arte ni maña de hombres y que se olvidan de las cosas de la fe que aprendían; decian que aquellas eran cosas para Castilla y no para ellos y no querian mudar costumbres ni dioses; no terian barbas y si alguna les nacia se las arrancaban; que con los enfermos no usaban piedad ninguna y aunque eran vecirnos y parientes los desamparaban al tiempo de la muerte - los llevaban a las montañas a morir con sendos pocos de pan y agua; cuanto más crecían se hacian peores, hasta 10 o 12 años parecía que habian de salir con alguna crianza y virtud y de alli adelante se volvían como brutos animales y en fin dijo: Que nunca crió Dios gente más cocida en vicios y bestialidades, sin mezcla de bondad o policía y que se juzgase para qué podían ser capaces, hombres de tan malas mañas y artes y que los que los habian tratado, aquello habían conocido por experiencia". (Herrera, Década III, Lib. 8, cap. 10) (1).

Estos indios sólo se exceptúan de esta descripción en lo que es andar desnudos en el todo, bien que muchos están andrajosos y a media ropa, descalzos, con el pecho y brazos descubiertos $y$, en lo que es comer arañas, que no se les ha visto. $Y$ aquel olvido de la fe expresando ser cosas para Castilla, tiene equivalencia en éstos, porque nos han gritado haber cortado las cabezas a la imágenes y santos de bulto (como lo han hecho en las iglesias) y que una vez que no los tenemos para encomendarnos, seríamos arruinados y víctimas de su furor bárbaro, que es lo mismo que haberlos

(1) Descripciones como éstas, tan alejadas del criterio optimista con que el P. Las Casas describía a los indios, en la misma época, son las que deben haber inspirado a Ginés de Sepúlveda para sostener que los indios eran seres amentes. destinados a servit por naturaleza. 
detestado, o que si los castellanos o españoles las adoramos, ellos no lo hacían (1), También se les exceptuaría del epíteto de no ser capaces de doctrina y castigo. Estos indios lo son, porque no tienen mucha malicia, astucia y reflexiones para conocer lo bueno y lo malo y saben cuándo obran bien y cuándo mal, cuándo están culpados y cuándo no, aunque es cierto que por natural condición tienen la pereza original para la religión; pero en lo demás de la descripción referida, es todo muy puntual y lo que se verifica a la letra con estos indios ingratos y crueles.

En este día domingo, se santíficó al Señor con la degollación de una india que llevaba de la ciudad coca al campo de los levantados, y la de un indio ${ }^{(2)} \mathrm{y}$, asimismo, con la continuación de la revista de la gente acuartelada y compañias de caballería. En lo primero se dice que a los indios prisioneros y alzados y a los que de la ciudad salen y los comunican, los sentencian a pena ordinaria de deguello, por lo ordinario, con sólo el mérito de su confesión tomada, sin intervención del protector de naturales, sin sumaria, $\sin$ un breve conocinicnto, que no exciuyen las ordenanzas militares y a que se adaptan no estando en campaña a las reglas de la milicia, sin confirmación del superior y sin oír las excepciones que puedan tener, porque muchos están coactos y propulsados de miedo, entre los alzados, al ver que éstos han destrozado y muerto a no pocos que resistieron levantarse, y también porque la pena de muerte por $\mathrm{cl}$ caso de la sedición tiene la falencia o se exceptúa por el de la multitud y si esta alteración la remedia Dios y se suspendiese obrar sobre la marcha, en tanta mortandad a sangre fría, de los condenados entro de las trincheras, meditándose la materia con alguna espera y más acuerdo, pudiera suceder que verificada la pacificación (mediante Dios), hubieran continuado estos indios pagando los reales tributos al Rey, siempre que para perdonarlos hubiesen dado testimonios

(1) Este proceder de los indígenas, que para cl Oidor revela su falta de fe, puede interpretarse hoy día como un dato sociológico interesante: los sublevados pensaban que degollando a las imágenes sagradas, quedahan los españoles sin la protección mágica de los santos tutelares.

(2) Conocida la constante contradicción que envueive el carácter del Oidor, no se sabe si relacionar estas líneas con los implacahles conceptos emitidos en el párafo anterior o con fas frases que escribe más adelante, cuando se refiere a los juicios sumarios y sentencias a los rebeldes, que está haciendo aplicar el auditor de guerra. en la ciudad. En el primer caso, su concepto de le santificación de las fiestas, tan ajejado de la esencia del cristimnsmo, vendría a explicar perfectamente el desinterés de los indigenas, a que alude, por entender esa religión de castellnnos. En el segundo, no sería sino una forma irónica de inroducir los juicios que verterá sobre la versión militar que se está dando al ejercicio de la justicia. 
de subordinación y arrepentimiento y fuesen así manos contribuyentes para el mejor deterioro del reino (1), pues su Majestad en /f.31 la Ley de Indias, con su gran caridad, desea que se les perdone aún por los delitos cometidos contra su real persona. Pudiera este punto haberse mirado con otra circunspección, como tan grave y gravísimo si no se fiase solamente de un mero abogado joven e inexperto, llamado auditor de guerra (2), como si esta ciudad fuese ya alguna plaza de armas, sin advertirse que no hay facultad para hacer guerra abierta a los indios, sin licencia del Rey y que aquí por ser agresores de esta población pacifica, donde ha verido de mano armada, sólo hay arbitrio para hacerles guerra defensiva y no la ofensiva, pues, para ella, se ha de ocurrir y dar primero cuenta al Supremo Consejo $\{3$.

En cuanto a lo segundo o la revista, que es muy plausible, pudiera celebrarse más, si también la hiciesen, como debieron hacerla, de las armas. Punto que aumenta el dolor del pueblo, porque hay compañías donde uno u otro tienen sus lanzas, siguiendo los demás sus guardias, sin arma alguna con que poder hacer la defensa en Jas trincheras, caso de alguna irrupción, porque asi en vez de guardar, huirían, y que por la misma falta se hacen irhábiles para salir a la campaña y despejar al enemigo y subordinarlo (que cs el punto esencial en que se debía pensar). Sábese que el capitán don Sebastiân V́a manifestó (hacen dos días) al Comandante, que estando de oficial de guardia en la trinchera y puente de San Francisco, reparó que de los 40 hombres que le cupieron aquel día para la misma guardia, sólo uno tenía lanza y otro, un cuchillo atado a la punta de un palo; la respuesta fue decirle: que se defiendan como puedan. Y esta misma tarde se reconvino al capitán don Juan José de la Barra por las lanzas que echó equivocadamente menos el Comandante; je significó que a él, desde que se acuarteló la gente, le habían entregado las 40 lanzas que actualmente estaban entre los individuos de su compañía sin que para los demás se hubiese practicado el reintegro de ellas. Tan crítico y lastimero es este defecto que en su comprobante sucedió un día de los anteriores, que el doctor don Felipe Loayza, doctoral de esta iglesia y provisor del obispado, que ha acreditado su notorio celo y amor al servicio del Rey y de la patria,

(1) ¿Hasta qué punto habría sinceridad en las frases del Oidor? Estudiando sus opiniones tan contradictorias y conociéndose su acuuación posterior, se podría pensar que más que la falta de justicia, le disgustaba la inobservancia de una formalidad juridica y el peligro de perder los tributos indígenas.

(2) ¿No le molestaría a Diez de Medina que en lugar de solicitarse su asesoramiento legal se consultara y nombrara como auditor de guerra a un joven e inexperto abogado?

(3) Rara observación en un hombre que se queja continuamente porque el Comandante reduce su actividad a la defensa y no sale de la ciudad amurallada para atacar a los indios. 
en presencia de varios circunstantes y a tiempo de la parada, a las 11 del dia, dijese a un hombre: Tráigame vuestra merced a cualquiera de aquetlos soldados que allí ve vuestra merced, el que quiera, aqui a mi presencia. Hizose así y, preguntándole qué arma tenía puesto que estaba sin lanza, contestó que nirguna y ni siquiera cuchillo.

Por una parte, los capitanes andan desidiosos, pues no saben tomar razón diaria de las lanzas y cuchillos que se les repartieron; los han vendido o empeñado los soldados, en secuels del desorden, y por otra pudiera este daño haberse reparado si a los capitanes se les impusiese y se les celase por tan recomendable y precisa obligación y también se reparase de contado con la fábrica de nuevas lanzas a imitación de las que proporcionó dicho doctor a expensas de sus diligencias para surtir a algunos, en vista de aquel pasaje. Pero como no se trata de disciplinar la gente ni actuarla en el manejo de las armas ni en el menor ejercicio, no habrá necesidad ni de revistar las armas ni de reintegrar el desgreño con que las han traido (1).

Si al pueblo romano no se le quita el motivo u objeto de la emulación, con la destrucción de Cartago, después de conguistada, no hubjera faltado el ejercicio militar ni empezado el de los vicios por causa de aquella inacción o del ocio, que suceden regularmente a las victorias y embotan los filos de las armas. ¿Qué segura camina a su ruina repriblica que, olvidada de los medios que la sostengan, abraza los del descanso y mera confianza de sí propia! El ocio irrita la justicia divina como causa de infinidad de pecados, debilita las fuerzas corporales y afemina los ánimos y de esto se han originado el desprecio y vilipendio de muchas naciones que, poco temidas de los contratios, con seguridad las invadieron y con felicidad las conquitaron (2).

Lunes 14 de Mayo. Amanecimos en tranquilidad y se avistaban uno que otro indio en las cejas de las serranias de la ciudad y los ganados que tienen pastando en las campañas de la Capilla. Dícese que el Apaza, con mil indios, partió el jueves de madrugada para Calamarca a resistir a las tropas nuestras auxiliares y que su amasia (a quien la da de palos cuando está borracho), se trasladó / f.31v. de!

(1) Como los atros Diarios no hacen referencia a esta revista, no podemos saber por otros testimonios el alcance de la misma. Lo que si resulta evidente, en todo caso, a través de la documentación que existe sobre el cerco de La Paz, es la gran pobreza de anmos que afectaba a los vecinos. Escasez que, por supuesto, no era imputable tan sólo a los descuidos del Comendante.

(2) En un estilo muy neociásico, el Oidor no puede menos que demosirar su conocimiento de la historia de Roma así como su elocuencia morulista. 
alto de Potosí a la estancia de Achachicala, río arriba de esta ciudad, media legua distante, a mula y en sillón encamado (1). Por bajo de la trinchera de San Juan de Dios o las inmediaciones, mataron los alzados un soldado nuestro y un cholito que había salido a la campaña por viveres. Dicese que tomaron unos indios o indias que se iban al campo enemigo o comusicaban de comercio con los contrarios (2). La noche empezó con cornetas y vocería de los pocos que se regulan en los extramuros: pausaba por instantes y así siguió lo ulterior de ella.

Martes 15 de Mayo. Amanecimos con quietud. Subirían al alto de San Pedro, a la aurora, cosa de 750 indios que anoche hicieron la vocingleria que han tomado por costumbre. A tas 11 del día trajeron al Comandante una carta abierta envuelta en un pañuelo, con una bala de bronce de cuatro onzas y más, de pedrero, que Mariano Murillo, estando a cabalio con los indios alzados, habiendo echado a éstos adelante, la tiró en la calle ancha de San Sebastián, a presencia de los nuestros que habían salido fuera de trincheras, sin ser sentido de dichos indios, con quienes siguió caminando muy disimulado, después de haberla así tirado a vista de los nuestros. Conociéndose que la bala vino para dar mejor impulso y peso al pañuelo y aventarla a distancia, que no percibiesen los rebeldes, como sucedió (3).

El ser̃or Comandante, que estaba en la antesala de este Ayuntamiento, se entró a lo interior de ella, a leerla y cuando salió hizo bicn el papel de sacramentar su contenido, como debe ser, pero la desgracia tue que lo mismo fue inquirirlo de él, los ladillas o consultores, comensales y domésticos vecinos (cuyo partido ha tomado), que divulgarse a poco rato el contexto de ella (4). Dícese que publicó que la carta es del religioso Borda, agustino, firmada por sí y a nombre de dicho Murillo, su fecha, 13 de corrlente, y que en ella asevera que el borracho sacrílego de Catari o Apaza

(1) El Oidor se empeña siempre en mostrar a Bartolina Sisa como ta querida de Cutari. Es curioso, sin embargo, cómo se arrepiente de ello al final de la segunda parte del Diario, cuando comprueba que es realmente su esposa.

(2) Este dato pareceráa indicar que los indios "trajineros" seguian practicando su actividad comercial; como se había producido una gran inflación de los precios, eta tentador correr tan graves riesgos.

(3) Segurola también hace una referencia a esta carta asignándole el número 12. Dice, en cambio, que fue arrojada envuelta en un pañuelo por un indio. Los otros Diatios tampoco mencionan a Murillo. Puede ser que ln narración dej Oidar esté recogida de los decires que corren en la ciudad, pero no puede descartarse que haya sido así. En todo caso, la referencia liene mucho más colorido que el dato discrelo del Comandante.

(4) Nuevo reproche al Comandante por su indiscrecion; sin embargo, es curioso que habiéndose convertido el tema de la carta en un becho tan público como sostiene el Oidor, el capitán Ledo y Castañeda lo ignoren por completo. 
regresó del pueblo de Ayoayo donde había ido y hecho sus justiciadas con algunos (que quizás no quisieron seguir su partido). Que receloso de que los indios del pueblo de Sicasica, sus competidores, parece le contrarrestan (y no es creible), tuvo que volversc al alto de San Pedro. Que el pueblo de Sorata, cabecera de la provincia de Larecaja, estaba sitiado y atrincherado, sin poder tomarlo los indios levantados, igualmente que esta ciudad 13. Que los nuestros de la villa de Puno y pueblo de Lampa, hacian mucho fuego en los enemigos. Que el sábado 12 de éste recibió el Apaza, carta del maldito 'Tupac Amaru, incluyéndole copia de la que éste escribió pidiendo perdón al señor visitador general y que paxece se explicaba con su falacia de no haberse levantado contra su Majestad sino contra los repartos de los corregidores y otras cxacciones, sentando tenerlo así informado al Rey (2). Con cuya carta había mucha celebridad y borrachera en dicho alto de San Pedro y oportunidad para ganarlo, tanto por esto cuanto porque el número de los indios alzados iba en decadiencia y era corto como lo podrá acreditar el Comandante, siempre que amague con alguna salida fuera de trincheras o que se resuelva salir al Alto, si lo tuviere por conveniente. Que él no se había venido recelando la muerte de sus compañeros eclesiásticos. Que espera en María Santísima se serenase esto, breve, con el auxilio de los nuestros. Y para saber el recibo de esta carta se le pusiese la señal de una bandera negra, quedando los autores al cuidado de contestar a ella con dos cañonazos en El Alto, sin hacer daño a los ruestros, antes sí, en los enemigos como puedan y como gue a su tiempo lo harían.

Alborotado [yucdó] e] pueblo con dicha carta y lo sustancial de ella. Sucede que a la 1 del día, se mandó poner en el penacho de la pila o fuente de esta plaza mayor, bandera negra, tocíndose al mismo tiempo al arma, con el tambor corriendo por las calles. Añadió el populacho al tenor de dicha carta, que luego que disparasen los dos cañonazos, era señal de que Murillo con un partido de indios, había muerto al Apaza y que con estos partidarios suyos y la cabeza, bajaría consecutivamente a la ciudad en compañia de dicho religioso, debiendo salir los nuestros al pie de la cuesta

i1) Sorata estuvo sitiada desde Marzo hasta el $S$ de Agosto, en que cayó después de ser invadida por las aguas de una represa hecha construir por Andres Tupac Amaru. Por escapar de las aguas se descujdaron las defensas, aprovechando los sublevados para entrar a la ciudad y matar a toda su población masculina. Los vecinos de la ciudad y los que se habían refugiado en ella, sufrieron los mismos percances de hambre, pestes y ataques que los de La Paz.

(2) La carta a que se refiere el Oidor la dirigí Tupac Amaru el 5 de Marzo de 1781 al visitador Areche; el documento es, en realidad, th planteamiento de las razones que le han movido a sublevarse y no una demanda de perción al visitador o al Rey. La carta está publicada en: Odriozola Manuel. "Doc. Históricos del Perí en la Época del Coloniaje". Lima 1863. También lo reproduce la Col. Doc. de la Independencia del Perú. Tomo ll vol. $2^{\circ}$. 
para auxiliarlos. Elio es que esta voz cundió tanto, que muchos principales, de juicio y crítica, de la ciudad, la esperan ver para creerla. Los dos cañonazos se oyeron con efecto, con mucha distancia de tiempo, uno de otro, en el alto de San Pedro y se dispararon mucho después / f.32 que salieron los nuestros, hasta el número de 800 a 1000 personas, con 250 fusiles, según opinión común (1), habiendo partido en dos trozos, el uno por San Pedro y sus cabezadas y el otro por San Sebastián hastà que se combinaron al pie de la garita o cuesta de Potosí, siendo comandante el pobre de Franco, con quien iba toda la gente nuestra displicente, así por su impericia, desgracia y juventud, como porque ni tiene respeto ni circunstancias (2), quien refirió a varios llevaba la orden de recibir a cuántos indios viniesen a entregarse y pedir perdón, procediendo con letura en el dispararles, si viniesen sin hondear o sin combatir (es confianza nimia y poco conocimiento del carácter y tendencia de los indios). El Cotnandante se puso de mirón en el alto y trinchera de la Paciencia y los levantados luego que vieron a los nuestros empezaron a bajar con toda celeridad hasta que algunos de los nuestros que habian ascendido hasta la garita retrocedieron; haciendo lo mismo, bajaron los nuestros de orden del dicho Franco, que previno la retirada sin rrás que ver bajar dispersos cosa de 300 a 600 indios o, cuando más, 800 , según opinión de otros, tanto que contra los nuestros corre que sólo se presentaron cosa de 24 hondeadores que los pusieron en fuga precipitada y desconcertada y les ganaron la retaguardia emboscándose entre las paredes de las casas quemadas, de donde les arrijaban piedras y deñaron a algunos en el acto de la retirada por las cabezas de la calle de San Francisco, angosta, fragosa y llena de piedras y adobes; allí no pudieron jugar los fusiles sino los de la retaguardia. Cuando correspondía retirarse por obviar este daño, por la calle de San Sebastián, aunque con algún rodeo y pensión de deshacer lo andado por uno de ambos rozos. $Y$ si la acción se gobiarna con algún juicio y viveza, poniendo algunos piquetes emboscados entro de aquellas casas por donde se introducen los enemigos (y están manifiestas por los bujeros abiertos) y se les arrostra sin volver ignominiosamente y sin el menor movimiento la cara, pudo haberse conseguido gran satisfacción, porque al pie de la cuesta de Potosí hay una quebrada y río que es tránsito preciso para la ciudad, cuyo paraje pudieron aprovechar los nuestros para que, asaltados desde la parte superior de la quebrada, llevasen su merecido, en especial si se pone un cordón a trechos que cerrase hasta el alto de las Recogidas, para no dejarles libre el paso a entrar y $\in$ mboscarse en las casas quemadas (de ellas, si fuesen muchos, como otros días; nos hubieran causado

(1) Segurola habla de 400 hombres y de 400 armas de fuego.

(2) Como puede verse, la antipatía que el Oidor siente por Tomás Franco llega a extremos increíbles en un hombre que quiere presentarse como una persona equjlibrada y sensata. 
notable perjuicio), y saldría con más acierto la defensa. Como los indios nos vieron huir en desorden, nos siguieron con pedrea y alaridos y a la media hora empezaron a disparar consecutivamente los cuatro pedreros que nos quitaron días pasados, siguiendo la vocería de desvergüenzas y desafío hasta las 8 de la noche ${ }^{11}$.

Cuando bajaban los indios, venía un mandón a todo andar de caballo con un sable en la mano y su cabriolé encarnado, a quien fácilmente y por la inmediación pudieron derribar o dispararle las armas, lo que se prohibió, por decir Franco que pudiera ser el religioso referido. Ello es, que el día pareció de pantomima más que de otra cosa.

Un Ochoteco hirió de muerte a un granadero nuestro al disparar erradamente su escopeta, y los contrarios dieron un balazo al capitán de indios amigos, Velarde, pero no de peligro. Se previno en las puertas de las trincheras que si venían algunos indios a pedir perdón, se les admita e introduzca sin daño, pero no parece ningano. Entre el día de ayer y hoy, han muerto de hambre y peste sobre 140 personas que se han humado en el hospital de San Juan de Dios y foso que el Ilustrísimo prelado mandó prevenir en la capilla del seminario viejo y en otras iglesias. $Y$ si el auxilio se tarda en venir y nos mantenemos aguardándolo solamente, cuando el poco nómero de los enemigos en vida a desbaratarlos, es regular que los moradores perezcan en la mayor parte y que acaso cl conjurado logre avanzar la ciudad.

Miércoles 16 de Mayo. Todo el día lo tuvimos silencioso y aunque de noche hubo algún ruido de enemigos, duró poco. Y sigue la mortandad de las gentes pobres por causa de la hambre.

Jueves 17 de Mayo. Se amaneció con el mismo silencio que ayer por la mañana. Nos mataron los rebeldes dos personas que salieron al campo en rebusca de frutos y verduras y, después de medio dia, asimismo cercaron un granadero y un escopetero que satieron por el mismo fin y les /f.32v. cortaron las cabezas que se llevaron con la escopeta y fusil al alto de San Pedro. Dicen que también murieron tres soldados más que los acompañaban y que los demás pudieron huir para las trincheras. Luego, que en dicho alto recibieron las noticias de este hecho y las cabezas, dispararon, a las 3 de la tarde, en celebriclad, cuatro cañonazos de pedreros

(1) Narrados los hechos en esta forma, vienen a dar razón at Oidor; sin embargo, Segurola y los autores de los otros Diarios cuentan los acontecimientos como si se tratara de una retirada normal. Diez de Medina, buen conocedor de la zona y los accidentes del terreno, puede opinar de esta manera y lamentarse de que no se haya realizado tal o cual maniobra; lo cierto es que no hay nada más fácil que ser gencral en un escritotio y después de la batalla. 
y se pusieron los alzados en la misma ceja en fila y en el medio una bandera que la batian frente a la ciudad en alarde de tal logro (1). Estas hostilidades casi diarias se sienten más al verse la rareza de que sin comparación es mayor el número de los sitiados y con superioridad de armas, de razón y juicio, y sólo por haberse acordado desde el principio del sitio aguardar el auxilio que de positivo no sabemos si vendrá tarde o temprano, con el teniente coronel don Igracio Flores, comisionado privativo de su excelencia.

Viernes 18 de Mayo. Tampoco hubo novedad considerable. Por la tarde salieron algunos oficiales y graniaderos al alto de Santa Bárbara, con el Comandante, por tierra para salitre y luego que los rebeldes empezaron con la grita a conmoverse y concurrir aıdicho puesto y que se introdujo dicho material a la ciudad, se retiró consecutivamente casi en pos de ella el Comandante, y a poco rato le siguieron los granaderos y demás circunstantes, de modo que los contrarios, inmediatanene después de la retirada se posesionaron de dicho alto y empezaron a arrojar algunas piedras y disparar sus escopetas sin daño, de parte a parte. La noche fue quieta. Sólo en el foso y capilla del colegio se enterraron 37 personas, fuera del hospital y otras iglesias, porque en las calles se van cayendo muertos de hambre.

Sábado 19 del Mayo. Amanecimos con la misma quietud y con ella siguió todo el día y nosotros aguardando, sin otra diligencia, cl auxilio del señor Flores y consumiendo cada dia los pocos viveres que podrán quedar dé rezagos, cuando no sabemos de positivo dónde se halle en el día, ni cuándo vendrá, porque aquellas nuevas del religioso que se vino al campo enemigo entre los rebeldes, que dice misa sin licencia del Ilustrísimo prelado, ni de nadie, en la camparia, que hace casamientos sin ella, que entierra y que por hacer granjería de estos sacramentos es de presumir se vino al Alto, iqué fe ư que ascenso podrá merecer en sus letras! (2). Cuando más, se ie prestaría deferencia a posteriori y por sus obras, pues se hace sospechoso. Circunstancia que podia mover para no vivir tan confiados en sólo el auxilio, dejando morir de necesidad a los pobres y gente de medianía y para procurar que con alguna disciplina militar, siquiera de los preliminares, para formarse, retirarse y

(1) Segurola también menciona la agitación de los sublevados en El Alto, pero no hace alusion a lo que la inctivó, reftriéndose sblo a que murió un granadero. La explicación del Oidor es mucho más lógica; en todo caso lo interesante es comprobas cómo se veía lo que pasaba en la Ceja desde la ciudad, o desde arriba lo que acontecía entre los nortos, lo que puede explicarse por la claridad de los días en el mes de Mayo y la transparencia de la atmásfera en el ambiente del altiplano.

(2) La desconfianza que le merecen a Diez de Medina las noticias del padre Boróa no corresponde sino a un nuevo exabrupto de un hombre iuritado por la situación; siendo muy amante de las legalidades, olvida la imposibilidad de cumplir con los trámites canónicos habituales en las épocas normales. 
avanzarse, actuase una salida formal de uridad $y$ sin las etiquetas que infundadamente preocupan los ánimos (1), a efecto de despejar al enemigo, tna vez que cada dia tiene menos gentes y confederación. Esta noche se vino una india del alto de la casa de Cañizares, a quien nos aprisionaron los rebeldes, quien dice que el conjurado Julián Apaza marchó con 1200 indios al encuentro de nuestras tropas auxiliares al pueblo de Sicasica (25 leguas distante de esta ciudad) (2), y que en esto, concuerda con otro indio, medio tonto, que también se vino de dicho Alto. Dícese también estar comunicado un papel de orden, por el Comahdante, a sólo una trinchera, para admitir a dos personas que se presume puedan venirse nocturnamente, siempre que den la contrasena: Nuestra Seiton del Rosario, y que puestos en el cuerpo de guardia, se dé cuenta luego al diustrísimo señor obispo y al comandante. ¡El corrido lo dirá en uno y otro! La noche fue quieta.

Domingo 20 de Mayo. Se amaneció en sosiego y se vio que los indios de ta parte de Potopoto subieron al alto de San Pedro, infiérese que a oir misa, los que regresaron para la cuesta de Laja y cerro del Calvario. Por la tarde entraron a la ciudad cosa de 200 y por la noche hicieron la bulla que han tomado por costumbre. En el nuevo camposanto se enterraron 38 cuerpos, fuera del hospital y otras iglesias. Sigue la epidemia y la rigurosa necesidad que obligan a comer desde días antecedentes carnes de gatos y de perros sobre las de mulas y borricos, con el desconsuelo de verse por las calles, expirando o desfalleciendo, agonizantes, pálidos, secos los labios, en deliquios y suspiros y arrojados, los miserables vivientes. Dícese /f.33 que esta tarde bajó a dormir la amasia del conjurado Apaza a la quinta o chacarilla del Oidor Medina, que han tomado los rebeldes y el Apaza, para hacer sus estaciones en ella o la han hecho espelunca de ladrones.

Lunes 21. No hubo novedad y hoy martes 22 a las diez y media del dia (3), dispuso el Comandante una salida compuesta de los granaderos, regidos por don Carlos Rogers, el inglés y su buen capitán Iturralde, de los de la compañia de la Caja Real, varios de lanzas y cosa de 400 hombres a caballo, pero sin destinarse oficiales (como siempre), para las compañías, ni quién las comande y gobierne, porque el

(1) Hemos podido apreciar, tanto a través del Diario, como en su correspondencia, informes y querellas, que cuando,el Oidor habla de las "etiquetas", se refiere, por to general, a situaciones enojosas para él o que hań herido su susceptibitidad. Posiblemente, ahora, su maléstar se derivaba de que el Comandante to le hubiera mostrado la carta del padre Borda ni le hubiera conunicado las noticits ni los planes que emanaban de ella.

(2) Con mayor precisión da también esta noticia Segurola. Dice que el día 17 de Mayo se fue Apaza a Sicasica con macha gente y lievấndose los cuatro pedreros.

(3) El capitán Ledo y el Oidor narran estos bechos como ocurridos el dia 22; Segurola, en cambio. jos consigna el día 21 . 
Comandante que los lievó hasta la puerta de la trinchera de las Recogidas, allí se quedó (1). El designio fue traer algunos ganados que con efecto introdujeron de la campaña de la Capilla y aprehender a la concubina del rebelde Apaza que se decía estar por aquellos puestos y también por dar lugar a que se hubiese venudo hoy a medio día el religioso de San Agustín fray Matías Borda que entró por la misma trinchera con seis escopeteros esparioles y mestizos con sus armas respectivas (que le siguieron), interín nuestras tropas se hallaban combatidas de los indios enemigos que las cercaron, derrotaron y acabaron, al huir con mucha ignominia y mortandad de más de 50 hombres, muchos de brio y espíritu, que hacían la flor de esta ciudad, habiéndolos tomado de sorpresa, a la retirada, los emboscados en la calle o callejón que desde la campaña viene por la carrera de las Recogidas. Ello es que todo fue un tragedia que excitó el común llanto y dolor de los que desde la ciudad y las esquinas y corredores miraban la escena (2).

Y a no ser don Pedro Palacios, que en su caballo andaba solo por arriba de San Pedro, entreteniendo a los enemigos, con sable en mano y un valor admirable con que los ponia en huída, hubieran éstos más, tenido tiempo para bajar al callejón y no dejar que alguno salvase [?]. Es el dia en que en menos de una hora, se ha experimentado cual en ninguno tal fatalidad y desgracia, con pérdida de fusiles, muchos sables, espadas y pistolas, seis granaderos y varias birretinas suyas, que en triunfo llevaron los rebeldes, colgadas en palos; y atros las camisas de los muertos, a quienes dejaron desnudos, despojándolos de todas sus ropas y cortándoles las cabezas que también se llevaron $y$ a muchos, las piernas y otras partes ocultas, habiendo muerto, entre aquellos don Miguel Mariño, capitán y oficial mayor de la

(1) El Comandante anota, en cambio, 50 hombres moncados. 300 de a pie, 50 granaderos y algunos oficiales sueltos.

(2) Los otros Diarios, salvo el de Castañeda, no pintan la situación con un acento tan trágico. Segurola sólo anota 25 a 30 muertos, señajando, en cambio, que al comienzo hubo mucha mortandad de indios; todos reconocen en el fondo, sin embargo, que las acciones de aquel día fueron desastrosas. En lo que sí varían mucho es en el análisis de las causas del fracaso.

(3) Este don Pedro Palacios, que figura aquí como un hombre tan valiente y decidido, es un espariol que en el segundo cerco tiene. en cambio, una actuación bastante dudosa. En efecto, aparece en de donfesión de Miguel Bastidas, asi como en la de los otros coroneles, que escribió en dos ocasiones al caudillo, pidiéndole indios que lo sacaran desde el convento de San Francisco al Alto, para salvar su vida y sus bienes, descorazonado porque veia la ciudad perdida. Por la documemtacion. AGI, B. Aires 319, se sabe que cuando se conoció esto en La Paz se le mandó prender, pero ya Palacios había levantado el vuelo. sin que se stupiera a dónde se había dirigido. 
Caja Real, gran aritmético, de honor y buenas costumbre, de más de 60 años, con dos hijos, el uno de 12 años, a quien dejaron salir en pos de su padre. Un cuñado suyo y hermano de la viuda, quie'n en igual confusión consterna al ver su desamparo; don Francisco Farfán de los Godos, oficial mayor de la Aduana; don José Taboada, don Mariano Paredes, don F. Tapia y otros mozos de valor y espíritu, criollos que se sacrificaron axin viendo el desorden con que se encaminan y salen todas las acciones por falta de disciplina 0 de no habérseles enseñado la obediencia para mantenerse y comportarse en la campaña y por el pavor que comumente han tomado las gentes y arredra a los más, de sólo ver al enemigo, poniéndolos en fuga y tropel a su voluntad por falta de oficiales que no: se señalan ni mandan salir para que les rijan, obligando a lo mismo a los demás de honor que, por no quedar solos en la campaña, se desordenan $y$ los siguen. Esta tarde, dice el pueblo, trajeron 43 muertos, aunque algunos los disminuían en el número, para lisonjearnos; los cuentan hetsta 26 y otros hasta 39, gue es lo más corriente. Se solicitan los restantes para sepultarlos. La introducción excitó ol llanto y gemidos de los interesados y del pueblo todo, que no hay voces para explicarlos.

La causa son las expediciones dimintutas, repentinas, desordenadas y $\sin$ precedente disposición, con una gente bisoña y nada ordenada, sin conocimiento práctico del terreno a donde los envian, para prevenir la seguridades y senderos de las retiradas, que es ctrando han sucedido nuestras desgracias (l).

El dicho religioso refiere, entre muchas cosas, que en Potosi, Chuquisaca y Oruro, en Pumo, Sorata y Larecaja, no había novedad y quie estaban por nuestro anabilísimo Rey y Señor de las Españas. Que en dicha villa de Oruro, estaban varias tropas de Cochabamba haciendo el ejercicio militar (que aquí no vemos), aguardando al señor Flores para seguir su marcha, que regularmente la seguirá para esta ciudad. Que /f.33v. el rebelde Apaza dejó gobernando en su lugar a la india, su concubina, llamada virreina (2), y pasó a combatir a los de Sicasica (que parece se le oponían) con los cuatro pedreros y Mariano Murillo, quien iba con ánimo de insidiarlo, cortarle la cabeza y entregar; con los que había fieles, los pedreros; sin que hoy se sepa de sus progresos y estación aún a costa de los propios que le ha dirigido su amasia, regulando que puede, en el dia, estar cercado de los de Sicasica, comandados por Bolaños. Que los indios del pueblo de este nombre, escribieron una carta (cuya copia trae el religioso), al común de los de Curaguara, en que les dice ya es tiempo de que conozcamos nuestros yerros y obedezcamos a nuestro Rey de las

(1) Es evidente que no era esa la única causa de los descalabros militares, pero también es cierto que el juicio del Oidor es, en este caso, bastante acertado.

(2) Mientras el Oidor trata a Bartolina Sisa con tanto desdén. Segurola la supone "su mujer legítima" y el capitán Ledo la denomina respeluosamente "la virteina". 
Españas, porque el indio Apaza es un borracho amancebado con la que llaman su mujer, alzado que trae, con sus maldades y ladrocinios, enganados a los naturales; y que habiéndose practicado varios castigos contra los levantados por los españoles que estaban ya en Oruro, se les avisaba para que no aleguen ignorancia. Cuya carta, parece haber principiado a circular por dicho pueblo y el de Calacoto de la provincia de Pacajes (1). Dice que no queda sacerdote alguno en el alto de San Pedro, que han muerto ocho curas y varios eclesiásticos y que el famoso Orellana tiene en Puno tres mil indios de su partido, con varios trofeos de los secuaces de Tupac A manu, cuyo hijo le tuvo sitiado en aquella villa y se retiró porque su padre le llamó en auxilio suyo, por estar cercado de nuestro bizarro visitador general del reino, el señor consejero don José Antonio A reche y sus tropas, con que entró combatiendo a los rebeldes desde la provincia de Andaguailas.

Hoy se puso en una bandera tha carta que el dicho religioso escribió a los capitanes del alto de San I'edro en que les manifiesta al buen recebimiento que han tenido en esta ciudad y que asi se vengan a ella segures del perdón, la que vieron llevar a los rebeldes (2). El fin es atraesfos ahora que cl caudillo se halla ausente en Sicasica y es de opinión que importaria acometerlos y despejarlos porque no pasan de dos mil indios y por que es ocasion menes peligrosa por la conducción de los pedreros, ofreciéndose el religioso a salir y dar el modo y las reglas, lo que seria útil si ta gente estuviera disciplinada y no acobardada como se halla con las golpes repetidos que ha ocasionado el despilfarro y desgracia nuestra. Murió taribién don N. Arís Navarrete, vizcaíno, uno de los tres o cuatro europeos que este día salieron y, entre ellos, don Juan Fernando Iturralde, capitán de granaderos y don Carlos Rogers. Dicen unos que murieron 60 indios y otros que 10 y otros que tres. Es supuesto, porque no hubo sustancia y todo fue confusión de parte nuestra, ni puede ser menos, porque los principios desordenados no producen los fines de acierto, por lo regular.

Miércoles 23. Amanecimos en sosiego y con los más indios en el alto de San Pedro y Potopoto. Bien que este dia, con el entierro de los cuerpos del día de ayer, fue funestísimo, melancólico y de notable desconsuelo. El religioso Borda, parece, volvió a escribir por la mañana a los indios del Alto. Por la tarde y la noche nos hicieron bastante fuego los indios, con los fusiles que ayer nos ganaron y está vảlido

(1) El Comandame consigna esta carla con el núnero 13. Sin embargo, en este caso se ve que el Oidor no la conoció direciamente porque altera un lanto su contenido: en efecto. la carta no está dirigida a los del común de Curuguara, sino a la comunidad del pueblo vecino de Callapa. En elli se trata a Julián Apaza de virtey supuesto, que comete herejías y disparates, pero no se hace la menor referencia a su embriaguez ni a su amancebamiento.

Segurola no bace ninguna referencia a tal carta. 
que ftreron 30 en nimero. Y'sigue la mortandad crecida de nuestras gentes epidémicas y desfallecidas de necesidad.

Jueves 24 . A las 2 de la tarde hubo en las trincheras bastante fuego de fusiles de parte nuestra, sin saberse el efecto. poryue los enemigos estaban atrincherados entre las paredes de las casas quemadas. Del fuerte de la Paciencia les dispararon tres veces el pedrero y una, con la media cujebrina desde el camposanto, que mató dos de ellos en la garita de la cuesta de Potosi. Nos hirieron esta tarde de un balazo en una pierna. a un granadero, gue con otros habia salido por tierra de salitre para la pólvora que escasea no poco.

Viernes 25 de Mayo. A las dos y media de la tarde, se disparó dos veces dicha culebrina, desde el camposanto $y$, del fuerte de la Paciencia, otros tos el pedrero y hubo fuego de fusiles de parte a parte, pero no con la continuación que ayer. Despues de anochecer siguierm los indios con sus tiros de escopetas y suliciente grita, por los altos de San lirancisco, acompañada de algunas cometas.

Sábato 26. No hubo novedad, a la reserva de algunos escopetaxos de los indios, que tiraban vagamente. Vino una india del Alto, que dice la aprisionaron y, en presencia del Combndante, examinata del padre Borda, refirió que el rebelde Apaza halria pedito por segunda vez auxilio / 34 de indios a su amasia que dejó gobernando en El Alto, para combatir, como se dice, a los de Sicasica, donde marchó el jueves pasado 17. Se iznora si caminó este auxilio y si hubo algún combate y dónde prede estar en el día.

El dicho religioso regula se halle ya cercado y derrotado y entregados los pedreros a los de Sicasica, cuyo designio ljevaba Murillo y aún el quitarle la cabeza, para lo que tenia de facción a los 11 a 12 escopeteros que, dice, llevó el indio del alto de San Pedro, con dos mil honderos. De los cuales, refiere, desertaron en el camino varios, obligándole a pedir primeramente el auxilio, que se le mand $\delta$, de 700 indios que salieron en alcance suyo. Y añade que en Sicasica había cosa de 7000 indios por el Rey, con varios españoles y que en la villa de Oruro estaban las gentes auxiliares venidias de Cochabamba y otras provincias sin que supiesen nada del caballero Flores y que ellas hicieron una gran derrota de rebeldes en la campanta de Panduro y volvieron a reunirse con los que quedaron en dicha villa de Oruro que ya estaba qutieta, con las provincias de Chayanta y Paria, en que se había hecho por ellos tuna gran mortandad y escarmiento.

La ciudad sigue con la epidemia de la disenteria, toda ella es una congoja; en las calles se van cayendo los hombres, muertos de necesidad, tanto que dos personas que hoy se reputaron cadáveres y se condujeron a la Misericordia, al tiempo de conducirlos al nuevo composanto que destinó la caridad de nuestro llustrisimo prelado, los hallaron vivos y tuvieron que auxiliarlos de alimento, con que se repusieron. Comen los del pueblo carnes de perro y gato que se han agotado y no se 
encuentran, principalmente los primeros que, huidos, andan a manadas fuera de trincheras sin que se reserven los cueros de mulas y vacas, las petacas y correas de to mesmo, que las queman, muelen o asan y asi Jos tomatn con raro dolor de los que aún teniendo dineros no pueden remediarlos ni remediarse 11 \% Las salonas o unos borregos hechos cecina, que se vendian a cuatro reales de plata, no sc hallan y se han vendido a cuatro, seis y ocho pesos. Las mulas tambien van escaseando y es cosa rara de que a un abogado Avellaneda, habiendo muerto una mula suya que muchos días subsistió comiendo tierra y que estaba flaca como un esqueleto, le instasen a vender a la rebatiña cada cuarto de ella por cinco pesos, tanto que las cames de esta bestia (que no valdria cuatro a seis pesos), rindieron treirta pesos, bo que se ve diariamente (2). El auxilio de que trataron lisonjear al pueblo no parece ni se sabe de él a punto fijo y cuando este gobierno desde el principio quiso vivir confiado en él y contraído a aguardarlo sin que por ello tengan las tropas nuestras, la instrucción y disciplina tan necesarias. Viven por esto kos hombres, bien marchitos, aguardando la muerte, si Dios por su alta misericordia no nos auxilta mediante las proficuas disposiciones oportunas del extedentísimn señor Virrey de Butenus Aires, don Juan José Vértiz..

Domingo 27. Tumpoco hubo novedad. Less indios de Potopeto con 50 de a mula, más o menos, subjeron al alto de San Pedro, sería para oir misa, porque la indja que ayer vino, dijo que los alzados habian traide cinco exlesiásticos presos de diferentes pueblos y entre ellos, un Bustillo, un Torres, un Iorado y otros dos. For la tarde salieron los granaderos por salitre, con algunos oficiales y el comandante. Dicen que acudieron pocos indios al alto de Santa Bárbara de donde al retirarse mataron uno o dos de ellos.

En este día, pasó el comandante con el padre Borda, agustino, a la cárcel del cuartel y pieza donde se halla prisionero el tuerto teo Pedro Obaya, quien por medio de su confesor don Bernardo Manchego, presbitero, hizo llamar al primero, con el designio de rectractarse de las falsedades con que tenía maculados a manchados este picarón cizañero (pensando que asi le harian favor el comanuante y su director) (3) a sujetos de carácter y privilegios y al comuin de criollos de esta ciudad, con unas expresiones de diabólica, falsa invectiva. cuyas inepcias

(1) Estas trases tan trigicas del Oidor ayudan a comprender como lo que se dice del lambre que se padeció en los dás del cerco no fue an mero lugar común.

(2) Este tipo de datos, sumados a los que aparecen en los ntros Diarios, como asimismo los que se encuentran entre las cuentas de Cajas Reales y de la Real Provisión, han servido a la autora de este estudio para realizar un uabajo sobre uma "Aproximacion a la Historia Econónica de la Paz en 1781". Revista de Antropología N*2. Instituto de Antropología. La Paz. 1980.

13) Cuando el Oidor usa esta expresión se está re[iriendo siempre à Fernando Márqutez de la Plata. 
mandaron adnitir o ingerir en su confesión, por el abogado que hace de auditor de guerra, (quien se ha entrometido a conocer de lo civil y criminal de los delincuentes de la sedición pensando lavarse así las manos por el desarreglo, a costa de la sangre de tantos criollos, muertos y sacrificados en la campaña por su fidelidad y amor al Rey y a la patria, que no se han arredrado de obedecer y salir al frente del enemigo aún éstando incultos, sin la menor disciplina ni prevención y a costa del honor de los que viven $y$ han hecho lo propio 15, porque si no tienen firmeza para seguir $y$ mantenerse al frente de los enemigos es porque no se les ha instruido lo que deben hacer en la obediencia y permanencia en este $/ 134 \%$ acto y cómo o en qué formaciones deben mantenerse y principalmente porque si el jefe es el primero que echa a correr $y$ huye, cono se le ha visto en las salidas a Santa Barbara, y las más veces no sale fuera de trincheras, ique mucho que sus súbditos le initen y se hayan questado con el habito de este mal ejemplo! (2), Lo cierto es que en la ciudad, desde antes del sitio de los reheldes, se suscitó con poca política no sé qué especie de etiqueta perniciosa entre los españoles europeos y criollos, las que él que manda y gobierna debió apagarlas y humarlas sin la adhesión que da a entender y en que el llustrisimo señor obispo le dijo lo convincente en una ocasión, sabedor de que los liamaba tupamaristas. Porque estos puntos odiosos y de cotejo: si los unos sirvan o sean fieles más que lus otros, si sean más o menos utiles, son de malas consecuencias, como se vio en la villa de Oruro, y promueven las guerras intestinas o civiles y son ajenns de toda maxima racional o porque todos son hijos de un padre que es el Rey o vasallos de un mismo solverano o porntue an el mundo sólo deben considerar'se dos naciones, una the hombre's de bien y utra de picaros (3).

Cuya ticfueta se fermentó con motivo de la dicha confesión del referido tuerto, por presentirse que la procuraron como apoyo del desconcierto y suma desgracia de nuestras cosas y defensa de la actual rebelión. En efecto, pues, se le hincó el dicho reo al Conandante y le dijo que cuanto había declarado o confesado, en especial, enredando a dichas personas y a las que tocaba en sut confesión, era falso y que, pues tenía de morirse, lo proponía así para el descargo de su conciencia.

11 En esta doble queja Diez de Medina se lamenta del perjuicio que producen a los criollos las actuaciones judiciales que se esı́n practicando con Pedro Obaya, puesto que resultan irjustamente intplicados en ellas. Al nismo tiempo, su protesta se dirige a que se practican las causas penales sin formalidad jurídica. Lo curioso es que más tarde, cuando el Oidor actúa como auditor de guerra en Peñas, Fernando Márquez de la Plata le acusá en el mismo sentido. (Correspondencia de FM. de la Pláa con el Virtey Vértiz. AGNBA 9/5-5-3).

(2) Essa vez la acusación del Oidor contra el Comandante es bastante clara y directa.

(3) En estos comentarios de un paisano importante pero marginado puede captarse la profundidad de la tensiơn que existía entre peninsujares y criollos. Diez de Medina acusa a Segurola de fomentar tan odiosa situación. 
Parece que el Comandante hizo poco juicio puesto que de contado no mandó recibir jurídica y jurada esta retractación (1).

Lunes 28 de Mayo. Fue sosegada la mañana; apenas parecian indios. Como el religioso Borda tjene sentado haber pocos indios en el campo y que juzga accequible despejarlos del Alto y sitio ventajoso de San Pedro, en el día en que el rebelde Apaza, con la gruesa de los indios se hallaba, sin duda, combatiendo con los de Sicasica para probar el corto número de enemigos que expresa, dispuso el Comandante una salida para el alto y cerca de San Francisco, al extreino de la ciudad y casas quemadas. Después que salieron cosa de 80 fusileros y las compañías de lanza y espada, se mandó tocar al arma con la campana grande que despierta y atrae a los indios y ya conocen se toca para alguna refriega. Es cierto que bajaron y vinieron de la parte de Potopoto muy pocos indios que, con los bajados del Alto no pasarían de 300, aunque otros, por mayor aumento, los computan hasta 500, sin que pareciesen más. Pudieron haber logrado en ellos algún castigo, pero como no se dieron disposiciones ni salieron oficiales más que Higuera, el inglés y Sota, y el Comandante se plantó entro de la trinchera (distante) de la Paciencia, tuvieron que retirarse como acostumbran. Los enemigos se aproximaban sin que los de lanza, que fueron sobre 600, pudiesen tener proporción de operar. La calle dicha, para la retirada es rnala, los indios ganaron las paredes colaterales $y$, abrigados de ellas, tiraron piedras y balas. En el acto de hacerlas, nos hirieron de un balazo a dn vizcaíno, don Pedro N., de gran brio, dependiente del gran Zavala, en la pierna. Parece le rompieron una arteria, por dónde se desangró mucho hasia que expiró a las 8 de la noche. Vieron heridos de los nuestros, cosa de seis y más y uno de Larecaja en la cabeza, de otro balazo. Y de los enemigos, aunque quicren decir murieron sobre 60 indios, ésta es una multiplicación de los ponderativos, porque los de juicio los regulan hasta seis o siete de ellos y no más. ¡Es caso extraño que sieñdo superior el número de los nuestros al de los contrarios y nosotros con superiores armas, tengamos, por falta de aquella generosidad de ánimo y denuedo militar, que retiramos sólo al ver cuatro gatos y no hacer cosa de provecho! Lo cual embaraza aún el tomar mañana El Alto con la facilidad que ofrece la demostración veridica del día, acerca del corto número de enemigos, que pudieran superarse con otras disposiciones sobre la marcha, para que, ganado el sitio ventajoso del Alto, remediásemos las resultas ulteriores.

(1) Pedro Obaya, que era hombre inteligente y perspicaz, había captado muy bien la rivalidad criollo-peninsular y en sus declaraciones, de tas que después se retractó, no hizo sino sembrar desconcierto y discordin para fomentar tales iensiones, lo que siempre venía a resultar favorable a los sublevados. (Pleito del Corregidor Gil de Alipazaga contra S. de Segurola y F.M. de la Plata... ). 
Entre las cosas que refiere el religioso agustino del rebelde Apaza, se mencionan las siguientes: Que en la misa y tiempo de alzar el sacerdote la hostia y cáliz, se pone este idólatra a mirarse en un /f.35 espejo y a decir luego, estoy viendo y sé todo lo que past en todas partes del mumo. Que a cada rato saca del bolsillo el porta viático (hurtado de alguna iglesia), lo ve y se lo aplica aI oíto y a los ojos y repite lo mismo, de que todo lo sabe y entiende, con cuya patraña los indios quedan admirados y muy satisfechos de su saber y poder (1). Que cuando la primera irrupción noctuma bajaron sicte mil indios, fuera de ocho mil que quedaron reservados en el alto de San Pedro y que al avisarle supuestanente que ya el fuego había recalado entro de trincheras y a la ciudad, dijo que desde el llustrísimo señor obispo para abajo, ninguno quedase vivo en ella y que a todos los pasasen a cuchillo sin reservar a nadie. Que fantásticamente nombró de obispo de la ciudad al cura de Calamarca don Antonio Poblete (eclesiástico de mucho honor y juicio que no tuvo parte en ello). Que cuando recibió y entendió la carta que le escribió, pot mano del Comandante, el Oidor don Francisco Tadeo Diez de Medina, recordándole sus obligaciones para la subordinación al Rey y la quietud, con motivo de saber su contenido y que el papel que el rebeldo le escribió en cuartilla lo pasó at Comandante con el nismo conductor, dijo: Este Oidor es mi mayor enemigo, a quien princranente' se to ha de cortar la cabeza az. Que Orellana, corregidor de Puno, había tenido varias campanas y muerto sobre seis mil indios, con mucho valor y ordenamiento de su gente, sabiendo conservar los tres mil indios ainigos que mantiene a su disposición, sin arredrarse partir hasta Ilave, gobiemo de Chucuito, con el fin de la subordinación de los alzados. Que tiene el Apaza nombrades cuatro oidores; el uno, Marcelo Calle, indio de Ayoayo, socio del rebelde, quien libró los edictos a la provincia de Omásuyos; el otro, es un tío del rebelde, tanibién Apaza; el tercero, otro tío suyo y el cuarto, otro de los alzados. Los cuales tienen la incumbencia, uno, de custodiar la plata sellada y labrada y el oro que han robado, porque todo lo traen y ofrecen los indios a su cabildo. Otro, la de guardax, recibir y distribuir la coca que venía de estos vecinos hacendados y del público comercio de los Andes de Yungas y que también lo han arrebatado con muerte de los arrieros espanoles y mestizos; lo que han acostumbrado en las campañas y demás caminos del alto de San Pedro, con las cargas de vino, aguardientes, efectos de Castilla y de la tierra y otros bastimentos que venían y conducían los viajantes para esta ciudad. Que el otro, se dice, tenía la incumbencia de especie del ají y guarda de dichos

(1) Estas descripciones del P. Borda, recogidas más tarde en el informe que eleva a Segurola el 30 de Mayo, perfikn a Tupac Catari con las características sociologicas de un personaje carismático y mesiánico.

(3) El subrayado de estas frases tiene mucha importancia, como se verá más adelante, por la forma en que las declaraciones de Obaya afectaban al Oidor. 
licores, siendo la obligación del cuarto oidor, otro mecanismo semejante. Que después de tomar la ciudad de La Paz, se prometía el conjurado el delirio de pasar a la de Arequipa a sitiarla, tomando todos los pueblos del tránsito y luego dar guerra al rebelde inicuo Tupac Amaru, cacique de Tungasuca, en la provincia de Azángaro, y quitarle la acción de simularse rey de este reino por aspirar a serlo el Apaza (1); y así es que con motivo de haber recibido la carta del conspirado Tupac Amaru, tuvo este figurón el pretexto para hacerse jurar rey en dicho Alto y haberio celebrado con juego de toros que llamaron los indios fiestrs reales. Que así, semejantemente, se extendía en sus ridículos entusjasmos, hasta la conquista de Buenos Aires, para donde proyectaba escribir, seduciendo a aquellos indios que falsamente le parece haber por alli, reducidos y civilizados.

En este día destrozaron los enemigos las casas y tiendas de la chacarilla o quinta del oidor don Francisco Tadeo Diez de Medina; se llevaron las maderas al Aito, que acarrearon desde las 10 del día hasta eso de las 4 de la tarde, y hecho el exterminio y corte de los árboles cuantiosos y hermosos del jardin, que destrozaron, $y$ después de haberse retirado, como se dijo, los nuestros incendiaron las maderas menudas y paja, que habían arrojado de los tejados con las tejas y algunos cuartos que dejaron de destruir (2).

La mortandad de las gentes sigue, y estando ya repleta la capilla del colegio viejo, el celo de ruestro caritativo e Ilustrísimo pastor se halla proveyendo lugar para otro nuevo camposanto, aparte de deberse a sus esmeros y cuidado el recojo de los cuerpos muertos por las calles, para su entierro y que no se los coman los perros como sucedía (3).

Martes 29 de Mayo. Se amaneció con quietud. A las 11 del día se oyeron algunos tiros de camaretas y por la tarde se pusieron dos escopeteros en el cementerio de Santa Bárbara y otros dos más abajo, que tiraban los primeros a la calle de La Merced en derechura, y los otros a la del palacio episcopal. La india concubina del rebeide vino de hacia Potopoto y al subir hizo man- / f.35v. sión en la garita que está al calce de la cuesta de San Pedro o Potosi, con la comitiva de 18 a 20

(1) Esta información del P. Borda, en la que insistirá en el documento del 30 de Mayo, muestra a Tupac Catari en una actitud de insubordinación con respecto a Tupac Amars.

(2) Esta prolija descripción de Diez de Medina del incencio de su propia chacarilla, fuera del vakor docunental tiene también importancia en relación con las declaraciones de Obaya.

(3) La cristiana actitud de Gregorio Francisco de Campos de dar sepultura a los muertos revela que el Obispo de La Paz estaba supliendo con su celo to que el coltegidor no cumpliera por inoperancia o por haber quedado marginado de sus funciones. 
de a mula y cosa de 800 indios, haciéndole salva uno con su escopeta y siguiendo después de un buen espacio la cuesta, bajaron algunos indios más del Alto, en alcance suyo, con dos escopetas más y subieron con aquellos y ella, haciéndole salvas.

El capitán don Pedro Parra, estando de guardia en su trinchera, divisó que los indios de Potopoto iban desatando las maderas y destruyendo las casas que están a la espalda de las de don Julián Guzmán y logró derribar muerto a uno de ellos que estaba en el tejado, con la huída de los otros, desde un corralón de la casa inmediata a su trinchera. De la iglesia y parroquia de Sănta Bárbara, se llevaron el retablo de San José y otros marcus y piezas para la capilla que con cacerías han fabricado en su fuerte de Potopoto, a la otra banda y falda del cerro, nombrando el puesto, Machacamarca, que quiere decir población nteva (1). El mismo acarreo han hecho de las iglesias y parroquias que han despojado de San Pedro y San Sebastián, porteando el despojo al alto de San Pedro y su principal fuerte, sin reserva de las flautas de los órganos, que se dice haber aprovechado para balas y para pitos que bajan tañendo en sus algazaras.

A las 5 de la tarde se disparó desde la fortaleza de la Paciencia sin que se sepa cl efecto. Esta tarde degollaron a un indio de orden, sentencia e informe (como todos los que se han tomado vivos) del llamado auditor de guerra y a otro de los amigos por haber transportádose al campo enemigo y comunicado con los rebeldes. Bien que todo corre y' pasa por la vista y aprobación del Comandante, con cuya autoridad hace inventarios en esta ciudad, entiende en causas civiles, como la demanda de umas harinas que a petición de ton Ramón de Anchorís, corregidor de Sicasica, se embargaron, y se actíta en todo lo político, como si la comisión del señor teniente coronel Flores no fuese para un solo y cierto efecto, como el de vice gobernador de armas, porque el gobierno de ellas le está encomendando por su excelencia al caballero Flores, que to subdelegó en el caballero Segurola, sin perjuicio de las facultades del corregidor, a quien tienen arrollado como un estafermo, por el mucho celo de la autoridad de los que gobieman (??).

11) El traslado del retablo de S. José y otras piezas de la parroquia de Sta. Bárbara al nuevo puesto de Machacamarca en Potopoto, demuestra que Jos sublevados, acusados siempre por el Oidor de horejes, idólatras y sacrílegos, tenían, sin embargo, un fuerte sentido de religiosidad cristiana.

(2) Ya se ha hecho referencia a la escasa delimitación jurisdiccional de la administración duraute ef cerco. Es evidente que el Oidor nunca quiso aceptar que al Conandante le cupieran tareas de orden civil o políico. Túmbién está cluro, y esto puede apreciatse por la documentación contenida en el Pleito del corregidor Gil de Alipazaga contra Segurola y F. Márquez de la Plata, que aquél se vio completamente despojado de toda responsabilidad grave. AHNM. Consejo de lndias. Leg. 20397. 
Miércoles 30 de Mayo. Se pusieron cosa de 300 indios en cordón, en el alto de San Pedro y bajaron a las 9 o 10 del día. La india bajó a la dicha garita (donde dicen comió), con la misma comitiva y salvas que el día de ayer. Se oyeron ajgunos fusilazos de los indios emboscados hacia las calles de San Francisco; los nuestros les respondían. A eso de las 2 de la tarde se publicó un bando por el Comandante para que todos manifestasen sus armas de fuego, entro de 4 días, pena de confiscación, para que se sellasen y numerasen. Diligencia que debió ser el preliminar de la sedición y de nuestra desgraciada defensa, pero más vale tarde que nunca. ¡Ojalá! y se reintegren las lanzas y enseñen el ejercicio a las gentes acuarteladas (1). Que así ya pudiéramos salvar la ciudad, las vidas y haciendas y sujetar a los rebeldes como quizá hubiera sucedido con otras disposiciones como las que supo tomar el gran corregidor don José Joaguín Orellana, a quien llama un talento de excelente doctrina y admirable gravedad en esta ciudad, con el epiteto de general nato; porque a la verdad ha hecho su deber, no con flamencos, alemanes ni suizos, sirto con unos pocos hombres incultos, rudos y, los más, de los que llaman por acá cholos que son los que le han obedecido, cedido a la disciplina militar, guardado y ocupado su lugar y sabido cumplir las instrucciones para mantenerse a la frente del enemigo y hecho la costa en tan importantísimo objeto, el más supremo del mundo, en que no se debía perdonar medio alguno. Lo cual si aquí se observase, hubiera redimido el incendio de la ciudad con tan crecida mortandad de los nuestros, los daños y exterminio de las haciendas y conercio público, las de las contribuciones reales detenidas y perdidas, los gastos y sueldos que siguen todavia a expensas de la Real Hacienda y los deservicios insolentes y más escondalosos de los indios contra Dios y el Rey, sin saberse nuestro último fin y paradero que ya conocemos cuál sería si no nos viene algún auxilio o la Señora de La Paz no prosigue con sus raros portentos en el trance último en que ya se ve la ciudad ${ }^{2}$ ?.

Los fusilazos enemígos fueron muchos este día, por las calles de San Agustín, San Juan de Dios y Riverilla, pero sin daño. Por los altos de San Francisco, que llaman de Supaicalle, hallaron degollado un espa /f.36 nol de los nuestros que se presume salió en solicitud de leña para la cocina, por las casas quemadas, $y$ el lunes pasado, 28 del corriente, se halló otro, por hacia un lado de dicho convento y altos, como que se va para las Recogidas. Desertaron tres soldados nuestros de los del valłe y debieton salir por un parendón, hasta que vieron a los alzados, con quienes se incorporaron y se fueron por el alto de Quilijiquilli. Esta tarde se castigaron dos

(1) Esta revista de armas debió ser cosa de simple rutina, pues no la consigna ninguno de los otros Diarios.

(2) El Oidor, que ignoraba las terribles anguslias de Orellana, suponiéndolo siempre victorioso, se basa en sus hazañas para suponer al Comandante cuipable de todas las consecuencias que trajo para la ciudad la sublevación indigena de 1781. 
negros, por ladrones, con azotes, en la plaza y pie de la horca, en presencia de nuestros granaderos. jRara comisión tan amplia!

Jueves 31 de Mayo. Bajó muy de mañana la india, por abajo de la iglesia de San Pedro y regulan fue para Potopoto, con su comitiva acostumbrada.

Se retractó el reo Pedro Obaya, alias el Tuzrto, de las falsedades de su confesión absurda, er vanos hechos falsos contra varias personas. Nos quiso alucinar con la venida próxima de dragones y tropas del señor Flores y en especial con la fálacia que maquinó (al ver el semblante del gobierno), para implicar a personas de carácter y privilegio (1) y al común de los españoles americanos que estan muriendo con notoria fidelidad y exterminio de sus casas, haciendas y demás intereses $y$ anhefan en el servicio del Rey y de la patria, con el amor al soberano que

(1) La imitación conıra Segurola que padece el Oidor en esos días se debía a hechos muy graves que sólo estin insinuados en su Diırios y que no apurecen en el del Comandante. Sin embargo, es posible conocerlos tanto a través del tan citado Pleito de Gil de Alipazaga como en un documento mal consignado que existe en la Biblinteca Central de la UMSA bajo el título de: "Memoria sobre el Cerco de La Paz., hecha por Francisco Tadeo Diez de Medina. Col. Rosendo Gutiérez M/126". A trivés de estos papeles puede apreciarse que historias como la del "Rey Chiquilo". apodo con que se conocía a Pedro Obaya, no pasaban indiferentes al Comandante; nuy por el contrario, dieron origen a todo un expediente que éste envió a la Audiencia. Con el documento se aciaran mucho las cosas; en primer lugar, se desprende que Obaya fue interogado por el licenciado Fermin Escudero (el joven auditor de guerra, incxperto y bisono a que alude Diez Ue Medina) el 28 de Abril; el interrogatorio se efecturo en la cúreel del cuartel de Granaderos. En las declaraciones sostuvo Obaya que Apaza tenía cartas del Obispo y del Oidor Diez de Medina, y que a este últino le había proclamado con caja y clarín "Capitán General de Mar y Tierra" y que por ese motivo habria dado orden para que no se incendiase su chacarilla. (foja 28 , pieza N. 6). Sin embargo, según el expediente, el auditor tono dos ntevas decharaciones al reo Obaya; en la última, del 31 de Mayo, desmintiéndose éste de muchos puntos, âurmó que era fajso todn lo dicho sobre el Oidor y el obispo. Esta rectificacion jurada se efectuó en vista de que Ohaya se había relractado verbalmente en presencia de Segurola, lo que demuestra que no fue cierto que el Comandante, como lo afirma el Oidor, no diera importancia a la rectificación ni la tomara jurada.

Ahora bien, sabiendo que el acto sólo se efectuó el 31 de Mayo, se explica que Diez de Medina, que sólo sabía de la retractación verbal, consignara el día 28 la frase atribuida al padre Borda sobre cl odio que sentía Apaza por el Oidor, como asimismo la noticia del incendio de la casa de su chacarilla.

Con ello Diez de Medina dejaba en salvo su honor puesto que no se cumplían las aseveraciones de Obaya respecio a sus connivencias con Apaza ni en to tocante a que respetaría sus propiedades. 
es muy constante y dificilísimo de obumbrarse (1), por ser ésta una de las verdades triunfantes que se esclarecen a medida que se quieren oscurecer y que fortificándose de día en día, no pueden jamás apagarse sus claridades aunque la pasión los anime, los agite y les dé hallazgos en las circunstancias más indiferentes para las precauciones del crimen más enorme. Retractación que hizo el Tuerto hacen días ante el Comandante, a quien hizo llamar con su confesor con motivo de habérsele mandado confesar y prepararse para la muerte; con cuya vista cesaron los motivos que tendría de interés o respetos y complacencia; cayó la máscara y apareció la realidad. Esto no es más que la verdad quien habla, y se exprime todo sin velos y sin disfraces. Las declaraciones de los moribundos son de gran peso por considerarse en el punto fijo donde se puede distinguir la verdad de los artificios precedidos o de los circunloquios o interpelaciones preparatorias que primero suelen hacerse al recitar los hechos del crimen pesquisado y, acaso, fuera de tiempo, por prevenir la sagacidad y malicia de los delincuentes, de los hechos que desean que él confiese, porque ya hubo jueces que, desnudados del candor y probidad, rehusaron recibir las deposiciones por entero, tan presto como se reencuentran en los hechos que son del descargo de los calumniados. Que supieron preverir al demunciador que sale de su resorte para la persecución de un crimen imaginario, creyendo que la calidad de juez o sub comisionado para el efecto cierto y determinado de contener y remediar los delitos de rebelión, regir la disciplina militar (el más fuerte vínculo y más seguro amparo de la potestad, pues, como dice Séneca, en la lanza está la salud) e instruir la gente de la ciudad, basta para ponerse en derecho de ser inquisidores miversales y sojuzgadores de toda la provincia y aún de causar, acaso, la turbación intestina de las familias y americanos de la ciudad con semejante borrón de su inocencia y esto por medio de un ớrgano como el nominado auditor y abusándose de la falsa delicadeza o astucia del pernicioso tuerto Obaya (2). Bien que los calumniados gimen con el pueblo esta desgracia y mala nota de su honor después de la destrucción đe sus heredades y penas que los circundan. No claman porque no dan voces ni se atreven,

(1) Sic. En el texto figura esa expresión en corrección del propio Oidor.

(2) Estas frases están en concordancia con una carta que figura en el Plejto aludido como en el manuscrito 126 UMSABC., y que dirige el Oidor a Segurola el 29 de Mayo, provocando una respuesta burlona, altiva y desdeñosa del Comandante. Le escribe Diez de Medina en la carta. que ha llegado el momento en que debe hablar porque andan en corrillos "el honor, pureza y fidelidad de personas de carácier y alta distinción del conún de los fieles criotlos de esta ciudad y de mi persona, de resuluas de la confesión que en la casa donde hoy habita V.S. se tomó al prisionero rébelde y causa de la sedición. Pedro Obaya alias el Tuerto" (foja 40, pieza N. 6), Le recalca, enseguida, esto último diciendo: "Este cizañero y perverso fue acogido varios días al lado de V.S. Si fuese pata prepararlo para aquella maquina, en desahogo de 
pues lo mismo tuera explicar sus quejas o lo que conviene al servicio del Rey y a la utilidad pública que darse margen a llamarlos alzados y pensar en aquella arrogancia que sucede a algunos (como al corregidor) (1), nacida de la relación con que expiden, conciben y resuelven las ocurrencias y acaso con aquel vicio de la phylancia, que llaman los griegos, despreciando llamar a nadie para un consejo de guerra, que no se ha visto, y menos consultar aún, a las personas de esfera, que por sus obligaciones y expertencias pudieran conducir al acierto, pues que ésta es una guerra de ingenio o industria para castigar a los rebeldes, correspondiendo a sus traiciones $y$ emboscadas con que no podrán atinar los que no tienen conocimiento

aquellos ardores 5atíricos bacia mi, individuo con que en público concurso se explico V.S. en la antesala capitular. y no los negará a ley de caballcro" (foja 40, pieza N. 6). Más adelante le insiste que él supo "que le recibió, le agasajó y le destino vivienda en la casa que V.S. mora basta el caso de su confesión primera inclusite con aquel trato propio de su generosidad ".

Segurola, en respuesta teminante, el dí 31, contesta diciéndole que las palabras del Oidor se reducen a "Iratarine el los términos nós inegulares que es posibie", estilo que no le extraña dada "la notoria prudencia, talento, y bellas circunstancias de V.S." y que es igual al que usa en los corrillos, conversaciones y particularmente en la certulia de su casa para ultrajar mi honor y conducta" foja 42, piczai N. 6). A la clara ironía igrega que si él diera importoncia a lo dicho por Diez de Medina perdería tanto liempo en el escritorio que no podría atender a lá guerra y que por fo tanto deja para su debido tiempo aclaiar los insultos que le ha lanzada, como son el "de la carin̄osa acogida que se supone hice al reo Pedro Obaya. agasajándole y destinándole vivienda en mi casa y poco costaba haber dicho que le metí en mi cama" y "el hacerme V.S. cómplice con el auditor de guersa para el hecho más vil e infame que se puede atribuir a lombre". (foja 42, pieza N. 6).

El expediente no incluye réplica alguna del Oidor.

(1) A través de los acontecimientos de la Aduano de 1780 y de los preliminares de la sublevación, puede verse que el corregidor había sido una persona artogante y arbitraria; sin embargo, el Comandante logró no sólo marginarlo de la esfera política sino también, más tarde, sofocada la rebelión, consiguió que se le despojara de su cargo y se le hiciera salir en forma ignominiosa de la ciudad. Muchos años después obtuvo Gil de Alipazaga, alegando ante el propio Consejo de Indias, que el monarca revocara castigo tan excesivo y ordenara a las herederas de Segurola y a Fernando Márquez de la Plata que le pagaran los daños y perjuicios, cosa que no obtuvo nunca el ex corregidor, que murió en la miseria en un hospital de Madrid. Tampoco sus hijas, pobres, olvidadas y solteras, obtuvieron ninguna compensación. AHNM. Pleito del corregidor Gil de Alipazaga contra Segurola... Consejo de Indias. Leg. 20397. 
del piso y situaciones de este lugar quebrado y lleno de escondrijos. $Y$ porque el sistema presente es reprochar a cualquiera advertencia o insinuación de buena fe, increpando los sujetos con el amor propio de que no necesitan consejos; circunstancia que aumenta aquellos gemidos sin desahogar el corazón, como /f. 36v sucede al que clama, sino reconcentrando el dolor en él, verificándose en ésto aquel género de hombres que aún la voz y queja quieren quitar, dejando al desdichado pueblo con el gemido, que no es voz ni queja. De aquí es la desgracia y mortandad de las expediciones y salidas diminutas y ciegas, fuera de trincheras; la pérdida del sitio ventajoso del Alto, que el 15 de Marzo se dejó voluntariamente, sin comprender la dificultad de reasumirio; la dilatación del cerco, con tanta epidemia, hambres y muertes de las gentes desfailecidas y confundidas, la mayor insolencia y soberbia en que están los indios alzados. Porque se mandan las salidas sin composición del Iugar o situación y sin decir más que salgan a tal puesto (cuyas inmediaciones no conocen) y lo mismo que el capitán Azaña, embarca, embarca y se queda en tierra, sin hacer juicio de las resultas o si navegarán bien o mal, porque esto, porece, se mira con indiferencia.

En este día vire un indio, quien llamó al licenciado don Domingo Silvia, presbitero, nombrado Pedro, de su estancia Condori, provincia de Omasuyos, hacia ei pueblo de Laja, y le habló por las inmediaciones o cerca del convento de San Francisco, y le dijo que en estos 15 días nada sabian del paradero del rebelde Julián Apaza que habia partido del alto de San l'edro con dos mil indios, de los cuales se le habian separado muchos. Que en dicho alto habia muy pocos indios y estos reducidos a los de este pueblo de San Pedro y parroquias de San Sebastián y Santa Bárbara y los tejedores y mañazos o camiceros de la ciudad. Que muchos estaban enfermos y aburridos, deseosos del perdón, que no lo habian pedido porque les decían que ya no lo había para ninguno y que todos serían degollados, de cuyo desengaño falso y malicioso le disuadió el eclesiástico y le previno se viniera con todos los que pueda traer, de dicha estancia y otras, que serian perdonados. Con to cual, ofrecio volver el indio y hacerlo aún, si era posible, conduciendo presa a la india amasia del rebelde, que dice estaba acompañada sólo de algunos hilacatas que son los caporales mandones de las estancias y de los ayllos de las comunidades de indios, en los pueblos y sus reducciones y hacen hoy de capitanes de sus gentes ${ }^{113}$. Desde antes de la una de la mañana dispararon tiros continuos de considerable traquido.

(1) Esta clase de detalles menudos que no añaden nada importante a los hechos militares, que son los que preocupan a Segurola, dan a las anotaciones del Oidor el calor humano del acontecer cotidiano de una ciudad en la que se segufa viviendo conforme a las antiguas relaciones paternalistas entre patrones blancos y colonos indigenas, pese a todas las rebejiones, batallas y matanzas. 
Viernes 1 de Junio. Empezaron los indios, muy de madrugada a menudear los tiros de sus escopetas, por los altos de San Francisco y San Sebastián, en cuyas casas se emboscan escoltados. Por un muchacho a quien apresaron los rebeldes y por otros más, se sabe que los tiros de estruendo de la noche pasada fueron en celebridad de la revuelta del sedicioso Apaza al alto de San Pedro, sin pedreros y con sólo 20 indios, sin saberse el motivo o suceso que pudo tener con los de Sicasica. Que por una india alzada de Achachicala que trató con otra de don Vicente Rojas, presbítero y capellán muy solícito de nuestras tropas, dueño de dicha finca, solicitaban los indios de ella el perdón; a cuyo efccto envió éste buen eclesiástico un indio y una india de su casa, que salieron esta tarde por la fortaleza de la Caja del Agua, con permiso que el Comandante mandó comunicar al alcalde provincial don Bernardino de Argandonaa, de buen celo al servicio, que estaba de oficial de guardia en ella. También los indios de las haciendas de los monasterios del Carmen y la Concepción gritaban a sus señoras que los hicieran perdonar (1). Aunque estos estultos son mudables como la luna, sin tino ni fijeza en sus acdones y pareceres.

Sábado 2 de Junio. Fue silencidso y no se oyeron los tiros de escopetas sino seis que parecieron de pedreros, a las 5 de la mañana. A las 10 de ella, se vió que ¡ban con bandera encarnada los rebeldes de Potopoto para el alto de San Pedro por el de Quilliquilli, fomando un circulo. Al anochecer, empezaron sus connetas como lo acostumbran. Esta tarde, perecieron dos, ahorcados y pendientes en la horca del alto de San Pedro.

A las 8 dadas de la noche, dispararon tres cañonazos de pedreros, otro de mayor estallido y un tíro de fusil, continuaron con los pedreros y fusiles con mucha vocería y algazara, por las fortalezas y circunferencia de la ciudad y aquellos apostados en el alto de las Recogidas. De nuestras trincheras se les hacia algún fuego, al divisar los bultos con la luna; pero, por más que los rebeldes se empeñaron en gritar y aparentar muchas gentes, se conocia que eran pocos y no como las noches primeras. Amanecieron disparando toda la noche, fusiles y pedreros y gritando insolencias contra nosotros, nos desafiaban y decian: ¡Pies de gallinas, salid fuera si /f.37 sois hombres! Llamábannos y decian: iVénganse con nosotros y no comerán carnes de mula y perros, que los mantendremos sin causar daño!

Los muertos diariamente con la hambre, epidemia y los hielos rigurosos siguen a centenares, que amanecen en las calies, iglesias, casas y conventos,

(1) Es interesante este dato sociológico, que permite comprobar que las monjas, pese a sus votos de pobreza y su renuncia a! mundo, seguran siendo "señoras" de los indios de sus baciendas. 
expuestos por tierra, los cadáveres, principalmente de niños, que dan compasión (1), y fueran muchísimos más a no ser la gran caridad de nuestro Ilustrisimo prelado el señor doctor don Gregorto Francisco de Campos que, con su amor paternal y ejemplar atención a los pobres de Jesucristo, se esmera en dar albergue en su propia antesalä, asistir y curar a los enfermos, expuestos al contagio de los hálitos corruptos de la respiración epidémica, en sus diarias y crecidas erogaciones de limosnas y aún por horas y minutos, en dinero, comida y otros consuelos, teniendo que deshacerse de platos de plata, su esposa y otras alhajas, por sólo subvennir en sus estrecheces a los afligidos y necesitados, hasta el extremo de estarse empeñando en sumas de adinero, por continuar sus limosnas, así incrementedas, aún estando hoy, como todos, sin renta ni congrua alguna; siendo corto cualquier elogio, al ver cómo con este bloqueo y sus resultas, gime y llora este gran pastor, como tan piadoso y afectísimo a lás ovejas de este su rebaño, anhelando por el comb́n beneficio y bienestar de la ciudad (2).

Domingo 3 de Junio. Siguieron los tiros de cañones may consecutivos desde la aurora, toda la mañana, tarde y noche, con nuerte de una india en la esquina de Santo Domingo, a quien traspasó una bala de cinco libras por el pulmón al pecho. Nos arrojaron muchas de cadibre de cuatro libras, por las calles y casas y como se hizo prueba y no tienen cabida en los pedreros y su embocadura, se discurrió las arrojaban por elevación y medio de camaretones, hasta que por la tarde sc divisaron por anteojos, ser dos cañones y culebrinas competentes, de aquel calibre, con cuyo motivo, dijo el religioso agustino Borda, que en el obraje de esta rivera abajo, se proyectaba fabricarlos. Los enemigos tienen facilidad para acopiar cuantos materiales qdieran; se les ha dado salvoconducto para prepararlos y fundirlos y para que cada dia tomen más vuelo y fuerzas y nosotros cerrados entro de casa, sin tratar de despejarlos y castigarlos, como se hizo la noche del 14 al 15 de Marzo, confiadas únicamente en las tropas auxiliares del teriente coronel don Ignacio Flores y contraídos a aguardarlas y, por más que con la palabra quieran negarlo, las

(1) Alusiones como ésta, que muestran con tanto realismo la acción del hambre, la miserja, las pestes, el rigor del fíco, se encuentran raramente consignadas en el Diario del Comandante, que parece ignorar todo lo que sucede més allá de los cuarteles.

(2) Las notables obras sociales del obispo Campos pueden apreciarse a través de los Diarios como tambien del texto de su renuncia y del Elogio Fúnebre: gasló y distribuyó cuanto tenia para aliviar a los pobres de la ciudad de los flagelos del hambre, las epidemias y el frío. - Texto de la Renuncia. AGl Charcas 532. - Elogio Fúnebre de Gregorio Fco. de Campos. Biblioteca del Inst. de Cult. Hispánica. Madỉid. 
obras y 83 días de corco y encierro nuestro, sin salir a campaña con el debido arreglo $y$ formalidad, son otros tantos testigos fidedignos que lo autorizan (1).

Al fin se ha desvanecido hasta aquí la venida próxima del auxilio de que tanto se lisonjearon y, pues se han numerado 216 escopetas del vecindario, con $300 \mathrm{y}$ más pares de pistolas, fuera de los 60 o 70 y tantos fusiles de los granaderos (2), cómo se compongan las descompuestas y se discipline la gente, siquiera en preliminares del ejercicio militár y se haga una expedición fornalizada y presidida del mismo Comandante, hay esperanza de que triunfe el Rey Nuestro Señor, mediante el divino favor y la mediana aplicación.

Nos hirieron de un balazo de cañón a un Figueroa, procurador de causas, quien falleció. Todo este día y la nuche fueron de muchos balazos y tiros de cañones y algunos fusiles por Santa Bárbara, habiéndose colocado dos pedreros en el alto de Quilliquilli, dos hacia Munaipata, frente al fuerte de la Paciencia, y por eso de San Pedro umas veces, otras por el alto de las Recogidas, los nuevos cañones. Se llevaron arrebatadanente los rebeldes a un mozo de don Cayetano Silva, a quien llamaron los indios de su estancia, astuta y engañosamente; dejó la escopeta a los compañeros (que entraron con ella a la ciudad), y se les llegó a ver lo que querian, hasta que lo aprehendieron, y lo mismo sucediese con don Vicente Rojas, capelián de la tropa, quien salió antes te que le hubiesen fijado la señal de una bandera blanca, como lo previso por un indio emisario, el dia anterior, con el fin de atraer a los de su estancia de Achachicala y después de haber hablado con un indio rebelade de esta parroquia de San Sebastián, que le convidaba para servirlo y asistirlo, como se fuese al campo enemigo. Se retiró dentro de la fortaleza de la Caja del Agua, donde al poco rato se divisó fjjada la dicha bandera por uno de vestido encarnado y emboscado con varios indios quc no tendrían el fin de contribuir al oficio de este eclesiástico. Se retiraron a la madrugada cosa de qui- / f. 37v. nientos indios escasos, para el alto de San Pedro. Al salir los fieles de la iglesia y misa mayor les dispararon del aito frontero de Quilliquilli, dos pedreros. A las 10 y más del día se divisó de esta plaza mayor, que el conjurado Apaza dio con un sable a uno de cara blanca, contra quien de contado cargaron los indios, le trucidaron y arrojaron talado en piezas su cuerpo, cerro abajo.

(1) El Oidor, que no capta lá amplitud de la Rebelión a pesar del tiempo transcurrido, cu]pa siempre a Segurola de los desustres que ocurren; así, no le perdona nunca el no haber derróado a los sublevados en El Alto el día 15 de Mazo, cuando se inició el cerco.

(2) Los datos sobre ef mímero de atmas no están consignados en los otros Diarios, puesto que, cono se ha dicho. no se refieren para nada a la revista de armas a que alude el Oidor. 
Lunes 4 de Junio. Se retiraron a la madrugada los indios del bullicio de la noche pasada, a dicho alto de San Pedro; fueron pocos por la mañana los cañonazos y balas rasas de los enemigos, y por la tarde y toda la noche los aumentaron con tesón. Por la mañana pusieron un medio mercado aparente en la plazuela de San Sebastián, de algunos viveres, como que querían comerciar con los nuestros, que salieron incautos fuera de trincheras para comprarlos, $y$ como tenían sus emboscadas entro de las casas quemadas que acordonan dicha plazuela, salieron repentinamente y nos arrebataron y aprehendieron sobre 60 personas, entre muchachos $y$ muchachas y algiunos mozos $y$ las más indias $y$ una que otra esclava $y$ los condujeron al alto de San Pedro (1), donde este dia se divisaron tres bultos pendientes de la horca que tienen fija. Por la tarde salieron cosa de 48 granaderos. por salitre, y mataron de cinco a seis rebeides, fuera de los heridos que dicen se retiraron. Nuestro corregidor mató tres de ellos desde la cerca del monasterio del Carmen, de los que estaban en Santa Bárbara. La noche continuaron los cañonazos hasta el amanecer (2).

Martes 5 de Junio. Sigtieron desde la nadrugada, con tesón irregular, los tiros de pedreros y las dos piezas más que se declararon y reconocieron ser de calibre de cuatro a seis libras, de modo que no se podian atravesar y andar las calles, sin mucho riesgo. Taladraron de parte a parte los mojinetes de algunas casas, penetrando toda la habitación y destrozando varios tejados y quebraron una mano a una india en la esquina de la plaza mayor, junto a la iglesia catedral; y a otra mujer le arrancaron o cortaron también la mano, hacia el fuerte de San Sebastián, con las balas rasas que arrojaban.

Por la tarde se reintegró la compañia de granaderos (diminuta), hasta el número de ciento, bajo del comando del inglés don Carlos Rogers; se formó una compañía de otros cientos, surtida de oficiales de milicias y vecinos nobles de la ciudad, al comando de tres coroneles, uno, el marqués de Feria (quien se ha acreditado muy puntual en su celo y servicio), como primero; don Benito Novoa, segundo y don Gaspar Carrillo y Oruzate, hijo del primero, tercero; y asimismo dos companúas más, una de forasteros, al comando de don Juan de Higuera (creado - coronel), del capitán don Pedro Parra y el capitán don Berito Santalla y la otra, surtida con elección de las compañías, que parece, ha de comandar don Manuel Franco. Las que constan de fusiles que se han alistado y numerado y ayer se

(1) Este dato del mercadito instalado por los indios frente a la plazuela de S. Sebastín está recogido también por el capitan Ledo; Segurola, en cambio, no to menciona. aún cuando. siendo una celada, lograron los sublevados apresar 60 personas, según el Ojdor y 100 según Ledo; no se trataba de gente importante ni había caído allî soldado alguno.

12) Esta es una de las raras ocasiones en que se tiene noticia de una actuación del corregidor. 
mandaron juntar, para que empiecen desde mañana a instruirse en el ejercicio militar $y$ tomar disciplina, habiéndose reservado formar y entresacar (como en aquéllas) los te otra compañía de caballería al comando de don Ventura Carpio, para que pueda así verificarse una asamblea respetable, por llegar hasta este día las escopetas, fusiles, carabinas y trabucos, al número de 500 piezas, con las que se han ido manifestando y confiscando, y considerarse que con otras que puedan manifestarse, pueden quedar prontas algunas armas en la ciudad, cuando haiga de salirse a cualquiera expedición al Alto, con dichos 400 hombres fusileros y escopeteros que, acompanados de los de arma blanca, pistolas y lanzas pudieran ya haber logrado un progreso y evitar los daños de la demora y dispendio de la Real Hacienda. Al fin vale más, tarde que nunca (1).

Este día corrió haber venido una carta de Mariano Murillo, del campo enemigo, en una redecilla o cofia negra, con una bala, para el Comandante (2), y bajo de cubierta, otra para el padre agustino Borda, a quien parece le dice haber actuado las prevenciones que le comunicó y se terminabarn a prevenir algunos ánimos del campo enemigo, de alguna insidia contra /f.38 el rebelde, siempre que haya oportunidad. Al primero, le da parte del cumbate que el Apaza tuvo más acá del pueblo de Sicasica con el auxilio venido de Oruro, que no supo gobernarse, pues murjeron sobre ciento de ellos, por haberse dispersado; con despojo de dos cañones (que son los de la lucha de los dos días anteriores), ciento y tantas escopetas y 50 sables, sin que tuviese parte el dicho Murillo, que no pudo, actuar por ello, sus intenciones (3). Que ya venían otros de Oruro en auxilio nuestro y, pues él hacía los tiros de los cañones con puntos de elevación para no dañamos (como se observa), no era receloso, y atin corre, decía que tuviésemos cuidado de guardar las trincheras, pues los indios carecian de sujetos que manejasen las bocas de fuego. Esta falta, sin duda, es la causa porque los alzados están gritando: jvénganse, vénganse, no se mueran de hambre, vámonos al Alto donde tendrán toda asistencia y no les haremos nada! $Y$ a la verdad, que muchos cholos pícaros, oficiales mecánicos y acuartelados

(1) Es curioso que el único Díario que hace mención a hechos de este tipo sea el del Oidor, que no es militar. Tampoco se aprecia cambio alguno en el uimero de las compañías en las listas de repartos de raciones y sueldos de la tropa. UMSABC. M/99, M/115, M/134 y M/139.

(2) En la compilación de Segurola figura esra carta con el N. 15. Sin embargo, el Comandante anota su llegada el dia antetior, 4 de Junio.

(3) Se refiete al desastre sufrido por las tropas auxiliares comandadas por Gavino Quevedo, en las cercanfas de Sicasica, a fines del mes de Mayo. 
y de Larecaja, se nos han descandillado, desertando al campo enemigo. La noche concluyó con los mismos cañonazos y varios tiros continuados de escopetas [1].

Miércoles 6 de Junio. Amanecieron con los mismos titos y cañonazos hasta cosa de las 7 y más de la mañana en que cesaron y, por la tarde a las 4 , los siguieron con empeño. En el alto de Quilliquilli, junto a los dos pedreros, levantaron hoy una horca, a la vista inmediata de la plaza mayor, dominada de aquel puesto. En la casa del doctor don Antonio Paredes, empezaron con el ejercicio los de la cumpañía de oficiales y Marqués de Feria, bajo la dirección de don Dionisio Escauriza, exactísimo sujeto y hábil para todo. $Y$ en el colegio de jesuitas que sirve de cuartel y sus dos patios interiores, lo iniciaron las otras dos compañías de forasteros y granaderos a la inducción de dicho Rogers e Higueras. El 2 de Enero se hizo cargo de este comando de armas el caballero don Sebastián de Segurola y el 15 de Marzo comenzó este bloqueo funesto y lastimoso por todas partes, pero a los cinco meses de lo primero y a los 85 días de lo segundo, en que estamos acabando y han acabado muchos a centenares; se principia por el preliminar del ejercicio ${ }^{2}$.

A las 5 escasas de la tarde, asomaron sobre mil indios a la fortaleza de Santa Bárbara, a tiempo que estaba la puerta abierta por la poca pericia y actividad del oficial de guaxdia, sin que hubiese un fusil para hacerles fuego, ni artilleros que lo hiciesen con el pedrero que hay en cada fortaleza, $y$ acaso se introducen en la ciudad si don Angel Vázquez, dependiente del oidor Francisco Medina, no se comide (al pasar casualmente por aquella esquina, al ejercicio de armas) a bajar la calle y cerrar la puerta dicha. Quien después de poco rato vio que traian los alzados un hombre con los dos brazos mutilados desde la parte superior de los codos y que le dijeron ser Mariano Murillo. Pasó inmediatamente a dar parte al Comandante, de uno y otro casa y logró sacarlo y acompañarle hasta dicho fuerte, donde se hallaba este infeliz, puerta afuera, porque dicho oficial tontificado, se negó a abrirle sin orden del jefe, quien habiendo mandado franquearla, confirmó que era el mismo Murillo que, sin vestido, en calzones y camisa, con ligaduras que le pusieron para la amputación con machetes, se presentó bien desfallecido, hasta que lo pasaron al hospital de San Juan de Dios, para su curación y asistencia \{3!. En compañia suya despacharon los

(1) Si estos gritos y llamadas de los indios eran efectivos queria decir que nuchas veces éstos podían acercarse bastante a los muros sin que se les disparara.

(2) Ya se ha visto que no es ésta la primera vez que el Oidor se refiere a que por fin se inician los ejercicios; como en las anteriores ocasiones, ninguno de los otros Diarios alude a ellos.

(3) Este trágico episodio, que el Comandante reduce a dos frascs escuetas y lrias. cobrá, con los detalles dados por Diez de Medina, una riqueza vivencial tan grande que permite captar mucho mejor todo el dramatismo que debe haber rodeado apueila escena. 
rebeldes un indio que el día antes habia salido de la ciudad con aprobación del Comandante y su dirección, conduciendo al campo enemigo una carta que el religioso fray Matías Borda escribió a dicho Murillo en la casa del mismo Comandante, quien le ilustró. El indio azotado de los rebeldes, que le desconocieron por ser de la ciudad, puso la carta que le entregó el mismo Comandante, en mano del rebelde Apaza o Tupac Catari supuesto, quien montado en cólera y furor, vino al alto de Quirhiquilli, dontie manejaba dos pedreros (bien que en los cuatro cañenes de quienes era el principal, hacian el manejo los subalternos de su confianza) y, arrostrándole con esta carta, ordenó que en el alto de Santa Bárbara le cortasen las manos y brazos con que entendía en la comunicación con dicho religioso y que en la trenza del pelo le introdujesen el sobre escrito de la carta citada que le escribió el religioso. La que con efecto /f.38v trajo en la misma desposición, siendo conductor de la respuesta a ella (que produjo el rebelde) el misno indio que con efecto la trajo y se halla en prisión. La respuesta, al paso que se oculta de las personas condecoradas y de consejo, corre en el pueblo y está concebida en los términos siguientes (1): "Señor Comandante: Habiendo visto una escrita a Mariano, les prevengo que salgan por día que gustase, que por tener lástima a los criollos, no les había dado el combate hasta aquí, pero a vista de la traición que los dichos criollos hacen, he resuelto arruinarlos a totos, por lo que les despacho a dicho Mariano a fin de que no les haga falta, para ver lo que hice en Sicasica, con todo el auxilio que han tenido. $Y$ sobre todo espero su determinación para el dia en que han de salir y no estén encorralados como lus animales, senalándome dónde y cómo, trayendo al padre fray Matías de capellán, quién les está dirigiendo, con el seguro que tengo dado avance en dicho Sicasica a más dic tos mil y quinientos soldados de Cochabamba, Chuquisaca y Oruro, Buenos Aires y Potosí. No me da cuidado de vuestrn merced. Interín espero su respuesta, Dios guarde a vuestra merced muchos años. 7 de junio de 1781 . Yo el señor Virrey Tupac Catari" (2).

Las manos de dicho Murillo aparecieron a poco rato pendientes en la nueva horca en el alto y ceja de Quilliquilli. Después de habérsele destinado para su curación, se sabe por referencia de sus oyentes que cuando el rebelde partió para Sicasica, quedaron en el alto de San Pedro de 500 a 600 indios y no más. Que los

(1) A pesar de lo sostenido por el Oidor, el capitán Ledo, que era hombre del pueblo, no conoció lì ciertál y, en cambio, él. "persona condecorada". no sólo la conoció sino que pudo hasta copiarla.

(2) La carta, que tiene el N. 16 en ha compilación de Segurolá, está copiada al pie de la letra por Diez de Medina. La publicada por Ballivián y Roxas ticne incluso la frase "hacer lo que he hecho en Sicasica", donde el Oidor copia "ver to que hice en Sicasica", expresión que tiene mucho más sentido en el contex to. Segurola la fecha cl 6 de Junio. 
indios de Sicasica se remontaron a las serranias, fugitivos; que hubo considerable mortandad de los que moraban en dicho pueblo, inclusa la mujer del buen Bolaños. Que el cura doctor Barco le obsequió con una cigarrera y caja de oro y los ajuares del corregidor Anchorís. Que con su gente derrotó a 200 hombres españoles que se portaron mal gobernados y dispersos; que por eso atrajo y sujetó así a los de Sicasica. Que murieron de los nuestros hasta el número de 100 hombres, los que con los demás que retrocedieron prófugos, pelearon y se defendieron con mucho espiritu y valor, con destrozo considerable de los indios rebelados, y se fueron a juntar con las tropas que dejaron atrás y dice venir comandados de un don Gavino (sin saber su apeilido) (1). Que ganaron a los nuestros dos mulas cargadas de pólvora; una, de las balas (que ya se dijo nos arrojaban estos días) y olra, de granadas, con los dos cañones o falconetes referidos, 120 fusiles, que mandó forrar en cuero húmedo para malograrlos, por no tener quienes los manejen, y 50 sables, los dos o tres con el puño guarnecido de piedras, que reservó Apaza para sí. Que aquella noche de esta desgracia tan sensible y melancólica en todas sus partes, pasó en compañía del rebelde Apaza a explorar la retirada de aquéllos y las tropas que ya sabían venir atrás y que divisándolas acampadas con dilatación de terreno, conjeturando que bien podrían componer más de dos mil hombres, se retiraron aquella mesma noche y se pusieron en camino para El Alto de esta ciudad, con la gente muy aminorada. Que después, por los espias supo el Apaza que ya estaban en Viscachani (hacen cuatro días), a distancia 19 leguas de esta ciudad. $Y$ añade que el señor Flores, se supo, quedaba en la villa de Oruro, próximo a partir para ésta, por las provincias sublevadas de Carangas y Pacajes y que en esta última debía unirse con las tropas auxiliares de Arequipa y Tacna que estaban ya caminando de Chucuito para ésta, con el desigrio de la combinación.

Este día fue funesto, porque después del pesar que nos presentó el espectáculo de Murillo, con dichas nuevas inesperadas, con motivo del ejercicio de armas (que cesó esta tarde) y distribución de compañías, se mandaron retirar de las fortalezas y espaldones los oficiales de guardia, con cuyo hecho la soldadesca anduvo a su libertad y los puestos desamparados, de modo que por la noche es claro que los indios no quisieron entrar a la ciudad ni usar del salvoconducto que palparon en algunos fuertes y principalmente el de la Caja del Agua, donde estuvieron con irregular inmediación. Portentos todos visibles, que debemos a la protección de la Señora soberana de La Paz.

También dice Murillo que nuestros Andes de Yungas, sin reserva de Chulumani, estaban arrasados por medio de los comisionados que envió Apaza para conmover a aquellos indios, que se levantaron obligando a dejar la provincia al

(i) Se refiere a Gavino Quevedo, el militar derrotado en Sicasica. 
corregidor don José Albizuri con su gente dis-/f.39 puesta para el valle de Cochabamba, habiendo muerto a los que lo seguían en segundo trozo y convoyaban a las mujeres españolas en el pueblo de Irupana. jPérdida la más sensible para esta ciudad que depende de aquellos Andes y fruto de la coca y de mucho atraso para la Real Hacienda, minas y comercio puiblico!

Jueves 7 de Junio. Amanecieron con el fuego de los seis cañones, batiendo la ciudad desde la noche pasada y con fusilazos continuos por las calles. Los nuestros mataron a un mozo o medio indio de capa, que había salido fuera de trincheras, a quien, desde la de San Sebastián, Lizargarate le tiró con una bala de escopeta y le dejó muerto en el sitio, a consecuencia de la orden que por punto general tiene comunicada el Comandante, para hacerlo con todos los nuestros que saliesen fuera de trincheras, por los muchos que van desertando al campo enenigo (1). Los relseldes emboscados salieron y se cargaron este cadáver; ignórase si por aprovechar y despojarle de sus ropas o si por ser de su facción.

Hoy se supo que Murillo, refiriendo la condición carnicera del Apaza, dijo que éste había mandado ahorcar y degollar en su campo más número de los indios alzados que los que habian muerto en refriega con nosotros y ahorcado y degollado en la ciudad, porque todo to castiga con pena de la vida y azotes, sin reservas de un hermano a quien hizo ahorcar, estando ebrio, por una levedad. También hirieron los enemigos, de un balazo en la boca, a un mozo del alcalde Indaburu, a quien le guitaron dos muelas. El fuego enemigo pausó desde las 7 de la mañana hasta las 2 de la tarde, en que lo continuaron hasta toda la noche, como que tomaron bastante pólvora, bien que les quedaban muy pocas balas de calibre, por decir Murillo, procuró consumir por elevación cuasi el todo de ellas. $Y$ así es que ayer y hoy nos baten con piedras. En este dia se dispuso que dos compañías, de las cuatro alistadas de asiento, hiciesen la guardia en las trincheras y fuertes con sus armas de fuego, alternando por días con las otras dos nuevamente formadas y compuestas de igual número. Por la noche hubo trompetas, grita y pífanos como las más y acudieron los enemigos al fuerte de las Recogidas, más que a otros, con seguido fuego de sus escopetas.

Viemes 8 . Sigue el fuego enemigo de cañones y escopetas, lo mismo que el día de ayer. Por la noche publicaron en Santa Bárbara, despidiéndose y diciendo que ya por fin habjamos salido con nuestro gusto: ¡Ya nos vamos, sólo esta noche os la daremos mala pero nosotros sabremos lo que haremos! Siguieron la algazara hasta

(1) A medida que avanzaban los días y la situación se iba haciendo más desesperada, el número de desertores iba en aumento; de ahí que fuera explicable la medida tan drástica tomada por el Comandante para detener el desbande de la población militar, que habría terminado por dejar a la ciudod sin defensores. 
Jas 12 de la noche y al amanecer continuaron con el fuego de los cañones. Según sus movimientos presurosos, parece que se hallan traskadando al campo de Potopoto todo lo que tienen hurtado de dineros, plata labrada, alhajas, comestible y otros bienes, con ganados, desde el alto de San Pedro, sin que por eso se les pueda creer תada, ni tomar substancia (1).

Sábado 9. Siguió el fuego a pausas y, por la noche, incendiaron la casa de las Recogidas y su iglesia, que está fuera de trincheras y amanecieron ardiendo. El domingo siguiente, murió Mariano Murillo con las llagas de los brazos gangrenadar (2).

Domingo 10 de Junio. Sigujeron el fuego dicho de canones, remisamente y a espacios de tiempo. Por la tarde salió la compañía de granaderos, con don Juan de Higueras, al alto de las Recogidas, por tierra de salitse para la pólvora. Se dice mataron 10 indios (que no creen muchos, porque an este punto es mucho lo que claudica la verdad), pero lo cierto es que los alzados nos hirieron de bala dos granaderos, uno en la cabeza y otro en el pulmón, ambos de muerte. La noche, siguieron batiendo la ciudad y, a la 1 de la mañana, nus invadieron por el empeño de entrar a la ciudad con la algazara acostumbrada de voces, injurias y curnetas y con raro tesón arrojaban piedras por las hondas, principalmente por las fortalezas de las Recogidas, Santa Teresa, San Francisco, San Sebastián (donde nos hirieron un oficial barbero en una mano con un balazo) y en otras. Tambien corre, murieron algunos indios y que otros se retiraron heridos, lo que es verosimil, porque los nuestros les hicieron competente fuego y ellos se atrincheraron entro de las paredes fronteras de las casas quemadas, de donde juegan la houda y disparan incesantemente sus escopetas contra la fortaleza, como por todas las que circundan la ciudad.

Lunes 11 de Junio. Siguieron batiendo la ciudad con fusiles y cañones, a menudo. La noche fue parecida a la pasada, pero no con tanta furia. Parece vino del alto de San Pedro un muchacho de un carpintero, con la nueva de haliarse varios españoles de auxilio en un pueblo de Pacajes $/ f .39 \mathrm{v}$. donde mataron siete mil indios. Es mucho numero para creerlo; pudieron haber hecho alguna mortandad si es que viene, como se dice, don Andrés Ordónez, aunque necesita confirmación. También refiere que el indio Apaza les mandó 500indios de auxilio a consecuencia del que le

(1) Catari, que sabía muy bien la ubicacion de las tropas de auxilio, ordenó con buet criterio el traslado tanto de los bienes saqueados como de los comestibles y ganados, desde el cuartel deI Alto al de Potopoto. La medida fie tan decisiva para sus tropas que exjlica en gran parte la facilidad con que los sublevados volvieron a rodear la ciudad en cuanto Flores se retrí el 5 de Agosto del $8 \mathrm{l}$.

(2) La frase dedicada a la muerte de Murillo. que ocurritía al dia siguiente, demuestra que el Oidor no siempre escribia sus notas dia a dín. 
pidieron por un extraordinario. Pero en todo es de suspender el juicio hasta la confirmación. La noche fue de grita pero no tanta como la pasada y repararon que sólo batían la ciudad con cuatro cañones, acaso porque los otros pudieron haberlos conducido con dicho auxilio de 500 indios, si es efectivo. La noche tuvo sus intervalos en el batirnos los enemigos, con dichos cañones.

Martes 12. Batieron igualmente la citudad a pausas. Se vieron muchos indios que de la parte de Potopoto pasiron con el caudillo rebelde, con aparato de bailes o danzas que estilan para la fiesta del Corpus, para el alto de San Pedro. No hubo novedad mayor. Nos mataron por una bala un muchacho o cholo de pechos, hacia la fortaleza de San Francisco, y la madre quedó damnificada. La noche la siguieron batiendo con dichos canones, pero poco, hasta la madrugada. $Y$ las trincheras estín hoy bien resguardadas, porque dos compañias de las de 100 hombres con sus fusiles, tuman diariamente con las otras dos. El pueblo se queja que teniendo pedreros la ciudad no se piense en hacer fuego con ellos, ni concurtan los artilieros que del todo se han cchado con la carga, aún viendo a los enenigos a boca de cañón y que pudieran haberse castigado muchos, para que sirviese de algún escarmiento a apagar la sunta osadía y altivez en que están los indios. Un espanol se venía con su fusil, del campo enemigo, a quien nos lo mataron los rebeldes que le siguieron y aprehendieron por ver que tomaba el sendero para la fortaleza de las Recogidas, a cuya inmediación fue el suceso.

Miércoles 13 de Junio. Continuaron los enemigos con el fuego de sus cañones; se acordonaron en el número de seis mil computados, en el alto de San Pedro y camino para Potosí, con multitud de bailes. Por la noche tuvieron allí iluminaciones, muchos coletes, cuatro castillos y otros juegos de diversión, con muchas cajas, grita $y$ borrachera, y los que estaban en las circunferencias de la ciudad los acompanaban desde abajo, con el bullicio de cornetas y vocinglería, como las noches pasadas ${ }^{(1)}$.

Jueves 14 del Corpus. No se celebró esta festividad en la ciudad porque los indios en la procesión no nos causasen averias, con sus cañones. Lo que tuvo a la vista el celo de nuestro Ilustrísimo prelado, quien la mandó transferir para mejor ocasion (2). Los indios sí que tuvieron su celebridad y muchedumbre de

(1) A pesar de que los alzados tenian el avance de los auxilios que traís Flores, como lo demuestra el traslado de los víveres, ganado y plateria, no pueden perder la ocasión de festejar, en una forma un tadio pagana, pero ya entonces tradicional, la fiesta del Corpus.

(2) Los sitiados, aunque eștán esperanzados con las noticias del arribo de las tropas de auxilio, no pueden ni siquiera cejebrar la procesión de Corpus: sin embargo, se ve que para ellos tenía lambién tanta importancia la celebración de la fiesta que el abispo tuvo que prometerles transferirla para otra cóasión. 
concurrentes aún de los Yungas, que les han porteado en homenaje nuchos frutos y verduras de aquellos Andes y, aún se dice haber venido y tener su campamento separado, en el valle de Potopoto, espaldas de esta ciudas. Cejebraron su procesión en dicho Alto, y tuvieron dos castillos de fuegos que, con los de anoche, se dispararon a nuestra vista. Cuando el último, salieron a las dos y media de la tarde dos comparias de forasteros y granaderos con 50 de a caballo, para el alto o puesto del Calvario, con el designio de tomar los pedreros que tenían en la cima. La una, salió por la Caja del Agua comandada por don Juan Higueras y la otra por la cuesta de Coroico al alto de Quilliquilli, con dicha cabalieria comandada por don Ventura Carpio. Don Manuel Franco partió con otra compañia a Santa Bárbara a tomar los enemigos por el medio. Los granaderos fueron acosados de 70 a 80 indios que les arrojaban muchas piedras por sus hondas, pero guiados del inglés don Carlos Rogers (en fila), que avanzaba con su sable y rodela en mano, animando a que le siguieran los suyos, con presencia de ánimo y generosidad ganaron la cima sin diffcultad, hicieron fuego bastante y aún dice Rogers que pueden haber muerto cosa de 40 indios. Estos, luego que se vieron perdidos, tuvieron el ardid de echar los pedreros cerro abajo, para la parte de l'otopoto $y_{f}$ si los furasteros no se echan al pillaje de las frutas y comestibles, con el desorden que se deja entender, turbando la empresa, pudieron haber bajado algunos a recogerlos, sostenidos de los otros que de arriba pudieron mantener graneado el fucgo, con estrago y desrota de los enenigos que, unos estaban a la parte inferior y otros venidos a vista de ella, del alto de San Pedro y Potopoto y, si tenían que subir, pereciesen sin remedio; pero, como estas gentes y en especial los forasteros del / f.40 pucblo de Palca y el de l.arecaja, se terminan primero al pillaje que a la acción, por vicio que han tomado desde el principio, por falta de disciplina y obediencia militar, se fustró el empeño y tuvieron que retirarse de orden del buen Rogers que to previno al ver que la multitud de los enemigos ctecia por instantes y los acordonaban, como que bajaron del alto de San Pedro cosa de dos mil indios en auxilio de los suyos; contentándose con enviar cerro abajo, para la ciudad, las dos cureñas, que son las mismas qute nos ganaron en Potopoto el 26 de Marzo y se hallan ya en casa. A cuya retirada hubo una media refriega en el alto de Santa Bárbara, pero sin desgracia de nuestra parte pues a las tres y media de la tarde, ya estuvieron los nuestros entro de trincheras. Los indios en despique apuraron el fuego de los cañones escondidos y los que mantienen por ta parte de San Pedro (1).

(1) La narración de la acción despleguda para recuperar los dos pedreros del Calvario es más o menos parecida en los Diarios de Segurola. Ledo y el Oidor. En cuanto al resultado de la empresa, Segurola lo considera un éxito. puesto que, si bien no se recuperaron los cañones, quedaron inutilizados desde el momento en que los indios los desbarrancuron; además, se recuperaron las cureñas y plata labrada y se obiuvieron cargas de coca, oomida y frutas, y lodo 
Esta mañana se tomó un indio enemigo de Potopoto herido de una bala muestra, desde la trinchera de San Juan de Dios, a quien lo condujeron preso. Sábese por él, que el Apaza mandó dos mil indios contra nuestros auxiliares que dicen vienen caminando del pueblo de Ayoayo para acá. No es lo peor para nosotros, porque asi en trozos tienen menos fuerza y llevarán su merecido por nuestro gobernador de armas, don Ignacio Flores. $Y$ si con esto, como piensan los rebeldes, le arrostran en el Alto, será más breve muestra restauración, porque se encontraran con todo lo contrario a la blandura y descaecimiento de esta ciudad, sin que el Apaza tenga quizá tiempo para huirse, según piensa, a los Yungas. Lo que dilataria nuestro trabajo por lo áspero, fragoso y montuoso de aquellos caminos estrechos que dificultarían e] tomarlo y redimir aquellos Andes que, como se dijo, hacen la costa de la ciudad.

Entre las particulariciades precedidas en esta tarde se cuenta que nuestro Comandante, después de haber montado a caballo para el despacho o expedición de la tropa, se fue a apear a la fortaleza nombrada San Miguel que fabricó Zavala en la línea del Calvario, de donde vio aquella función o desgreño raro (1). Que en el Alto habia algunos víveres y frutas. Que un soldado nuestro tomó y bajó una bolsa de dincros compuesta de 300 a 500 pesos, según opiniones. Que otros trajeron diferentes piezas de plata labrada; que dos de caballería, un odre de vino cada uno, en su bestia. Que uno rodó cerro abajo, porque al descender recargado del pillaje, lo atraparon y gholpearon los intios con sus palos, de modo que si el capitán don Pedro Parra no to auxilia disparándoles su escopeta y obligándoles a correr con la muerte de uno, le matan. El nuestro salió con vida y algo herido de la rodada. Que una galga de un pedrón de doce arrobas o más que, al retirarse los nuestros, les echaron de la cima del cerro, capaz de haber causado mucho estrago pasó por un lado, dejando los nuestros indemnes. A las cuatro y media de la tarde se empeñaron en batir la ciudad con dichos dos pedreros de la empresa del día, que los repusieron y manejan en el mismo puesto sobre un acerbo de piedras y tierras y así mesmo

esto sin la pérdida de un solo hombre. En cambio, Ledo, sin exagerar los tonos como lo hace el Oidor, considera que le expedición no tuvo el fin deseado por el afán de pillaje que distrajo a la tropa. El Oidor. que considerát todo como un desastre, culpa en sus juicios a los forasteros y larecajeños dedicados al piliaje.

11) Esta es una forma de acusar a Segurola por no haber salido a luchar fuera de los muros; se había contentado con quedarse a contemplar la escena del rescate de los cañones desde el fuerte de S. Miguel. -Segurola, en su Diario, dice este día: resolví hacer una salida, para ver si podía lograr con ella quitarios o por lo menos clavarlos" (los pedreros). Sin embargo, a traves de sus notas se ve que verdaderamente se redujo a preparar el plan, dejando que sus capitanes lo realizaran. 
con las dos culebrinas nuevas que estaban arriba de San Pedro, hasta las 7 de la noche habiendo sido el resto de ella, tranquilo.

Viernes 15 de Junio. Bajaron muchos indios y mujeres del alto de San Pedro y se fueron emboscando en diferentes lugares de la campaña. Se manifestaron en el del Calvario y su ceja, sobre 300, en cordón y, presumiendo que hoy repitiésemos la salida de ayer alli, se fueron engrosando con muchos bailes y danzantes que acostumbran en tiempos del Corpus. A las 11 del dia nos manifestaron seis mulas cargadas de coca, como dando a entender que la que ayer les despenaron y arrojaron los nuestros, no les hacia falta, aún cuando ayer mismo y esta mañana la estaban recogiendo con prolijidad. Los que bajaban del alto de San Pedro se iban congregando al pie de la cuesta de Potosi, donde hicieron su conciliábulo, acaso para molestarnos esta noche, según sus muestras acostumbradas. El picaro Apaza se manifestó por la mañana de cabriolé encarnado, en la cima o ceja del cerro del Calvario, como que alentaba a los indios y que había bajado a reconocer lo que ayer precedió. Batieron a pausas con tiros de pedreros, la ciudad, y con algunas escopetas, porque tienen pocos que las manejen, aunque ahora cuatro dias se nos fueron dos gra-/f.40v. naderos con el uniforme y su familia y se les conoció en el mismo traje, haciéndonos fuego entre los alzados. La nuche nos batieron igualmente con mucho bullicio, porque con sus cornetas, grita y aullidos, acometieron emboscados ien las casas, hacia las tronteras distantes de las fortalezas de San Juan de Dios, Recogidas, San Francisco, Sm Sebastián y la Paciencia, con incesante pedrea de hondas. En la de las Recogjoas, hubo fusilero que se vino a tirarnos al mesmo puente, línea recta de la trinchera. Parece que de ella derribaron con tiros de balas cinco enemigos y que el uno arrojó los sesos que se hallaron con lagos de sangre y las huellas de los cuerpos heridos o muertos, que observan arrastrarlos. En las otras fortalezas citadas pudo suceder lo mismo, más o menos (como en otras noches, aunque el efecto de nuestro fuego nocturno es inaveriguable) porque los nuestros lo hicieron muy competente. Salió herido de una pedrada entre la frente y cábeza el dependiente del oidor Medina, don Angel Vázquez, que estaba de guardia haciéndoles fuego y se acredita con aplicación y honor. Sucedió la particularidad que al retirarse de la misma trinchera el armero don Juan Manuel, con su capa de paño terciada en el hombro, le dieron los alzados un balazo, que calando por los pliegues o dobleces de la capa en siete ut ocho partes o bujeros, quedó la espalda sin lesión alguna. De cuyos prodigio semejantes se han visto muchos que parecen miraculosos (1).

(1) Estos detalles anecdóticos, que jamás aparecerán en el Diario del Comandante, escrito en estilo militar, son como siempre los que dan calor de vida a las anotaciones del Oidor. 
Sábado 16 de Junio. Se recogieron los indios de anoche a las 7 de la mañana para el al to de San Pedro, pcro no todos. También batieron la ciudad, pero muy poco. Con dichos bailes y la marcha que suelen acostumbrar, se nos presentaron en cordón, a las 11 del día, en la ceja del cerro y línea del Calvario. A la mesma hora empezaron a bajar del alto de San l'edro, por puntas y alguilas ordenadas en filas para volvernos a incomodar a la noche. $Y$ aunque se dice que hay mucho número de indios, no parece trascienclan de cuatro a cinco mil, chando más. La noche la principiaron batiéndonos con sus cañones, piedras y balas pero con digresiones. A las 11 empezaton con cuatro cañonazos sucesivos y mucha más vocinglería de la anterior. Acometieron a nuestras fortalezas $y$ paredones con piedras y fusiles y con mucho tesón y empeño, sin reparar en la mmerte ni ponerse a boca de cañón; de modo que, si no son las prineras dos incursiones nocturnas, se puede decir que en ninguna noche nos pusieron en ritayor riesgo y aprietos, ya porque lograton incendiar una casa entro de trincheras, arriba del barrio que llaman de Carcantia, otra a un lado, por bajo del monasterio de la Concepción, en el Molino Viejo de don Cristóbal de los Barrios, y otra hacia la Caja del Agua; ésta y la primera se discurren hechas por la emisión de flechas en cuyas puntas vienen encendidas las candelillas o por cohetes con mechas, que también se les ha visto arrojar para el caso, aunque sí se cortó la combustión al principio, bien que la primera tomó cuerpo y logró cortar el celo de nuestro Conandante, mediante los carpinteros y otros auxiliares que destinó con presura y eficacia (1). Yal porque a diferentes puestos acometieron los sublevados con barretas y empezaton a foradar las paredes, lo que hubiesen logrado a no ser las guardias que esta noche $y$ las pasadas, desde el miércoles en que se vino Murillo, aumentó, con escopetas, nuestro general; quienes las dispararon con alguna mortandad, según las señales de la sangre efundida, y los ahuyentaron, habiendo contribuido mucho el que desde esta tarde hubiese mandado convocar las companías de fusil y oficiales, en esta plaza mayor, donde estuvieron presentados a las 10 de la noche. Porque sin esta cautela, mientras los juntaban (en tales apuros cualquiera tardanza de las que se han notado en otros casos anteriores) pudieran habernos quizá perjudicado, ya porque aún con esto hubo mucho que sentir, porque varios de los señalados a resguardar la trincheras se retiraron con sus armas o las ajenas a dormir a sus casas, con no menos peligro de la ciudad y obligando que de diferentes trincheras viniesen unos en pos de otros por refuerzo all Comandante, aún habiendo librado y repetido dos y tres veces para un mismo lugar. Unos que venían oficiosa y maliciosamente a pedirle por librarse mientras tantorde las pedradas, otros por embelecos y embustes, ponderando ya la entrada de los indios a la ciudad y

(1) El episodio del incentio y su exlinción da ocasión para que siquiera por una vez Diez de Medina aplatuda el celo del Comandante que toma tan eficaces medidas. 
otros porque de verdad no habían cumplido con el destino los enviados para el refuerzo, cuyas irregularidades fatigaron y exasperaron al Comandante ${ }_{t}$ con fundada razón (1).

Hacia el molino y la calle frontera, pasado el río, se notó efusión de sangre en varios pa-/f.41 rajes, como en la calle recta para San Sebastián. Lo mismo sucedió en las Recogidas y paredón calle derecha del monasterio del Carmen, donde a los fusilazos nuestros dejaron los indios que manejaban las barretas y sus palos, que recogieron los nuestros, porque huirian heridos y de priesa. Lo presumible es que hubo alguna mortandad de rebeldes, aunque con el ardid de guerra que éstos tienen para ocultar y llevarse los muertos, para que no tome satisfacción el enemigo, no cabe juicio positivo en este punto.

El avance que intentaron fue por toda la circunferencia de la ciudad a un tiempo, menos en jos fuertes de Santa Bárbara y la Riverilla. Esta noche se portó generosamente en el de las Recogidas don Pedro Martinez que, destinado a reforzarlo, lo halló con los dos oficiales de guardia y no más, a tiempo que los indios acometieron con barretas, en multitud. Los desparpajó a gritos con la descarga de su trabuco y pistola; resolvió que les hicieran fuego con el pedrero (con que parece murieron aigunos), y así los ahuyentó. En la Paciencia hirieron de un balazo a don Roque Manzaneda, muy hombre de bien y a un Pacheco de Arequipa en la cabeza, en otro puesto. En este día murió don Mariano Gisbert de resultas de otra percusión igual, que se dijo ser rasguño en la cabeza, cuando la salida a los altos de San Francisco, en que mataron al vizcaíno don Pedro . . dependiente de don Juan Bautista Zavala. Los indios se despidieron para repetir la noche venidera, protestando entrar a la subsiguiente a la ciudad. ¡Estupendo tesón de bribones, que han hecho una la causa común de sedición! Sin que se vea uno que se haya venido y se les hubiese rebelado, cuando los nuestros se han rebelado y desertado de la ciudad (2).

Día domingo 17 de Junio. Se retiraron los indios de madrugada para los altos de San Pedro, Santa Bárbara y Quililiquilli; fueron raros los cañonazos que entre día nos dispararon. A las 6 de la tarde, en que ya habían bajado, aunque no tanto como los de ayer, empezaron a tañer sus trompetillas, señal de ambocarse para el acometimiento. En esta tarde mutió el axequipeño Pacheco, de la herida de anoche y

(1) No hay duda de que ese día el Oidor pasaba por un buen momento; no sólo no culpa al Comandante de la irresponsabilidad y cobardía de tu tropa sino que comprende y aplaude el que tratara duramente a sus hombres, movidu por la exasperación que le producia su proceder.

(2) Es notorio el ardor que ponen los sublevados en los ataques de esos días; se tratabn de derrotar a los sitiados antes de que recibieran los refucrzos. Si no se les había podido vencer en tres meses de encierra, mucho más difícil sería lograrlo después. 
se acabaron de cerrar las brechas que por la línea del Calvario habían abierto anoche los indios, y en particular la una, por donde al descubrirse, mató dos sublevados el regidor don Turibio Castro con su escopeta a boca de jarro y así ahuyentó a los demás de aquel lugar, donde dejaron sus palos, una montera y una honda. Por la tarde se pegó fuego en la fábrica de la pólvora en 50 libras de ella, que se estaba secando, por causa del cigarro que fumaba un negro, y están contaminadas y de peligro cuatro personas que estuvieron inmediatas a la ituflamación (1).

Habiendo bajado los indios del alto de San Pedro, en considerable número esta misma tarde, al fin, a las 11 de la noche, con la señal de un cañonazo, se levantó una simultánea algazara de éstos, por la parte de las Recogidas, San Juan de Dios, San Sebastián, la Paciencia y en especial en la plazuela de San Francisco, frente a la trinchera, a la que acometieron despechados y con precipitación nunca vista, que súlo el ardor bárbaro pudiera prevenirla sin temor del fuego y de la muerte. Ý por eso fue raro el tiro nuestro que no operase en los grupos que formaron al presentarse, tanto que el pedrero de este fuerte, que nunca se había disparado por Falta de proporción, a vista de esto, se manejó con conacido efecto. Fueron muchos los que murieron y se los iban arrastrando, de ambos sexos, y asimismo los heridos, pues por la mañana se vieron varios puestos bañados de sangre, unas ojotas ensangrentadas, veinte $y$ tantas hondas, que serían de los muertos y heridos, por curyo castigo tuvieron éstos que pausar con la grita y retirarse bien temprano o trasladarse a otra parte, porque los indios del alto de Santa Bárbara, que por la bajada de Quilliquilli fueron descendiendo y desfilando con raro silencio y acopiando piedras hacia el fuerte de Santa Teresa (bien que sentidos de los nuestros, que por medio del celoso capitán don Pedro Ramírez de la Parra, se pusieron en buena disposición de defensa), al golpe de las 12 de la noche y reseña de otro cañonazo, levantaron a un tiempo sus voces insultantes y se presentacon juntos y apiñados como si resultase un hormiguero en el río Seco que está al pie e ínmediato, acometiendo con la misna o aún mayor impetuosidad e intrepidez que aquéllos. Unos foradaban con barretas, otros solicitaban quebrantar con piedras la puerta de la fortaleza $y$ otros se presentaban frente a /f.4lv, ella con rara insolencia $y$ atrevimiento increible. Otros arrojaban por sus hondas una lluvia de piedras contra los nuestros y por eso, habiéndose jugado tres veces el pedrero cargado de metralla contra aquel mormollo, es regular que causase, como se notó, considerable estrago.

(i) Los oluos Diarios no mencionan el incendio de la fábrica de pólvora. El Comandante sólo anola que ese día se quemó una casa dentro de los muros pero logró apagarse sin que el fuego se comunicara a otras casas. Puede haberse tratado del mismo acontecimiento, pero Segurala lo supone efecto del ataque indigena y no consecuencia del descuido del negro. 
Por otra parte el fuego continuo e inerrable de nuestros fusiles lo causaba manifiestamente, de modo que aquel que por impericia no era certero, lo fue en esta ocasión.

Lograron los indios abrir una brecha formidable por una pared que confina con dícho río Seco y salieron a un corralón cercado de las paredes de una casa, desde cuyos tejados, prevenidos los nuestros, les hicieron el mismo fuego y mataron a muchos ahuyentando a los demás, sin que se osasen a volver o a asomar. La sangre se puede decir que corrió y aún hizo su raudal con varios lagos, así en este corralón como en diferentes puestos del rio dicho y en el cerizal inmediato; pero, con todo, siguieron tenaces con la grita y la pedrea hasta más de las 6 de la mañana en que se retiraron. Conieurrirían aquí más de dos mil indios $y$, entre muertos y heridos, computa el dicho Parra, que es parco en esto, 80 personas, por la parte que menos. En otras trincheras y paredones, por donde acometieron igualmente, foradando con barretas, en especial en el de la Carcantia o línea del Calvario, donde abrieron y rompieron algunas brechas, como en el espaldón de Salazar, murieron y profugaron heridos algunos y lo mismo en las demás trincheras, porque de todas partes donde acometian, salían con buenas roseadas, habiendo dejado varios palos y hondas en dicha línea del Calvario, donde al foradar tenian emboscados sus fusileros en las casas quemadas y fronteras, para resguardarlas; pero sin desgracia nuestra a excepción de un centinela nuestro, que por quedarse dormido en el paredón de Riva se cayó del tejado fuera de trincheras y fue el infeliz sorprenidido de los indios que le degollaron. Regulan unos hasta el número de 400, pero, moderadamente, de 180 a 200 indios, entre los muertos y heridos en esta noche, que hasta hoy no la hemos tenido, ni de más riesgo entro de trincheras, castigo considerable que quizá arredre para lo futmro a estos bárbaros, locos y brutos feroces.

Concurrieron y murieron entre ellos algunos indios de los Yungas que vinieron en auxilio y homenaje del Apaza maldito, pues se hallaron aquellos anchos talegones tejidos de los chunchos, en que guardan la caca y viveres y llaman maris y son del uso especial de aquéllos (1). Esta noche se notó que algunos de los fusileros enemigos nos tiraban sin balas; se presume sean los desertores, que por la hambre se fueron a servir así al campo enemigo. Los enemigos sólo juegan dos cañones y se echan menos los cuatro restantes que deben tener. Dícese haberlos conducido a recibir o resistir nuestros auxiliares, pero vagamente y sin fundamento (2).

(1) Puede apreciarse que Tupac Catari había logrado captar a su partidn a los indios sublevados de Yungas, que ya no sólo actuaban en sus valles, sino que ahora habian subido hasta el altiplano para colaborar en el sitjo de La Paz.

(2) El acarreo de los pedreros hasta Sicasica y Calamarca no está señalado en los otros Diarios, que sólo se refieren a que Catari ha sido llamado para detener el avance de las tropas de auxilio. 
Lunes 18 de Junio. Fue silencioso y apenas se oyó uno u otro tiro de escopeta de los enemigos. La prima noche fue igual y se oían algunas cornetas y por instantes alguna grita. A las 11 de ella, acudieron algunos hacia San Francisco, con intermisiones de la misma algazara, pero sin atteverse ya a presentar los cuerpos por el escarmiento de la noche pasada. A las 12 hubo la señal de los dos cañonazos y gritaron consecutivamente alrededor de la ciudad por poco espacio y luego cesaron, aunque con las mismas digresiones. El Comandante mandó que no se cerrasen las brechas que abrieron Ia noche pasada; las repararian los enemigos existentes y entraron acaso en sospecha de ser asaltados al entrar, y así no se atrevieron, como que de verdad lo hubieran pasado mal. Al amanecer salian de entre las casas donde se emboscaron y mataron los nuestros a algunos, con tiros de fusil, desde algunos puestos. Hoy se hallaron casualmente dos arrobas de pólvora a vendèr en una tienda, con que Dios parece compensó la inflamación de ayer (1). Por la mañana estuvo el Apaza tendido en el alto del Calvario, con una bandera encamada en la mano y cruz blanca en el centro, la que la hizo después fijar allí, dice el padre fray Matías Borda ser de Tupac Amatu, enviada al verdadero Catari de Chayanta, con copia de una carta que éste escribió al señor Visitador General, las que interceptó Apaza, mandan-/F.42 do degollar al conductor (2).

Martes 19 de Junio. Por la mañana corrieron varios fusilazos de los enemigos hasta el mediu dia. Desde las 2 de la tarde, nuestras trincheras hicieron algún fuego $y$ le continuarom hasta las 5 , segun la proporción de los objetos divisados. Los enemigos pusieron unas tiendas de campaña hacia la garita y cuesta que sale para Potosi, donde hoy se vieron grupos de concutrentes. Discúrrese que allí han puesto alguna plaza o mercado de víveres, porque ellos, a la verdad, se hallan dueños de los extramuros y ciudad quemada, donde moran y habitan y duermen con sus mujeres, de modo que están echados en sus camas y gritando muchos, para contribuir a la algazara noctuma de los invasores, con lo que en mucha parte se han relevado de la

11) El hallazgo de estas dos autobas de pólvorn no está señalado en los otros Diarios. El hecho de haber encontrado tal cantidad, cuando se corría tanto peligro para acarrear tierra salitrosa con qué prepararia, indica an descuido increible en las requisas o una desidia o mezquindad any grave en los tenderos.

(2) Ninguno de los otros Diarios se refiere a este episodio. No queda por ello muy en claro si fue esa copia de la carta de Tupac Amaru al Visitador Areche, que podría haber estado acompañada de algunas indicociones para Tomás Catari, la misma que se supone inter iriố Julián Apaza cuando eligió su nombre de guerra: si existió y no es fnuto de la imaginación de sus contemporáneos, no se ha podido identificar ni siquiera a través de su confesión. 
pensión de subir al alto de San Pedro y tener que bajar diariamente y a veces por día y noche (1); con cuyo respeto y el de oponerse a que los nuestros salgan al rio por agua, han levantado una trinchera de piedras sillares, arrancadas de las portadas de calles y tiendas de las casas quemadas, a la frente de la de San Sebastián, de donde arrojan piedras y balas contra los nuestros, sin permitirles la salida y haciendo oposición a los guardias de ella, con mayor inmediación y seguridad para batir la ciudad. Supónese que nuestro gobierno tomará la providencia conveniente para remediar esta insolencia y este dar̃o ${ }^{22\}}$.

La noche fue de mucho ruido consecutivo y de alguna pedrea desde distancia. Les disparamos pausadamente, en especial de la citada trinchera de San Sebastián; pero los otros nos batieron con fusiles y cuatro canones, y a cada hora los disparaban éstos, hasta el amanecer, menos los falconetes que ganaron y se extranan, acaso porque, con efecto, los pudieron conducir a la contestación que blasonan, de nuestros auxiliares. Esta tarde, con motivo de estar apedreando la trinchera y casa del prebendado Bernardino Uría Illanes, salió éste a un altillo de su traspatio, de donde les exhortó y amonestó con oportuna providencia, por sus excesos, procurando atraerlos con diferentes discursos al servicio de Dios y del Rey. Los indios se quitaron las monteras y uno de ellos se le hincó y aungue los otros se le oponían, él decía ser sacerdote. La sesión duró hora y media y se retiraron dejando de acometer, pero dificilmente comencidos. Entre las cosas que respondieron, una fue decir que nosotros les ensenábamos a matar las gentes y quemar las casas, con los sucesos y nuestra expedición a los pueblos de Viacha y Laja y que si no fuese esto, nunca se hubiesen atrevido a hacerlo con la ciudad, que es la cantinela frecuente que ellos han tomado como el tema de sus sucesos (3). La otra fue que les entregasen a los cinco corregidores que estaban en la ciudad y que con esto se mitigarían y se subordinarían. Sobre uno y otro les redargüió sólidamente y con un espíritu apostólico el dicho prebendado, concluyeudo que el Apaza o Catáui

(1) La idea de instalarse en aquellas casas abandonadas y semi destruídns, fuera de facilitar los movimientos indígenas y ayudar a controlar las salidas de los sitiados, ventia a significar un asentamiento de los rebeldes en zonas que si bien no estaban dentro de los mujos, pertenecian a la ciudad española propiamente ta!.

(2) La instalación de estas trinchejas frente a las españolas es una demostración muy cabal de la forma en que los rebeldes aprendieron y utilizaron los sistemas bélicos espatioles. Resultaban tan eficaces para sus planes que fue preocupación inmediata pot parte del Comandante el destjujsias.

(3) Cono los otros Diarios no se refieren a estas quejas o reproches de los indios, queda la duda de si representaban la cantinela constante suya o la del Oidor puesto que se sabe que en él este era uा temn reiterado. 
supuesto, indio mostrenco y sacristán de Ayoayo, los había engañado y era el móvil de tantos daños y condenación de aquellos infelices que murieron en pecado, pues venian a matar y hurtar, lo trajesen y entregasen a la ciudad, y que el dicho prebendado mismo saldría fuera a recibirlos, para que así puedan ser perdonados o merecer las piedades del Rey y ser indultados bajo de su real bandera. Nos hirieron con balas de escopetas, dos indios, una muchacha y mozo, en diferentes puestos y, como no hay cirujanos, es regular mueran, como acoptece con cuasi todos los heridos hasta aquí(i).

Día mićrcoles 20 de Junio. Fue de sosiego y sólo se oyeron algunos pocos tiros de escopetas y de los pedreros enenigos. Ya parecen estar perfeccionados dos que se fundicron, de tamaño más que regular y mayor que aquéllos y de recámara bien capaz. A las 7 de la noche empezaron los rebeldes con la grita acostumbrada pero bien piana o tibia. En esta mañana amaneció otra trinchera de medio adobe de lodo, a los 40 pasos, frente a la trinchera y ptiente de San Francisco, puesta con el mismo designio que la de San Sebastian (que todavía existe). Algunos indios, parece que por bajo de la fortaleza de la Paciencia, hablaron de paces con el buen capelán don Vicente Rojas; son unos fementidos sin ley ni palabra. Dijéronle que es- / f.42v cribiese un papel a dicho fin, al caudillo conjurado, porque si Catari no convenia en la amistad, que ellos lo entregarian vivo o muerto. Dícese que consecutivamente se le escribió y que llevaron dicha carta; otros lo nicgan (2). ¡Dios obre! Aunque son muchas las astucias del indio y no pocos los casos del engaño y su malicia. Por la mañana estuvo Catari en la ceja y cerro del Calvario, con su cabriolé encarnado y guarnecido de galón de oro; le gritason de la trinchera de San Miguel, los nuestros jladrón de cera! Se enfureció y bajó con sable en mano, fưioso y colérico, imaginando que se vulneraba la autoridad que ha soñado tener este traidor ruin. $Y$ si no bajan cosa de 15 indios que le detuvieron el paso y to cargaron, acaso se nos viene a la mano, porque estaria borracho como de ordinario lo estila y lo acredita el mismo caso. Thubo proporción de matarlo o con el pedrero o con fusiles, pero la torpeza de los guardas lo excusó, esperando bajase más inmediato.

(1) A través del tan citado Pleito de Gil de Alipazaga así cono de los pagos efectuados por las Cajas Reales, se sabe que habia médicos en los hospitales de La Paz durante el Cerco; posiblemente la referencia del Oidor se dirige más bien a la imposibilidad de electuar operaciones quirúrgicas en las condiciones que se Jaban en ese momento en la ciudad.

\{2) Ninguno de los otros Diarios se refiere a una carta del capellán Rojas. Tampoco figura una copia en la compilación de Segurola. 
Se libró orden por nuestro Comandante para no hacer fuego a los enemigos, la que con efecto, se comunicó en las trincheras y paredones, a consecuencia del armisticio incoado, el que quedó burlado (1), porque cuando se esperaba la razón o respuesta de los rebeldes, dispararon cuatro cañonazos contra el fuerte de la Paciencia. Nos mataron a un Castañón, a un soldado en el de la Caja del Agua, una mestiza y otro individuo. Este es el efecto de las paces y promesas de los indios. Hoy se nos presentó en la horca puesta en el cerro del Calvario uno de los nuestros a quien vieron azotar y que lo colgaron de ella para haberlo arcabuzado, tres por un costado y cuatro por otro, con sus escopetas. Lo mantuvieron pendiente y después dicen que lo arrojaron cerro abajo. Quiérese decir que es el granadero Machicao, uno de los dos que se apuntó arriba, haber desertado.

La mortandad ha seguido con los dias, por la causa de la hambre; la ciudad se halla exhausta de gentes en sus calles; pero se nota que los más de los muertos son del número de los indios amigos, de Jas indias y sus hijos. Las calles estan regularmente con cadáveres arrojados. Los niños y muchachos gritan pidiendo socorro por las calles, esquinas y plaza mayor (i). Los alimentos se han consumido sin arbitrio para auxiliar a los menesterosos hambrientos. La libra de harina se vende por 10 reales plata, que en España son 25 reales de vellón. La azúcar que al principio se puso a peso, subió a 10 y 12 reales libra y hoy a dos pesos, cuando la arroba, por lo regular, no pasaba aquí de cuatro pesos y medio y la fanega de harina, compuesta de siete arrobas, 10 libras, en siete u ocho pesos y de este modo en otras especies que aún así no se encuentran (3). Aunque en este caso no ha habido justicia para reprimir y castigar estas usuras y monipodios de muchos que teniendo facultades y preciando de honor, debieran dar el ejemplo de piedad, con la erogación a los pobres, que de justicia les incumbe, principalmente en este caso de necesidad extrema y urgentísima del prójino. Poco amor de la patria tan digna de respeto y veneración delante de Dios y de los hombres, cuando ni al padre ni la madre, ni todos los parientes juntos, es menester honrar tanto como a ella, ceder a sus importancias y llevarla con dulzura en el tiempo de la mayor cólera o conflicto, porque los sabios consejos nos llevan a respetuosas demostraciones, in someternos a

(1) El Comandante no menciona Jada sobre la posibilitad de un almisticio. Sin embargo, si e] dato del Oidor es verídico, tendría que haberse derivado de la carta del capellán Vicente Rojas a los sublevados.

(2) Una vez más se aprecia que los que sufrieron con más rigor los efectos del hambre y las pestes eran los indios fieles y los desposeídos, que no tendrian cómo pagar los precios desmesurados que alcanzaban los escasísimos comestibles existentes.

(3) Las noticias del alza de los precios dadas por el Oidor. aún cuando se refieren solamente al azúcar y a la harinia, son una buena muestra de la extraordinaria inflación de los precios que se produjo a través de los meses del asedio. 
sus órdenes y sufrir con resignación todo lo que ella ordenare. Esto es responder a la defensa y protección de la república para con sus ciudadanos (il.

A dicluas calamidades se añaden las noches muy frías del hielo más intenso del invierno presente, que a nuestras gentes tienen rendidas con la continuadas guardias y vela nocturna, asistiendo a las trincheras y paredones, sin fuego, sin alimento $y$ sin cubierta. Esta noche fue sosegada y no hubo mayor novedad, aunque a espacios poca grita. Y en ella pasaron al tuerto Pedro Obaya a la cárcel, porque se le hallo practicando otro forado en el cuartel con una lanza y un clavo, que no faltaron pérlidos que se los dieron (2).

Dí jueves 21. Mandó el Comandante deshacer por la mañana las trincheras que levantaron los sediciosos frente a los fuertes de San Francisco y San Sebastián, bajo la correspondiente escolta de gente armada. En la primera se hizo considerable fuego y se retiraron los indios a carrera, pero conocidamente heridos de nuestras balas. En la segunda, sucedio lo mismo y hubieron mueto cinco indios, fuera de uno que se trajo vivo, de la estantia del prebendado Ca-/ 4.43 jal, junto a Laja. Quien, parece, refiere que el conjurado A paza tuvo (hacen tres días) propio de los indios del pueblo de Sicasica que, contextando en la venida de nuestras tropas auxiliares, le pedían pasasc en persona, porque ellos no podrian sustentarlos. Que les respondió no podía hacerlo y que ellos se defendiesen como pudiesen (buena es por cierto la fidelidad que se decía, de los de Sicasica). Que anoche recibió otro expreso de Calamarca, con carta de aquellos indios que ya se apuntaron y se dice los envió en alcance y oposición a nuestro auxilio dicho, con los cañones o falconetes que ganaron en Sicasica, de los nuestros, en la cual le decían que si no pasaba en persona con más gente, ellos no se juzgaban capaces de sostener a tantos españoles que venían en crecido número, para cuyo efecto estuvo consecutivamente en el alto del Calvario, de donde se llevó un pedrero. Lo que conviene con haberse sentido que de allí sólo

(1) Resulia sorprendente que el Didor hiciera estas reflexiones sobre el castigo de la usura teniendo, como tenía, tejado de vidrio, puesto que consta a traves del pleito tantas veces aludido la prolongada polémica que tuvo con el comandante Segurola para proteger a un criado suyo, pulpero, de apellido Samiento, á quien le dabn una tienda con ptierta a la calle, donde ésle aprovechaba para ocular alimentos que un día le fueron requisados ppr unos oficiales. Pleito de Gil de Alipazaga... $N^{\circ} 6$.

(2) Nada dicen los otros Diarios snbre este episodio; no era extraño, sin embargo, que hubiera sido así, porque ya había denosundo Obaya su valentia y su decisión. Por lo demás. podrá verse más tarde, cuando caiga prisionera Bartolina Sisa, que los carceieros, ya fuera por simpatía o por venalidad, estaban siempre dispuestos a ayudar a estos indios principales cuatido eron encarcelados. 
se dispara uno solo y no los dos que han continuado sucesivamente; y que su árimo era pasar en persona, acompañado de 900 indios, los más valientes, que mandó entresacar a razón de ciento, de nueve ayllos o parcialidades, por medio de sus capitanes. La noche no hubo, tampoco, novedad. Esta tarde se enterraron 81 personas en el campo santo o Colegio Viejo, fuera de los del hospital y otras igiesias. Y lo mismo se experimentó en los días anteriores, incluyendo los esclavos negros, que muchos amos han desamparado por no tener cómo mantenerlos y porque hasta los cueros se han acabado. Dícese se nos fue al Alto o campo enemigo, un clérigo, don Clemente Rodriguez. ¡Raro espíritu!

Día viernes 22 de junio. A las 6 de la manana, salieron por la trinchera de la Caja del Agua, con el orden de apear la que frontera pusieron los indios bastante prolongada, a la espalda de la misma Caja. Y la compañía de Higueras con 60 hombres y la de forasteros con 50 caballos más, actuaron la diligencia puntualmente $y$ de paso tuvieron una refriega con los indios que alli y en las inmediaciones dormian. Mataron veinte y tantos de ellos, scgún opinión juiciosa, aunque varian muchos en el número, aumentándolo. La caballería hizo algún daño en ellos, con los sables y se vieron retirar a muchos, heridos de ćstos y de nuestras balas. Mataron los enemigos, con una baja en la frente, al oficial don Luís Cerna, muy homore de bien, que cayó muerto en el puesto y a un Contreras, que volvió muy herido de dos lanzadas mortales, con otros dos, maltratados a palos y también don Ventura Carpio que mandaban la caballería, quien tuvo el ardor de apearse del caballo para tomar a un indio viejo, vivo. A cuyo tiempo le sorprendieron con sus palos los contrarios y le dañaron bastante, pero no de peligro; él se defendió con su cuchillo y con éste bañado en sangre logró entrar a pie, asiendo a dicho indio. También se tomó y trajo otro muchacho de 14 años, a quien conocen los nuestros, era el mayor gritón entre los indios, los cuales en esta refriega huyeron sin sostenerlos y sin que muchos se atreviesen a bajar, como otras veces, del alto de Quilliquilli, donde se mantuvieron parados o intimidados. Por ambos prisioneros, parece, se confirman las noticias del auxitio que nos viene, $y$ dio el indio aprehendido el día de ayer; y que el rebelde quedó en disposiciones de pasar a Calamarca con varios indios a ayudar a los suyos y contrarrestar los nuestros.

Esta tarde salieron las dos compañías de nobleza y granaderos a Santa Bárbara, por salitre para pólvora, a las órdenes del Comandante que los guió acompañado del señor fiscal Plata, bien que éstos se retiraron prudentemente y con anticipación. Bajaron furiosos los indios, hubo un principio de refriega y luego se retiraron los nuestros, desordenados como siempre. Los granaderos quedaron a la retaguardia; virieron golpeados dos de ellos $y$, si no apuran el paso les dan alcance los indios que a pedradas y grita descendieron hasta la trinchera de Santa Bárbara. Murieron cosa de 15 indios y, si creemos a los del prurito de multiplicar muertos, no 
faltará opinión que los compute hasta 40. La noche no hubo novedad y no se oyó tampoco un cañonazo.

Día sábado 23 de Junio. Tampoco hubo movimiento. Por parte de mañana hicieron los indios, hasta mil de ellos, un conciliábulo, en el mercado nuevo de la garita, camino de Potosi, de cuyas resultas unos partieron para la ciudad y otros para el alto de /f.43v. San Pedto y, alginos de éstos, se presume, iban renuentes, puesto que a látigos los echaban adelante sus capitanes (como regularmente lo hacen con muchos, cuando los traen a combatirnos). Dicen que estos son los destinados a seguir la escolta de Apaza, en su empresa de arrostrar nuestros auxiliares. Esta tarde degollaron los tos indios sublevados, que ayer y anteayer se tomaron prisioneros. $Y$ la noche no hubo novedad.

Domingo 24. Los enemigos dispararon algunos tiros de escopetas contra nuestras calles y los nuestros. Fue tranquilo y por la noche murió el indio alzado Zúñigä, entro de la cárcel, aquel que trajo la carta fingidá del anxilio (1). A las ánimas nos dispararon un pedrero.

Lunes 25 de Junio. Se experimentaron los mismos tiros de escopetas que ayer por la mañana y tarde, y de dos pedreros, pero pocos. Salieron algunos por salitre y acaso por explorar el campo enemigo y número de indios, a San Pedro; a la retirada nos hirieron de un balazo en el pulmón al bueno y diligente don Juan de Higueras; le sacaron ya la bala que parece no haber internado mucho, aunque raro de los aquí heridos, aun en carne muerta, es el que salva, por la penuria de profesores peritos (2), que clama la común consternación, cayéndose por instantes muertos de necesidad por calles y plazas los hombres y niños, que es compasión y acrecientan aquel numero, pues don Pedro Ramirez de la Parra, dedicado a recoger por las calles los cadáveres por medio de una bestia y mozos que paga el doctor don Juan Antonio Zepeda, prebendado y secretario de su Ilustrísima, dijo que en 10 dias, que por la curiosidad había formado el cálculo de ellos, sacó la cuenta de 600 sepultados en la capilla y campo santo nuevo, sin consideración de los del hospital que son de mayor numero, y las iglesias y por eso, éstas, los cementerios, calles y casas, se hallan días

11) Se refiere a Antonio Zúñiga que trajo la cauta con ta que el tuerto Obaya o Rey Chiquito penso engainar a Segurola para obtener que suliera con sus tropas fuera de los muros, el día 27 de Abril.

12) El hecho de que se le pudiera extraes la bala al coronel Higueras dernuestra que por entonces se podia pracicar la cirugia en La Paz. En el proceso del tuerto Obaya figura un informe médico sobre las malas condiciones de salud del prisionero, firmado el 4 de Agosto de 1781, por Francisco Castañeda, cirujano y profesor de medicina. Pleito de Gil de Alipazaga... Pieza $N^{\circ} 6$. 
ha desembarazados de las pobres gentes que los tomaron por albergue (1) Y a la verdad que el corto resto del pueblo, donde grasa la epidemia de cámaras, disenterías y fiebres malignas se halla en el último y mäs subido punto de las calamidades y necesidad del auxilio del señor Flores, cuya esperanza es la que dilata los ánimos y mantiene a muchos, para cuya prueba sucede un discreto pasaje del doctor don Toribio Bernuy, canónigo de bellas letras y selecta instrucción. Preguntóle, políticamente, un amigo suyo, cómo lo pasaba y respondió: jah, amigo, como lo he de pasar, cuando Flores non aparuerunt in terrn nostra! Algunos probabilistas: supónese que el rebelde Apaza no ha pasado a lidiar con nuestros auxiliares porque hoy se observó que bajaron 100 hombres más o menos, de caballería, por la parte que llaman de Achachicala y cosa de 40 por la cuesta de Potosí, todos a Potopoto, a donde los días anteriores y hoy mismo se han visto convoyan mulas cargadas y manadas de cameros (2). No hay trabajo ni industria y así el comercio ha descaecido; la miseria toma su lugar. Las artes perecen, todo desaparece y sigue en abandono. La plata labrada se vende a razón de tres y cuatro pesos marco y a cambio de víveres recargadisimos y lo mismo ol oro, athajas de diamantes, perlas, etc. A las 8 de la nodie dispararon un pedrero y hubo alguna algazara que duró poco rato $\{3\}$.

Día martes 26. No hubo novedad y los contrarios nos dispararon unos pocos pedreros, por lo que se conoció tenían tres de ellos al manejo. Ahorcaron al cholo sastre, que se dijo arriba haber entrado clandestinamente y estar de inteligencia con los sublevados. Se trasteaban y acarreaban ganados hacia Potopoto, Río Abajo y lado de Hampaturi.

Día miércoles 27 de Junio. Hubieron los mismos tiros escasos de pedreros y de noche alguna grita de indios. Continuaron con el acarreo de ganados, por la tarde como ayer. $^{2}$.

Día jueves 28. Fue lo mismo que los pasados. Volvió un muchacho de 10 años de edad, que se dice lo envió el Comandante esta mañana a saber de nuestro

(1) Nada puede saberse sobre las cifras exactas del múmero de muertos por causa de las pestes y el hambre, puesto que no se jlevaron registros de este tipo. Puede apteciarse. al través de los Diarios, que la gente caía muerta en cualquier parte, quedando los cadéveres en tierra expuestos a ser comidos por los perros y gatos hambrientos; lo importante era, entonces, enterrarlos lo más pronto posible y donde se pưdiera, para cvitar les pestilencias.

(2) Desde este día hasta la llegada del auxitio, todos los Diarios se refieren al acarreo permanente de ganado, plata labrada, alimentos y todo género de bultos desde la región del. Alto a la de Potopoto donde era mus fácil esconderlos o protegerlos.

(3) Puede apreciarse en las frases del Oidor el esiado de animo de los pobladores de La Paz. cuyo desaliento los fue lievando a abandonat todo tipo de actividad urbana o conercial. 
auxilio tan deseado del señor Flores y explorar, al campo enemigo; trajo la señal de carne fresca de llama o camero de la tierra y unas manzanas y dijo haber oído en El Alto que en Ayoayo o Calamarca habian derrotado los nuestros y sus tropas a los enemigos y quitádoles los canones, con mucha mortandad de ellos; de lo cual había tenido carta la india cuncubina del Apaza pidiéndola en ella más auxilio de gente (1). Siguen con acarreos de ganados/f.44 como los días pasados. Subieron y bajaron algunos de a mula con bandera blanca y ello es que se hallan en continuto movimiento los indios.

Día viernes 29 de Junio, del glorioso apóstol San Pedro. Entraron muy de madrugada Cayetano Silva, a quien los indios llevaron prisionero, otro desertor nuestro, un inctio de la estancia de la marquesa de Aro y otro más, según se dice, los que con éste dan razón del combate que presentó ayer jueves el Apaza, escoltado de dos mil indios, a ntestros auxiliares y comandados del señor Flores, hacia la estancia de Vilaque, más acá del pueblo de Calamarca, donde los nuestros tomaron el cerro y mataron a dos mil indios, menos dos, que se dice quedaron mal heridos y que el Apaza, parece, huyó a los cerros de Calamarca, en cuya persecución iban los españoles, conjeturando que anoche to hubiesen aprehendido. Aseguran que se recuperaron dos de los pedreros, el uno de esta ciudad y otro, de los falconetes perdidos en Sicasicit. Que anoche llegó al campo enemigo, razón de esta derrota. Que se le tomaron dos cargas o zurrones dé plata sellada y cuantas escopetas llevó el rebelde. Que vino una prevención de Apaza para que las mujeres se trasladen a Potopoto y los hombres, que dicho Silva regula lleguen de 1200 a 1500 indios, sigan en El Alto; sin duita por la bárbara tenacidad de querer arrostramos todavia, en cuyo comprobante siguen los indios batiendo la ciudad con los pedreros, aunque pausadamente y han mantenido un cordón en el alto de San Pedro, toda la mañana, y a cosa de las 2 de la tarde se pusiẹron en corro o pelotón a tratar acaso de algún conciliábulo ${ }^{2}$.

(1) Las derrotas de Tupac Catari frente a las tropas de Flores están descritas con detalle en el Diario de Guerra que llevó Javier de Cañas. uno de los capilanes de la expedición. UMSABC M/2287 Col. J.R.G. La autora de este trabajo ha podido establecer que J.R. Gutiértez lo copió de la abra de Andrés Lamas: "Col. de Memorias y Doc. para la Hia. y la Geog. de los Pueblos del Río de la Plata", Montevideo, 1849.

12) Segurola explica en su Diario que el ajetreo a que se refiere el Oidor el día 29, en El Alto, se debió a que los indios simularon una batalla con fos ejércitos auxiliares, en un último intento de hacer salir a las trapas sitiadas, que cayendo en la celada podrían acudir en ayuda de los supuestos españoles; estando fuera de los muros y camino a las cuestas habrfa sjdo facil derrolarlas antes de lá llegada de Flores. 
El citado Silva se mantuvo prisionero con unos grillos que anoche se le quitaron, por ponerlos a otro que fue desertor nuestro. Al que vino en su conpanía se le ha puesto en prisión, por denunciarlo aquel que manejaba muy inicuanente el fusil contra nosotros, infirjéndose que la necesidad le trajo a la moderación de su retiro. También dice conoció a Bonifacio Chuquimamani (que se fingió ser el Calvijo, natural del pueblo de Yunguyo), hecho el diablo secretario del rebelde Apaza y acérrimo enemigo o inspirador primero de la sedición. Que el pueblo de Sorata, capital de la provincia de larecaja, se mantenía atrincherado y sitiado de los indios sublevados de Achacachi y otros de Omasuvos. Que habiendo fingido alli, los indios, tratar de amistar con aquellos sitiados, salió fuera de trincheras don José Pinedo (a quien nuestro Comandante había comisionado para auxiliar a Orellana), acompanado de don Gregorio Santalla y, aunque se dice los mataron los indios sublevados a la señal de un sombrero que se quitó aquel cauditlo, necesita de confirmación (1). Que quemaron parte del pueblo sin poderlo remediar, y que los españoles seguían atrincherados en él. Que de seis días a esta parte, corría en dicho alto de San Pedro, que el Tupac Amaru erá muerto (2), noticias que con la venida de nuestro ansiado Flores se esclarecerán y que a la verdad colman nuestros votos de alegría y dulzura al ver que se aproxima nuestra redencion y se halla a la puerta tan oportuno restaudador para coronamos, con las de su probidad, de las gurirnaldas propiamente de Flores. Para el complemento del placcr tute recibe este pueblo se repicaron las campanas, se hizo una salva general de cañones y se manifestó en acción de gracias a su Divina Majestad en las iglesias

$Y$ aunque la mayor parte de los semblantes se hallaban pálidos, lánguidos, enfermos, con los labios secos y cuasi sin respiración, como que estaban a los umbrales de la Parca, se les ha visto revivir y renacer hoy los colores en las mejillas a muchos, en su anterior lozanía y antiguos alientos, llenos dé júbilo y contento y regocijándose mutuamente las voluntades y los ojos, al celebrar tan felices nuevas 13 .

También se refiere que el rebelde Apaza, en la refriega que experimentaron los suyos antes del pueblo de Calamarca, perdió la caballería y sc desbarrancó por

(1) Se sabe que Josef Pjnedo y Santalla, defensores de Sorata, labían perecido a manos de Andrés Tupac Amaru. Se ha podido delerminar que fueron asesinidos después de que ruevon descubiertos por el joven caudillo, cuando aquéllos intentaban sorprenderle para mitarle o arrestarle; sin embargo, siempre se había interpretado el acontecimiento conno una traición de Andrés Tupac Amaru. Lillian Estelle Fisher, "The Lisi Inca Revolt". 178(1-1783. Univ. of Oklahoma.

(2) Josê Gabriel Tupac Amaru cayó prisionero el 6 de Abril de 1781. Fue sentenciado el 15 de Mayo y ejecutado el 18 de Mayo de 1781.

(3) Segurola, utilizando un estilo más sobrio. también describe esta escena que el Oidor pinta con tanta emoción. 
un cerro abaio bien escarpado, que así pudo salvar y pedir auxilio de mula y de los dos mil indios que ayer salieron (1). Que los cochabambinos pelean en buen orden y silencio, con sus lanzas, avanzando los indios que trae, amigos, con banderas y listones de cintas blancas en las monteras, con vigor y la pena de matat al que de ellos así no se desempeñase. jOh, y cuanto menos hay de peligro en la campaña, cuanto menos hay de temor, siendo por eso obvio que / f.44v, no aprovecha tanto la multitud cuanto la virtud en todos los conflictos! Que por estas nuevas, los indios sublevados se hallaban en El Alto aturdidos, regulando que los que venían eran otros hombres que peleaban como leones, destrozando la gente de contado y sin dejarlos respirar y que asi iban trasponiendo el oro, dineros, plata, ropas y otros bienes que han hurtado, sin que por la muchedumbre de estas especies y comestibles y por la falta que sienten de mulas, pueden tener tiempo para concluir con el acarreo en que entendian con mucha confusión y desorden.

Pareçe que el cielo continúa en favorecernos y nos señala este día del príncipe de los apóstoles para tal satisfación y ayer, de sus vísperas, para el castigo de aquellos malvados, apóstatas de nuestra sagrada religión y enemigos acreditados de nuestra madre la Iglesia, fundamentadia por Cristo, nuestro Redentor, sobre aquella piedra, sin que las phertas infernales puedan prevalecer contra ella, como es del evangclio. Esta noche llegó otro indio que dice, vino acompañado de otro que conducia carla del señor Flores, quien los destacó de hacia la Ventilla, pues venían en su compaña. Que al compañero le interceptaron los indios la carta y le ahorcaron en El Alto en conjunto de otro desertor nuestro (que esta tarde pendían y se vio en la horca) y que mientras tanto pudo rehundirse el primero y retirarse a ésta. Que por la larde degollaron los alzados a cuantos habia en El Alto, de cara blanca, de ambos sexos, de cuyos cuerpos se hallaba regado aquel campo y las serranias de la bajada a esta ciudad, sin duda en despique de lo precediuo ayer y en los otros días desde Sicasica, con el señor Flores. Que el rebelde Apaza profugó al Palomar, Río Abajo, seis leguas distante de la ciudad, habiendo presenciado el último combate de un alto o pináculo de un cerro, donde se colocó y tomó la fuga. Que mandó decir a los sublevados que no se expongan a otra repasada, porque los que venían eran más que hombres. Que los indios proyectaban pasar a conducirlo y presentarlo al señor Flores, pues que él fue el seductor, para que así los perdone; pero la mucha obstinación en que están no permite dar asenso por ahora.

(1) Javier Cañas cuenta en el Diario anolado más arriba, que el día 28 de Junjo, después de una larguísima batalla cerca de Calamarca, Catari entregó su caballo agotado a un indio para que se Jo cuidara. Un soldado cochabambino se lo arrebató a éste y Apaza. indignado, hizo ahorcar a su subordinado esa noche. 
Día sábado 30 de Junio. Se puede decir que fue el de nuestra redención o resurrección, pues parece que en él tomamos nueva vida al reputar cuasi perdida la que contrajimos al nacer, como lo dirán los 109 dias del sitio, hoy cumplidos y contados desde el 14 de Marzo y los trámites de este diario y el mismo término a que en lo natural pudo llegar nuestra necesidad extrema, cuando ni cueros encontraban ya los hombres para poder meramente sustentarse. El caso es que a las 4 de la tarde. después de haberse sentido anteriormente el susurro de fusilazos y reparádose que combatían los indios en el alto de San Pedro, con la algazara acostumbrada, se vio un trozo de nuestros auxiliares presentados a caballo y en fila, en la misma ceja de aquél, tremolando la bandera de nuestro augusto Monarca y otras que tomaron de los enemigos y que por otra parte exhalaba una humareda como efecto del incendio que actuaron en los ranchos fabricados allí por los sublevados, en considerable extensión, durante el sitio. La ciudad le hizo el saludo con los cañones de su fortaleza y de la plaza y repique general de campanas. Respondieron con cinco cañonazos y con todo siguió consecutivamente nuestra salva, duplicando su gratitud este pueblo oprimido a vista del igual auspicio. Y si el dia de ayer fueron los júbilos y los contentos tan extremados, como se apuntaron, cuánto más se dilatarían los ánimos festivos, rebozando placeres y expresiones de alegría a la vista efectiva de igual felicidad y de tal auspicio. El discreto y entendido podrán formar la computación como dificil de explicarse menudamente. Día, por fin, sábado, dedicado a nuestra Señora Madre de Dios y de La Paz y dia, ayer 29, de los trofeos merecidos y de la memoria y devoción mensual al arcángel señor San Miguel, patrones invocados señaladamente para nuestra protección en este trabajo.

Sábese por algunos auxiliares que entraron a la cludad que de los treinta y tantos expresos que dirigió nuestro Comandante al señor Flores (nuestro redentor actual), sólo uno fue logrado y le presentó la carta que condujo, entretejida en el centro o conmedio de una honda. Por la cual quedó impuesto de nuestras indigencias y que en aquella data llevábainos 87 dias de cerco. No era tiempo de que se determinase para la ciudad / f.45 por lo túrbido de algunos pueblos que deja a la espaida arriba, pero como había estado (por fortuna nuestra) el año inmediato anterior en esta ciudad con motivo de auxiliar la reposición de la Aduana (1), y constaban a su gran penetración las calidades opulentas e importancia de este pueblo, más que los otros, para la Real Corona, que tiene cuantiosos intereses, tanto por sí misma cuanto por los vasallos o ya por las haciendas pingües y sus frutos, que

(1) Efectivamente, Ignacio Flores había venido a La Paz con el fiscal Fernando Márquez de la Plata para tranquilizar la cjudad cuando se produjeron las sublevaciones de 1780 contra el corregidor y los oficiales de la Aduana. que habían establecido la elevación de las alcabalas, obedeciendo las ordenes de] visitador Areche. 
hacen un vasto comercio y surte las manos contribuyentes de todo el reino; porque los comerciantes de Lima y Buenos Aires expiden la mayor gruesa de sus negociaciones en este lugar y en el de Potosí, o ya porque sucede lo mismo con los azúcares del Cuzco, con los vinos y licores del obispdo de Arequipa y la costa y con los trigos del valle de Cochabamba, que aquí se expenden en la mayor parte con conocidas ventajas y sin los notables atrasos que esta turbación les habrá sin duda irrogado (1). Por eso y porque supo graduar la entidad y preferencia de los negocios, resolvió venir a marchas dobles, todo envuelto en patetismos de confusión, dudando su caritativo celo si alcanzaría a tiempo de poder salvar La Paz. ¡Qué testimonio tan noble de humanidad! ¡Y qué prueba de un consumado general! |Asi acude con aquella celeridad al remedio que es tan provechoso en la guerra! Así quita a los enemigos el tiempo de conocer su peligro y trazas de su remedio. Así les confundió el juicio, les tiene atadas las manos y así sé logró que vayan sobre ellos los golpes, tan de repente. Y así también puede decirse con verdad, qtie se hizo otro Atlante del hemisferio de la paz o más propiamente, otro Gylipe, famoso general de Lacedomonia que vino al socorro de la gran ciudad de Siracusa, no menos sitiada y reducida a la extrena, que ésta, donde al arribo de tal guerrero todo mudó de semblante, perdiendo los atenienses en tal combate insensiblemente la superioridad hasta que fucron forzados para la retirada y acto de su estrago y muchos prisioneros con los tristes despojos de sus tropas. Jamás hubo parecida alegria que penetrase a los siracusanos de su victoria. Ellos decoraron las armas cautivas, los más hermosos y los más grandes árboles que se hallaron en las riveras del río Asinare, teatro de su triunfo. Ellos se coronaron de diademas de flores y adornaron con magnificencia sus cabellos y ellos, al fin, entraron a su patria con tode la grandeza y celebridad que inspira un suceso inesperado (2).

Parece detallada la historia para el día, pero con la diferencia que sí allí siguieron el dictamen de Dinclez para el castigo severo de los prisioneros, aquí se admira el espiritu de caridad con que este general procura y ansía por el perdón, verificado ya en algunos, por tal de atraerlos con suavidad y, dulzura al servicio de Dios y del Rey. No puede, desde luego, ser insensible a la queja cruel que lo compete vindicar contra tantos y tan execrables delitos sobre delitos de rebelión contra la majestad divina y humana. No puede dejar de aborrecerlos y detestarlos y procurar su punición como asesinos, matadores de tantos hombres y autores de perjuicios inumerables $y$ atrocidades nunca vistas. $Y$ aunque no puede disimularlos

(1) Con esas frases nostálgicas sobre las antiguas grandezas de la ciudad, se capta la importancia que tenía la Paz a fines del siglo XVIII como nudo y puesto intermedio del tráfico comercial entre los dos virreinatos.

(3) En su entusiasmo, el Oidor pierde todo sentido de la mesura o de la sencillez para caer en estos pesados alardes de eradición clasicísta. 
y conoce que merecen los más grandes suplicios, los más rigurosos tratamientos por la insolencia y audacia de la injusta guerra que han declarado a Dios, al Rey y a la patria, pero dotado, al mismo tiempo, de aquella máxima cristiana de perdonar a los enemigos y que Dios nuestro Señor, justo vengador de los delitos, les ha castigado bastantemente en los cinco combates precedidos, desde el pueblo de Sicasica hasta este alto de San Pedro, con destrozo de cerca de cuatro mil indios expuestos en esas campañas (según lo sabeinos) y que asi nos ha vengado (sin que sepamos lo futuro), no se desdeña de conservar la vida a los rendidos y vencidos (1\}. No quiere, como asecla de las piadosas intencinnes de nuestro soberano, deshonrar sus victorias correspondiendo a la crueldad bárbara de aquéllos; no ijuiere, con razón, que sus glorias se marchiten ni que sean excluídos del templo de la misericordia todos cuantos se acogieron a ella. Estas son las victorias y estos los triunfos que acreditan para siempre, de ilustre, a un jefe que hace brillar la clemencia de su principe en los enemigos vencidos, Ia moderación en la más grande prosperidad y el temor de irritar al príncipe de los príncipes por la senda del orgullo que se le ve detestar.

Las obligaciones y vínculos de gratitud y reconocimiento /f.45v. en que se halla la ciudad para con este buen general, son de la más recomendable atención y así se expljica ella dando muchísimas y rendidas gracias a la piedad del Rey y publicando sus efectos en la generosidad de este jefe aventajado en el valor y en la fineza, a aquel Phylopemen heroico de Megalópolis, el más grande de los griegos de su siglo, erudito, un dechado de virtudes, que jamás estaba ocioso. Así, ejercitado siempre, desde su infamcia y su ilustre cuna en la capital de Quito, de este continente americano, en la aplicación de las letras y virtudes politicas y morales que surten su bella amenidad y yasta erudición. Trasladado a la Europa, a las funciones honoríficas de Marte y Belona, no ha tenido punto que no haya sido (como en esta expedición), de ejercitar su noble espíritu (2), AI viajar para ésta, en sus instantes de soledad, él se pasea solo; su ánimo y sus ojos del todo ocupados y embargados con los cuidados de esta ciudad y por los aciertos de sus obligaciones. Tan presto, se examina a sí mismo, tan presto considera, como filósofo, los diferentes objetos que

(1) Una vez más puede apreciarse que, si bies en el Oidor suelen asomar frases de comprensión o de caridad hacia los indios, derivan éstas de un paternalismo tan propio de la época que le impedirá siempre aceptar la posibilidad de reconocer causas justas en el levantamiento. Para el, los españoles y los criollos no tíenen en su conciencia la menor culpa: ellos no han creado la situación existente; el levantamiento se debe exclusivamente a la ingratitud, perversidad, insolencia y herejia de los índios.

(2) No puede dejar de captarse el orgullo con que Diez de Medina. destacando tos mériros de Flores, señala su origen quiteño. El héroe de la jornada, para quien no escatima alabanzas, es ahora un criollo. 
lo rodean y tan presto contempla con magisterio en la táctica y situación de los lugares. El se pregunta lo que haría si, estando a la cabeza de su tropa, el enemigo le sale de repente de una emboscada a sorprenderlo y atacarle. ¿Qué posición (dice) tomaré yo? ¿Qué orden daré yo a nis tropas? ¿Deberé yo resistir o huir? Y si debo resistir, ¿dónde colocaré yo mi campo? ¿'Dónde pondré yo las guardias avanzadas? ¿Dónde dispondré yo mis cuepos de reserva? El lo prevee todo, lo combina todo y sabe comparar ciertamente las campañas a las campañas y los terrenos a lo terrenos. $Y$ bajo de un prócer tan admirablemente ejercitado, ¿qué providades de cordura, celo, constancia y sufrimiento no serân las de nuestro general? Las que (ya se ve), exceden en mucho a cuantos puedan colmar los grados de herósmo delante de él, que pucden servir de modelo para lo futuro y que de verdad han producido y producirán todavía el desempeño del real servicio y utilidad pública en especial beneficio de la patria redimida (1). X pues al momento que el gran Phylopemen acompañado de una juventud csclarecida y floreciente, que habia formado en el gran arte de la guerra y que muchas veces había triunfado bajo de sus reglas y auspicios, entraba en la asamblea de los juegos nemeenios, el músico Pylades cantó por casualidad en su lira aquel poema de Timoteo intitulado Los Persas. Pronuncie y cántelo de propósito y a su nombre y con tudas las veras del corazón la ciudad de La Paz y diga reconocida en dulces acentos y aclamaciones:

\section{Yo soy el que corona vuestras cabezas de las flores de la libertad.}

La majestad de este verso, maravillosamente sostenida por la melodía de la voz del que le cantaba, tocó toda la asamblea y movió a los griegos para echar los ojos sobre su I'hylopemen, con golpes de manos y grandes gritos de alegría, renovando en su memoria que sabria recuperar los bellos siglos de la Grecia triunfante. Y puede decirse que nos empeía a la emulación de tan merecido ejemplo y es la misma que conmueve y anima el brío, la confianza y los ecos sonoros de esta ciudad, lisonjeada de la dulce esperanza que revivirán los antiguos tiempos de felicidad, bajo de tanta gloria y de un jefe tal, como nuestro caro y nuevo Phylopemen (2).

Día domingo $1^{\circ}$ de Julio. Se supo que ayer en el combate que los indios presentaron a nuestros auxiliares en la campaña delante del pueblo de Achocalla y parte de ellos que se emboscaron en las quebradas a la cabezada de dicho pueblo,

(1) La exageración, ingenuidad y relorcida cursilerfa con que el Oidor ensalza la figura del comandante Flores impiden que sus frases hubieran podido aprovecharse para un cuadro psicológico o biográfico del personaje descrito.

(2) Es sabido que entre los doctores formados en la Universidad de San Francisco Xavier de Chuquisaca solía darse una retórica de tipo clasicista, pero evidentemente no era cortiente encontrar una tán altisonante y pretensiosa. 
fueron derrotados con la mortandad de más de mil y quinientos de ellos, que están expuestos en ese campo, pues los corrieron los nuestros hasta la capilla de Colpani y serranías, a distancia de más de cuatro leguas, en cuyo empeño el teniente coronel don José de Reseguin, sub comandante, recibió por piadoso, una horrible pedrada en la cabeza, por un indio a quien perdonó y le correspondió consecutivamente, con igual persecución. En dicho alto, parece, se hallaron algunas piezas de plata labrada que no tuvieron tiempo de trasponer los indios. Hoy bajaron muchas reses y corderos en crecido número para el socorro que debe esta ciudad a la compasión del señor Flores, que tuvo la prudencia de meditar nuestras calamidades extremas y proporcionó su acopio y conducción en el camino /f.46 sin más intereses que el de su noble índole, de beneficiar a un pueblo misero y desdichado, habiendo acreditado su piadoso corazón, en la misma larde de ayer, manifestando el dolor de ver arruinadas las tres partes de la ciudad, no menos que por los ojos. El pueblo se surtió hoy del auxilio de las carnes, sin reserva de pobres, aunque este gobierno mandó vender el socorro, contra la orden e intenciones del general que, al saberlo, parece, ha tenido que sentir no poco. Pero con todo, el beneficio es conocido del pueblo que se incrementa en sus gratitudes.

Por personas de excepción que concurren en la expedición venida, se sabe que el inicuo Tupac Amaru fue aprehendido en Tungasuca (donde se hizo fuerte) el 5 de Abril, mediante las activas operaciones de ruestro sabio y valeroso señor Visitador General y sus tropas cuantiosas, y conducido con su familia o parientes a Lima, bien que con pérdida de españoles y muchísina mortandad de los rebeldes, en los días que duró por los nuestros el asedio de aquel lugar y con prisión de muchos indios fuera de los que la gran prudencia de dicho señor supo atraer $y$ conservar de amigos, lo que parece se habia comunicado por la costa a la villa de Oruro, donde se vio una carta que lo anuncia con otras menudencias que esperamos se confirmen o liquiden cuando los caminos se pongan en claro y giren las correspondencias, hoy entorpecidas en la mayor parte del Perú $\{1\}$.

En la ciudad de la Plata también procuraron los indios de Chayanta y otras provincias, su bloqueo. $Y$ aunque se mantuvieron hacia la Punilla, dos leguas distante, con aquel designio, algumos pocos días, los rechazaron con destreza y animosidad aquellos nobles ciudadanos, con una más que considerable mortandad de los levantados que, con igual escarmiento, tuvieron que profugar a sus reducciones. En cuyo acto importó no poco la heroicidad del señor oidor don Alonso González Pérez, que combatiendo a caballo, con generoso impulso, dio el más vivo ejemplo de amor por la patria y celo del real servicio que, animando no

(1) Se ve que ni aún los componentes de la expedicion de Flotes conocían bien las noticias de lo que ocurría en el Perú. Tupac Amara no fue llevado jamás a Lima; fue sentenciado y ejecutado en el Cuzco. 
poco aquellos espiritus, puede decirse fue una de las principales columnas para firmar aquellos trofeos tan puntualmente obtenicios, subordinar los rebeldes y que se mantengan en paz aquellos estados del Rey.

En la villa de potosí no se ha experimentado la menor novedad, porque aquel sabio y celoso gobierno supo tomar con mucha anticipación sus medidas, próvidas de precaución y defensa, con fortalezas y trincheras sólidas de cal y piedra que asegurando la villa aterró a los indios con los preparativos de disciplina militar, patrullas nocturnas y demás disposiciones muy oportunas que supo tomar aquel ambidiestro grobernador, el señor don Jorge Escobedo, oidor de Lima, que tan bien maneja la espada como la justicia.

La provincja citada y la de Paria, con la villa de Oruro, quedaban en estado de quietud igualmente consolidadas por las bellas máximas del señor flores que, con sus tropas, transitó por ellas. Amnue consterna la memoria al saberse que en el pueblo de San Pedro de Buenavista mataron aquellos rebeldes entro la iglesia, a su cura el dotor don Isidoro de Herrera (sujeto que por su virtud y excelente literatura, tuvo el primer lugar entre los sabios de este continente americano) al mismo tiempo guc les iba predicando con su espíritu apostólico para contenerlos de sus execrables yerros y alreviniento. Quiso morir verdaderamente con la palma del martirio porque no se convino a retirarse en tiempo, según se lo previno la selecta penetración del ilustrísino señor arzobispo. Murieron con él otros cuatro eclesiásticos y muthisimas personas acogidas al asilo de la iglesia $y$ aún corre fueron los asesinados sobre mil seiscientas personas. Pero las cosas quedan tranquilas con el castigo de los cabezas y tránsito de nuestros auxiliares.

También en la provincia de Chichas hubo su movimiento, porque, amotinados aguellos indios y congregados hasta el número de cuatro mil, en el pueblo de Tupiza, de donde se retiraron el cura, doctor Dávalos y los españoles y varios mineros $y$ hacendados que allí concurrian $y$ aún se dice que peligrados algunos), se dio buena maña el dicho teniente coronel don José Reseguin (que venía con 300 hombres para auxiliar estas provincias de orden del excelentisimo señor Virrey, desde la capital de Bue-/f.46v. nos Aires, de sorprenderlos en una madrugada, después de haber pasado felizmente el riesgo de la angostura que en aquel río concurre y era temible, mediante la maxima de mantener el acampamento de su orden las candeladas nocturnas, para que así lo juzgasen los enemigos en él y no en el camino que durante ellas habia tomado. $Y$ asi es que logró pasar aquel peligro sin novedad y acordonar una madrugada aquel pueblo, en términos que cuando los levantados recordaron, no podían huir ni resistir sino rendirse y subordinarse, como sucedio, entregando los cabezas que fueron condenados a muerte con otros, que corre pasan de 60 individuos, con lo que quedó la provincia sujeta y en sosiego, no menos que la confinante de Lipez, la cual con igual ejemplar y pronto remedio tuvo que ceder de los bullicios y alteraciones en que también 
estaban. Así se apaga con puntualidad el fuego, cuando como en todos aquellos países se vela y no hay el retardo con que vieron levantarse el incendio por todas las circunferencias de la ciudad, dejando que tome el vuelo y se engrosase más y más cada día, de modo que pasó a ser volcán difícil de extinguirse y que necesita días y muchos afanes, gentes y trabajo para ello, como lo dirá el tiempo y lo demuestra la obstinación en que han llegado ya a radicarse estos rebeldes que se suponian dueños absolutos de la ciudad, haciendas, intereses y de todo, como de libertinaje sin Dios, sin Rey ri razón y grasados con despotisno y crueldad en todo género de vicios y maldades.

También sabemos que el corregidor de Yungas, don José Albizuri, de su capital de Chulumani, se retiró antes de exponerse, por un efecto de sus recelos y desconfianza, aunque aquellos indios (que no congenian con los alzados de la Puna) (1) se mostraban fieles y le prometían no desampararlo y resistir cualqquiera incursión enemiga. Tenía en dicho pueblo y cl de lrupana (inmediato) sobrc mil doscientos hombres, entre españoles y mestizos, y con todo resolvió su retirada precautoria para el valle de Cochabamba, con todas aquellas gentes, mujeres y niños, quedando aquellos indios, con su ausencia, desahogados para contraerse (como lo receló y to acreditaron) a los levantados. De modo que éstos, aprovechando esta ocasión, internaron con superioridad de fucrzas y los atrajeron fácilmente, con muchos atrasos y perjuicios ingentes de esta ciudad y su vecindario que tiene las haciendas gue sostienen su brillo y comercio, en dicho Yungas. Los que asi se contagiaron y fueron de la confederación del Apaza, como ya se tocó. Hoy se dice que viene dicho corregidor con gentes de Cochabamba y las que surtieron su conitiva desde que partió de su provincia, para reforzar a nuestros auxiliares y contribuir a la pacificación de su provincia (2).

(1) A través de los juicios seguidos posteriormente a los vencidos, en Peñas, La Paz y Oruro, se puede establecer que no siempre los indígenas seguían de buen grado las imposiciones de Catari, porque pretendian seguir bajo la conduccióla de los otras caudillos o coroneles vinculados mús bien con el movimiento de Diego Cristóbal Tupac Amaru. Sin embargo, se puede apreciar en las páginas del propio Diez de Medina, que Julián Apaza habia logrado imponerse sobre los indios de Yungas y aliarlos a su causa. El Oidor anota que en los últimos ataques han aparecido atuendos que demuestran la presencia de yunguerios en las baialtas.

(2) Diez de Medina, al narrar lo acontecido en Yungas, reprocha veladamente al corregidor Albizuri por haber abandonado esos pueblos. "cuyas haciendas sostenlan el brillo y comercio" de La Paz. No mjde. sin embargo. el Oidor, la razón de tal decisión. Por una representación del alcalde ordinario José Ramón de Loayza, que se refiere extensamente a estos hechos, en Jos que actú como comandante de las milicias de Irupana, puede apreciarse que Albizuri y la población yungueña decidieron emigrar a Cochabamba, por la imposilidad de defender la 
En fin, se hallan también sosegados aquellos pueblos cercanos a Cuchabamba, cuyos indios también se levantaron y asesinaron muchos españoles y asimismo los de la provincia de Carangas. De suerte que si las de esta Caja Real de La Paz logran la mesma ventura, se puede contar con el reino ya tranquilo y subordinado. porque las del Cuzco y que están a la carrera de esta ciudad para aquélla, la próvida y diligente conducta del señor Visitador General ofrece a nuestros votos la fortuna de las ventajas que se anuncia y aún se consideran mayores \{11.

Asimismo se sabe que el 21 de Mayo salió de la villa de Oruro don Gavino Quevedo comandando 725 hombres, amados de 300 fusiles y dos culebrinas o falconetes, con el buen deseo de auxiliar y socorrer esta ciudad; que el 22, a las 7 de la noche, salió de la posta de Panduro a el pueblo de Sicasica, con un trozo de su gente, habiendo otorgado la libertad de venir la siguiente mañana, con el equipaje en su seguimiento, a todos los que quisieran hacerlo y no seguirle y aún muchos de los que le acompañaron parece se quedaron por el rigor del hielo, a medio camino, a vista de que la jornada constaba de ocho leguas y por eso pudieron marchar cosa de 200 hombres juntos y no más, fuera de los que iban arribando y venían carninando disper-/f.47 sos en alcance de los primeros. Asomaron a las tres y media de la mañana y antes del amanecer a dicho pueblo. Los rebeldes, que los sintieron, empezaron a batirles con los pedreros que nos gararon. Los dichos españoles, por defenderse y conturbados de igual recibimiento, entraron en acción; el fuego les hacian los indios, junto con la pedrea o lluvia de sus hondas, atrincherados entro de las casas y paredes del pueblo, sin atinar los nuestros, por la oscuridad, a corresponderles ni saber cómo regir la defensa. Fatigados ya, cuando aclaró el día, tuvieron el mensaje, por un artillero, de haberse perdido los dos falconetes que traía consigo esta expedición, que con los preparativos de balas y metrallas ganaron los indios. Llenos por esto de pavor, se pusieron en fuga desordenada y precipitada los nuestros, retrocediendo el camino andado. Los indios los siguieron arrojando piedras y descargando en ellos sus palos y lanzas, hasta la distancia de ocho leguas y

provincia, en vista de la falta de bastimentos y la dispersión de los pequeños pueblos, a los que no era fácil acudir en auxilio ni lampoco congregar en uno solo de los poblados. Efectivamente, las alzados se enseñorearon en la región, peto los cinco mil vecinos españoles se salvaron; de haberse quedado en Yungas. Ios indigenas habrian triunfado igualmente. pero acabando además con aquella pobre gente. AGNA 9/5-6-3. Documento porporcionado por el señor Rolyerto Cloque.

(i) No pasaria sino algo más te un mes, desde el día en que el Oidor escribiera estas palabras. para que el "reino ya tranquilo y subordinado" se viera nuevamente envuelto en llamas. El mismo 5 de Agosto en que el conandante Flores abandonó La Paz para buscar mayores refuerzos militares, Tupac Catari cercó nuevamente la ciudad. 
fueron matando por todo el campo de la carrera a cuantos no pudieron merecer la celeridad convenjente y fueron aprehendidos, por to que se reputó el número de los desgraciados en más de 240 españoles. Los pocos que salvaron e iban a tomar el asilo de la villa de Oruro, contaron su derrota con la buena suerte de haber hallado en Caracollo mil setecientos hombres bajo las órdenes de don José de Ayarza (sujeto de valor y juicio que hoy viene con nuestros auxiliares) combinados unos y otros. después de haber acampado alli, el 24 de Mayo. El 25 tomaron todos el camino para esta ciudad, logrando tocar en Sicasica el 27 a las 11 del día. $Y$ como no hallaron indios dispusieron pasar de este pueblo adelante y acamparon alli, aquella noche. Noticiosos de que el enemigo era de mayores fuerzas y múmero que los españoles, deliberaron la retirada, que se actuó el 28 siguiente, con tal desorden, que cada uno giró y caminó cuando y como quiso. El de la nueva, fue un cholo traidor que simulando hacerse del bando de los españoles y ponderando riesgos y ruegos afectados para que no se aventurasen, trataba, en sustancia, de dejar libre el partido e intenciones de los indios y que no fuesen rechazados y obstados de estos auxiliares que con tanta sinceridad se retiraron.

De la villa de Oruro salieron para ésta las tropis del señor Flores el 15 de Junio, habiéndose congregado para viajar en la plaza y destinádose a la vanguardia a los batidores de Chuquisaca, siguiendo a ellos los dragones y la demás tropa; cubriendo la retaguardia la media compañía de dragones y unidos el 16 en Caracollo 300 hombres de la anterior retirada que hicieron aquelios en Sicasica el 28 de Mayo, con más 180 indios del pueblo de Toledo, provincia de Paria, arzobispado de los Chatcas, que condujo en persona su propio cura, el doctor don Juan Mantel Gaviño y Argueda (quien, deseoso de servir a su Majeslad, is incorporó con la expedición manteniéndolos a su costa). Tocaron en el pueblo de Sicasica el 19, a distancia, antes de una legua; se destacaron exploradores que trajeron la nueva de hallarse los indios formados en orden de batalta. Mandó el general se echase pie a tierra, bajo la respectiva formación, con los dragones, batidores y oficiales, milicianos voluntarios (que han venido en competente nimero de Oruro y Cochabamba), quienes se anticiparon a escaramuzarlos, interín llegaba la infansería. A poco rato se oyeron tiros de fusil, porque los indios intrépidamente los acometieron, tanto, que cuando asomó la infantería, ya habían retrocedido y garlado el cerre inmediato a Sicasica. El general ordenó que la gente de Cochabamba les cortase la retirada y que la infantería se dividiese en tres trozos y acordonasen el cerro. Asi los combatieron, desde las 11 del día hasta las cinco y media de la tarde, con la mortandad de 300 indios; de nuestra parte, un satgento y 64 heridos de cirugía, sin computar los golpeados. El 20 marcharon al mismo pueblo de Sicasica, quedando un trozo a sus extramuros, se posesionaron de la plaza y siguieron el camino a acampar delante. 
Se aprehendió en el pueblo la mujer del indio que comandaba allí a los rebeldes, con otras. El general les lizo proponer el perdón y no lo admitieron, por decir no tenian arbitrio, sin permiso de su virrey fingido; el cual se les repitió por medio del eclesiástico ayudante, a quien respondieron el 21 estar perdonados y no necesitar de tal perdón. Se mandó incendiar el pueblo, asegurados antes los vasos sagrados y bienes de la iglesia (que se reservó), y en aquel acampanento se experimestó una tentativa de los levantados, en que murieron nueve de ellos y los demás amenazaban a los muestros que Tupac Catari los volvería cenizas. El 22 se acordó retroceder al campo del Vicario a aguardar las gentes de Cochabamba, comandadas de don Juan de Ayarza, chileno de bravura y honor, y hallándose la $/ f .47 \mathrm{v}$. trope sobre las armas, mientras cargaban el equipaje para esta retirada, dos leguas distante del cerro donde se mantenían, se osaron los rebeldes a querer violentar las cargas del equipaje, obligando a los nuestros a contenerlos y a que en media hora hubiesen muerto en refriega a más de 600 indios, con cuya satisfacción siguieron la empresa, duplicándose aquélla, con la combinación de 700 hombres de Cochabamba, a las 5 de la tarde. Fi 23 se previno una corrida en que mataron 22 indios y nueve indias y se trajo algún ganado lanar. El indio vice caudillo de Sicasica clanó por su mujer, of reciendo entregar al principal Apaza, lo que le fue concedido a ver si por este medio se le atraía pero sin efecto, tal que siguieron en su obstinación. El 24 volvieron a Sicasicn y se entregaron aquellas piezas de la iglesia al dicho eclesiástico escusador, por haber sido una de las solicitudes de los indios, afectundo implorar el perdón. Siguieron la ruta y pasado este pueblo divisaron a las 4 de la tarde a los rebeldes apostados en distintos lugares y que a poco espacio empezaron a batir los muestros, con tres cañones. El general mandó acometer y las tropas to hicieron con bizarria, matando cosa de 100 indios en dos puestos de llanada, con huída de los otros que se incorporaron con los suyos y los cañones. Dispuso el jefe que los granaderos y dragones marchasen por el costado izquierdo de la serranía donde estaban a tomarles alguna altura. Al combatir los indios con los batidores de Chuquisaca y la gente de Aiquile, se vieron asaltados con el fuego graneado de aquéllos y precisados a desamparar los dos cañones que les ganaron, huyendo con uno a cierta elevación, sin dejar el tañido de sus cornetas. Los siguieron los nuestros y desalojaron de aquel sitio donde se contemplaron seguros. Murieron en esta refriega cerca de mil y quinientos indios, según el apunte de uno de los circunstantes y común contestación. De los nuestros quedaron algunos contusos y maltratados de las piedras y ninguno de cuidado.

El 25, caminaron los auxiliares al ingenio de Patacamaya y se hallaron con unas mujeres que, llorosas y prosternadas de rodillas, daban a gritos muchas gracjas a Dios, clamando por la justicia y besando el suelo repetidas veces, pues a la vista de tal socorro libraban sus vidas y salían de los fosos subterráneos donde se habían mantenido el espacio de cuatro meses, por el rigor de los rebeldes, gracias a la caridad de unas indias que tenian de su parte. Por las noticias que dieron se evitó la 
muerte de un sacerdote y una señora, que estaban en Belén, próximos al degüello, mediante la partida que destacó el general y trajo ilesos a estos individuos, habiendo ahuyentado a los indios que acababan de degollar una esclava y su hijo, por no avisarles el paradero de sus señoras. El 26 se acamparon los auxiliares en el campo de Ayoayo y allí mataron nueve indios, y el 27 en Calamarca. Los indios los desafiaron desde unos peñascos y algunos que los acometieron mataron seis de ellos. Se les propuso el perdón y contestaron que pensaban morir o vencer. El 28 se tocó a marchar con todo el aparato de tambores, pitanos y trompas marinas, tomando el camino llano y seguro de emboscadas, de la parte inferior, en virtud de la noticia que de esta ciudad se previno y dio el mozo conductor de aquelia carta entretejicla en el centro de una honda. Al ver los indios frustradas sus redes por el camino de la parte superior, se precipitaron obstinados a querer cortar el camino de los nuestros y, con extraordinaria intrepidez y celeridad, tocando cornetas, cajas y otros instrumentos, tirando fusilazos y gritando a los nuestros, de alzados. Llegaban las piedras sobre los auxiliares, que los maltrataban y, bajo órdenes próvidas y puntuales del general, se trabó un combate sangriento y murieron en él cerca de dos mil indios. Le ganaron al caudillo Apaza el caballo tordo, enjaezado y huyó éste derrotado. Y el 30 de Junio (feliz para esta ciudad), antes de tocar en el alto del pueblo de Achocalla, al ver que los indios los aguardaban formados y en mejor disposición que en las funciones antecedentes, con un trozo de caballería y otro de a pie y muchos que rodeaban a los auxiliares por todas partes, mandó el jefe formar un cuadro, colocando en el centro todas las cargas y mujeres e iniciando la refriega por el frente. A poco instante, avanzaron a los nuestros por el costado izquierdo, con la felicidad de haber avistado, los del derecho, una emboscada en la quebrada y diferentes puestos del alto de Achocalla, sobre quienes se echaron de repeso y destruyeron su malicia con crecida mor-/f.48 tandad, por lo cual empezaron a huir todos los rebeldes. Se tocó al degüello y se les persiguió este dia por todo el campo llano hasta tocar a las inmediaciones de los altos de esta ciudad y al pie de los cerros de la izquierda, quedando asi destrozado el ejército del malvado Tupac Catari, habiéndose señalado todos los dos mil hombres, con positivo denuedo y generosidad, y las gentes de Cochabamba que, con sus garrotes en mano, casquillados de plomo y estaño y asidos de un chicote, hacen esfuerzos de robustez al seguir y destrozar los indios, que a cada golpe los traen al suelo, semi vivos por lo regular, si no los dejan muertos (1).

(1) En las anotaciones del tía 1 de Julio, el Oidor casi se reduce a trazar una sintesis de lo que había acontecido er el resto de las provincias, haciendo un recuento de las noticias que habían trádo las tropas auxiliares. Como los hechos narrados corresponden a los que los vecinos de la ciudad no habían vivido, habiendo heclso en cembio frecuentes conjeturas, es muy explicable el interés que pone el Oidor en anotar datos que para los demás eran de sobra conocidos. 
Lunes 2 de Julio. Entraron a la ciudad muchos corderos, ovejas y ganado vacuno, del mismo modo gue el de ayer, acopiados en el camino, por medio de las proficuas providencias del señor Flores, con otros comestibles y harinas que el Comandante de La Paz mandó destinar en la provisión, habiéndose comprado ellas al precio exorbitantísimo de 35 pesos la fanega, sólo porque los abarcadores y regatones hicieron levantarlas de punto, para sus granjerías, sin que la ciudad a quien toca, tuviese parte en estos precios de abasto (1).

Se aprehendió a la concubina del caudillo Apaza, nombrada Bartolina Sisa y a un indio joven, nombrado Ascencio, alias el Cañarito, que dormía al pie de su cama y con particular velocidad iba y venía a los pueblos levantados y seducir otros, por medio de sus cartas y órdenes, trayendo razón menuda de los hurtos y ocurrencias. A quienes aprehendieron las gentes venidas de Cochabamba, por noticia de unos 20 ó 30 indios que se reconciliaron y los condujeron al puesto (2). El general dio al principal una medalla sobredorada, con el retrato de su Majestad para firmarlo en la fidelidad y que atrajese a los demás [3\}. Mataron a Juan Crisóstomo Hinojosa, del pueblo de Caquiaviri, en l’acajes, de quien se dijo era de los fieles, aunque parece se vició una vez que no quistr venirse a la ciudad, como otros (4).

(1) Como siempre ocure en estos casos, a pesar del control que se trataba de mantener en la distribución de las harinas, catnes y demás alimentos por parte de la Proveedurfa General, no pudieron faltar en esta ocasión los comerciantes abusivos y calculadores que especularon con el hambre de los vecinos, aprovechándose del desorden de aquellos días. Todos los Diarios de] Cerco se refieren a estrs abusos.

(2) El Oidor da la noticia de la captura de Bartolina Sisa, tan de paso y con tanto desprecjo, que no cabe sino pensar que no captaba la importancia del acontecimiento ni el valor del personaje. No podía adivinar por entonces que a él le cabría más tarde el condenarla a muerte.

(3) Se trataba de una medalla que Hevaba, rodeando la efigie de Carlos IIl, la incripcion "En premio de la Fidelidad". Había sido ideada por Geronimo Manuel de Ruedas, presidente da la Audiencia de Charcas, para premiar a los caciques fieles de Porco y Yamparáez; después sc hizo extensiva a los otros, por autorización de Vértiz y Gálvez. El dato lo da Alejandro Rosas en "Medallas y Moneđus de la República Argentina". Buenos Aires, 1968.

(4) Leyendo el Diario de Segurola puede apreciarse que el Oidor no se enteró de que Juan Crisóstomo Hinojosa fue entregado por los indios junto con Bartolina y el Cañarito y que era un mestizo que hacía de amanuense a la virreina. Llama la atención que a éste Flores lo hizo pasar por las armas en su mismo campamento; en cambio, a los dos primeros los envio a La Paz para que se les juzgara. 
Martes 3. Continuó la internación de víveres a la ciudad. $Y$ en las campañas del alto murieron más de 60 indios rebeldes por la correría de nuestros auxiliares. Bajó el general a la ciudad, con general aplauso de ella y trajeron prisioneros a la fingida virreina y el Cañarito, después de haber tomado el general una razón circunstanciada de ambos acerca del paradero del conjurado y demás cabezas, en Higuañahuma, a la espalda de Calamarca, como de los caudales y ganados hurtados.

Miércoles 4. Se supo que el rebelde se aproxinó a la estancia de Hamachiuma, con más de dos mil indios que todavía le quedaban. El Comandante de La Paz dispuso se hicieran salonas de los borregos internados. El señor Flores empezó a escribir ctutas circulares y exhortatorias de suavidad y dulzura a los pueblos amotinados y al de Achacachi, capital de la provincia de Omasulyos, por un indio de aquel lugar, a quien perdonó, ofreciendo hacer lo mismo con todos y darles papel de indulto (iniciado a distribuir) siempre que vengan a acreditar su lealtad y obediencia. Se retiró dicho señor a su acampamento a las 3 de la tarde y le siguicron los diputados de este Ayuntamiento para cumplimentarlo en crédito del reconocimiento de la ciudad, habiendo practicado lo mismo, los del venerable Cabildo eclesiástico y denás cuerpos, que al siguiente de su arribo pasaron a felicitarle a su acampamento, con todo el noble vecindario (1). Desde la 1 del dia, se notó la humareda de los cebadales y sementeras que por los contornos distantes de la ciudad, abrasaron los rebehdes.

Jueves 5. Repitieron otra correría los auxiliares y mataron cosa de 150 de aquéllos. Por la tarde se sintió la humareda que ayer. El general removió su campamento a mejor situación, más internada a la campaña dentro.

Viernes 6. Aprehendieron los rebeldes al clérigo don Vicente Rojas en su estancia de Achachicala y se lo llevaron a presentar al rebelde. Mataron en aquel puesto varias mujeres y niñas que salieron por comidas y algunos hombres en el lugar del primer campamento y cuestas de la salida de esta ciudad arriba. El pedrero que quitaron dos o tres soldados del regimiento de Saboya y enterraron por no considerarse sulictentes a conducirlo, le restauraron $/ \mathrm{f} .48 \mathrm{v}$. los alzados, quienes persisten obstinados e insolentes, pues entraron hoy a medio día a estas campanas y campo de la Capilla, de donde se llevaron mil doscientos corderos que pastaban, de la provisión del señor Flores, ignorándose el motivo de su rezago. El Comandante

(1) El comandante Flores se mantuvo con sus compañías en El Alto, posiblensente para evitar un nuevo encierro y mantener a las tropas en acción en pleno altiplano. A los pocos días de establecerse allí, tuvo que trasladar el campamento a distancia de una legua por falta de agua y pastos. Pasaron otras jomadas y se moviń nuevamente para instalarse en la Ventilla, a cuatro leguas de Lo Paz. 
dispuso una expedición de los ciudadanos para restaurar aquel rapto, pero salió tarde y vano ${ }^{(1)}$.

Sábado 7. Cometieron los rebeldes otra mortandad de niñas, españoles y mestizos que salieron fuera de trincheras en solicitud y compra de víveres. Acosaron en la cuesta de laja a dos soldados auxiliares y mataron al teniente de artilleros, Piedra, de los mismos (2).

Domingo 8. Se encaminó el señor Flores a explorar el campo y situación de los rebeldes, en compañía del Comandante, de 300 y más hombres de la ciudad con fusiles y alguna caballería auxiliar. Destacó cinco sujetos de caballería para ofrecer el perdón a tres indios que avistaron a mula y cosa de cinco a pie. No to admitieron diciendo querían guerra. Consecutivamente, apedrearon a los nuestros de retirada y don Ventura Carpio mató a dos de ellos con el fuego de sus armas. Al anochecer fijaron hacia la trinchera de Santa Teresa una bandera blanca en gue vino una carta del clérigo Rojas, con ruego de canjear su persona con la concubina de Apaza, quien asi lo solicitaba (3).

Lunes 9. Se repitieron en la misma forma tres cartas. Una de Apaza, que pide a la amasia y la llama su mujer, la corona de oro que dice le envió el rey (extravagante delirin), el caballo tordo enjaezado que le ganaron y un cajón de papeles importankes, que expresa tenía en El Alto. Amenaza que, de lo contrario, seguirá la guerra más sangrienta, con mil y yuinjentos indios chunchos que refiere tener a su disposición. La segunda, del clérigo Rojas, que insiste en dicho canje, asegurando que el rebelde tiene muchos indios (inducción suya). La tercera, es de los comunes de indios, que solicitan la restitución de la india y que con ella, harán paces. Se contestó al clérigo solamente, con repulsa de la pretensión como es regılar (4).

(1) Segurola, que anota todos estos sucesos el dia 7 y no el 6, como lo hace Diez de Medina, explica el robo del ganado cono una traición de una parte del regimiento de Palca que se plegó a los indios.

17) Ni aún estos datos de lo gue ocurre con los que salen fuera de los nuros a pesar de encontrarse en El Ato el ejército auxitiar. le hacen reconocer al Oidor la caustl por lá que Seguroja no salfa con sts tropas fuera de las fortalezas, cuando se encontraban alli todas las milicias de Tupac Catari.

(3) Segurola menciona esta curta y las sucesivas escritas por el capellán Rojas, pero no vienen consignadas en la edición de su Diario, porque se las envio al comandanle Flores.

(-) Se ve que el Oidor no conoció esta vez el contenido de la carta de Julián Apaza; con elia enviaba tna cabeza de indio diciendo que cra la de Marcelo Calle, con el cual él sabía que Segurola mantenía correspondencia. El Comandante no dio ninguna importancia al hecho ni a la acusación. Sabía, por lo demás. que a ese caudilio lo habian matado varios días antes los del ejército auxiliar cưando venían hacia La Paz. 
Día martes 10. Salieron nuestras tropas al alto de Santa Bárbara. Fueron enviados Franco, Aparicio y Palacios a Potopoto. Puestos arriba del río Orcoaviri y tres de los rebeldes enfrente, con su bandera blanca, convinieron éstos en las reflexiones de los primeros y que el Apaza era un borracho, cruel y alzado. asintiendo con la cabeza. Al nombrar a nuestro Soberano, se quitaron las monteras, ofreciendo conferir con los comunes acerca de la paz de que se les trató $y$ dejaron enteramente la petición de la india.

A tiempo y antes de esta expedición, destacó el señor Flores 800 hombres auxiliares al pueblo cercano de Achocalla, en que estaban muchos amotinados (1). Huyeron, se incendiaron sus casas y perdieron sus viveres y ganados; con cuyo golpe pueden contenerse los demás pucblos, meditando les suceda lo mismo, y moverse a la subordinación. En este día se presentaron al señor Flores las dos parcialidades de indios del pueblo de Pucarani, rindieron obediencia a su Majestad y clamaron por el perdón y en prueba de su fidelidad condujeron nueve zurrones chicos de plata sellada, 18 petacas de plata labrada que custodió el rebelde en su pueblo en poder del clérigo don Julián Bustillos que vino asocizdo de la conducta, en virtud de la reconvención política que le hizo el señor Flores, por la razón de la india, de la existencia de estos, alli y en el pueblo de Cuarina. Los del pueblo de Laja también escribieron implorando el perdón, que se les franqueó; puede ser, vengan a presentarse. Los de Achacachi contestaron iban juntándose para lo mismo. Se repartieron boletines del perdón a los primeros. Vino a la ciudad otra carta del clérigo Rojas, repitiendo en el canje y que el rebejde decía que, de lo contrario, se volvería loco y que aspiraba a la paz, con tal de que se quemen las armas por ambas partes, con otras claúsulas que irritan (2). También parece que el clérigo ayudante del pueblo de Araca, provincia de Sicasica, escribió al señor Flores ofreciendo un trozo de indios para el real servicio. Continúa el ingreso de víveres /f.49 que actúan y venden los auxiliares de Cochabamba y sigue el acopio de ellos en la Provisión, despojándose a la puerta de la trinchera de San Sebastián (que es la única abierta) de todos los que han pasado a conducir de los altos, los particulares, artesanos, y demás

(1) El Oidor no se enteró del por qué de todos esos movímientos hacia Potopoto y Pampajasi: en realidad, obedecian a la idea de que se distrajera a los sublevados en esa zona para impedir que acudieran a auxiliar a los de Achocalla, contra quienes Flores había preparado la expedición punitiva, a la que se refiere el Oidor sin captar su conexión con la prinera.

(2) Tanto las cartas de Rojas como las de Catari y la de ta comunidad de los indígenas, nuestran claramente el estado de depresión en que cayó Julián Apaza por el cautiverio de su mujer. Augusto Guzmán, en sư "Tupaj Katari”, México. 1944, hace un estudio psicológico, algo novelesco pero muy hermoso, de lo que sucedia en el ánimo del caudillo. 
pobres de la ciudad, de ambos sexos, que gimen al ver frustradas sus fatigas $y$ adquisición y porteo, y que se quedan como al principio.

Miércoles 11 de Julio. Prosiguió la internación de víveres, ganado vacuno, cerdos y corderos del pueblo de Achocalla, en que nurieron ayer 40 indios y se aprehendieron algumos de ambos sexos.

Jueves 12. A la 2 de la tarde, se pos presentaron los rebeldes en el alto de Quilliquilli, venidos desde su campo de Pampajasi a la otra parte del ró de Potopoto. Nos desafiaron por aquel puesto, con diferentes injurias y batieron la ciudad con cuatro tiros de un pedrero con bala rasa y se retiraron a las cinco y media de la tarde.

Viernes 13. Se supo la repetición de los cochabambinos auxiliares al pueblo de Achocalla por el pillaje, a que parecen aplicados (1); haliaron muchos indios sublevados, mataron sobre 150 de ellos; profugaron los demás y se despeñó uno de dichos auxiliares. Trajeron los frutos alli cosechados a su real y algunas reses. Se vio en este dia otra bandera blanca con carta, pero se proveyó el acierto de prohibir su recojo.

Sábado 14. Mudó el señor Flores su campamento hacia la Ventilla, cuatro o cinco leguas distante de la ciudad, noticioso de que en aquellas inmediaciones se hallaban muchos rebeldes, con el designio de escarnentarlos o de atraerlos y ver si con la ayuda de los nismos logra su deseo ardiente de aprisionar al rebelde y demás cabczas, en aquel puesto quebrado de serranías, donde hoy se mantiene y es difícil su acceso.

Domingo 15 de julio. Corrieron las fuentes de la ciudad, por las proficuas providencias del señor Flores, que obligó a los indios reconciliados y en especial a algunos de esta parroquia de San Sebastián, para el curso de las aguas y refacción de las cañerías quebranladas (2). Esta mañana, a vista de la mutación de dicho acampamento, se posesionaron algunos sediciosos del alto de San Pedro. A medio día se tomó en la garita del camino de Potosí una india presa, que estaba con tres alzados que de allí corrieron. Por la noche se oyeron algunas cornetas de los rebeldes por los extremos de Santa Bárbara.

Lunes 16 de Julio. Subieron algunos alzados al alto de San Pedro, de donde descendían cargados por los hombros, sin saberse la especie, y aún corre exhumaron

11) Hay absoluta conformidad en todos los Diarios, asi como en los informes de Flores, Reseguín y Segurola al Virrey Vértiz, sobre el constante pillaje de los soldados cochabambjnos que arriesgaban la vida, retrasaban las marchas, perjudicaban las campañas y ahondaban los rencores por el cominuo pillaje que realizaban en los pueblos y regiones reconquistadas.

2) Segurola, en su continus actitud de mantener un diario de guerra, no menciona lo del agua que corte nuevamente, aconlecimiento tan importante para los vecinos; el Oidor y el capităn Ledo se regocijan, en cambio, con la noticia. 
algunas piezas de plata labrada del campo que está al lado de dicha garita, manteniéndose varios en corro, por bastante espacio de tiempo.

Martes 17 de Julio. Pasaron cosa de mil indios de Potopoto al alto de San Pedro y a las 3 de la tarde se presentaron otros en el frontero de Quilliquilli, sin acción.

Miércoles 18. A las 8 de la mañana se vieron desfilar los indios levantados desde el alto de San Pedro para las campañas de la Capilla y que algunos se desbarrancaban acosados de la caballería de los cochabambinos auxiliares, los que en dicho alto mataron 30 más o menos y 20 en las quebradas del descenso. Las tropas de La Paz salieron tarde "1' y no alcanzaron al intento de cercarlos, pero mataron cosa de 12 junto a la laguna de la Capilla. Amanecieron este día las fuentes sir agua sin duda porqque los rebeldes volvieron a cortar la cañería.

Jueves 19. Bajó el señor Fiores de su acampamento, últimamente trasladado al campo de Seque, con la comitiva de algunos dragones y oficiales, a la misa de gracias al Omnipotente por los lavores que con la venida de este jefe recibe esta ciudad, de sus misericordias. $Y$ en muestra de su reconocimiento se le adornaron las calles de arcos y se le recibio en la puerta de la trinchera de San Sebastián, por este Ayuntamiento, el sejor comandante con su comitiva la nobleza y oficiales / f. $49 \mathrm{v}$. de la ciudad con todo el pueblo que, con vivas y aplausos le celebraban llenos todos de regocijo. Después de Ja misa y el Te Deum de la catedral, ie acompañaron a la casa de don Juan León de la Barra (vecino de honor y fidelidad al Rey y a la patria, que vistió a su costa una companía de caballería y ofreció todos sus caudales sin reserva de las alhajas de la señora, su madama, siempre que haiga necesidad de echar mano de ellos para el real servicio), dispuesto para su alojamiento. Allí le celebraron lúcidamente y con magnificencia en la mesa y refrescos abundantes en la noche y desempeñaron ambos la gratitud de la ciudad a expensas de sus propios esmeros aún a pesar de las escaseces de la ciudad. Se oyeron por parte de los primeros cuerpos de ella varios discursos ercomiásticos, de elocuencia y erudición (2).

Viernes 20. Las religiosas de los dos monasterios de la Concepción y Carmen Descalzo, celebraron sucesivamente misa de gracias, con asistencia suya y de la ciudad. El general tomó sus medidas y disposiciones para acometer el campo

(1) Cuando el Oidor señala que las tropas de La Paz satieron tarde, el Comandante dice que salieron a la brevedad. ¿Cuál de los dos decfa ba verdad?

(2) La descripción del recibimiento de Flores hecho por los vecinos. con todos los detalles que permiten revivir la escena de la ciudad regocijada, constituyendo un cuadro sociológico muy interesante, está escrita con el mismo entusiasmo tanto por el capitán Ledo como por el Oidor: Segurola, en cambio, da la noticia en la forma más cscueta posible. 
enemigo por distintos lugares y mediación de prácticos y aprehender al caudillo. Se retiró con este designio a su acampamento, para regresar esta noche, bien que no prudo lograrlo, porque arribó tarde y no estaban a mano las caballerías. Las principales fuerzas de esta ciudad le aguardaban para combinarse y se recogieron. porque a la media noche recibió carta el Comandante de aquel impedimento.

Día sábado 21. Llegaron al fin de la tarde, treinta y tantos viajeros de la villa de Cochabamba, cargados de harinas, bizcochos y granos y pasaron sin novedad por los pueblos levantados de Sícasica y Ayoayo y aunque del de Calamarca, se dice, les salicron 300 indios, no hicieron nada, antes sí les regalaron came, compraron pan y otras cosas. En la Ventilla si que tuvieron moviniento con unos indios amotinados; mataron a dos, se defendieron y les robaron algunas cargas de harina y a poco rato les pidieron pertón y pesarosos de las facciones y tumultos en que engañados por las seducciones de Apaza, dijeron haber estado. Todo es efecto del escarmiento que han recibido con la venida del señor Flores, lo que nos da una idea satisfactoria de que las cosas van sedando y que pueden pacificarse.

Por la noche a las 8 y más, entró a la ciudad el señor Flores con sus tropas, habiendo dejado fuera de trincheras por San Pedro, 600 hombres cochabambinos y de infantería al comando de don Juan de Ayarza (1), con el designio de hacer un ambage por el Río Abajo y tomar la espalda de las serranías (2), donde está acampado el rebelde con sus gentes. El designio es partir antes de la aurora, con las fuerzas de la ciudad para que, tomada la parte superior por aquéllos, acometerlos en aquella situación muy' quebrada y áspera con menos riesgo, desalojarlos y aprehender al coudillo Apaza y demais cabezas.

Dia domingo 22. Salió la expedición a las 4 de la mañana, al valle inmediato de Potopoto, en que se incluyeron 400 hombres de los caballeros oficiales y otras personas de fusiles, con 70 granaderos de la ciudad y ałgunos de caballería. Los que debian ganar la eminencia al enemigo, por disputas de los prácticos, se vinieron faldeando aquel cerro por la frente misma y, como a distancia dispararon (sin ser vistos de los nuestros) sus fusiles, consideraron los señores Flores y Segurola (que comandaban), el que ya estaban avanzando por la espalda y en este supuesto, ordenaron el acceso, actuado en buen orden y fuego de más de 500 fusiles y algunos pedreros y con igual suerte. Cuando, al ganar los ranchos, capilla y cabildo de la

(i) El Oidor comete un error. Se trata de Josef de Ayarza.

(2) Seguramente el Oidor se refiere a la parte baja del río Orkojawira (Orcoavira) porque, de haberse dirigido a la región de Río Abajo, las tropas habrían matchado precisamente en sentido contrario al de su destino, puesto que debían llegar a Pampajasi dando un rodeo por detrás de los cerros. 
construcción de los rebeldes, repararon inmediatos a los de Ayarza que venían asifaldeando por el mismo frente, sin proporción ya para ganar la ceja del cerro, con lo que vio el señor Flores trastornada su disposición y notó no se podría ya lograr la empresa. Sin embargo, huyeron los enemigos a la cima y arrojaron una lluvia de piedras, inclusas las mujeres y golpearon a los nuestros sin reserva de ambos comandantes, en especial el señor Flores, que recibió una disforme pedrada en el pie y otra en el brazo. Les avarzaron los nuestros con bizarra intrepidez, notándose que los de la ciudad se señalaron y avanzaban de los primeros, con la presencia de este ge-/6.50 neral y sus órdenes oportunas. Faltábales una cuadra escasa para ganar el mismo alto, pero como media un corte o salto difícil de superarse sin riesgo o a costa de mucha sangre por las galgas de piedras que despeñaban los indios, fue prudencia el que se mandase la retirada, que se practicó con feliz suceso después de haberse incendiado aquellas rancherías de los indios. Sin más desgracia de nuestra parte, que la de un Lora de los de Chuquisaca, a quien degollaron los indios por haberse desfilado solo a saquear una casa en que lo sorprendieron los rebeldes y haber recibido un tiro de fusil en el vientre don Benito Santalla, oficial de Larecaja. De los indios murieron ciento y tantos. Y por una chola que tenían prisionera y se nos vino, se sabe que el Apaza se retiró a los Yungas con pocos indios. Lo que confirmaron dos indios rebeldes que las amigos aprehendieron y condujeron al acampamento del señor Flores, añadiendo que el miércoles 18 de éste, partió del sitio actual para aquel destino, receloso de los indios que no se le subyugaban con la generalidad pasada, que le iban ya dejando, como los de Collana, Viacha, Pucarani y otros pueblos, y de una carta qua los de Pucarani escribian a los sediciosos que existen en Potopoto, manifestándoles era un trapacero y engañoso, que lo amarrasen y asi lo entregasen para lograr el común sosiego, contexto que parece le dio en qué pensar. Por la noche se oyeron algunas cornetas a los extremos de la ciudad.

Día lunes 23. Se supo que desde ayer se hallaban aguardando en su acampamento al señor Flores, 50 indios de Viacha a pedirle perdón. Por otro que vino de los Yungas, de los fieles, esta tarde, a quien despojaron los rebeldes en Potopoto de cinco cestos de coca, se sabe que el Apaza se halló el jueves 19 de éste en el pueblo de Chupe de los Yungas con el designio de trasladarse al de Chulumani que es la cabecera. Alli, se dice, mataron los indios a un comisionado suyo y otros de su facción, por haberles engañado el Apaza con sus astutas falacias y asegurándoles que esta ciudad la tenía ya ganada, en cuya fe se le confederaron y se discurre o que le maten o que le prendan y avisen, porque iba con sólo 30 indios. Lo cierto es que la sedición se va dividiendo, para asi desolarse con el favor celeste. La india Gregoria, hermana del Apaza, se intitula ya virreina y está en el pueblo de Guarina de Omasuyos, tumultuada con aquellos indios. En el santuario de Las Peñas, se halla otro patrañista que se finge Diego Tupac Amaru, joven, y dice ser hijo del rebelde de Tungasuca a quien llaman los indios Guayna Inca, y hoy adhieren con mucha novedad, aborreciendo y notando las crueldades y hurtos del Apaza y 
aplaudiendo la sagacidad y buen trato que reciben de aquél. jRara felicidad de bárbaros que con ligereza se subordinan o entregan ciegamente a cualquiera! (1).

Martes 24 y siguientes 25,26 y 27 . No hubo novedad sino algunas correrias nocturnas de los rebeldes de Potopoto por algunos extremos de la ciudad y algunas cornetas. El general chvió un trozo de cochabambinos comandados por don Juan de Ayarza, a las estancias del común de Laja, que se hallaban juntos y amotinados en un puesto y fueron cercados sin más arbitrio que rendirse con ruegos y pedir perdón, habiendo quedado a congregarse todos y venir a presentarse al señor Flores en su acampanento y obtenerio por medio de boletines, a cuyo efecto les dejó una bandera, el dicho Ayarza, para que bajo el salvamento de ella, puedan tomar el camino seguros, para el mejor logro de la subordinación. Y por la carta última del eclesiástico don Vicente Rojas, se sabe también que los indios iban retirándose diariamente del campo rebelde y quc se hallaban disminuidos en el número anterior. Es cierto que las cosas van tomando favorable semblante, aunque los cochabambinos incomodan demasiado al general, desertando diariamente en trozos y turban la prosecución de sus disposiciones obligándole a la precisión de mandar venir otros, en mayor numero, puesto que la necesidad lo pide y no se gradúan por suficientes para la empresa los venidos con dicho señor [??.

Nos los escribanos de su Majestad (que Dios guarde), que signamos y firmamos, certificanos y damos fe en cuánto podemos y ha lugar de Derecho, que habiéndonos enterado del Diario antecedente, formado y arreglado por el señor don

(1) La forma en que el Oidor apanta todas estas noticias revela que en La Paz solo se tenían ideas vagas de lo que sucedía en el campo enemigo o en las regiones de Omasuyos y Larecaja. Se ve que no se sabia hacia dónde ni cuándo se había marchađo Tupac Catari y que sólo se tenían rumores de la existencia y actuaciones de Andrés Tupac Amanu y Gregoria Apaza.

(2) Con estos datos apresurados, el Oidor corta la primero parte del Diario. Se puede apreciar que no quiere finalizario reconociendo la realidad de la situación, que era mala, y se refiere, entonces, a los indios que acuden a pedir el perdón o a los que se evaden hacia la ciudad. Sin embargo, a su pesar confiesa que hay deserciones entre los cochabambinos y que "la necesidad" pide la trajda de mayor número de tropas. Posiblemente con ello está disculpando la medida de Flores de abandonar la ciudad para ir en busca de mayor refuerzo, tema del que ya se hablaba con temor en La Paz. 
Francisco Tadeo Diez de Medina, del Consejo de su Majestad y su Oidor previsto de la Real Audiencia del Reino de Santiago de Chile (que reside en esta ciudad), hallamos que en lo que toca a los sucesos y acaecimientos ocasionados en el tiempo del bloqueo o cerco que ha hecho a esta ciudad, el indio alzado y rebelde Julián Apaza que se nomina Tupac Catari, desde 14 del mes de Marzo hasta 30 del inmediato pasado de Junio de este presente año, que está muy veridico en sus relaciones, pues según y como en él se asientan los diarios sucesus y el estado de la ciudad, nos consta a nos, los dichos escribanos, con ocasión de que el prinero, como actuario de la Real Hacienda de esta Caja, ha presenciado y actuado en varios expedientes y los otros dos tenemos visto y experimentado, el uno de Cabildo y el otro / f.51 del Número, tanto por lo que hemos acluado cuanto por nuestra continua asistencia a las trincheras y fortificaciones de ella, y por estos motivos sabemos de todo lo referido en dicho Diario, de unos puntos por vista y experiencia y de otros por común voz que ha corrido y corre, de tal meido que no encontramos los tres, apócrifa ninguna en todo su contexto, de lo sucedido en esta ciudad, únicamente salvando de algmos otros puntos que no hubiésemos sabido. Y para que de ello conste donde convenga, de orden de dicho señor Oidor, dimos la presente. En la ciudad de Nuestra Señora de La Paz, en 30 días del mes de Julio de 1781. años. Enmendado- catorce-vale (1).

Crispín de Vera y Aragón

Escribano de S.M. y Real Hacienda.

Pedro de Mariaca

Escribano de S.M., Público y de Cabildo.

Rafael de Villanueva

Escribano de S.M. y Público.

(1) La certificación de los escribanos era muy importante para el Oidor, puesto que no había dicho en el Diario que él era el autor, refiriéndose a su persona en forma indirecta. Por otra parte, necesitaba tal certificación de los notarios porque comprendia que, abierto el paso para el correo hacia Buenos Aires, el Comandante y el Fiscal darian cuenta de muchos acontecimientos que lo implicaban, y de los cuales. naturalmente, descaba dar su propia versión. - A través del pleito tantas veces mencionado, de Gil de Alipazaga contra Segurolu y F.M. de la Plata, puede verse que no sólo envjó el Diario a Buenos Aires con destino a España, sino también uno larga cortespondencia a la Audiencia de Charcas sobre cada una de las controversias y problemas que tuvo con esas dos autoridades. 


\section{NOTA PRELIMINAR A LA SEGUNDA PARTE DEL DIARIO DEL OIDOR FRANCISCO TADEO DIEZ DE MEDINA}

En 1981, cuando se conmemoraba el II Centenario de la Rebelión de Tupac Catari en las provincias del Obispado de La Paz, Gunnar Mendoza, el gran Director de la Biblioteca y Archivo Nacionales, dijo, refiriéndose a la publicación de la Primera Parte del Diario del Cerco de La Paz de Francisco Tadeo Diez de Medina (AGI.Charcas 583), que abarcaba descle Febrero de 1781 al 27 de Julio de ese año, y que yo había editado, que existía una segunda parte "que quedaba inédita" y como "único ejemplar conocido" en posesión de una familia paceña. Gunnar Mendoza lamentaba entonces que la oportunidad "acaso única" de publicar el Diario completo hubiera quedado malograda a pesar de nuestio personal empeño. El agregaba que "ojalá no fuera asi".

Y no fue asi. ¿Qué pasó para que sobreviniera este cambio tan beneficioso?

Simplemente, un confunto de coincidencias de esas que aparecen en las tareas de los investigadores.

Casualmente, Hegó a manos de un prestigioso anticuario y coleccionista de La Paz, don Luis Wallpher, un documento para ser vendido. Wallpher, con su innata curiosidad y su afán de conocer las cosas interesantes que le llegan, revisó en profundidad el tex to advirtiendo que si bien demostraba tratar de los acontecimientos de 1781 , no podía asegurarse nada más respecto de su contenido puesto que carecía de firma y título, ya que faltaban las primeras 19 páginas. Con fina intuición, Luis Wallpher comprendió que se trataba de un texto importante y se puso en comunicación con historiadores amigos. Ellos, a su vez, le mencionaron mi nombre recordando mis publicaciones sobre los diarios del cerco.

Efectivamente, bastó que yo mirara el documento para reconocerlo de inmediato, puesto que, como veremos más adelante, ya to habia leido anteriormente. Pude incluso demostrar a Wallpher la evidencia de lo que sostería basándome en mis estudios anteriores.

Por otro lado, estando tun día en mi casa la Presidenta del Banco Boliviano Americano, María Isabel Siles de Mazzi, hablamos de la publicación de la Primera Parte del Diario de Diez de Medina que habíamos realizado gracias al auspicio brindado por su padre, Luis Eduardo Siles, en su calidad de Presidente anterior de 
dicha institución bancaria. A propósito de esto, y como resultado de nuestra conversación e intentos previos de algunas personas con María Isabel, afloró la idea de que el Banco comprara este documento reaparecido después de casi 20 años, con la mira de regalarlo a la U.M.S.A. para su conservación en el Archivo de La Paz, dependiente de esa Casa de Estudios.

En esas andanzas habia participado otro protagonista importante, don Pedro Querejazu, que fue quien terminó de convencer a la l'residenta del Banco y quien concretó, como hábil promotor de actualidades culturales, las conversaciones entre los otros dos personajes y desinterados protagonistas: Luis Wallpher, que no quería que este documento saliera del país, a pesar de las tentadoras proposiciones que le habian hecho, y la Presidenta del B.B.A., que comprendió con un gesto generoso que un Banco puede dar al país algo más que ventajas económicas, contribuyendo también a enriquecer st acervo histúrico y cultural.

Cuando fuimos, por fin, con Pedro Querejazu, para que yo demostrara con la documentación que poseo la autenticidad del texto y Pedro entregó su importe llevandose el Diario para su depósito en el B.B.A., había llegado para mí la realización de un sueño sostenido durante tantos años en mi mente y en mi corazón. Cabría preguntarse ahora dónde radica el valor del documento que vemos aqui y por qué es tan significativo este obseguio a la Universidad, a la ciudad y al país por parte del Directorio del B.B.A. y de su Presidenta.

La respuesta es fácil, y podemos captarla a través de un significativo informe:

La rebelión de Tupac Catari en las provincias de Sica Sica, Pacajes, Omasuyos, Larecaja, Yungas y, sobre todo, el prolongado y dramático cerco de La $\mathrm{Paz}$, así como los problemas que se suscitaron dentro de la ciudad, fueron recogidos en varios Diarios que constituyeron un elocuente testimonio que refleja la forma en que los acontecimientos, fueron vividos por qaienes resistieron el asedio.

De aquellos diarios, sólo habían sido publicados el del Sargento Mayor Castañeda y el del Comandante Segurola; el primero ha tenido muy poca difusion y es muy difíell encontrarlo hoy en día, siendo el de Segurola, reeditado por el Municipio de La Paz, el único conocido, utilizado y citado en los diferentes estudios sobre la sublevación de Tupac Catari.

Las primeras noticias que tuve de este documento se debían a José Vázquez Machicado, quien lo encontró en el Archivo de Indias de Sevilla, copiándolo con bastante fidelidad. Posiblemente, Vázquez pensaba realizar su edición con algún estudio; no se tiene, sin embargo, noticia alguna de que hubiera llegado a hacerlo.

Estando la autora de aquel trabajo sobre Diez de Medina haciendo un estudio comparativo de los Diarios que se escribieron durante el cerco, fue informada de la existencia de la copia antes mencionada por parte del escritor Mariano Baptista 
Gumucio, quien la puso en contacto con su dueño, el Dr. Carlos Serrate Reich, que generosamente le obsequió una reproducción de la copia de Vázquez Machicado. Con ella en mano, pudo pedir una fotocopia al Archivo de lndias. Ese Diario abarcaba en sus anotaciones todo lo ocurrido durante el primer cerco de La Paz. Cuando le correspondió salir a luz a la Primera Parte del Diario de Diez de Medina 9 , pude contribuir con un importante aporte a la historiografia.

Publicado el trabajo sobre la comparación de los diarios, tuve ocasión de diagnosticar un documento que parecía ser un nuevo diario. Se trataba, efectivamente, de unas anotaciones cotidianas que, Ilegando hasta Octubre de 1781, habian perdido los folios iniciales, por lo que no se sabía cuándo se había comenzado a escribir ni quién lo había hecho. Empezaba el escrito el 19 de Marzo. La consulta me fue hecha por el historiator Alberto Crespo Rodas, a quien le habia facilitado el documento original el doctor Jaime Retamoso Zuazo, quien seguramente lo heredó de su señor padre, don Ramón Retamoso, que era historiador y uno de los fundadores de la Academia Boliviana de la Historia. Ramón Retamoso pudo haber conocido a Fray Nicolás Armentia porque sus vidas se tocaton cronológicamente. Fácilmente se pudieron cotejar las notas del señor Crespo Rodas con las del Diario de Francisco Tadeo Diez de Medina, comprobándose que se trataba de un mismo texto. Había, sin embargo, una novedad; el diario del Archivo de Indins llcgalra hasta el 27 de Jutio, día en que se cortaba bruscamente el hilo de la narración con una cerlificación de verdad hecha por los notarios de La Paz; éste, en cambio, sin aquel corte ni alusión alguna a una interrtpción, continuaba sus anotaciones hasta el 28 de Octubre. Ninguno de los dos textos estaba escrito de puño del autor; el de Sevilla acusaba una sola mano de copista, mientras el de La Paz denotaba cuatro, presentando además varias correcciones hechas por el propio autor, cuya letra la autora de este estudio podía fácilmente reconocer.

El Dr. Retamoso Zuazo permitió a la investigadiora conocer el texto, e incluso la autorizó a tomar algunas notas de aquella segunda parte, pero desgraciadamente no consintió en que se hiciera una fotocopia de él porque pertenecia a sus hijas.

Más tarde, en Agosto de 1976, tuve ocasión de trabajar en el Archivo General de Indias, donde busqué afanosamente alguna otra copia de aquella parte, con resultados negativos. Encontré, en cambio, otros documentos del Oidor Diez de

.4*) Francisco Tadeo Diez de Medina. Diario del éerco de La Paz. 1781. Introducción y estudio рог Maria Eugeniá del Valle de Siles. Edición hecha con el auspicio del Banco Boliviano Amcricano. La Paz, 1981. Talleres-Escuela de Artes Gráficas del Colegio "Don Bosco". 275 pgs., más láminas. En la presente edición se reproduce íntegramente el tex to de esa publicación, manteniéndose sin variaciones las notas de introducción de la autora. si bieo algunts referencias contenidas en ellas reaparecen en esta Nota preliminar. 
Medina y unas cartas que explicaban la razón del envio de la primera parte del Diario, así como el anuncio, después de finalizado el segundo asedio, de la remisión de la primera y segunda parte, escrita sin solución de continuidad, ya que se temía que por intervención de las autoridades de La Paz, se hubiera impedido el arribo a España de la primera encomienda. Paradójicamente, llegaron a la Península las cartas referentes al diario del primer cerco, pero no llegó, en cambio, el texto completo ofrecido por Diez de Medina.

He buscado prolijamente en Buenos Aires los doctmentos emarados del oidor Diez de Medina, pero no he encontrado nada que corresponda a un diario. Sin embargo, no considero imposible que algún día salga a flote su texto traspapelado entre otros documentos del Virrey Vértiz

En el conjunto de los diarios que se escribieron durante el cerco de La Paz. incuestionablemente es el del Oidor Diez de Medina el que reviste mayor significación, sobre todo si se considera que el Diario más amplinmente estudiado es el del comandante Segurolia.

El Diario del Oidor viene a ser la antítesis de el del defensor de La Paz. Este había sido escrito por un militar español de carrera, que había llegado a la ciudad por mandato superior dos meses y medio antes del cerco; no conocía bien, por lo tanto, la villa, sus contornos, sus vecinos; no sabia nada de las costumbres y etiquetas del lugar, no conocía las lenguas aborígenes ni la idiosincrasia de los indígenas que se agrupaban en los barrios periféricos. I'or todas estas razones, sus anotaciones tienen un carácter castrense, siendo, en realidad, verdaderos partes de guerra, a través de los cuales el comandante da cuenta de lo sucedido o explica un determinado plan de acción, en un lenguaje correcto, preciso, sobrio, pero sumamente frío; raramente se encuentran en sus páginas referencias a personas que no estuvieran vinculadas con la actividad bélica o a ocurrencias de tipo local que lo muestren como una persona que vibre, sufra o sienta toda la tragedia que vive la ciudad.

Frente a ese Diario, aparece, en cambio, el de Francisco Tadeo Diez de Medina; su autor es un criollo con importante actuación pública, que se siente orgulloso de haber nacido en La Paz, donde tiene una posición social y económica destacada. Ama entrañablemente a su ciudad y la conoce barrio por barrio, casa por casa. Ubica y distingue a los vecinos, habla quechua y aimara, conoce la mentalidad indígena y sabe hablar a los indios con el tono paternalista al que se les había acostumbrado hasta entonces. Conoce también la toporimia de la villa y sus alrededores, sufre con verdadera angustia todo lo que le sucede a La Paz y a las otras provincias. Por todo ello, las páginas de su Diario, a pesar de estar escritas en un castellano pretensioso, altisonante y alambicado, revelan la vida íntima de la ciudad, con todos los detalles de tipo antropológico que tanto enriquecen el cuadro social y cultural de la historia. 
Representa también este Diario una expresión reveladora de la tensión que en ese momento viven los criollos y peninsulares. Puede verse a través de sus juicios y observaciones cómo la innegable rivalidad de los dos grupos blancos, en lugar de atenuarse o verse desplazada ante la presión del indígena, ahora enemigo común, se exacerba, crispando los ánimos y acrecentando los mutuos recelos, desconfianzas y menosprecios.

Con una lectura penetrante del texto puede apreciarse también el juicio que el criollo tiene del indio, a quien respeta y estima en el plano teórico-jurídico, menospreciántóle en el plano real. En el caso del Oidor, puede verse cómo este dualismo animico lo lleva a contradicciones increibles dentro de las observaciones anotadas en un mismo día. Vacilaciones tan hondas en la mentalidad de aquellos hombres lacen más comprensibles las reacciones que adoptan cuando, sabiéndose vencedores, quieren aplicar lecciones imborrables y castigos definitivos, llevados a cabo con una saña tan horrible o peor que la de los alzados a quienes tanto acusaron y reprochason anteriormente.

Todas estas caracteristicas son las que hacen de este Diario un documento excepcional; si el otro Diario conocido fue escrito por un militar español, defensor de la ciudad, éste fue he'cho por un Oidor criollo que, como auditor de guerra, habría de condenar a cruel suplicto al principal caudilio indigena, a su mujer, a su hermana y a sus principates cormeles.

La Primera Parte de este Diario se inicia con largas frases que, más que un epígrafe, corresponden a un anuncio del tema a que se refiere el escrito. $\vec{A}$ ellas siguen cuatro folios y medio destinados a ser un resumen de lo acontecido en los dos Vireinatos a consecuencia de los levantamientos de Tomás Catari en Chayanta, de Tupac Amaru en Tintary de Tupac Catari en Sica Sica. Enseguida se corta la sintesis con un subtítulo que dice: "Ocurrencias en la ciudad de La Paz desde el $1^{\circ}$ de Febrero de $1781^{\prime \prime}$. La narración de tales ocurrencias prosigue sin ninguna interrupción hasta el 27 de Julio de 1781; bruscamente, entonces, aparece la certificación de Crispín de Vera y Aragón, Pedro de Mariaca y Rafael de Villanueva, los tres, escribanos de La Paz, dando testimonio de que el Diario pertenece al oidor Francisco Tadeo Diez de Medina, quien lo ha llevado a lo largo del cerco, y añadiendo que "está muy verídico en sus relaciones".

Las anotaciones que van desde el $1^{\text {th }}$ de Febrero hasta el 11 de Marzo corresponden a tum preámbulo del cerco, y no están escritas día a día; se ve que el autor las redactó acordándose de lo acontecido entonces y basándose en uno que otro apunte.

Sin lugar a dudas la introducción anterior al cerco de La Paz fue añadida después de haberse iniciado el Diario, seguramente cuando el autor lo dio a copiar, porque se refiere a liechos que se producen después del $1^{\circ}$ de Febrero y a personajes 
que Diez de Medina iría conociendo a lo largo del asedio. No cabe dưa que ideó este sistema para poner en antecedentes al lector que, ubicado en el contexto de la sublevación general, captaria mucho mejor el sentido de lo que habia ocurrido en La Paz.

No sin habilidad, Diez de Medina escribe este Diario cono si fuera otra persona, con lo que encuentra una fácil coyuntura para atacar a quienes no aprecia, como asimismo destacar indirectamente su propia actuación. A veces utiliza la primera persona del plural y habla de "nuestro comandante" o de que "nos acometieron"; otras, en cambio, especialmente cuando hace reflexiones, consideraciones y loas, utiliza la forma impersonal.

La segunda parte del Diario que, como se ha dicho anteriormente, conforma un manuscrito diferente, integra otra copia del Diario; éste ha perdido las fojas iniciales, como deciamos, y no posee, por lo tanto, ni la introducción ni el preámbulo anterior al cerco ni lo sucedido en los primeros cinco dias del asedio, materia que en el de Sevilla ocupa 13 folios escritos en ambas caras. Continúa, en cambio, más allá que en el del Archivo de Indias, que finaliza con las anotaciones resurnidas de los días $24,25,26$ y 27 de Julio. La copia de La Paz prosigue sin la menor interrupción hasta el día 28 de Octubre. Sus folios están numerados con postcrioridad, el día 18 de Abril de 1906, posiblemente por el Ohispo Nicolás de Armentia, que fue su primer dueño identificable. La numeración comienza en el folio 20, 10 que significa que la desaparición de las primeras hojas ocurrió después de 1906, y llega hasta el 176. La narración del segundo cerco, que falta en cl de Scvilla, abarca desde la foja $118 \mathrm{v}$ hasta la foja 176, es decir, ocupa 58 folios escritos por ambos lados, lo que corresponde a una tercera parte del Diario completo.

El nuevo texto revela la mano de cuatro copistas diferentes, que varian tanto la ortografia como la puntuación. Este hecho produjo mayor descuido en la copia, e hizo que las correcciones $y$ añadidos del autor fueran mucho más frecuentes que en el primer manuscrito. La redacción, en cambio, no varia, manteniendo las formas indirectas del de Sevilia. Por tratarse, una vez más, de una copia que no estaba destinada a sałir de La Paz, no tiene ninguna certificación de verdad por parte de los notarios. Posiblemente, a la salida del Oidor, en 1782, cuando se dirigió a ocupar su cargo en Santiago de Chile, quedó el Diario en manos de algún amigo o pariente suyo, pero con el tiempo debió traspapelarse olvidándose con ello su origen, porque cuando Armentia certifica ser su propietario no hace alusión alguna a quien fue el autor.

Por todo ello, una pubbicación del texto completo debe ocupar de preferencia el texto de España en sul parte primera, para continuar con la segunda parte del Diario, que henıs podido estudiar sólo en oportunidad reciente, según queda dicho al comienzo de esta nota introductoria.

Aunque el Diario de Diez de Medina, tanto el que queda en posesión del Archivo de La Paz, como el otro! no fueron escritos de puño y letra por el Otdor sino 
por copistas, sus páginas tienen igual valor que si fueran manuscritos del autor. Ciertamente, fueron obra de copistas quienes, por lo general, eran notarios u hombres cultos que hacian copias autorizadas de documentos importantes, los que muchas veces tienen correcciones personales de los propios autores, como sticede con estos documentos. Se trata de copias contemporáneas que se iban haciendo día a día y que for eso coincidian exaclamente con lo anotado en la jornada por el autor. De ahi que la copia obsequiada por el Directorio del Banco a la Universidad Mayor de San Andrés se considere una pieza auténtica, original e invalorable que enriquecerá inmensamente a su archivo y que debe ser guardada como tal en caja fuerte, facilitánduse a los investigadores sólo fotocopias de ella. Gracias a una de esas copias he podido efectuar mi trabajo sobre la segunda parte del Diario que, con sus transcripciones, notas y estudio, se suma a lo ya realizado con la primera parte.

Dios ha quexido que nuestra esperanza se hiciera realidiad.

La señora Maria Isabel Siles de Mazzi y su Directorio se hacen merecedores de la gratitud de los paceños por una donación de estas características, en circunstancias en que vemus cómo por eslos mismos días se negocian y venden en el extranjero tesoros invalorables de nuestro acervo cultural. Ella, por el contrario, con su amplio y generoso gesto ha contribuido a la tarea de conservación de los documentos histónicos de lrechos tan importantes como fueron los acontecidos durante el cerco de La Paz en 1781. A esa decisión, de tan alto contenido patriótico, se añade la determinación aduptada por el mismo Banco de asumir los gastos de la edición definitiva del Diario de Diez de Medina, que comprende la primera y la segunda parte de ese documento, resolución ante la que no puedo dejar de manifestat mi gratitud más intima. Diciembre de 1993.

\section{MARIA EUCENIA DEL VALLE DE SILES}

\section{LOS ULTIMOS DIAS.-}

La autora de la presente edición trabajó tesoneramente en la preparación de la segında parte de este libro, sobreponiéndose a las adversidades de la enfermedad que la condujo a la muerte, el 17 de Enero de 1994. Conociendo claramente la gravedad del proceso maligno que sufria, se empeñaba, día a día, por avanzar en las páginas tel manuscrito de Francisco Tadeo Diez de Medina, en la continuación de su Diario del Cerco de La Paz, que por fin pudo conseguir años después de que le fuera negado el acceso a ese documento, como queda explicado en el Prólogo de Gunnar Mendoza y en la Introducción que antecede a esta nota. El trabajo realizado por María Eugenia, hasta pocos días antes de su muerte, es un ejemplo de abnegación en el cumplimiento de un compromiso intelectual, consistente, en este caso, en la publicación de un testimonio de grande importancia para la historia de la rebelión indigena de 1781. No alcanzó, por desgracia, a completar plenamente su propósito. Del total de 109 folios, anverso y reverso, del manuscrito, transcribió y revisó el texto íntegro, pero no llegó a redactar las notas de los últimos doce folios, 
como lo habia hecho en todos los anteriores. En sus últimos dias, trabajaba en cama, componiendo, con impresionante capacidad de sacrificio, nota tras nota, hasta que se agotaron sus fuerzas. Hubo ocasiones en que, al acercarmc a su lado, se le iluminaba el rostro al entregarme, sonriente, una hoja tecién escrita, diciéndome que era una nota más que habia podido añadir para avarzar en su tarea. En el / fol.103v sólo pudo consignar los tres números de las notas que debía elaborar, sin que hubiera podido lograr su intención. Se ha querido dejar registrados esos tres números sin cita al pie de página, manteniendo las páginas que siguen sirn anotación aliguna, pues ninguna persona que no hubiese sido ella misma habría podido reemplazarla en ese trabajo. Estimo que es muy poco lo que queda sin anotar y, afortunadamente, el texto final, redactado por Diez de Medina cuando ya sonaba la hora tan esperada de la liberación de la ciudad, adquiere la claridad espontánea de lo que se escribe sir retorcimientos ni digresiones innecesarias, cosa que se hace frecuente, en cambio, en muchas de las páginas anteriores, mientras duraba el cerco.

Cuando María Eugenia se hallaba al línite de sus fuerzas, expresó el deseo de hacernos un encargo, desde su lecho de muerte, a nuestro amigo el historiador Alberto Crespo Rodas y a mí. Con voz entrecortada, pero firme, superando la inseguridad de expresion que en los días anteriores le causaba frecuentes confusiones, mostrando una reacción de lucidez que nos causó asombro, nos estuvo hablando durante unos 20 minutos para decimos que nos confiaba un encargo final. Nos dijo que ponía en nuestras manos la publicación de la segunda parte del Diario de Diez de Medina en el que había estado trabajando desde haçia un año. Nos hizo una relación sucinta de cómo logró por fin obtener el manuscrito que le permitió recomenzar el trabajo imerrumpido por tantos años. Con precisión de datos, nombres y referencias cronológicas, insistió sobre el valor de dicho documento reiterando su deseo de que no qued ise sin publicarser contaba con el ofrecimiento de Marita Siles de Mazzi para la publicación del texto completo por cuenta del Banco Boliviano Americano. Ella no quería teminar su existencia sin oirnos decir que nos encargaríamos de llevar a cabo esa aspiración tán íntima. Con lá emoción que puede suponerse, le prometimos ser fieles a esta última voluntad.

JORGE SILES SALINAS.

NOTA.- Los trabajos de composición computarizada han sido realizados por la Sra. Alejandra Palenque de Moscoso, quien puso en este trabajo no sólo su capacidad profesional sino también su afectuoso interés personal. 


\section{SEGUNDA PARTE DEL DIARIO DEL OIDOR DIEZ DE MEDINA}

\section{Segunda Parte.-}

/ fol.51v. Sábado 28 de Julio. Bajó el General de su campamento; vino a manifestar la precisión en que le tienen los de Cochabamba y demás, para retirarse por falta de viveres y volver anticipadamente con otras gentes, y mayor número y los viveres necesarios. Se le suplicó para que mandase un emisario y se interesaron Su llustrísima y el oidor don Francisco Medina ofreció sacrificarse, como se convengan siquiera 250 a quedarse con él "1).

Domingo 29. Siguió en la ciudad previniendo sus órdenes; vino el envío, y ofreció bizcochos, carnes secas y alguna pólvora, y se fue en derechura a la Ventilla, cuatro leguas, donde dispuso trasladar el campamento desde el puerto de Seque, donde estaba.

Lunes 30. Hubo alguna mortandad de los nuestros y mujeres que fueron a lavar y por viveres a Callapampa y Achachicala, cometida por los rebeldes que se insolentaron y presentaron en aquellos / fol.52. puestos y a la vista, luego que sintieron que el Auxilio se retiraba. Vino razón de que el Jefe estaba necesitado a retirarse porque sus gentes estaban cuasi amotinadas para retirarse a su origen. Los vecinos le enviaron un escrito suplicatorio por mano de nuestro Comandante.

Martes 31. No hubo especial novedad; el Comandante y el señor Provisor, doctor Loayza pasaron a la Ventilla con comitiva, a tratar de la quedada del jefe y persuadir a ella las gentes de su campo; volvieron a las 5 de la tarde, con buena esperanza del intento.

(t) Todavia habla el funcionario en tercera persona, cuando se refiere al Oidor, actitud que se justifica por la copia en que trabajamos desde el 28 de Julio, puesto que forma un solo todo con la copia de la prirnera parte, no señalándose ningứn rompimiento o reiniciación, como hemos señalado en el Estudio lntroductorio. No debenos olvidar que en la versión oficial del AGI el Diario termina bruscamente con una síntesis de lo ocurrido en los días 25 - 26 - 27 de Julio. a la cue se añade la certificación de los notarios públicos acerca de su autenticidad y veracidad, así como sobre la autoría, que se atribuye clara y categoricamente al Oidor Francisco Tadeo Diez de Medina. 
Miércoles $1^{\circ}$ de Agosto. Vinieron 120 hombres, 80 saboyanos y 40 milicianos de Chuquisaca y el Tucumán, con un oficial o capitán, don Joaquín Salgado y tres subalternos, para guardar la ciudad. Se supo que el Jefe no tenía arbitrio, ni podia contener las gentes insolentadas para su retirada y que estaba muy consternado y dispuesto a marchar a Oruro y Cochabamba; y aún dijo que aquellos se precipitaron de modo que le vulneraron su autoridad y decoro, con prudente disimulo y sufrimiento suyo.

Jueves 2 de Agosto. No hubo novedad especial.

Viernes 3. Partió el Comandante con el senor Fiscal y varios de escolta y volvieron desenganados de que ni pendía la retirada (por ahora) del arbitrio del Jefe, ni que este había faltado a su palabra como quisieron indecorarle fácilmente con diferentes alborotos que ayer ocurtieron / fol.52v en el pueblo porque pensaron desamparar la ciudad, sacar a Su Ilustrísima, monjas regulares, clérigos y habitantes, vasos sagrados y a Nuestra Señora de La Paz y seguir al fefe, y estando todos en el Alto, pegar fuego a la ciudad. Su Ilustrísima, con quien contaban para semejante disparate, respondió que era un pensamiento pueril y que él con su clero y los venidos del campamento defenderia la cjudad. Mandó fjjar un edicto en la esquina de las calles principales manifestando al pueblo (conmovido) que Su Ilustrísinna no se iba. El señor oidor Medina, por otra parte, publicaba que él contribuiría a lo mismo, porque de lo contrario fuere operar traición e infidelidad; con esto le siguieron otros (ya dispuestos a marchar, con muchos movimientos y recojo en sus casas y principalmente las mujeres) con cuya ocurrencia lo pensaron mejor y se convinieron a defender la ciudad.

En esta tarde resolló el Apaza en los altos y cejas del Calvario (ya regresado de Yungas donde se ignora las maldades que hubiese hecho) de cabriolé encarnado, a cabalio, con 500 o más indios, 7 granaderos de uniforme que dicen ser de bayeta blanca, chupa y calzón encarnado, sus birretinas hurtadas, escopetas y uno más de uniforme amarillo, chupa y vuelta encarnada, aunque otros aseguran que contaron 11 de ellos. Arrojaron algunos tiros de pediero a esta Plaza Mayor, y de uno nos mataron con una bala rasa, de rechazo, a don Nicolás Escobar, arquitecto que pudo lucir en Europa, y de particular dibujo y curiosidades en varias clases / fol.53 de artesanos. Hicieron bastante algazara y alegria y el Apaza muy orgulloso nos desafiaba a salir con varios ademanes de manos. Y a poco antes de las oraciones se retiraron a su campo del cerro Orcoaviri. Para mejor demostración del movimiento de la ciudad se transcribe el dicho edicto del llustrisimo señor Obispo que es el siguiente: Edicto de Su Ilustrísima: "Se hace público a todos estos habitantes que habiendo llegado a noticia de Su Señoría Ilustrísima, el Obispo mi Señor, haberse esparcido la voz de que se va de esta ciudad por el motivo del nuevo asedio que se contempla experimenta este vecindario, me manda fije este carteI para hacer notorio a todos, ser falsa dicha noticia, por no haberlo pensado ni imaginado y, antes bien, se halla $y$ ha estado en la firme y constante resolución de no desamparar la ciudad, sino mantenerse y subsistir en ella, hasta rendir el espíritu, en compañía de todos sus vecinos y moradores, fieles vasallos del Rey, que han acreditado y acreditan su amor 
a la religión, a los derechos de Nuestro Soberano y a la Patria, siguiendo su defensa con el mayor empeño y tesón hasta perder la vida. Lo que en virtud de dicha orden paso a noticia de todos. Paz y Agosto 3 de 1781.- Don Juan Antonio de Zepeda. Secretario.

Sábado 4 de Agosto. Volvió el caballero Segurola a las 4 de la mañana (con lo ya dicho) y, como esperaba viniese escolta a conducir los que quisiesen retirarse con el acompañamiento, publicó un bando por la tarde en el que mandó salir a / fol.53v. todos los indios e indias de la ciudad y demás mujeres de españoles que quisieren hacerlo: asi como que no saquen armas de fuego ni víveres y que así mismo comparezcan los que quedaren para alistarse en la Plaza Mayor.

Domingo 5 de Agosto. Vino a mediodía, del campamento del señor Flores, una escolta de 40 o 50 hombres. Pareció corta y por eso no marcharon el señor Fiscal con dos religiosos de la Buena Muerte, el administrador de correos Nava, y otros que estaban dispuestos, y lo hicieron. Don Manuel Tellería que ya tenía su mujer y familia (dias ha) en dicho acampamento, don Bemardino Nieto y Aperrique, enfermo y salió en sillón de mujeres y lo hizo con la suya y otras personas del vulgo, aunque ayer lo hicieron, Mateo Tagle con la suya y varios y en los días anteriores, don Diego Quint, don Manuel Nerivalde, los corregidores de Omasuyos, Pacajes y Sicasica, Retana, don José Tellería y otros, como también religiosos, fuera de algunas mujeres decentes y señoras de las visibles, habiéndose llevado consigo el General a don Pedro Ramirez de la Parra como práctico de estos lugares. El dicho bando en buena razón se inutilizo y fuc mejor porque las pobres que acopiaron sus víveres y están radicadas en la ciudad era contra caridad echarlas a peregrinar fuera. Este día vino una chola y un indio chipana de Yungas, de la hacienda de Urbina, quien / fol.54 parece se refiere que salió de aquellos Andes por San Pedro y que no hubo novedad ni que las casas se habían quemado, aunque los cocales es regular estén perdidos e inundados de malas yerbas que allí crecen de un mes para otro y es preciso limpiarlas de continuo. Aquella dice que hay en el campo enemigo miseria y pentrita de víveres, que dan 16 papas por medio real, lo que es mucha desdicha entre los indios; que los más están displiscentes con el Apaza, que conocen y publican los ha enganado y puesto en tantos trabajos y que ya lo entregasen a no ser los mandones que se hallan a favor suyo y los contienen con paciencias y patrañas indefinibles. También parece vino una carta del clérigo Rojas en una bandera, instando por su disparatado canje con la india Bartolina Sisa, amasia del Rebelde.

Lumes 6 de Agosto. No hubo novedad. Y se advierte que el 4 de éste, marchó el señor Flores una legua o dos adelante de la Ventilla donde estuvo últimamente acampado, con el designio de ir a tomar refacción de gente y víveres en las villas de Oruro y Cochabamba.

El 5, se dice, que pasó de Calamarca y hoy pueden estar en Ayoayo; se puede decir lleva tres días de marcha y que estos se hallan avanzados para los 40 a que ofrece regresar, Dios mediante, pero los rebeldes no hacen movimientos, sí para el nuevo cerco a que volverán / fol.54v. mediante su extrema obstinación y audacia. 


\section{Martes 7 de Agosto. No hubo novedad, ni tampoco hoy miércoles 8}

Jueves 9. Asomaron los indios al alto de Quilliquilli, hicieron alguna algazára por la tarde y se retiraron después de habernos batido con algunos tiros de pedreros. $Y$ puede ya con esto decirse que estamos con el nuevo cerco anunciado.

Viernes 10. No hubo novedad y el sábado 11 se presentaron a las 10 y más de la mañana, en el mismo alto de Quilliquilli (como otras veces) con mucha grita y su caudillo Apaza. Un soldado blanquillo o saboyano mató con bala de fusil a uno de a caballo y según los minutos se fue apagando la vocería, aunque después de los escarmientos que hizo el señor Flores ya no se atreven, intimidados y tibios en sus acciones.

Domingo 12 de Agosto. Anduvieron los rebeldes en diferentes novimientos de acarreo de víveres, desde Potopoto o su campo de Pampajasi, a los altos de la Puna. Pasó el Apaza o Tupac Catari con su comitiva a caballo por el alto de Quilliquilli en que se nos presentó, al de la cuesta del Cuzco y no se les vio regresar a su campo.

Lunes 13. A las 11 y más del día se nos vino el clérigo don Vicente Rojas, a quien habrían apresado los indios, con permiso de Faustino 'tito Atauchi, mestizo de Copacabana, que se intitule Coronel, y uno de los tres del mismo emplco supuesto que / fol.55 dice son de la facción del Guama han Diego Tupac Amaru y su tín, que se fíguran hijo y hermano del caudillo de Tungasuca José Gabriel Tupac Amaru (1). Refiere que anoche a las 9 llegó el dicho T'ilo Atauchi a Pampajasi, (tonde le tenian prisionero los indios al clérigo) hizo entender a los indios rebeldes que a su cabeza, Tupac Catari, le tenía preso en la estancia de Vilaque, por sus cruejdades y picardías cometidas con los mismos indios. $Y$ asimismo que le rindiesen obediencia, (como lo hicieron con pronta facilidad) a nombre de los dos nuevos caudillos, hijo y hermano de Tupac Amaru, de quien expresaba artificiosamente, de hallarse de Virrey en Lima, con la prevención de que la intención de estos era tratar de su beneficio y quitar impuestos y tiranías de los corregidores. Que en substancia es el mismo trampantojo (2) del conjurado de Tungasuca. Se lamentó a consecuencia de éste, de la falta de los curas y eclesiásticos en los pueblos y envió a dicho Rojas para que alcanzase de este Ilustrísimo Prelado providencia para enviarles a las doctrinas que

(1) Los errores y la inexactitud de los datos supuestos por el Oidor con respecto a la farmilia Ameru, revelan cuán poco se sabfa, a medidados de Agosto, de lo que pasaba al otro lado del Laga, denlro del seno de la jurisdicción queclrua.

(2) Trampantojo = Trampa; jlusión con que se engania a uno haciéndole ver lo que no es. En realidad, Tito Atauichi está recurriendo a los mismos argumentos de engaño utilizados por Diego Cristobal Tupac Amara y Andres para mantener en alto el ánimo de Jas tropas rebeldes. Todos los caudillos y coroneles sabian que José Gabriel Tupac Amaru, su mujer y muchos otros habian sido ya ejecutados en la plaza det Cuzco. 
es el modo como pudo libertarse (1). Añade que el Apaza, a su regreso de Yungas, trajo todos aquellos indios sin reserva de muchachos, actualmente acampados en Pampajasi con muchos despojos de oro y plata de mucho valor. Que 300 a $400 \mathrm{de}$ estos pasaron a las 12 del medio día ordenados (como se les vio salit por la cuesta de Potosí) al Alto, en compañía del prevenido coronel Tito Atauchi. Que el pueblo de Sorata, capital de / fol.55v. larecaja, se perdió el domingo 5 del corriente Agosto y la ganó el Andrés Tupac Amaru quien se finge Marqués de Alcaniza (2), habiéndose agregado a su facción varios cholos del dicho pucblo que tuvieron a bien salir de él, con quienes venia a sitiar esta ciudad; otros, por no partir de Sorata, hoy de la fecha habrían perecido, porque no quisieron subordinarle la ciudad, entre ellos un don Anastacio Barela, minero y sujeto visible, don Juan de lbarola, cajeto del corregidor don Sebastián de Segurola, ambos europeos de honor, y muchos criollos con otro mozo espanol Castro que estuvo en Sorata (cuyo sitio inició el 3 de Mayo), se sabe que habiéndose retirado el 25 de fulio de aquel pueblo le cautivaron aquellos rebeldes y que enviado por ef Andrés Tupac Amaru en calidad de amanuense con el indio Pedró Pablo Córdova (quien de su origen de los Yungas le llevó $11 \mathrm{mil}$ pesos en dinero de tributos y hurtos), a quien con sus facultades y comisión mandó volver a aguellos Andes, fue prisionero de Tupac Catari en los mismos Yungas, de dende le trajo perdonado en su compañía a Pampajasi, habiendo muerto al dicho Pablo Cordova, y que con la llegada anoche del Tito Atauchi a aquel campo y su retirada para el Alto pudo desfilarse [salirse de las filas] y venirse a esta ciudad, con cuya venida se confiman las nuevas que trajo el dicho clérigo Rojas. También dice éste, mataron las mujeres rebeldes al cura de Timusi don / fol.56 Joaquín Sinosaín. Por la tarde entró el clérigo don Juan Trujillo que ultimamente se mantuvo en Sicasica, $y$ al venir le lomaron los de Calamarca y le condujeron esta mañana a la presencia del Tito Atauchi en el alto de San Pedro, quien le besó las marios, se le hincó y le đijo:que él no hacía dano a nadie y menos a los sacerdotes que podian entrar y salir de la ciudad con franqueza, y luego le dio permiso para bajar a ella. Que vio muchas cargas apostadas en dicho alto, despojos conducidos del campo de Pampajasi y robados por el Tupac Catari, y que a su vista partió para Vilaque muy de prisa el dicho Tito Atauchi, quien le expresó tener allí preso a aquel. Ultimamente nos dice el Castro que saliendo fuera de trincheras en Sorata, don José Pinedo y don Gregorio

(1) Estas frases son una clara demostración -fueran ciertas o tendenciosas- de que, durante la rebelión de 7781 . el lenguaje y la argumentación religiosa utilizadas aran las habituales del lenguaje católico, de raigambre hispúnica y no las propiamente indígenas, muy sumergidas ya por el fenómeno de aculiuración y mestizaje.

(2) Nueva confusión, por desconocimiento de las circunstancias. Se trata del título de marçués de Alcalices o Alcañices que a veces se adjudicó Andrés Tupac Amaru, suponiendose asimismo que cl título pertenecía al propio Tupac Amaru. Puede, sin embargo, haber sido el título de otro caudillo, del que no tenemos mayores datos. El error del apellido puede ser también descuido del copista. 
Santalla, a una capitulación y tratados con aquellos rebeldes sitiadores, éstos los mataron después de mucho rato de conversación, al ver que el primero al montar a mula hizo caer una pistola del bolsico, con cuya vista gritó al caudillo, "Gruactay", que quiere decir en idioma quichua, cárguenle, y lo hicieron asi los indios hasta que los acabaron, habjendo incendiado el pueblo el día de la Cruz, de modo que aquelios infelices se mantuvieron atrincherados en el recinto de la plaza, iglesia y cementerio, con las mismas necesidades $e$ indigencias y falta de víveres que sufrimos en esta ciudad y con iguales calamidades, sin reserva de carne de perros y gatos/fol.56y. y etc. Si estas nuevas se confirman pues son relativas a las aguas turbiadas que ambos eclesiásticos bebieton entre los indios y sus falacias, ya podremos contar con dos conjurados caudillos, a talta de uno, que es el Apaza, o que en su lugar se subrogan dos sediciones y aquellos pretendidos coroneles (t). Asegurando el clérigo Rojas que uno de estos, Títo Atauchi, publicó que ninguin indio de los rebeides nos provoque ni nos ofenda y que sólo hagan la defensa cuando se vieren provocados y acosados, no subsistirá por su volubilidad.

Desde el martes 14 hasta el domingo 19 de Agosto, no concurrió especial novedad y se repararon sí, los continuos movimientos en que andan los indios, acarreando bienes en bestias y a sus espaldas, desde el campo o cerro de Pampajasi a los altos de la ciudad y de éstos a aquel, muchos ganados y viveres, pero sin acometer la ciudad, ni los bullicios que acostumbraban y sin hacer daño ni sorprender a los nuestros que salen por lena fuera de trincheras; aunque a otros los han acometido con sus garrotes y los ahuyentaron. En cuyo particular, no se les puede tomar tino, porque el indio varia de parecer con los nimutos del dia y en nada tienen fe, permanencia, ni sustancia.

Lunes 20 de Agosto. Pasaron muchos indios a pie y 100 más o menos de a mula de Pampajasi a los altos / fol.57 de la citudad, por diferentes senderos y las cuestas de Potosí y el Cuzco, con bandera encarnada. Al subir dispersamente les aguardaban otros en varios pelotones en la cuesta de Potosi o la Ceja, y uno más, internado a mula con su bandera blanca. Y congregados partieron los más por la cuesta del Cuzco a la derecha de la subida. En cuya ceja se vió una horca fija de tres paios y que en ella se hizo la ejecución de la nuerte de uno que no sabemos quien sea! Allí en corra [anillo o aro] de ella se mantuvieron desde las 11 del dia hasta la 1 y media de la tarde en que desfilaron de regreso para el lado de la cuesta de Potosí, por la misma ceja, divisándose en este día, pendiente de dicha horca un bulto. Al tiempo de retirarse, los más vieron que allí quedó trozo de indios en muralla y así

(1) Con este comentario del Oidor podemos comprobar cómo, ya en plena rebelión. los paceños, que en otros aspectos están tạn al margen de lo que verdaderamente ocurre fuera de la ciudad. captan ahora la existencia de dos movimientos, de dos "sediciones" en las provincias paceñas, una, dirigida por Tupac Catari, que se centra en el sitio de la ciudad; y otra que actúa en las provincias paceñas al N. E. del Titicaca, conducida por Andrés Tupac Amanu y sus coroneles. Los dos movinienlos marchan a veces en buen entendiniento, pero en otras ocasiones, como en el caso de las actuaciones de Tito Atauchi, se producen roces y mutuas condenaciones. 
estuvieron apostados en distintos lugares de dicha ceja, sin comprenderse lo que significaba esta turba militar que pasaba de 3.000 indios, según cómputo.

Por la tarde mandó degollar el Comandante de la ciudad dos indias, que de verdad salieron por leña y dice comunicaron con los rebeldes; las supondrían espías. Lo cierto es que de estas nuertes a sangre fría, fuera del acto de agresión o refriega, sin más causa que sus confesiones, sin oir al Protector de Naturales y sin convencimiento, contra todo derecho y sin dar cuenta para la confirmación de la pena ordinaria a la Real Audiencia del distrito, son muchas, en indios de ambos sexos, aprisionados y sospechosos y / fol.57v. tienen el público reparo al ver cuánto se apuran a decidir ligeramente de la vida de los hombres, sin que sea temedio para la pacificación y subordinación que necesitan (1).

Martes 21. No hubo especial novedad y las gentes vuelven por la necesidad, a las carnes de perros y mulas.

Miércoles 22 de Agosto. Se presentaron por parte de tarde cosa de 600 indios y después de haber batido la ciudad con algunos cañonazos, desde el cerro y alto de Quilliquilli, se retiraron a poco después de las cuatro de ella, a su campo de Pampajasi o Potopoto.

Jueves 2.3 de Agosto. Repitieron al mismo puesto que ayer y le ocuparon cosa de 1000 indios que, desde las 11 del día, nos batieron con dos pedreros y balas rasas de bronce y por el mucho aire y frío tuvieron que retirarse a las dos de la tarde.

Viernes 24 de Agosto. Hubo el mismo curso que los dos días pasados en el mismo al to de Quilliquilli, con mayor número de indios, bailes y danzas que se vieron y algunos cholos vestidos de uniforme amarillo y sus fusiles; batieron la ciudad con las inismas balas y los dos pedreros y con alguna más algazara que los días pasados; dijo el vulgo, era obsequio o celebridad del cumpleaños de Bartolina Sisa, amasia del nominado Tupac Catari. Y en los altos de San Pedro y cuestas de Potosí y Lima, se divisó un crecido número de indios acordonados, con sus cornetas y banderas / fol. 58 .

Sábado 25. A las 9 del día se pusieron los indios en orden y en distintos sitios de la ceja del cerro y cuestas de Potosi y otros que lo formaban desde la embocadura del camino y cuesta de Lima hasta el cerro mayor, que al descender esta a la

(1) Como en la primera parte del Diario. el Oidor clama al cielo por el proceder tan drástico de Segurola. Olvida, sin embargo, que en otras paginas del documento también êl suele lamentarse de que no se procedo con más rigor contra los alzados. Su condjción de abogado y futuro Oidor le hace emitir consideraciones sobre el respeto a las prácticas judiciales, como si todo sucediera dentro de la mayor normalidad, olvidando hasta la imposibilidad en que la ciudad se encuentra de comunicarse con la R. Audiencia de Charcas. Las frases de Dan F.T. Diez de Medina guardan relación con un vago sentido de justicia y un criterio humanitario, pero no condicen con otras expresiones del Diario, como las registradas unos pártafos antes. 
izquierda hace un trecho muy competente; se vieron muchos bailes y a poco espacio empezaron a bajar por ambas cuestas en línea de procesión y otros a pelolones por varias veredas. Allí bajaban varios a caballo de uniforme amarillo y encarnado con sus armas de fuego y uno de cabriolé encarnado que parecía a Tupac Catari, algunas mujeres a mula y varios cholos en caballos enjaezados. De modo que los de caballería pasaban de 100 y tantos. Los indios apostados en Pampajasi, más allá de Potopoto, también virieron al alcance de aquellos, con multitud de danzas, flautas y tambores y otros sublevados de a mula, y en la garita de la cuesta de Potosi, combinados ambos trozos, después de un rato, que sería de algún recibimiento, acto de obediencia o besa manos a alguno, según el aparato con que venia, con clarines, a caballo, por la vanguardia; sería algún cabeza recién venido. Siguiernn bajando y pasaron muy cerca de la trinchera de San Juan de Dios, a tiro de canón que no se jugb, y en carrera sucesiva y prolongada, que pasado el río de la ciudad, se transfrieron a su campo de Pampajasi. Mientras bajaban estos las cuestas, otros indios se hallaban en el alto de Quilliquilli, batiendo la ciudad con balas rasas y mucha voceria, al mismo tiempo que manifestaban hacer salva / fol.58v a los recién venidos, hasta que a la una y media del día se les vio retirarse a dicho campo. Por la multitud de indios que ofrece la vista, los que quedaron apostados en la ceja de dichas cuestas (aunque habian vuelto algunas mujeres y bestias) en el alto de Munaypata y los que se manteníar de pie fijo en dicho l'ampajasi se computaron prudentemente de 5 a 6 mil indios acopiados, y dados al manifiesto.

En este día se conoce que va lomando nuevo incremento la sedición y que alguna nueva traza e ideas concurren para semejante colección[sic], que desde que llegó el socorro del Señor Flores, no se habia visto hasta hoy de la fecha, presumiéndose que ya tenemos algunos indios de la provincia de Onasuyos, porque de los de Pacajes, que habían pedido perdón no sabemos nada, acerca de su alteración nueva o si han variado de la espectativa en que supimos estaban resueltos a subordinarse y aguardar al Señor Flores.

Domingo 26 de Agosto. No hubo novedad y es de regularse estuviesen en alguna celebridad y borrachera con el pretexto de la misa y de la fiesta, que corrió, habian celebrado en el obraje de la Asunción, una legua rio abajo de la ciudad.

Por la tarde vieron subir a Tupac Catari con varios de a mula y mujeres del lado de Potopoto por la cuesta de Potosí: uno parecía religioso de hábitos negros, hizo seña a los nuestros de la trinchera inmediata con un pañuelo y dijo: mañana vendrá el embajador; a cuyas palabras siguió otro diciendo: y que salgain a recibirlo los dos cabilidos, Eclesiástico /fol.59 y Secular. Les tiraron con el pedrero nuestro pero sin operación por más que alguno se empeñe en esparcir que murieron cuatro y entre ellos un religioso, porque otros veraces desmienten la especie (1),

(1) Segurola hace referencia en su Diario al envío de un sacerdote con carácter de emisario; se trata del padre Eustaquio Caravedo, a quien Diez de Medina Ilama Mariano Caravedo. 
Lunes 27. No hubo novedad hasta las dos de la tarde en que bajaron de las cuestas de Potosí y Lima varios a mula con muchos indios y entre ellos el clérigo don Mariano Caravedo, presbitero que se halló sitiado en el pueblo (perdido) de Sorata. Los cholos y mestizos de a mula e infantes que, como sublevados, vinieron armados y con fusiles, dejaron a un lado las armas, llamaron a varios de los nuestros y se pusieron a quererlos seducir y persuadirles que de lástimá y como paisanos, les aconsejaban para retirase al campo enemigo, porque de lo contrario perecerían en la ciudad y serian destruídos como los sitiados en el pueblo de Sorata, con otras expresiones maliciosas e inicuas que pudieron haber perjudicado. La confabulación fue en la plazuela (incendiada) de San Sebastiân, donde dejaron salir a varios de nuestra plebe que, con todo, volvieron, aunque corre que dos o tres se incorporaton $y$ se fueron con ellos.

Del fortín de la Paciencia, dispararon a los alzados los morteros y pedreros reforzados nuevos y los retiraron con alguna operación en ellos, aunque corta y probable.

Fi dicho eclesiástico trajo tres pliegos, uno rotulado al Ilustrísimo Señor Obispo de ésta, otro para el vecindario y otro para los criollos del populacho. Los tres se los llevó al Comandante el capitán Don Dinnisio Escauriza que estuvo / fol.59v. a la sazón en la puerta de la trinchera de San Sebastián. El Comandarte abrió los dos y vio y deprimió el veneno de la seducción y el primero lo mandó pasar a Su Ilustrisima, con el misno Escauriza. Es regular, las cartas (bien deprimidas) por el jueblo, contengan el tejido y patrañas que reșultan de la de $\mathrm{Su}$ Ihustrisima, la que con un edicto o fárrago que lo acompaña, uno en pos de otro, es en la forma siguiente: Edicto. En el nombre de S.M. (que Dios guarde) Yo el señor don José Gabriel 'Tupac Amaru. Inga, descendiente de la Sangre Real y tronco principal de los Monarcas que gubernaron estos reinos del Perú. Vuestra Señoría. Por el presente auto circular convocatorio, hago saber a todos los vecinos españoles, criollos y naturales estantes y habitantes en las ciudades, villas y lugares de este Reino del Peri, a donde llegase este documento que un ministro celoso nombrado el señor Doctor don Ventura Santelices y Bencro, gobernador y superintendente general que fue en la Imperial Villa de Potosí, irformó a S.M. el Senor Don Carlos III, a instancia y pedimento de Don Blas Tupac Amaru Inga (mi deudo), que estuvo de residente en la ciudad de la Plata, sobre los gravisimos perjuicios y total ruina que ocasionaban los corregidores en sus crecidos repartos, los alcabaleros, con excesivas cobranzas, los europeos con negociaciones y tratos usurarios y principalmente las inmensas fatigas, desvelos y destrucción de naturales / fol.60. que causaba la pesada mita de Potosí y al mismo tiempo la mucha ruina que ocasionaban los duplicados servicios que los mismos corregidores, curas y otros ministros ocupaban de los infelices naturales. Y que todos eran dignos de la primera atención y su correspondiente remedio. $Y$ con el católico deseo de poner el necesario [remedio] a semejantes abusos y corruptelas mal introducidas, de que le informó la justificación de dicho señor don Ventura Santelices, lo ascendió a éste a la dignidad de su ministro para el Supremo Real Consejo de Indias, y lo llamó para España, pero en 
cuanto con este destino llegó a la Corte de Madrid, le quitaron luego la vida con venero que le dieron en carta a tiempo de apearse, mediante cuya iniquidad consiguió la malicia el efecto de no exterminarse tanto desorden y maldades desatinadamente ejecutadas. A vista de esta perversa operación, repitió recurso dicho don Blas Tupac Amaru Inga, como uno de los interesados en el Reino, a quien, por mejor informarse de la verdad y proveer el remedio que se frustró en la primera ocasión se le llamó a España, donde habiendo ido de facto, dicho mi deudo y dádole largas cuentas de las injquidades sus referidas al Rey Nuestro Senor, se sirvió nombrarlo por capitán perpetuo y defensor de naturales para la villa de Potosí, con un buen sueldo o salario, en sus Cajas, dándole igualmente amplia facultad para extinguir y quitar el mal gobierno de corregidores, / fol.61v. alcabaleros, usuras de extranjeros, pesada mita de Potosí y otras gravosas pensiones y servicios que hacian los naturales, lo que sabiendo la iniquidad de los interesados, tomaron el reprobado arbitrio de hacerle traición y quitarle la vida per segunda mano a dicho Blas Tupac Amaru, cuando éste regresaba por el mar a la ejecución y cumplimiento de sus comisiones en este reino del Perú, sobre cuyas dos alevosas muertes, practicadas a trajción y motivos que para ello hubieron, que asi mismo, da noble cuenta de que siempre se ocultaban por los ministros interesados dadas las anteriores providencias libradas al propósito de quitar el mal golieno y públicos ladrocínios; sobre que hice tercer informe a S.M. cuya real integridad resentida y aún indigrada me comunicó, y a su comisión amplia para la total ruina y último exterminio de corregimientos, alcabalas, chapetones y otros muchas persecuciones con que estaban cargados los míseros naturales y criollos del Reino, con particular prevención de que en caso de formarse alguna oposición por los corregidores auxiliándose de los vecinos criollos, - que los naturales no concurriesen con empeño a esta operación y su propia defensa, que determina el común beneficio, se ahorquen, degïellen y destruyan a todos ellos.

En efecto, haciendo yo, comisionado a hacer justicia con dichos corregidores, sucedió que algunos de ellos se remontasen y otros con pretexto de hacer defensa a la Corona, hubiesen formado tropas militares / fol.62. para estorbar el cumplimiento de superiores mandatos por lo cual a fuerza de guerra viva sea continuado el castigo, destruyendo a todos los rebeldes y porque todo esto he cumplido con arreglo a la real cédula expedido en su razón, sea servido S.M. aprobar todo lo obrado destinándome en premio al Virreinato de Lima, cuyo empleo voy a tomar $\mathrm{y}$ posesionarme por lo que usando de las mismas facultades que se me concedieron ampliamente, las transfiero en forma de derecho en el marqués gobernador don Andrés Tupac Amaru Inga, mi hije legítimo primogénito, para que inmediatamente pase de esta provincia a las que componen la ciudad de La Paz, Chuquisaca, Potosí, Cochabamba y más adelante con sus respectivos pueblos y distritos, conduciendo los 200.000 soldados naturales que se hallan dispuestos con 4.000 fusiles, 12 cañones de 6 leguas, 8 pedreros, juntamente los criollos y naturales que están a la mano a dar los combates y avances que se ofrezcan contra los rebeldes enemigos y de paso vayan juntando igualmente, dicho mi hijo y sus coroneles, todos los soldados asistentes en aquellos lugares, quienes acudirán a dar los auxilios necesarios 
alistándose desde los siete años para arriba $y^{\prime}$ haciéndose cargo de que todo se endereza a propio beneficio de naturales y criollos, especialmente de los que no se han rebelado y que han procurado hacer las defensas contra los enemigos. En cuyos términos, y para que de una vez acabe ya de tener debido efecto la citada orden superior, debo mandar y mando que respecto al / fol.62v. destino que tengo de ir a dicha ciudad de Lima y no poder caminar a todas las provincias de arriba, prosigue el citado mi hijo don Andrés Tupac Amaru, con especial tacultad que le traspaso para que en cualqquier caso de enfermedad u otros defectos pueda nombrar o nombre otros conisionados y coroneles que se ofrezcan para que prosigan las guerras adelante, bajo la precisa calidad de que primero y antes de entrar a cualesquier ciudades, villas o lugares donde hubiese oposición, se despacharán embajadas y embajadores que podrán repetir en el progreso, proponiendo paces y perdón con tal que se rindan las armas y se acojan a nis banderas y en caso de omiso o de denegado se continuarán las batallas y avances a fuerza de guerra viva y sangre y fuego por éste el último subsidiario remedio con que se castiga la repentina rebeldía y se quita el mal gobierno para que viva por nuchos años don Carlos III y a fir de que este auto llegue a la noticia de todos y ringuno alegue ignorancia de su contenido correrá circularmente por los parajes y provincias de este reino que se intinará y publicará a son de caja y clarin con la debida solemnidad, despachándose las copias que convengan con su original, que es hecho en esta capital de Tinta, provincia del mismo nombre a 7 de Julio-- Don José Gabriel Tupac Amaru. Inga. Es copia de su original, como lo certifico. Andrés Tupac Amaru. Inga. (1)/fol.63.

llustrisimo Scñor Ductor Don Gregorio Francisco de Campos: Muy Señor Mio y de mi más justa éstimación. No dudo que V.S. Ilustrísima y todos los vecinos de esa ciudad se hallan bien cerciorados de la Real Orden que S.M. el Señor Don Carlos IIl (que Dios guarde) expidió en ei año próximo pasado de 1780, mandando extinguir los abusos, excesos y mal gobiemo de los corregidores, las aduanas que cobraban excesivamente, las usuras perjudiciales de los europeos y las perniciosas consecuencias resultantes de la mita de Potosí en que se arruinaron los naturales, sin otro adelantamiento del Real Patrimonio, que utilidades de los azogueros, sucediendo lo mismo con los duplicados servicios y pensiones que los pobres indios cargaban sobre si, de suerte que con todo, venia el Reino reduciêndose sensiblemente a su total exterminio, cuyos daños notorios por quitar de raíces y poner remedio en lo necesario libró el Rey Nuestro Señor una Real Cédula, cometida

(1) Este oficio, dirigido a los criollos y habitables de La Paz, estaba obviamente fraguado por Diego Cristóbal Tupac Amaru y por su sobrino Andrés. Como puede versé, está fechada en Tinta el 7 de Julio de 178I. siendo asi que José Gabriel Tupac Amaru había caído prisionero en Sangarara el 6 de Abril, siendo ajusticiado el 18 de Mayo. Los jefes quechuas Irataban a toda costa de mantener la ficción de que Tupac Amaru estaba vivo y dirigía todavía ta sublevacion; temían francamente que el conocimiento de la muerte del jefe hiciera pensar a los indígenas que habian sufrido una derrota definitiva y que cualquier otro intento de lucha estaria destinado al fracaso. 
su ejecución a mi Señor Padre, el Marqués de Alcalices Don José Gabriel Tupac Amaru, Inga, descendiente de la Sangre Real y Tronco Principal de los monarcas que gobernaron estos reinos del Perú $y$, con efecto, habiendo comenzado a practicar su comisión, castigando algunos corregidores se refundieron los demás con el objeto de hacer oposiciones por medio de tropa militar que formaron aunque sin otro fruto que ocasionarle su total ruina y de sus familias por haber ido contra / fol.63v. expresa orden de S.M.

Mas la equitativa piedad de mi padre, dicho señor marqués, por acreditar su clemencia y el fín de proteger tanto a los indios naturales cuanto a los criollos del Reino y manifestar su arreglada conducta y sanas intenciones, perdonando o dispensando sus rebeldias, prometió su absolución con la calidad de que rindiendo las armas con que hacian frente y resistencia al mandato superior de nuestro propio Monarca el Señor Don Carlos III, se acogiesen a sus banderas porque su real voluntad, les maneja su comisionado mi padre. Y éste en la ocasión por su legítimo embarazo de hallarse destinado a tomar posesión del Virreinato de Lima y ejercer el ministerio, me ha transferido su comisión con las mismas facultades que se le concedieron y yo en ejecución de ellas, por evitar los muchos daños que podrian subseguirse con la continuación de las achuales guerras, he juzgado conveniente esta embajada, proponiendo las paces que mi piedad, lástima y compasión a los españoles les apetece para que puedan vivir con la quietud y sosiego de antes, sin discordias ni controversias entre cristianos, con destrucción de sus vidas, familias y haberes. Pues aunque antes de ahora habia sucedido, esto fue porque los vecinos criollos, dejándose engañar con los corregidores salieron a su voz y delensa, sin advertir que éstos eran, sus adversarios perseguidores y los que se hacian opulentos con el trabajo y sudor ajeno grabándolos / fol.64. con cuantiusos repartos y otras muchas pensiones de que los recargaban, las mismas que el Rey ha mandado quitar por medio de su comisionado dicho señor mi padre, cuyo celo llanó a los vecinos criolios y naturales, $y$ ha procurado cumplir exacta y puntualmente cuanto se le ha ordenado por el santo celo del Rey, sin ejecutar tatiga, afăn ni desvelo que no hubiese vencido en todas sus actuaciones.

Y para que todo se dirija al consuelo, alivio y desahogo de los naturales y criollos que piadosamente procuró aliviarlos por medio de que queden en tranquilidad y sosiego, desde luego les franqueó mi benignidad como última muestra del paternal amor con que los miró, afecto de que aprovechando mi generosa conmiseración rindan sus armas todos los existentes en esa ciudad de La Paz y que entregándomelas en crédito de su resignación, se pongan bajo las banderas que obtengo, en que protesto recibirlos, favorecerlos y ampararlos en nombre de S.M. bajo la palabra real y de honor, pues de lo contrario les anuncio las funestas tragedias y desdichas que ofrece la miseria humana y que todo lo ocasionará la pertinaz rebeldía, según puntualmente sucedió con los alzados de Sorata, quienes aguardando auxilios que nunca les quiso proporcionar Jesucristo por sus altos e inescrutables juicios, se acabaron de consumir el día 5 del corriente mes. $Y$ lo contrario se verificó con más de 3.000 personas que se hallaban remontadas en las 
cumbres de Hiani, Ananea / fol.64v y Tacacoma, quienes a primera propuesta de paz las abrazaron y aprovecharon de tal manera que en el día se quedaron gozando de su antigua libertad, comodidades y conveniencias antecedentes, con muy poco quebranto de ellos; pero con la esperanza de ventajosos adelantamientos en lo futuro, de los cuales se hallan varios en mi compañía, reconocidos del beneficio de mi liberal mano y porçue esto mismo deseo que lo participen todos los existentes en esa ciudad [1!. Prevengo a V.S. Llustrísima se los comunique a efecto de que las ovejas de su grey reciban por thedio de su pastor el consuelo que necesitan, a cuyo fin se ha de servir congregar ambos cabildos eclesiástico y secular, con cuyos individuos y otros vocales que convengan se consultará la materia y se comunicará sus resultas en respuesta porque yo en su inteligencia determine el modo de practicar en adelante lo que más convenga, ya sea en la celebración de paces si se admiten con la gratitud debida a mi benignidad, o ya en la prosecución de guerras que hasta hoy habia seguido don Julián Tupac Catari, como su hermano el otro comisionado don Tomás Tupac Catari a quien, a traición le habian quitado la vida, lo que no surederá en la presente ocasión pues aunque agora no tengo a la mano aquellas fuerzas necesarias, por el ánimo que tengo de perdonar, empero, tengo sobradas facultades para arruinar ciudades de más consideración que esa de La Paz y sus auxiliares, como acaeció con Ignacio/fol.65. Flores y sus aconpañados, que se fueron derrotados a numca más volver 27 . - Nuestro Señor guarde a V. S. Ilustrísima, muchos años. Cruz Pata y Agosto 27 de 1781 . Andrés Tupac Amaru. Inga (3).

(1) Andrés Tupac Amal'u se refizre en este pasaje a an hecho desconocido por entonces en La Paz y olvidado después $e n$ las consideraciones históricas sobre la rebelion de 1781. Los documentos que permiten il la aulora de estas notas estudiarlos en todo su dramatismo están en el Arthivo Nicional de Bolivin, en Sucre, en un juicio de Segurola contra Antonio Molina. El aconlecimiento ocurrió en las regiones vecinas a Sorata, junto a th pueblo llamado Ananea, donde Andrés Tupac Amarı tuvo una figuración importantísima que significo un entendimiento colt un grupo de criollos que pasaron a engrosar, voluntaria oforzadamente, acosados por el hambre y lát sed. Jas tropas indígenas del caudillo; este hecho constituyó, según testimonio de algunos sorateños y de ciertos coroneles de Tupac Amaru, la causa decisiva de la caída de Sorata. Esta suposición está desmentida con calor, en cambio, por el comandante Artonio de Molina, que protagonizó el acuerdo y la celebración de paces con el joven Andrés.

(2) Nucvamente. Andrés Tupac Amaru maneja las noticias y los dotos históricos a su manera con lal de amedrentar a los vecinos de La Paz. Ignacio Flores no sufrió ninguna derrota a manos de los rebeldes; salió de La Paz, como hemos visto. después de largas meditaciones y consultas. No significó esto, ciertamente, que su campaña fuera un triunfo, ni mucho menos; cuando abandonó La Paz lo hizo.para bnscar refuerzos de hombres y armas.

(3) La fecha de esta misiva, enviada desde Cruz Pata el 27 de Agosto de 1781, donuestra que ya a fines de este mes los Amaru estaban instalados en El Alto de La Paz, dispuestos a derrotar a la ciudad. contando con Tupac Catari o desplazándole si fuera necesario. 
Se les ha despreciado en esta su emboscada de pantomima, sin contestarles más que con nuestros cañones de los fuertes como merecen estos insolentes; habiendo sentido nuestro Ilustrisimo Prelado, sobremanera, el perdimiento de respeto a su decoro y dignidad de estos audaces, porque osados a invocar el nombre augusto de nuestro soberano Rey y Señor natural, para querer paliar sus maldades execrables y rebelión y cometer la traición contra Su Majestad, sus vasallos, dominios y reales establecimientos, solicitan interesar a Su llustrísima para mediador de estas iniquidades y patrar̃as cuando su rectitud de intención, amor y fidelidad a la religión, al Soberano y grey, son de primera esfera y la más recomendable atención.

Por las noticias que trae dicho eclesiástico Caravedo se confirma la pérdida lastimosa del pueblo de Sorata, capital de la provincia de Larecaja, que nos es muy sensible y dolorosa tanto por los desastres y tragedias con que fueron sacrificados en subido número aquellos buenos criollos y españoles asesinados, comerciantes, mineros de consideración y entidad y los que de otros pueblos se acogieron a él por la causa misma de la sedición de indios, pues a la reserva de don Benito Valverde / fol.65v. a quien lo condujeron a este alto de La Paz, no dejaron uno con vida, matándolos a palos, balazos, ahorcados y arrastrados a la cola de los caballos, con varios modos de muertes, las más ignominiosas, crueles, a excepción de mujeres y clérigos a quienes (decian) que los perdonaban como lo hicieron, cuanto por las ruinas y exterminio de este pueblo quemado enteramente sin exceptuarse la casa parroquial sino es la iglesia y dos casas, y asimismo por el saqueo que hicieron los levantados, de muchos y cuantiosos caudales en monedas selladas y allhajas de oro y piedras preciosas, perlas, plata labrada, vestuarios, aún de las mujeres, homenaje y otras presas de valor, y principalmente, en oro fundido en rosa y en pepitas del famoso río Tipuani que en sus veneros y entrañas poderosas, excede con mucho a las riberas del Pactolo (1) y los demás minerales. Eran crecidas las porciones de oro de aquellos de varios sujetos y moradores mineros. El portugués don Anastacio Varela que vino con carta real de origen y naturaleza y estaba allí casado, con diez hijos, era un minero de mucha importancia para el público y real haber y aunque muy reservado, que no dio luz de su caudal, hay opirjones de que pudo pasar de 600.000 en oro y aún tocar en 800.000 . Todo lo robaron los indios, y lo descubrieron por un hijo suyo tierno a quien salvaron y por temor y amenazas, lograron declarase el lugar donde se había humado por su padre a quien, /fol.66. tiernamente lo mataron (2), como a don Juan Simbrón a quien corre arrastraron y despedazaron a

(1) Pactolo: río de Lidia que arrastraba arents de oro.

(2) No puede leerse tan triste nouicia sin una sonrisa, pues resulta curioso que el autor suponga ternura en tan cruel asesinato. 
la cola de un caballo, minero de diferentes labores en dicho Tipuani, y reputado si no de igual caudal al dicho portugués, con exceso al de éste, cuyo oro y bienes fueron parte del pillaje de los indios o del Andrés Tupac Amaru (verdadero o fingido) que se nos ha presentado. El cura de Ilavaya que no estaba débil de facultades las perdió, también parte de los bienes y productos del corregidor de aquella provincia y nuestro Comandante. Los de los comerciantes mineros ricos de aquellas provincias, vecinos y acogidos que habían conducido consigo lo más fungible y acendrado que tenían, son comprendidos en les mismos hurtos y desgracia fatal de sus personas. Ello es que la pérdida viene a ser, por todos términos, más considerable de lo que parece y se pueda comprender por los que no han visto aquellos lugares y provincia, todas de minas de oro hasta el mismo asiento de Suches, donde fueron venicles alli varios individuos vasaflos fieles por causa del levantamiento. Son por ello muchos los españoles criollos que han perecido y entre ellos cuentan seis u ocho europeos, y todos se defendieron desde el principio hasta el último término, con la más bizarra fidelidad al Rey y a la Patria, como otros saguntinos, porque si estos quisieron morir en las llamas, aquéllos sacrificaron su fidelidad inundados en las / fol.66v. aguas, sin ceder un punto a las tentativas contrarias, con que los rebeldes desde el principio de aquel sitio trataron de seducirlos para la entrega que solo pide amistad, y en buena conformidad procuraron de aquel pueblo, con tal de salvar sus vidas. En qué ruina entraron sosteniendo su defensa. sólo con seis escopetas, tres trincheras en la plaza, iglesia y cementerio, faltos de viveres pues el que tenía cuero a mano se tenía por bienaventurado y ultimamente faltos de gentes y fuerzas naturales porque aquella plebe de cholos, con el apuro extremo de las hambres se comian hasta los sapos y otras sabandijas, se fueron retirando del pueblo al campo enemigo donde unos lograron buena acogida y otros fueron muertos y en el más crecido punto de angustias, debilidad y falta de los desertores y muerlos por necesidad, más que en esta ciudad (se sabe pues consumieron las carnes de perros, gatos y mulas) fueron asaltados de los indios e inmolados el 5 de agosto, como se ha tocado después; durante el sitio los irrumpieron los rebeldes inundando el pueblo y sus edificios, con unos torrentes formidables de agua (represas) en aquellos puestos ventajosos y de elevación que lo dominan y llaman por allá cochas de qué estifan los mineros para aprovechar el descubrimiento de los aventaderos de oro mediante los conductos que rompen en la tierra el agua continuada y de avenidas por dicho torrente. ¿Qué conflictos y apuros no padecerían aquellos infelices / fol.67. sitiados con estas avenidas precipitadas que anegarian el corazón, el ánimo y el pueblo!. Lo cierto es que la consideración sola, horroriza, confunde y es muy melancólica, y que por otra parte, esta pérdida con la pasada de los Yungas, nos acaba de acreditar el nrayor descaecimiento de esta ciudad y su obispado, sostenidos de ambas provincias, con el comercio opulento y cuantiosos de los renglones dej oro y de la coca, que eran todo el nervio y fundamento de su mayor auge, muy ventajoso para el real patrimonio y los vasallos. Sin que en Sorata y Larecaja haiga de pronto arbitrios ni interesados ni caudales para 
continuar las labores de aquellas minas ricas y las más sobresalientes del Reino en la actualidad. Que es otro sentimiento (1).

Martes 28 de Agosto. Nos batieron los rebeldes la ciudad desde las 11 y media del día, con los dos pedreros desde el alto de Quilliquilli, con mucha algazara.

Por la tarde salieron fuera de trincheras los blanquillos o saboyanos (que nos dejó el señor Flores) con los granaderos de la ciudad, a las cabezadas de San Sebastián, chacarilla de Villaverde, hasta Munaypata, donde suclen aquellos fijar los pedreros y rechazaron con el fuego a los enemigos cue se pusieron en fuga. Mataron uno de a caballo y vestido de encarnado que capitaneaba a los sediciosos y, aunque al retirarse volvieron sobre los nuestros, quedaron escarmentados/fol.67v. y rechazados por segunda vez y fueron de 20 a 24 rebeldes entre muertos y heridos, según el cómputo que hacen los concurrentes, aunque esto es inaveriguable alti.

En esta mañana a las 11 y media del día, don Crisanto Rafael de España, europeo de toda honra, que estuvo de oficial de guardia en la trinchera de San Agustín, usó de una estratagema graciosa y discreta y por medio de ella hizo aprehender a un cholo de a caballo, petimetre de calzón colorado, con su trabuca, que por seducir e inquietar nuestras gentes se habia presentado con otro (htuido) en el callejón frontero de las Recogidas, inmediato a la trinchera, pidiendo respuesta a las tres cartas que ayer nos trajo el eclesiástico Caravedo. Este traía en sus bolsillos varios papeles y entre ellos, justamente, uno de ensayus de las mismas firmas varias, cuasi y desemejantes entre sí, de las tres cartas dichas. Se infiere ser amanuense o confidente o antisecretario del diablito Tupac Amaru (recién venido de Sorata) y aún estaba válido ser concolega por decirse que estos dos estuvieron o concurrieron en el colegio de San Bernardo en la ciudad del Cuzco. Este reo, nombrado Mariano

(1) Después de La Paz, Sorata fue el segundo objetivo en importanciá de los rebeldes. En los primeros días de 1781 , su población ljegaba a los diez nil habiantes, debido a que allí se habían recibido refugiados procedentes de Lampa, Carabaya y Azángaro, que querían ponerse a salvo de la rebelión que asolaba toda la región.

El 4 de Mayo, al mando de Andrés Tupac Amaru. unos quince nil indios comenzaron a sitiar Sorata para vencerla por el hambre y el agotamiento. Los padecimientos sufridos por los sitiados como las duras peleas que soshuieron para impedir el ingreso de los rebeldes, son menos conocidos que los de La Paz, debido a la inexistencia de "diarios" o informaciones consisteotes. Lo que sí se sabe es que al ver que los asaltos no daban resultados. Andrés Tupac Amaru dispuso la construcción de una represa en uno de los rios para arrasar li ciudad por las aguas. El 5 de Agosto, la represa fue soltada con efectos devastadores, pues las aguas inutilizaron las defensas y Tupac Amaru pudo entrar criunfante. Después virieron los ríos de sangre. Sin perdonar a nadie, la totalidad de la población adulta masculina fue masacrada con la horca, armas de fuego y cuchillos. La ciudad fue íntegramente saqueada. casa por casa. y las riquezas de oro y plata encohtradas fueron enviadas a Azíngaro. A.C.R. 
Aliaga, refiere la pérdida de Sorata con otras particularidades y lástimas y que los caudales de oro allí saqueados los hizo conducir aquel caudillo a Azângaro. Que el Tupac Catari estaba comandando en el campo enemigo, muy intimidado [intimado?] con el Andrés Tupac Amaru y de inteligencia recíproca y que el señor Visitador aprehendió y castigo / fol.68. con una corona de hierro ardiendo y el suplicio a Jose Gabriel Tupac Amaru, el rebelde de Tungasuca, en la ciudad dicha de Cuzco (l). Se le tomó confesión judicial y sacramental y luego, a la 1 del día se le ahorcó y dejó peridiente en esta plaza mayor. Es justo el remedio, pero no había de ser tan pronto, en hora y media, o por la hunanidad de alguna más tregua para disponerse a la muerte o porque de éste pudo saberse mucho que fuese útil a nuestras defensas y al público, segtin los ofrecimientos de los diez.

Parece segín su relación que varios cholos de los de Sorata venían forzados y que estaban con el designio de venirse y revolver los ánimos que traen contra el mismo enemigo; el tiempo es quien nos lo dirá. Volvieron heridos, un soldado de Saboya con un brazo intercutáneamente, un grantadero por azia [sic.] el hombro, de balazos enemigos, y otro granadero, de una pedrada en la manu. También añade el dicho Aliaga, que el Visitador General venía ya con nucha gente en auxilio de esta ciudad y que su campamento ocupaba cuatro leguas de distancia, pero necesita de confirmación.

Miércoles 29. Siguieron batiendo la ciudad los enenigos, desde las 12 del día, con los dos pedreros, lo nismo y en el mismo lugar de ayer. Por la tarde salieron los de Saboya con su capitán don joaguin Salgado (que acredita su valor) y otros dos y los granaderos con olros oficiales y particulares de la ciudad, fuera de las trincheras de la Caja del Agua, al campo / fol.68v. de Cusipata; alli mataron e hirieron a más

11. Lats anolaciones del Ojdor sobre el triste estado en que quedó Sorata demuestran una vez más, claramente. el desconocimieno que se tenía en La Paz sobte Jo que pasaba en Larecaja. Segurola levantó toda una averiguación sobre lo acontecido en la capital de su provincia, que después utilizó para alacar a lgnacio Flores por no haber socorrido la ciudad, acusación de la gule. a su vez. cl Presidente de Charcas se defendió ardorosamente. En todo caso, se comprende yue se ignorase el hecho de que la ciudad habia sido cercada por las huesies de Tupac Catari neses antes de que llegara allí el joven Andrés Tupac Amatu y sus coroneles quechuss a rines de Marzo. El Oidor hace un recuento de la situación de la ciudad antes de la caída, pero cometiendo graves errores, puesto que el Comandante Segurola había dejado bustante provista la defensa de la citadad anles de irse a La Paz a hacerse cargo de su nuevo empleo.

Por otra parte, Ja versión de los torrentes de las aguas de la "cocha", es también exagerada. Se sabe que el estallido hizo eeder a la ciudad más que nada por haber remojado las murallas, que cayeron dejando destruidas bas fortalezas defensoras. Las hambrunas sufridas por los habitanles, descritas por los declafantes posteriores, correspondieron exactamente a las experic mentadis en la capital paceña.

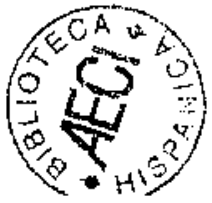


de 50 rebeldes, aunque otros to regulan hasta 100. Don Ventura Carpio que salió con tres más que los primeros, mató a un indio de a mula, capitán de indios venidos de Xungas, y el negro de nuestro comandante partió de un hachazo a otro infante.

Al pasar los indios de la parte de San Sebastián al rio que baña esta ciudad, recibieron en él y su plaza, buenas rociadas de fusiles y quedaron muertos algunos y huyeron los demás con los heridos allí. Lo mismo sucedió entro del cerco de la chacarilla de las monjas de ia Contepción y en el campo dicho. Al retirarse los nuestros y al embocarse los saboyanos en una quebrada, en vista de que los enemigos venian sobre ellos, también los escarmentaron muy bien con el fuego graneado con que los pusieron en retroceso de fuga precipitada. Trajeron un indio vivo de los Yungas y a dos, parece, los mataron al entrar por la misma trinchera de la Caja del Agua, habiéndose retirado los nuestros victoriosos e indemnes. El Tupac Catari arriaba a sablazos a los indios que resistian o excusaban presentarse a las manos con los nuestros y estaba con el manto capitular blanco de la orden de Santiago que hurtaron en Sorata a nuestro Comandante y aún se dice que con su venera (1).

Jueves 30 de Agosto. Empezaron los indios a batir la ciudad con un pedrero, desde el cerro de Quilhquilli / fol.69. y otro que apostaron hacia San Sebastián, inmediato al campo de Cusipata, recelándose que hoy repitan los nuestros salir a él como ayer. Nos mataron dos mozos con Bala rasa del primero, en la esquina del doctor Riva y una mujer en otra calle. A las cuatro y más de la tarde, salieron los dichos oficiales, vecinos de la ciudad, aficionados y el padre Juan Sainz de la Buena Muerte, precedidos de nuestro Comandante por las trincheras de la Riverilla, de Santa Bárbara y Santa Teresa, al mismo alto de la parroquia de Santa Bárbara (en que otras veces se actuaron las retiradas siempre con tragedia de los nuestros) prendieron dos indios de Yungas y uno de Mecapaca de la hacienda del 24 Castro, Gregorio Sepúlveda que estaba con otros embuscados en la casa quemada de don Julián Guzmân, sorprendió y ahuyentó a los que estaban sentados y descuidados en el seminario de dicha parroquia, con muerte y heridas de algunos. Los acosaron y siguieron, y después de haberse retirado ellos a la ceja de los cerros de Santa Bárbara, amagando retirarse los nuestros, volvieron a bajar en algazara sobre ellos, que llegaron hasta el número de 1.000 indios más o menos,quedando otros acordonados en la ceja de dichos cerros. Los nuestros revolvieron sobre ellos con fuego vivo y continuo; mataron e hirieron a muchos a boca rie jarro. Los pusieron en nueva fuga que hacian precipitados, cayendo en tierra y levantấndose y otros

(1) La noticia de que Tupac Catari hubiera participado en los ataque a Sorata, del todo desconocída anteriomente, se va comprobando cada vez más gracias al estudio reciente de la documentación. Esto sucedió, posiblemente, por la intervención de Gregoria Apaza, amante de Andrés. Su ausencia en La Paz se explicaba por la presencia de Flores en el Alto de la ciudad. Primero se había dirigido a Yungas, de allí pasó a Achacachi para proseguir a Sorata y observar personalmente lo que hacía en su propia jurisdicción el joven Amaru. 
muertos y heridos al correr, de suerte que regulan a unos y otros, /fol.69v. en 150 . Hubiera sido mayor el golpe si los nuestros, que salieton por la trinchera de Santa Teresa, se hubiesen anticipado con tres o cuatro minutos de tiempo, porque los hubieran cortado y cercado y actuado un castigo muy competente (i). La acción del dia salió limpia, sin daño alguno considerable, porque la retirada se hizo con aquel orden de la Milicia y acierto consiguiente, con buen ejemplo de las gentes de la ciudad y compañias de criollos que a la vista de los Saboyanos, los imitan y siguen con presencia de espíritu y con juicio, aprobados no menos que por los mismos de Saboya y sus oficiales. Lo que pueden el orden y la disciplina y así mismo la presencia del comandante en la función! (2). Si hubiéramos tenido de uno y otro ni hubieran perecido tantos de los nuestros en las retiradas, ni los indios hubieran tomado tanta alteración, pedreros y armas blancas y de fuego, ni la sedición tuviese la duración que hasta aquí, ru hiciese los vuelos con que ha subido de punto, con tuina irreparable del Estado y de la Real Hacienda.

Viemes 31 de Agosto. Sacaron al degüello, fuera de las trincheras a los tres indios vivos que ayer se tomaron prisioneros. Los rebeldes batieron, desde las 10 del día, la ciudad con sus pedreros; por la tarde siguieron la misma operación con uno, desde el alto de Quilliquilli y con el olro tban variando de puesto, porque le fijaron a la espalda del cerco y huerta de San Francisco, el frente y distancia / fol.70. de una cuadra poco más de aquella trinchera y a poco tiempo, después de dos tiros, lo condujeron a mula y lo colocaron en un portal o corredor de una casa quemada en el alto de las Recogidas, acompañado de varios cholos, negros y mulatos fusileros que estos días y hoy nos han hecho con ellos bastante fuego, aún con algunas disgregaciones de tiempo. El día fue lluvioso y frio y no se vio en los enemigos aquel ardor y cmpeño con que nos invadían, metiéndose a boca de cañón con rara intrepidez. como se vio antes de la venida de los Auxiliares y el señor Flores; se conoce claramente que este buen caballero los escarmentó y que los retiene hoy, intimidados tibios y aún cobardes, tanto que es necesario que los echen por fuerza, a palos, chicotes, sablazos y amenazas de muerte y de ahorcarlos (como lo sabe hacer el Tupac Catari) para acometer a los nuestros y aún así muchos se ocultan y quedan

(1) La visión de Tupac Catarj "arreando" a sus hombres para el ataque de La Paz, cubierto con el manto capitular de la Orden de Santiago, es perfectamente comprensible. Según las declaraciones de los sorateños. después de la caj́da de la ciudad, a Tupac Catari le fue concedida tal capa por pertenecer a Segurola, miembro de aquella aristocrática orden. $\mathrm{Ya}_{\mathrm{a}}$ a fines de Agosto. Julián Apaza podía lucirse provocativamente con ella fuera de los muros.

(2) Cuando el Oidor lanza su exclamación sobre la importancia que tiene en materia de orden y disciplina la presencia del Comandante, no hace más que aprovechar el elogio para demostrar, según su criterio, que aquella conducta fue la que precisarnente Segurola no llevó a cabo en el primer cerco, produciendo con ello los fracasos sufridos y la ruina de la Real Hacienda. 
en medio camino; los invasores a cualquier fuego tuestro se ahuyentan (1). Dios quiera que con la nueva venida del señor Flores y su refacción de más gentes, conozcan sus yerros, barbarie y locura, los detesten, y sepan arrepentirse y humillarse con la obediencia verdadera a que son obligados por todos titulos. Lo cierto es que con estas salidas diminutas y repentinas, fuera de trincheras y la corta mortandad de rebeldes, hemos vislo que ya no son, ti sirven hoy de remedio alguno, porque al dia siguiente vuelven a molestarnos y siguen sus pasos / fol.70v. de tenacidad que no es extraña y antes propia del frenesí y audacia de los indíos que por otra parte manifiestan bien el temor con que se hallan. Supónese que los mandones rebeldes, son los implacables y obstinados hasta el extreno, que siempre y por siempre convendrá extinguirlos. Se ha aumentado la necesidad del pueblo y los combustibles andan muy escasísimos sin que basten de abaslecerlos los árboles, troncos y sus raíces exhumadas, de las cercanías de la ciudad, porque todos y aún los arbustos de espinos, se van concluyenda a toda prisa. Y por eso son raros los que comen pan, aparte que las harinas no se hallan y algunas que existen en la Provisión se reservan caltamente para las afectunsas personas de devoción. $Y$ asi es que muchos no la consigan aún cuando aumentasen los 35 pesos, de su valor actual (2). Hoy se inició nueva rogativa y novena solem en esta iglesia Catedral, en el culto de Nuestra Señora de La Paz, Nuestra Señora Tutelar y l'atruna; y aunque con la combustión de las casas de la ciudad en que estaban impuestos muchos censos, capellanías y obras pias, con el desorden y ruina de las haciendas y sus frutos, y con la turbación y entorpecimiento de las rentas y entradas eclesiásticas y seculares de los diezmos de la Iglesia y los ramos del Real Patrimonio de S.M., corren las cosas igualmente desordenadas, pues aún con los ministros subatternos que contribuyen al culto, divino servicio, asistencia y música de esta santa / fol.71. iglesia Catedral, han dejado de concurrir a tan santa obligación por falla de emolumentos y paga de su trabajo y asistencia y por no haber fondos para actuar sus rédilos devengados; con todo, se debe en muchas partes la posible solemnidad de este novenario y los anteriores, como de otras funciones, al buen celo, piedad y edificación del señor doctor don Antonio González Pavón, deán de ella, de nobles partidas y mucho más

(1) Se ve claramente que, a fures de Agosto. los Amaru, instalados en Cruz Pata y el Tejar. zona diametralmetne opuesta a la jefaturizada por Tupac Catari en Quilliquilli, el Calvario. Potopoto y Pampajasi, no actúan en la lucha con vigor ni organización. En esos dias, los alaques a la ciudad así cono la presencia en los combates están clarísimamente determinados por Julián Apaza y sus aymaras.

(2) La queja sobre el aprovisionamiento discriminado de los alimentos también aparece en los otros diarios, salvo, por supuesto, en el de Segurnla que se preocupa ciertamente de la alimentación de las tropas pero deja in otros, al Cabildo por ejemplo, tal cuidado, en cuanto a la población civil. Lo que sí llama la atención es el escándalo que manifiesta el Oidor en circunstancias en que él y, más que él. un empleado y arrendero suyo. se ven complicados en un odioso pleito por ocultamiento de viveres y especulación de precios en el ramo. (Pleito de Gil de Alipazaga.- Archivo Histórico Nacional, Madrid. Consejos, Leg. 20397 ). 
por su vida ajustada, loables costumbres y esmeros al culto de su Iglesia. Persona que cuanto más avanzada en la virtud, tanto más se halla deficiente de toda suntuosidad, por su sencillez, modestia y hunildad aún en el traje, que sabe llevar hasta su colmo, sin desdeñarse de las distribuciones inferiores de la iglesia y el coro y hacer de músico lleno de espiritu de caridad, para que la religión cristiana se extienda sobre los hombres. Y asi fue que al entrar la Semana Santa, usando modos imaginarios para consolar y convertir al pueblo en sus conflictos y necesidades del bloqueo, escogió por una oración sólida, sublime, sabia y piadosa, exhortar al pueblo, dispensándole en sus obligaciones cristianas cuya falta era la causa de nuestros males y tener irritada la divina justicia exitando a la paciencia y a los demás socorros espirituales para evitar las ofensas y deprimir las usuras de este tiempo crítico. Remedio salvifero, digno de nuestra más grande atención que de verdad sirvió de universal lenitivo de los ánimos.

Sábado $1^{\circ}$ de Septiembre. Nos batieron los indios / fol.71v, con los pedreros y fusiles cosa de dos horas, sin dano, y luego se retiraron a las dos de la tarde por el tiempo de nieves y lluvioso. Lo mismo con poca diferencia practicaron y le sucedió, hoy domingo 2 de Septiembre de dicho.

Lumes 3, Martes 4, Mirirnles 5 del mismo mes. No hicieron movimiento por el tiempo nebuloso, de aguas, aire y frío. Se dice con la entrada de un muchacho prisionero en el campo énemigo que el Tupac Amaru (Andrés) se retiró y se llevó todos los despojos de valor y preciosos que tenía el Julián Apaza, hurtados y acopiados, dejándofe solamente los odres de agua ardiente que desde luego debe estimar en nás. Que al Apaza le libró patente de Gobernador y se la mañdó con una orden para ahorcar al clérigo que se nos restituyó, don Vicente Rojas, por decirse era capitán de los españoles, trocando su desmo de capellán de nuestra tropa (1). Las que recibió el nismo día que el pretendido coronel Tito Atauchi le dio libertad para volver a esta ciudad, con que asi ya tenemos al Apaza o diantre de Tupae Catari descendido de Virrey y otras veces de pseudo rey a gobernador, conformidad, variación y apariencias estúpidas propias de indios borrachos o bárbaros.

Jueves 6 de Septiembre. Volvieron a batimos la ciudad los amotinados, siempre del alto y cerro de Quilliquilli, con tres pedreros que parece se percibieron, y varios tiros de fusiles que corrieron por algunas trincheras, pero con intermisiones.

(1) Como puede verse. la permanencia de Andrés Tupac Amaru en La Paz no duró mâs alłá de un nes. Hoy se sabe que fue llamado por su tío Diego Cristóbal Tupac Aman para someter o mantener otras regiones ante el avance de las tropas de Flores en Charcas, asi como el de las fuerzas de Lima en la sierra peruana. Andrés dejó en El Alto a sus dos grandes coroneles, Diego Quispe el mayor y Juan de Dios Mullupuraca. Más tarde ocuparía la jefatura Miguel Bastidas. En todo caso, lo interesante es que a esus alturas y a pesar de la importancia del papel jugado por Tupac Catari, el joven Amaru se permitió quitarle el título de virrey que se había adjudicado Apaza y lo rebajó a la calegoria de Gobernador, sin importarle el golpe moral que esto signilicuba para el jefe aymara frente a sus seguidores. 
De tuna bala / fol.72. nos hirieron en la rodilla y el pie a un soldado de Sorata y le quebraron el hueso y se retiraron entre las tres y cuatro de la tarde, habiendo principiado sus movimientos a las 11 de este día.

Viernes 7 de Septiembre. Nos batieron igualmente que ayer, aunque fueron pocos en número los tiros y los rebeldes concurrentes. A las cuatro de la mañana salieron los saboyanos y algunos granaderos fuera de trincheras río arriba y quebrada de Challapampa con el designio de sorprender algunos rebeldes que andan conduciendo mulas cargadas de bienes y sus envoltorios a hombros. Pero como el coadjutor Sainz de la Buena Muerte fue el práctico (aún no teniendo el conocimiento que se requiere de estos terrenos) no se logró el deseo, aunque tampoco se proporcionó. $Y$ así se retiraron a la 7 de la mañana con un indio y una india que condujeron prisioneros, y a ésta hirió con un tiro de escopeta (al ver que huía cuesta arriba y se iba rehundiendo) el dicho Coadjutor (11. Por los que se sabe que el Andrés Tupac Amaru estaba acampado en la estancia de Vilaque y que el Catari o Apaza, su gobernador, iba altá y se venía a Pampajasi que llama Collana, donde tenúa su fuerte (2). Los enenigos nos mataron a una niña tierna de Bolaños, el sordo, y a otra mujer y dejaron por muerta a otra muchacha a quien después auxiliaron los nuestros, que como aquellas habían salido por leña fuera de trincheras.

Sábado 8 de Septiembre. No hubo más movimiento que habernos disparado los enemigos, uno o dos tiros de un pedrero con / fol.72v, balas rasas desde Quilliquilli y habernos muerto un hombre de un balazo de las escopetas que disparaban por frente de las trincheras y bocacalles. A las 10 del dia, poco más, sacaron fuera de ellas y degollaron de orden del Comandante, al indio e india que trajeton hoy presos de orden del gobierno.

Domingo 9 de Septiembre. Entraron a la ciudad, sucesivamente, dos indias, una de la casa de doña Ana Parada y otra de la del doctor don Agustin Luna, cura de Pucarani que fueron prisioneras de los rebeides. La primera da noticia infundada de haber oído entre estos que el Auxilio que dicen venía de los de Lima estaba muy

(1) Causa extrañeza este comentario del Oidor Diez de Medina. Se pensaría que su reclamo escandalizado se dirigiría al hecho de que un fraile de la Buená Muerte no sólo participara en un ataque a los jndios rebeldes sino gue, además, lo organizara y capitancara; sjn embargo, la reacción enojada del autor se refiere al hecho de que se hubiera atrevido a cenducir a los saboyanos sin el suficiente conocimiento del terreno. El hecho de que el coadjutor dirigiera un destacamento español de saboyanos y que no conociera "los tertenos" denuestra claramente que el padre Sainz no era un criollo sino un peninsular.

(2) Tupac Catari persiste en permanecer en Pampajasi o Collana a pesar del alejamiento de Andrés Tupac Amaru de las regiones del Tejar y Cruz Pata. Apaza mantuvo sus campamentos separados de los quechuas hasta la venida de Reseguín y la retirada de los rebeldes a Peñas y Achacachi. 
irumediato, como también el de Cochabamba del señor Flores y podian llegar ambos a un tiempo a esta ciudad. La segunda añade que los indios proyectaban fortalecerse en unas serranías a las espaldas de las del Calvario, donde habían trasteado los bienes hurtados y aún los despojos de Sorata.

Parece nos hirieron en una mano a un soldado saboyano, en el fuerte de la paciencia, con una bala de las escopetas que hoy continuaron disparando contra las trincheras y calles de la ciudad. Hoy cortaron el brazo izquierdo al capitán Valencia que pasó y se halló en la desprevenida expedición de don José Pinedo y desempeñó con honor en las funciones de Vilque y Campo de Quequerani, el que estuvo padeciendo sobre tres meses de resultas de un balazo (1). Y también murió aquel granadero que el día 28 de Agosto / fol.73. salió herido en el hombro de otra bala, en la salida de Munaypata y alto de San Sebastián, hallándose el saboyano, su compañero, de otra herida padeciendo de grave cuidado. A las 7 de la noche salieron, parece que, tres piquetes de a doce cada uno, con fusiles por las trincheras de San Francisco, San Sebastián y la Caja del Agua, con el designio de tomar preso un indio para alguna averiguación, quizá del auxilio anunciado de Lima, que es el que más desean, los que siguen el sistema de etiqueta suscitado con el señor Flores. A más de las 11 de la noche se disparó un cañonazo nuestro en ser̉al de la retirada que actuaron sin suceso alguno.

Lunes 70 de Septiembre. A las 9 y media de Ja mañana se presentaron los indios acampados on las serranías de Potopoto o Pampajasi, en los cerros de Quilliquillli, a un lado del Calvario, y Santa Bárbara, en cordón, con mucha grita, flautas, cornetas y algazara. Batieron la ciudad y plaza, con uno o dos pedreros. Y los rebeldes de los altos de la l'una y cuesta del Cuzco, cono los que estaban más abajo, igualmente acampados en Munaypata, bajaron asimismo y de sorpresa se intrudujeron en la huerta del convento de religiosos de San Francisco por las brechas, que corre, abrieron la noche pasada, y osaron incendiar sacrílegamente los patios interiores de él, en crédito del último despecho y arrogancia en que se hallan

(1) El Oidor se refiere a unas batallas que se produjeron poco antes de que se iniciata el cerco de La Paz. Fueron estos los episodios linaies de una expedición preparada por Segurola y José Pinedo; ella estaba destinada a auxiliar a Joaquín Orcllana, gobernador de Pțno, que sufńa e] ataque de las fuerzas de Diego Cristóbal Tupac Amaru y de Tupac Catari. Las columnas paceñas no siguieron el camino tradicional al sur del Tilicaca, sino que tomaron la dirección noroeste del lago para juntarse con las fuerzas que salieron de Sorata. Unidos, marchan bacia la sierra peruana yara continuar desde el norle hacia Puno. No bien traspuestos los límites del Virreinato de Lima fueron atacados por las huestes de Tupac Amaru dirigidas por Diego Quispe el Mayor, que derrotaron a las compañías españolas. Con este fracaso quedo demostrada la incapacidad inilitar de Pinedo frente al cornnel quechua. Se producía asf, con este primer gran destistre de los ejercitos reales, la incontenible penetración de los coroneles de Tupac Amaru en el Obispado de la Paz, y se preparaba en esta forma la entrada de Andrés Tupac Anaru, cuyo objctivo inicial era la toma de Sorata. 
estos rebeldes, y a la deses-/fol.73v. perada, acaso porque contemplan próximos nuestros Auxiliares. Las compañías de saboyanos, de granaderos y forasteros se hallaban en la plaza sobre las armas. Al Comandante se le dio parte de aquel Iastimoso incendio cuyas liamas tomaron mucho vuelo $y$ humarcda a vista de toda la ciudad, (consternada con tal espectáculo) y cuando vimos que salieton estas tropas calle abajo de la iglesia Catedral, todo el mundo se congratuló de la providad del remedio de este pobre convento y sus religiosos mendicantes. Pero, cuando se vieron los tiros de fusiles en el alto de Santa Bárbara se pudo salir de aquel concepto errado, ya que no se tuvo por conveniente auxiliar a dicho convento y retirar. castigando con ventajas a aquellos insodentes, y procurando cortar el fuego, como en todas partes lo ministran la piedad y la más loable policia. Al fin, en Santa Bárbara que está al noreste donde no habia motivo fundado, no se hizo nada y estando San Francisco cuasi al oeste necesitado del socorro de aquellas gentes se le deja. No es nuevo: porque así se ha visto entrar al bloqueo a los rebeldes, quemar la clidad y mantenernos entro de trincheras a puerta cerrada. Y habiendo seguido la combustión por varias celdas y oficinas lastiunadas de la tragedia, salieron seis hombres ptadosos, y voluntarios de los nuestros, con fusiles y ottos sin ellos por aquella trinchera e introducidos por la iglesia, ahuyentaron de ella tres indios que estaban ya introducidos para / fol.74. robarla y estando sobre quinientos indios entro del mismo convento saqueando y porteando pelacas y los utensillos de los religiosos y transponiendo y cargando en hombros, unos pocos granos of frutos y otros depósitos de seculares fuera de la cerca del Convento y por los forados abiertos, los sorprendieron con el fuego de sus fusiles y los ahyyentaron sobre la marcha matando de una bala a uno de ellos, a más de otro escopetero, traidor de chupa encarnada, que de un fusilazo voltearon desde el fuerte de la Paciencia, entre las puertas del Convento, y a ambos condujeron los rebeldes cargados en unas mantas, y los extrajeron por dichas brechas de la puerta. Con cuyas demostraciones se retiraron fuera de ella a la una del día manteniéndose en algazara, emboscados entro de las casas, quemadas y a grupos fuera de éstas disparándonos sus fusiles desde que principió el incendio con muchas voces, contentos y risotadas de celebración. $Y$ ultimamente, se retiraron a su campo cerca de las 3 de la tarde, con lo cual se cortó el fuego de dicho convento, quemado en 13 celdas interiores y la sala Librería, cuyos libros se salvaron menoscabados. Y es de advertir que el padre guardián fray Joaquín de Arrivi, recelándose justamente la sustracción de las alhajas de la iglesia, pidió a la una del día, auxilio al Comandante para poder extraerlas y asegurarlas entro de trincheras; se le dio, compuesto de algunos soldados saboyanos y asi pudo salvar la custodia, vasos sagrados / fol.74v. y ornamentos, plata labrada, frontales de lo mismo, imágenes de la Virgen Purisima y de otros santos, sus insignias y demás bienes preciosos y de valor (1).

(1) El incendio del Convento de San Francisco está nartado en forma algo diferente en los otros Diarios. Castañeda y Ledo cuentan que el convento fue atacado por los rebeldes que lo saquearon sin piedad, salvándose solamente la iglesia, porque cuando los indios penetraron en 
Se halló un indio quemado y muerto de los rebeldes, en dicho convento, que al tiempo de aquel saqueo fue abrasado del fuego por Divina Providencia. Se aprehendieron $y$ condujeron dos vivos y medio quemados por los pies, de los mismos levantados ladrones y profanadores de la inmunidad sagrada y eclesiástica, lo que han apuntado tanto sus exccrables maldades e insolencias que irritan y sublevaban al espiritu más equitativo y exigen un remedio muy severo y circunspecto y mucho mayor del que correspondió a los principios y a los medios de esta sedición porque de lo contrario durará ésta más de lo que se piensa, con deterioro del servicio de Dios y del Rey y bien de la Patria, y mayores perjuicios y expensas del real patrimonio, que cada día se ven incrementadas por las negligencias de precaución a los principios para cortarla y remediarla con la brevedad que requiere ef caso.

Nos mataron hoy, los rebeldes, entro de dicho Convento a un violinista, de una bala que le traspasaron por el pecho, a un muchacho y al sastre arequipeño Bernardo le hirieron igualmente por la superficie externa de la mano, y fueron de aquellos auxiliares. Por el indio prisionero, (porque el otro murió en el cuartel, luego que lo introdujeron) se sabe que el Auxilio de Cochabamba, inferían los rebeldes estar inmediatos por la señal de las candeladas, que los suyos continuaban en el pueblo, / fol.75. y cerros de arriba por donde debe venir, que el que se dice de Lima lo consideraban distante porque de èl nada sabían, y que el Andrés Tupac Amaru o Guayna Inca como le llaman, estaba acampado en una tienda señalada con una bandera, entre blanca y encarnada, en el alto de Munaypata, internando de los altos para la ciudad, donde salieron días pasados los saboyanos y granaderos. Aunque hay personas de cxcepción que aseguran haber visto hoy, a las tres de la tarde, que se levantó dicha tienda lucgo que bajaron con algtin mensaje (presumible) algunos de caballería del alto y cuesta de Laja, y que con ellos se retiró este caudillo, quien

ella. acudió mucha gente en su defensa. Añaden que los rebejdes se llevaron a dos religiosos conn prisioneros, los que volvieton despues de dos dias con nolicias del Alto y con cartas de unos supuestos criollos invitando a los de la ciudad a plegársejes puesto que la rebelión les compete también a ellos. (carta $n^{\circ} 24$, en pubitcación de Ballivián y Rojas). Segurola, por su parte, se refiere también a ia aparición de los rebeldes por San Francisco y por Santa Bárbara y el Calvario, pero señaja que se atacó a estos sitios primeramente por la cercanía, siendo dispersados con rapidez, matándose incluso a algunos. Despejados esos sectores, se dirigieron a San Francisco, que sufrió el ataque e incendio por parte de los sublevados.

En el fondo, la gravedad de la anotación de Diez de Medina estriba en que el Oidor acusa al Comandante de voluntaria negligencia en la defensa del convento. Aunque en los Diarios no hay mayor ahondamiento sobre el tema, Io hay, en cambio, en la correspondencja y en los informes al Virrey, por parte de Segurola y del Obispo. el cual se queja de las actitudes del Comandante frente a los franciscanos a quienes muchas veces supone colaboradores de los rebeldes. Ver Historia de la Rebelión de Tupac Catari. M.E. del Valle de Siles. La Paz, 1990. 
acompañado del Apaza, estuvo esta mañana regentando y echando a la gente al incendio del convento de San Francisco (11). Esta noche desde las 11 y media se dispararon tres o más tiros de nuestros morteros, desde el fuerte de la Paciencia; pueden haber hecho alguna operación porque el canonazo de la pasada a las $11 \mathrm{y}$ más, en señal de retirada de los nuestros, parece que por su bala rasa llevó la cabeza a un niño y a otro hirió en el brazo o mano, en el mismo acampamento enemigo de Munaypata, según la confesión de los dos indios prisioneros del día. Aún quieren decir que este suceso fue a la inmediación de la tienda de dicho Tupac Amaru y que si bajan el punto del cañón nuestro, alguna cosa, le toca a este conjurado la bala. Del dicho convento al principiar el incendio, se llevaron prisioneros los rebeldes a dos religiosos de edad avanzada, el padre Bernal / fol.75v. y el padre Villalobos (éste enfermo), gue estando en sus celdas, tratando de preservar sus utensilios y libritos del incendio, fueron sorprendidos con violencia y extraídns por la cerca de su religión, y desptiés conducidos a mula al campo rebelde.

Martes 11 de Septiembre. Degollaron por la mañana al indio prisionero que tomaron ayer. Se presentaron los de Potopoto en la ceja del cerro de Quilliquilli, acordonados y con vocerías, nos dispararon algunus tiros de pedreros con bala rasa y antes de las II se pasaron al al to de la cuesta del Cuzco (donde hoy están fortalecidos los de la Puna) y aún corre que tuvicron su conciliábulo o congregación en la estancia de Achachicala. No volvieran a insultarnos en todo el día. A la 7 de la noche bajaron con clarines por la misma cuesta del Cuzco a los altos de San Francisco con cornetas y flantas y actuaron su grita y amenaza de acometernos. Lo que también practicaron los de Potopoto desde el cerro de Quilliquilli.

Miércoles 12 de Septiembre. Comenzaron los rebeldes a disparar sus escopetas desde las 6 de la mañana a espaldas y cubjerta de las troneras (abiertas) de la cerca del convento de San Francisco. El designio, parece, era continuar con el incendio de este y al efecto, entraron algunos indios que intermaron por las brechas. Los que estaban de guardia en la trinchera dominante de la Paciencia dejaron muerto, al parecer, / fol.76. tendido de un balazo a uno de ellos que estuvo arrojado (de quien se dice que después de buen espacio se levantó y huyó), e hirieron igualmente a otro que a gatas pudo retirarse; dos rebeldes foradaron la cerca por la calle llamada de los Tambos y por él se salvaron y huyeron porque los nuestros salieron por la iglesia a autxiliar el convento y los pusieron en fuga sin que osasen entrar para segundo acto. Siguieron con muchos fusilazos y descargas que formaban con varias escopetas disparadas a su tiempo y nos hirieron a un soldado saboyano en el brazo, quien se halla en peligro, con sentimiento universal.

$Y$ en el alto de Quilliquilli estuvieron acordontados los de Pampajasi o Potopoto con alguna grita y nos dispararon los pedreros; a la una del día empezaron a retirarse unos y otros a sus respectivos campamentos. Los dos religiosos del

(1) Todas estas contradicciones se debfan, seguramente, a la confusión producida por fa marcha de Andrés Tupac Amaru y su reemplazo en la persona de Miguel Bastidas. 
convento de San Francisco que sacaron prisioneros volvieron, por libertad que dicen les dio el Andrés 'Tupac Amaru, quien hizo el papel de desaprobar su extracción y conducción; los alojó en la capilla o tienda acompañando al eclesiástico don Reimundo Romero a quien tiene de capellán y los recibió con agrado y buen trato; que tiene un tío suyo a su lado que se traga el tratamiento de Vuestra Alicza, que le dan los traidores; y que ordenó su restitución a la ciudad y les dijo que sus intenciones no se terminaban sino contra corregidores, europeos y aduaneros y quitar impuestos, y que hacían mal los criollos sus paisanos en no salirse y seguir su partido, porque de lo contrario cuando hubiese de / fol.76v. entrar a la ciudad con la multitud de indios que aguardaba de todas partes, no sabría distinguir entre los europeos y aquellos y haría pasar a cuchilio a todos (1). Les dio una carta, en substancia, de sedición abierta y dirigida a los criollos, en que tratándolos de paisanos y amigos los concita a sus depravados y traidores pensamientos, cuya carta pasaron los religiosos en derechura a manos del Comandante, quien la deprimió aunque con tanta mortandad del criollismo actuada por los rebeldes aquella astucia diabólica no podría producir efecto algumo en los criollos de la ciudad que han acreditado su fidelidad en el rigor de las hambres y calamidades y que estái viendo las muertes $y$ atrocidades que contra sus ofertas van cometiendo cuasi diariamente y en Sorata en los mismo crjollos, falsificando así sus promesas vanas para no daủarles (2). Nos hirieron en la trinchera de las Recogidas de otro balazo en el muslo a un granadero, Feliciano el relojero, y un soldado de Larecaja y en la de San Sebastián a otro soldado de la misma Larecaja. Y palpamos que desde la venida del maldito Antrés Tupac Amaru con los tholos desertores del sitio de Soratal y Larecaja, nos hacen estos mucho daño con los fusiles, como que ellos los manejan y no los indios sublevados quienes por no saber, ni se atreven o no se aplican a manejarlos (3), Y

11) Este personaje, que se hace dar trataniento de "Vuestra Alteza", y que el Oidor seinala como lóo de Andrés, es Miguel Bastidas, el cuî̀avo de José Gabriel Tupac Amaru. Es interesante en el mensaje del nuevo caudillo el criterio con que identirica a criollos y mestizos como "paisanos". Al relerirse a él mismo, que es precisamente un componente mestizo en la dirección de la rebelión, está tratando de presentarsc como un elemento de enlace entre indios y criolles.

(2) La carta de Bastidas llumando a los criollos, conocida por todos los paceños, produce, como era de esperar, cierta alarma en el Comandante. quien desiste de disminuir su importancia; también produce efecto en el Oidor, portavoz, en este caso, del sector criolio, quien se refiere a que el mensaje no tentará a los paisanos porque después de lo que han visto, sobre lodo en Sorita, ya no creen en las prontesas de los alzados. Diez de Medina, conocedor de los recelos de Segurofa y de las evidenles rivalidades entre los dos sectores, se apresura en señalar que los criollos siempre "han acredilado su tidelidad, en el rigor de las hambres y calanidades".

(3) Esta aseveración del Oidor no está muy de acuerdo con lo sostenido en otras páginas del Diario, puesto que señala a la gente de Tupac Catari disparando machas veces fusiles y pedreros aún antes de la llegada de los quechuas y los "cholos", tan despectivamente 
de los mismos que vinieron auxiliares de Larecaja, desertaron hoy mismo, dos hombres y se fueron al campo enemigo, como continuamente lo han practicado los más de estas gentes comelonas y flojas / fol.77. hasta el extremo. En esta noche, desde las 7, hicieron pruebas de los morteros, disparándolos ел esta Plaza Mayor con mechas encendidas $\mathrm{e}$ introducidas entre las balas para computar su alcance. Sería alguna diversión porque cumplidos hoy mismo, los 40 días de este segundo cerco desde el 4 de Agosto, de la retirada del señor Flores y estando próximo y a la puerta su regreso ofrecido a la cuarentena, no se alcanza para qué se ejecuta, evitando semejante ensayo cuando pudieron hacerlo desde el principio para aprovechar con ellos el aumento de este tiempo corrido. También se sabe por otros religiosos que el indio Tupac Catari tiene que presentarse diariamente al cholito Tupac Amaru pretendiendo en señal de obediencia y de recibir sus órdenes; que en el plan de su campo se imprime el sello de sus armas del segundo y que un francés muy hábil perdonado en Sorata se halla fabricando balas (1).

Jueves 13 de Septiembre. Amaneció muerto el soldado del regimiento de Saboya que ayer nos hirieron los rebeldes y fue dañado en Argel cuasi cn semejante puesto del bacío [brazo] de otra bala. Y también murió el granadero herido en el brazo el día 28 de Agosto pasado, en la primera correría a Munaypata, después de haber sufricio la amputación del brazo. Los indios anduvieron en movimiento del acarreo en mulas cargadas, y a sus hombros, bajando del alto de la Puna por la cuesta llamada Potosí dirigidos así a la Capilla y de alli a Potopoto y Pampajasi / fol.77v. y por la parte asimismo de Achachicala y Calvario, al mismo puesto. No hicieron de día cometimiento alguno. La noticia del próximo regreso de nuestro General refaccionado de tropas y gentes, según el objeto de su ausencia, parece sc anuncia infundadamente, puede suceder del Sábado próximo al Lunes, como parece lo escribió ayer al Comandante de la ciudad el eclesiástico don Reimundo Romero, aunque otros dicen ser el clérigo don Isidro Escobar. $Y$ aún se añade igualmente, que el Corregidor de Arica y Tacna, don Andrés..., se incorporó con sus gentes en la Villa de Oruro con la expedición del señor Flores y que al transitar por la provincia

considerados por el autor. Por otra parte. en las páginas anteriores a esta declaración. coincidente con la de los sobrevivientes de Sorata, apuma repetidamente que los ataques con amas de fuego son mucho más intensos en la zona comandada por el jefe aymara, quien, en lo posible, no quiso contar con soldados y coroneles de los Anana ni mucho menos con los "cholos" venidos desde Larecaja.

(1) Ninguno de los otros Diarios insiste, como lo hace el del Oidor, en señalar tan fuerte dependencia de Tupac Catari ante los Amaru. Sin embargo, según las declaraciones de los juicios de Peñas, una vez producida la derrota indigena (AGI, Bs. Aires 309) se evidencia que, si bien no se admite un sometimiento semejante al descrito por Diez de Medina, se aprecia ciertamente una relación dificil y de poca aproximación, como que el propio Diego Cristóbal Tupac Amaru Jlana Ja atención a Bastidas y a Andrés porque todo ello puede ser muy contraproducente. 
de Pacajes, dertotó a aquellos indios. Que vienen los soldados saboyanos, que quedaron en Charcas y utros con otras milicias de las provincias de Tucumán fuera de los que hace días arribaron a Oruro y aún se dijo estar acampados hacia Panduro. Dios lo traiga con felicidad porque la ciudad, sus calamidades y muertes continuas, principalmente de personas visibles en estos días pasados, bien lo han menester por instantes. Esta noche a las 9 , poco más, se suscitó la vocingleria de los rebeldes, se presintió ser pocos en número y que andaban circunfiriendo las trincheras y mudando de puestos para aparentar aumento de concurrentes; el acometinniento fue más de amago que de verdadera ejecución porque se presentaban, hondeaban con piedras (aunque poco), gritabar y dispa-/fol.78. raban fusiles de lejos sin abocarse (come anteriormente) a las trincheras. Se conoce que están tímidos y escarmentados de las novedades pasadas. Nuestro Comandante se mantuvo en vela toda la noche, reforzó los fortines y paredones de tropas y armas para recurrir con ellas donde la necesidad lo pidiese. 'También estuvieron presentes y listos en el Ayuntamiento los del cuerpo de Oficialidad y muchos individuos del vecindario; se iluminaron las calles y en substancia no hubo especial novedad sino los fusilazos de parte a parte $y$ morteros que se dispararon desde la Paciencia a donde se sentia el murinullo contrario. $Y$ a las 6 de la mañana (en que se oyeron algunos escopetazos de los rebeldes) tuvieron que retirarse éstos a su respectivo canpo. Este día vino un indio que reconoce ser de Santiago de Pupuja, provincia de Azaingaro, a quien el Comandante mardó la ración y libertad en lá ciudad; parece que trajo un mensaje o carta del campo enemigo gue será en buena cuenta, algún trampantojo.

Viemes 14 de Septiembre. Nos batieron desde el alto de Quilliquilli con algunos tiros de pedreros entre 10 y 11 del día. En lo demás no hubo otro movimiento que tl de los fusilazos que con intermisión de tiempo nos fueron disparando por diferentes puestos y calles, y la conducción que hacian de víveres al campo de Potopoto. A las 2 y más de la mañana repitieron la grita, amagos / fol.78v. de acometer y escopetazos que en la noche pasada y así amanecieron.

Sábado 15 de Septiembre. A la aurora nos mataron de una bala en la cabeza a un artillero en la trinchera de la Paciencia. Siguieron por los alrededores los fusilazos enemigos, entre día, y separados algunos undios se presentaron con la algazara acostumbrada a las 5 y más de la tarde en la calle arriba de San Francisco en la banda del convento y emboscados dentro de los tambos fronteros y quemados. $Y$ después del mediodía nos batieron con sus pedreros desde Quilliquilli con bala rasa pero con disgreciones de corriente; ei cholito Tupac Amaru o Tupac Amarillo que así lo llamaremos para distinguirlo del rebelde de Tinta y Tungasuca, estuvo esta tarde en la iglesia de San Sebastián con música de violines y clarines y bajó de Munaypata con la conitiva de cholos de Sorata y otros de a caballo con su camiseta o unco (asi llamado en la quechua o ccava en la aymara, que es una especie de cotón hasta abajo del pecho, sin mangas) pero no tejido de lana como lo estilan los indios, sino de terciopelo negro con galón de oro igual al que trae el perverso Tupac Catari quien vino en su compañía y estuvo en la casa quemada de don Juan Delgado en la plazuela del mismo San Sebastián, habiéndose hallado anteriormente en el al to de 
Quilliquilli regentando el manejo y disparos de los pedreros. Esta misma tarde nos mataron un / fol.79. muchacho en el fuerte de la Paciencia que estuvo hondeando a los enemigos; de un balazo hirieron en la pierna a una india en la esquina de las monjas y se sentó que a un hombre lo condujeron iguaimente herido, en una manta por la plaza mayor; lo que vemos es que los levantados, al disimulo, nos van agotando las gentes por todos términos. A prima nodhe hicieron bulla de cometas y vocería, pero cesaron luego y asi siguió esta noche sin movimiento y cuanto más con alguna grita a espacios entre el molesto sonido de las cornetas.

Domingo 16 de Septiembre. Se atravesaron entre día por diferentes calles de la ciudad algunos balazos enemigos, pero no con el tesón y número crecido de ayer; entre 1 o 2 de la tarde, estando la puerta de las trincheras de las Recogidas sin el oficial de guardia, logró abrirla de un envión y salir fuera don Bemardo Gallo (genovés de nación), capitán de artilleros, muy hombre de bien y administrador de esta Aduana (suspensa) con mucha integridad y pureza y ventajas del Real Haber. Este buen vasallo, durante el cerco de la ciudad, se desvelaba en celar las trincheras y la permanencia de sus artilleros en ella, y así fue insultado de una fiebre maligna o tabardillo en la cabeza; convaleció dañado de ella o del cerebro, con algunas preocupaciones de locos, aunque en mucha parte contestaba con regularidad (1). Habia dado en la manía de anurallar la ciuded desde la cordillera / fol.79v en su entrada a la ciudad y saquearla. Raro delirio cuando, ni los cholos bajos consienten en semejante urdido de perfidia (2). Enviaron, así mismo, unas cartas pendientes de una bandera que fijaron a la vista del fuerte de Santa Teresa, las que pasaron al Comandante. La una parece de dicho Gallo, a lo menos firmada por él, al mismo Comandante. Refiere que el gobernador Tupac Catari es benigno y lo recibió con agrado y que así como a él le ha perdonado, también perdone a su llamada mujer Bartolina Sisa porque si la matan o quitan la vida, reducirá a cenizas la ciudad (amenaza continua y vana) y aún dicen escribe otra esquela el dicho Gallo a su sobrino. Y la otra carta del mismo Tupac Catari al Ayuntamiento de la ciudad, que parece, la pasó y abrió el Cabildo, en la que solicita en sustancia a dicha india. En la refriega y acometimientos noctumos nos mataron de un balazo en la frente a un centinela nuestro que estuvo al descubierto, fumando tabaco o cigarillo, en la trinchera de la Caja del Agua, y con frecuentes tiros de escopetas, grita, pedrea y cornetas siguieron empeñadisimos hasta mucho después del amanecer y fueron

(1) Como antes señala el Oidor, este don Betmardo Gollo era el jefe adninistrativo de la Aduana contra quien se produjeron los levantamientos fiscales de La Paz en 1780, cuando le tocó aplicar las inedidas tomadas por Areche subiendo las alcabalas del 4 al $6 \%$, Mestizos e indios habian identificado su odio a las decisiones del Visitador Areche con este pobre personaje. haciendo circular pasquines y panfletos con versos o dinojos agresivos que pedian la horca para Gallo.

(2) En estas frases debe haber algún enor del copista. Realmente, los textos son contradictorios y no tienen ningún sentido. 
resistidos de nuestros fuegos con mortandad de varios, como lo indican los vestigios de sangre y despojos de varias morteras y talegos de coca que dejaron al correr o huir heridos. Y esta tarde, con el mortero de la Paciencia, se hirió a algunos emboscados en las casas quemadas que salieron a carrera huyendo y cargaron tres cuerpos en mantas. / fol.80

Martes 18 de Septiembre. A la mañana y tarde no hubo movimiento; los nuestros que salieron por combustible, por la trinchera de Santa Teresa, aprehendieron esta madrugada a un desertor nuestro, sastre (1) de la cuarta compania, según se asienta, a quien mandó a ahorcar el Conandante a las 2 y media de la tarcle, cuyo cadíver quedó el resto de ella pendiente de la horca. A las dos entró el clérigo don Reimundo Romero, presbítero a quien violentó el Tupac Amarillo y le trajo de su capellán. Este nos trae razón del campo enemigo y dice que todas sus miras fueron retirarse de él, y cuanto más dice, el Tupac Amarilio remitió todos los caudales de Sorata y robos que ha hecho al Tupac Catari en estos altos, a Azángaro, a casa de su padre Diego Tupac Amaru, que alí se supone existe, y donde tenía dispuesto marchar pasado mañana jueves, conduciendo a dicho eclesiástico en calidad de capellán; refiere que las dos ültimas petacas que tenia de bienes, ya las había despachado con anticipación a su partida, debiendo quedar mandando el tío que trajo en su compania. Que hoy vio 10 indios muertos fuera de herios (2).

Que esta mañana castigaron con crueles azotes de parte de Tupac Catari y coronarom de espinas al desgraciado don Bernardo Gallo y que descalzo y sin birrete, con un par de grillos y en chupa, lo ilevaron de Herodes a Pilatos o al campo de Tupac Amarillo, quicn igualmente le mandó a azotar / fol.80v. preguntándole de los ciudales de la Aduana y por suponer que se finje loco. En cuyo intermedio y alboroto de indios, tuvo el eclesiástico ocasión de retirarse a esta ciudad desmandado como vino, por decir que hasta los adherentes de caballeria y sus ropas (decentes) se habian hurtado los rebeldes y que los indios alistados en la actualidad son 12.300, aunque los más cuando bajan a acometer la ciudad, se quedan ocultos en las quebradas y casas quemadas, de miedo de no ser heridos o muertos con nuestros fuegos; que no pudo saber de las determinaciones del enemigo ni de la vuelta del señor Flores porque el Tupac Amarillo se reservaba de los eclesiásticos y cholos y expedia asuntos con cautela; que es cierto que el señor Visitador General mandó castigar al rebelde Tupac Amaru de Tungasuca, en el Cuzco, el 15 de Mayo, coronándole con una corona de hierro ardiendo, remachada con unos clavos por las

fir Nuevamente salta una frase ininteligible que no puede ser sino error del copista.

(2) Como puede apreciarse, el sentido del humor de Diez de Medina es bastante pobre. Sin embargo, el Oidor se regocija una y otra vez llamando Tupac Amarillo a Bastidas o a Andres Tupac Amari. Es notorio, рог otra parte, el desconocimiento que se tiene en la ciudad de lo que sucede en el Alto, puesto que se sigue confundiendo a los caudillos y no se sabe bien quién es ni dónde actúa el propio Diego Cristóbal Tupac Amaru, jefe supremo de la rebelión. 
sienes y sentándole en una silla del mismo metal caldeado (1). El cholo sastre difo que Faustino Tito Atauchi, el coronel supuesto, partió con 5.000 hombres a contestar las tropas del señor Flores quien le derrotó en Sica Sica y que a su instancia fueron después 2.000 indios más de refuerzo, lo que necesita de confirmación (2). Los rebeldes siguen con el acarreo de ganado $y$ víveres y se dice sorda o vagamente que los destinan a la serranía o cordillera de Coroico que se Ilama Asinonarca, lugar bien fragoso y elevado pero no difícil de acceso, pues tiene tres caminos por donde tomarlo. A las 11 dej día nos hirieron con la bala de un pedrero a un soldado en la pantorrilla / fol.8I. en la esquina de la Plaza Mayor y Catedral. En estos días fallecieron el granadero Feliciano, el relojero y el capitán don Francisco Valenz, quien había marchado a Quequeraní en la expedición desaparecida de don José Pinedo (3); heridos de bala son 29 y granaderos 15 que hemos perdido en las refriegas, según lo dice su capitán don Juan Fernando de lturraide.

Miércoles 19 de Septiembre. Dispararon de parte a parte algunos fusilazos y tíros de pedrero de los rebeldes y nos hirieron seis personas de ambos sexos y algunas de peligro. Por la tarde estuvieron los sublevados acordonados y sentados en la ceja del cerro de Quilliquilli y emboscados por los alrededores de Ia ciudad, entre las casa quemadas, de donde manejan sus escopetas. $Y$ de noche hacian sı grita de voces y cornetas sin acometer (4).

Jueves 20 de Septiembre. Empezaron los cholos alzados escoltados de los indios rebeldes desde las 6 de la mañana, desde las casas quemadas, con sus tiros de escopetas, contra los nuestros que están en las trincheras y andan por las calles; se introdujeron aquéllos dentro del convento de San Francisco, asímismo escoltados. Cerraron la portería y desde las ventanas de las celdas que caen a bazuela, nos

(1) Todavia en la segunda mitad de Septiembre de 1781, hay dudas sobre la mtierte de José Gabriel Tupac Amaru. El cerco era tan fuerte que, aún mediando el tiempo en que Flores estuvo en La Paz. las cosas no se conocian oficialmente y podían circular noticias tan truculentas como la de la corona ardiendo y la silla caldesda. Por lo demés, la pena aplicada a Tupac Amaru por el Visitador Areche era lo suficientemente despiadada y cruel como para originar cualquier otra interpretación.

(2) Tampoco las roticias de lo que sucede en el campo indigena próximo son ciertas. Se confunde evidentemente a los coroneles rebeldes y se abultan las cifras, como es el caso de los combates de Sicasica.

(3) Ver nota $n^{\circ} 24 /$ fol.72v. Referencia a la campaña de José Pinedo destinada a auxiliar a Joaguía Orellana en Puno.

(4) El cerro de Quilliquilli, actualmente cerro de la Bandera, está a pocas cuadras de la Plaza Mayor (hoy Plaza Murillo). De alı́ que los sublevados podían sentarse en el borde de aquel monticulo y observar tranquiłamente lo que ocurría en la ciudad, así como emboscarse en las casas quemadas de las faldas del cerro. 
hicieron fuego vivo y continuo. Al tiempo de montar la guardia hirieron de una bala en la pierna al que corría la posta del correo, y a Chavarria en el paredón de la Cruz Verde y entre día hirieron a una mujer en el vientre y a un muchacho. A las 10 de la mañana bajaron los indios de /fol.81v. la plazuela de San Sebastián con banderas, cajas y clarines, en pelotones y se fueron emboscando entre las casas quemadas; y empezaron los del alto de Quilliquilli a batir la ciudad con un pedrero, pero pausadamente; entre 2 y 3 de la tarde salieron los saboyanos, los del Tucumán y nuestros granaderos a una correría, unos por la trinchera de la Caja del Agua y otros que se descolgaron por el fuerte de San Miguel. Lograron tomar a varios indios rebeldes en el medio, les hicieron fuego y acosaron. Mataron cosa de 10 de ellos, aunque otros dicen que seis; hirieron a varios que huyeron con los demás; un granaderito, así llamado, de los de Chuquisaca aprehendió dos indios vivos, quien, asido fuertemente de ellos, no los perdió de cada mano por más que ambos se lo arrebataban y lo conducian al aire o como un peso de balancin y que un voluntario nuestro indiscreto, le rompió la cabeza con la culata del fusil por equivoco, sin duda, pero que aún dañado asi los fue sujetando hasta que los nuestros liegaron, le ayudaron e introdujeron a esta plaza y cuartel a ambos y otros más que condujeron vivos. Primeramente les mandaron confesar y a las 5 o poco más de la tarde, los degollaron de orden del Comandante, fuera de la trinchera de las Recogidas. For los tres prisioneros se supo que los espanoles o tropas del señor Flores se iban combinando en la posta de Panduro, ocho leguas más allá del pueblo de Sicasica y que era muy crecifa la porción de gentes $y$ aún añaden otras circunstancias que se omiten porque han menester mejor testimonio. Por la mañana/fol. 82, trajeron, parece, una carta del Tupac Amarillo en que escribe al IIustrísimo Señor Obispo, Cabildos y vecindario para que se salgan y desamparen la ciudad retirados a su campo: delirios de la barbarie. La noche fiee quieta. 'También se sabe que el Martes 14 de éste murieron 30 indios con nuestros fuegos, sin computarse los heridos, según la confesión de los indios; y que a don Bernardo Gallo te azotaron porque anduvo a porrazo con los indios, persuadiéndolos a que no tengan más Rey que al Señor Don Carlos III (Que Dios Guarde).

Viernes 21 de Septiembre. Empezaron los rebeldes a disparar un pedrero desde las 7 de la mañana, y los otros sus escopetas en conjunto desde las trincheras y aumque en una y otra operación no manifestaron el empeño y ardor que en otros días, parece que con todo nos hirieron de bala a cuatro personas. La noche fue quieta $y$ a las 7 u 8 de ella, aprehendieron los nuestros hacia la trinchera de las Recogidas a una cholita de 14 años que iba ronceando la ciudad, y fue vista, la introdujeron, y le hallaron unos ocho panes, dos quesos y cinco pesos en plata sellada, que traía para Ia india amasia de Tupac Catari, Bartolina Sisa, prisionera en la cárcel pública, con otra india, cuya hija es la cholita conductora y con más una carta escrita a ella del conjurado Tupac Catari solicitando robarla para su campo y ofreciendo al alcaide de la cárcel sus tesoros y hacerlo su valido para cuando gane la ciudad. Corre que el carpintero Martín la descolgaba por una ventana de su casa 
que cae al río fuera de Trincheras. Y según / fol.82v. las averiguaciones puede ser resulte uno u otro del populacho complicado en la trama, supónese que no se ha pensado en fugar ninguna pieza "1" con dicha india amasia, aún viéndose que el conjurado se manifiesta $\tan$ apasionado y empeñado en su libertad. Si con pretexto de ésta se le pidieran víveres, ganados, frutos, combustibles y denás menesteres, ofreciendo actuar el suplicio de la india, en str defecto pudiera ser que los ofreciese y se socorrería la ciudad que ha vuelto a su indigencia, tomando los arbitrios de azotarla en público sucesivamente y poco, para que llegase su noticia y aún amagándose con la ejecución de la pena ordinaria, que con cualquier pretexto pudiera suspenderse, y aumentasen mediante cualesquiera dilatoria o suterfugios (lícitos en este caso de necesidad extrema por causa de su perfidia y traición) (2), 0 para que nos trajesen las armas de fuego, pedrero, y cuanto se quiera, o para retirarlos, acaso subordinarlos y pacificarlos, la ciudad se ha mantenido los 50 dias del nuevo sitio, desde: la retirada del señor Flores y los anteriores, sin pensar en acción alguna, dejándonos estar mano sobre mano, guardando trincheras y no más, sin pensar en otra cosa que esperár la revuelta [e] retorno] del señor Flores. Lo mismo sucedió la vez pasada, cuando el primer sitio, a los principios del aproximarse la rebelión a la ciudad y al suscitarse el fermento en el puteblo de Sicasica, donde pudo breve y fácilmente apagarse con poca genté y pronto y aún a poca costa, y también al empezar a discurrir por los valles de Caracato y Sapaaqui / fol.83 y Río Abajo de esta ciudad, sin tratar del remedio de disiparla sobre la marcha con una pronta acción y expedición que hubieran sido muy oportunas (3), y por quienes clamaban las primeras ocurrencias, del mismo modo que nos hemos comportado con la india Bartolina cuya captura no se ha tratado de aplicar a nada de lo que es evitar nuestros daños supervenientes [sic], y aún siquiera para los combustibles de que carece la ciudad; porque están las cocinas sin más pábulo que el cuero ensebado, lanas, y trapos igualmente ensebados, las sillas, mesas, puertas y

(1) Se refiere a negros esclavos que deben haber estado en la cárcel.

(2) No hay mucha concordancia entre to que el Oidor sostiene ahora con lo dicho en otros momentos sobre la crueldad practicada por Segurola con los indios aprisionados. Aquí aparece como un funcionario duro y casi maquiavélico que se queja más bien de la blandura del Comandapte quien no aprovecha las circunstancias para castigar a Bartolina, amedrentando, de paso, a los alzados.

(3) La acusación de Diez de Medina a Segurola por no haber dispersado a los rebeldes desde los primeros días, tan frecuente en la primera parte del Diario, se mantiene igual en la segunda parte. Parece que las tristes experiencias de las fuerzas militares, tanto del Comandanle como de Ignacio Flores en el primer sitio así como en el mes que permaneció éste últino en La Paz, no le sirvieran de nada. El Oidor opina en estas materias comọ el clásico funcionario burócrata que critica toda acción militar sin poseer dingún conocimiento de! tema. 
madera de las casas, y oficinas que han tenido que destechar varios, por subsistir, fuera de haber el gobierno mandado destechar otras de los pobres por la precisión de no haber materia para el tuego y beneficio de la pólvora, que nos importa, lo que pudiera evitarse si se tomase a la india por instrumento para que ella u otras máximas que dicta la prudencia y no sabemos si nos resultasen propicias cuando detentarlas con espiritu de prudencia e ingenio nada se aventuraba ni se perdía (3).

Sábado 22 de Septiembre. Bajaron los indios por toda la circunferencia de la ciudad, se emboscaron en las casas quemadas, batieron la ciudad con distancia de tiempo y su pedrern y nos acribillaron con las balas de sus escopetas por todas parles y calles, con extraurdinlario tesón, sin que fuese permitido el salir fuera de casa. En la esquina de la calle de Mercaderes nos hirieron con una piedra a una niña de cinco años, y en la trinchera de San Sebastián nos hirieron de otra, en la tetilla a un soldado que hacía la guardia / fol.83v. La noche fue quieta porque los más enemigos se retiraron a las 6 de la tarde y algunos antes a su campamento; y entre el dia de ayer y hory han bajado los indios hacia la parte de Potopoto con muchos ganados lanares que se regulan hasta el número de 10.000 , fuera de los dias anteriores y así fue que mientras las lograban pasar, apuraron los enemigos los tiros de sus escopetas con el fin de entretenernos y salvarlas. Parece que su fin es dejar sin ganado las estancias de los espanoles y las campañas por donde deben venir nuestros Auxiliares con ol seinor Flores, y todas sus inmediaciones, y tener cames a mano para subsistir en el puesto o puestos donde piensan fortalecerse durante la estación de estas tropas auxiliares en los altos de la ciudad y sus contornos. Juzgando volver a sitiar y perseguir la ciudad luego que se retiren, porque ellos cuentan quedar impunes y libres y que el Auxilio no ha de durar para ésta mucho tiempo, y que en su ausencia tendrán el campo franco y por suyo para sus pérfidas intenciones. Por lo cual y por la suma rebeldía e insolencia de ellos, es forzoso ya tratarlos a primera instancia, con inexorable rigor, quitar los cabezas del medlo y hacer un severo escarmiento en algunos pueblos, para que después, según se comporten, sobre ver, y tratarlos con la piedad que resplandace a los pies del trono augusto de Su Majestad Católica, el Rey Nuestro Señor.

Domingo 23 de Septiembre. A las 6 y media de la mañana dispararon los enemigos el pedrero, y entre la mañana dos tiros más y se oyeron como en tiros de escopetas que fueron raros / fol.84. A las 11 se salió el Tupac Amarillo por la cuesta de Lima con la comitiva de 50 de a caballo, fingiendo que se retiraba temeroso del auxilio próximo, pero estas han de ser las variaciones inteligibles de los indios. La tarde fue de sosiego y aunque a primera noche corrieron algunos tiros de escopetas suyas, en lo demás dé ella no hubo novedad.

(1) Precisamente por no habesse propuesto hacerlo, le resulta af autor en estas líneas un cuadro espontáneo y vigoroso del estado de pobreza y escasez que se vivía en la ciudad en el último mes del segundo cerco. 
Lumes 24 de Septiembre. Dispararon a las 6 de la mañana su pedrero una vez y siguieron algunos varios tiros de escopetas; desde la 9 y media de la mañana volvieron a disparar tres veces el pedrero y cesaron con él en el resto del día, en el cual se dieron unos tiros pausados de algunas escopetas, distribuidos a la frente y emboscada de las trincheras; en la noche se oyeron algunas cornetas y alguna grita de los levantados por San Pedro. Este día corrieron las aguas del rio grande de la ciudad, muy turbias e impotables, lodosas por la mucha tierra con que las mezclaban los rebeldes por las cabezadas, mediante la maniobra, de una fanea [sic.] para represar las aguas e inundar la ciudad y de una toma ell que se hallan también empeñados en crecido número, con el designio, según por ahora lo gritan, de extraviarlo y darle su curso distante, por San Sebastián, a distancia de nuestras fuentes para privarnos de las aguas y destrozar a salvo conducto, aguardando emboscados a cuantos por la necesidad pudiesen resolverse a buscarla a tal distancia. La empresa es clara, pero no se indaga cuál sea la intención, mas nos la descubrirán los días venideros. Se fueron prótugos de la ciudad tres o cuatro negros esclavos de los vecinos y / fol.84v. desertaron dos hombres de los de Larecaja en este presente día.

Martes 25 de Septiembre. A las 6 de la mañana nos saludaron los rebeldes con su pedrero y a cosa de las 10, les disparon una y otra vez, y por las trincheras algunas escopetas entre día. A las 5 y media de la tarde se llevaron el pedrero cargado a mula del puesto de Quilliquilli, en que le tenian. Continuaron con la fábrica del nuevo cauce para extravasar el rio o para el proyecto que ignoramos y asimismo con el acarreo del ganado ovejuno que pasaron en manadas crecidas, por la mañana y la tarde. Por la noche hicieron alguna algazara de cometas, grita y escopetas disparadas sin formal acometimiento.

Miércoles 26. Se amaneció en sosiego y los indios siguen con el transporte de los ganados hurtados y aún se dice que con la partición entre ellos. No jugaron el pedrero, ni hubo los concurrentes que siempre lo regulan y que se presentaban en la ceja de Quilliquilli, y entre día tampoco hicieron movimiento. A las 3 de la tarde salió nuestro Comandante con el señor Plata y 200 hombres, más o menos, de fusiles, a una correría fuera de la trinchera, al alto de Santa Bárbara. Los rebeldes se conmovieron y descendieron del alto de Quilliquilti, les hicieron fuego y los ahuyentaron. Tocaron a la retirada que amagaron emprender, siguieron los indios a los nuestros con estrépito y algazara, pero volviendo la media vuelta sobre ellos, los rechazaron por segunda vez. El fuego nuestro fue activo y numeroso / fol.85. Y en todo regulan de 10 a 12 indios muertos, fuera de varios heridos; supónese que todas las inmediaciones de Santa Bárbara constan de infinidad de abujeros y conejeras en que se soterraban ellos, y que las casas quemadas les servian de mucho respaldo y son contrarios a la operación de nuestros fuegos. Se retiraron nuestras gentes con el Comandante a las 5 y media de la tarde y al ejecutarlo, les siguieron algunos rebeldes a distancia. Y estando dentro de la trinchera se pusieron entre las almenas del cementerio de dicha parroquia y dispararon de allí algunos tiros de escopeta, sin 
daño alguno. La acción salió limpia y habemos confirmado que los indios no nos aguardan en la campana, ni resisten a nuestros fusiles bien gobernados, y que estas correrias desde que tenemos a los $100 \mathrm{y}$ tantos saboyanos con sus oficiales, nos han salido sin desastre alguno. $Y$ asi, siente el pueblo que esta correría no se actuase esta mañana, ayer y los días pasados en que los enemigos a nuestra vista han transportado muchas partidas de ganado ovejuno, fácil de abdicación [sic.] a vista de estos ejemplos de dominación sobre ellos para proveeria de estos viveres en la grande necesidad a que hemos vuelto, con alguna mortandad de gentes. La norhe no hubo novedad pero los indios continuaron con la maniobra de la nueva toma de agua junto a nuestro río grande, pero se ignora el motivo o fir de ella (1).

Jueves 27 de Septienbre. Por la mañana anduvieron los indios en movimiento a las 11 y media de ella, se nos presentaron / fol.85v. en la orla del alto y cuesta de Potosí vestidos de españoles, con sables en mano, escopetas y a caballo o mula, unos 150 de ellos, queriendo aparentar eran nuestros auxiliares a cuyo intento initaron las acciones practicadas cuando la venida del sefior Flores, formaron una fila dilatada en la misma ceja, tremolando una bandera en la ceja de la cuesta de Potosí, dispararon los pedreros adentro del campo y nos hicieron creer la vuoita del senor Flores, hasta que bajando algunos por la cuesta de Potosí al crucero sin descender el camino regular a la ciutad sino el que se termina [se dirige] a la de Lima y el Tejar, y a las inmediaciones de Munaypata y campo nuevo del Tupac Amarillo, volvieron a subir de contado [immediatamente] al alto y la cima de Ja cuesta de Lima, siguiendo los indios rebeldes en cordón tupido que ascendían desde el río de la ciudad por olra vereda inmediata con mucha pausa y confianza; por éste y otros ademanes se vino en conocimiento de la ficción y apariencia engañosa $y$ mandó nuestro Comandante cesara el repique extraordinario de campanas que había principiado en las torres de la iglesia catedral y a las 2 y media de la tarde nos presentaron a la vista los dichos a mula e indios a pie, otra fingida refriega (pero más torpe) como la que urdió el tuerto Obaya el 27 del mes de Abril. En lo demás, la noche fue tranguila y sólo se oyeron los fastidiosos sonidos de sus cornetas tañidas a espacio.

Viernes 28 de Septiembre. Salió don / fol.86. Joaquín Salgado, capitán del regimiento de Saboya, con dos oficiales, comandando a los saboyanos, y algunos granaderos nuestros que bien pasarían de 100 hombres, por la trinchera de la Caja

(1) Pasam los díns y los rebeldes siguen haciendo urabajos en las cabezas de los ríos; los vecinos hablan de nuevas tomas de agua junto al rio grande, pero no caen en cuenta para rada sobre cuál es el objelo de estas maniobras. Hacía tan poco que habian oldo los detalles de la construcción dc la "cocha" o represa en Sorata y. sil embargo, en estos momentos en que se practicaba Jo mismo en la región de Achachicala, en La Paz, olvidaron por completo aquel episodio. 
del Agua a las 3 y más de la mañana. El designio era tomar alguno o algunos indios vivos y sorprenderlos para que conducidos pudiesen dar alguna luz de nuestros Auxiliares y disposiciones de los rebeldes. En efecto, se terminó cerro arriba por unos lugares pendientes, penosos y de gran distancia por la capilla del Calvario y de allí marchó al acampamento que tienen formado en el alto de Quilliquilli desde donde nos han batido con los pedreros; el coadjutor Juan Sainz, de la Buena Muerte, (quien le acompañó) tomó prisionero a un cholo de fuerzas y corporatura y le aseguró conjuntamente de don Mañtel Navarre, alférez de dicho regimiento y fueron también aprehendidos, un indio de Yungas y una india de este pueblo de San Pedro con su hijo y una hija, tiernos de edad; mataron uno u otro de los levantados e hirieron a algunos que huyeron al sentirlos, sobresaltados del fuego de los fusiles, a tiempo que estaban durmiendo. Al retirarse a la ciudad $y$ traer a dichos prisioneros, estando los nuestros a distancia, amagaron los indios acometerlos con variedad de injurias y voces, peto sin daño. Condujeron los soldades los pocos víveres que hallaron y aplicaron para su beneficio. El cholo es natural del pueblo de Guaqui, provincia de Pacajes y vivía arraigado en la hacienda del Río Blanco de don Justo Valdés en los Yungas y territorio/fol.86v. de Chulumani de oficio labrador de cocales, llámase Maroelino Montes de Oca, quien a Ios azotes que le dieron primeramente al tiempo de tomarle la confesión (que es la receta común y preliminar para los rebelkies vivos) ratificó en sustancia lo nismo que había confesado anteriormente. Y es que hacia tres días que habian venido de los Yungas transportando una partida de coca que vendió a los amotinados con el fin de regresar a su habitacion con carnes y comestibles, que le habían forzado ellos a su facción y partida, que tomó inevitablemente y por temar de las crueldades del bárbaro Tupac Catari; que entre ellos y por ellos supo que el llamado Andrés Tupac Amaru se ausentó el día Domingo próximo 23 del corriente (según se la vio salir y consta de dicho dia) que se llevó las mejores escopetas y a los cholos de Larecaja, negros y mulatos en su compañía, habiendo dejado gobernando a sut tío y de gobernador al borracho Apaza, quienes todavía terían más de 100 escopetas; que era corriente que el señor Flores se halla combinando con sus tropas en la posta de Panduro, próximo a venir al socorro de esta ciudad y aún dijo, que con 10.000 hombres. Bien que la india dijo que con 9.000, o al contrario (no será tan subido el número, según los designios que llevó). Que los indios de Coroico y Yungas se mantenían acampados en la quebrada de Achachicala y los de Chulumani en Potopoto. Que el Apaza tenía su campamento en Pampajasi que llaman ellos Collana o Machaca- / fol.87. marca y el tío del Tupac Amarillo, arriba de Munaypata a un lado de Tejar, de la cuesta y camino de Lima y que la maniobra de la nueva toma o acequia tenía el objeto de extraer las aguas de su cauce o álveo para privarnos de ellas y sojuzgarnos en su defecto, por dictamen de un cholo de Achacachi de la provincia de Omasuyo llamado Tomás, para regar y sembrar de paso las tierras de las circunferencias fuera de la ciudad. La india que, parece, se retiró al campo enemigo hostigada del hambre, subsistía fabricando y vendiendo el licor de maiz o cuasi cerveza, que llaman chicha, y es el pábulo nutricio de los indios. A ella y al indio de Yungas mandó degollar esta tar de el Comandante y, al cholo Marcelino se le condenó por el 
asesor de Guerra al último suplicio, que se ejecutó esta misma tarde a las 3 más o menos, dejando como está su cuerpo pendiente de la horca que está fija en esta Plaza Mayor. En lo demás, el día y la noche fueron de tranquilidad. Parece que la granada que en una de las roches pasadas arrojaron de esta plaza, por el impulso de un cañón nuestro, hacia el alto de Quilliquilli, cayó allí y mató cinco o siete indios que estaban acampados junto al pabellón o tienda del rebelde Apaza quien a la sazón, estaba ausente, segun lo refiere el dicho Montes de Oca (1).

Sábado 29 de Septiembre. Fue igualmente tranquilo. Parece que los indios han acordado no molestarnos, aunque no son de fiar. Don Pedro Palacios, europeo, salió valerosamente en su caballo tordo a los altos de San Pedro y se encontró con 25 - 30 indios / $601.87 \mathrm{v}$. emboscados que se le presentaron repentinamente solicitando hablarle. Les previno cautelosamente que para ello dejasen sus palos y hondas; lo hicieron así y después de darle razón del Auxilio nuestro que se hallaba en el pueblo de Sicasica, le pidieron se interesara con el senor Flores a quien aguardaban, para que les perdone, y que nada querian con nuestro Comandante, por ver que a todos los indios que habia aprehendido los degollaba. El principal era cl capataz de los de este pueblo de San Pedro, Andrés Flores, con quien el dicho Palacios tenía conocimiento antes de la sedición, quien con los olros, le aseguró que por dicha razón ellos no invadian a la ciudad y que si se habian incorf̧orado con el levantado era porque la mayor parte de los pueblos levantados y venidos de fuera de la ciudad, los habian avasallado y subyugado y los tenían violentados y forzados, de miedo de yue no los maten como to habian hecho con muchísimos que resistieron confederarse con eltos, cuya razón es también sabida desce el principio, y es muy considerable para ejercer a su tiempo con prudencia la piedad y la misericordia. También entró a la ciudaci una indiecita venida del campo enemigo, a quien aprehendieron estando lavando en el río los levantados, y dice, pudo hoy librarse de

(i) Los prisioneros cogidos por el belicoso coadjulor Juan Sainz de la Buena Muerte dan noticias muy confusas de lo que ocurre más allá de la ceja del Alto. Como siempre, se demuestra la. total ignorancia en que viven los sitiados acerca del estado de la rebelión. Desole luego, los caulivos venían desde nor o sur Yungas, y se quedan entre Acliachicala, la zona de Potopoto y el Calvario, de modo que poco podían saber de lo que sucedía en la zona opuesta de Munaypata, el Tejar, la cutesta de Lima y, en general, las provincias del sur y del oeste. De ah́ que las cifras y datos que proporcionan $\mathrm{cn}$ lo referente a hombres. lugares de acampamiento y planes de Flores, son todos inventados o supuestos. Otro tanto ocurre con las noticias. sobre la cocha, cuyo verdadero destino parecen desconocer, no sabemos si por ignorancia o por picardia.

Es de notar el sistema con que se procede con los prisioneros para condenarles. A los dos indios los manda degollar el Comandanle de inmediato, sin nayores preámbulos. Al cholo, en cambio, se lo condena a la horca por medio del asesor de guerra. El cuerpo quedó pendjente de la horca; el ambiente debe baber sido tenso pues se anota: "en lo demás. el día y la noche fueron de tranquilidad". 
su maltrato, la cual coincide con la buena disposición de los indios que refiere dicho Palacios, y la proximidad de nuestros Auxiliares. Por la noche se sintió a ratos alguna grita de los levantados y cometas a las circunferencias de la ciudad (1).

Domingo 30 de Septiembre. Repitió don / fol.88. Pedro Palacios su correría fuera de las trincheras en su caballo que es un bruto famoso y veloz. Confabuló hacia el río con el indio Andrés Flores, quien le repitió en substancia su deseo del perdón y expectativa del arribo del señor Flores con los suyos, que nada querían con nuestro Comandante que a todos pasaba a cuchillo. Le dijo que se ocultaba para hablar con él y no quería ser visto, porque el maldito Catari degüella y mata a azotes a los indios que llegaba a sabet trataban con los españoles, no los matan o no los conducían prisioneros [sic]. El día también fue quieto y no sabemos qué idea o qué fragua será ésta? Porque los indios se han hecho obstinados carniceros, y esta mutación repentina es suspicaz, aunque tenga por principio el pavor de la vuelta próxima del señor Flores; porque los bárbaros hasta el último punto de sus desengaños son tenaces en sus diabólicas opiriones, como lo hemos visto.

Lunes $1^{\circ}$ de Octubre. Fue quieto, salió Palacios por parte de tarde, a caballo, habló con el indio Andrés Flores, cuatro capitanes de a mula y uno de la Puna y los otros de este pueblo de San Pedro, fueron hasta cl número de 30; le manifestó el primero que traiga a sus compañeros sin honda ni palo para hablarles y que no tuviese recelo de ellos y de la buena intención con que deseaban el perdón del señor Flores hasta el número de 500, como eran ellos, y para obtenerlo había de ser su mediador el dicho Palacios. Le repitieron que el Auxilio nucstro estaba de esta parte de Sicasica, esto es / fol. 88v. del pueblo de Sicasica para esta parte de la ciudad, y después que le regalaron queso, plátanos frescos y secos y el día de ayer, pan, se vino y entró. Luego se notó que los indios formaron un pelotón numeroso arriba de San Pedro que será algún conciliábulo o acordata [sic] a consecuencia de lo conferido con el susodicho para sus disposiciones ulteriores. La noche fue de alguna grita y cornetas y desde las 11 y más de la noche, empezaron por los fortines de Santa Bárbara, Riverilla, San Francisco y San Sebastián, y otros, con tiros continuados de escopetas errantes y acompañados de mucha vocinglería pero a distancia y sin acometerlos. Este día empezaron con el escrutinio de víveres pero con muchas extorsiones y violencia de algunos comisionados que nominó el Comandante, de poca cordura, inferida en la pobre gente despojada de sus pocos víveres enteramente; causa dolor el oirlo!.

Martes 2 de Octubre. También fue tranquilo, se oyeron algunos tiros muy ralos de escopeta entre día. Los indios siguen con la aventura de la acequia nueva en forma de fanea [sic.], así a un lado del trabajo tenían fijada una bandera blanca,

(1) Sobre este español, ver nota en la primera parte del Diario acerca de su actuación el día 22 de Mayo. Se recordará que se trataba de un personaje bastante ambiguo. al cual Segurola habría tratado en forma más dura si en lugar de ser un vecino peninsular lo hubiera sido criollo. 
serían los concurrentes de 800 a nil indios, pero hasta el día no sabemos de positivo qué objeto tenga la presa. Salió por la tarde don Pedro Palacios con dos religiosos agustinos, no halío al indio Andrés Flores y confabuló con otros que ratificaban el pensamiento de pedir perdón a nuestro Comandante General, parece / fol.89. ésta alguna trama de los rebeldes porque se percibe alguna variación en sus dichos. Lo que hay es que los indios no son de fiar, mientras no nos entreguen a los caudillos y demás cabezas. Por alguna trincheras hicieron su algazara con tiros de escopetas en esta noche,

Miércoles 3 de Octubre. No hubo novedad, volvió el muchacho del cura, bachiller Machicado, con unos panes y otra carta en que le llaman para llevárselo a la Doctrina, que primeramente sirvió, de Ancoraimes. Don Pedro Palacios continúa con sus correrias a caballo tratando de suavizar a los indios de San Pedro, pero es de temer, le salgan a la cara por alguna prodición [alevosía]; a su ejemplo se han movido a salir hoy algunos, y tratar con los indios. Yo no sé para qué los permiter porque se presiente el espiritu de seducción de los rebeldes para con los nuestros y disminuir nuestras fuerzas, tomarnos descuidados y darnos un asalto nocturno $y$ repentino; y porque volvieron con carne fresca y algunos víveres que les vendieron diciéndoles que no perezcan de hambre en la ciudad, que se salgan al campo enemigo para disfrutar de los alimentos y buen trato que ofrecen, y no hicieron otra cosa que seguir la obra de la toma o acequia de agua aunque no en tanto número como ayer.

Jueves 4 de Octubre. Pusieron los indios un mercado o especie de plaza en la subida arriba de este pueblo de San Pedro, salieron algunos de ambos sexos fuera de / fol. $89 \mathrm{v}$. trincheras y volvieron con los viveres que habian comprado. Con este fin y buen suceso se conmovió la plebe de la ciudad y resolvió salir al mismo efecto de compra para apurar la necesidad y porque los pocos víveres que tenían los han recogido para la Casa de Provisión a beneficio de la soldadesca, dejando algunos sin parte, aún extorsionándolos a uno u otro de los comisionados para el escrutinio de viveres de las casas y tiendas, que por barrios y calles se empezaron a actuar el lunes $1^{\circ}$ del corriente Octubre, con los llantos y conflictos y miserias de estas pobres gentes; estando en el fervor de los tratos de compra en dicha plaza, los rebeldes la iban retirando más arriba o retrocediendo a mayor distancia de la ciudad. Los nuestros, o incautos o urgidos del hambre los seguían y se iban alejando, más cuando de orden de algunos mandones rebeldes que bajaron a mula del campo enemigo de Munaypata, mandaron rodear a todos los que salieron de la ciudad con los amotinados y los condujeron prisioneros a dicho campamento y también al que llaman Collana en Potopoto; entre ellos fueron comprendidos seis granaderos nuestros de los más sobresalientes y un Vásquez alférez de la Compañía, Esprella, Ascarrunz, y un cabo y otro Boza, Eugenio Rojas y además el tambor de ellos, el hijo tierno de doña Ana Parada, de los visibles de esta ciudad; otro el 24 don Juan Calderón, el hijo de Gregorio Ortiz, un monigote que llaman Bobiscum, el clérigo /fol.90. moqueguano don Tadeo Dábola y otros varios niños y mayores en edad de ambos sexos. De suerte que computan, pasan los hombres que se llevaron de 100 
personas. Aunque es verdad que a algunas mujeres dieron libertad y volvieron, el ardid de los indios es el más refinado que puede verse en su barbarie, porque proceden con dos fines, uno es descantillarnos [quebrantar] los hombres, desmembrar las fuerzas y defensa de la ciudad que consiste en ellos, seducirlos y lograr que vuelvan las armas contra nosotros, otro dejar las mujeres que por no contribuir a nuestra tujción no las gradúan opuestas, por ello a sus pérfidas ideas y les dan francatura con las miras de que, regresadas, han de ser concurrentes a consumir nuestros viveres de la ciudad, siendo lo más sensible que con este desengaño y acontecimiento precedido entre 11 y 12 del día de hoy todavía se hubiese permitido la puerta franca de las trincheras para que, con todo lo visto, hubiesen todavia salido por la tarde fuera de trincheras al mismo fin de comprar víveres. De este descuido, son la principal cansa los oficiales de guardia que los consienten o no asisten. Nuestro Comandante, por otra parte, parece estar ya cansado o abrumado de sus reconvenciones para que cumplan con su obligación. $\gamma$ así se le vio en este día que no tomó formal deliberación para el remedio. Dios nos favorezca en tal desorden que trae consternado al pueblo y muy expuesto a su perdición (1). Parece que el clérigo \}uanes / fol.90v vino del campo enemigo donde corre se fue por la necesidad, antes de ayer martes, y que trajo este y otro no sé qué carta que un cholo del campo enemigo se la dio original, cscrita al rebelde, en que le dan parte de una derrota de los suyos, con pérdida de armas y aucha mortandad de sublevados causada por las gentes fieles venidas de la cosla y pueblo de Tacna, Io que no se hace creible, ofreciendo venirse con los demás cholos y las armas de fuego en uno de estos días. Los indios operan con tal astucia, que no quicren dar a los nuestros razón del señor Flores y nuestros Auxiliares y antes se jactan de haberlos derrotado. Así sucedió hoy con un indio y un soldado nuestro que le preguntaba del Auxilio y su paradero hasta que un cholo se le llegó a éste y le dijo: miente, el Auxilio estará aquí pasado mañana y yo estoy rabiando por él para pasarme a la ciudad lo que no puedo conseguir por éstos que ve usted al lado custodiando mi persona. Con esto ya sienten los incomodados con las glorias del señor Flores de

(1) El relato de los pequeños mercados que instalaban los indios en las inmediaciones de San Pedro, estó recogido también en los otros Diarios. Sólo que los demás no hablan de descuido en dejar las puerlas abiertas en los muros, sino que anotan claramente que las abrian para poder acarrear agua del río. Por otra parte. señalan con datos precisos el estado de hambre que padece la población, que se alimenta de cueros y petacas. Los soldados, a quienes siempre se atiende mejor, consumían 4 onzas de carne dín por medio y 8 de chuño en Ios intermedios. Es interesante, en cambio, la interprelación que Diez de Medina da al acarreo bacia el Alto, preferentemente de hombres. No sabemos si sería éste el pensamiento de los caudillos o del Oidor, pero no carece de lógica pensar que a aquéllos les era más fácil e interesaute atraer hombres al campo rebelde seduciéndolos no sólo con los víveres sino también con las ideas de la sublevación, disminuyendo así, por lo denás. las fuerzas detensoras de lá ciudad. Las mujeres. en cambio, consumian los cada día mós escasos alimentos sin contribuir para nada a la defensa. 
que primero vendrán los Auxiliares de la costa que no de dicho señor y su socorro tan decantado como te llaman; ojalá estuvieran aquí ambos que bien los habiamos de menester!

Viernes 5 de Octubre. Amanecimos sin novedad, a las 7 de la mañana repitieron los rebeldes la posesión del mercado de viveres en el mismo lugar que ayer, salieron / fol.91. las mujeres y fueron conduciendo sucesivamente a la ciudad los primeros que fueron comprando y cuando a vista de esto salieron fuera de trincheras muchisimas mujeres, niñas, cholas, e indias tieles de la ciudad, las cercaron los rebeldes que al sonido de un clarín acudían de diferentes partes a toda carrera; a unas las condujeron desde la plaza de San Pedro a dicho mercado (donde habrá media legua de distancia) y a las más las acondicionaron y retuvieron combinadas con las primeras una hora y más de tiempo entro de aquel murmullo que bien contaría de más de 5.000 personas de los nuestros y los levantados alli teniar fija una bandera blanca en ser̃al de paz por el engaño de atraer más gentes; hicieron una grita disforme a tiempo de sorprenderlos y las fueton entresacando y separando en dos clases: la una, de toda mujer de cara blanca, de buen parecer, de buen ropeje, niña o vieja, casada, las que llevaron a lâs 11 y media del día prisioneras al campo enemigo de Munay pata, en que se halla el otro rebelde 'Túpac Amarillo. La otra de indias y las de mal pelaje fucron repudiaclas y las enviaron con libertad a la ciutad donde volvicron, y varias sin la provisićn de viveres a que habían salido y que al bajar a la ciudad se la quilan los rebeldes. Nuestro Comandante en vista del fraude, que igualmente pałfecieron, ayer mandó que no se permitiera salir por las puertas de las trincheras a ninguno de los / fol. 91v. hombres, ni soldados de la ciudad y por eso se remedió el que no saliesen muchos incautos y necios, según sucedió el día de ayer, aunque con todo, salieton algunos saitande la tapia de los paredones en que, o no se libró aquella orden, como se dice, o no estuvieron presentes los oficiales que hacen la guardia en cada una para evitar este inconveniente, los que también fueron comprendidos en esta redada de los amotinados, que computan hasta el numero de 10. El permiso que se libró para que puedan salir las mujeres que quieran fuera de las trincheras, nos trae el justo temor de que aquellas mujeres réprobas y fáciles de seducirse, por la liviandad regular del sexo atraigan a sus maridos, hermanos y allegados que existen en la ciudad o por algunas trazas de los rebeldes o por si mismas y el afecto que éstos las tributan, o porque el cuidado pueda arrebatar a muchos para el fin lícito de obviar algún estupro, ofensas, o violencias de los amotinados en sus mujeres, hijas, herrlanas o parientes, no era mucho que por esto deserten y tengamos esas menos fuerzas en la ciudad y eses-más; vueltos en contrarios, como lo estamos palpando porque el discurso de esas mujeres retiradas de nuestra plaza (como están), esas menos habrắn que consuman víveres, de más de tener aquel efecto perniciosisinto, no es bien adaptable en esto porque a la revancha de la soldadesca alistada, los demás del pueblo y esas mujeres no gozan de / fol.92. reacción pública ni se les acude con la Casa de la Provisión, con alimento alguno: cada cual subsiste para sí y como pueda y cuando no tiene arbitrio se niuere de recesidad como lo vimos en el bloqueo primero y lo estamos en el actual y así es que, con su separación de la ciudad nada se 
adelanta porque no se ha visto tampoco introducir pocos ni muchos viveres en la Casa de la Provisión. Los indios bárbaros se salen con el logro atin de las redes torpes que han maquinado ponernos y si no se procuran los remedios, nosotros mismos nos dejaremos llevar al término de nuestra perdición y desastre (i).

Esta tarde dispuso nuestro Comandante una emboscada en la trinchera y puente de Santa Bárbara y en la de la Riverilla. Mandó llevar los fusiles ocultos y que los saboyanos se disfrasen el traje o imiforme blanco, y salir la tropa sin orden por no ser vista ni presentida de los rebeldes. El caso fue que después de medio dia, recibió dos cartas de los rebeldes, de las cuales corre que la una tiene este rótulo: $A$ mis anados los Criollos; sea el que fuese su contenido, lo que se notó fue que inmediatamente que las recibió y leyó, ordenó la dicha emboscada y se encaminó antes o después de ella, a cosa de las 4 de la tarde al puente de Santa / fol.92v. Bárbara. Allí mandó sacar de la prisión que guardaba en el cuartel a Bartolina Sisa, concubina del rebelde Apaza, sin los grillos que tenía puestos, muy lavada y compuesta de ropajes ajenos y decentes, la hizo poner visible en la tronera del cañón de dicha trinchera, a tiempo que muchos indios rebeldes la esperaban en el alto inmediato de esta parroquja de Santa Bárbara. La distinguieron y conocieron; pasaron algunos a llamar o anoticiar al conjurado caudillo Apaza, vino éste a caballo, con sortuy verde de paño y calzón negro de terciopelo, asociado de varios cholos rebeldes, a mula y con fusiles, y de su secretario o amanuense, que parece nuevo y es un cholo relobado o renegrido, vestido de paño encarnado con su unco o camiseta, que estilan los indios, que no se atrevió a aproximarse a la trinchera y puesto a distancia de una cuadra, parece envió primeramente, de enisarios, dos indios de los rebeldes con recaudo o soljcitación o memoria (réproba)[sic] del dicho Apaza. La india entrasendida [sic], les dijo a estos que ella se hallaba bien atendida y tratada de los españoles, y con decencia sacó y mostró sus pies para que vieran que no tenía prisiones, y les dijo llamasen a Apaza de quier pendía su libertad, y que viniera y que no tenia prisiones; y les dijo llamasen, y viniese, sin recelarse de los españoles, que no procedian con traiciones, como ellos. El rebelde, aconsejado de la maldita sagacidad de los cholos, se indispuso con la llamada, y a gritos decia que /fol.93. no quería bajar, conocier do bien el intento de aprehenderlo (que dio mérito para este caso). Y sólo se repitieron varjos mensajes por medio de la emisión de un indio; éste le trajo pan, maíz tostado, carne, dinero y una talega de coca (que nombra chuspa) del tuso del mismo Apaza, recordándola que si conocín esta prenda. Al fin se

(1) Este comentario, tan propio del Oidor. nos muestra que su extremo misogenisno no pudo ser vencido ni siquiera con la consideración de los horribles padecimientos que sufrian las mujeres, tanto como los hombres. No podía dejar de mirar al sexo femenino en forma despectiva general, sin señalar si se trataba de blancas o indias, criollas o mestizas, como presas "fáciles de seducir por la liviandad regular del sexo". Tales mujercs se hallaban en el campo enemigo, habiendo terminado por ser seducidas por los sublevados, agregándose la circunstancia de que los maridos, hemanos y conocidos de la ciudad la abandonarían por seguirlas; este parece ser el criterio del Oidor. 
retiró Apaza y se malogró el proyecto. Muchos opinan que hubo lugar, tiempo e inmediación para matarlo, si el Comandante hubiera dado la orden de hacer fuego. No se alcanza qué nimia credulidad sea ésta para tropezar tanto, diferir a cada paso a las patrañas de los rebeldes y conferir por si por dichas cartas, a sacar a luz y a la vista de su amasio, a la india Bartolina, evitando aquella impúdica llama que mutuamente (es de presumir) inflame aquellos corazones y deseos de la torpeza. Parece que según se compaginan nuestras cosas y la desgracia con que la eslabonan diariamente, se ha transformado aquí en una metamorfosis la sabiduria, cordura, instrucción y destreza de los españoles con la intrepidez e imbelicidad de los indios, porque estos bárbaros, vemos que trazany que velan, que sutilizan el ingenio y que saler con sus ardides y tramoyas, como lo acreditan las de hoy y ayer. Parece que el cielo nos castiga y nos ciega por nuestras culpas o que a lo menos no nos puede ayudar cuando así le ofendemos con un acto tan público y escandaloso, de mal ejemplo abusivo y pecaminoso de aquella especie de lenocinio, que se ha ejecutado con / fol.93v. indecoro de la potestad real del Rey por querer adaptarla y regirla por un medio inhonesto, indecente y deservicio de Dios Nuestro Señor, conto lo es el de aquellas vistas y correspondencias de obra y de palabra, cuando nadie ignora ser concubina y no mujer, como la misme india lo confiesa sin empacho, y cuando nuestra religión cristiana y en los estados de un Rey tar Católico, santo, edificante y justo, como el que nos deparó la l'rovidencia, no cabe por ningún caso el que se ejecuten bienes de donde se siguen males o, al contrario, y con más estrechura (si pudiera decirse) en un tiempo en que tenemos la muerte a los ojos y que las acciones debieran regirse con el seguro norte del santo temor de Dios y caridad del prójimo para hacernos merecedores de su misericordia para el asiento. El punto es gravísimo, y se deja a la penetración de los teólogos, moralistas, juristas, políticos y timoratos y a todo cristiano, por ser de los pmimeros rudimentos de nuestra sagrada religión, que prohiben los actos deshonestos y ofensivos, ni por mil mundos ni por cuanto hay ni pueda considerarse de interés en él [1\}.

Parece que ya ha salido a luz la pseudo virreina de Guarina, la india Gregoria, hermana del Apaza maldito, la que tuvo hoy la audacia de bajar a mula

(1) Està escena, hermosa e impresionante, tan mal comprendida y comentada por el Oidor, está analizada en detalle en mi Historia de la Rebelión de Tupac Carori en la parte dedicada a Bartolina (página 250). Con sus absurdos moralismos, Diez de Medina minca percibió las notas humanas en los acontecimientos que presenciaba. Por fijarse en detalles jurídicos insignificantes o por enconrar el medio de acusar públicamente a Segurola de algún descuido en el mando de la plaza fuerte, se mostró ciego en su injusticia. Sintiendose intérprete de la cólera de Dios o del juicio supremo del Rey, se olvidó de que los intios eran tiombres y que si cometieron excesos no fueron éstos menores que los de los espatioles. Diez de Medina pretendió dejar estampados para siempre su celo de gobemante, su ecuanimidad como juez, su catolicismo intachable, su corrección imperturbable, en suma, pretendio que nadie dejara de valorar la templanza de sus condiciones. La impresión que dejó para las generaciones posteriores fue exactamente la contraria, 
muy ataviada hasta la Cruz o alto de San Pedro y llamar a las mujeres y aún a los hombres, diciendo: Vénganse, que nada les harán, tendrán qué coner y / fol.94. Ia pasarán bien sin los trabajos qute alli dentro; es la cantinela general que han tomado por costumbre y preliminar de la seducción todos los cholos rebelados de Larecaja que asi o equivalentemente tratan de seducir por todas las trincheras a los nuestros (1).

Sábado 6 de Octubre. Se permitió salir fuera de éstas a cuanta mujer quiso y sucedió lo mismo que ayer en el mercado aparente de rebeldes, conduciendo a las entresacadas prisioneras al campo enemigo y dejando en libertad a las desechas. Lo que tiene irritado al pueblo, al ver que se repite el daño por falta de remedio y porque parece considerarse propicio a la ciudad, cuando es tan riesgoso y nocivo como se dijo. O cuando no fuera más que evitar las ofensas de Dios, pues los sublevados eligen a las de buen parecer, era motivo supremo y muy obligatorio para celar y no permitirlo. Esta mañana antes del mediodía, corre, entró a la ciudad un indio de Chirca en los Yungas, con carta de algunos indios para el Comandante, ofreciendo la cabeza del Apaza y demás cabezas y exporiendo lo que ellos recelaban, eta no ser perdonados después de entregarlas; se les ofreció el perdón y se les despachó con carta respuesta que la porteó dicho indio; pero la desgracia es que mucho ha precedido para creerles hoy sus promesas falsas y de necedad, pues han faltado tantas veces a ellas. También se vinieron del campo enemigo / fol $94 \mathrm{v}$. algunas mujeres de las desechadas y algunos muchachos que dan diferentes razones: Uno dice que las tropas del señor Flores tenían cercados a los rebeldes que fueron a combatir más allá de Panduro y que el jueves 4 del corriente por la tarde, llegó un correo y detrás otro, con carta y noticia del suceso, al tío de Tupac Amarillo, pidiéndole auxilio, y que el viemes siguiente, a la oración, fueron destacados 400 indios de los de Collana. Es noticia de nin̄os que se junta a ver su fundamento en lo ulterior porque no es creible que los indios arrostren al señor Flores cuando viene con mayores tropas, como se debe suponer, y están bien escarmentados con las inferiores que trajo anteriormente. Hoy mandó sacar fusiles encubiertos, nuestro Comandante, para la trinchera de la Riverilla, y mandó se tuviese mucho cuidado a tiempo que algunos indios se pusiesen a bailar en rueda hacia la chacarilla del señor Medina para salirle al punto (2). Seria alguna senal que le previnieron los rebeldes para algún prometido que no cumplieron. También parece se le notició por un cholo

(1) Esta es la segunda vez, en el Diario del segundo cerco, en que Gregoria Apaza aparece oficialnente. Sabemos, sin embargo, de muchísinas actuaciones suyas durante ese tiempo por la correspondencia jndígena y por las declaraciones de los presos de Peñas (AGI. Buenos Aires 319). En esas actuaciones, Gregoria es la verdadera virreina que porle paz, apacigua resquemores y recelos y relaciona con prudencia y sabiduría los dos campos. el quechua y el aymara.

(2) El autor se refiere a su propia chacarilla, pero vuelve a emplear un lenguaje indirecto como lo hacía corrientemente en el primer Diario. 
del campo rebelde que desde esta noche nos combatían los enemigos, tres consecutivas, y no parecieron, ni hubo novedad.

Doningo 7 de Octubre. No hubo particular ocurrencia a excepción del desorden formidable y comercio de mujeres, cholas e indias, unas que por suelta de los / fol.95. enemigos se restituían a la ciudad, otras que salían, iban y venían en solicitud de viveres, o a la verdad, desengaños y maldades de los rebeldes. Lo que tuvieron la abusiva elección de ellas en su campo con permiso del Tupac Amaru inícuo en que según nos lo dicen las que han vuelto y unos muchachos o niños que lograron profugar de entre ellos para la ciudad, por quienes se dice que ayer ahorcaron y balearon dos indios por haber traído unas cartas del señor Flores para la ciudad y que los castigó con él en la frente el dicho Tupac Annart, o caudillo hoy existente. Sigue la necesidad con más apuros que en el primer bloqueo, por haber caducado aún aquellos rezagos de algunas especies que después de él habían quedado; a proporción, son muchas las gentes que van muriendo por falta de alimentos de los pocos que quedaron existentes y en cada minuto se clama por la breve tomavuelta del señor Flores, cuya detención la atribuimos a algún contratiempo grave, a las contingencias que para caminar en Indias son muchas y muy regulares. Por otra parte las casas entro de trincheras, de los pobres vecinos, se destechan a toda prisa para el uso urgente y beneficio de la pólvora pero con el desconsuclo, llantos y gemidos de las gentes que consteman, y angustian no poco el corazón porque ni les yagan el valor de sus casas deshechas, puertas y ventanas, ni ain siquiera se actúa el avalúo preliminar de ellas para reservar la satisfacción a su tiempo, sin que ninguno halle remedio ni recurso / fol.95v. alguno por el espiritu de dominación con que se expiden las cosas, los oprimen y extorsionan; de modo que, si se tiene la incursión o guerra de los rebeldes, acá entro de la ciudad la tienen también estos pobres vasallos maltratados con aspereza, rigor y menosprecio, en un tiempo tan critico en que, por sus perjuicios y ruinas, se hacen acreedores en sus conflictos, miserias y exentos de toda humana compasión y la caridad que resplandece en el real ánimo de Su Majestad y debiera servir de ejemplo para la imitación (v).

Lunes 8 de Octubre. Entró un indio viejo de Ambaná con su bastón, por la manana, y con dos cartas, una para nuestro Comandante y otra para el Ilustrísimo Señor Obispo, escrita por otra tercera entidad y por Miguel Tupac Amaru Inga, que ahora ha resollado, quien decía ser hermano del Tupac Amarillo (Andrés, retirado a la provincia de Azángaro); la escrita a su Ilustrísima se transcribe y es regular conviene con la del primero, y se explica audazmente en esta forma: Muy venerado Señor de mis rendidas atenciones: habiéndome propuesto el religioso (esto es, el padre Vizcarra, agustino, que de oftcio les amonestó a pedir perdón) a proponerme

(1) Todo ese caos, narrado esta vez con espontaneidad, nos hace ver el desorden, la inacción y la incertidumbre que se vivía en los dos sectores en guerra por aquellos días de indecisión y falta de noticias precisas y verídicas. 
las paces que deseo a fin de precaver las malas consecuencias que de las continuas guerras se experimentan hasta el día, así crecida mortandad de los naturales como /fol. 96. de los españoles, que tanto he sentido, avengo a elias, para lo que suplico a la atención de su Señoría Ilustrísima interponga su respeto a fin de que se verifiquen éstas, con tal de que saliendo el Comandante y demás jefes y cabezas que gobiernan esas milicias se traten con hermandad y amor que requieren las presentes circunstancias. Yo confieso igualmente a Vuestra Señoría Ilustrísima que el estrago que ha experimentado la ciudad y la mortendad de sus moradores me ha sido tan sensible que no tengo labios para poderlo explicar, cuya lástima me puso en precisión de ponerme en camino desde tan lejanas tierras a corregir el mal gobierno, pues si desde los principios hubiera estado en este campamento, no se hubiesen experimentado tan lamentables acaeelmientos. Esto supuesto, Vuestra Señoría Ilustrísima, como cabeza y príncipe de la Iglesia, disponga aquello que fuere más agradable al servicio del Rey Nuestro Señor, $y$ bien de esa república, pues mi ánimo se encamina únicamente al beneficio de los criollos y poner remedio al mal gobierno. Nuestro Señor guarde la apreciable satud de Vuestra Señoría Ilustrísima, con aumento de mayores dignidades, como yo to deseo. Tejar, 8 de Octubre de 1781. Beso la mano de Vuestra Señoría Hustrísima.- Miguel Tupac Amaru Inga.- Ylustrísimo Señor Doctor Don Gregorio Francisco de Campos 11 ./ fol.96v.

Con esta astucia de cartas piensan los rebeldes contar con el mismo intento de Sorata y asesinar a nuestro Comandante y demás que le acompañan, como sucedió con Don José Pinedo y Don Gregorio Santalla. La gran penetración de Su Iłustrísima conoció el fraude y veneno y repudió contestar a tal contenido insolente y pérfido. Pero nuestro Comandante, pensando aprehender a este caudillo y otras cabezas de su sociedad, lo hizo, y con la respuesta mandó salir a un indio que vino de Ambaná. Y por la tarde dispuso salir a la trinchera de San Sebastián, por la parte interior, con 200 hombres armados y 8 de a mula. Los rebeldes se apostaron en grupos en diferentes morros y altos de San Sebastián y en el de Munaypata, en multitud, con una bandera blanca fijada en uno más próximo a la ciudad y barrio de San Sebastián; enviaron sus emisarios de a caballo, bajaron después con la bandera y unos se llegaron a la trinchera a llamar y que saliera fuera de ella el Comandante (rara altaneria!) quien justamente se negó. Don Manuel Franco había también salido, y parece les dijo que para perdonarlos y tratarlos con benignidad era menester que entregasen los caudillos y demás cabezas lo cual, entendido por ellos, que comprendieron que se frustró la producción que traían tramada, dio / fol.97. mérito para que descubriesen la emboscada que tenían dispuesta y que nos hiriesen con efecto de fuego con sus escopetas de entre las casas quemadas de la plazuela de San

(1) Estas cartas, compiladas por Segurola, con los $n^{\circ} 29$ y 30 en la publicacion de su Diario hecha por Ballivián y Roxas, demuestran claramente que, estando ya a pmito de producirse la llegada de Reseguín, se desconoce lo que acontece fuera de la ciudad. Las cartas escritas por Flores y Reseguin fueron abundantes, pero, como se aprecia en el mismo Diario, se perdían, no llegaban o eran interceptadas por los indios. 
Sebastián y calle Ancha y que consecutivamente, nos batiesen con un pedrero la ciudad desde el alto de Quilliquilli a pausas; y hasta las 7 y media de la noche dispararon sus escopetas por las circunsferencias de la ciudad y las fueron disparando el resto de la tarde y noche con algazara de voces, clarines, tambores y cornetas, en algunos espacios de ella pero sin daño nuestro.

En la madrugada volvieron del campo enemigo varias mujeres que con pretexto del mercado de víveres nos intersepararon. Se quedaron muchas en el campo rebelde por no perecer en la ciudad, pues tuvieron salvo conducto para venirse o quedarse, menos las de buen parecer que se hallan custodiadas por los que las eligieron. $Y$ es corriente que de los que nos aprehendieron con dicho engaño fueron alistados y acuartelados hasta el número de 120 hombres capaces de tonnar las armas, fuera de niños y muchachos, de negros y negras esclavos de la ciudad, que se nos huyen por liberarse; y las maldades que diariamente cometen en un rúmero crecido (t). Fue providencia del Cielo que la ciudad no quedase exhausta de cstas gentes incatutas puesto que la necesidad de las hambres estrechaba y estrecha cuanto no es posible, una vez que ni cueros ni mulas/fol.97v. ni perros se hallan ya para comer.

Martes 9 de Octubre. Ananecieron los sublevados con sus pedreros y escopetas que nos disparaban a menudo y así siguieron el día y la tarde; nos mataron de una bala a uma negra esclava que salió por agua y una muchacha tierna de edad, hacia la botica de Bejarano que quedó muerta en el mismo acto. La noche no hubo mayor novedad. Por la mañana entró o se nos vino ur moto llamado Juan y por la tarde otro criado del eclesiástico don Pedro Lino; ambos confrontan que por Araca y por Río Abajo vieneu nuestros auxilios y que el Apaza estaría rruy conmovido forzado a destinar indios para resistílos y que envib cierto número a los Yungas receloso de que allí se hallen los españoles, con orden de arrostrarlos y que en caso necesario se le avise para pasar en persona.

Miércoles 10 de Octubre. Antes del amanecer vinieron del campo enemigo ocho hombres de los que se hallaron en el sítio de Sorata y después entraron dos más de los mismos y todos con escopetas y algunos con dos, y así son 13 ellas, con dos esmeriles y un pa: de pistolas más. Fue el principal de ellos Miguel Martínez Chuquicallata, natural de Azángaro, sobrino del cacique Chuquihuanca (a quien persiguió el conspirado de / fol.98. Tungasuca José Gabriel Tupac Amaru); éste fue electo gobernador de armas por el Miguel Tupac Amaru (supuesto) y de su

(1) En estas frases hay tales complicaciones de lenguaje que se comprende de inmediato que no son sino la consecuencia del trabajo descuidado del copista. Se ha procurado, en lo posible. hacerlas legibles al lector. 
confianza. Hasta de su teniente Pablo Monroy, del pueblo de Moho en esta diócesis, quien vino en su compaña con los otros; tuvieron la sagacidad de imponer combate nocturno a dicho caudillo y así lograron retirarse a la ciudad y hacerlo con algunas llaves y tornilios de las otras escopetas que quedaron en el campo enemigo y no pudieron traerlas. Por la razón coincidente que traen en especial los dos citados, parece que el conjurado Miguel tuvo razón de que el domingo 7, día del Rosario de Maŕa, entró el señor Flores con sus tropas en el pueblo de Sicasica que con efecto venia otro trozo por Yaco, Araca y el Río Abajo. Que tambićn sentaban que venía otro trozo de gentes de la costa y otro por Carangas (lo que el tiempo nos lo dirá) que por eso estaba el rebelde albbrotado y dispuesto a retirarse a los cerros de las Peñas o Suriiguina, donde partía a fortificarse por hoy y esta noche. Que se llama Miguel Bastidas (a quien vieron en esta ciudad como viajante y expendedor de aguardientes) y no Tupac Amaru, como se simula, por haber sido criado doméstico de Diego Tupac Amaru, que existe en Azángaro, tín del Andrés en cuya compañía vino. Que el primero no sabe leer, firmar ni escribir y que le sirve de amanuense y /fol.98v. confidente un Cuentas, medio pariente del cura de Caquingora. Que al Andrés, su socio, le sirve en igual ejercicio Valentín Gemi, quien le sigutió, y al rebelde Apaza, un reo criminoso de: muerte que profugó de esta ciudad y fábrica de la pólvora durante el sitio actual, apellidado Miranda, alias Tumbito, quien es sabedor del Diego Tupac Amaru, del oro y caudates hurtados en Sorata y demás lugares; dio la orden al Andrés que no lo condujera (como le previno) a Azángaro sino a las misiones de los religiosos franciscanos de Apolobamba de este Obisparto donde, por él, los internaron sus confidentes. Que los rebeldes enviaron casi 2.000 indios a resistir al señor Flores, comandados de un indio (supuesto coronel) juan de Dios Mullupuraca, quien vino con ellos desde Azángaro. A quien derrotaron en el cerro de Berenguela y le ganaron los nuestros los fusiles que llevaron los suyos con cierta mortandad de indios, por lo que pudo huir al pueblo de Yaco de la provincia de Sicasica, del que salió fugitivo e igualmente derrotado por los españoles el 5 del corriente Octubre y se vino por el pueblo y asiento de Araca, Río Abajo de esta ciudad y llegó desacarreado ante ayer 8 del mismo con noticia que trajo de su derrota a los caudilios conjurados, que al señor Flores, es siniestro [falso], que los rebeides le hubiesen hurtado las mulas de su campamento / fol.99. como se sentó en días pasados y que antes parece tuvo la fatiga de trasladarse en persona a la ciudad de La Plata por las tropas que allí dejó y conducir mulas y otras gentes más, y es lo que se considera la causa de su dilación para su vuelta. Que el perverso Catari proyectaba hacerse fuerte en las serranias de Pampajasi, que ellos Ilaman Collana, con el designio (ambos) de que retirados nuestros auxiliares tendrán arbítrio de repetir el bloqueo de esta ciudad. También aseguran que los levantados quitaron la vida a balazos al pobre don Bernardo Gallo y a don Miguel Eisgua, ahora más de 16 días (1).

(1) Se puede percibir, por las últimas páginas del Diario del Oidor, que en la ciudad prevalece un grave desconocimiento de lo que pasa fuera de los muros, así cono de quiénes son los 
Por la tarde, ordenó el Comandate una correría a Potopoto y campo de Catari, comandada del capitán de ejército don Joaquín Salgado. Llegaron al pabellón de aquel maldito, quien huyó con anticipación de los nuestros. Los indios (intinidados) con el auxilio próximo del señor Flores también le siguieron cobardes. Aprehendieron un indio vivo de Atacallani; mataron muchas mujeres, indios, párbulos y aún corre, a una chola que, sentada, ocultaba su cara. Volvieron con 60 borregos vivos, algunas carnes y comestibles y con mulas y burros que encontraron los nuestros en el campo de Potopoto. Con que tienen ya los pobres algunas cames. Al medio dia levantaron los pabellones y acampamento del alto de Munaypata (junto al Tejar) y se fueron retirando los /fol.99v. indios por la cuesta de Laja y, es regular, lo iban siguiendo al rebeide Miguel Bastidas, que se siente se retiró a las reñas; la noche fuc de silencio.

Jueves 11 de Octubre. Tambien lo fue de calma, algunos indios raros o centinelas se repararon en las cejas de los cerros. El Comandante hizo degollar al indio vivo que ayer trajeron preso. Por la noche se oyeron algunas cometas de los indios.

Viemes 12 de Octubre. Siguieron los rebeldes retirados; algunos andaban por la mañana por los bajos del pueblo de San Pedro y nos mataron cinco personas entre hombres y mujeres que? salieron fucra de trincheras al campamento por leña, en la confianza de que se hubiesen desaparecido enteramente. A las 10 y media de la noche se sintió por el cauce del río que bañaba por el centro de esta ciudad (y hoy con la ruina se puede decir que está fuera de muros) un susurro irregular o estruendo de aguas que bajaron como unos montes causando el temblor de la tierra y edificios y el estrago no sólo de las incendiadas que estaban al borde de él, sino también de los que se precipitaron por la combustión, por tener su situación entre las trincheras de la ciudad, y terminar por sus interiores al brocal del río. Fue tan abundante la imundación, que no sólo llevó la Caja, y su álveo (cual no se vio jamás / fol.100. aśn en el incremento mayor del tiempo de aguas) sino que rebalsó los puentes de San Sebastián, las Recogidas y San Francisco. Este lo deshizo y destruyó enteramente desde los cimjentos, sin dejar cuasi vestigios por el choque de las piedras de extraordinaria magnitud que traían arrebatadas las aguas y porque con motivo de la excavación que se hizo en él para el trazo y situación de la trinchera o

verdaderos caudillos; se ignora, por ejemplo, quién es realmente Miguei Bastidas o qué papel ticne Juan de Dios Mullupuraca: no se menciona para nada a Quispe el Mayor; no se saben las direcciones de los posibles alaques ni los planes de defensa de las regiones de Sicasica y de los valles del Oriente de aquellas provincias, asi como las relaciones que mantienen los indigenas de aquellos lugares con los de Araca, Río Abajo y La Paz. A pesar de todo, es fácil apreciar que en la ciudad existe ta convicción de que quien decididamente está dispuesto a llevar las cosas hasta el final es Tupac Catari, el cual junta a sus ayntaras y organiza el atoque tanto por la rula de Oruro y Sicasica como por las zonas sur orientales de La Paz, mientras el sector de los Amaru no piensa sino en la retirada y concentración en Peñas. 
promontorio que se le cargó de todo y piedras, se hallaba sin solidez, con que fue construído, y por rendido con dicha carga de la fortaleza. Robaron las aguas mucha parte de la plazuela de San Francisco, la que estando con una elevación de más de 30 varas de longitud desde el cauce, fue inundada de las mismas aguas. $Y$ así sucedió que en las casas de altos, del regidor (difunto) don José Valdés, y en las inmediatas de Don Joaquín Vea Murguía (quien falleció epidémico en este sitio) se introdujeron al primer golpe las aguas por las ventanas y consecutivamente asolaron aquellos lienzos y edifidos inmediatos que servían de ante mural, causando el exterminio de ellos que se desaparecieron en un momento con muchos bienes, plata labrada, vestuarios y homenajes en las casas dichas; en las puertas del prebendado Doctor Juan Tomás Cajal, contigua a dicho puente, y la dél eclesiástico Domingo Solaya, quedando en pie los extremos que tocan a la calle y parte de la ciudad y los colate/ fol.100v. rales de ambos. Siendo también sensible que se desaparecieron de los altos de dicho Vea Murguía, don Manuel Delgado, una negra esclava de la viuda y dos criados (quienes se hallaban en aquellas viviendas); los arrebató de improviso esta avenida. El puente de San Sebastián quedó maltratado y por una parte sín fundamentos y todos tres sin el tajamar y si no se refaccionan con anticipación es regular se desplome a las primeras aguas del invierno próximo o en otro tracaso semejante. El de las Recogidas quedó sin el tajamar pero cubierto de mucha carga de cascajo y arena, en términos que hoy cubte el rio tocando en la misma cornisa, el cual también necesita de pronta refacción porque de lo contrario se quedará la ciudad sin comunicación ni entrada de víveres, comercio, giro y correspondencia en el invierno, como que las avenidas de él son, entonces, muy cuantiosas y hacen el río intransitable por sulrapidez, multitud de aguas y peligro manifiesfo. Este daño y el exterminio de muchas casas incendiadas que como acjuellas estaban junto al río (y pudieran haberse repuesto, y techado a menos costo) pues el sitio de ellas está hecho playa, nos han ocasionado los indios rebeldes con la cocha maldita o represa de aguas que supimos, y se inscribió arriba, haber actuado en las cabezadas del mismo río arriba; a distancia de una legua de la ciudad (según opinión comúr) fueron estancando las aguas / fol.101. y su curso cuasi en el todo por la maniobra que observan los mineros de Larecaja $[1\}$. Decantaron ellos mismos que habían de anegar y

(1) Como en pocas ocasiones, el Oidor, despojado de sus tonos grandilocuentes de otras veces. hace una descripción vigorosa de la catástrofe del 12 de Octubre de 1781, cuando revienta la cocha. Entre las narraciones que traen los Diarios civiles y militares, correspondientes a aquel día, la de Diez de Medina es la más gráfica; sin caer en desmesuras históricas, va describiendo el avance de esas murallas de agua, la destrucción de los puentes, el arrancar de ventanas que saltan por el aire, lievando tras de sí a los moradores de las casas que dan al tío, el espanto de los pobres empleados y esclavos negros de aquellas casas que son precipitadas a las aguas junto a los muebles y vajitlas de plata de esas casonas que Diez de Medina ubica perfectamente como pertenecientes a gente amiga suya o difunta en el transcurso del cerco.

El tema de la cochá de La Paz guarda relación con un hecho realmente misterioso en el desarrollo de la historia de la ciudad. Cuando los indios rebeldes la construyeron, entre 
destruir la ciudad por muchos días y muy repetidas veces y en la ciudad se mantuvieron incréculos, despreciando por vanas aquellas amenazas y cualquier proyecto suyo, sin tomar por ello las diligencias de evitarlas, o de la precaución y ni aún de siquiera averiguar la calidad de la operación, para, según ella, tomar las medidas y cautelarlas, hasta que el mismo estrago despertó el conocimiento y la razón. A semejanza del mismo desprecio con que desde los principios de la sedición presente se miraron los preparativos y acciones pérfidas de los indios y el nacimiento de su operación en el pueblo de Sicasica e inmediaciones de la ciudad; se ha constemado demasiado con estos desastres y teme justamente que si se repite la misma represa del río con alguna más dilatación de dias, sean mayores los montes de agua, y que dilaten la inundación de los edificios internados entre las trincheras, por lo cual, y por considerar que cada día crecen las ruinas, ro haya habitante ni vecino que no piense abandonarla y abandonar sus casas de haciendas, dejando despoblada y sin concurrentes, que seria la mayor lástima, d porque estos desgraciados vasallos quedarán entonces perdidos y los más por puertas y al perecer, o porque siendo ésta después de la de Lima / fol. $101 \mathrm{v}$, de las ciudades más espléndidas del reino, de mucho brillo y muy vasto comercio, se depauperará el Estado, y el Rey llegará a perder una de las más opulentas, cuantiosas y entimables que tiene en el Perú, por cuyos términos de conflicto y angustias sólo el brazo poderoso de Su Majestad y su real piedad con el término de la esperanza para el remedio y consuelo de un pueblo así angustiado para que mediante el celo y compasiva corazón del Excelentísimo Señor Virrey de Buenos Aires, se tomen las providencias más oportunas y convenientes a evitar semejantes daños y auxiliarlas de tropa fija que contengan los excesos desmedidos de los indios rebeldes.

Sábado 13 de Octubre. Salieron algunas pobres gentes por leña y hierbas al campo y fueron sorprendtdas de los indios, quienes mataron hasta 14 de ellas; las más del otro sexo. En dias pasados salvaban a las mujeres y ahora se ve lo contrario; constancia propia de bárbaros. Y corre sorda e infundadamente haber igualmente muerto a 81 mujeres de las que aprisionaron y retuvieron eon el engaño de la plaza de víveres. También salí a cazar vizcachas o cuasi liebres el coadjutor Juan Saenz de la Buena Muerte con un granadero (según corre), por Santa Bárbara y es efectivo que le aprehendieron los indios / fol.102, levantados en emboscada y se Io llevaron, cuando lo ansiaban mucho; ya se infiere lo que habrá sido de su desgraciada suerte!.

Septiembre y Octubre, los vecinos se hicieron mil preguntas respecto a su objetivo y realmente no cayeron en cuenta de que se repetía la historia de lo sucedido en Sorata. Después, con el transcurso de los acontecimtegtos, sólo quedó en la mente de los vecinos el caso de la represa de Sorala y se fue olvidando la existencia de la de La Paz. Hoy en dia es raro que algún texto le dedique atenclón, en circunstancias de que evidentemente ésta fue macho más grave que la de Sorata. 
Por la tarde se practicó una correría de los saboyanos, compañía de forasteros y la de granaderos a Potopoto. Los indios se ahuyentaron a distancia y no hubo cosa considerable; gritaban sí, haber muerto al dicho coadjutor Saenz. Trajeron una vaca lechera con su cría; la noche no hubo novedad (1).

Domingo 14 de Octubre. Tampoco la hubo y considerando el arribo de nuestros Auxiliares se destacaron 400 hombres a San Pedro para aprehender y castigar a los rebeldes que de tos altos pueden escurrirse fugitivos a la vista o inmediación de ellos según lo sentó el público.

Lunes 15 de Octubre. No hubo movimiento; los indios siguen desaparecidos hoy más que nunca y por lo propio recitan en la ciudad que están en alguna maniobra de iniquidad o habilitando la nueva coch o represa de agua parn inundar la ciudad y aún se dice vagamente, que la tienen dispuesta paro arrojarla por los cerros del Calvario y Quilliquilli que dominan con mucha altura la ciudad. Por otra parte, con la detención del socorro del señor Flores y la extrema penuria de víveres y /fol.102v. mortandad de gentes, todos los más habitantes se hallan muy patéticos, confirmando sus propósitos de desamparar la ciudad con la verida de nuestros auxiljares. Los que gobiernan publican dejarla y retirarse el domingo próximo o lunes inmediato caso de que no se verifique su arribo. Las monjas y las del otro sexo, se hallan por esto anegadas en un continuado llanto, llenas de confusión y dolores. Y la ciudad por lo mismo crece en sus pesares, cuidados y sobresaltos. Cuánto mejor fuera pensar en no perder la ciudad, y marchar a la campaña por víveres y los corderos que en días pasados han acopiado en su campo los enemigos, para que así se repare este último desastre y sirviese al Rcy como conviene! (2). Por ser obvio que en las últimas correrías desde que tenemos los 120 hombres saboyanos, tucumanos y chuquisaqueños, hemos quedado dominantes y dueños del campo en cuantas correrias se actuaron durante este segundo bloqueo, y los enemigos rechazados y ahuyentados, con lo cual se pone en claro que achuada una expedición completa y arreglada con todas las fuerzas de la ciudad, no sería difícil socorrerla de víveres para aguardar a nuestros Auxiliares, sin pensar en tal abandono (proyectado desde los principios y medios) que fuera perjudicial al Estado

(1) Si anteriormente los rebeldes habian buscado con saña a Bernardo Gallo, el Administrador de Aduanas, por suponerle culpable de las medidas que fueron tomadas. en réalidad, por el Visitador Areche, bien puede calcularse el encono con que se pretendía coger al coadjutor de la Buena Muerte, cuyas feroces persecuciones y castigos constaban en todos los de La Paz, dentro y fuera de los muros. Sus hazañas en este sentido constituían casi jalones deportivos que, mirados con espanto si hubieran sido cometidos por cualquiera de los habitantes de la ciudad, escandalizaban mucho más si se veia y se proclanaba que quien las efeculuba era un sacerdote de una institución destinada a auxiliar religiosa y médicamente a los que morian.

(2) ¿A qué otro sexo se referirá el Oidor con tan cxıraña reflexión?. 
y de servicios de Dios y del Rey (1); y así muchos vasalios / fol.103. cuentan aguardar la muerte en sus camas y casas y no exponerse al riesgo próximo de morir y marchar a pie, sin abrigo y al rigor de los tiempos e inclemencias de la campana exhausta de ganados y alimentos que los rebeldes han tenido la cautela de retirarlos de los caminos del tránsito("). El caso es que no les duelen prendas y que en la ciudad no tienen qué perder y parece la miran con la neutralidad que dicen estas prevenciones.

Martes 16 de Octubre. Salieron al aito y cuesta de Potosí don Pedro Palacios $y$ don Juan Salinas, quien también es animoso notoriamente, a ver si asomaban nuestros Auxiliares. Estuvieron en la cima a las 11 y media del día; el primero se fue hasta el alto de Achocalla a distancia de tres leguas, allí se encontró con un vizcaíno Mendieta, venido de la villa de Potosi, un mozo de ésta, Carlos Quirquincho, y un Crespo que trae harinas. Son parte de los Auxiliares que anticiparon con aquétlos a la ciudad a la una del día y dan razón de que venian en la expedición de 8 a 10.000 hombres y víveres al comando de don José Reseguín, Teniente Coronel de Ejército, por haber quedado enfermo en la villa de Oruro el Comandante General don Ignacio Flores, de resultas del viaje que tuvo que emprender a la villa de / fol.103v. Potosít ciudad de la I'lata, y aún a Mizque, según se dice, por tal de surtir la expedición, como debe venur y viene; se conocen sus fatigas, trabajos, empeños, y desvelos por el real servicio y bien del gobiemo. Y es cierto que la ciudad estaba en el último punto de la necesidad cuando Dios Nuestro Señor haciendo ostentación de su misericordia por intercesión de Maria Santisima Señora Nuestra, (cuya novena del rosario termina este día) así nos consuele y redime segunda vez del cuchillo y furor bárbaro de los indios y de la indigencia; pues en este mismo día entraron las harinas de dicho Crespo con que han empezado a socorrerse los de La Paz, míseros, perseguidos aún intestinamente de la dominación que les oprime, perdidos, sin bienes, rentas ní haciendas, cuyas calamidades parece no se meditan cuando nuestro Comandante mandó que el dueño las vendiese al precio que pudiese y quisiese inhibiendo al Cabildo que había puesto la talla de 20 pesos por fanega qque es exorbitante, pues lo corriente era de seis a siete pesos por cada una) y mandó intimár al alcalde ordinario Don Francisco de Oquendo y al fiel ejecutor, por medio de don Protasio Armentia y de don Antonio Bilbao, sus edecanes, que pues él estaba encargado de la ciudad sobresellasen ambos diputados de mezclarse en la tasa de arancel del abasto, y así viendo que el Crespo vende a razón de / fol.104. 34 pesos la fanega y aún corre que a razón de cuatro reales libra que sale entonces por más de 90 pesos, es regular que a este paso pocos coman el pan, porque sin rentas ni entradas, sin giro, ni comercio, y con tantos daños crecidos se hace insoportable aquel precio tan supremo. Triste y

(1) Ni aún en las últimas anotaciones pnede Diez de Medina dęar en paz a Segurola, señalándole él, un connotado abogado, sus deberes al defensor de la plaza, excelente militar formado en la propia Península. Erróneo habría sido salir de los muros en esos momentos en que se sentía el final tan próximo del cerco, cuando los atacantes desaparecían de día en día dirigiéndose a Yungas o a Peñas en requerimiento de sus caudillos. 
desgraciada ciudad de La Paz, tus ecos, tu Hanto, tus gemidos y dolor reconcentrado; ya zes los escucha el cielo piadoso pues hoy re auxilia! Firmas vuestros alientos yllows tus culpas que son la causa de tus males para atie asi scas fortalecida y algun da recinas cl galndon $y$ satisfacciones de tu constancia, fidelidad y amor al Rey y a la Patriat

Miércoles 17 de Octubre. A las 12 del medio día se presentaron nuestros Auxiliares, en cordón, en la ceja de los altos de la ciudad, cuyo acto se celebró con repique general de campanas y salva de cañones, lo mismo que la vez pasada, aunque no se ve aquel regocjjo que entonces acreditaron las gentes. Así, por lo subido en que ayer pusieron los precios de harimas, hallándose muy pobre la ciudad, sin entradas, como porque se dice minó la vaga especie de que el señor don José Reseguín, Teniente General del Ejército y Comisionado en segundo lugar por el Gobierno de Armas por su Excelencia, quien viene con el comando de la expedición, por haberse quedado en Orturo el señor Flores, por justas causas de subvenir al mejor logro de ésta, traía la determinación de levantar su / fol.104v. canpamento $y$ retirarse al Collazo el 8 de Noviembre próxino. Con cuya nuticia este caballero ha hecho ver sus intenciones de no desamparar La Paz, sin radicar la subortinación de los indios y lograr su pacificación, salvo si los cochabambinos que son muy rotables o inconstantes, sin obediencia, razón ni temor a Dios quieran practicar lo mismo que en el socorro anterior, de desertar sucesivamente a su arbitrio y hostigar al jefe a hacerlo, dejando la ciudad en los conflictos del nuevo sitio frustrado, el objeto importantísimo del Real Servicio e inutilizadas las crecidas expensas de la Real Hacienda y desvelos de su Excelencia el Schor Virrey. Bien que ya conre entre los sensatos, ser muy contrarios los designios con que viene el nuevo jefe, de afianzar la obediencia en estas provincias primero que seguir adelante. Entraron hoy muchos viveres y harinas que se venden a razón de 24 pesos la fanega aunque los regatones perjudican al público por hallarse el Ayuntamiento impedido por nuestro Comandante que en todo pone la mano al querer reglar las obligaciones, que por las leyes y la costumbre incumben a aquel en todas partes(*); se confimma la plausible grata noticia del castigo y último suplicio del rebelde Tupac Amaru de Tungasuca, su mujer, dos hijos y otros cabezas, mediante las activas providencias y celo notorio del señor/fol.105. Visitador General del Reino(*). Aunque nos contrista que el señor Inspector del Valle, estando en la villa de Puno, no pase a esta ciudad por la distancia corta de 28 leguas, todo camino muy llano y provisto de mulas, peces, comestibles y buenos pastos porque asi pudo quizá remediarse mucha parte de nuestras ruinas, desgracias y fatalidades y los acaecimientos que importa este diario, hecha la computación del tiempo que se halló en dicha villa y de 12 o 15 dias de camino, porque desde que pudo arribar a esta ciudad, se hubieran acaso evitado los sucesos ulteriores y quizá las crecidas expensas del Real Patrimonio en las expediciones que han repetido, como la ruina de las rentas reales y manos contribuyentes de estos estados que cada día han tomado el incremento, que hoy nos es cuasi explicable por la dilatación. Y también se hubiera evitado el incendio de la ciudad de Chucuito, que sabemos fue a cometer en persona el malvado de Tupac Catari quien no tuviese tal valor a vista de aquel ejército( $\left.{ }^{*}\right)$. 
Jueves 18. Bajó el jefe de esta expedición, don José de Reseguín, Teniente Coronel de Ejército, a la ciudad y toma sus medidas a efecto de expugnar el día de mañana al enemigo en el campo de Pampajasi aunque es corriente que Tupac Catari profugó al Santuario de Las Peñas a combinarse con la rebelión de Miguel Bastidas/fol.105v.

El gobernador don Ignacio Flores, sabemos, tuvo que transferirse a Potosí, La Plata, Mizque y Cochabamba con el designio de contribuir a la mejor refacción de su Campo y ciertamente viene con más de ... |borrón en el original] hombres inclusos los vivanderos; 7.000 alistados para el servicio. Queda en Oruro con el designio de reparar que los cochabambinos deserten, como se teme, de subvenir a la expedición de víveres y menestras, al mismo tiempo de consultar a la conservación de aquellas provincias recién pacificadas y estar a la mira de ellas. Es arbitrio digno de aprobación y en especial si logra contener los desertores supuestos de Cochabamba o de proveemos de otras gentes, si estos no subsistieren.

Viernes 19 de Octubre. Partió el comandante don José de Reseguín con el de La Paz y 4.000 hombres al campo' enemigo de Pampajasi a las 3 de la mañana. Lo atacaron [impulsaron] bellas y oportunas disposiciones y con mucho espiritu y extremidad por todas partes siendo el primero en el ejemplo; se conoce que es un perfecto soldado. Los indios se aturdieron, huyeron, rodaron y muchos se desbarrancaron por esos riscos y serranias. Murieron en opinión de unos sobre 150, en la de otros pasan de 400 y en la de algunos que hicieron de comandantes de las columnas de 1.000. Se quenaron las casuchas que fabricaban, como el / fol. 106 . Cabildo o su Pretorio Pilatuno. Se trajeron varias imágenes y adornos de las iglesias, ornamentos, vasos sagrados. Se libertaron algunas mujeres y hombres que allí nos presentaron cautivos y todos los de la expedición volvieron cargados de verduras y víveres que vendieron; se ganó un pedrero de los que perdió Franco y una culebrina o falconete de los dos que en Sicasica perdió don Gavino Quevedo y al fin se logró desalojar a los indios de aquel puesto que en su errado concepto era inexpugnable.

Sábado 20, Domingo 21 y Lunes 22. No hubo más novedad que haberse retirado el jefe a su Campamento a tomar sus disposiciones para perseguir a los dos caudillos, y demás cabezas, aprehenderlos ...[borrón en el original] conforme a los encargos especiales del Excelentísimo Señor Virrey, pacificar la Provincia de Omasuyos (abundante de mulas, pastos y víveres) pasando a la de Larecaja y pueblo de Sorata a recoger aquellas pobres gentes o mujeres perdidas y lo principal de su pacificación, en el entretanto que por otra parte auxilia a la recuperación de los Yungas que son todo el nervio y sostenimiento de la ciudad. Aparte de tener redestinado a don José Ayarza con 2.000 hombres actuando correrías por varios pueblos y para que, mientras su ausencia, resguarde con un trozo los altos y alrededores de la ciudad. Todas disposiciones muy completas y de buena esperanza, como los / fol.106v. cochabambinos no sigan desertando, pues sabemos que la noche del domingo profugaron en crecido número. Lo que tiene al pueblo muy constemado y cuidadoso porque si volvemos a las andadas nadie podrá decir 
...[borrón en el original] de la suerte de La Paz porque los indios han cartado sus intentos del tercer asedio, que no habrá fuerzas para resistirlo si el Señor no hace ostentación de sus misercordias. Continúa el comercio de los cochabambinos con los víveres y granos que extrajeron y los regatones perjudican al público que se halle en lo principal desproveído.

Martes 23 de Octubre. Bajó el Jefe a las cabezadas del río de La Paz a registrar y remediar el lugar y maniobra de la coch o represa de las aguas del rio que hicieron los rebeldes. Después de la inundación que sufrimos, no la habian repetido los rebeldes y ahora con la actividad y celo de este buen caballero logra salir la ciudad del cuidado porque entro de ella nadie pensaba ni repararla y ni siquiera en mandarla a reconocer pues por nuestras culpas parece que el cielo niega el concurso para todo lo que hemos padecido por talta de precaución desde los principios y nacimiento o cuna de la sublevación en Sicasica y Ayoayo, donde a poca costa y con menos gentes pudo la vigilancia (bien consultada si hubiera gustado) apagar el incendio / fol.107. y deprimir al caudillo Tupac Catari allí erigido, y por eso se juzga que salvando el acierto único del atrincheramiento de la ciudad en cue se han acreditado buena aplicación y celo (aunque debió ser a prevención y en último subsidio y no para cerrarse desde los principios contra las órdenes encarecidas de su Excelencia por tomar la campana en que hay mucho desembarayo y proporciones para hacer respetable el nombre augusto del Soberano), todo lo demás ha sido un infortunio y una pura desgracia propia de nuestras culpas que tienen airada a la Divina Justicia.

Miércoles 24. Vino el General de su campamento a la ciudad que le recibió públicamente manifestando su reconocimiento. Se celebró la Misa de gracias en la iglesia Catedral, con asistencia de lo principal y nobleza de ella y se cantó el Te Deum.

Jueves 25 y Viernes 26 . No hubo novedad.

Sábado 27. Salió el Comandante de La Paz, Río Abajo, con sus gentes a Mallasa cuyas casas incendiaron con muerte de algunos rebeldes y por las cabezadas hacia el pueblo de Achocalla; hizo nuestro Genteral una correxía contra un motín de rebeldes que hacian muchas extorsiones y averias en el camino; hurtaron 12 pearas de harinas en él y aún corre que con una parte de los conductores. Y ayer numeraron / fol.107v. a algunos cochabambinos que clandestinamente desfilaron del Campamento por hurtar y saquear las casas de dicho pueblo y dar pábulo a su genio adherido al pillaje, a qujenes los sorprendieron dispersos entre las casas; y parece que en opinión juiciosa pasaron de $200 \mathrm{y}$ tantos los indios que murieron en dicha correria, huyendo y desbarrancándose muchos por aquellos lugares ásperos de serranías gredosas, torriones, abujeros profundos y conejeras.

Estando así el Jefe ausente llegó a su Campamento un indio de Azángaro, Vilca Apaza, de los cabezas, muy galano con el unco o camiseta de terciopelo negro, con galón de platá, calzón de lo mismo, cuyos buches tenía de tisú, medias de seda, 
botín blanco de paño, sombrero de rico castor, el caballo muy enjaezado, con estriberas y espuelas de plata; el que aparcció acompañado del cura de Santiago en Omasuyos, Zuninga, y un clérigo, don losé Antonio Machicado y de 12 indios del pueblo de Achacachi. Aguardó al Jefe sin turbarse por su genio intrépido y audaz y cuando regresó, le entregó dos cartas del Miguel Tupac Amaru o Bastidas y del Julián Apaza o Tupac Catari, acompañada la una de un impreso o indulto de perdón general librado por el Excelentísimo Senor Virrey de Lima a aquel Virreinato y enviado por el biego Tupac Amaru / fol.108. hermano del principal cabeza desde Azángaro para que procurasen obtenerlo o implorar el perdón. El señor Reseguín le recibió con agrado, le dio discreto buen pasaje, respondió que para un negocio tan ... [borrón en el original] y grave que no podía tratarse bien a distancia, se pondría en marcha para aproximarse a ellos, quienes si gustaban podrían hacer lo propio con el ánimo de atraerlos, o prender en todo evento las cabezas. Envió a un eclesiástico cuzqueño don N. Manchego y a un don José Loayza para que fuesen actuando las conferencias de lo que querian los indios. Dios quiera que las resultas sean propicias para la obediencia al Rey y sus Ministros, y que se pacifiquen las cosas. También llegó este día don José Santa Cruz y Villavicencio, Maestre de Campo de las Misiones de Apolobamba, con las vituatias del ejército, 80 o 100 personas de su escolta, 300 y tantos indjos de Challapata, provincia de Paria y 70 o más de Sicasica o Ayoayo que se les agregaron para servirlo. No tuvo novedad en el paso de Oruro a ésta, porque antes biern, los pueblos últimos se ratificaron en su obediencia entregándole el primero 14 de los cabezas y entre ellos uno que estuvo en las funciones del Cuzco, Puno y esta ciudad. A quien entre el número de 12 tuvo a bien despachar al señor Flores a la villa de Oruro mandando balear o ahorcar a los dos restantes / fol.108v a pedimento de los mismos indios que quedaron gustosos, tranquilos en todos los ayllos inclusos los dos que quedaron rebeldes y remontados al transitar el señor Reseguín, y en segundo trámite le entregaron un granadero o escopetero de Tupac Catari que le condujo a presencia del Jefe. Los indios de Caracato también le salieron a pedir perdón a Sicasica, a quienes dio sus boletines conforme a las facultades que trajo del señor Flores. El de Cavari, días ha está subordinado por don José de Ayarza y el de Calamarca igualmente. $Y$ así contamos seis pueblos recién sosegados en esta provincia de Sicasica. En la de Pacajes se sabe que los de Calacoto, Callapa y Uyuma se perdonaron en Oruro por el señor Flores, a quien fueron a perdirselo; y tenemos al de Achocalla, aurque algunas gentes de éste se hallan remontadas; en la de Omasuyos sólo tenemos al de Pucarani y éste en parte porque la mayor se halla transtornada mientras la retirada de los auxiliares porque el de Laja volvió enteramente al cuerpo de los rebeldes.

Domingo 28 de Octubre y Lunes 29. No hubo ocurrencias y el Jefe se prepara a pasar a las Peñas, donde se hallan los cabezas y el tumulto y habiéndose presentado en la ciudad el Bolaños / fol.109. de Sicasica, nos confirmó las nuevas que en el primer cerco tuvimos de su lealtad y conducta. Se lamenta de su desgracia y que teniendo de parte del Rey sobre 14.000 indios con que ya .............. [borrón en el original] al Tupac Catari hasta el pueblo de Ayoayo, todo se le desgració y salió mal por la inconstancia del indio. Arvade que un tiempo tuvo al Apaza de oficial infimo 
de panadero en su casa en Sicasica, que es de lo más ruín que hay entre los indios, sin representación ni talento, que está admirado cómo pudo levantarse en cabeza un indio $\tan$ bajo, crapuloso y limitado. $Y$ añade que la Bartolina es su mujer y no concubina, cuyo apellido es Valero y no Sisa, del pueblo de Caracato. Lo que se sienta para la reforma del concepto y esclarecer la verdad y para que lo discurrido en el día Viernes 5 de Octubre no corra ni pueda tener lugar en el todo. Aunque la duda de ser o no su mujer pudo entonces evitar aquella nota y reflexiones que se hicieron.

[Este manuscrito fue obsequiado por el IImo. y Rmo. Obispo Nicolás

Armentia en 18 de Abril de 1890]

(Escrito al final del texto original) 


\section{VOCABULARIO 1}

A.--

abatcadores: acaparadores. abujeros: agujeros.

alcabala: impuesto a la compraventa que pagaba el vendedor. Tributo que pagaba el indio forastero por los géneros que vendía.

a) arma: ja las armas! alarma.

almofrez: funda de la cama de campaña.

ambidiestro: el que usa ambas manos con destreza. La Biblia y Aristóteles usan esta expresión para referirse a varones fuertes.

annbocarse: abocarse.

asecla: seguidor.

ayllo: ayllu; comunidad indigena en Perú y Bolivia; implica asentamiento territorial.

11. Este Vocabutario se ha conformado con el criterio de facilitar la comprensión del texto, ya sea porque recoge palutias de origen quechua o aymaru no conocidas por el lector de habla castelJana que no habita en las regiones de Perú y Bolivia, o térninos jurídicos, institucionales o costumbristas propios de lá colonización española en estas regiones. Otras veces se dirige a Iraducir al lenguaje actual vocablos antiguos que se has abandonado o que hoy tienen otra signifícación.

Dado el estilo altisonante del autor, que utiliza expresiones de la cultura clásica grecolatina para realzar algunos acontecimientos o personajes, tambien ha sido necesario esclarecer ciertos términos que no se utilizan on el lenguaje actual o palabras que obedecen a una mera castellanización de témuinos tatinos.

Como la autora de este trabajo no es ura especialista en linguística, se ha limitado a lo más necesario sin ahondar en el análisis de expresiones que podrían dar lugar a un interesante estudio sobre el lenguaje que hablaban los criolios cultos, en las postrimeŕas de la colonia.

En la búsqueda lexicograffica se ha utilizado: Tesoro de la Lengua Casteliana o Española de Sebastión de Covarnubias, según la impresión de 1611. Barcelona 1943. - Diccionario de la Lengua Castellana compuesto por la Real Academia Española. 3a. Edic. Madrid 1791. Diccionario de la Lengua Española de la Real Academia. Madrid 1947. - Nuevo Díccionario llustrado de la Lengua Española de Alemany. Barcelona 1975. - Diccionario llustrado Latino Español. Bibliograf. 1973. 


\section{B.-}

batidores: técnicos de milicia y montería.

Belona: diosa de la guerra, hermana de Marte.

boletería: volátiles.

bujeros: agujeros

C.-

cabriolé: especie de capote con mangas o aberturas en Jos lados para sacar los

brazos.

calce: cuña que se introduce para ensanchar el espacio entre dos cuerpos.

calidad nuda: no expedita.

camaretas: cañoncitos que se disparaban en las fiestas indígenas.

cámaras, epidemia de: diarrcas.

carcelaria, relajar la: relevar, aflojat, hacer menos severa la cárcel.

carneros de la tierra: llamas.

casas quemas: casas quemadas.

cajas: tambores.

casquilla: pieza de madera o metal reforzada por un anillo o abrazadera metálica.

concionatorio, discurso: destinado a reclutar o a poner en moviniento.

conmedio: dentro de, en el centro.

cornerías: ruidos producidos por cornos.

costa, hacer la: surtir de algo.

cureñas descuadernadas: curertas que carecen de cañones.

CH.-

chapetones: nombre despectivo que se daba a los españoles nacidos en la península. chiriguanos: indios de la zona sur este de Bolivia.

cholos: nombre que se da al mestizo que habita especialmente en las ciudades.

chunchos: indios que habitan los regiones del norte en la zona tropical de La Paz.

chuxllas: ranchos de paja construidos por los indios.

D.-

descaecimiento: que ha ido a menos, que ha perdido poco a poco.

descandillado: roto en las aristas, rebajado, reducido.

desparpajar: deshacer una cosa con desaliño y poco aseo.

despique: acción de despicarse, vengarse.

disforme pedrada: pedrada que carece de medida.

E.-

elación: orgullo, arrogancia. 
embida: embestida.

entra: dentro de.

escusador: el que eximía o liberaba del pago de tributos, el que evitaba pleitos y discordias.

espaldón: valla artificial con altura suficiente para detener y resistir el impulso de un tiro.

espelunca: cueva.

exaurida: agotada.

F.-

ficta: falsa, fingida.

fiesta real: corrida de toros celebrada entre los indios.

foradar: horadar.

G.-

galga: piedra grande que los indios arrojaban desde una altura.

gentilismo: paganismo, idolatría.

granear el fuego: reducir el fuego a granos, disminuir el fuego.

grasar la epidemia: atmentar la epidemia.

grasados: grasos, gordos, pingües

guayna: joven.

guiñar: torcer.

H.-

hacer la costa: surtir de algo.

hilacata: alcalde indígena; caporales o mandones en las estancias de campo.

I.-

imaginaria: milicia fuera de servicio, dispuesta a actuar en caso necesario.

imaginativa: sentido común.

improbó: no aprobó.

indio mostrenco: indio que no tiene casa ni asiento con ningún señor.

inulta: no vengada, no castigada.

J.-

juegos nemeenios: juegos que se celebraban en la Grecia antigua en honor de Hércules.

K.-

Karas: biancos en tono peyorativo; insulto dirigido a los españoles. 
L.-

ladilla: parásito que vive en la parte vellosa del cuerpo humano. Pegarse como ladilla: arrimarse a otro con pesadez.

ladrocinios: robos.

letura: cuidado, atención, advertencia.

líbito: voluntad.

M.-

malsín: el que de secreto avisa a la justicia de algunos delitos con mala intención y por su propio interés.

manga: cierta forma de escuadtón en una milicia.

mañazo: carnicero. Puede referirse también a una persona que actúa con ardid, astucia, engaño.

maris: talegones o bolsones de lana confeccionados por los indios.

mascaipachas: mascarillas de oro que se colocaban los senores incas en las rodillas y hombros, según Diez de Medina.

mesada: lo que se da todos los meses. Derecho o regalía que cobraba la Corona en las Indias cada vez que presentaba a un eclesiástico para un beneficio minero. mita: trabajo minero obligatorio que realizaban por turno los indios de las regiones vecinas a Potosí.

misturados: mezclados, confundidos.

monipodios: usuras, convenio de personas que se asocian para fines ilícitos.

mostrenco: que no tiene hogar, ni lugar fijo donde vivir.

mojinete: cubierta o tejadillo de un muro.

N.-

nema: cierre o sello de una carta.

nudamente: desnudo, solamente, sin añadido.

O.-

obumbrarse: cubrirse de sombra.

ojotas: sandalias hechas de cuero.

P.-

patrañista: mentiroso, embustero.

peara: piara, manada de yeguas o mulas.

pechado: el que asume una carga, el que se sujeta a su perjuicio.

pechos: tributos 
pedreros: los cañones que poseian los españoles durante las rebeliones indígenas. pergenio: presentación, traza, apariencia.

pervigilio: noche de vigilia.

piana: lenta, suave.

pongo: indio que por turno realizaba trabajos en la casa del señor.

portear: llevar, acarrear.

pretensa: pretensión.

presura: prisa.

prest: haber diario que se da a un soldado.

priesa: prisa.

probabilista: optimista, que cree que las cosas son probables.

R.-

reales tributos: tasas que debian pagar los indios a la Corona en concepto de vasallaje al Rey.

rebabas: asperezas dentro de un cañón que impiden el buen funcionamiento del arma.

recusa: rechazo.

regatones: que vende los comestibles al por menor; compran por mayor para revender por menor.

relajar (la carcelaria): hacer menos severa la peja de cárcel.

repartos: compra forzosa de mercaderías superfluas o innecesarias que debían hacer los indios.

repeso: fuerza, eficacia.

rochela: bullicio, algazara.

rodela: escudo redondo.

S.-

seba: sebo o grasa que sé ponía en la boca de los cañones como lubricante.

T.-

tósigo: ponzonaa, angustia o pena grande.

trucidar: despedazar, matar con crueldad.

trapacero: el que usa engaños o defrauda a una persona.

trasteado: sin trastos, revuelto.

traquido: estruendo causado por tiros o disparos.

tupamarista: criollo con inclinación a favorecer los levantamientos indígenas.

túrbido: turibio.

V.-

vizcacha: roedor sud ameriçano con cola larga. 


\section{INDICE ONOMASTICO 1}

Acuña, Juan Antonio; Justicia Mayor de Chayanta. Despeñó a Tomás Catari: 1. Alarcón, Tomás; español muerto en Sicasica: $4 \mathrm{v}$.

Aliaga, Mariano; amanuense o confidente de Andrés Tupac Amaru: 67v, 68.

Aliaga, N.; capitán de la provincia de Omasuyos: $12 \mathrm{v}$.

Albizuri de, José; corregidor de Chulumani (Yungas): 38v, 46v.

Alós, Joaquín; corregidor de Chayanta: 1.

Ambrosio, ?; alcalde de Sicasica: 4.

Anchoris, Ramón; corregidor de Sicasica: 4v, 7, 38v,

Andrés,?; Corregidor de Arica y Tacna: $77 \mathrm{v}$.

Angel,?; sastre de La Paz: 29v.

Anover, Lorenzo; español muerto en Sicasica: $4 \mathrm{v}$.

Aparicio,?; miembro de las milicias paceñas: $48 \mathrm{v}$.

Apaza,?; cacique de Sicasica: $4 \mathrm{v}$.

Apaza, Felipe; tío de Tupac Catari: 35.

Apaza, Gregoria: véasc Relación Biográfica.

Apaza, Julián, véase Relación Biográfica.

Apaza, Vilca; jefe rebelde de Azángaro: 107v.

Aragón, Lorenzo, acompañante del corregidor de Sicasica: $4 \mathrm{v}$.

Aréchaga Bizarros, Ramón; capitán muerto en Sangarara: 2v.

Areche, José Antonio: véase Relación Biográfica.

(1) La autora de este libro ha dudado largamente sobre la utilidad de confeccionar un Indice Onomástico en el que solamente se ordenen en forma alfabética, junto a personajes importantes que actuaron en tos acontecimientos narrados por el Oidor, innumerables nombres de personas que se limitaron en un día dado a disparar una escopeta, abrir una puerta de la fortaleza, traer un mensaje, vender una mula o simplemente morirse. Sobre estos útimos, el escueto dato conocido estaba anotado en el diario; repetirlo en el índice no renía ningún walor. ¿No era mejor, entonces, reducir el trabajo a las figuras destacadas sobre las cuaies se podían añadir nuevas nolicias? Pero, ¿qué criterio se debía seguir en la selección? ¿El de destacar a los personajes por los datos novedosos y de primera mano que de ellos se tenía? $\downarrow \mathrm{O}$ el de seleccionarlos porque sus nombres eran ya conocidos a través de otras publicaciones? ¿No podía darse que personajes insignificantes para el criterio actual fueran decisivos para el Oidor o viceversa?

Ante tales dudas, se llegó a la conclusión de que lo más acertado era continuar utilizando el método tradicional en la elaboración de un Indice Onomástico, porque así se lograria, respetando el criterio selectivo del autor, apreciar su calidad de vecino conocedor de la gente de la ciudad en cualquiera de las extracciones sociales, así como su grado de información de 
Argandoña, Bernardino; oficial de fortaleza: 36v.

Arís Navarrete, N.; vecino de La Paz: 33v.

Armentia, Nicolás; Obispo: 109.

Armentia, Protasio: véase Relación Biográfica.

Aro de, Marquesa; Bartolina Fernández Pacheco de Bilbao la Vieja: 44.

Arteaga de, Rafael; teniente de alguacil: $10,10 \mathrm{v}$.

Arzabe, Bartolomé; azoguero de Sicasica: 4v.

Arzadúm, Agustín; sacerdote que actuó en Pocoata: 1.

Arrivi, Manuel; padre guardián de San Francisco: 16.

Ascarrunz,?; soldado: 89 .

Ascencio,?; alias "El Cañarlto"; guardaespaldas de Bartolina Sisa: 48.

Atauchi, Faustino Tito; coronel indígena, 54v, 55, 55v, 56, 56v, 80v.

Avellaneda,?; abogado de La Paz: 34.

Avendaño, Cayetano; sacerdote paceño: $17 \mathrm{v}$.

Ayarza,?; vecino de Oruro muerto en la sublevación: 4.

Ayarza, José: véase Relación Biográfica.

Ayarza, Juan; chileno que luchó contra Catari: 47.

Barco,?; cura párroco de Sicasica: $38 \mathrm{v}$.

Barela, Anastacio; minero: 55v.

Barra de la, Juan León; rico vecino de La Paz: $49 \mathrm{v}$.

Barra de la, Juan José; capitán de milicias de La Paz: 31.

Barriga; Francisco Manuel; franciscano que sube voluntariamente al Alto: 19, 20v. Barrios, Cristóbal de; vecino de La Paz: 40v.

Bastidas, Miguel; alias Miguel Tupac Amaru, coronel cuzqueño que llegó a Omasuyos para colaborar en la caída de Sorata; luego, se hizo cargo de las tropas de Andrés Tupac Amaru cuando éste volvió al Cuzco: 95, 96, 98, 99v, 107v.

buena fuente sobre los acontecimientos y sus actores. De este modo, los nombres elegidos, acompañados de datos muy escuetos sobre su identidad, fueron ordenados alfabéticamente con su respectiva ubicación en los diferentes folios.

Con plena conciencia, sin embargo, de que podía desaprovecharse la oportunidad de ofrecer al lector noticias fidedignas de personajes historicos sobre los cuales se sabe muy poco o se posẹen informaciones eтróneas, la autora recurrió más adelante a conféccionar una Relación Biográfico de aqueilas figuras sobre las cuales ha podido encontrar datos documentales respecto a su actuación.

En el Indice Onomástico sơlo se hain incluído los nombres que figuran en el propio texto. dejándose de lado los de las notas explicativas. Para prestar una mayor ayuda al investigador, se ha inclufdo en la cita de las fojas las ocasiones en que un personaje deterninado figure con su oficio, apodo o con alusiones irritadas, irónicas o indirectas. Así por ejemplo, Francisco Gregorio de Campos aparece muchas veces como el Sr. Obispo, el Ilustre Prelado, etc.; Sebastián de Segurola figura también como el comandante, "Ia persona que rige nuestros destinos", etc. Tupac Catari figura también como Julián Apuza, como "traidor cizañero", etc. 
Bausas, José; español muerto en Sicasica: $4 \mathrm{v}$.

Benavides,?; asesor del corregidor Alós: 1.

Bernuy, Toribio; canónigo paceño: $43 \mathrm{v}$.

Bernal??; religioso del convento de San Francisco: 75.

Bernardo,?; sastre arequipeño: $74 \mathrm{v}$.

Bilbao, Mariano; capitán de fortaleza: 25v.

Bilbao la Vieja, Antonio; edecán de Segurola: 9v, 12, 103v.

Blanco, Juan; vecino de Oruro muerto en la sublevación: 4.

Bodega y Llano de la, Manuel; corregidor de Paria: $3 \mathrm{v}$.

Bolaños,?; alias "El Sordo", militar que dirigia la fabricación de la pólvora: 33v, 72.

Bolaños,?; capitán de indios amigos de Sicasica: 29v, 35v, 38v.

Borda, Matias; véase Relación Biográfica.

Borges, Manuel; portugués avecindado en La Paz: 10, 14v.

Bolello,?; militar que auxilió a José Pinedo: $12 \mathrm{v}$.

Boza, ? cabo: $89 \mathrm{v}$.

Bullin?; vecino de Oruro muerto en la sumievación: 4.

Bustamante,?; vecino de Oruro muerto en la sublevación: 4.

Bustillos, Julián; teniente cura de Puçarani: 34.

Cajal, Juan 'Tomás; prehendado paceño: 43, 100.

Calderón, José; español muerto en Sicasica: $4 \mathrm{v}$.

Calderón, Juan, reğidor y capitán de milicias de La Paz: 15v, 16, 22, 89v.

Calvijo,?; seudónimo de Bonifacio Chuquimamani: 44.

Calle, Marcelo; caudillo indigena: $15,35$.

Campos, Gregorio Francisco de, Obispo de La Paz; véase Relación Biográfíca.

Campos de, José; hermano del Obispo Campos: 14.

Campos de, José Antonio; sobrino del Obispo Campos: 13.

Canizares," Fatuo"; vecino de La Paz: 19v.

Caravedo, Mariano; ctérigo de Sorata: $58 \mathrm{v}, 65,67 \mathrm{v}$.

Carios III; rey borbón que gobernó a España desde 1759 a 1788: 16v, 29, 53, 59v, 60 $62 \mathrm{v}, 63,63 \mathrm{v}, 65,66,82,83 \mathrm{v}, 93 \mathrm{v}, 96,102 \mathrm{v}, 108,109$.

Carrillo y Oruzate, Gaspar; hijo del Marqués de Feria: $37 \mathrm{v}$.

Carpio, Ventura, vecino de La Paz: 37v, 39v, 43, 48v, 68v.

Casas,?; vecino de Oruro muerto en la sublevación: 4.

Castañón,?; militar muerto en la defensa de La Paz: 42v.

Castel, Mariano; secretario del corregidor de Sicasica: 4v.

Castro, Toribio; Regidor de La Paz: 41, 41v, 55v.

Catari, Tomás; véase Relación Biográfica.

Catari, Tupac; véase Julián A paza en Relación Biográfica.

Caypa, Pedro; cacique de Pocoata: $1 \mathrm{v}$.

Cerna, Luis; oficial paceño: 43.

Cipriano,?; teniente cura de la parroquia de San Sebastián: 7. 
Condori, Ascencio; hilacata de Sicasica: $4 \mathrm{v}$.

Contreras,?; vecino de La Paz: 43.

Córdova, Pedro Pablo; indio: 55v.

Cortés,?; sacerdote franciscano: 16 .

Crespo,?, "el harinero": 103, 103v, 104.

Cruz, Juan; nombre falso del indio Zúñiga: 24.

Chavarría,?; herido en el asalto del convento de San Francisco: 81.

Chuquihuanca, Diego; importante cacique fiel a los españoles: $2,7,8$.

Chuquihuanca, José; hijo de Diego Chuquihuanca: $2 v$.

Chuquimamani, Bonifacio; secretario de Tupac Catari: 15, 15v, 16v, 18v, 23, 44.

Dábola, Tadeo; clérigo moqueguano: 90.

Dávalos, ?; párroco de Tupiza: 46.

Deheza, José Ignacio; teniente paceño: 14v, 26.

Delgado, Juan, vecino de La Paz; 78v.

Delgado, Manuel; español muerto al reventar la cocha: $100 \mathrm{v}$.

Díaz Ortiz, José; español muerto en Sicasica: $4 \mathrm{v}$.

Diez de Medina, Félix; vecino de La Paz: 20.

Diez de Medina, Francisco Tadeo; véase Estudio Preliminar: 6v, 7v, 9v, 13v, 14, 18v, $19,20 \mathrm{v}, 22,26,27 \mathrm{v}, 29 \mathrm{v}, 33,35,38,40 \mathrm{v}, 50 \mathrm{v}, 51 \mathrm{v}, 94 \mathrm{v}$. Citado como Oidor: 7 , $7 \mathrm{v}, 13,14,18,19,19 \mathrm{v}, 20 \mathrm{v}, 22,26,26 \mathrm{v}, 51,52 \mathrm{v}$.

Dioclez,?; héroe de Siracusa: 45.

Donayre, N.; vecino de La Paz: 28.

Dorado, Guillermo; militar paceño: 12, 16v, 22.

Dorado,?; sacerdote prisionero en El Alto: 34.

Dután, Antonio, clérigo ayudante de Viacha: $8,8 \mathrm{v}$.

Eisgua, Miguel; vecino de La Paz: 99.

Endara, Antonio; mestizo que lievaba y traia correspondencia entre ambos campos:

$19,20 \mathrm{v}$.

Endeiza, José; vecino de Oruro que murjó en el levantamiento: 4.

Escajadilla, Francisco; capitán muerto en Sangarara: $2 \mathrm{v}$.

Escauriza, Dionisio; véase Relación Biográfica.

Escobar, Enrique; mestizo que se entendía con los sublevados: $23 \mathrm{v}$.

Escobar, Isidro; clérigo: 77v.

Escobar, Nicolás; arquitecto radicado en La Paz: 52v.

Escobedo, Jorge; véase Relación Biogxáfica.

España, Cristanto Rafael de; oficial de guardia: 67v.

Esprella,?; soldado, $89 \mathrm{v}$.

Esteban,?; indio fiel a los españoles: $21 \mathrm{v}$. 
Farfán de los Godos, Francisco; oficial mayor de la Aduana: 33.

Farfán, Gregorio; capitán de una compañúa de Sicasica: $17 \mathrm{v}$.

Feria, marqués de; antiguo corregidor de una de las provincias paceñas; $37 \mathrm{v}, 38$.

Fernández Castañeda, Diego; justicia mayor de Azángaro: 1v.

Feliciano,?; relojero $76 \mathrm{v}, 80 \mathrm{v}$.

Figueroa,?; procurador de causas: $37 \mathrm{v}$.

Fierro, Vicente; vecino de Oruro muerto en la sublevación: 4.

Flores, Andrés; capataz del pueblo de San Pedro: 87v, 88.

Flores, Ignacio, ver Relación Biográfica.

Foronda,?; alférez real: 16.

Franco, Manuel Tomás; véase Relación Biogrática.

Fray Joaquín, N.; predicador franciscano: $18 \mathrm{v}$.

Fuentes, Manuel; español muerto en Sicasica: $4 \mathrm{v}$.

Gallo, Bernardo; véase Relación Biográfica.

García,?; vecino muerto en Oruro: 4.

García Lanza, Gavino; licenciado paceño: 22.

García Loayza, F.; presidente del Consejo de Indias en tiempos de Carlos V: $31 \mathrm{v}$.

Gavino y Argueda, Juan Manuel; párroco de Toledo en Paria: 4.

Gemi, Valentín; amanuense y confidente de cuentas de Andrés Tupac Amaru: 98v,

Gil de Alipazaga, Jermin; véase Relación Biográfica.

Gisbert, Mariano; vecino de La Paz: 41.

González Pavón, Antonio, deán de la iglesia catedral; 71.

González Pérez, Alonso; vidor de la Audiencia de Charcas: 46 .

Gregorio,?; vecino de La Paz: 15v.

Guirior, Manuel; Virrey del Perí: 107v.

Guruchaga,?; vecino de Oruro: 4.

Gutiérrez,?; cacique de Capiñata: $\bar{c}$.

Guzmán, Julián, vecino de La Paz: 35v, 69.

Guzmán, Pedro; vecino de Sicasica muerto en la sublevación: $4 \mathrm{v}$.

Gylipe,?; general de Lacedemonia: 45.

Herrera,?; vecino de Oruro: 4.

Herrera de, Antonio; cronista oficial del Consejo de Indias: $31 \mathrm{v}$.

Herrera de, Isidoro; párroco de San Pedro de Buenavista: 46.

Herrera de, Mánuel; vecino de Larecaja: $12 \mathrm{v}, 14 \mathrm{v}$.

Higueras, Juan; teniente corónel paceño: $19 \mathrm{v}, 34 \mathrm{v}, 37 \mathrm{v}, 38,39 \mathrm{v}, 43,43 \mathrm{v}$.

Hinojosa, Juan Crisóstomo; indio de Caquiaviri, amanuense de Bartolina Sisa: 48.

Tharola, Juan de; cajero de Segurola: $55 \mathrm{v}$.

Illanes, Mauricio; sacerdote paceño: 25.

Indaburo de, Juan Pedro; alcalde ordinario de La Paz: 29, 39. 
Ingaricona, Andrés; coronel de Tupac Amaru: 7.

Iturralde, Juan Fernando; véase Relación Biográfica.

juanes?; clérigo: 90.

Juan Manuel,?; debe referirse a Juan Manuel González, amero de La Paz: 40.

Lagrava,?; vecino de Oruro muerto en el levantamiento: 4.

Landa, Tïburcio; capitán muerto en Sangarara: $2 \mathrm{v}$.

Larao,?; vecino de Oruso muerto en el levantamiento: 4.

Laray, José; vecino de La Paz: $17 \mathrm{v}$.

Larteinaga, Mariano; administrador de tabacos, muerto en Ayoayo: 4.

Lego, Pedro; correo de Tupac Catari: 16.

León de la Barra, Juan; rico y generoso vecino de La Paz, 49.

Limachi, Sebastián; párroco de Guaqui, capellán en El Alto: 19, 27.

Lino, Pedro; eciesiástico: $97 \mathrm{v}$.

Lizargarate, Sebastián; vecino de La Paz: 39.

Loayza, Felipe; proveedor y doctoral de la Catedral: 10, 31, 52.

Loayza, José, vecino de La Paz; 108.

López, Pablo; cacique fiel al corregidor de Sicasica: $4 \mathrm{v}$.

Lora,?; militar muerto por saquear: 50 .

Loyola, Casimiro; mayordomo de hacienda en Mecapaca: 9.

Loza de, Josefa; vecina de Ayoayo muerta en la sublevación: $4 \mathrm{v}$.

Lucero, Manuel Lorenzo; alférez de La Paz: 12, 14v.

Luna, Agustin; cura de Pucarani: $72 v$.

Lupa, Gregorio; cacique de Moscari, fiel a los españoles: 1.

Llano,?; alcalde ordinario muerto en Oruro: 4.

Llano, Miguel Antonio; véase Relación Biográfica.

Llanquipachas, caciques de Condocondo en Paria: 1.

Machicado, José Antonio; bachillex: $89,107 \mathrm{v}$,

Machicao, Pablo; cura rector de la catedral: $15 \mathrm{v}, 30$.

Machicao,?; granadero desertor: $42 \mathrm{v}$.

Mamani, Antonio: nombre supuesto del indio Zúñiga: 24.

Manchego, Bernardo; sacerdote confesor de Pedro Obaya: 34.

Manchego, N.; eclesiástico cuzqueño: 108.

Manzaneda de, Roque; vecino de La Paz: 22, 28v, 41.

Mariaca, José; cura de Achacachi que rindió homenaje a Catari: 27.

Mariaca, Pedro; escribano de S. M. y de cabildo: 13v, 51.

Mariño, Miguel; matemático y capitán de milicias: 33.

Mariano,?; sastre paceño, $15 \mathrm{v}$. 
Marqués de Feria; corregidor y justicia mayor de la provincia de Sicasica en 1780 : $37 \mathrm{v}, 38$.

Márquez de la Plata, Fernando; véase Relación Biográfica.

Martin,?; carpintero: 82.

Martínez, José: vecino de Oruro muerto en el levantamiento: 4.

Martínez, Juan Antonio; vecino de Oruro: 4.

Martínez Chuquicallata, Miguel; natural de Azángaro, indio principal del sirio de Sorata, llegado a La Paz para sumarse al asedio: $97 \mathrm{v}$.

Martinez, Pedro, vecino de La Paz: 41.

Mendieta,?; vizcaino venido de Potosí: 103.

Menéndez, Cayetano; mayordomo de un obraje minero: 9.

Merlo, Gregorio José; párroco de Macha que ayudó a Tomás Catari: 1, 2.

Miranda, "Tumbito"; fabricante de pólvora: $98 \mathrm{v}$.

Monroy, Pablo; teniente de Miguel Tupac Amaru: 98.

Monroy,?; sastrì muerto en campaña: $12 \mathrm{v}$.

Montes de Oca, Marcelino, labrador de cocales, 86v, 87,

Moya y Villarreal de, Ramón; véase Relacióni Biográfica.

Muguruza,?; alcalde de Oruro: 4.

Mullupuraca, Juan de Dios; coronel indio derrotado en el cerro de Berenguela: $98 \mathrm{v}$, Mundaca, Juan; párroco de Viacha: $7 \mathrm{v}$.

Murillo, Mariano; véase Rełación Biográfica.

N, Pedro; vizcaino avecindado en La Paz: $34 \mathrm{v}$.

Nava?; administrador de correos: $53 \mathrm{v}$.

Navarre, Manuel; alférez del regimiento del coadjutor Sainz: 86.

Nerivalde, Manuel; vecino de La Paz: $53 \mathrm{v}$.

Nieto y Aperrique, Bernardino; vecino de La Paz: 53v.

Nina, Eugenio: indio muerto en la sublevación de Sicasica: $4 v$.

Novoa, Benito; coronel de milicias: $37 \mathrm{v}$.

Núñez, Simón; capitán de indios amigos: 19v, 24v, 29.

Obaya, Pedro; véase Relación Bjográfica.

Oblitas, Diego; vecino de Larecaja: 24.

Ocaña, Cipriano; español muexto en Sicasica: $4 \mathrm{v}$.

Ocaña, Vicente; español muerto en Sicasica: $4 \mathrm{v}$.

Ochoteco,? vecino de La Paz: 32.

Oquendo, Francisco de, dueño de una chacarilla en La Paz: 15v, 103v.

Ordónez, Andrés, militar de las tropas de auxilio: 39.

Orellana de, Joaquín; véase Relación Biográfica.

Ortiz de Foronda, Tadeo; alférez real: 15v, 16. 
Ortiz, fray Tomás; dominico de la época de Carlos V: 30.

Oyardo, Bartolomé; vecino español de Sicasica: $4 \mathrm{v}$.

Pacheco,?; vecino de La Paz: 16.

Pacheco,?; arequipeño avecindado en La Paz: 41.

Pacheco, Xavier; capitán criollo con posibles connivencias con Tupac Catari: 26.

Palacio, Pedro; vecino de La Paz: 33, 48v, 87, 87v, 88, 88v, 89, 103.

Palazuelos,?; vecino de Oruro muerto en la sublevación: 4.

Parada, Ana; vecina de La Paz: 72v, 89v.

Paredes, Antorio; sobrino del párroco de Mecapaca: $7 \mathrm{v}, 38$.

Paredes, Mariano; vecino criollo de La Paz: 33.

Paredes de, José; magistral de La Paz: $2 \mathrm{v}$.

Patra, Pedro; capitán de milicias: 35v, 40, 43v.

Pasiego, el; persona muerta en la sublevación de Oruro: 4.

Patón,?; mestizo que se entendía con los indios: $23 \mathrm{v}$.

Pavía,?; oficial mayor de caja, muerto en Oruro: 4.

Pedro,?; platero muerto en Sicasica: $4 \mathrm{v}$.

Pedro,?; vizcaíno avecindado en La Paz: 41.

Peralta, Bernardo; párroco de Vilque: $12 \mathrm{v}$.

Pérez de Arescurinaga, Gregorio; párroco de Mecapaça: 7v.

Pérez, José; corresponsal de Paredes en Cuzco: $2 \mathrm{v}$.

Pestaña,?; vecino de La Paz: 22.

Phylopeman; héroe griego de Megalópolis: 9v, 45v

Piedra,?; teniente de artillería: $48 \mathrm{v}$.

Pineda, Pablo; vecino muerto en Sicasica: $4 \mathrm{v}$.

Pinedo, Antonio; véase Relación Biográfica.

Pinedo, Ignacio; véase Relación Biográfica.

Pinedo, José; véase Relación Biográfica.

Poblete, Antonio; párroco de Calamarca: $35 \mathrm{v}$.

Portillo,?; vecino de Oruro: 4.

Pradel, Bernardino; alférez muerto en Potopoto: 14v, 26.

Prado, José; militar paceño muerto en el cerco: 14.

Puma Catari, Carlos; caudillo indígena: $18,20 \mathrm{v}$.

Pylades; griego, cantor de epopeyas: $45 \mathrm{v}$.

Quevedo, Gavino; véase Relación Biográfica.

Quint, Diego; vecino de La Paz; 53v.

Quinteros, Hipólito; notario de La Paz: 7v.

Quiroga,?; vecino de Oruro: 4.

Quirquincho, Carlos; mozo potosino: 103. 
Ramallo, Manuel; sacerdote de Cavari: 5.

Ramírez de la Parra, Pedro; capitán de fortaleza: 9v, 10, 12, 25, 37v, 41, 43v, 53v. Ramos, Fernando; dueño de una estancia en Ayoamaya: $4 \mathrm{v}$.

Reseguin de, José, véase Relación Biográfica.

Reyes, Mariano; escribano y capitán de milicias de Pacajes: $19 \mathrm{v}, 20 \mathrm{v}$.

Riva,?; vecino de La Paz: 69.

Rodriguez, Clemente; eclesiástico paceño que se fue con los indios: 10, 43.

Rodriguez, Melchor; cura párroco de Santa Bárbara: 7v, 43.

Rodríguez, Melchor: vecino muerto en Oruro: 4.

Rogers, Carlos; véase Relación Biográfica.

Rojas, Eugenio; vecino de La Paz: $89 \mathrm{v}$.

Rojas, José; sargento mayor de La Paz: 15v.

Rojas, Vicente; capellán de mìlicias, dueño de hacienda en Achachicala: 36v, 42, 48, $48 \mathrm{v}, 50,54,54 \mathrm{v}, 55 \mathrm{v}, 56 \mathrm{v}, 71 \mathrm{v}$.

Romero, Reimundo; capellán de Andrés Tupac Amaru: 76, 77v, 80.

Royo,?; vecino de Oruro: 4.

Rubín,?; vecino de Oruro: 4.

Saenz de Tejada, Antorio; véase Relación Biográfica.

Sainz, Juan; hermano coadjutor dc los frailes de la Buena Muerte: 11, 14, 16v, 17, 29v, $69,72,85 \mathrm{v}, 101 \mathrm{v}$.

Salazar, Matías; barbero de La Paz: 19v.

Saldaña, Marcos; trujillano, ayudante de las milicias de Larecaja: $22 \mathrm{v}$.

Salgado, Joaquin; véase Relación Biográfica.

Salinas,?; muerto en la sublevación de Oruro: 4.

Salinas, Juan; vecino de La Paz: 103.

Sanca, Nicolás; coronel de Tupac Amaru: 7.

Sánchez,?; vecino de Lampa instalado en La Paz: $19 \mathrm{v}, 20 \mathrm{v}$.

Sánchez,?; capitán paceño: 28.

Sánchez, Pedro; nombre equivocado de Pedro Obaya: 25.

Sanjinés, Alejo; párroco de Calamarca: 5.

Sanjutjo Diez de Medina, Mariano; véase Relación Biográfica.

Sanjurjo y Montenegro, José Antonio; tenienté coronel gallego avecindado en La Paz. Maestre de Campo: 11.

Santa Cruz y Villavicencio, José; maestre de campo: 108.

Santalla, Benito; capitán de la compañía de forasteros: $37 v, 50$.

Santalla, Gregorio; vecino importante de Sorata: 44.

Santalla, Manuel; teniente coronel de las milicias de Larecaja: 10v, 12.

Santander, ?; vecino de Oruro: 4.

Santelices,? vecino de Oruro: 4.

Santelices y Benero, Ventura; Gobernador y Superintendente de Potosi; $59 \mathrm{v}, 60$. 
Sata y Zubiría, Lorenzo; corregidor de Azángaro: $2 \mathrm{v}$.

Sebastián,?; platero muerto en Sicasica: $4 \mathrm{v}$.

Segurola de, Sebastián, véase Relación Biográfica.

Sepúlveda, Gregorio; vecino de Larecaja: 69.

Sesenarro, Lucas; comisionado de Tupac Amaru; 6v, 12v.

Silva, Cayetano; vecino de La Paz: 37v, 44.

Silva, Domingo; presbítero con propiedades en Omasuyos: $36 \mathrm{v}, 44$.

Simbrón, Juan; minero de Tipuani: 66.

Sinosain, Joaquin; cura de Timusi: 56.

Sisa, Bartolina; véase Relación Biográfica.

Solaya, Domingo; eclesiástico, 100.

Sorzanos,?; hermanos que vivian en Oruro: 4.

Sota,?; vecino de La Paz; 34v.

Soto?; chileno avecindado en Oruro: 4.

Soto, Manuel; vecino de Oruro: 4.

Sosa, Ignacio; vecino de La Paz: $29 \mathrm{v}$.

Taboada, José; vecino de La Paz: 33

Taboada, Nicolás; capitán de milicias de Sorata: 12

Tagle, Mateo; vecino de La Paz: 53v.

Tapia, Antonio; niño indio de Chúa: 20.

Tapia, F.; vecino de La Paz: 33.

Tellería, José; vecino de La Paz: 53y.

Tellería, Manuel; vecino de La Paz: 53v.

Téllez, ?; escribena del corregidor Alós; 1.

Timotheo; poeta griego: $45 \mathrm{v}$.

Tito, Pedro; indio correo de Tupac Amaru: 2v.

Torres,?; sacerdote prisionero de Tupac Catari: 34.

Torres, Esteban; dueño de hacienda de Sicasica: 7, 11.

Tristán y Muzquía, José Joaquín; corregidor de Omasuyos: 9, 24.

Tupac Amaru, Anđrés: véase Relación Biográfica.

Tupac Amaru, Blas; deudo de José Gabriel Tupac Amaru; 59v, 60, 60v.

Tupac Amaru, Diego; nombre con el que Diez de Medina confunde a Diego

Cristóbal y a Andrés Tupac Amaru: 50, 55, 55v, 80, 94v, 98, 98v, 108.

Tupac Amaru, José Gabriel; véase Relación Biográfica.

Tupac Catari; véase Relación Biográfica.

Trujillo, Juan; clérigo: 55v.

Umaveitia,?: vizcaino ayudante de Segurola: 13.

Urbina, Eusebio; cacique de Ayoayo: 5. 
Uría Illanes, Bernardino; prebendado de La Paz: 42.

Urízar, José Antonio; capitán muerto en Sangarara: 2v.

Urrola, Casimiro; teniente muerto en Potopoto: $14 \mathrm{v}$.

Valdés, José; regicor español: 100.

Valdés, Justo; hacendado de Yungas: 86.

Vaidés, Tomás; vecino de Ichoca: 5 .

Valdivia, Martin; teniente cura de San Sebastián: 7, 26.

Valencia, Francisco; capitán escolta de José Pinedo: 7v, 12v, 72v,

Valenz, Francisco; capitán español: 81.

Valverde, Benito; vecino de Sorata: 65 .

Varela, Anastacio, minero portugués; $65 \mathrm{v}$.

Vargas, Isidro; sacerdote de Palca: 27.

Vargas, Juan Bartolomé; indio de Sicasica: 4v.

Vázquez,?; alférez: $89 \mathrm{v}$.

Vázquez, Ambrosio; propietario de minas de oro en Larecaja: 12.

Vázquez, Angel; dependiente del oidor Diez de Medina: $40 \mathrm{v}$.

Vea Murguía, Joaquín; vecino de La Paz: 100,100v,

Velarde, N.; capitán de indios amigos de La Paz: 18v, 32.

Vera y Aragón, Crispín; escribano de S.M. y de Real Hacienda: 51.

Vera y Aragón, Teodoro; vecino de La Paz: 22.

Verástegui, Mateo; cacique que luchó por los españoles: 12v.

Vértiz de, Juan José; véase Relación Biográfica.

Vía, Sebastian; oficial de guardia en las fortalezas: $31 \mathrm{v}$.

Villacorta, Javier; vecino muerto en Ayoayo: $4 \mathrm{v}$.

Villalobos,?; cura enfermo y prisionero de los indios: $75 \mathrm{v}$.

Villalobos, Felipe; caudillo indígena: 15.

Villanueva, Pablo; voluntario que murió en Potopoto: 14v.

Villanueva de, Rafael; escribano de S.M. y público: $51 \mathrm{v}$.

Villegas, Martuel Inocente; justicia mayor de Pacajes: $8 \mathrm{v}$.

Vizcarra,? padre agustino que amonestó a los indios para que pidieran perdón: 95.

Zavala, Juan Bautista; véase Relación Biográfica.

Zelada, Tomás; maestro de postas muarto en Sicasica: $4 \mathrm{v}$.

Zepeda, Juan Antonio de; secretario del obispo de La Paz: 53.

Zúî̉iga,?; cura de Santiago en Omasuyos: 107v.

Zúñiga, Antonio; indio minero del Cuzco: 24, 43v.

Zúniga, Esteban; pariente de Tupac Amaru: 2v. 



\section{RELACION BIOGRAFICA 1}

APAZA, GREGORIA: natural de Ayoayo, se casó con Alejandro Pañuni, sacristán de dicho pueblo. Desde Ayoayo, la trajo, con su marido, su hermano Julián Apaza al Alto, donde permaneció un mes. Como amante de Andrés Tupac Amaru pasó a Soratia para colaborar activarnente en el sitio de aquella ciudad. Con el joven Tupac Amaru actuó en los juicios y matanzas de los vencidos de aquella capital. Concluída la destrucción de Sorata se vino a La Paz con Andrés para ayudar en el sitio de esta ciudad. Según el Defensor de Indios, Diego de la Riva, participó en los tres mercados de víveres que se establecieron en el Alto de San Pedro y en las tiranías ejercidas por Andrés Tupac Amaru en el Alto de Cruz Pata. Por las declaraciones de otros testigos se asegura que vestía como varón. Antes de la llegada de Reseguín se dirigió a Peñas, donde fue apresada después de la derrota de Tupac Catari. Conducida a La Paz, fue enjuiciada por el oidor Diez de Medina que la condenó al mismo suplicio que a su cuñada Bartolina 5isa. Fue ejecutada el 5 de Septiembre de 1782. f. 50, $93 \mathrm{v}$.

APAZA, JULIAN: Indio forastero natural de Sicasica, tributario del ayllu de Sulcabi. Fue trajinante de coca y bayeta. Casado con Bartolina Sisa. Encabezó la

(1) Esta pequeña relación biogrática ha nacido de la convicción de que aun hoy se conoce muy poco a los actores más destacidos de la época del asedio. Muchas veces se ignoran los nombres $y$ actuaciones de gentes que, a través de tos documentos, se ve que tuvieron un papel importante y que, sin embargo. en las épocis posteriores quedaron sumidas en el olvido. Otras veces se ha podido comprobar que los datos que se tienen de alguna que otra de estas figuras son erroneos porque generalmente se ha confundido a niembros de una misma familia, 0 a individuos de apellidos más o menos similares. En este tipo de fallas cae continuamente la obra de Nicanor Arunzaes. "Diccionario Hiśórico Biográfico del Departamento de La Paz". Las defjciencias anotadas se deben en gran parte a que se recurrió raramente a la documentación existente, o la investigación se limitó a consultar el Diario del Comandante Segurola, que es precisamente el que menos referencias tiene el el aspecto biográfico.

Los datos que se proporcionan en esta Relación no fueron buscados con el fin de elaborar un Diccionario Biográfico: ellos fueron surgiendo paulatinamente, a medida que se avanzaba en la revisión de los diversus archivos consulados para un trabajo más amplio de las Reteliones. Fueron encontrados en fuentes de primera mano, como son las actas notariales de La Paz, hojas de servicjos, rejaciones de méritos, informes de funcionarios a las autoridades civiles y militares, pleitos, renuncias a diversos cargos, listas de sueldos, etc. 
rebelión de las provincias de La Paz, llamándose a sí mismo Virrey Tupac Catari. Inició el movimiento en Febrero de 1781 en Sicasica. Sitió La Paz en el primer cerco desde el 15 de Marzo hasta el 29 de Junio, cuando fue liberada por el Comandante Ignacio Flores. Volvió a sitiarla el 5 de Agosto cuando Flores abandonó la ciudad para buscar refuerzos, manteniéndola cercada hasta mediados de Octubre de 1781. A la llegada de Reseguín huyó hacia la provincia de Omasuyos, dunde, traicionado por el coronel indígena Tomás Inga Lipe, fue capturado por los españoles. Juzgado por el oidor Diez de Medina en Peñas, fue sentenciado el 11 de Noviembre a horrorosa muerte. Ajusticiado en igual forma que Tupac Amaru, murió el 14 de Noviembre de 1781 - La numeración de las fojas en que se cita su nombre incluye las veces en que se le denomira Tupac Catari. f. $4 \mathrm{v}, 7 \mathrm{v}, 9$, $15,16 \mathrm{v}, 17,17 \mathrm{v}, 18,18 \mathrm{v}, 19,19 \mathrm{v}, 20,20 \mathrm{v}, 23,24 \mathrm{v}, 25,26,27,27 \mathrm{v}, 29 \mathrm{v}, 30,31 \mathrm{v}$, $32 \mathrm{v}, 33,33 \mathrm{v}, 34,34 \mathrm{v}, 36 \mathrm{v}, 37 \mathrm{v}, 38,38 \mathrm{v}, 39,39 \mathrm{v}, 40,41,42,42 \mathrm{v}, 43,43 \mathrm{v}, 44$, $44 \mathrm{v}, 46 \mathrm{v}, 47,47 \mathrm{v}, 48,48 \mathrm{v}, 49 \mathrm{v}, 50,50 \mathrm{v}, 52 \mathrm{v}, 53,54,54 \mathrm{v}, 55,55 \mathrm{v}, 56,56 \mathrm{v}, 57 \mathrm{v}$, $58,58 \mathrm{v}, 64 \mathrm{v}, 67 \mathrm{v}, 68 \mathrm{v}, 70,71 \mathrm{v}, 72,74 \mathrm{v}, 77,78 \mathrm{v}, 79 \mathrm{v}, 80,82,88,92 \mathrm{v}, 93,93 \mathrm{v}$, $99,105,107,107 \mathrm{v}, 108,109$.

ARECHE, JOSE ANTONIO DE: Funcionario español de la Nueva España. El Ministro Gálvez, basándose en la eficaz ayuda que le había prestado en su visita a México, le nombró Visilador General en el Virreinato del Perú, en 1776. Debia ejecutar los planes reformistas de Carlos III en los planos administrativo, judicial, militar y, especialmente, económico. Tenia poderes sumamente amplios que le colocaban muchas veces por encima del Virrey. Su actuación en el Perú ha sido considerada un fracaso, pues, sin dotes para el cargo, se indispuso con el Virrey Guirior, con las Audiencias, los Cortegidores y los organismos económicos. Elcvó desmedidamente las tasas y alcabalas, persiguió con implacable saña a los rebeldes indígenas del 80 y 81 , terminando por ser destituído y reemplazado a fines de 1781 por Jorge Escobedo en su papel de Visitador. f. 33v, 46, 67v, 68, 80v, 105.

ARMENTIA, PROTACIO: En 1772 era Ayudante Mayor de la Compañia de Forasteros que pacificó Pacajes. En 1776 el Virrey Amat le nombró Sargento Mayor del regimiento de Dragones de Songo, en la provincia de Larecaja. Llegó después a los grados de capitán de infantería y teniente coronel. Fue edecán de Segurola y combatió en Laja y en El Alto de las Animas. Acompañó a Segurola a Oruro al juicio de los Rodríguez. En 1784 obtuvo la vara de Alcalde Ordinario en La Paz. f. 15v, 103v.

AYARZA, JOSE: Coronel que, al mando de las tropas cochabambinas, integró el ejército auxiliar del comandante Ignacio Flores, desde Mayo de 1781. Anteriormente había sofocado la rebelión de las provincias de Cochabamba después de vencer a los sublevados en 22 refriegas. f. $47,49 \mathrm{v}, 50$. 
BORDA, MATIAS: Fraile agustino, conventual de Copacabana, que por la presión de Tupac Catari, fue enviado por sus superiores como capellán del caudillo. A fines de Mayo logró escapar hacia La Paz, donde el 30 de Mayo de' 1781, redactó, a instancias de Segurola, un informe de lo ocurrido en El Alto. f. $29,31 \mathrm{v}, 33,33 \mathrm{v}, 34,34 \mathrm{v}, 37,38,38 \mathrm{v}, 41 \mathrm{v}$.

CAMPOS, FRANCISCO GREGORIO DE: Nació en el Virreinato de Nueva Granada en Maracaibo en 1718. Hizo estudios eclesiásticos en España donde permaneció largos años. Volvió a Anérica como arcediano de Santa Fe, llegando a ser más tarde deán de la catedral. Elegido obispo de La Paz, llegó a la ciudad en 1765 y allí permaneció hasta su muerte ocurrida en 1789. En el ejercicio de su vicariato realizó tres prolijas visitas pastorales a su diócesis. Participó en el Conciliso Platense en Cluquisaca, donde hubo de permanecer por cinco años.

Organizó el primer archivo del obispado con las Reales Cédulas, la correspondencia y las Cartas Pastorales.

Reorganizó los Aranceles para evitar los abusos y corruptelas de algunos curas párrocos. Con gran espíritu de empresa, antes del cerco de 1781, hizo refaccionar conventos y claustros, reedificó la parroquia de San Pedro extramuros y terminó los caniones de las bóvedas de Sar Francisco. También reconstruyó ocho iglesias en el altiplano. En el hospital de San Juan de Dios hizo construir dos salas que dotó con camas y ropas y destinó a la atención de sacerdotes enfermos y necesitados. Durante el cerco dio y vendió cuanto tenía para asilar en el Obispado a quienes se habian refugiado dentro de los muros; distribuyó alimentos y ropa, enterró a los muertos que quedaban hacinados por las calles debido a las pestes, calmó los ánimos de los vecinos e hizo cuanto pudo por apaciguar el furor indígena. También se le cita como Obispo, Ihustre Prelado o Su llustrísima en: f. $6,6 v, 7,7 v, 8,9,13,13 \mathrm{v}, 14,16,16 \mathrm{v}, 17,29 \mathrm{v}, 32 \mathrm{v}, 34,34 \mathrm{v}, 35,37 \mathrm{v}, 39 \mathrm{v}$, $43 v, 51 v, 52,52 v, 53,55,59,59 v, 63,65,82,95,96,96 \mathrm{v}, 107$.

CATARI, TOMAS: Cacique indio del pueblo de Macha. Desde 1778 luchó legalmente contra los abusos en el cobro de tributos y en el reparto de los Corregidores. A fines de 1778 llegó a Buenos Aires, donde fue atendido por el Virrey Vértiz quien dictó la sentencia a favor suyo, la misma que se encargaron de dejar sin cumplimiento tanto las autoridades locales como las de la Audiencia de Charcas. En vista de ello, inició una política de resistencia pasiva, designándose a sí mismo gobernador, realizando nombramientos y organizando a ojos vista a su gente para la sublevación a la espera de las órdenes de José Gabriel Tupac Amaru. Hecho prisionero, se levantaron los indios en Pocoata, en Agosto de 1780, tomando preso en rehén al Corregidor Alós. Liberado Catari en un intento de canje con aquél, prosiguió en sus andanzas hasta que el minero Manuel Alvarez Villarroel le apresó en Aullagas cogiéndole por sorpresa. Cuando le conducía a La 
Plata, el Justicia Mayor Juan Antonio Acuña, viendo que acudian milicias indígenas a rescatarle, le despeñó en la cuesta de Chataquila en la provincia de Yamparáez, desencadenándose así la rebelión en la Audiencia de Charcas. f. $1 v, 5,41 v, 64 v$.

ESCAURIZA, DIONISIO; Capitán español del regimiento de Dragones de la provincia de Omasuyos, que residia en La Paz desde mucho antes de las aconteccimientos de 1780. Se había caracterizado siempre por un temperamento impetuoso y alborotador que le habia llevado hasta a amenazar de muerte al Corregidor en 1772, novido por el desprecio que entonces sentía por la población criolla. (Autos contra Francisco Santelices... ANB.1772). Como militar tuvo actuación destacade durante el cerco. Como vecino tuvo choques más o menos violentos con el Comandante Segurola. f. $14,16 \mathrm{v}, 27,38,59 \mathrm{v}$.

ESCOBEDO Y ALARCON, JORGE: Siendo Gobernador de Potosí en la época de las rebeliones, logtó mantener su provincia libre de los levantamientos que se produjeron en las vecinas. Habiendo actuado durante su gobierno como subdelegado del Visitador Areche en Potosí, fue nombrado en su reemplazo, el 15 de Enero de 1782, cuando éste tue relevado de su cargo. El 25 de Junio ocupó la plaza para continuar la Visita encomendada a su predecesor, la que concluyó en 1785. Creadas las Intendemcias en el Virreinato del Perú, Escobedo ejerció paralelamente a sus funciones las de Super Intendente de la Intendencia General de Lima. A través de su carrera administrativa Escobedo desarrolló un gobierno muy acertado, realizando amplias reformas a pesar de las graves dificultades de orden interno y externo que se le presentaron. Finalizada su misión en Perú, pasó a España, donde integró el Consejo de Indias, volviendo a mostrarse allí como hombre ecuánime y prudente. f. 46.

FLORES, IGNACIO: Teniente Coronel, Gobernador de Moxos, a quien el virrey Vértiz confía el gobierno militar de Charcas durante las sublevaciones. Llegó más tarde a la presidencia de la Aưdiencia de Charcas. Había nacido en Quito, y era por lo tanto criollo. Había hecho la carrera de armas en España. Murió prisionero en Buenos Aires en 1786, adonde le enviaron sus enemigos de la Audiencia, acusándole de haber fomentado desórdenes y motines en Chuquisaca. f. 1v, 5v, 6v, 15, 15v, 21, 27, 27v, 28, 29, 32v, 33, 34, $35 \mathrm{v}, 36,37,38 \mathrm{v}, 40,43 \mathrm{v}, 44,44 \mathrm{v}, 45 \mathrm{v}, 46,48 \mathrm{v}, 49,49 \mathrm{v}, 50,53 \mathrm{v}, 54,54 \mathrm{v}, 58 \mathrm{v}$, $65,67,70,71 \mathrm{v}, 72 \mathrm{v}, 73,76 \mathrm{v}, 77,77 \mathrm{v}, 80 \mathrm{v}, 81 \mathrm{v}, 82,83 \mathrm{v}, 85 \mathrm{v}, 86 \mathrm{v}, 87 \mathrm{v}, 88,90 \mathrm{v}$, $94 \mathrm{v}, 95,98,98 \mathrm{v}, 99,102,103,104,105 \mathrm{v}, 107,108 \mathrm{v}$.

FRANCO, MANUEL TOMAS: Natural de Galicia, vino como Capitán de Milicias en 1770. En 1774 ya era Coronel de Dragones. En La Paz, sirvió desde el principio de la rebelión sin percibir sueldo ni gratificación alguna. Corrió con la dirección de la fundición de cañones, confección de cureñas y construcción de las fortificaciones con que se rodeó la ciudad. Con la Compañía 
de Granaderos de Songo participó en el ataque a Viacha el 10 de Marzo de 1781, población que quedó convertida en cenizas. Participó también en el ataque a Laja. Segurola lo empleó para que comandara varias salidas y destacamentos. Liberada La Paz, participó en la pacificación de Río Abajo y Yungas. Murió en La Paz en 1790. f, 5v, 8, 8v, 14, 14v, 17, 19v, 28v, 32, $37 \mathrm{v}, 39 \mathrm{v}, 48 \mathrm{v}, 96 \mathrm{v}, 106$.

GALLO, BERNARDO: Administrador encargado de la Aduana, contra quien se habían levantado los indios en Enero de 1780, pidiendo su cabeza. Había nacido en Génova. Murió trágicamente el 18 de Septiembre del 81, cuando, enioquecido, se salió de las muratlas para caer en manos de los indios que lo reclamaban contisuamente. f. $26 \mathrm{v}, 79,79 \mathrm{v}, 80,82 \mathrm{v}, 99$.

GIL DE ALIPAZAGA, FERMIN: Nació en la villa de Bilbao en 1715. Pasó a América y en 1765 el Presidente de la Audiencia de Charcas, Juan de Pestaña, le nombró Capitán de una de las compañias del Tercio de Milicias dé La Plata. Más tarde, en 1767, pasó con el miśmo cargo de Capitán a la Compañia de Forasteros de esa ciudad, con aprobación del Virrey Amat. Alti se casó con doña Braulia Camberos. En 1774 volvió a España a disponer asuntos de herencia, por la muerte de su padre. En esa estancia en la peninsula obtuvo el titulo de Caballero de la Orden de Santiago. Fue electo Corregidor de la ciudad de La Paz en 1776 y, como tal, le tocó actuar en los alborotos producidos a raiz de la creación de la Aduana y de las medidas económicas tomadas por el Visitador Areche. Estando todavía en el desempeño de ese cargo se produjo la sublevación de Tupac Catari y la venida del Coronel Segurola como Comandante de Armas de la ciudad, sobreviniendo graves problemas entre ambos personajes. En 1782 fue depuesto de su cargo por el Virrey Vértiz, el cual atendió las quejas que en su contra lanzaron el Comandante Segurola y el Fiscal de la Audiencia de Charcas, Fernando Márquez de la Plata.

Don Fermin Gil de Alipazaga protestó de tal medida ante la Audiencia, ante el propjo Virrey y posteriormente ante el Consejo de Indias. En España fue aiendido y, reconsiderándose la medida, se dispuso restituirle su dignidad; se ordenó, asimismo, a Márquez de la Plata y a las herederas de Segurola indemnizarle por los daños y perjuicios como tam. bién por los sueldos no percibidos. Desgraciadamente, debido a la lentitud burocrática y a la imposibilidad de presionar a aquellos personajes, el antiguo Corregidor murió en la mayor indigencia en Madrid. Sus hijas, pobres y abandonadas, prosiguieron el trámite hasta los años de la Independencia sin obtener ningún resultado positivo. Citado también como Corregidor. f. 5v, 9v, 13, 13v, 35v, 36, 37v.

ITURRALDE, jUAN FERNANDO: Capitán de la Compañía de Granaderos. Vecino de honor y distinción, fue Alcalde Ordinario de Segundo Voto en 1775. Casó con María del Carmen Diez de Medina, hija de don Tadeo Diez de 
Medina, importante y rjco criollo que mantuvo larga actividad en el Cabildo de La Paz. f, 12, 33, 33v 81 .

LLANO, MIGUEL ANTONIO: Coronel de Caballería. Ministro Tesorero de Real Hacienda. Ocupó ese cargo en La Paz, porque, como lo era en propiedad, debía reemplazar a Pedro Nolasco Crespo que estaba en Lima. Confeccionó una "Certificación Referente a los Quebrantos y Padecimientos de la Ciudad de Nta. Sra. de La Paz", por mandato de Segurola, cuando éste era Intendente de $\mathrm{La} \mathrm{Paz}$, en 1787. Ł, 27.

MARQUEZ DE LA PLATA, FERNANDO: Nació en Sevilla en 1740. En 1776, Carlos III le nombró Fiscal Protector de Indios en Charcas y luego Fiscal del Crimen de la Audiencia. Llegó a América con Ceballos, el primer Virrey de Buenos Aires, en la misma expedición en que venía Sebastián de Segurola, pero permaneció en Buenos Aires hasta 1779, como Auditor de Guerra. En 1780 recibió comisión del Virrey Vèrtiz para que fuera a La Paz como Comisionado y Juez, con el Teniente Coronel Ignacio Flores, con el fin de sofocar los levantamientos ocasionados en la ciudad por las cuestiones de la Aduana. Ejerciendo todavía esas funciores le sorprendió la rebelión general, por lo que se le ordenó permanecer en la ciudad para que asesorara al Comandante Segurola en lo econónico y jurícico. Aún cuando en Julio de 1781 fue nombrado Alcalde del Crimen de la Real Audiencia de Lima, por las razones anotadas no ocupó su cargo sino hasta 1782. Creadas las Intendencias se hizo cargo de la de Huancavelica. En 1789 volvió a Lima como Oidor. En 1796 fue nombrado Regente de la Audiencia de Quito y en 1803 de la de Santiago de Chile. En 1806 se le designó Consejero de Indias, cargo que no alcanzó a ocupar por los acontecimientos provocados por la invasión de Buenos Aires por los ingleses, así como por los de Napoleón en España. En 1810 integró, como español, la Primera Junta de Gobierno en Santiago de Chile. Por apoyar la independenica americana, debió huir a Mendoza durante la reconquísta española. En 1818 O'Higgins le encargó la presidencia de la Cámara de Justicia, la que no alcanzó a ejercer porque murió ese mismo año. f. $5 \mathrm{v}, 6 \mathrm{v}, 7 \mathrm{v}, 13 \mathrm{v}, 37 \mathrm{v}, 43,52$, $53 \mathrm{v}, 57,84 \mathrm{v}$.

MOYA Y VILLARREAL DE, RAMON: Gobernador de Chucuito que participó, junto al Corregidor Joaquín de Orellana, en las campañas contra las fuerzas de Tupac Amaru y Tupac Catari. Destruída Chucuito, se refugió con su gente en Puno, que abandonó más tarde, a causa de una herida que le obligó a refugiarse en Arequipa. Tuvo desavenencias con Orellana, que le recriminó su alejamiento; para justificarse escribió una relación de todos los acontecimientos en forma de un Diario. f. 7 .

MURILLO, MARLANO: Soldado de La Paz que fue cogido prisionero por los indios el 9 de Mayo. En El Alto le ocuparon para enseñar a los alzados el manejo de las armas de fiego y para disparar pedreros a la ciudad. Allí se puso en 
contacto con el padre Borda, acordando desviar los disparos y buscar modos de enviar avisos a Segurola. Siendo sorprendido, le fueron cortados ambos brazos, enviándosele en esas condiciones a la ciudad. Alcanzó a informar al Comandante sobre la situación real de los sublevados, asi como del avance de las tropas auxiliares, muriendo a consecuencia de la hemorragia el 10 de Jumio de 1781. f. 27v, 29v, 31v, 33v, 34, 37v, 38, 38v, 39, $40 \mathrm{v}$.

OBAYA, PEDRO: Tuerto Obaya. Indio de Azángaro que, haciéndose pasar por el sobrino de Tupac Amara, llegó hasta las regiones levantadas por Tupac Catari. Con gran inteligencia inspiró muchos de los asaltos y planes de Apaza. Se le llamaba el Rey Chiquito; habiendo cajdo en manos de los españoles durante el cerco, se le juzgó y ejecutó el día 5 de Agosto de 1781 . f. $18 \mathrm{v}, 19,25,25 \mathrm{v}, 34,36,42 \mathrm{v}, 85 \mathrm{v}$.

ORELLANA DE, JOAQUIN ANTONIO: Corregidor de Puno. Desde el 1 de Enero de 1781 adiestró y disciplinó milicias para hacer frente a la sublevación de Tupac Amarta. Pidió auxilios a Lampa, Azángaro, Carabaya y La Paz y salio el 7 de Febrero a realizar expediciones a las regiones levantadas sosteniendo luchas con las huestes de Andrés ingaricona. El estado de Ia rebelión le convenció que debia hacerse fuerte en Puno; allí pudo resistir dos ataques, el 10 de Marzo y el 9 de Abril de 1781, siendo su ciudad la única que quedó en pie en esas regiones. Por fin, el 24 de Mayo, después de un último cerco realizado esta vez por Diego Cristóbal Tupac Amaru, quedó la ciudad libre en los momentos en que llegaba el auxilio de las fuerzas veteranas de Lima. José del Valle, el 26 de Mayo de 1781, le obligó a abandonar la ciudad llevando consigo a todos los vecinos en una dolorosa marcha al Cuzco. La medida constituyó un grave error militar que Orellana nunca perdonó. f. 6v, 7, 12, 23v, 33v, 35, 35v, 44 .

PINEDO Y MONTUFAR, ANTONIO: Caballero de la Orden de Santiago, nacido en Madrid. Nombrado Coronel de Milicias de Intantería por el Comandante Segurola, fue propuesto más tarde como Capitán de Caballería en mérito de su participación en la defensa. Se casó en La Paz en 1751 con Micaela Justina Bilbao la Vieja. Según Aranzaes, este matrimonio le convirtió en vecino importante y en hombre de gran fortuna. Entre 1750-52 fue Corregidor de La Paz. Por tres veces fue Alcalde Ordinario del Cabildo. $f$. $5 v, 6,9 v, 10$.

PINEDO Y MONTUFAR, IGNACIO: Hermano de Antonio Pinedo, también nació en Madrid. Instalado en La Paz se casó en segundas nupcias con María del Carmen Bilbao la Vieja Fernández Pacheco Diaz Escalante, hija de la Marquesa de Aso, con lo que obtuvo el título. En su calidad de Capitán de Ejército, acompañó a Segurola como su segundo en el ataque a Laja. Tuvo participación activa en la defensa de la ciudad durante el asedio de Tupac Catari. Todo ello le mereció ascender a Teniente Coronel. Antes había 
ocupado el cargo de Tesorero Oficial interino en las reales Cajas, cargo que dejó para colaborar dentro del campo militar al que pertenecia, durante la época de las rebeliones. f. $5 v, 9 v$.

PINEDO, JOSE: Coronel de Milicias nacido en España. Segurola le enveorganizar las fuerzas militares de Omasuyos y Larecaja para proseguir con ellas hacja Puno, con el fin de auxiliar al Corregidor Joaquín de Orellana. Por la gravedad de la sublevación en las provincias vecinas al lago sufrió varias derrotas que le impidieron llegar a Puno. Se contrajo entonces a preparar, junto a Gregorio Santalla, la defensa de Sorata, amenazada por Andrés Tupac Amaru. Tuvo con éste varios intertos de entendimiento y en una de aquellas entrevistas, poco antes de iniciarse el cerco de Sorata, fue asesinado junto a Santalla, después de un fracasado intento de prender o matar al caudillo indigena. f. $6 \mathrm{v}, 7 \mathrm{v}, 9,12 \mathrm{v}, 44,56,72 \mathrm{v}, 81,96 \mathrm{v}$.

QUEVEDO, GAVINO: Militar que comandaba un regimiento espanol destinado a auxiliar a La Paz y que fue derrotado por Tupac Catari en las cercanias de Sicasica. Allí pereció, con casi todos los hombres de su destacamento, a fines del mes de Mayo de 1781.t. 38v, 46v, 106.

RESEGUIN DE, JOSE: Militar español que vino a América como Teniente Coronel del regimiento de Dragones del Rey con destino a Montevideo. Producida la sublevación en Chayanta y Tucumán, el Virrey Vértiz le envió a sofocarla. Organizó entonces el contingente de Milicias Reales de un regimiento de Dragones de Saboya. Pasando por Salta a Charcas, pacificó las provincias de Chichas, Cotagaita y Tupiza. Participó en la expedición del Comandante Flores para liberar la ciudad de La l'az. Más tarde, la Audiencia de Charcas le nombró Comandante General y Cobernador de Armas. Cuando La Paz fue nuevamente cercada, en Agosto de 1781, le tocó organizar y conducir la expedición que liberó la ciudad el 17 de Octubre, después de haber vencido a las huestes indígenas de Oruro, Sicasica y Yaco. Continuó más tarde la pacificación instalando su cuartel general en el santuario de Peñas. Sin embargo, no pudo proseguir en sus funciones militares por haber contraido fiebres malignas, siendo reemplazado en sus tareas por el Comandante Segurola. Fue el primer Intendente de Puno, donde permaneció hasta 1789. f. 45v, 46, 103, 104, 105v, 108, 108v.

ROGERS, CARLOS: Cabaliero de nacionalidad inglesa, a quien el Virrey Ceballos autorizó a vivir libremente en el virreinato, puesto "que había abjurado de sus errores"; llegó a América en 1762. Vino como guardiamarina de una nave inglesa que atacó la plaza de la Colonia; prisionero en los primeros años, obtuvo más tarde su libertad. Establecido en La Paz, tuvo gran actuaciôn en la preparación y organización de las milicias que defendieron la ciudad durante el asedio. Como Ayudante de "Mayor General" participó en muchas salidas y expediciones, por lo que en 1783 el Consejo de Indias, a petición de Segurola, le concedió el grado de Capitán del Ejército. $\mathrm{t}$. 5v, $17,28,33,33 \mathrm{v}, 37 \mathrm{v}, 38,39 \mathrm{v}, 40$. 
SAENZ DE TEIADA, ANTONIO: PToveedor General de La Paz desde Febrero de 1781. Ocupó ese cargo hasta el 17 de Octubre de ese mismo año cuando, agobiado por el peso y las responsabilidades inherentes al oficio, renunció. Sus cuentas fueron aprobadas por el Defensor de Real Hacienda José María Sanjurjo, mereciendo en Enero de 1782 que se le agradeciese a nombre del monarca la eficacia, pureza y fidelidad con que manejó los bienes de la Real Hacienda. f. 7.

SALGADO, JOAQUIN: Capitán de Infantería que vino a Charcas con las fuerzas de Reseguín. Dirigió el regimiento de Saboya. El 5 de Abril cie 1782, fue enviado por Reseguin, con 50 hombres, para iniciar Ia pacificación de Cotagaita. Llega a Macha a reunirse con Ignacio Flores, junto a los saboyanos y dragones. Según Flores, Salgado cometió varios errores "por desobediencia e indisciplina", perdiendo varias acometidas. Sin embargo, cumple un papel importante al defender La Paz en el segundo cerco. Salgado es duro e implacable en sus órdenes contra los indios y desertores. Intervino en la pacificación de Cohoni bajo las órdenes de Segurola y en la de Sicasica, bajo el mando de Reseguín: f. 52, 68, 85v, 99.

SANJURJO DIEZ DE MEDINA, JOSE MARIANO: I lijo del Maestre de Campo José Antorio Sanjurjo y de una hermana del Oidor Diez de Medina. Estudió letras, filosofia y teología en el Colegio de San Cristóbal. Obtuvo el doctorado en cánones y leyes en la Universidad de San Francisco Xavier de Chuquisaca, examinándose como abogado en la Real Audiencia de Charcas y de Lima. Fue Asesor General del Cabildo en Potosí, Oruro y La Paz. Instalado en esta ciudad, fue Defensor de Menores y Defensor de Rea? Hacienda. Más tarde llegó a ser Aicalde Ordinario de Primer Voto. Agregado a las milicias, ocupó el cargo de Capitán Comandante de Dragones de la provincia de Omasuyos. Durante la sublevación, llegó a ser Teniente Coronel de Milicias y Comisario de Guerra. Cuando se realizaron los juicios y sentencias contra los alzados, actuó como Fiscal Acusador. $f$. $16 \mathrm{v}, 19,19 \mathrm{v}, 22,22 \mathrm{v}$.

SEGUROLA DE, SEBASTLAN: Nació en Azpeitia, Guipúzcoa, en Enero de 1740. En España hizo la carrera militar. Llegó a América con don Pedro Ceballos, primer Virrey de Buenos Aires. Venía con el cargo de Corregidor de Larecaja. El 30 de Diciembre de 1780, por orden de la Audiencia de Charcas, se trasladó a La Paz para ejercer la Comandancia de Armas ante la gravedad de los sucesos acaecidos en las regiones levantadas por Tomás Catari y Tupac Amaru, que hacian prever su prolongación hacia Sicasica, Pacajes y La Paz. Dispuso la fortificación de la ciudad, así como el abasteciniento y los medios de defensa. Dirigió la resistencia durante los dos cercos con admirable tenacidad y capacidad militar. Liberada La Paz, apagó la rebelión en la región de Collana y Río Abajo y, sucediendo a José de Reseguin, contribuyó eficazmente a la pacificación definitiva de Charcas. En 1784, después de haber ascendido a Coronel de Infantería y 
Brigadier, fue designado Intendente de La Y’az. En 1786 se casó con doña Josefa Ursula de Rojas y Foronda, con la cual tuvo dos hijas. Murió en La Paz el 2 de Octubre de 1789. Citado también como Comandante. f. 5v, 6, 6v, $7,7 \mathrm{v}, 8,8 \mathrm{v}, 9,9 \mathrm{v}, 10,10 \mathrm{v}, 11,11 \mathrm{v}, 12,13,13 \mathrm{v}, 14,14 \mathrm{v}, 15 \mathrm{v}, 16,17,17 \mathrm{v}, 18 \mathrm{v}$, $19,19 \mathrm{v}, 21 \mathrm{v}, 22 \mathrm{v}, 23 \mathrm{v}, 24,24 \mathrm{v}, 25,25 \mathrm{v}, 26,26 \mathrm{v}, 27,27 \mathrm{v}, 28 \mathrm{v}, 29,29 \mathrm{v}, 31,3 \mathrm{v}$, $32,32 \mathrm{v}, 33,33 \mathrm{v}, 34 \mathrm{v}, 35,35 \mathrm{v}, 36,36 \mathrm{v}, 37,37 \mathrm{v}, 38,39,40,40 \mathrm{v}, 41 \mathrm{v}, 42 \mathrm{v}, 43$, $43 \mathrm{v}, 44 \mathrm{v}, 48,48 \mathrm{v}, 49,49 \mathrm{v}, 52,53,57,59 \mathrm{v}, 66,68 \mathrm{v}, 69 \mathrm{v}, 72 \mathrm{v}, 73 \mathrm{v}, 74,77 \mathrm{v}, 78$, $79 \mathrm{v}, 81 \mathrm{v}, 84 \mathrm{v}, 85 \mathrm{v}, 87,87 \mathrm{v}, 88,88 \mathrm{v}, 90,91,93,94,94 \mathrm{v}, 95,96,96 \mathrm{v}, 99,99 \mathrm{v}$, $103,107$.

SISA, BARTOLINA: Mujer de Tupac Catari. Nacida en Caracato, se habia avecindado en Sicasica donde ejercía el oficio de lavandera y tejedora. Activa colaboradora de su marido, alistó gente, combatió junto a los suyos y dirigió el cerco de La Paz en las ausencias del caudillo. Cayó prisionera por traición de uno de sus companeros el 2 de Julio de 1781 y fue ejecutada, después de ser enjuiciada y condenada por el Oidor Francisco Tadeo Diez de Medina, el 5 de Septiembre de 1782. f. $31 \mathrm{v}, 33 \mathrm{v}, 35,35 \mathrm{v}, 36,48,48 \mathrm{v}, 54,57 \mathrm{v}$, $79 \mathrm{v}, 82,83,92 \mathrm{v}, 109$.

TUPAC AMARU, JOSE GABRIEl: José Gabricl Condorcanqui Noguera Tupac Amaru, indio noble, cacique de Pampamarca, Tungasuca y Surimana. Descendjente en línea directa de la hija de Tupac $\wedge$ maru, el último Inca, ajusticiado por el Virrey Toledo en 1572. Nació en Tinta el 19 de Marzo de 1740. Se educó en el Colegio de Indios Nobles de San Francisco de Borja del Cuzco y más tarde estudió Artes en Sar Marcos de Lima. Casó con doña Micaela Bastidas. Después de obtener el reconocimiento oficial de su cargo de cacique, se dedicó, aprovechando el gran ganado de mulas que poseía, al transporte de mercaderías por las rutas que unían los dos Virreinatos. A través de este continuo peregrinaje, preparó los ánimos de los indígenas y organizó la sublevación general que estallaría en 1780. En Noviembre de aquel año, tomó prisionero e hizo ahorcar en Tungasuca a! Corregidor Arriaga, con lo que se inició la sublevación en el Perú. Después de la victoria de Sangarara, se apoderó de Lampa y Azángaro, para terminar atacando el Cuzco, que no logró ocupar. A mediados de Enero, se retiró hacia las provincias del Collao, iniciándose una época de ataques y contraataques con las fuerzas españolas mandadas por el Comandante José del Valle. En Abril de 1781, traicionado en Langui por Francisco Santa Cruz, fue tomado prisionero con su mujer y sus dos hijos y conducido al Cuzco. Sentenciado por Areche el 15 de Abril, fue ejecutado con inaudita crueldad el 18 de Mayo del mismo año. $f$. Iv , 2, 2v, 3v, 4, 5, 7v, 9, 12, 15, $15 \mathrm{v}, 16,18 \mathrm{v}, 23 \mathrm{v}, 25,31 \mathrm{v}, 33 \mathrm{v}, 35,41 \mathrm{v}, 44,46,55,59 \mathrm{v}, 62 \mathrm{v}, 63,68,75$.

TUPAC AMARU NOGUERA, ANDRES: Hijo o sobrino de José Gabriel Tupac Amaru; sobrino de Diego Cristóbal Tupac Amaru. Vino al Collao desde el Cuzco, enviado por Diego Cristóbal para vigilar la sublevación de dicha región, junto con los coroneles Miguel Bastidas, Juan de Dios Mullupuraca, 
Pedro Vilca Apaza, los dos hermanos Quispe y Andrés Laura. Amante de Gregoria Apaza, la usaba de nexo para controlar a Tupac Catari, hermano de ella, logrando que le diera armas y gente bien entrenada. Se dirigió a tomar Sorata; para ello consiguió que españoles, criollos e indígenas, ya sea por miedo, como Molina, o por propia voluntad, como Gil Blas, to apoyaran y le dieran sus armas de fuego y luchen en el asedio de la ciudad hasta lograr su caída. Inició el asedio de Sorata el 4 de Mayo de 1781, con 18 a 20 mil hombres, cayendo la ciudad en sus manos el 5 de Agosto del mismo año. Más tarde, retorna al Cuzco, llamado por su tío Diego Cristóbal; deja a Miguel Bastidas en su lugar, colaborado por los otros coroneles antes citados: f. 55v, 62, 62v, 65, 66, 67v, 71v, 76, 76v, 78, 80, 80v, 82, 84, 85v, 86v, $87,91,94 \mathrm{v}, 95,98,98 \mathrm{v}, 104 \mathrm{v}$.

VERTIZ DE, IUAN JOSE: Personaje español que reemplazó a Ceballos, primer Virrey del Río de la Plata. Fue en realidad el gran organizador del Virreinato, realizando en su administración todas las reformas de la época ilustrada. Le tocó enfrentar el problema de las sublevaciones indígenas de Charcas, territorio que pertenecía al Virreinato del Plata desde su creación en 1776. $6.34,10] \mathrm{v}, 104 \mathrm{v}, 706$.

ZAVALA, JUAN BAUTISTA: Teniente Coronel del Regimiento de Dragones de Pacajes. Vizcairo de nacimiento, participó con gran valentía en todos los episodios de la lucha contra los alzados. Dirigió la fabricación de la pólvora y la construcción de los fuertes en la muralla defensiva. Desempeñó con acierto las tarcá imo le encomendó Segurola en la defensa. f. $11,14 v, 21 v, 22,29 v_{s} 34 v, 40.41$. 



\section{TOPONIMIA URBANA 1}

Achachicala; actualmente barrio ubicado en la zona N.O. de la ciudad de La Paz: 15, $31 \mathrm{v}, 36 \mathrm{v}, 37,43 \mathrm{v}, 48,51 \mathrm{v}, 75 \mathrm{v}, 77 \mathrm{v}, 86 \mathrm{v}$.

Alto, El; zona del altiplano ubicada al $O$. de La Paz al borde de la hoyada en que se sitúa la ciudad: $9 \mathrm{v}, 10,10 \mathrm{v}, 11 \mathrm{v}, 12,12 \mathrm{v}, 14 \mathrm{v}, 15,16,16 \mathrm{v}, 17 \mathrm{v}, 18,20,20 \mathrm{v}, 21$, $21 \mathrm{v}, 22 \mathrm{v}, 23,23 \mathrm{v}, 24,24 \mathrm{v}, 26,26 \mathrm{v}, 27,27 \mathrm{v}, 28,28 \mathrm{v}, 29,29 \mathrm{v}, 30,31 \mathrm{v}, 32 \mathrm{v}, 33 \mathrm{v}$, $34,34 \mathrm{v}, 35,37 \mathrm{v}, 38,38 \mathrm{v}, 43 \mathrm{v}, 44,44 \mathrm{v}, 48,48 \mathrm{v}, 50,52 \mathrm{v}, 55 \mathrm{v}, 65 \mathrm{v}, 57$.

Alto de la Batalla; denominación que da Tupac Catari a su campamento en El Alto: $16 \mathrm{v}$.

Alto de Laja; cuesta que sube al Alto y comunica con el camino a Laja: 11v, 13, 20v, $21,25,26 v, 30,32 v, 33 v, 48 v$.

(1) Con el ánimo de que el lectur no se limile a emplazar a La Paz dentro del gran ámbito geogrático abarcudo por las tebeliones indígenas de los Amaru y los Catari, se ha pensado en elaborar tombién un indice de la Toponimia Urbana, para que el interesado tenga una vivencia mejor de lo que ocurríu por entonces, mirando también hacia dentro de la ciudad, que era donde propiamente se desamollaba la tragedia contada por el autor del Diario.

Verdaderamente, las referencias del Oidor a calles, iglesias, conventos y casas son mucho más interesantes si se las puede identificar con los lugares correspondientes de la imagen actual que presenta la ciudad. Las referencias de Diez de Medina en este sentido son un testimonio muy rico porque corresponden a las de un vecino que por haber nacido en la ciudad la ama y conoce basta sus últimos detalles. Ello ha permitido que la localización de los sitios mencionados en el Diario haya sido relativamente fácil puesto que la estructura urbana, tan condicionada por la topografía, ba hecho que las líneas generales de la cjudad no hayan cambiado gran cosa, pudiéndose reconocer la ubicación precisa, aunque el aspecto de los edificios y la imagen de las calles sean hoy un tanto diversas.

Para facilitar el uso del Indice se ha acompañado esta publicación con el plano de la ciudad en 1781 ; la carta no tiene la perfección que podía pedírsele a un urbanista; simplemente es el resultado de la adaptación que se la hecho del plano de La Paz confeccionado por losé Rodriguez en 1948, cuando era Alcalde de la cjudad Luis Nardín Rivas. De esta carta se han eliminado los barrios que por entonces no existían y se te ha agregado, en cambio, el trazado de los ríos que hoy corren entubados, con sus puentes correspondientes, asi como el contomo de las murallas construídas por Segurola. 
Alto de Lima; también se denomina del Cuzco, cuesta que subiendo al Alto comunica con el camino a Lima. En él convergía el camino a Laja que pasaba por Viacha; el camino recto y abrupto pasaba por El Tejar y el actual cementerio, desembocando en la calle Ancha de San Sebastián, hoy Av. América: $9 \mathrm{v}, 10,11 \mathrm{v}, 18,55,57 \mathrm{v}, 58,58 \mathrm{v}, 84,85 \mathrm{v}, 87$.

Alto de Potosí; cuesta que subiendo al Alto comunicaba con el camino a Potosí. Bajando por el Deshecho, actual calle Villamil de Rada, y Sagárnaga, 1legaba al puente de San Francisco: 9v, 11v, 12v, 13, 14, 17, 17v, 18, 18v, 19, $20,21,21 \mathrm{v}, 22,23,23 \mathrm{v}, 24,25,26 \mathrm{v}, 28,29,29 \mathrm{v}, 31 \mathrm{v}, 32,35 \mathrm{v}, 39 \mathrm{v}, 40,42,43$, $43 \mathrm{v}, 49,55,57,57 \mathrm{v}, 58,58 \mathrm{v}, 77,85 \mathrm{v}, 103$.

Ayuntamiento; Casa Consistorial ubicada en la Plaza de Armas en el lugar que hoy ocupa el Palacio de Cobierno: $31 \mathrm{v}$.

Caja del agua; actual parque Riosinho: 15, 15v, 19v, 22, 22v, 27, 28v, 29, 36v, 37, 38v, $39 \mathrm{v}, 42 \mathrm{v}, 43,68,68 \mathrm{v}, 73,79 \mathrm{v}, 81 \mathrm{v}, 86,99 \mathrm{v}$,

Calpani o Colpani; cuesta que se derivaba de la de Lima o del Cuzco: 10v, 22, 45v.

Calvario; la denominación comprende a la ccja, al alto y a la línea ubicados en la zona norte de La Paz: 15, 16v, 18, 20, 21v, 22, 22v, 23, 26v, 27v, 28v, 29, 32v, $39 v, 40,40 v, 41,41 v, 42 v, 43,52 v, 72 v, 73,77 v, 86,102$.

Calle Ancha de San Sebastián: actualmente ocupa las calles Evaristo Valle y Av. de las Américas: $16 \mathrm{v}, 17,29 \mathrm{v}, 31 \mathrm{v}, 41,97$.

Calle de la Cercantia; véase Carcantia.

Calle del Carmen; véase Carmen, El.

Calle de la Paciencia: véase Paciencia.

Campo de la Capilla; lugar ubicado en la cuesta de San Pedro: 14, 15v, 16v, 18, 21, $28 \mathrm{v}, 31,33,48 \mathrm{v}, 49$.

Cámpo Santo de la Catedral; cementerio ubicado detrás de la Catedral en un alto que miraba a la cuesta de Potosi: $23,27,28,29,32 \mathrm{v}, 34$.

Campo Santo del Colegio Viejo; debe tratarse de un cementerio abierto por el Obispo en el antiguo Seminario; a veces se le denomina Cementerio Nuevo: $33 \mathrm{v}$, $35,43 \mathrm{v}$.

Carcantia: barrio que rodea a la actual calle Catacora: $19,40 \mathrm{v}, 41 \mathrm{v}$.

Camnen, El; calle, barrio, fortaleza y puente que rodean al monasterio del Carmen. También figura como Santa Teresa: 15v, 19v, 23v, 25, 29, 36v, 39, 41, 48v, $49 v, 69,69 v, 79 v$. 
Cárcel; (Cárcel Real) mazmorras que ocupaban la parte baja del Ayuntamiento. Actualmente corresponden a dependencias del Palacio de Gobierno: 34, $42 \mathrm{v}$.

Catedral; construida en el siglo XVIL y reemplazada en 1831 por la fábrica actual; ocupaba el mismo emplazamiento, tenía una nave central y capillas laterales, tenía dos torres laterales y una portada de piedra: $22 \mathrm{v}, 25 \mathrm{v}, 27 \mathrm{v}$, $28,29,29 \mathrm{v}, 30,37 \mathrm{v}, 49 \mathrm{v}, 60,71,73 \mathrm{v}, 87,107$.

Cenizal del Río Seco; nombre con que designa Diez de Medina a un cenizal que existía al pie del Quilliquilli por Santa Bárbara y al que se salía por la puerta de Santa Teresa. Seguramente debe tratarse del rio Mejahuira: 41v.

Colegio de Ios Jesuitas, ex; antiguo colegio de los Jesuitas, donde se encontraba El Loreto en la Plaza Mayor y que en 1781 servía de cuartel: 38.

Colegio Viejo: edificio del antiguo Seminario que estaba ubicado frente al Convento de las Carmelitas: $32 \mathrm{v}$.

Concebidas; calle, puente y barrio que rodeaban al convento de las Concebidas, actualmente ubicado entre las calles Ingavi y Genaro Sanjinés. También figura como la Concepción: $30,36 \mathrm{v}, 40,49 \mathrm{v}$.

Crucero, El; Jugar en que se encontraban los caminos de la cuesta de Potosí y de San Pedro: 13, 14.

Cusipata; campo cercano a la Caja del Agua: 22v.

Cuesta de Coroico; camino que llevaba hacia los Yungas: 27v, 39v.

Cuesta del Cuzco; véase Alto de Lima: $9 v, 11 v, 54 v, 57,73,75 v$.

Chacarilla de Diez de Medina; figura también como Casa de Campo de Diez de Medina; por las referencias del Oidor se puede pensar que estaba detrás de las zonas de San Francisco y San Sebastiấn: 26, 33, 35.

Chacarilla de Oquendo o de Monje; casa de campo posiblemente ubicada en la zona llamada La Chacarilla detrás de de San Sebastiấn: 15v.

Chocata; calle y barrio que servía de nexo a las zonas de San Francisco y de San Sebastiản: 14.

El Alto; véase Alto, El.

El Tejar; alto de la cuesta de Laja a la entrada de La Paz: 11v, 13, 15v, 18, 22v, 23v, $24 \mathrm{v}, 25$.

Espaldón de la Parada; una de las trincheras de la muralla defensiva de La Paz: 17v. Espaldón de Salazar; trinchera de la muralla que miraba al Calvario $41 \mathrm{v}$.

Estancia de Apaña; hacienda perteneciente a las monjas carmelitas: 23. 
Fosa del Seminario Viejo: véase Campo Santo del Colegio Vicjo.

Fuerte de la Paciencia; véase La Paciencia.

Fuerte de San Miguel; fuerte hecho construir por el Oidor Diez de Medina en la parte de la muralla que miraba a la Caja del Agua: 29v, 40, 42v, $81 \mathrm{v}$.

Fuerte de Zavala; fuerte que miraba al Calvario, cercano a la fábrica de pólvora: $22 \mathrm{v}$.

Hampaturi; región cercana a La Paz, situada al sur de la ciudad: $43 \mathrm{v}$.

Hospital de San Juan de Dios; véase San Juan de Dios.

La Merced; iglesia y convento que ocupaba la misma ubicación actual: $27 \mathrm{v}$.

La Misericordia; hospital y cementerio ubicados en la segunda y tercera cuadra de la actual calle Socabaya: 29,34 .

Las Recogidas; (Nazarenas) convento destinado a cárcel de mujeres, ubicado fuera de los muros al otro lado del río, en una casa donada por el Obispo Campos en la actual esquina de la calle Cochabamba con la Santa Cruz: 15, $23 \mathrm{v}, 24,26,27,28,29 \mathrm{v}, 32,33,36,36 \mathrm{v}, 37,39,39 \mathrm{v}, 40,41,67 \mathrm{v}, 69 \mathrm{v}, 76 \mathrm{v}, 79$, $81 \mathrm{v}, 82,100,100 \mathrm{v}$.

La Riverilla; región vecina a La Merced donde se hallaba un puente que conducía a un camino que se encontraba con el que sălia del fuerte de Santa Teresa y que conducían a Obrajes: $35 \mathrm{v}, 41,69,88 \mathrm{v}, 94 \mathrm{v}$.

La Paciencia; fuerte y plazuela que ocupaba la zona de la actual plaza Pérez Velasco: $15 \mathrm{v}, 20 \mathrm{v}, 22,27,29,32,33 \mathrm{v}, 34 \mathrm{v}, 35 \mathrm{v}, 40 \mathrm{v}, 41,42,42 \mathrm{v}, 59 \mathrm{v}, 72 \mathrm{v}, 74,75,75 \mathrm{v}$, $78,78 \mathrm{v}, 79 \mathrm{v}$.

Machacamarca: fuerte construído por los sublevados en el cerro de Potopoto: 35v. Mercaderes, calle de; una de las calles de La Paz ubicada dentro de los muros: 27v, 83. Mercado Nuevo: ubicado en la garita del camino a Potosí: 43 .

Merced, La; véase La Merced.

Misericordia; véase La Misericordia.

Molino Viejo; situado en la parte baja del monasterio de Las Concebidas: $40 \mathrm{v}$.

Munaipata; zona ubicada al frente del fuerte de La Paciencia: 37, 58v, 67, 73, 75, 77, $78 \mathrm{v}, 85 \mathrm{v}, 87,89 \mathrm{v}, 91,96 \mathrm{v}, 99$.

Orcoaviri; (Orcojahuira) río que corría por la zona noreste de La Paz, menos caudaloso que el Choqueyapu, desembocaba en éste: $14,19 \mathrm{v}, 48 \mathrm{v}$. 
Pạciencia; véase La Paciencia.

Palacio Episcopal; ubicado en la Plaza Mayor, actualmente en la esquina de las calles Ballivián y Bolivar: 35 .

Pampajasi: zona vecina a Potopoto en las inmediaciones de La Paz: 49, 54v, 55, 55v, $56,56 \mathrm{v}, 57,57 \mathrm{v}, 58,58 \mathrm{v}, 72,73,76,77,86 \mathrm{v}, 99,105$.

Plaza Mayor; actual Plaza Murillo: 9v, 13v, 14v, 22, 23, 24, 26v, 27v, 29v, 30, 31v, 36, $37 \mathrm{v}, 40 \mathrm{v}, 44 \mathrm{v}, 68,73,77,79,81,87$.

Potopoto; zona que ocupa actualmente el barrio de Miraflores: $13,14,14 \mathrm{v}, 15,17$, $19 \mathrm{v}, 20,22,26,26 \mathrm{v}, 27 \mathrm{v}, 29,30,32 \mathrm{v}, 33 \mathrm{v}, 34,34 \mathrm{v}, 35,36,36 \mathrm{v}, 39,39 \mathrm{v}, 40,43 \mathrm{v}$, $44,48 \mathrm{v}, 49,49 \mathrm{v}, 50,54 \mathrm{v}, 57 \mathrm{v}, 58,58 \mathrm{v}, 73,75,75 \mathrm{v}, 76,77,78,83 \mathrm{v}, 86 \mathrm{v}, 89 \mathrm{v}, 99$, 102.

Puente de Las Concebidas o de Churubamba; véase Concebidas.

Puente de San Francisco; véase San Francisco.

Puente de Santa Teresa; véase Santa Teresa y Carmen, El.

Quebrada Grande; quebrada que separaba los caminos de Potosí y de Laja, delante de la zona del Tejar: 25.

Quilliquilli; cerro tbicado en la zona noreste de La Paz, estaba sepatado de la zona de Santa Bárbara por una serie de zanjas: $18,20,22,23,23 \mathrm{v}, 24,26 \mathrm{v}, 27 \mathrm{v}, 29$, $29 \mathrm{v}, 36,36 \mathrm{v}, 37,37 \mathrm{v}, 38,38 \mathrm{v}, 39,41,43,48 \mathrm{v}, 54 \mathrm{v}, 57 \mathrm{v}, 58,67,68 \mathrm{v}, 69 \mathrm{v}, 71 \mathrm{v}$, $72 \mathrm{v}, 73,75,75 \mathrm{v}, 76,78,78 \mathrm{v}, 81,81 \mathrm{v}, 84,84 \mathrm{v}, 86,87,97,102$.

Recogidas; véase Las Recogidas.

Río Seco; véase cenizal del Río Seco.

Riverilla; véase La Riverilla.

Sagrario; parroquia del Sagrario, templo auxiliar de la Catedral: 29.

San Agustín; convento e iglesia construídos en el siglo XVII y que ocupaban la manzana de la actual parroquia: $21 \mathrm{v}, 35 \mathrm{v}$.

San Bernardo; establecimiento educacional en el Cuzco: $67 \mathrm{v}$.

San Francisco; barrio, puente, puerta y fuerte que rodeaban al convento e iglesia de San Francisco en los extramuros de la ciudad:10,13,13v, 14v, 15, 15v, 16, $16 \mathrm{v}, 17,18,18 \mathrm{v}, 19,19 \mathrm{v}, 23 \mathrm{v}, 24,26,27,28 \mathrm{v}, 3 \mathrm{l}, 32,33 \mathrm{v}, 34,35 \mathrm{v}, 36 \mathrm{v}, 39,39 \mathrm{v}$, $40 \mathrm{v}, 41,41 \mathrm{v}, 42,42 \mathrm{v}, 69 \mathrm{v}, 73,73 \mathrm{v}, 74 \mathrm{v}, 75,75 \mathrm{v}, 76,78 \mathrm{v}, 81,88 \mathrm{v}, 100$. 
San Juan de Dios, barrio, trinchesa y hospital que rodeaban al convento de los Hermanos de San Juan de Dios: 23v, 27, 28, 28v, 29, 30, 31v, 32, 35v, 38, 40, $40 \mathrm{v}, 41,58$.

San Pedro; camino, puente, alto, iglesia y barrio que ocupaban el antiguo pueblo de indios de San Pedro: 13, 14, 15, 15v, 16, 16v, 17v, 20, 20v, 21v, 22v, 23, 24, 26, $26 \mathrm{v}, 27 \mathrm{v}, 28 \mathrm{v}, 30,31 \mathrm{v}, 32,32 \mathrm{v}, 33,33 \mathrm{v}, 34,34 \mathrm{v}, 35,36,36 \mathrm{v}, 37,37 \mathrm{v}, 38 \mathrm{v}, 39$, $39 \mathrm{v}, 40,40 \mathrm{v}, 41,42,43,43 \mathrm{v}, 44,44 \mathrm{v}, 45,48,49,49 \mathrm{v}, 54,56,57 \mathrm{v}, 84,86,87$, $87 \mathrm{v}, 88,88 \mathrm{v}, 89,91,94,99 \mathrm{v}, 102$.

San Sebastián; puerta, camino, barrio e iglesia ubicados en el antiguo pueblo de indios de San Sebastián: 7, 7v, 14, 15, 15v, 16, 19v, 22, 22v, 24, 25, 26v, 27v, $28,29,29 \mathrm{v}, 32,35 \mathrm{v}, 36 \mathrm{v}, 37,37 \mathrm{v}, 39,40 \mathrm{v}, 41,42,42 \mathrm{v}, 49,59 \mathrm{v}, 67,67 \mathrm{v}, 68 \mathrm{v}, 69$, $73,78 \mathrm{v}, 81 \mathrm{v}, 83,84,88 \mathrm{v}, 96 \mathrm{v}, 97,100,100 \mathrm{v}$.

Santa Bárbara; puente, cementerio, barrio e iglesia ubicados en el antiguo pueblo de indios de Santa Bárbàra, en las laderas del cerro de Quilliquilli: 7v, 14, 14v, $15,16,17,17 \mathrm{v}, 18,19,19 \mathrm{v}, 20,2] \mathrm{v}, 22 \mathrm{v}, 23,24,25,26,26 \mathrm{v}, 27,27 \mathrm{v}, 28,28 \mathrm{v}$, $29,32 \mathrm{v}, 34,34 \mathrm{v}, 35,35 \mathrm{v}, 36 \mathrm{v}, 37,38,39,39 \mathrm{v}, 40,41,43,48 \mathrm{v}, 49,69,73,73 \mathrm{v}$, $84 \mathrm{v}, 85,88 \mathrm{v}, 92,92 \mathrm{v}, 101 \mathrm{v}$.

Santa Teresa, véase Carmen, El.

Santo Domingo; iglesia y convento que octupaban el actual local de la parroquia y el colegio Ayacucho: 36v.

Seminario; creado en el siglo XVII, había cambiado muchas veces de lugar. En 1781 estaba en la actual calle Ingavi esquina Sanjinés. Las referencias del Oidor se dirigen al antiguo Seminario llamado comunmente Colegio Viejo: 32 , $32 \mathrm{v}$.

Supaicalle; zona ubicada en los altos de San Francisco: 35v.

Tambos, calle de los; 76 .

Tambo y casa de Garicano; tambo ubicado en las inmediaciones de San Francisco: $19 \mathrm{v}$.

Tambo de las Harinas; tambo ubicado en la actual calle Sagárnaga: $19 \mathrm{v}$.

Tambo de Simbrón; tambo ubicado más arriba del puente y trinchera de San Sebastián: 16, 25, 27, 28.

Tambo de Soliz; tambo ubicado en la cuesta de Laja, arriba del Tejar: 13.

Tejar; véase El Tejar.

Trinchera de San Miguel; véase Fuerte de San Miguel. 


\section{INDICE TOPONIMICO 1}

Achacachi; capital de la provincia de Omasuyos: $7 \mathrm{v}, 27,44,48,48 \mathrm{v}, 87,10 \% \mathrm{v}$.

Achocalla; pueblo vecino a La Paz: 8v, 9, 9v, 20v, 45v, 47v, 48v, 49, 103.

Aiquile; pueblo de la provincia de Cochabamba: $47 \mathrm{v}$.

Ambaná; poblado en la provincia de Larecaja: 96v.

1 Este índice ha sido organizado con el fin de que el Jector pueda captar el ámbito geografico alcanzado por los movimientos indigenas de los años 1780 y 81 . A través de la lectura del Diarjo de Francisco Tadeo Diez de Medina se ha podido apreciar que, si bien la mayor parte de las anotaciones se refieren al acontecer de La Paz, durante el cerco, también hay en la introducción y en otras páginas la síntesis de lo ocurrido en el resto de las provincias de ambos virrejnatos como consecuencia de las acciones de Tomás Catari y de José Gabriel Tupac Amaru.

Si se ubican en un mapa los lugares anotados en el indice puede apreciarse con un sentido horizonial la amplitud del territorio convu)sionado, así como, en un sentido vertjeal, su profundidad, puesto que surgen a cada paso, junto a las ciudades bien pobladas, nombres de aldeas pequeñísimas aún entonces, así como de haciendas, obrajes mineros o simples comunidades indígenas.

Con el fin de facilitar la localización de los lugares mencionados, en la confección del Indice se ha utilizado la grafía modema conservándose la del manuscrito solamente cuando el sitio no ha podido ser hallado en los mapas actuales.

Las referencias se han hecho utilizando en lo posible la nomenclatura administrativa de 1780, que distribuía los puntos mencionados en los ámbitos del virreinato del Plata o del Perú, los que se dividian a su vez en provincias, así como éstas en partidos. Otras veces se han utilizado las denominaciones de la jurisdicción eclesiástica, generaimente coincidente con la civil, porque se ha encontrado la ubicación del lugar en Cosme Bueno, "Informe sobre diversos Arzobispados", Madrid, Academia de la Historia 11/1-6 leg.4, o en la "Descripción de todos los pueblos comprehendidos en el distrito y jurisdicción del Obispado de Nuestra Señora de La Paz, 1765". AGI, Charcas 531, emanada de la Visita Pastoral del Obispo Francisco Gregorio de Campos; ambos autores utilizan este sistema en sus descripciones. Cuando, por último, las dudas han sido muy fuertes en la identificación toponímica de la época, se ha recurrido al cuadro administrativo vigente hoy en día, utilizándose para elio los mapas del Instituto Geográfico Militar de Bolivia, compilados en 1970. 
Ananea; yacimiento minero en Larecaja: 64 .

Andaguailas, provincia del virreinato del Perú: 33v,

Apolobamba, Misiones de: 108

Araca (también Haraca); asiento minero de la provincia de Sicasica: 48v, 97v, 98, 98v. Arequipa; capital del Obispado de Arequipa en el virreinato del Perú: 35, 38v, 41, 45. Arica; puerto sobre el océano Pacífico: $77 \mathrm{v}$.

Aullagas; centro minero de la Provincia de Chayanta: $1 \mathrm{v}$.

Ayaviri; pueblo peruano cercano al lago Titicaca: $2 \mathrm{v}$.

Ayoayo: pueblo de la provincia de Sicasica: 1, 4v, 5, 7v, 8v, 9, 9v, 15, 31v, 35v, 40, 42, $43 \mathrm{v}, 47 \mathrm{v}, 49 \mathrm{v}, 106 \mathrm{v}, 108,109$.

Ayoamaya; estancia cercana al pueblo de Sicasica: $4 \mathrm{v}, 25 \mathrm{v}$.

Azángaro; provincia del virreinato del Perú, capital de la provincia: 1,1v, 2, 2v, 6v, 7, $25,35,67 \mathrm{v}, 80,95 \mathrm{v}, 97 \mathrm{v}, 98,98 \mathrm{v}, 108$.

Belén; hacienda e ingenio vecinos a Patacamaya en provincia de Sicasica: $47 \mathrm{v}$.

Berenguela; pueblo de la provincia de Pacajes: $15,98 \mathrm{v}$.

Buenavista, San Pedro de; pueblo de la provincia de Charcas en el departamento de Potosí: 46 .

Calacoto; pueblo de la provincia de Pacajes: $33 \mathrm{v}, 108 \mathrm{v}$.

Calamarca; pueblo de la provincia de Sicasica: $5,8 \mathrm{v}, 9 \mathrm{v}, 10,15,16,20 \mathrm{v}, 28 \mathrm{v}, 29,29 \mathrm{v}$, $30,31,35,43,43 \mathrm{v}, 44,47 \mathrm{v}, 49 \mathrm{v}, 54,56,108 \mathrm{v}$.

Calapuja; pueblo peruano cercano al cerro de Tacora: 7 .

Calpani; (también Colpani) capilla y cuesta que sube al Alto de La Paz, vecina a Achocalla: 10v, 22, 45v.

Capiñata; pueblo y doctrina de la provincia de Sicasica: 5 .

Caquiaviri; cabeza de la provincia de Pacajes: 48.

Carabaya; provincia del Perú que confina con Azángaro: 1v, 2, 7.

Caracollo; pueblo situado al norte de Oruro, doctrina del partido de Sicasica: $4 \mathrm{v}, 47$.

Caracato; pueblo y doctrina de la provincia de Sicasica: $4,4 \mathrm{v}, 5,7,7 \mathrm{v}, 9,82 \mathrm{v}, 108 \mathrm{v}$, 109.

Carangas; pueblo y corregimiento en la provincia de Oruro: $1,3 \mathrm{v}, 21 \mathrm{v}, 38 \mathrm{v}, 46 \mathrm{v}, 98$. 
Cavari; (también Cabari), pueblo y doctrina de la provincia de Sicasica: 5.

Cochabamba; provincia del Virreinato del Plata, capital de la provincia: 33, 34, 38v, $39,45,46 \mathrm{v}, 47,47 \mathrm{v}, 48,49,49 \mathrm{v}, 51 \mathrm{v}, 52,54,62,72,74 \mathrm{v}, 105 \mathrm{v}$.

Cohoni; pueblo del sur de La Paz, vecino a Collana: 8 .

Collao; (Collado), una de las cuatro partes del Imperio Incaico, comprende gran parte del actual territorio de Bolivia: 3v, 7v, 104v.

Collana; pueblo ubicado al sur de La Paz (D. de Medina habla también de Collana o Pampajasi): 8, 9, 15v, 50, 72, 86v, 89v, 94v, 99.

Colpani; ver Calpanj.

Colquemarca; pueblo del partido de Carangas: $3 v$.

Combaya; pueblo cercano a Sorata en la provincia de Larecaja: $12 \mathrm{v}$.

Condoriri; estancia en la provincia de Omasuyos: $36 \mathrm{v}$.

Condocondo; pueblo de la provincia de Paria: 1, 3v,

Copacabana; santuario y pueblo de la provincia de Omasuyos situado en el Lago Titicaca: $34,54 \mathrm{v}$.

Coroico; pueblo de los Yungas: $27 \mathrm{v}, 80 \mathrm{v}, 86 \mathrm{v}$.

Curaguara; pueblo de la provincia de Oruro: $33 \mathrm{v}$.

Cuzco; provincia del virreinato del Perú, capital de aquella provincia: $1,2 \mathrm{v}, 3 \mathrm{v}, 9 \mathrm{v}$, $18,25,45,46 \mathrm{v}, 67 \mathrm{v}, 68,80 \mathrm{v}$.

Challapampa; poblado en los extramuros de La Paz: 72.

Challapata; pueblo de la provincia de Paria: $3 \mathrm{v}, 108$.

Chanca; pueblo de la provincia de Sicasica: 7v, 9.

Charasani; pueblo de la provincia de Larecaja: $12,12 \mathrm{v}, 24,24 \mathrm{v}$.

Charcas; distrito de la Audiencia; 1, 3v, 5v, 13v, 15, 47, 77v.

Chayanta: corregimiento en la provincia de Potosí: 1, 1v, 3v, 4, 5, 15, 21v, 34, 46. Chichas; partido de la provincia de Potosí: 46.

Chirca; estancia en la región de Yungas: 94.

Chua; hacienda junto al lago Titicaca: 20.

Chucuito; capital y provincia del Obispado de La Paz: 5v, 6v, 7, 7v, 35, 38v, 105.

Chulumani; capital de los Andes de Yungas que perteneció primeramente a Sicasica: $1,38 \mathrm{v}, 46 \mathrm{v}, 50,86 \mathrm{v}$. 
Chupe; pueblo de Yungas: 50.

Chuquibamba; pueblo del virreinato del Perú donde acampó Tupac Amaru: 3v. Chuquisaca; capital de Charcas, sede de la Audiencia. Hoy Sucre: 1v, 15, 21v, 33, $38 \mathrm{v}, 47,47 \mathrm{v}, 50,52,62,81 \mathrm{v}$.

Desaguadero; río que nace en el Lago Titicaca y desemboca en el lago Poopó; pueblo de la provincia de Pacajes: $7 v, 15$.

Guamanga; provincia del Virreinato del l’erú: 3v.

Guancane; pueblo de la provincia de Paucarcolla: 12v.

Guaqui; pueblo de la provincia de Pacajes: 15, 27, 86.

Guaricara; hacienda de la región de Río Abajo en La Paz: 7v, 8v.

Guarina; pueblo de la provincia de Omasuyos: $15,15 v, 48 v, 50,93 \mathrm{v}$.

Guayguasi; hacienda en Mecapaca: 8v, 9.

Hachacachi; véase Achacachi.

Hamachiuma; estancia cercana a La Paz: 48.

Hampaturi; región al sur de La Paz, cercana al río La Paz: 43v.

Higuañahuma; región situada a espaldas de Calamarca: 48 .

Hilave: véase llave.

Ichoca; pueblo y doctrina de la provincia de Sicasica: 5.

Ilavaya; pueblo cercano a Sorata: 66 .

Ilave; pueblo de la provincia de Chucuito: 35 .

Inquisivi; pueblo y doctrina de la provincia de Sicasica: 5.

Irupana; pueblo y doctrina de la provincia de Yungas: 9, 39, 46v.

Laja; pueblo de la provincia de Omasuyos: 7, 9, 9v, 10, 10v, 11, 11v, 15, 23v, 24v, 36v, $42,43,48 \mathrm{v}, 50,75,99 \mathrm{v}$.

Lambate; pueblo de Yungas: 9.

Lampa; pueblo de la provincia de Puno: 3v, 6v, 7, 12v, 19v, 31v. 
La Paz; capital de la provincia y obispado de su nombre: $12 \mathrm{v}, 27 \mathrm{v}, 35,35 \mathrm{v}, 45 \mathrm{v}$, 46 , $51,51 \mathrm{v}, 52,52 \mathrm{v}, 53,53 \mathrm{v}, 55 \mathrm{v}, 58 \mathrm{v}, 62,64,67,68,70 \mathrm{v}, 73,79,79 \mathrm{v}, 81,82,82 \mathrm{v}$, $83,86 \mathrm{v}, 87,89 \mathrm{v}, 91 \mathrm{v}, 95,95 \mathrm{v}, 96,98,99 \mathrm{v}, 100,102,102 \mathrm{v}, 103,103 \mathrm{v}, 104,105$, $106,106 \mathrm{v}, 107,108 \mathrm{v}$.

La Plata; Arzobispado y capital de la jurisdicción eclesiástica de Chuquisaca: 46, 99, $105 \mathrm{v}$.

Larecaja; provincia de la Audiencia de Charcas, perteneciente al Obispado de La Paz: $5 \mathrm{v}, 6 \mathrm{v}, 7 \mathrm{v}, 11 \mathrm{v}, 12,13 \mathrm{v}, 22 \mathrm{v}, 24,28,31 \mathrm{v}, 33,34 \mathrm{v}, 38,40,44,50,55 \mathrm{v}, 67,76 \mathrm{v}$, $86 \mathrm{v}, 101,106$.

Lima, capital del Virreinato del mismo nombre: $62,63 \mathrm{v}, 72 \mathrm{v}, 73,75,85 \mathrm{v}$.

Lípez; provincia de la Audiencia de Charcas: 46v.

Luribay; pueblo de la provincia de Sicasica: 5.

Machaca; pueblo y doctrina de Ayopaya en Cochabamba: 15.

Macha, San Pedro de; pueblo de la provincia de Chayanta: 1.

Machacamarca: 87

Mallasa; valle al sur de La Paz: 107.

Mananchili; campo o lugar cercano al pueblo de Samán en Perú: 7.

Mecapaca; pueblo vecino a La Paz: $7 v, 8,8 v, 9,69$.

Misque; pueblo de la provincia de Cochabaraba: $1 \mathrm{v}, 103 \mathrm{v}, 105 \mathrm{v}$

Moho; (Mojo), pueblo de la provincia de Paucarcolla: 7v, 12, 98.

Moosa; (Moza, Mohoza), pueblo y doctrina de Sicasica: 5.

Moscari; pueblo de la provincia de Potosí: 1.

Omasuyos; una de las 7 provincias del obispado de La Paz: 1, 6v, 7v, 9, 12, 12v, 24v, $27,35,36 \mathrm{v}, 44,48,50,53 \mathrm{v}, 58 \mathrm{v}, 87,106,107 \mathrm{v}$.

Oruro, provincia perteneciente a la Audiencia de Charcas, capital de la provincia: $3 \mathrm{v}$, $4,4 \mathrm{v}, 5 \mathrm{v}, 15,15 \mathrm{v}, 21 \mathrm{v}, 26,27 \mathrm{v}, 28,33,33 \mathrm{v}, 34,34 \mathrm{v}, 38,38 \mathrm{v}, 46,46 \mathrm{v}, 47,52,54$, $77 \mathrm{v}, 103,104,105 \mathrm{v}, 108,108 \mathrm{v}$.

Pacajes; una de las 7 provincias del obispado de La Paz: $1,7 v, 8 v, 12,19 \mathrm{v}, 33 \mathrm{v}, 38 \mathrm{v}$, $39,48,53 \mathrm{v}, 77 \mathrm{v}, 86,108 \mathrm{v}$.

Palca; pueblo vecino a La Paz: 9, 27, 40.

Palomar; hacienda de Rfo Abajo, en La Paz: 44v. 
Pampajasi; zona vecina a Potopoto en las inmediaciones de La Paz: 49, 54v, 55, 55v, $56,56 \mathrm{v}, 57,57 \mathrm{v}, 58,58 \mathrm{v}, 72,73,76,77,86 \mathrm{v}, 99,105$.

Pampanarca; pueblo de la provincia de Tinta: $2 \mathrm{v}$.

Panduro; pueblo de la provincia de Oruro: $34,46 \mathrm{v}, 77 \mathrm{v}, 81 \mathrm{v}, 86 \mathrm{v}, 94 \mathrm{v}$.

Paria; provincia que confina con la de Chayanta: 1, 3v, 4, 15, 21v, 34, 46, 47, 108.

Patacamaya; pueblo de la provincia de Sicasica: $47 \mathrm{v}$.

Paucarcolla; provincia del Perú perteneciente al obipado de La Paz: 12.

Peñas; santuario de la provincia de Omasuyos: 50, 98, 99v, 105, 108v.

Pocoata; pueblo de la provincia de Chayanta: $1, I v$.

Potopoto; zona en las inmediaciones de La Paz; hoy Miraflores: 13, 14, 14v, 15, 17 , $19 \mathrm{v}, 20,22,26,26 \mathrm{v}, 27 \mathrm{v}, 29,30,32 \mathrm{v}, 33 \mathrm{v}, 34,34 \mathrm{v}, 35,36,36 \mathrm{v}, 39,39 \mathrm{v}, 40,43 \mathrm{v}$, $44,48 \mathrm{v}, 49,49 \mathrm{v}, 50,54 \mathrm{v}, 57 \mathrm{v}, 58,58 \mathrm{v}, 73,75,75 \mathrm{v}, 76,77,78,83 \mathrm{v}, 86 \mathrm{v}, 89 \mathrm{v}, 99$, 102.

Potosí; provincia de la Audiencia de Charcas, capital de la provincia: 1, 2, 3, 5v, 6v, $33,38 \mathrm{v}, 45,46,59 \mathrm{v}, 61,61 \mathrm{v}, 62,62 \mathrm{v}, 63,99,103,103 \mathrm{v}, 105 \mathrm{v}$.

Pucarani; pueblo de la provincia de Omasuyos: $15,48 v, 50,72 \mathrm{v}, 108 \mathrm{v}$.

Purilla, La; región vecina a Chuquisaca: 46.

Puno; capital de la provincia de Paucarcolla: 6v, 7, 7v, 9, 12, 23v, 31v, 33, 33v, 35, 105.

Quequerani; pampa, llamada también capilla de Santa Rosa en Mojo,

Paucarcolla: 12, 12v, 72v, 81 .

Quime; pueblo y doctrina de Sicasica: 5,

Quirpinchaca; liggar de las inmediaciones de Chuquisaca: 1.

Quito; capital de la Audiencia de ese nombre (Ecuador): $45 \mathrm{v}$.

Río Abajo; valle vecino a La Paz: $7 v, 8,9,28,43 v, 44 v, 49 v, 83,97 \mathrm{v}, 98,98 \mathrm{v}, 107$.

Sạnán; pueblo vecino al río Samán en Perú: 7.

Sangarara; pueblo de la provincia de Tinta en Perú: $2 v, 3$.

Santa Rosa, Capilla de Mojo, provincia de Paucarcolla: 12.

Sapahaqui; pueblo de la provincia de Sicasica: $4 \mathrm{v}, 5,7,7 \mathrm{v}, 9,82 \mathrm{v}$.

Seque, campo de; región de La Ventilla en El Alto de La Paz: 49. 
Sicasica; una de las 7 provincias del Obispado de La Paz, capital de la provincia: 1 , $4 \mathrm{v}, 5,7 \mathrm{v}, 8 \mathrm{v}, 9 \mathrm{v}, 15,24 \mathrm{v}, 25 \mathrm{v}, 28,29,29 \mathrm{v}, 31 \mathrm{v}, 32 \mathrm{v}, 33 \mathrm{v}, 34,34 \mathrm{v}, 35 \mathrm{v}, 36 \mathrm{v}, 38$, $38 \mathrm{v}, 43,44,44 \mathrm{v}, 45,46 \mathrm{v}, 47,47 \mathrm{v}, 48 \mathrm{v}, 49 \mathrm{v}, 53 \mathrm{v}, 56,80 \mathrm{v}, 81 \mathrm{v}, 87 \mathrm{v}, 88 \mathrm{v}, 98$, $98 \mathrm{v}, 101,106,106 \mathrm{v}, 108,108 \mathrm{v}, 109$.

Songo; pueblo de la provincia de Larecaja: 5v, 10.

Sorata; capital de la provincia de Larecaja: $12 \mathrm{v}, 15,27 \mathrm{v}, 31 \mathrm{v}, 33,44,55,55 \mathrm{v}, 56,58 \mathrm{v}$, $64,65,67,67 \mathrm{v}, 68,68 \mathrm{v}, 72,72 \mathrm{v}, 76 \mathrm{v}, 77,78 \mathrm{v}, 79 \mathrm{v}, 96 \mathrm{v}, 97 \mathrm{v}, 98 \mathrm{v}, 106$.

Suches; asiento minero de la provincia de Larecaja: $6 \mathrm{v}, 66$.

Taca; doctrina de la provincia de Sicasica: 9.

Tacacora; cerro vecino al pueblo de Samán en Perú: 7.

Tacna; (Tagna) puebio del sur de Perú: 29v, 38v, 77v, 90v.

Tejar, El; alto de la cuesta de Laja a la entrada de La Paz: 11v, 13,15v, 18, 22v, 23v, $24 \mathrm{v}, 25,85 \mathrm{v}, 87,99$.

Tiahuanaco; pucblo de la provincia de Pacajes: 15.

Tinusi; pueblo en la provincia de Larecaja: $55 \mathrm{v}$.

Tinta; provincia del virreinato del Peri, capital de la provincia de ese nombre: $1,1 \mathrm{v}$, $3,62 \mathrm{v}, 78 \mathrm{v}$.

Tiquina; pueblo de la provincia de Omasuyos: $29,29 \mathrm{v}$.

Tirata; hacienda de la región de Río Abajo en La Paz: 7v.

Toledo; pueblo de la provincia de Paria: 47.

Tomina; pueblo de Chuquisaca: $1 v$.

Tomoza; haclenda de Sapahaqui: 1.

Totoral, valle del; valle de Sicasica: 9.

Trujillo; ciudad del virreinato del Perú: 22v.

Tucumán; ciudad y provincia del virreinato de Buenos Aires: $1 \mathrm{v}, 52,77 \mathrm{v}, 81 \mathrm{v}$.

Tungasuca; pueblo de la provincia de Tinta en el Perú: $1 \mathrm{v}, 2,3,35,46,50,55,68$, 78v, $80 \mathrm{v}, 98,104 \mathrm{v}$.

Tupiza; pueblo de la provincia de Chichas: 46.

Ventilla, La; zona del altiplano inmediata a La Paz: 44, 49, 49v, 51v, 54. 
Verenguela; véase Berenguela.

Viacha; pueblo de la provincia de Pacajes: $7 v, 8,8 \mathrm{v}, 9,9 \mathrm{v}, 11,15,20,42,50$.

Vicario, Campo del; lugar vecino al pueblo de Sicasica: 47 .

Vilaque; estancia vecina al pueblo de Calamarca: 44, 56, 72.

Villaverde; chacarilla en la región de San Sebastián: 67.

Vilque; pueblo de la provincia de Paucarcolla: $7 \mathrm{v}, 12,12 \mathrm{v}, 72 \mathrm{v}$

Vilque Chiquito; pueblo vecino a Azángaro: 12.

Viscachani; pueblo de Pacajes: $38 \mathrm{v}$.

Yaco; pueblo y doctrina de la provincia de Sicasica: $5,98,98 \mathrm{v}$.

Yamparáez; provincia de Charcas: $1 \mathrm{v}$.

Ychoa; pueblo de la provincia de Sicasica: 5 .

Yungas; provincia del Obispado de La Paz, administrativamente nació con el nombre de Andes de los Yungas, como una división de la provincia de Sicasica: $4 \mathrm{v}, 5,9,35,38 \mathrm{v}, 39 \mathrm{v}, 40,41 \mathrm{v}, 46 \mathrm{v}, 50,52 \mathrm{v}, 53 \mathrm{v}, 55,55 \mathrm{v}, 67,68 \mathrm{v}, 69$, $86,86 \mathrm{v}, 87,94,97 \mathrm{v}, 106$.

Yungas Chapes; nombre que se le daba a Chulumani: 1.

Yunguyo; pueblo vecino a Copacabana en el lago Titicaca: 44. 


\section{INDICE}

Pág.

Presentación

Prólogo de Gunnar Mendoza

IX

Archivos consuitados y su nomenclatura

XXXVII

Introducción

El Oidor Francisco Tadeo Diez de Medina

Estudio Preliminar

Primera Parte del Diario del Oidor Diez de Medina

50

Nota Preliminar a la Segunda Parte del Diario del Oidor Francisco Tadeo

Diez de Medina

Segunda Parte del Diario del Oidor Diez de Medina

Vocabulario

Indice Onomástico

Relación Biográfica

Toponimia Urbana

Indice Toponímico 


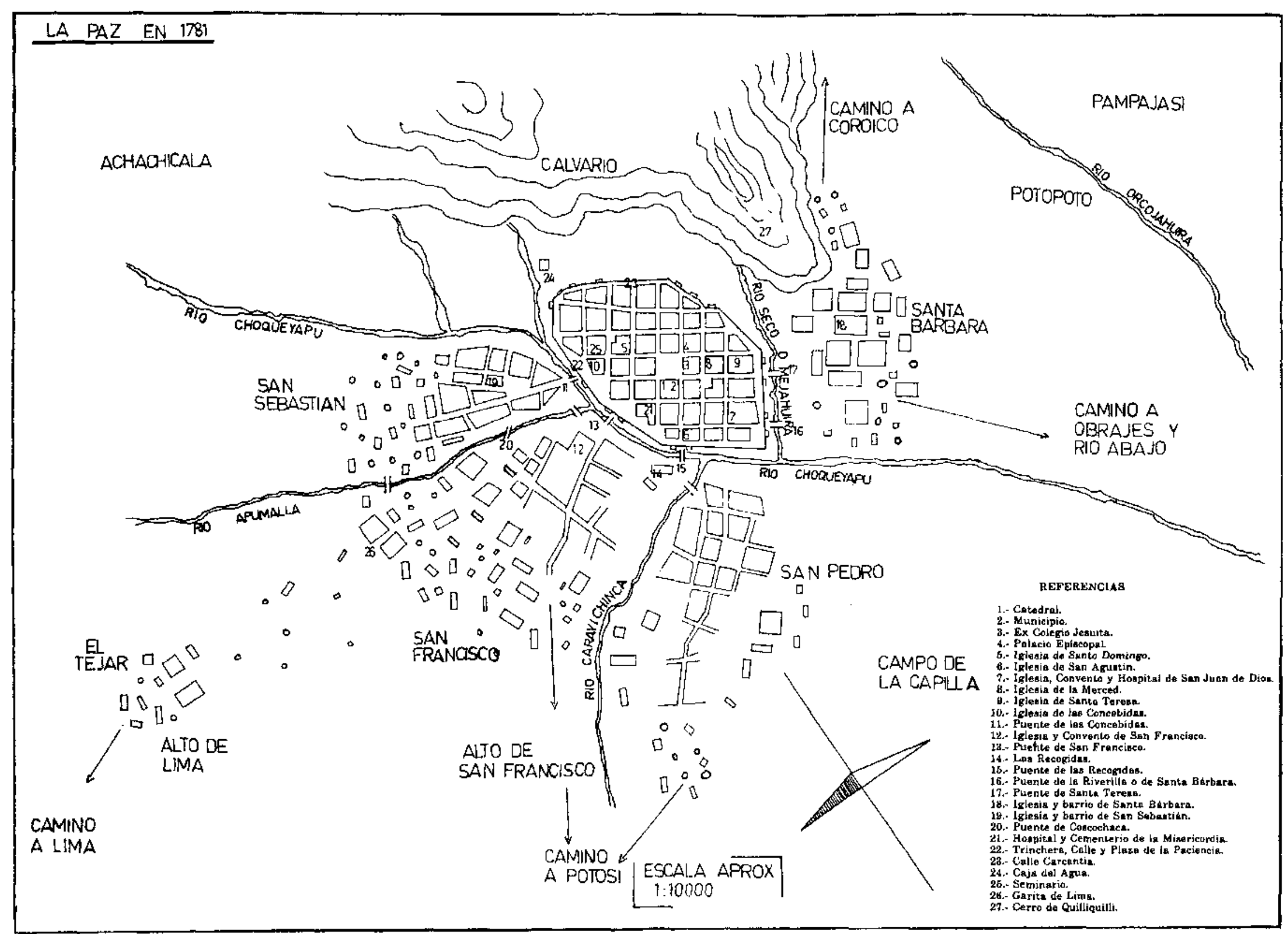





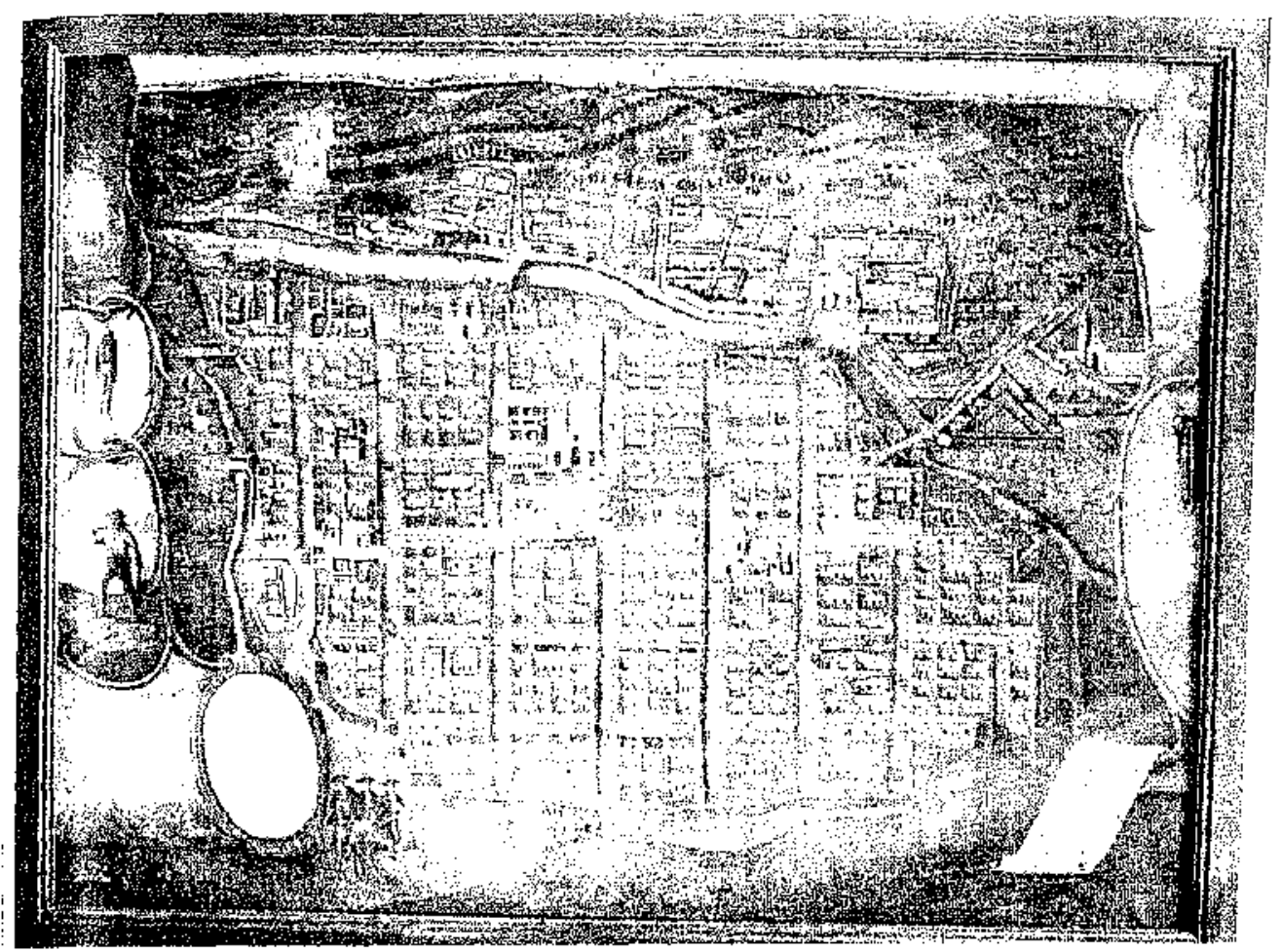

Vista de la ciudad de La l'az cercada y amurallada en 1781. Copia anónima deI cuadro original de Florentin Olivares. Municipalidad de La Paz.

Foto: Pedro Querejazu L. 
Vista parcial del cuadro de Olivares.

Rio Choumeyapu.-- Puente de San Francisco.- Puente y fuerte de San Sebastiañ.- Plaza Mayor.- Santo Domingo.- Las Concebidas.

Poto: Pedro Querejizu L.

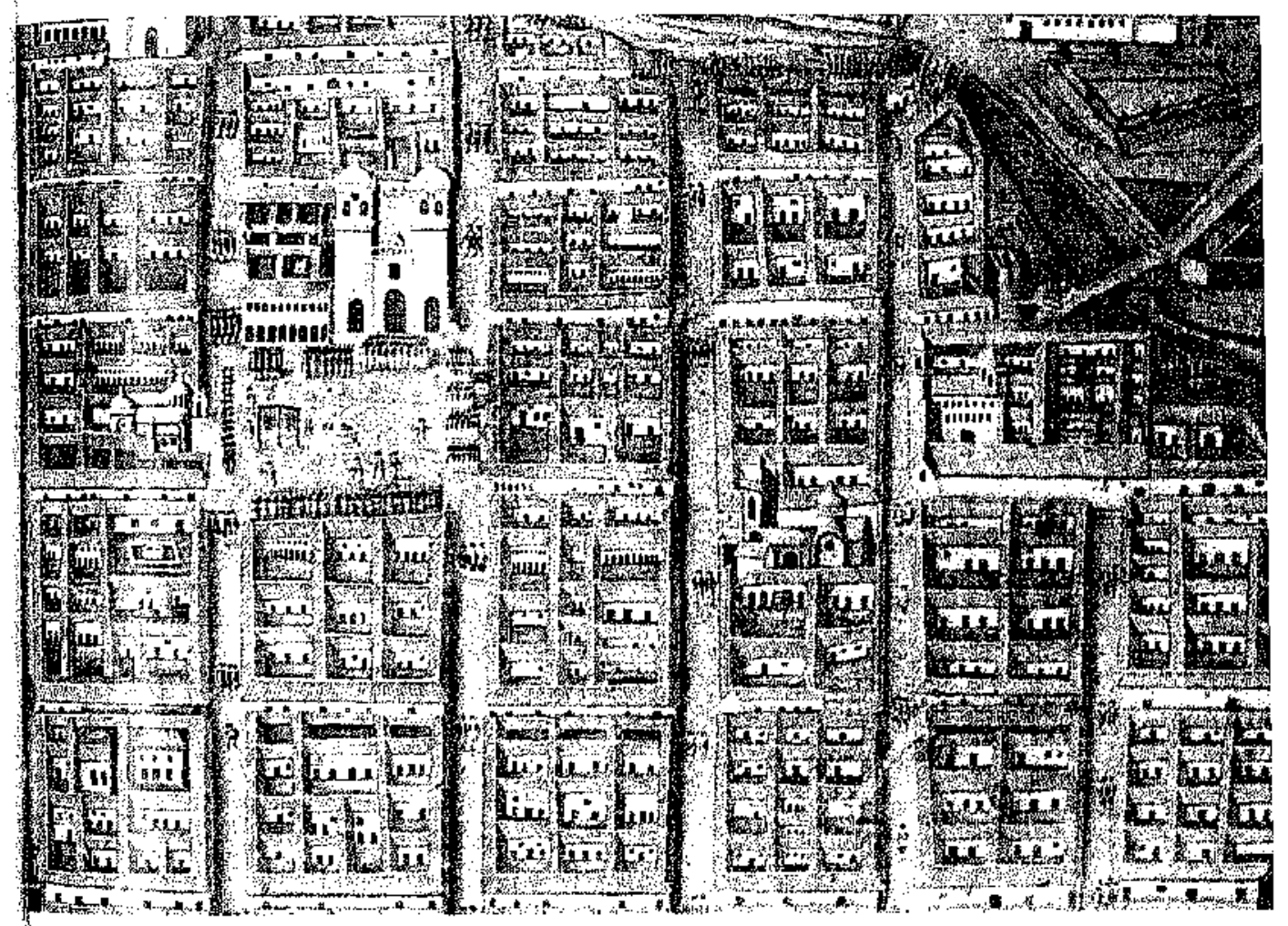




Vistá parcial del cuadro de Olivares.

Monasterio de las Concebidas. - Fuerte de la Paciencia.-- Fuerte del final de la actual calle Ingavi, uno de los más importantes en el trazado de las defensas.

Findo: Pedro Querejazul.

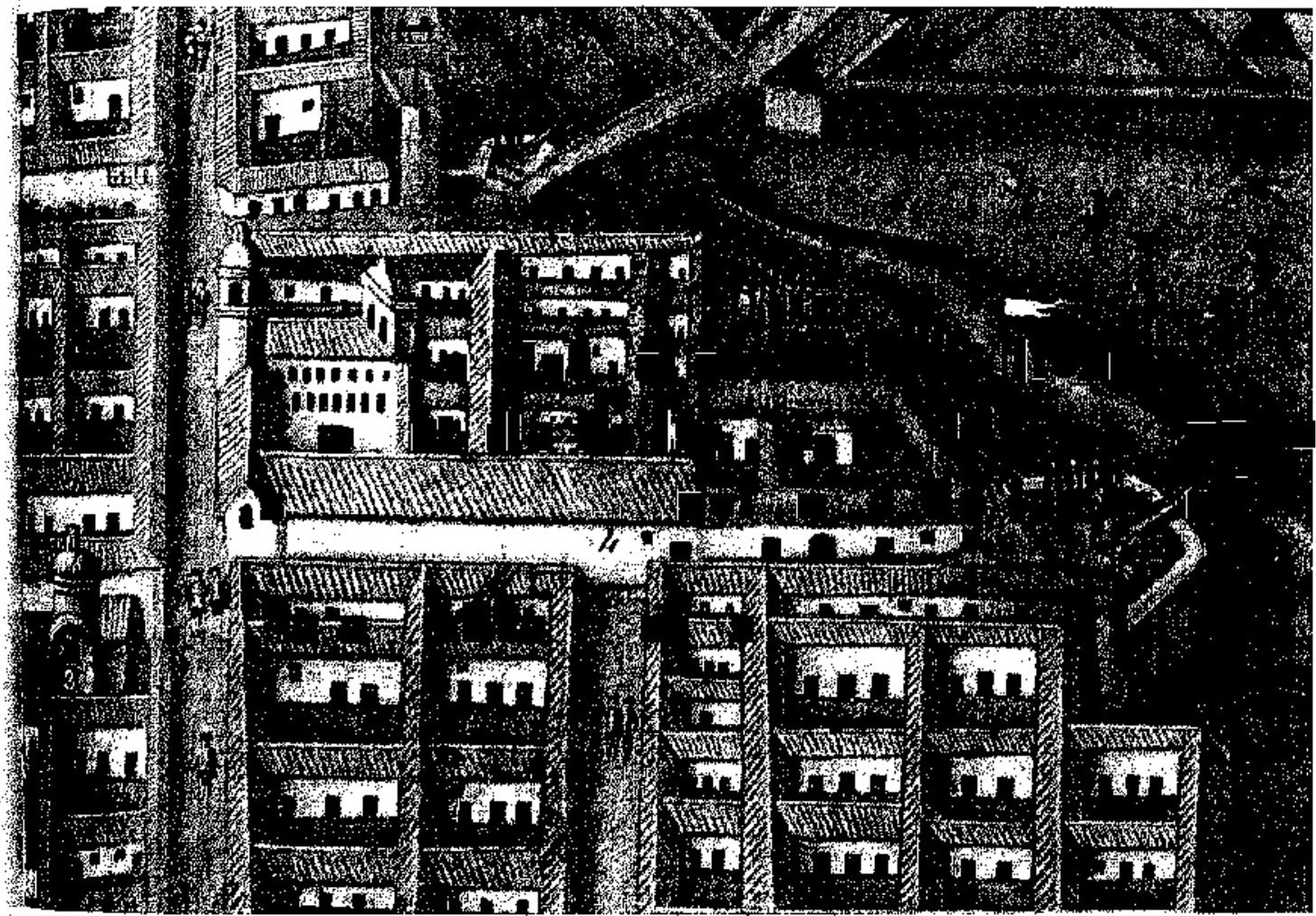





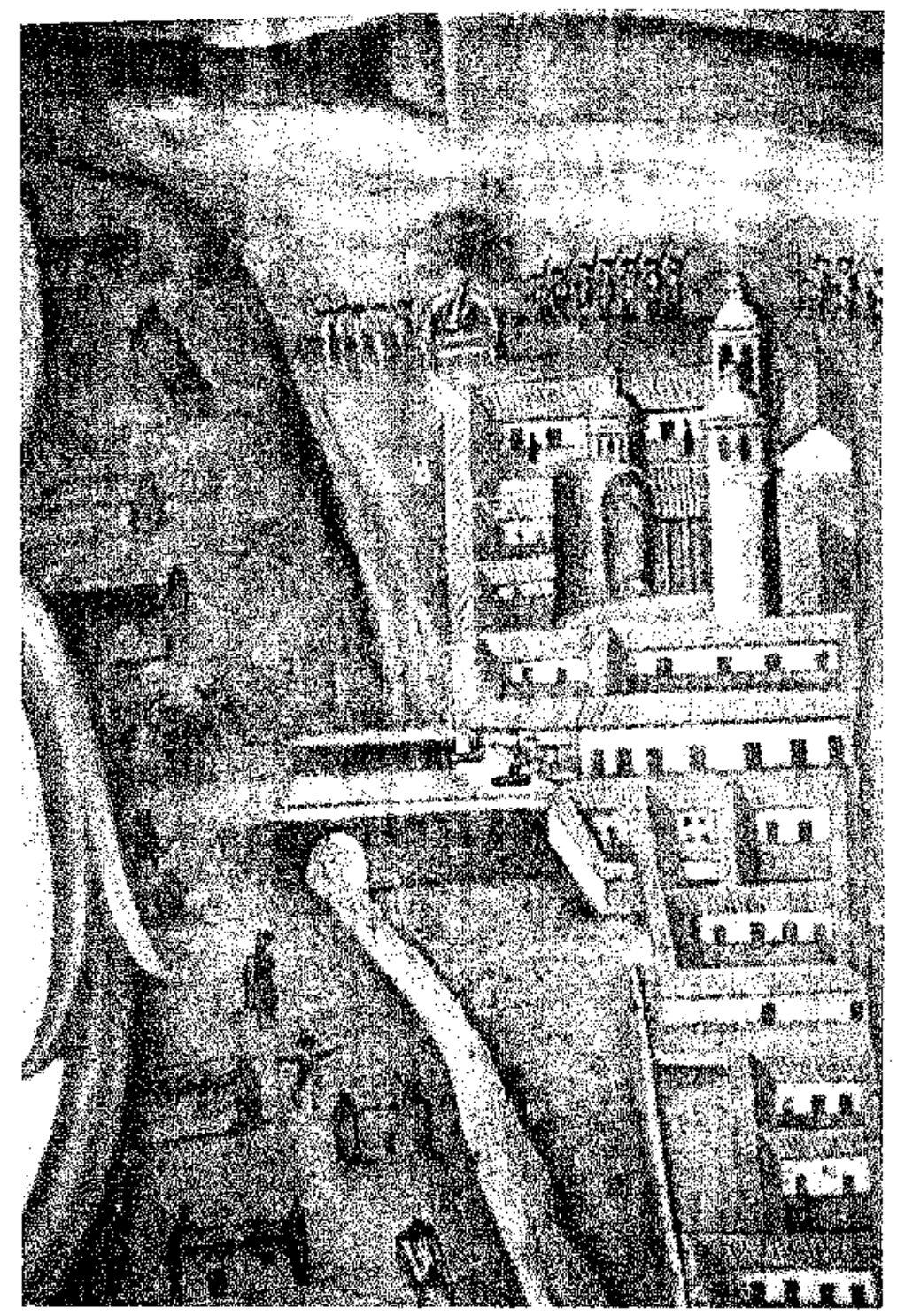

Vista parcial del cuadro de Olivares.

Parfe de las muraltas,-- Hospital, Iglesia y puente de San Juan de Dios.

Foto: redro Querejazu L. 

. 


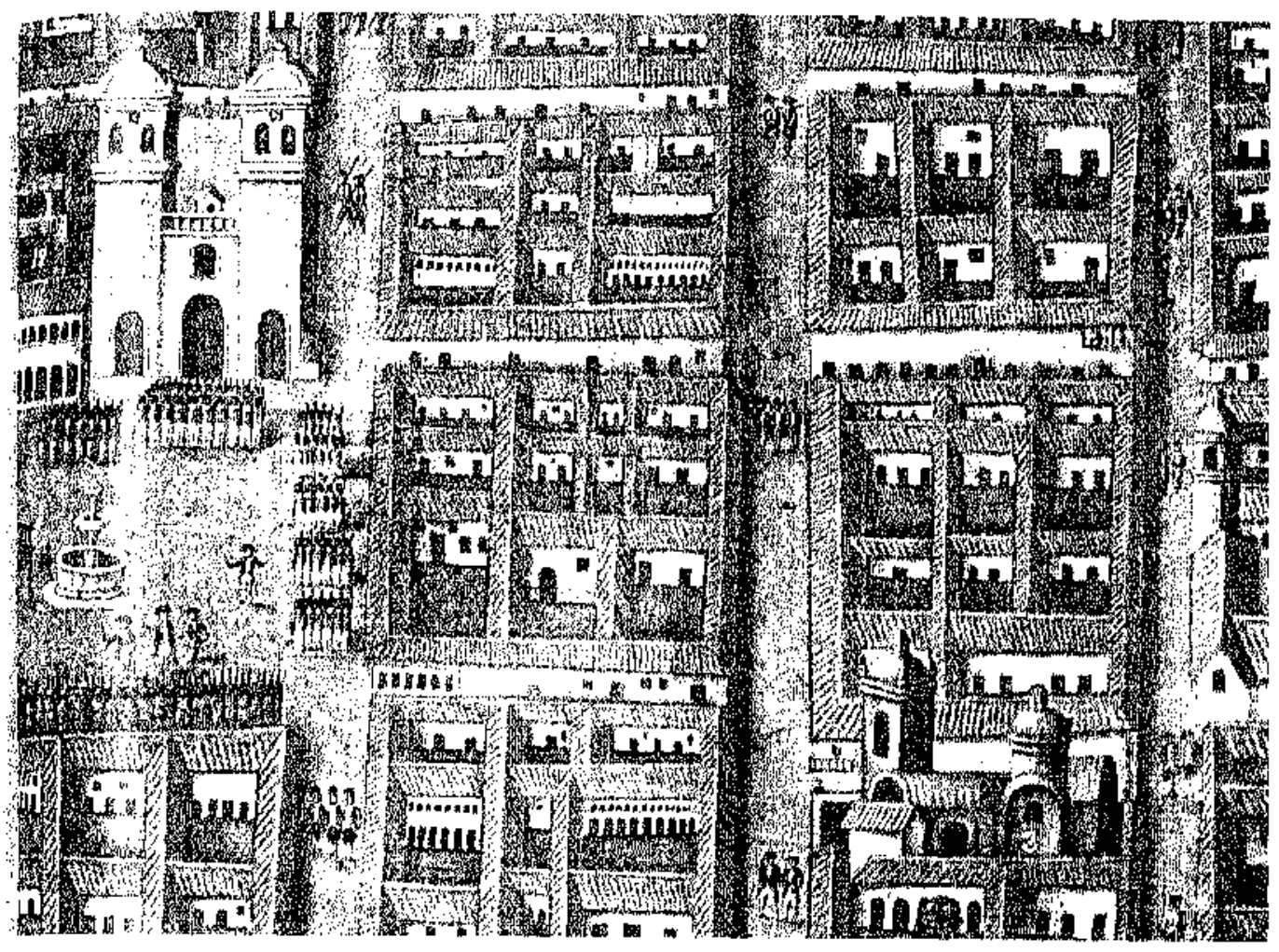

Lisla patcial del andro de Olivares.

Coshato derecho de la flima Mayor.-. Catedral- Casa des Oidor Diez de Medina, loy Museo Nacional a "Arte .- Santo bonningo- Casa de la inarquésa de Aro, donde labifaban tambion Sebastian de Seguroha y Fernando Márquez de l. Plata; hoy Palacio de Villaverde. ... Iglesia de Santo bomingo.

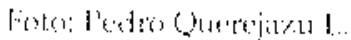



Vista parcial del cuadro de Olivares.

Irrlesia de San Sebastián,..- lglesia y convento de San Francisco..- Pucntey fuerte de San Sebastián.-- Calle Ancha, hoy Av. Anérica.

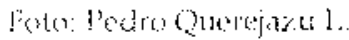

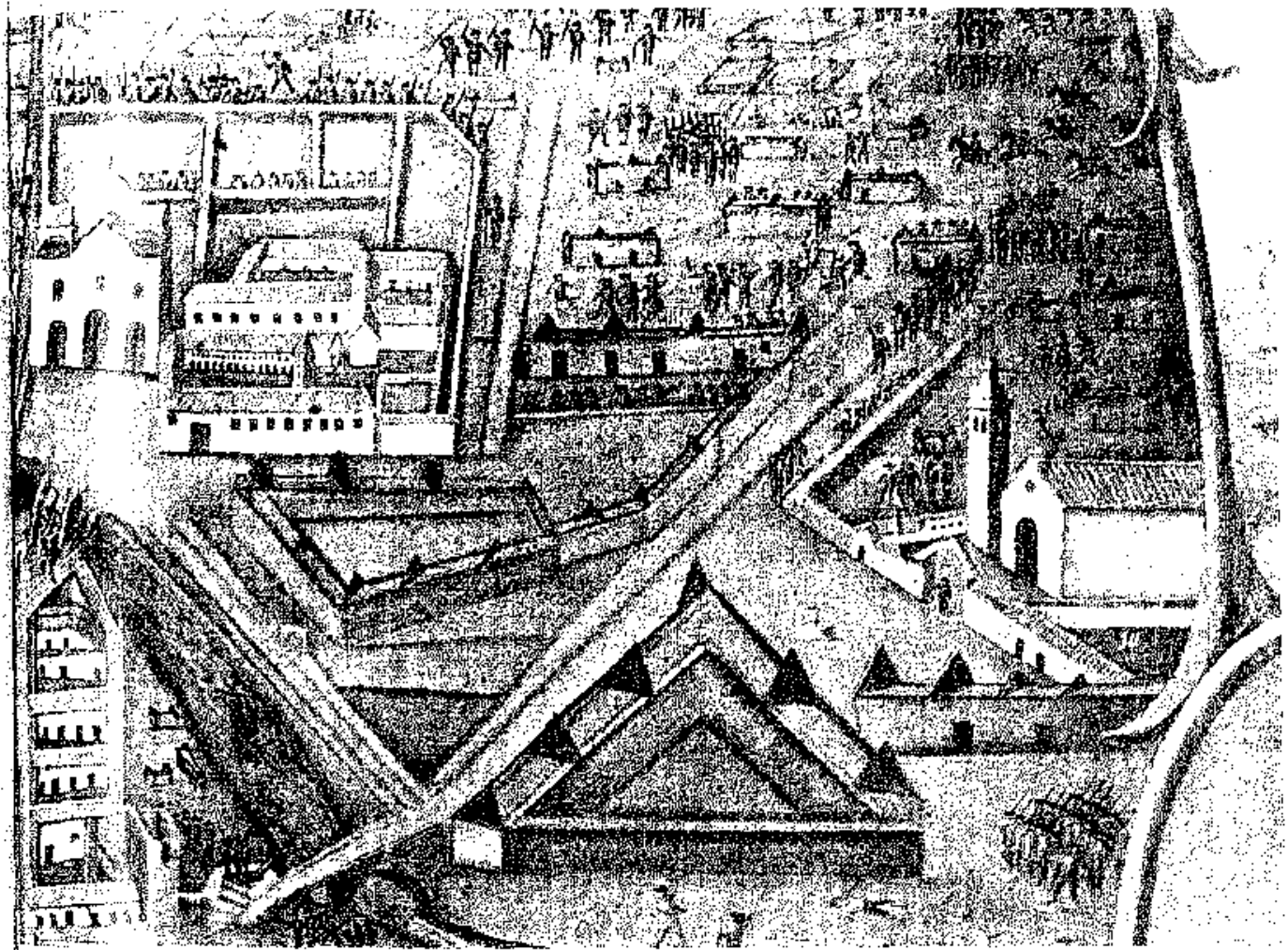





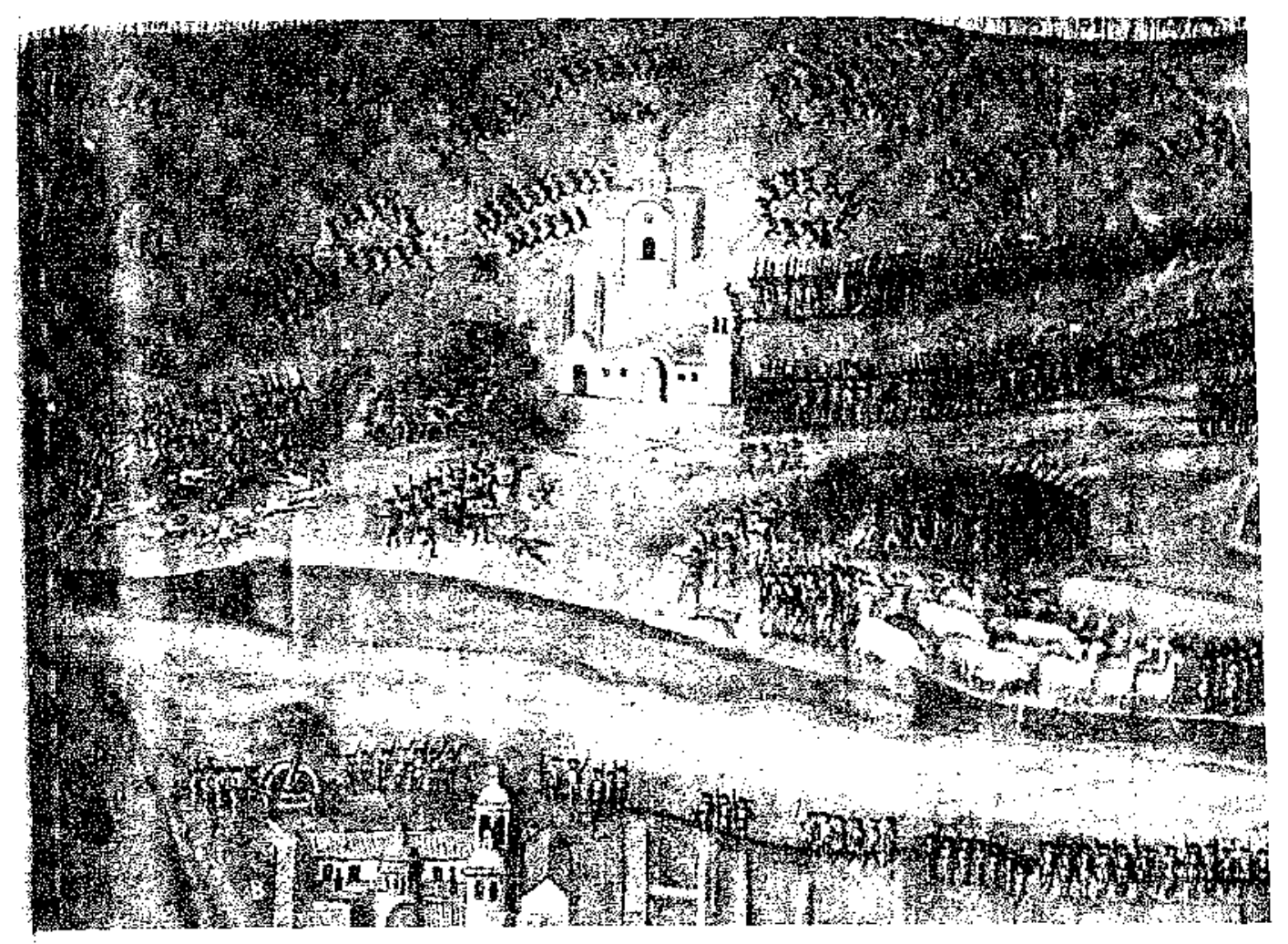

betalle del cundro de Olivares.

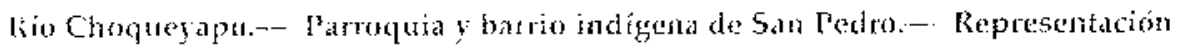
de un Combale de ambas ejércilos en ta cuesta y alto de San Pedro.

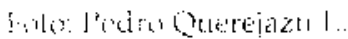





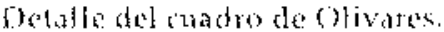

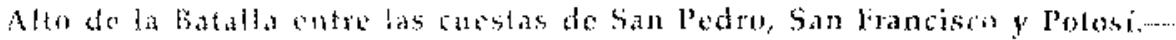

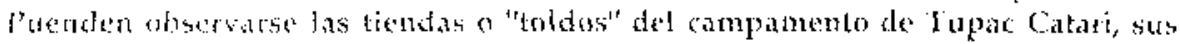
furstes y las horeas de las qua penden los cuerpos de afgumos prisioneros.

la parte baja corresponde a las dirsas de la ciodad en la zord comprendida entre San ledro. Ias Recopidas y San Fancisco, kodas allas fora de la muxalla.

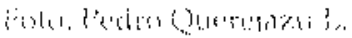

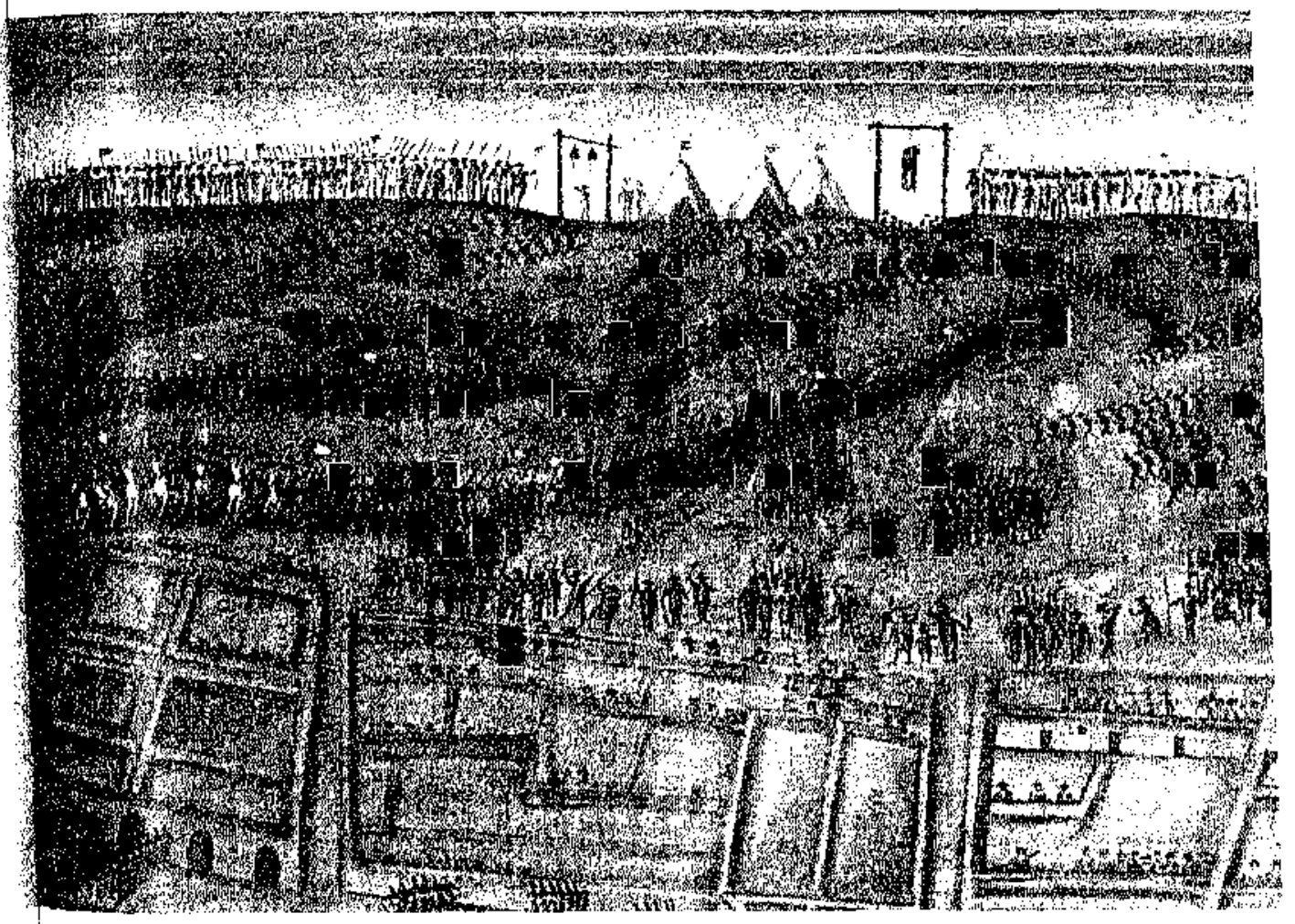





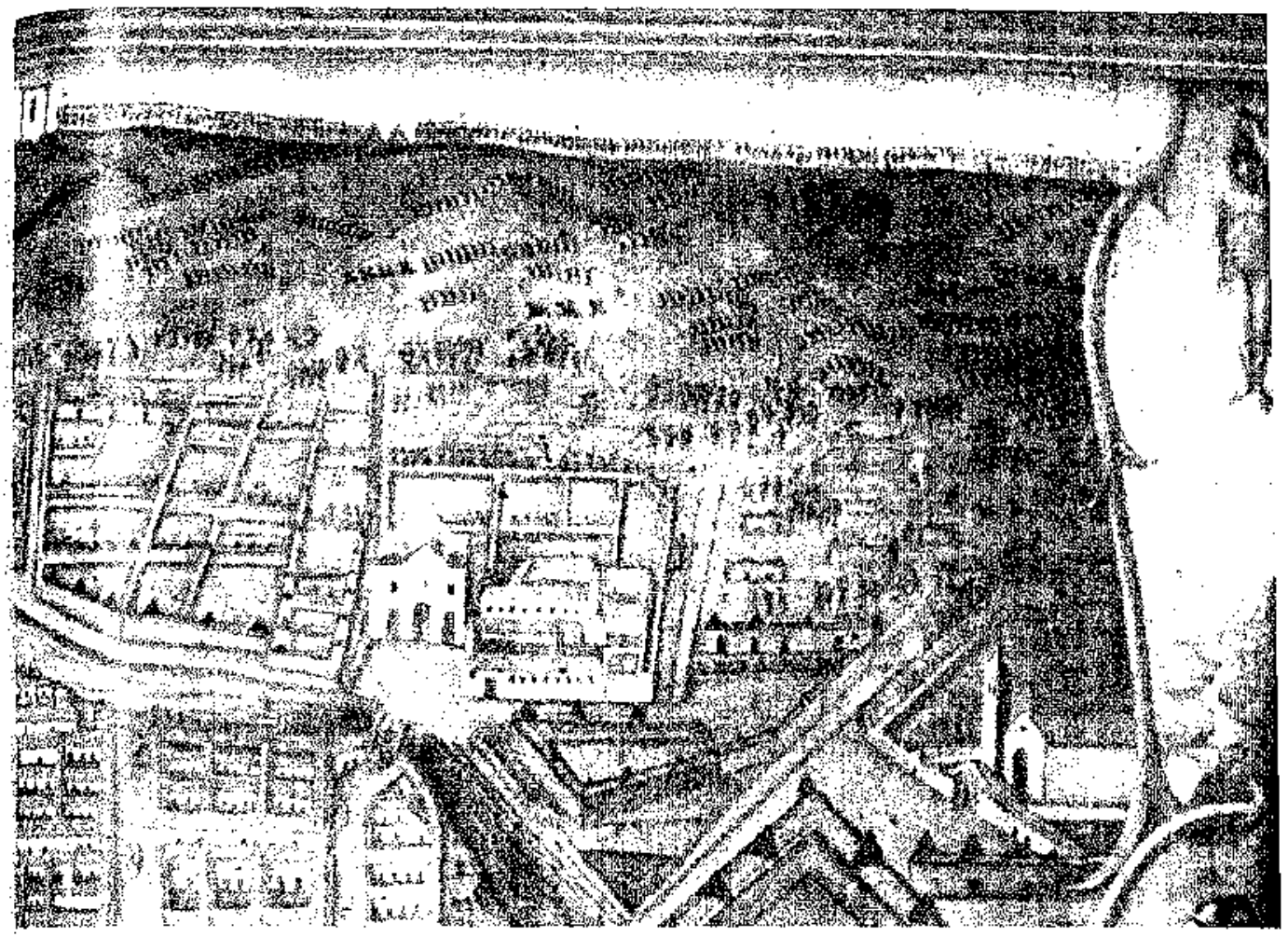

1)etalle del cuadro de Olivares.

Iglesia, convento y luerta de San Fancisco.-- Alto de San Francisco o barrio de Chocata,- En la parte inferior, fuerte e igglesia de San Sebastián.

Joto: Pedro onerazu [. 

Detalle del chadro de Givires.

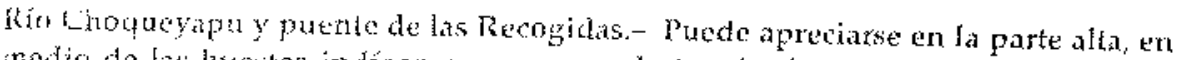
rredio de tas haestes indigenas, un grupo destacado de caudilos con caballos y banderas; sin duda, se trata de una de las bajalas solemnes de Tupac Catari $y$ Bartolina Sisa

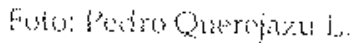

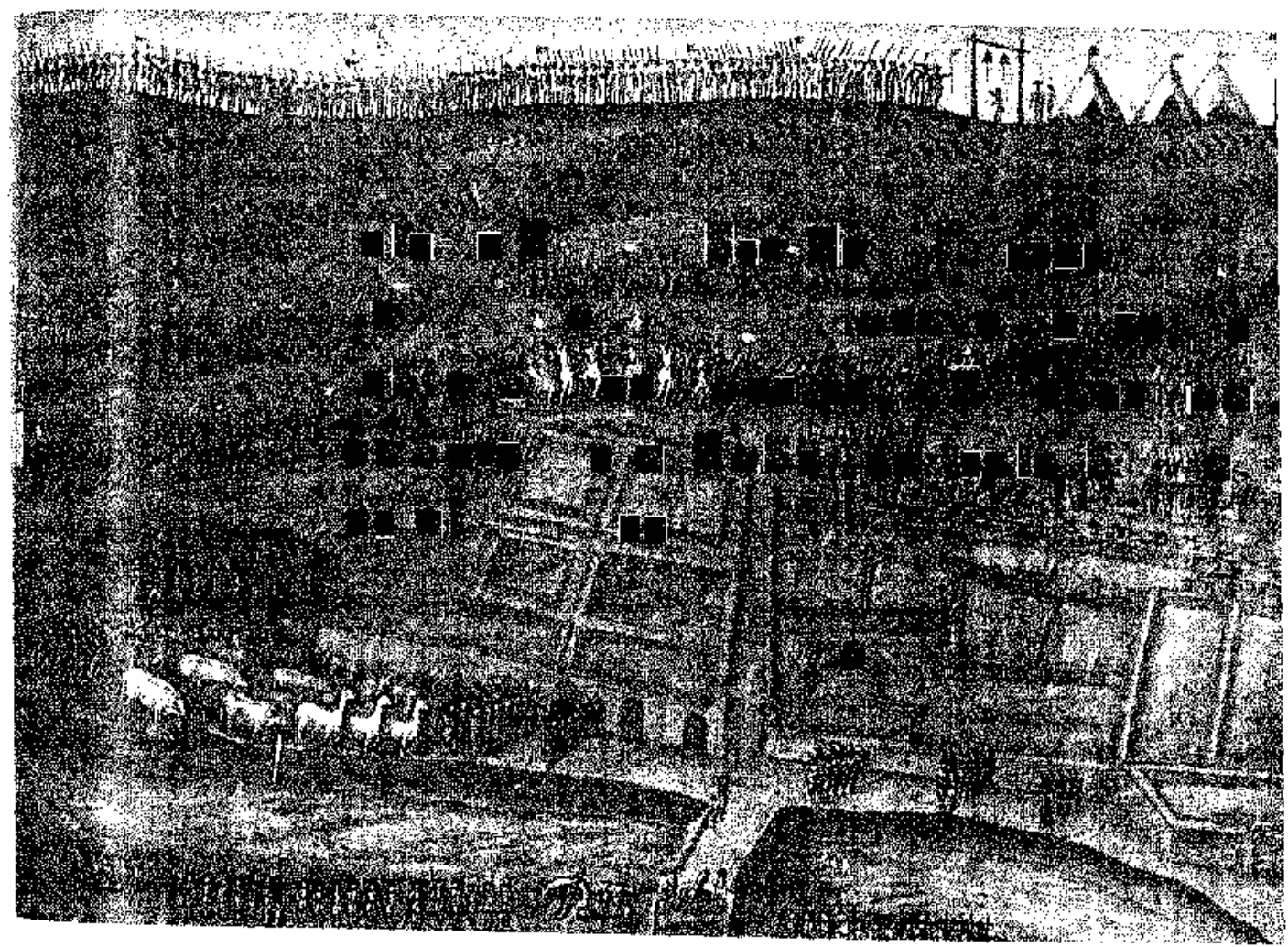





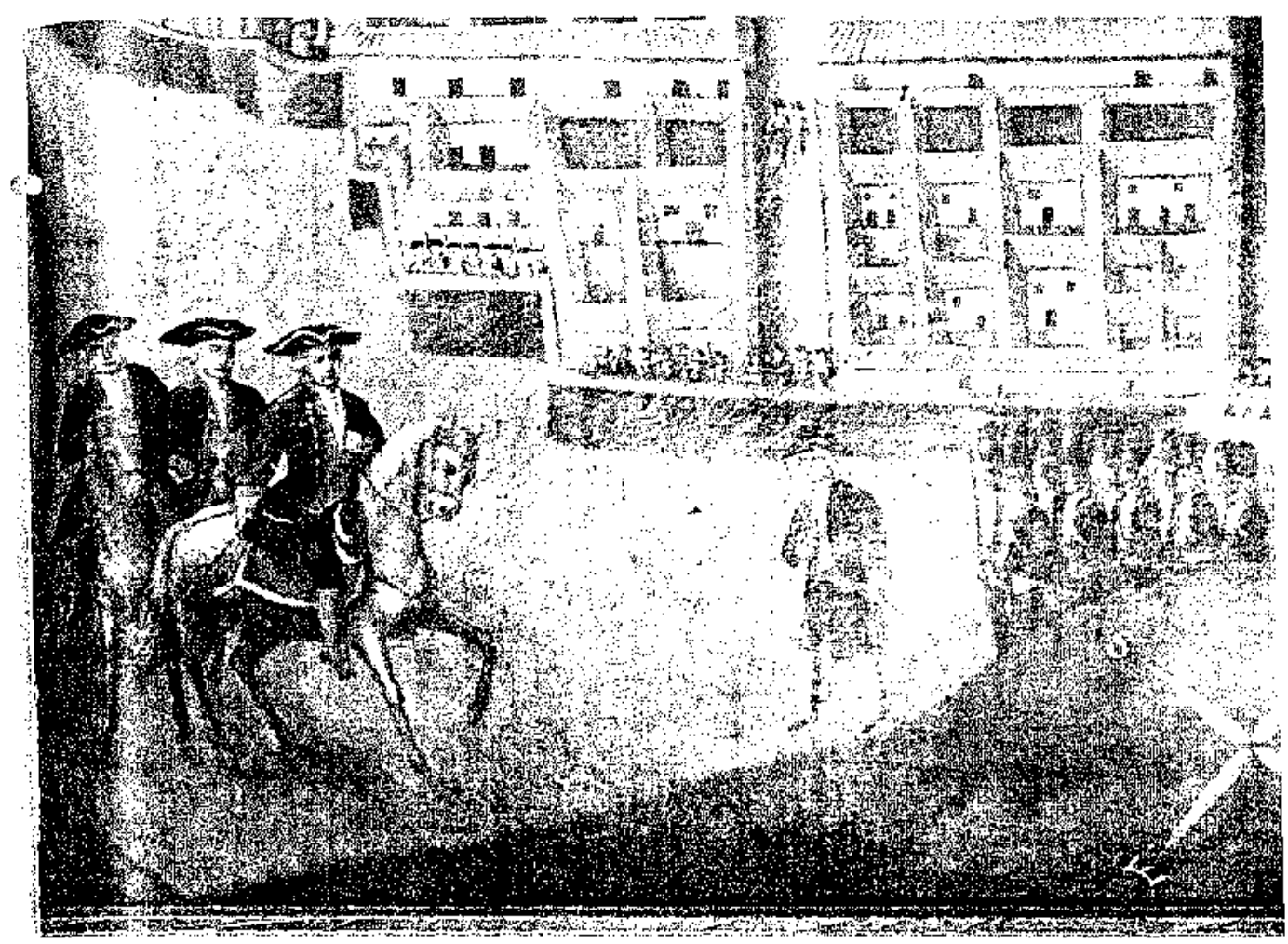

Defalle del cuadro de olivares.

larte de los muros de la zona este, frente a la Riverilla y cerro de Quilliquilli.En el ánguln izquierdo se ven tres figuras a caballo al frente de una compaña de infanteria; representan a Sebastián de Segurola, el comandante de la plaza, con dos de sus principales ayudantes, posibtemente, 'Tomás Fanco, Jean Bautista K...vala o Antonio I'inedo.

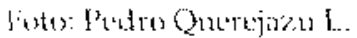





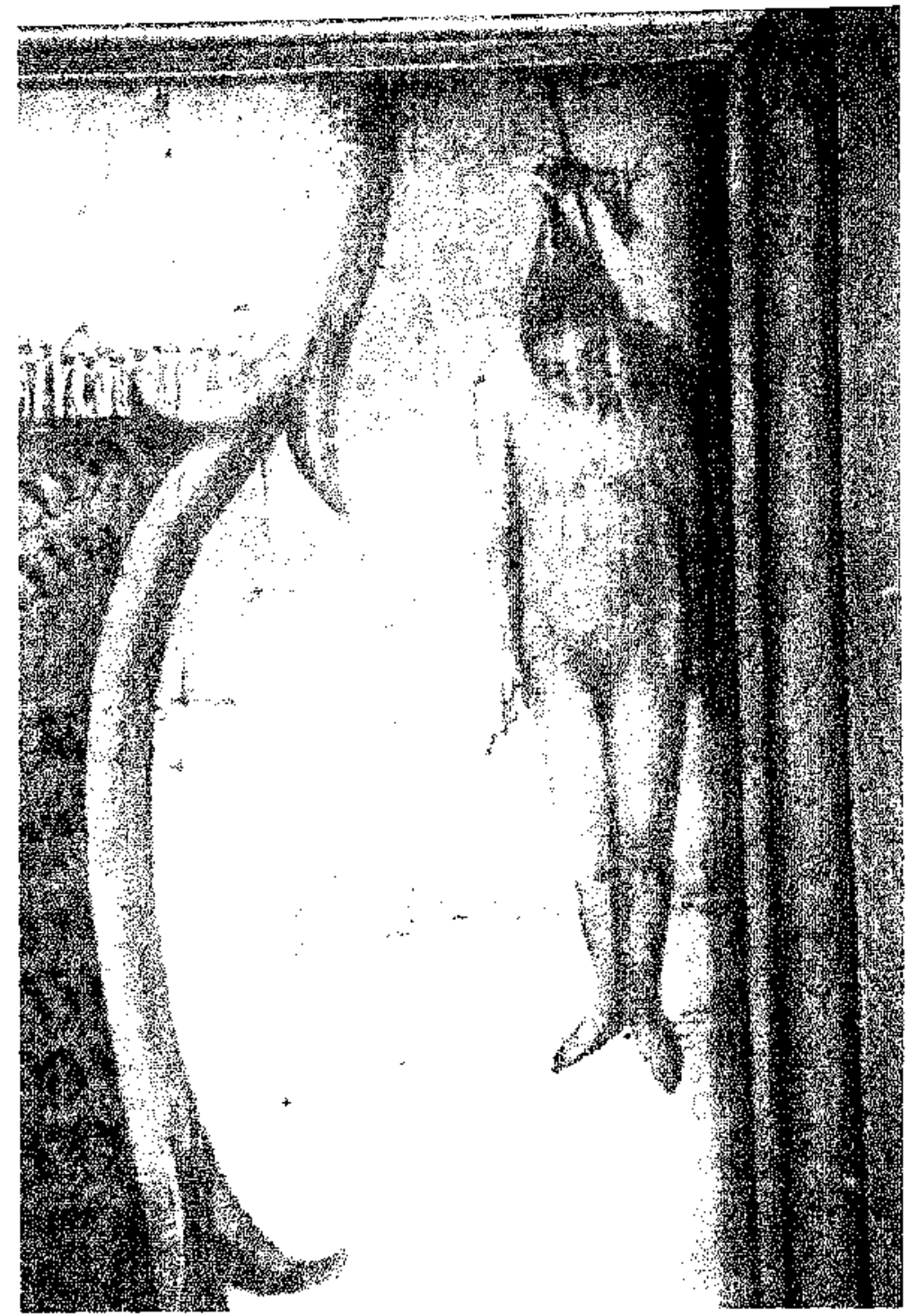

Detalle de los medaliones que adornan el cuadro de Olivares. Representación de una cautiva ahorcada en El Alto.

Foto: Pedro Querejazu I.. 

Detalle de otro de los medaflones que rodean el cuadro de Olivares.

Representación del martirio del padre Barriga, franciscano que subio voluntariansente al Alto para la atención espiritual de los indios. Fue ahorcado por los sublevados en una de las ausencias de Tupac Catari.

Foto: Pedro Querejazu L.

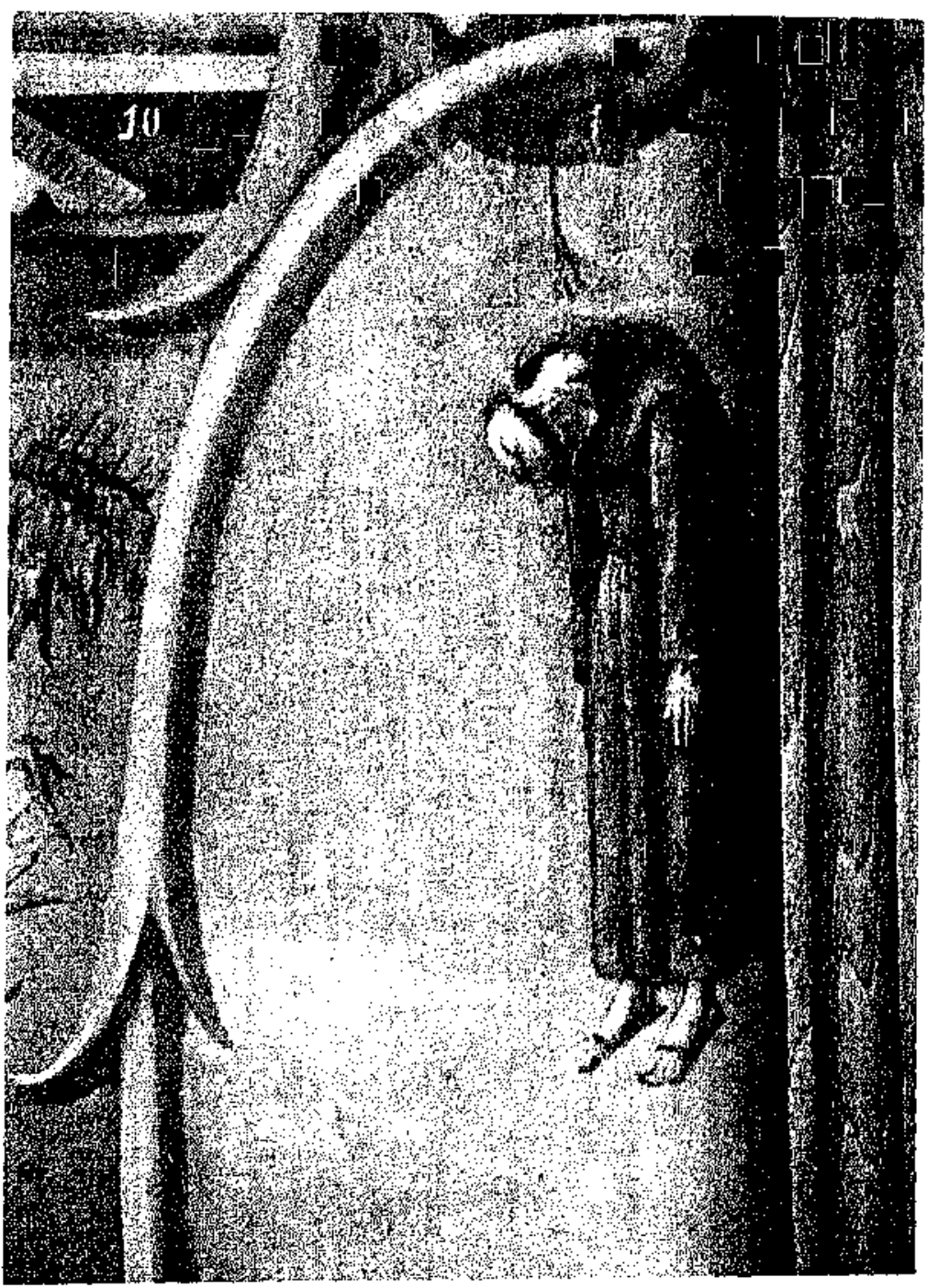




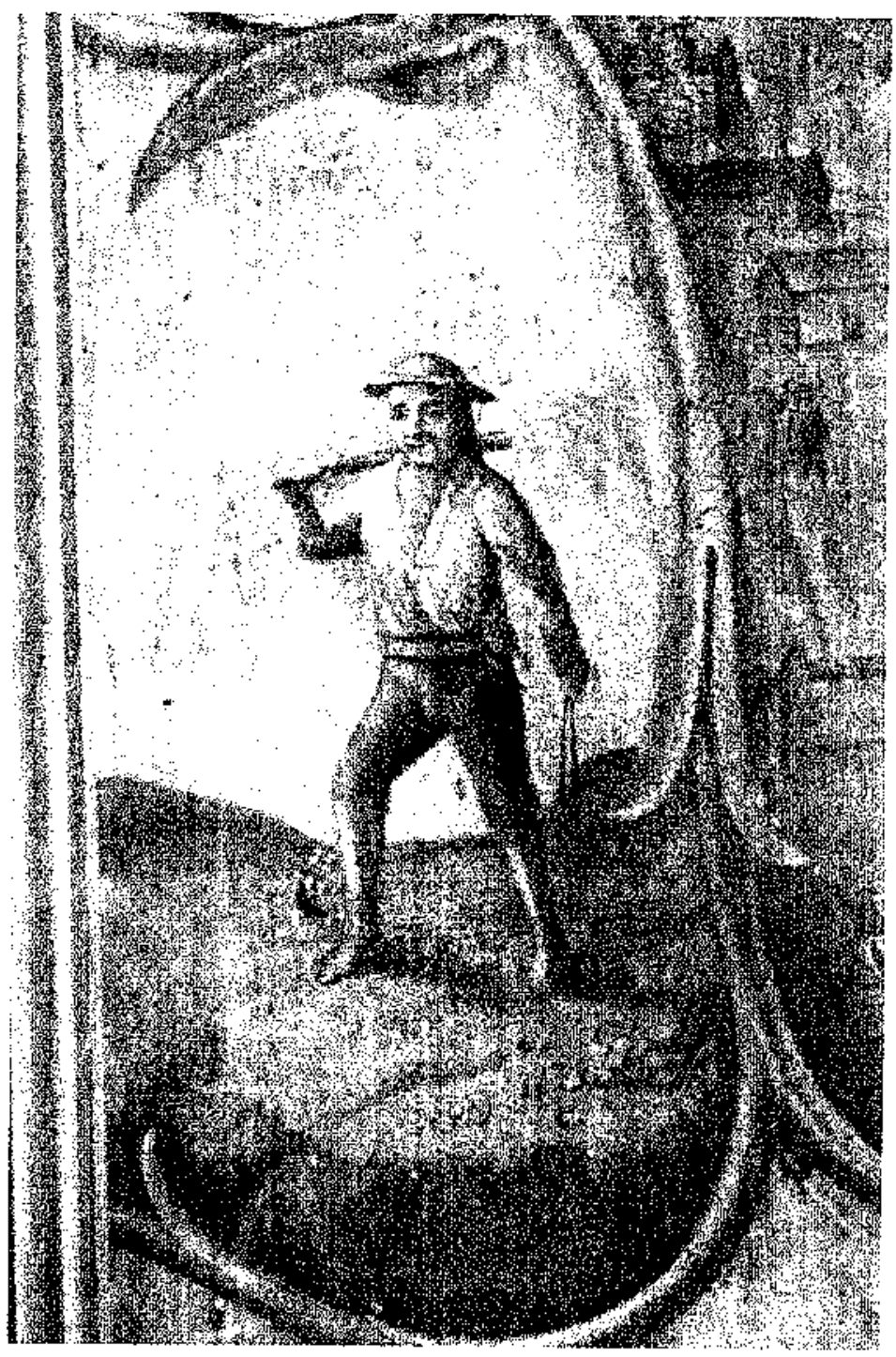

Detalle de los medallones que rodean el cuadro de Olivares. Representación de un indio, armado de palo, piedras y hondas.

Foto: l'edro Querejazu L. 



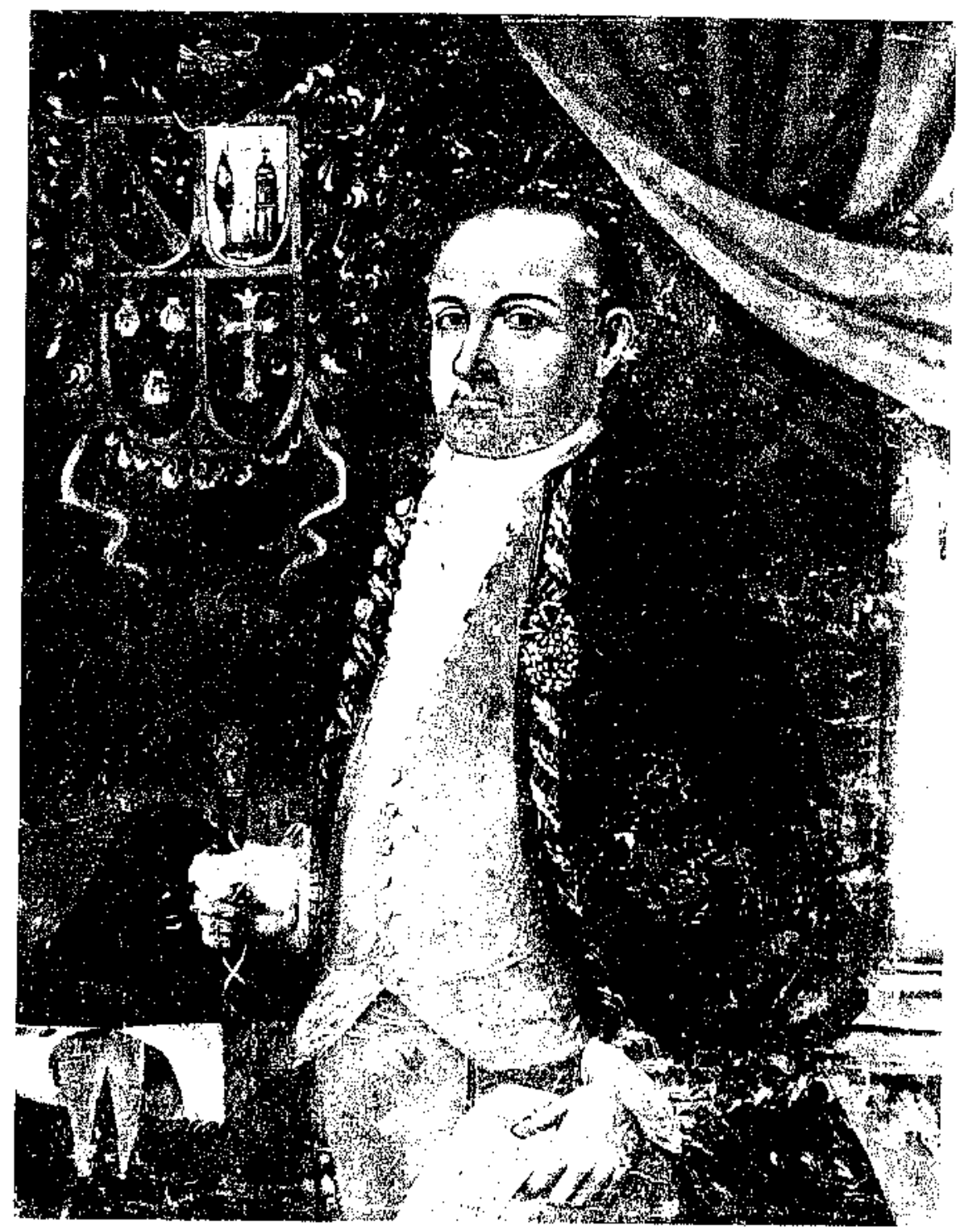

Don Sebastian de Segurola, comandante de la plaza y defensor de la ciu. dad de La Paz durante los dos sitios que sufrió en 1781 .

Retrato del Museo de la casa de Murillo.

ت̈cto: Pedro Quereiazu 



$$
\text { . }
$$




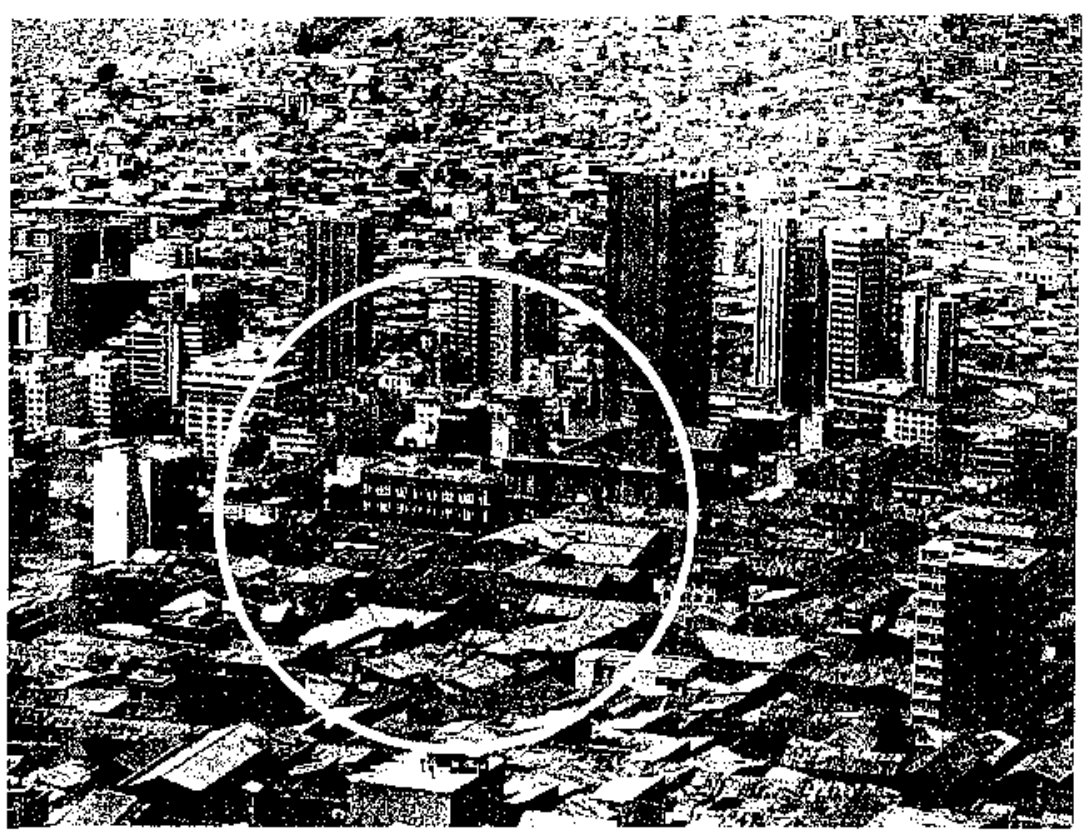

Vista de la Plaza Mayor y Caredral de La Pizz, desche el cerro del Cal. varlo. Puerle apreciarse in nitider cor que se observatsa desda aquel lugar lo gue courria dentro de la ciudad cercada

60. Llistr jgnacio 5 le

Vista de to que correspendia en 1781 a ła Plaza Mayor, Ayuntamiento, Catedral, Palacio arzobispal $Y$ casa del Oidar Dier de Medina, des. de el cerro de Quilliquilii, lugar en que habitualmence se instalaban a observar y atacar la ciudad las hues. tes de Tupac Catari

foto: Jiarl lgracio siles.

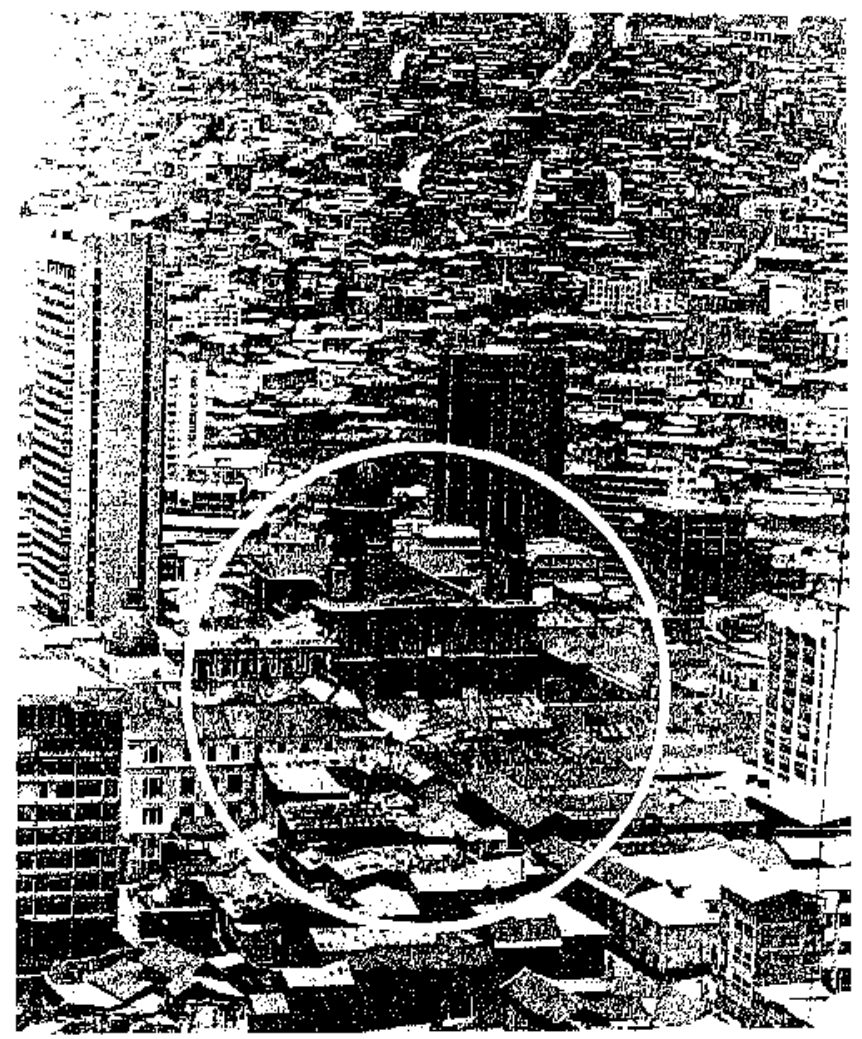



Vista del cerro del Calvario, desde la Catedral de La Pay. El Diario de Diex de Medina describe con mutho detalle las acciones de los rebe! kes desarroliadas alii, porque po. dian apreciarse muy bien desde la Plaza Mayor.

"uo: Juar Sgnardo Siles.

Višä del cerro de Quilliquilli 10mada descle la Catedral de La Paz. Deste fo Plaza Mayor se observaban perfectamente fas maniobeas milita. rés de las indigenas asi como sus bailes, procasiones y hasta corritas de toros.

Fon juar lgnacio siles

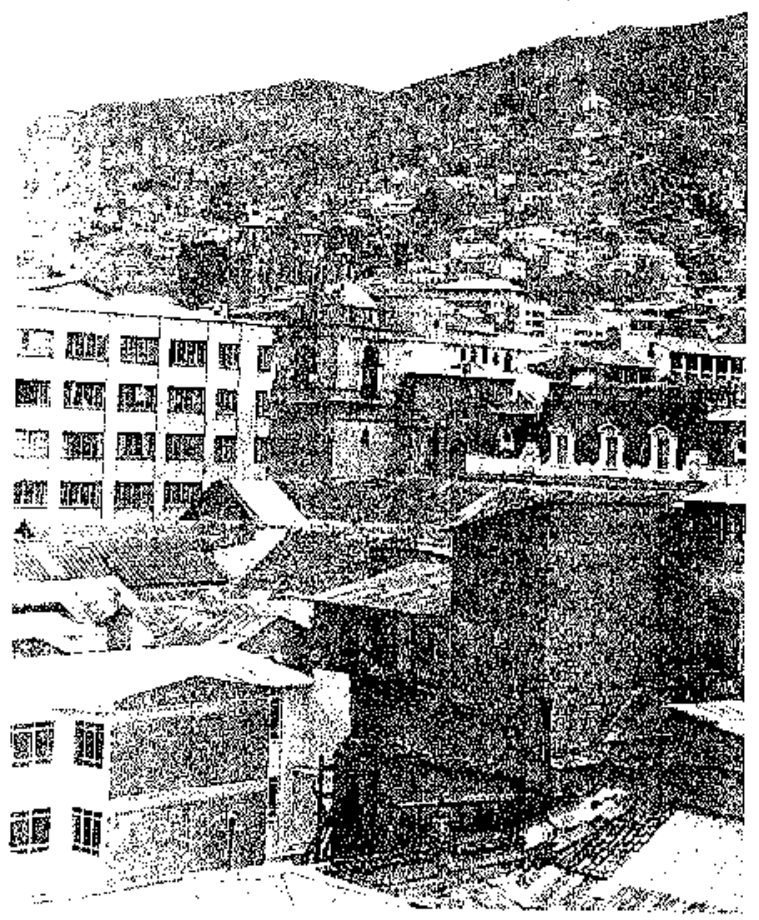

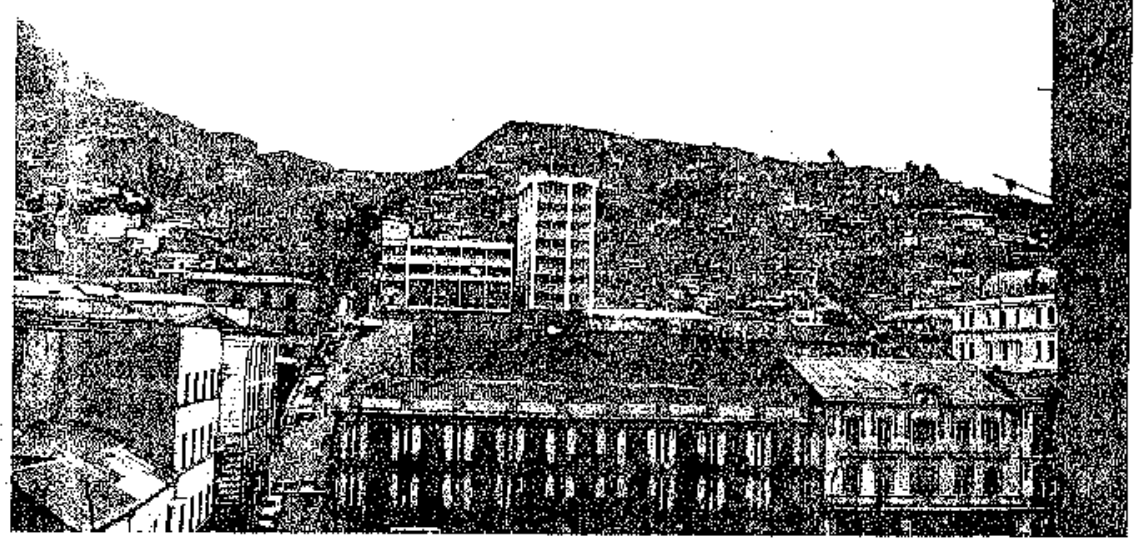




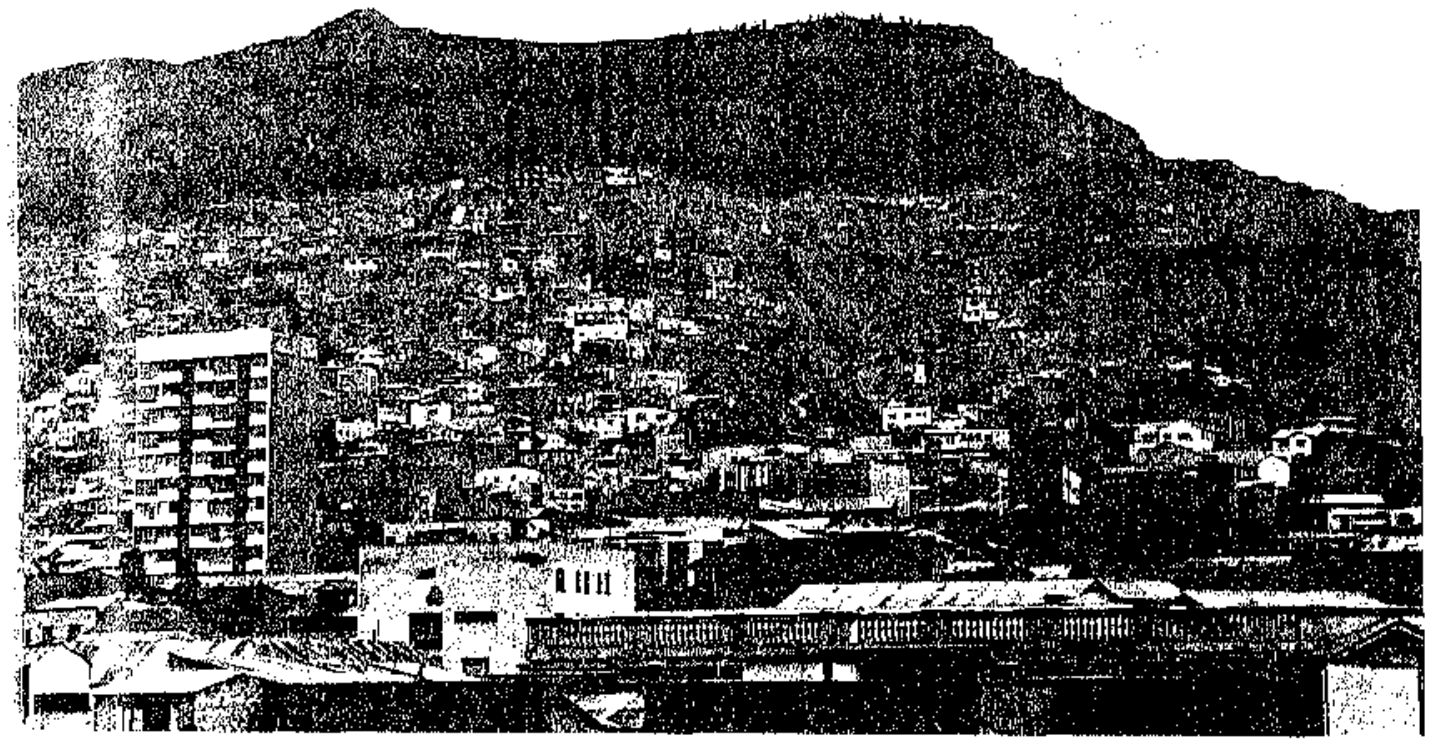

Vista de las regiones de Potopoto y Panmpajasi, tomadas desde to que corres. poricieria a la región sureste de la parte amurallada de la ciudad en 1781 . Los ejércitos españoles fracasaron siempre que intentaron sorprender en aquellos lugares a las fuerzas de Tupac Catari.

into: Juan Ignacio Siles. 



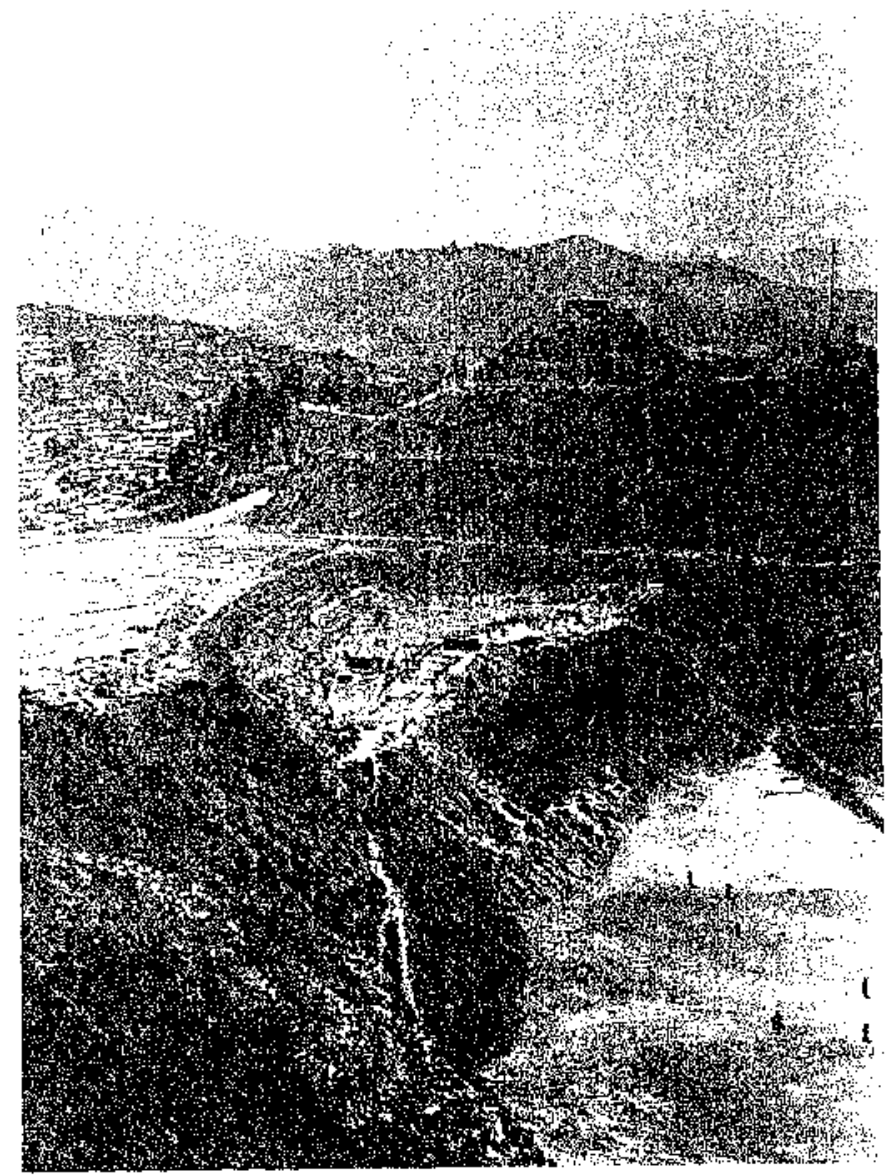

Explanada que une el cerro del Calvario con el de Ouilliquilti, cuya punta se cbserva en la foto. Tal conexión explica la facilidad con que se pasaba desde el Calvario al Quilłiquilli y deste este cerro a Santa Bárbara y Pam. pajasi.

roto Juar ignocio Siles 



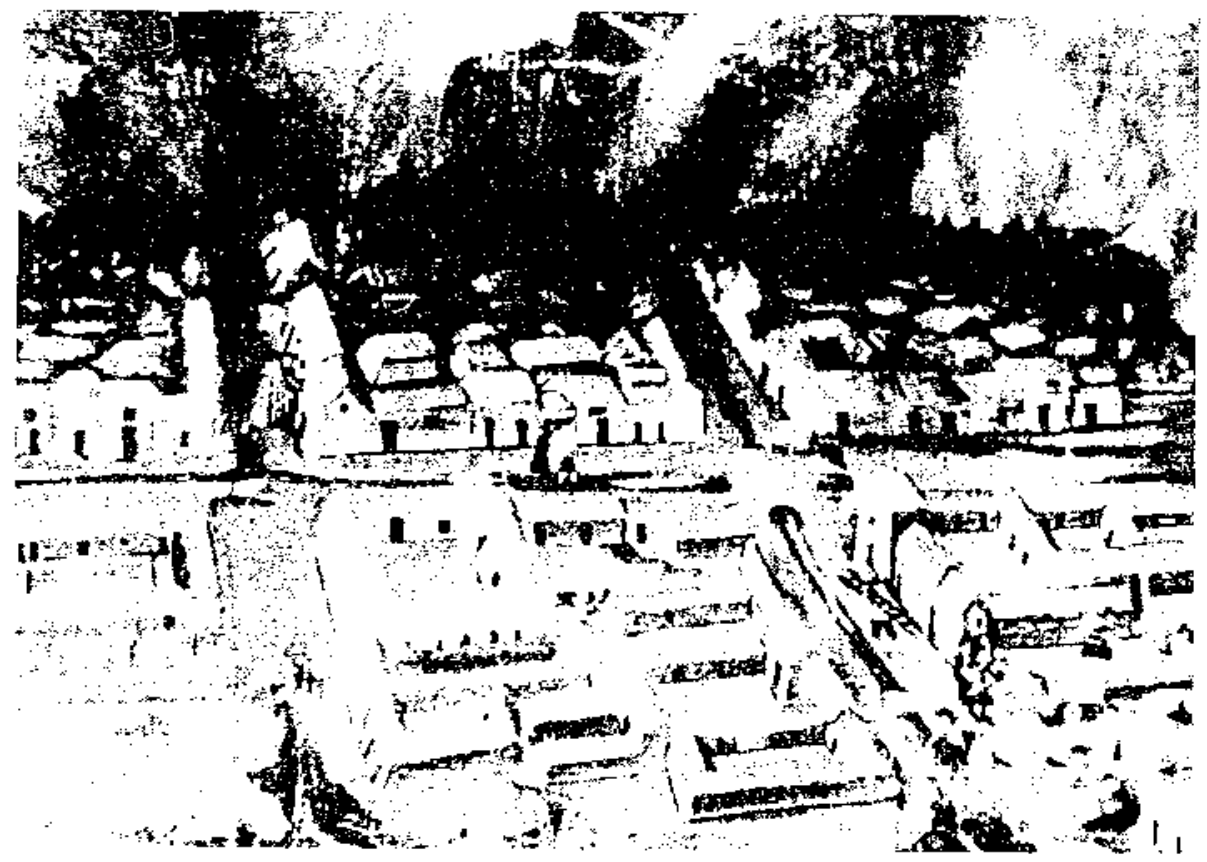

Detalie del "Retrato del General Juan de Landaeta". Corresponde a una vista parcial de la ciudad en la zona sur. Pueden apreciarse el puente de la Riverilla y lo iglesia y hospital de San Juan de Dios.

Foto: Mesa-Gisbert. 



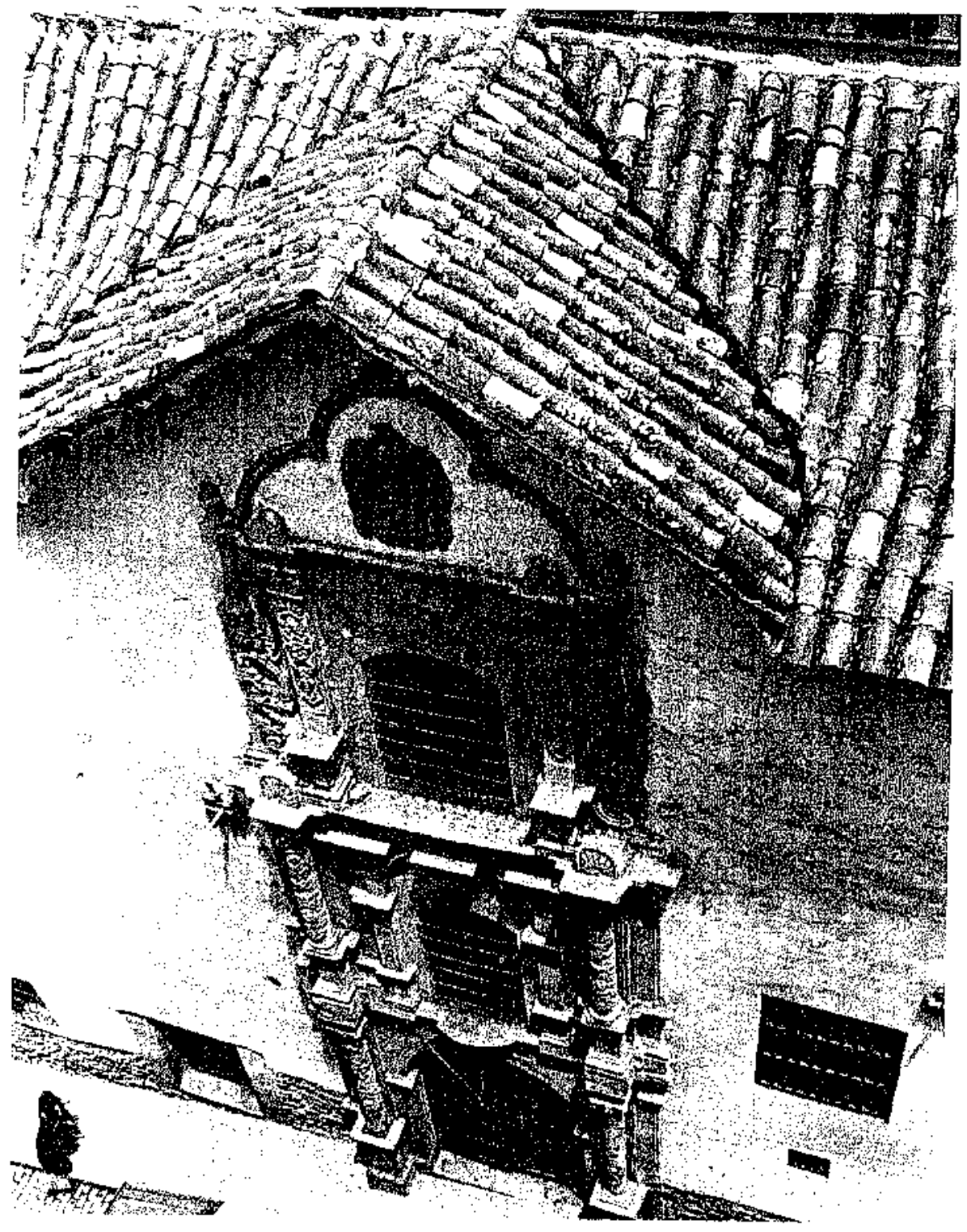

Vista de la entrada principal de la casa del Oidor Diex de Medina, tomada desde la Catedral. Hoy la ocupa el Museo Nacional de Arte.

futo. Juan Ignacio Siles. 



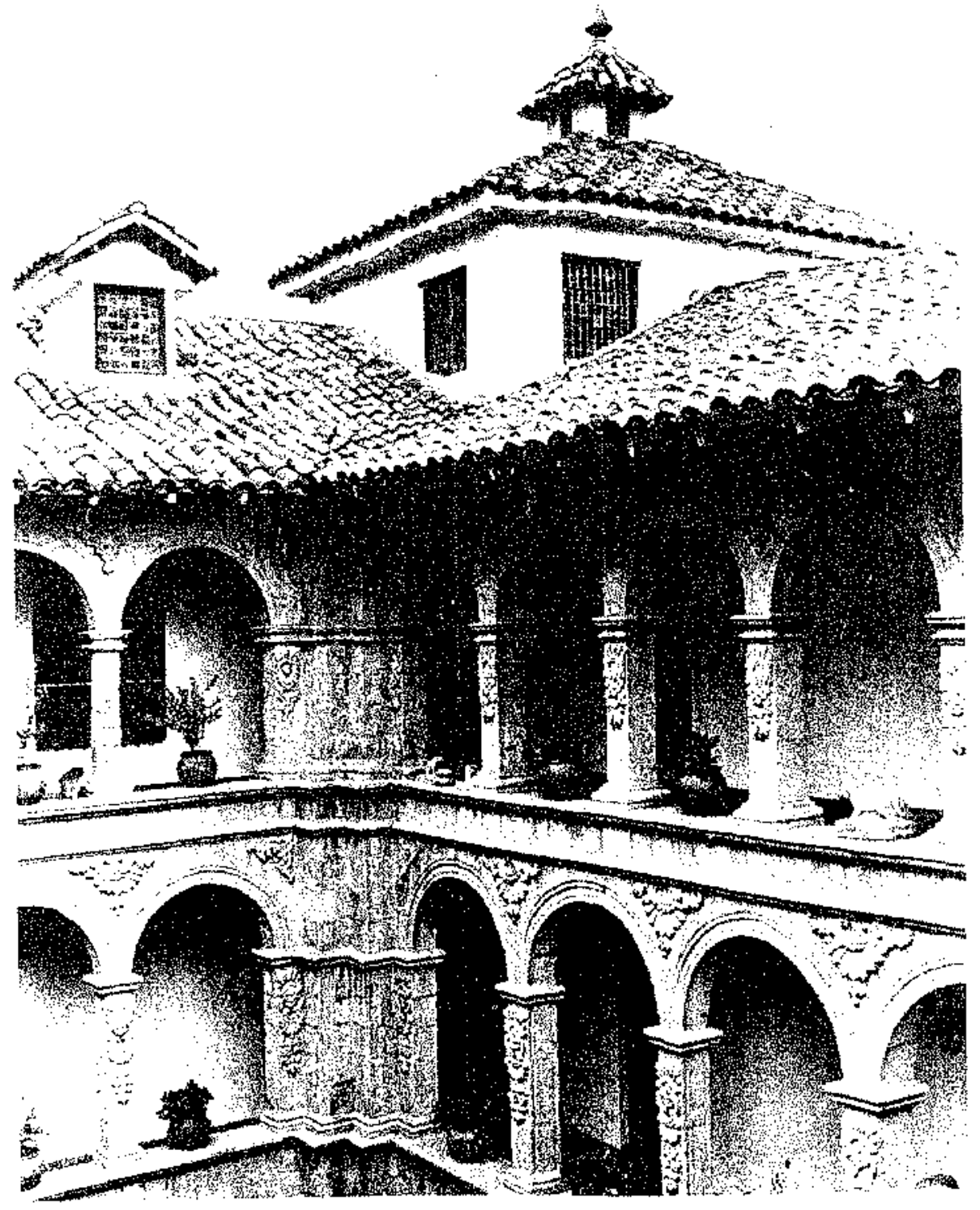

Patio y galerias de la casa del Oidor Diez de Medina. En dos ocasiones cayeron en ellas balas de los pedreros disparacios desde el Calvario o desde el Ouilit. quilti.

Fotr: Jum kgacir: Sites. 



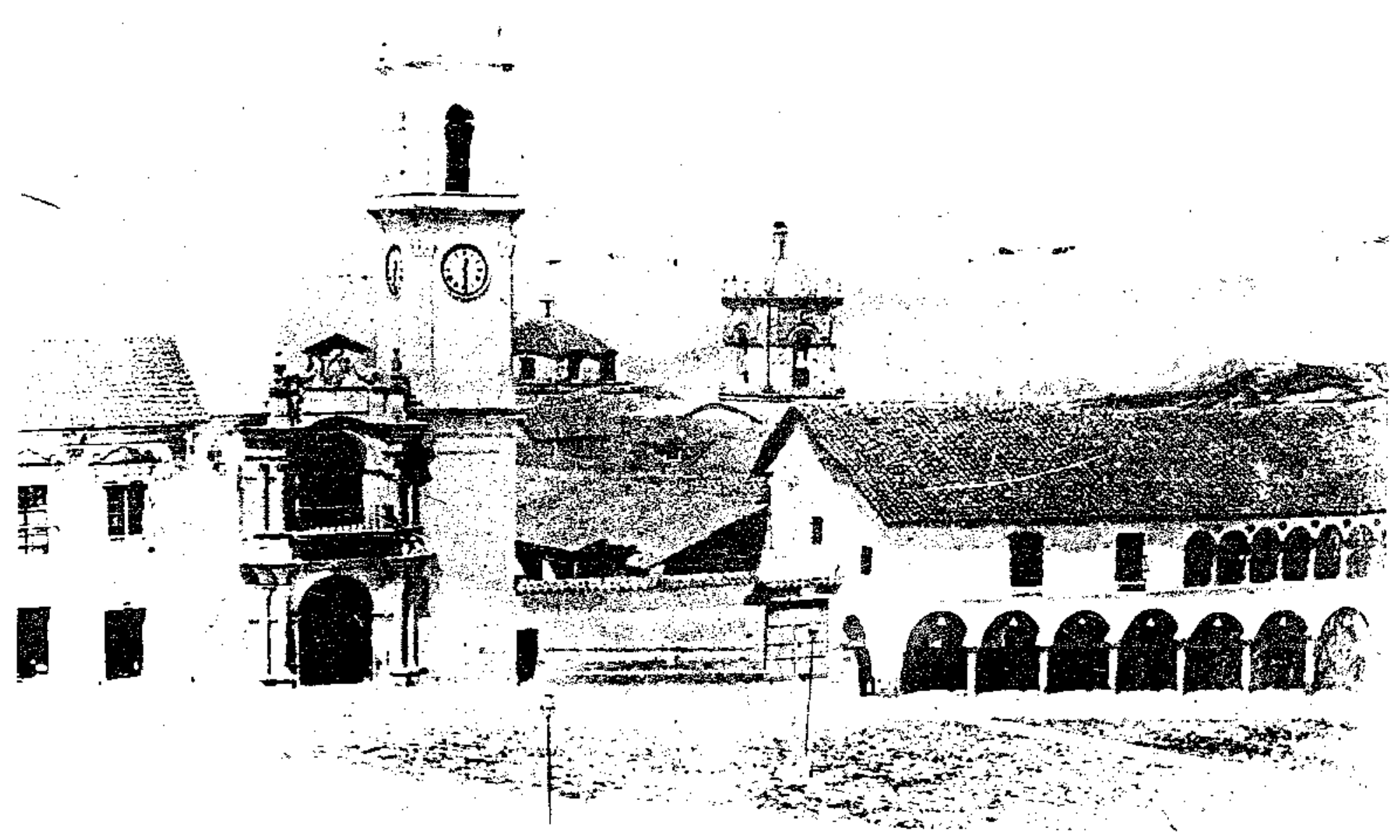

"El Loreto" - Colegio antiguo de "El Loreto". Ex Colegio de Josuitas, en la Plaza Mayor. Sus dependencias fueron ocupadas scmo cuarteles durante el cerco. En el sigla $X X$ fue derrlbado para canstrvir alli el Palacio Legislativo Foro: Pedro Quereizzu. 



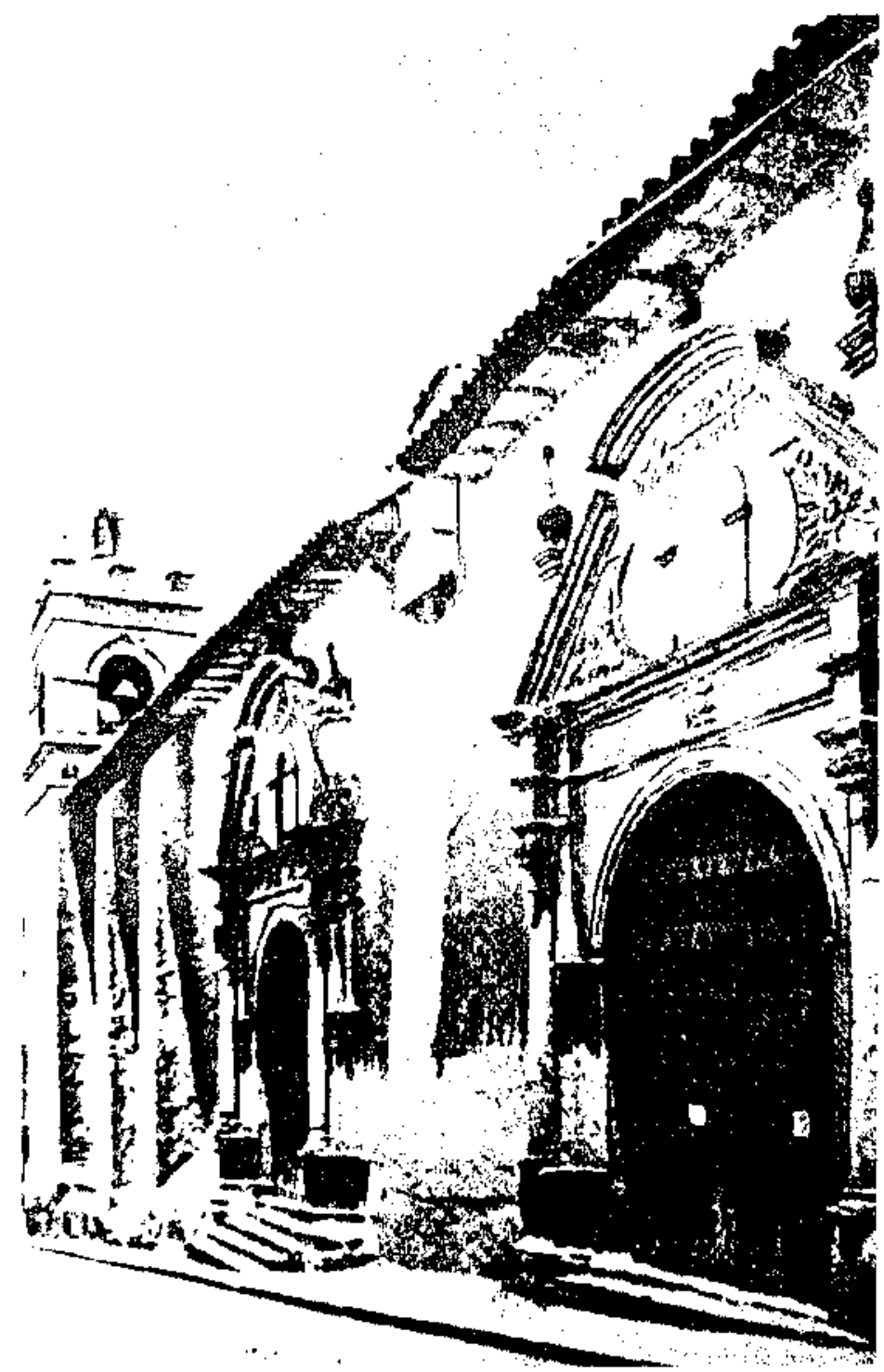

Portadas gemelas del convento de las Concepcionistas. Este convento fue destruido en gran parte a principios del siglo $X X$, conservándose solamen. te una parte del claustro. En los últimos meses del año 1980, la arquitec. ta Teresa Gisbert de Mesa encontró el resto de las piedras talladas del claustro que servian de cimientos a la construcción levantada sobre el antiguo monumento. Las piezas han sido salvadas y guardadas para una pos. terier reconstrucción del claustro.

Foto: Mesa.Gisbert. 



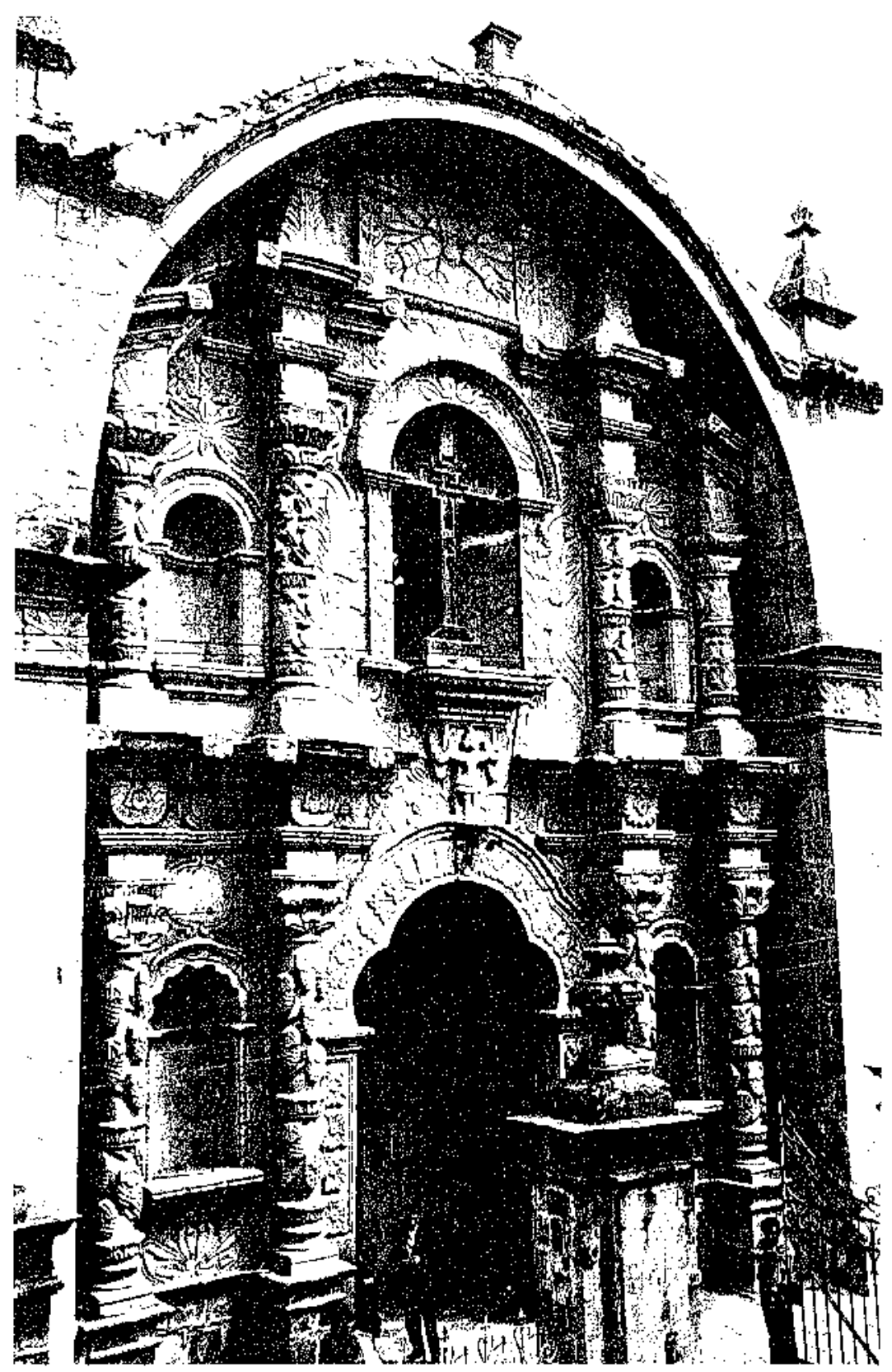

Iglesia de Santo Domingo. En ella se desarrallaron algunos de los actos religio sos celebrados durante el cerco. En este templo reposan los restos de Sebastián de Segurola, que mariria algunos años después de la sublexación sienda pri. mer intendente de La Pax.

Foro: Cerilio Albela. 



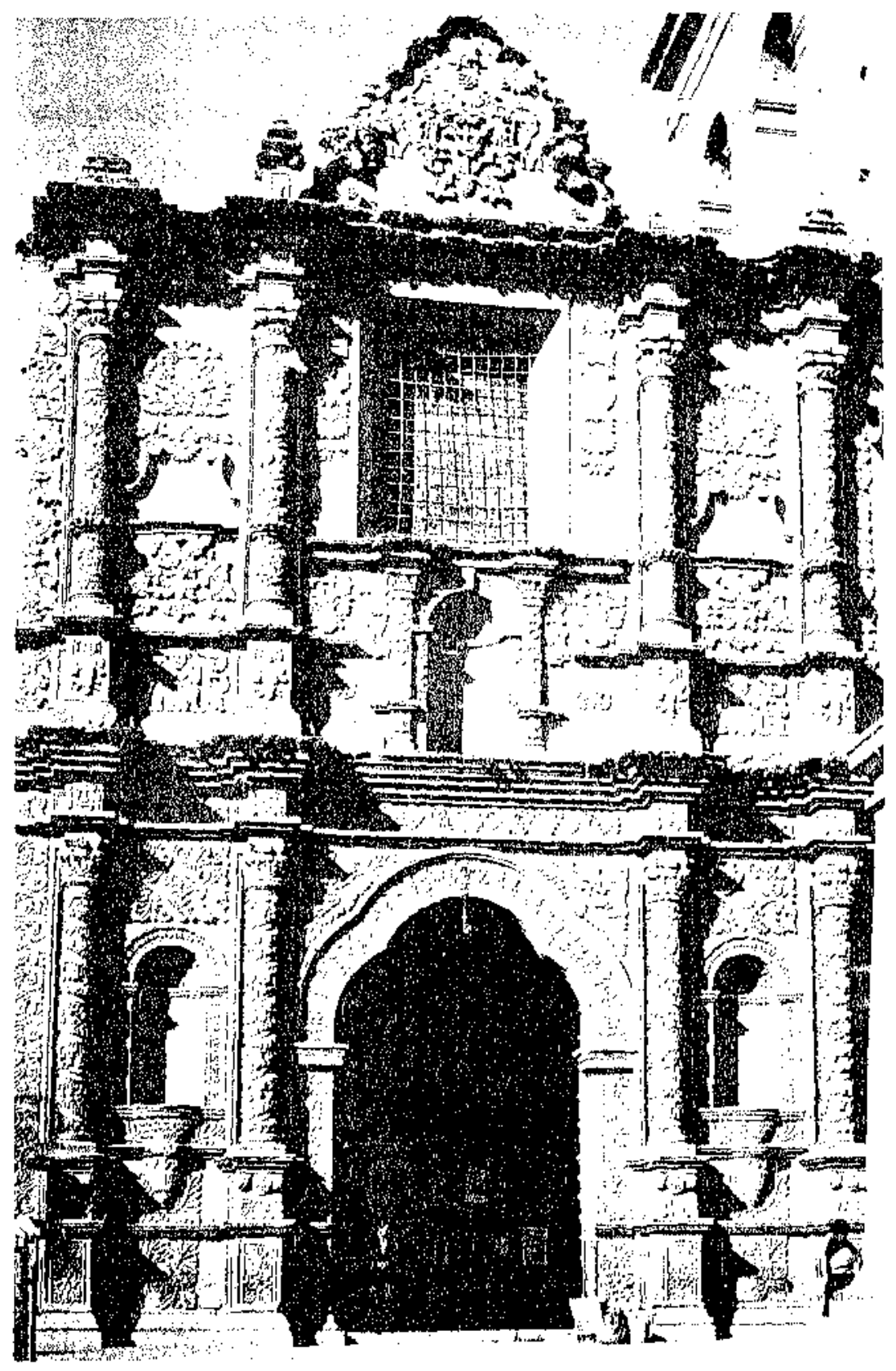

Igiesia de San Francisco. Rodeada del convento y la huerta, cstaba fuera de las muras al otro lado del rfo Choqueyapu. Estaba unida a la ciudad amurallada por un puente. En su huerta se celebraron muchos parlamentos con los indios y en sus re+ jas posteriores dejaron éstos, muchas de las cartas de Tupac Catari.

Foto: Cecilin Abela. 



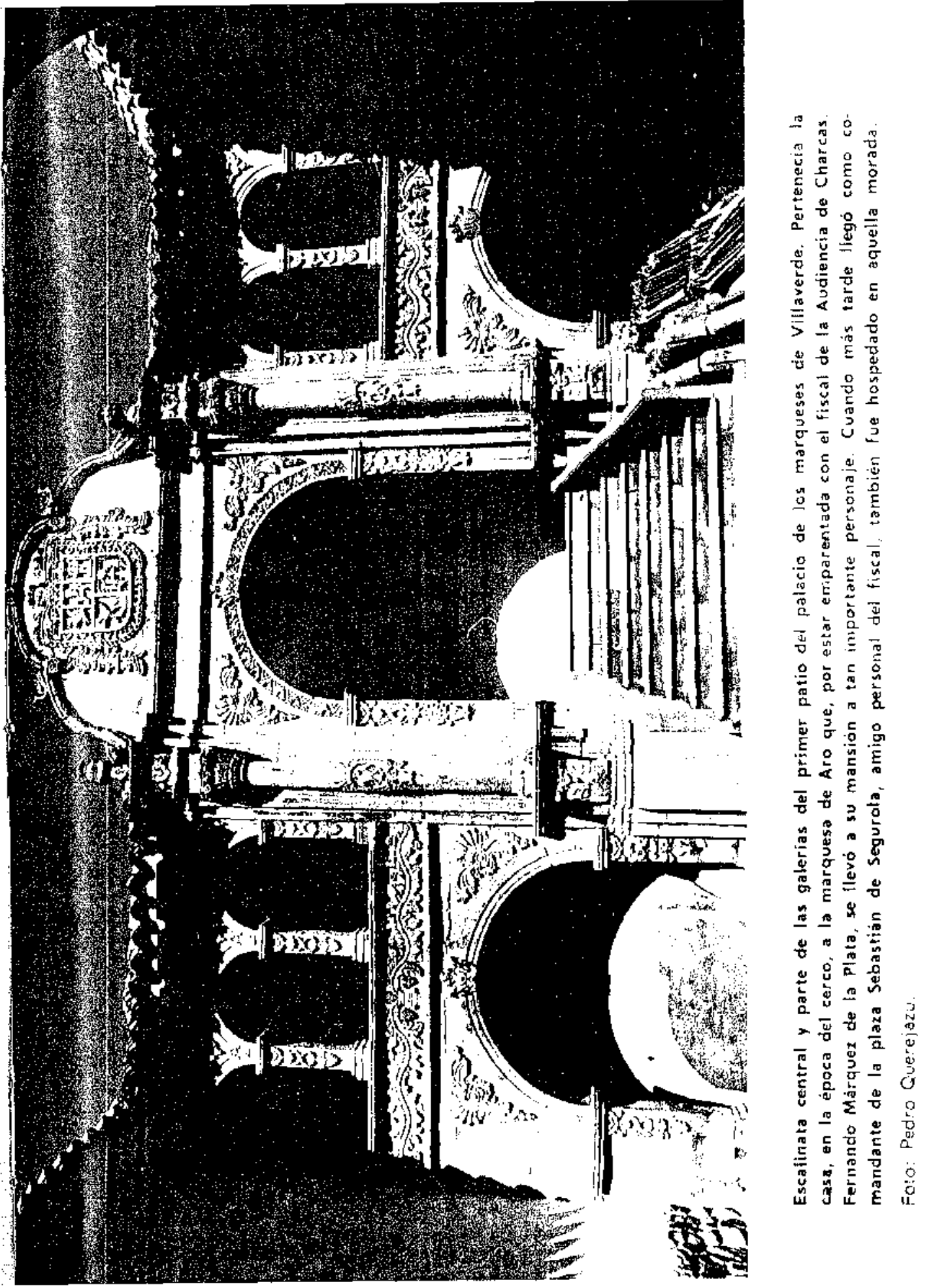





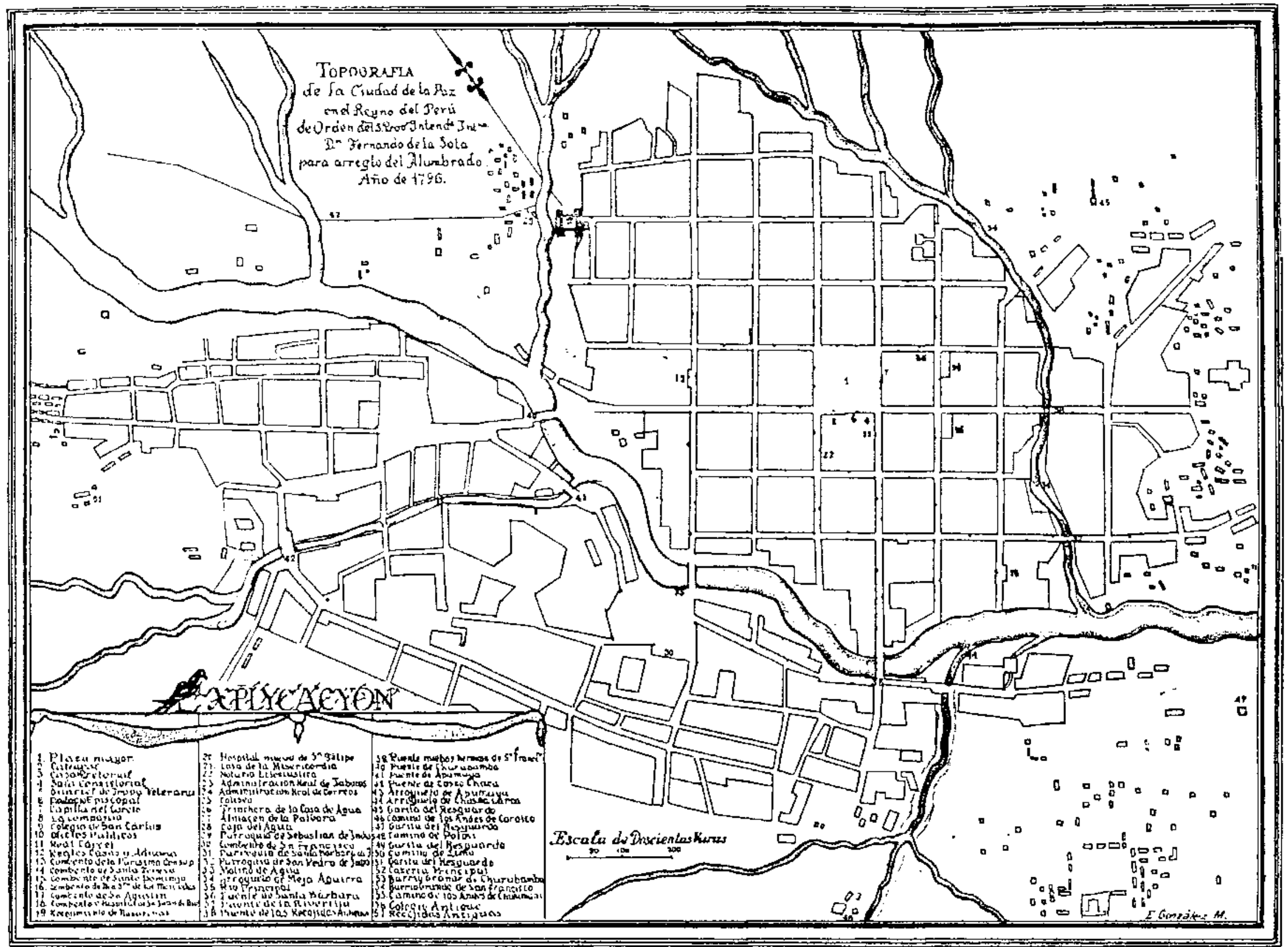

Plano de la ciudad de La Paz mandado a hacer por el intendente Fernando de la Sota en 1796, "para arreglo del alvmbrado". Esta carta permite apreciar muy bien el contorno que tuvo la ciudad amura. llada ontre los ríos Choqueyapu y Mejahuira. 
